\title{
Site U1337'
}

\author{
Expedition 320/321 Scientists ${ }^{2}$
}

\section{Chapter contents}

Background and objectives. . . . . . . . 1

Science summary............... 2

Operations.................6

Lithostratigraphy..............8

Biostratigraphy . . . . . . . . . . . 12

Paleomagnetism ................ 25

Geochemistry .................27

Physical properties . . . . . . . . . . . . 29

Stratigraphic correlation and composite

section..................... 31

Downhole measurements .... . . . . . . . 32

References.................... 36

Figures....................... 39

Tables................... 112

${ }^{1}$ Expedition 320/321 Scientists, 2010. Site U1337. In Pälike, H., Lyle, M., Nishi, H., Raffi, I., Gamage, K., Klaus, A., and the Expedition 320/321

Scientists, Proc. IODP, 320/321: Tokyo (Integrated Ocean Drilling Program Management International, Inc.).

doi:10.2204/iodp.proc.320321.109.2010

'Expedition 320/321 Scientists' addresses

\section{Background and objectives}

Integrated Ocean Drilling Program (IODP) Site U1337 $\left(3^{\circ} 50.009^{\prime} \mathrm{N}, 123^{\circ} 12.352^{\prime} \mathrm{W} ; 4463\right.$ meters below sea level [mbsl]; PEAT-7C site survey) (Fig. F1; Table T1) was sited in order to collect an early middle Miocene segment of the Pacific Equatorial Age Transect (PEAT) equatorial megasplice and is on 24 Ma crust between the Galapagos and Clipperton Fracture Zones, $390 \mathrm{~km}$ southeast of Site U1335.

Site U1337 is on a plateau between high topography to the south of the site, a gentle but pockmarked ridge to the north, and a deep to the east (Fig. F1). Sediment cover is thick on the plateau (300$600 \mathrm{~ms}$ two-way traveltime [TWT]; 200-500 m) (Fig. F2) but highly variable along the edges. Nevertheless, the seafloor is relatively flat because the sediment has filled in the basement topography, with a relief of $\sim 200$ ms TWT. To the north, along seismic Line 6 , the seafloor is dissected by a series of karstlike holes that cut through the seismic layering (Fig. F1). Based on correlation to the central equatorial Pacific seismic stratigraphy of Mayer et al. (1985), middle Miocene sediment has been exposed. Site U1337 is now north of the equatorial high-productivity zone but should have been within $\pm 2^{\circ}$ of the Equator between 8 and $24 \mathrm{Ma}$. The north-south grain of abyssal hill topography in the vicinity of Site U1337 is typically covered by $300-500 \mathrm{~ms}$ TWT of sediment $(\sim 250-400 \mathrm{~m})$ but is often interrupted by areas of significant erosion, as in the east of the PEAT-7 survey area (Fig. F1).

Based on stage-pole reconstructions of Pacific plate motion and observations of basement age from previous drilling sites, an aeromagnetic line south of the proposed site (Horner-Johnson and Gordon, 2003), and magnetic anomaly maps (Cande et al., 1989), we estimate that Site U1337 is on 24 Ma crust. The best control on age is information from Deep Sea Drilling Project (DSDP) Site 79, $\sim 180 \mathrm{~km}\left(1.6^{\circ}\right)$ east and $1.3^{\circ}$ south of Site U1337, apparently on the same ridge segment. The base of Site 79 reaches the Miocene/ Oligocene boundary, or $23 \mathrm{Ma}$ on the PEAT timescale.

Site U1337 was proposed for drilling to study the paleoceanographic events in the early and middle Miocene. The latest Oligocene through the middle Miocene appears to have been a time of relative warmth comparable to the latest Eocene. However, variability in the isotopic record of the early to middle Miocene is larger than that of the Eocene and may indicate more variability in climate and global ice volume. Nevertheless, the early Miocene 
calcium carbonate compensation depth (CCD) was not as variable as in the Eocene (Lyle, 2003), nor does there appear to have been as high a concentration of atmospheric $\mathrm{pCO}_{2}$ (Pagani et al., 1999). The climatic "optimum" at 15 Ma comes just before the major development of ice sheets on Antarctica and a marked increase in ice-rafted debris in circumAntarctic sediments. The early Miocene also marks a major evolutionary change from the relatively static Oligocene planktonic biota. In the equatorial Pacific, the late Oligocene to early Miocene marks the beginning of abundant diatoms in the stratigraphic record (Barron and Baldauf, 1989) and thus may represent a major change in carbon cycling as well.

The only major ocean boundary change proposed for the time near the Oligocene/Miocene boundary is the opening of the Drake Passage to deep flow; however, there is some debate as to the exact timing of this event (Barker, 2001; Pagani et al., 1999; Lawver and Gahagan, 2003; Scher and Martin, 2006; Lyle et al., 2007) and its direct impact on the tropical ocean is uncertain. It may be that, as in the Eocene/ Oligocene boundary section, the link between poles and tropics lies in the shallow intermediate waters that provide nutrients to lower latitude upwelling regions. For the equatorial region, an even more pertinent question is what changes were occurring in the Miocene tropical ocean that led to this burst of Miocene evolution.

\section{Science summary}

The latest Oligocene through the middle Miocene appears to have been a time of relative warmth comparable to the latest Eocene. However, variability in the isotopic record of the early to middle Miocene is larger than that of the Eocene and may indicate more variability in climate and global ice volume. Site U1337 (proposed Site PEAT-7C; $3^{\circ} 50.009^{\prime} \mathrm{N}$, $123^{\circ} 12.352^{\prime} \mathrm{W}$; $4463 \mathrm{mbsl}$ ) (Fig. F1; Table T1) was targeted to collect an early middle Miocene segment of the PEAT equatorial megasplice on $\sim 24$ Ma crust between the Galapagos and Clipperton Fracture Zones, $\sim 390 \mathrm{~km}$ southeast of Site U1335. In conjunction with Sites U1335 and U1336, it was also designed to provide a latitudinal transect for early Miocene age slices. The recovered sediment column at Site U1337 represents a nearly complete and continuous Neogene sedimentary section.

\section{Operations}

Four holes were cored at Site U1337. In Hole U1337A, advanced piston corer (APC) cores were taken from the seafloor to $195.5 \mathrm{~m}$ drilling depth below seafloor (DSF) (Cores 321-U1337A-1H through
21H). Nonmagnetic core barrels were used for all APC cores except for Core 321-U1337A-21H. FlexIt core orientation was conducted for all cores except Core 321-U1337A-1H. In addition, five successful advanced piston corer temperature tool (APCT-3) temperature measurements were taken with Cores 321-U1337A-5H, 7H, 9H, 11H, and 13H. Extended core barrel $(\mathrm{XCB})$ coring continued with Cores 321U1337A-22X through 48X. The sediment/basement contact was recovered at the base of Core 321-U1337A48X. Three logging strings (triple combination [triple combo], Formation MicroScanner [FMS]-sonic, and Versatile Seismic Imager [VSI]) were deployed in Hole U1337A.

In Hole U1337B, APC cores were taken from the seafloor to $245.2 \mathrm{~m}$ DSF (Cores 321-U1337B-1H through 27H). Nonmagnetic core barrels were used through Core 321-U1337B-20H. The FlexIt core orientation tool was deployed successfully for all but two APC cores (321-U1337B-17H and 18H). FlexIt and steel core barrels were used through Core 321-U1337B27H. APCT-3 measurements were obtained with Cores $321-\mathrm{U} 1337 \mathrm{~B}-15 \mathrm{H}, 17 \mathrm{H}$, and $19 \mathrm{H}$. Coring continued with a single XCB core (321-U1337B-28X) to 251.9 m DSF; however, this barrel could not be recovered and Hole U1337B was abandoned prematurely.

Hole U1337C was cored to recover sections that were missing from Holes U1337A and U1337B. APC cores were taken from the seafloor to $11.4 \mathrm{~m}$ DSF (Cores 321-U1337C-1H through 2H) using nonmagnetic core barrels and the FlexIt core orientation tool. A wash barrel (Core 321-U1337C-3W) was then deployed, and the hole was washed to $169.4 \mathrm{~m}$ DSF. APC coring resumed at that depth and continued through Core 321-U1337C-9H to $221.3 \mathrm{~m}$ DSF and then switched to steel core barrels. Coring with the XCB system continued with Cores 321-U1337C-10X through 33X. Basement was recovered in Core 321U1337C-33X.

Hole U1337D was planned to target the few remaining areas that had yet to be fully recovered and to duplicate recovery through those sections of the formation already recovered to provide additional sample material. The most troublesome material encountered in the previous holes was the large diatom mats located directly above and below a hard $\sim 0.4 \mathrm{~m}$ thick porcellanite layer. In Hole U1337D, APC cores were taken from the seafloor to $237.7 \mathrm{~m}$ DSF (Cores 321-U1337D-1H to 26H). Nonmagnetic core barrels were used through Core 321-U1337D-20H. The first XCB core (321-U1337D-27X) was designed to only core through the hard $\sim 0.4 \mathrm{~m}$ thick porcellanite layer. The APC was once again deployed and cored to $267.0 \mathrm{~m}$ DSF (Cores 321-U1337D-28H through 30H). 
At this point the XCB coring system was once again deployed for Cores 321-U1337D-31X through 49X to a total depth of $442.9 \mathrm{~m}$ DSF. The FlexIt core orientation tool was deployed successfully with all APC cores. The Sediment Temperature Tool (SET) was deployed for the first time from the R/V JOIDES Resolution after Core 321-U1337D-17X at 298.1 m DSF.

\section{Lithostratigraphy}

At Site U1337, latest Oligocene seafloor basalt is overlain by $\sim 450 \mathrm{~m}$ of nannofossil and biosiliceous oozes and nannofossil chalks that are divided into four lithologic units (Fig. F3). The Pleistocene through uppermost Miocene sediments of lithologic Unit I are characterized by multicolored (various hues of white, brown, green, and gray) nannofossil oozes, diatom oozes, and radiolarian oozes that alternate on meter scales with a general downsection increase in siliceous microfossils relative to nannofossils. The uppermost Miocene to middle Miocene lithologic Unit II is composed of green and gray biosiliceous sediments interbedded on meter scales with white and light greenish gray nannofossil ooze. Laminated decimeter-thick diatom ooze ("mat") deposits are commonly found in the unit. Meter-scale color variability in both lithologic Units I and II are associated with variations in lithology and physical properties. However, there is also millimeter- and centimeter-scale color banding that is also likely a response to redox conditions. White, pale yellow, and pale green nannofossil oozes and chalks with low abundances of silica fossils dominate the Unit III sediments of middle Miocene to latest Oligocene age. Seafloor basalt (lithologic Unit IV) was recovered at the base of the sedimentary section, dated as latest Oligocene.

\section{Biostratigraphy}

All major microfossil groups occur in the sediments recovered at Site U1337. Planktonic foraminifers at Site U1337 are rare to abundant with poor to good preservation throughout most of the succession but are absent or extremely rare in some intervals of the upper Miocene and lower Miocene. Biozones PT1b to O6 are recognized, with the exception of Zones PL4, M12, and M3 (Fig. F3). Calcareous nannofossils at Site U1337 are moderately to poorly preserved and some samples with high silica content are barren. Nannofossil Zones NN1 to NN21 are present, indicating an apparently complete sequence. The radiolarian stratigraphy at Site U1337 spans the interval from the uppermost part of Zones RN16-RN17 (upper Pleistocene) to RN1 (lower Miocene). The radiolarian assemblages of Pleistocene to upper Miocene age tend to have good preservation, whereas middle to lower Miocene assemblages show moderate preservation. In the lowermost part of the section, above the basement, sediments are barren of radiolarians. The high-resolution diatom stratigraphy at Site U1337 spans the interval from the Fragilariopsis (Pseudoeunotia) doliolus Zone (upper Pleistocene) to the lowermost part of the Craspedodiscus elegans Zone (lower Miocene). The diatom assemblage is generally well to moderately preserved throughout the recovered section; however, in several intervals valve preservation becomes moderate to poor. The base of the sediment column is barren of diatoms. The nannofossil, foraminifer, radiolarian, and diatom datums and zonal schemes generally agree, though some discrepancies occur in the lowest part of the core. Benthic foraminifers occur continuously throughout the succession recovered in Hole U1337A and show good to moderate preservation. The overall assemblage composition indicates lower bathyal to abyssal paleodepths.

\section{Stratigraphic correlation}

Stratigraphic correlation provided a complete spliced record to $\sim 220 \mathrm{~m}$ core composite depth below seafloor (CCSF-A; see "Core composite depth scale" in the "Methods" chapter). Several gaps were encountered over the next $50 \mathrm{~m}$ CCSF-A. Comparison of gamma ray attenuation (GRA) density records with well logging density data suggest that no more than $1 \mathrm{~m}$ of section was lost in any of the gaps. Correlation between the holes was broken again several times between $440 \mathrm{~m}$ CCSF-A and basement at $490 \mathrm{~m}$ CCSF-A. Growth factor for the correlation was 1.12. The linear sedimentation rate decreases from $\sim 21 \mathrm{~m} / \mathrm{m} . \mathrm{y}$. in the middle Miocene to $17 \mathrm{~m} / \mathrm{m}$.y. in the late Miocene.

\section{Paleomagnetism}

Paleomagnetic measurements were conducted on archive-half sections of 20 APC cores and 14 XCB cores from Hole U1337A, 27 APC cores from Hole U1337B, 8 APC cores from Hole U1337C, and 30 APC cores from Hole U1337D. The FlexIt core orientation tool was deployed in conjunction with all APC cores, and we conclude that the FlexIt orientation data are generally reliable. Measurements of natural remanent magnetization (NRM) above $\sim 93 \mathrm{~m}$ core depth below seafloor (CSF) indicate moderate magnetization intensities (on the order of $10^{-3} \mathrm{~A} / \mathrm{m}$ ) with a patchy but generally weak viscous remanent magnetization (VRM) or isothermal remanent magnetization (IRM) drilling overprint, and polarity reversal sequences from Chrons C1n to C3r (0 to $\sim 6 \mathrm{Ma}$ ) are recognized. Below $\sim 93 \mathrm{~m}$ CSF, remanent intensities after alternating-field (AF) demagnetization of $20 \mathrm{mT}$ are 
reduced to values close to magnetometer noise level in the shipboard environment $\left(\sim 2 \times 10^{-5} \mathrm{~A} / \mathrm{m}\right)$. In this zone, sediment magnetizations have been partly overprinted during the coring process, and remanent inclinations are occasionally steep after AF demagnetization at a peak field of $20 \mathrm{mT}$. Nonetheless, polarity reversals are apparently recorded to $\sim 200 \mathrm{~m} \mathrm{CSF}$ and are provisionally correlated to the geomagnetic polarity timescale (GPTS) from Chrons C3An to C5n ( 6-11 Ma) (Fig. F3). Magnetic polarity interpretation was impossible for APC cores taken with steel core barrels and XCB cores because of severe magnetic overprint during coring.

\section{Physical properties}

Physical property measurements on whole-round sections and samples from split cores display a strong lithology-dependent variation at Site U1337 (Fig. F3). A complete physical property program was conducted on whole cores, split cores, and discrete samples. Whole-Round Multisensor Logger (WRMSL) (GRA bulk density, magnetic susceptibility, $P$-wave velocity, and electrical noncontact resistivity), thermal conductivity, and natural gamma radiation (NGR) measurements comprised the whole-core measurements. Compressional wave velocity measurements on split cores and moisture and density (MAD) analyses on discrete core samples were made at a frequency of 1 per undisturbed section in Cores 321-U1337A-1H through 48X. Compressional wave velocities were measured toward the bottom of sections. MAD analyses were located $10 \mathrm{~cm}$ downsection from carbonate analyses (see "Geochemistry"). Lastly, the Section Half Multisensor Logger (SHMSL) was used to measure spectral reflectance on archivehalf sections. Variations in the abundances of nannofossils, radiolarians, diatoms, and clay in lithologic Unit I account for high-amplitude, high-frequency variations of all physical properties. Intervals enriched in biogenic silica and clay generally display lower grain density and bulk density and higher porosity, magnetic susceptibility, and NGR. Velocity is generally directly related to bulk density; however, it is commonly higher in low-density siliceous-rich sediments than it is in more calcareous intervals. Wet bulk density is low in Unit I, ranging from 1.12 to $1.46 \mathrm{~g} / \mathrm{cm}^{3}$. Porosity is as high as $92 \%$ in this unit. Velocity also is low, averaging $1525 \mathrm{~m} / \mathrm{s}$. The natural gamma record, as at previous sites, is marked by an unusually high near-surface peak ( 65 counts per second [cps]). Magnetic susceptibility varies between $4 \times 10^{-5}$ and $18 \times 10^{-5} \mathrm{SI}$. The color of Unit I is characterized by the lowest $L^{*}$ and high and variable $a^{*}$ and $b^{*}$ values. Lithologic Unit II is characterized by a continued high variability in grain density. Together, the grain density in Units I and II averages $2.51 \mathrm{~g} /$ $\mathrm{cm}^{3}$ and ranges from 2.17 to $2.85 \mathrm{~g} / \mathrm{cm}^{3}$. All other physical properties display less variability in Unit II than in Unit I, reflecting a less variable lithology. Wet bulk density increases and porosity decreases with depth in Unit II; however, in Units II and III these trends are interrupted by low-density highporosity diatom- and radiolarian-rich intervals. Unit II is slightly lighter colored (lower $\mathrm{L}^{*}$ ) and distinctly more blue (lower $\mathrm{a}^{*}$ ) and green (lower $\mathrm{b}^{*}$ ) than Unit I. Unit III is characterized by more uniform physical properties that accompany the high and uniform carbonate composition of the unit. The nannofossil oozes and chalks of this unit are characterized by a uniform grain density that averages $2.67 \mathrm{~g} / \mathrm{cm}^{3}$. The bulk density and porosity trends of Unit II continue in Unit III. The transition from ooze to chalk is marked by a change in gradient of these properties to a more rapid decrease in wet bulk density and an increase in porosity with depth. Wet bulk density and porosity at the base of the sediment section are $1.95 \mathrm{~g} / \mathrm{cm}^{3}$ and $47 \%$, respectively. The increase in velocity with depth also changes to a higher gradient in Unit III, with values increasing from $1510 \mathrm{~m} / \mathrm{s}$ at $\sim 340 \mathrm{~m}$ CSF to $\sim 1800 \mathrm{~m} / \mathrm{s}$ near the base of the hole. Magnetic susceptibility and NGR values remain low in Unit III but do vary in response to small changes in lithology. The sharp color change from greenish gray to pale yellow at $\sim 410 \mathrm{~m}$ CSF is marked by a sharp increase in $a^{*}$ and $b^{*}$. The change in color to pale brown chalk immediately above basement is marked by an increase in both $\mathrm{a}^{*}$ and $\mathrm{b}^{*}$ and $\mathrm{a}$ decrease in $L^{*}$.

\section{Downhole logging}

Three downhole logging tool strings were deployed in Hole U1337A. Two tool strings took measurements of NGR radioactivity, bulk density, electrical resistivity, elastic wave velocity, and borehole resistivity images in the 77-442 $\mathrm{m}$ wireline log depth below seafloor (WSF) depth interval. The third tool string measured seismic waveforms in a vertical seismic profile (VSP) experiment in the 214-439 m WSF depth interval. Measurement depths were adjusted to match across different logging runs, obtaining a wireline log matched depth below seafloor (WMSF) depth scale. The downhole log measurements were used to define three logging units. Unit 1 (77-212 m WMSF) and Unit 2 (212-339 $\mathrm{m}$ WMSF) have average densities of $\sim 1.3$ and $\sim 1.6 \mathrm{~g} / \mathrm{cm}^{3}$, respectively, that do not show any trend with depth, whereas Unit III (339-442 m WMSF) density increases with depth, reaching $1.85 \mathrm{~g} / \mathrm{cm}^{3}$ at the base of the hole (Fig. F4). Resistivity and $P$-wave velocity follow a pattern similar to that of density, suggesting that the major 
control on these physical properties are variations in sediment porosity. NGR measurements are low throughout the logged interval ( 5 gAPI), except for two pronounced peaks caused by uranium, one at the seafloor and the other at $240 \mathrm{~m}$ WMSF. The gamma ray peak at $240 \mathrm{~m}$ WMSF corresponds to the $\sim 40 \mathrm{~cm}$ thick pocellanite layer that has only been recovered as rubble in the cores but can be clearly identified in the downhole logs and borehole images as an interval of high density and resistivity. VSP logging measured arrival time of the seismic pulse from the sea surface at 16 stations. Together with the traveltime to the seafloor, VSP measurements are the basis for a traveltime-depth conversion that allows seismic reflectors to be correlated to stratigraphic events. Downhole temperature measurements and thermal conductivities of core samples were combined to estimate a geothermal gradient of $32.4^{\circ} \mathrm{C} / \mathrm{km}$ and a heat flow of $28.4 \mathrm{~mW} / \mathrm{m}^{2}$ at Site U1337.

\section{Geochemistry}

A total of 85 interstitial water samples were collected from Hole U1337A, 49 using the whole-round squeezing approach across the entire hole and 36 in the upper $100 \mathrm{~m}$ by Rhizon sampling. Alkalinity increases slightly downhole from $\sim 2.7 \mathrm{mM}$ in the upper $100 \mathrm{~m}$ to values scattered around $3.8 \mathrm{mM}$ below $300 \mathrm{~m}$ CSF. Sulfate concentrations vary between 26 and $29 \mathrm{mM}$, with slightly decreasing values with depth. A dissolved manganese peak of $\sim 150 \mu \mathrm{M}$ at $13 \mathrm{~m} \mathrm{CSF}$ is captured by the high-resolution interstitial water sampling. Dissolved iron is sporadically detectable in the upper $200 \mathrm{~m}$ and then increases to a peak of $\sim 5 \mu \mathrm{M}$ between 275 and $300 \mathrm{~m}$ CSF before becoming undetectable again below $400 \mathrm{~m}$ CSF. These variations in manganese and iron reflect changes in redox chemistry that also manifest as changes in sediment color. Calcium carbonate and inorganic carbon concentrations were determined on 283 and 28 sediment samples from Holes U1337A and U1337B, respectively. Calcium carbonate contents vary greatly in the upper two lithologic units, ranging from 30 to $90 \mathrm{wt} \%$ (Fig. F3). In lithologic Unit III calcium carbonate contents are generally high, scattered around $80 \mathrm{wt} \%$, but a distinctive decrease is observed between 350 and $400 \mathrm{~m}$ CCSF-A. In the upper $235 \mathrm{~m}$ CCSF-A, total organic carbon (TOC) content ranges between 0.10 and $0.34 \mathrm{wt} \%$ except for the high value of $0.72 \mathrm{wt} \%$ in the uppermost sample. TOC content increases at $44.00 \mathrm{~m}$ CCSF-A and in the interval from 87.28 to $108.59 \mathrm{~m}$ CCSF-A. Below 235 m CCSF-A, TOC values are generally $<0.10 \mathrm{wt} \%$.

Shipboard geochemical analyses of interstitial water and bulk sediment samples reflect large variations in sediment composition resulting from shifts in carbonate versus opal production. The large-scale redox state and diagenetic processes of the sediment column are related to overall changes in sediment composition. Interstitial water chemistry is also influenced by the porcellanite layer forming a barrier to diffusion at $\sim 240 \mathrm{~m}$ CSF and by seawater circulation in the basement. The basement itself appears to exert little influence on the geochemistry of sediments and interstitial waters.

\section{Diatom mat deposition}

Lithologic Unit II at Site U1337 is mostly composed of biosiliceous lithologies, notably diatoms. The abundance of diatoms in the middle and upper Miocene section at Site U1337 is much higher than encountered in any interval at Sites U1331-U1336. Several decimeter- to meter-scale intervals of diatom ooze are laminated, and smear slide analyses indicate that the diatom assemblage is composed primarily of pennate taxa, with abundant "needlelike" Thalassiothrix spp., indicating diatom mat deposition. The lowermost laminated diatom mat is in the upper portion of Unit III at $15 \mathrm{Ma}$. Much thicker intervals are present in Unit II at roughly $10 \mathrm{Ma}$ and shorter intervals at $\sim 4.5 \mathrm{Ma}$. Ages of laminated diatom mats at this site are similar to those found at Ocean Drilling Program (ODP) Leg 138 sites farther to the east (Mayer, Pisias, Janecek, et al., 1992), which have been interpreted to reflect regional bursts of silica export in the eastern equatorial Pacific (Kemp and Baldauf, 1993). No laminated diatom oozes were recorded during Expedition 320 at drill sites farther to the northwest.

\section{Oligocene-Miocene transition}

The Oligocene/Miocene boundary was recovered in Holes U1337A, U1337C, and U1337D. In Hole U1337A, the Oligocene/Miocene boundary is estimated to fall between Samples 321-U1337A-48X2, 85-87 cm, and 48X-3, $55 \mathrm{~cm}(445.56-446.75 \mathrm{~m}$ CSF; 490.92-492.11 CCSF-A). It occurs in white (2.5Y 8/1) nannofossil chalk with foraminifers, interbedded and heavily mottled with pale yellow (2.5Y 7/4) to very pale brown (10YR 7/4) nannofossil chalk. Abundant millimeter-scale dendritic manganese oxide grains occur throughout this interval. The lower $15 \mathrm{~cm}$ of the core catcher of Core 321-U1337A-48X is basaltic basement. No prominent change in lithology, GRA bulk density, reflectance, or magnetic susceptibility is seen through the Oligocene-Miocene transition. 


\section{Neogene carbonate dissolution}

The CCD of the Neogene is much more stable than that of the Eocene, but there are intervals of lower carbonate deposition at Site U1337 that probably represent significant changes of the Neogene CCD. In the early Miocene, a significant carbonate low reaches its minimum at $\sim 17 \mathrm{Ma}$ (340 m CSF in Hole U1337A), when the site was at a depth of $~ 3500$ meters below sea level. This early Miocene interval marks a significant carbonate minimum at Site U1334 as well, on crust with a depth of $\sim 4000 \mathrm{~m}$ at that time. Highly variable carbonate is also characteristic of the late/middle Miocene boundary interval, but the role of carbonate dissolution versus elevated deposition of biosilica needs to be determined.

\section{Operations \\ Honolulu port call}

Expedition 321 officially began at $0736 \mathrm{~h}$ (Hawaii Standard Time; Universal Time Coordinated [UTC] 10 h) on 4 May 2009, with the first line ashore Pier 2B in Honolulu, Hawaii (USA). The JOIDES Resolution arrived a full day early, having been scheduled in at $0700 \mathrm{~h} 5$ May. The early arrival added a bonus day to a schedule that already was planned as a 4 day port call.

The ship arrived with two propulsion motors out of service, requiring field coil replacement. This was the first priority activity upon arrival. The first day also included offloading all refrigerated core sections and replacement of the logging winch transmission. During port call, vendor representatives were aboard to replace the elevator mechanical interlocks with a solenoid-actuated variety, balance the heating/ ventilation/air conditioning system, and repair and calibrate the Rigwatch rig instrumentation system (RIS). Normal on- and offloading activities took place, including loading of 10 short tons of attapulgite drilling mud left over from the Expedition 320 Honolulu port call, and 1537 metric tons of marine gas oil were bunkered. Training was conducted on the Rigwatch RIS and on operation of the Schlumberger logging line winch and wireline heave compensator (WHC) systems. Other activities included a Det Norske Veritas International Safety Management audit of the ship and the arrival of Center for Deep Earth Exploration engineers to discuss the JOIDES Resolution's core winch regenerative braking system and coring tools.

Public relations activities were conducted dockside at the Pier 2B cruise ship terminal, the Waikiki Aquarium, and the Marriott Hotel Waikiki. Several highlevel dignitaries and other management personnel, including the directors of the National Science Foundation, Ocean Leadership, the University of Hawaii, and Texas A\&M University, were in attendance. Ship tours were conducted for dignitaries as well as University of Hawaii faculty and students and high school students and teachers.

The ship departed Honolulu with the last line away from Pier $2 \mathrm{~B}$ at $0512 \mathrm{~h}$ on 9 May. At $\sim 10 \mathrm{nmi}$ offshore the ship switched from cruise mode to dynamic positioning (DP) control and lowered thrusters. DP trials were conducted for $7.75 \mathrm{~h}$ to optimize system performance after changes in the ship profile were made during the Singapore refit. During this period a representative from L3, the Nautronics parent company, collected data and made adjustments to the internal windage modeling program that impacts the anticipatory commands of the system. The vendor was transferred from the JOIDES Resolution to the V/L Karake at the Honolulu Harbor outer sea buoy. At $1636 \mathrm{~h}$ the vessel got under way for Site U1336.

\section{Transit to Sites U1336 and U1337}

The transit to Site U1336 (proposed Site PEAT-5C) began at $1636 \mathrm{~h}$ on 9 May 2009. Transit speeds varied considerably as a result of fluctuating currents and eddies surrounding the Hawaiian Islands with average transit speeds from 9.9 to $10.7 \mathrm{kt}$ with 135 turns on both shafts. One propulsion motor remained offline as field coil replacement continued. On the morning of 11 May, after several days of discussions with the science team, the decision was made to divert our course from Site U1336 to Site U1337 (proposed Site PEAT-7C). The decision was driven by several issues including (1) slower than anticipated transit speeds, (2) time spent conducting automated stationkeeping sea trials took longer than planned, (3) addition of VSI to the suite of wireline logging tools to be deployed at Site U1337, (4) depth to basement projections deepened by $50 \mathrm{~m}$ because of results from Expedition 320, and (5) scientific tradeoffs in general between additional operations at Site U1336 versus conducting a more complete program at Site U1338. During the transit, routine readiness inspections were conducted by the drill crew on all of the drilling equipment. During the inspection it was discovered that the passive heave compensator rod seals were burned up and required replacement. The clocks advanced by $3 \mathrm{~h}$ during transit $(1 \mathrm{~h}$ increments on 13, 16, and 17 May). From here onward, times are local ship time, which was U.S. Pacific Daylight Savings Time (UTC - 7 h). The ship arrived on location the morning of 19 May. The total $2320 \mathrm{nmi}$ transit was accomplished in 9.8 days at an average speed of $10.0 \mathrm{kt}$. 


\section{Site U1337}

Although the Global Positioning System (GPS) was the primary positioning reference used for this site, a new-generation acoustic beacon was also deployed at $1250 \mathrm{~h}$ on 19 May 2009. The automated stationkeeping system can be configured to accept position inputs from both the GPS and the seafloor acoustic beacon. Both inputs were used for Expedition 321.

Four holes were drilled at this site using the APC/ XCB coring systems (Table T1). One hole (U1337B) was terminated early when the XCB core barrel became stuck in the bit seal. This necessitated the drilling of the fourth hole. The cause of the stuck barrel was later identified as an APC shear pin stub. The first hole was successfully wireline logged using the triple combo, VSI, and FMS-sonic tool strings. Overall recovery for Site U1337, using both APC and XCB coring systems, was $96.0 \%$. The basement contact was recovered in three of the four holes drilled at the site.

\section{Hole U1337A}

Rig floor operations commenced at $1200 \mathrm{~h}$ after the ship was stationary over the location coordinates. The pipe trip to the seafloor was slow because of the need for measuring (strapping) and drifting (internal diameter verification) of all tubulars and the picking up of the drill collars from the main deck storage rack. At $0300 \mathrm{~h}$ on 20 May, the top drive was picked up; however, the tilt/counterbalance feature was not functional. Troubleshooting and repairing the top drive took $4 \mathrm{~h}$ before spacing out the drill string and deploying the first APC core barrel. With the bit positioned at $4467.0 \mathrm{~m}$ drilling depth below rig floor (DRF) the first APC barrel was pressured up and fired. Upon recovery, the leading edge of the APC cutting shoe was found severely damaged and the core barrel was empty. To confirm the approximate seafloor depth the drill string was lowered and the mudline was "tagged" twice at about the same depth of $4472.0 \mathrm{~m}$ DRF. This depth was taken as the official seafloor depth for the hole, the bit was repositioned $1.0 \mathrm{~m}$ lower at $4468.0 \mathrm{~m}$ DRF, and Hole U1337A was spudded at $1115 \mathrm{~h}$. Core $1 \mathrm{H}$ recovered $0.19 \mathrm{~m}$ (Table T1) of core, and once again the APC cutting shoe showed signs of having impacted something very hard. APC coring continued normally from there, however, and was suspended at $195.5 \mathrm{~m}$ DSF because of a 90,000 lb overpull. Nonmagnetic core barrels were used for all cores except Core $21 \mathrm{H}$. A 60,000 lb overpull for Core $20 \mathrm{H}$ led to a return to steel core barrels. Average core recovery for the APC was 102\%. FlexIt core orientation was conducted for all cores except Core $1 \mathrm{H}$ with apparent good success. In addition, five successful APCT-3 measurements were taken with Cores $5 \mathrm{H}, 7 \mathrm{H}, 9 \mathrm{H}, 11 \mathrm{H}$, and $13 \mathrm{H}$ at 43.5 , $62.5,81.5,100.5$, and $119.5 \mathrm{~m}$ DSF, respectively. Only one core liner split (Core $8 \mathrm{H})$, coincidently the first barrel shot with all three speed control holes open. XCB coring continued with Cores 22X through $48 \mathrm{X}$, achieving an average recovery of $87 \%$. Two split core liners occurred during XCB coring (Cores $37 \mathrm{X}$ and $38 \mathrm{X}$ ). There was nothing significant noted in the coring parameters for these two cores other than the fact that Core 38X achieved only 53\% recovery compared to Core $37 \mathrm{X}$, which had 101\% recovery. The sediment/basement contact was recovered at the base of Core 48X. Total depth of Hole U1337A was $4921.8 \mathrm{~m}$ DRF (449.8 m DSF). Overall recovery for the hole using both APC and XCB coring systems was 93\%. Rig-up for wireline logging began at $1130 \mathrm{~h}$ on 23 May. Logging was successfully concluded and all logging equipment was rigged down by $0900 \mathrm{~h}$ on 25 May. Three logging strings were deployed. The triple combo reached total hole depth of $449.8 \mathrm{~m}$ DSF and obtained good-quality logs. The second logging string consisted of the VSI. This tool also reached total hole depth, and shooting stations were conducted at $\sim 15 \mathrm{~m}$ intervals. VSI logging was conducted during daylight hours to conform with established IODP mammal watch protocols, including a preshooting mammal watch and soft start procedures for the air guns. The third logging string (FMS-sonic) reached a depth of $440.0 \mathrm{~m}$ DSF ( $<10 \mathrm{~m}$ off bottom). With the end of pipe positioned at $82.6 \mathrm{~m} \mathrm{DSF}$, there were no reported issues with logging tools reentering the pipe. The drill string was pulled back until the bit cleared the seafloor at $0930 \mathrm{~h}$ on $25 \mathrm{May}$, ending operations in Hole U1337A.

\section{Hole U1337B}

The ship was offset $20 \mathrm{~m}$ west of Hole U1337A, and the bit was positioned at a depth of $4473.0 \mathrm{~m}$ DRF. This was to offset the core breaks between the two holes, maximizing the chances to recover a complete section. The seafloor "tag" depth of $4472.0 \mathrm{~m}$ DRF for Hole U1337A was used for Hole U1337B. APC coring continued through Core $27 \mathrm{H}$ to $245.2 \mathrm{~m}$ DSF. The FlexIt core orientation system was deployed successfully for all but two APC cores $(17 \mathrm{H}$ and $18 \mathrm{H})$. Nonmagnetic core barrels were used through Core $20 \mathrm{H}$ and successful APCT-3 measurements were obtained with Cores $15 \mathrm{H}, 17 \mathrm{H}$, and $19 \mathrm{H}$ at 143.5 , 162.5 , and $181.5 \mathrm{~m}$ DSF, respectively. Overpull for the APC ranged from 20,000 to 90,000 lb and all but five barrels (Cores $21 \mathrm{H}, 23 \mathrm{H}$ through $25 \mathrm{H}$, and $27 \mathrm{H}$ ) achieved full stroke. Two cores $(16 \mathrm{H}$ and $22 \mathrm{H})$ were recovered with split liners. The first split occurred after recovery with the sectioned cores in the rack. The 
latter split occurred in the core barrel prior to extraction. Average core recovery for the APC was $99 \%$. Coring continued with a single $\mathrm{XCB}$ core $(28 \mathrm{X})$ to 251.9 m DSF; however, this barrel could not be recovered, forcing Hole U1337B to be abandoned prematurely. The drill string was recovered and further analysis indicated that a shear pin stub from an earlier piston core had caused the XCB core barrel to jam in the bit seal assembly; the core barrel was empty. Operations in Hole U1337B officially ended at $2245 \mathrm{~h}$ on 27 May. Total depth achieved was 4723.9 m DRF (251.9 m DSF). Overall recovery for the hole using both APC and XCB coring systems was $97 \%$. The single XCB core (28X) recovered nothing.

\section{Hole U1337C}

The ship was offset $20 \mathrm{~m}$ west from Hole U1337B, and the drill string was tripped to the seafloor. Hole U1337C was spudded with the bit positioned at 4471.0 m DRF. Recovery from APC Core $1 \mathrm{H}$ established a seafloor depth of $4478.6 \mathrm{~m}$ DRF. Core $2 \mathrm{H} \mathrm{ex}-$ tended the hole to $11.4 \mathrm{~m}$ DSF using nonmagnetic core barrels and the FlexIt core orientation system. A wash barrel was deployed, and the hole was washed to a depth of $169.4 \mathrm{~m}$ DSF. APC coring resumed at that depth and continued through Core $9 \mathrm{H}$ to $221.3 \mathrm{~m}$ DSF. Steel core barrels were used at this point because of high overpull $>70,000 \mathrm{lb}$. Full stroke was achieved with all cores except Core $6 \mathrm{H}$, which was advanced by recovery. Average core recovery for the APC was 103\%. Coring with the XCB system continued with Cores $10 \mathrm{X}$ through $33 \mathrm{X}$, recovering $95 \%$ of the section. Total depth of the hole was $4918.9 \mathrm{~m}$ DRF (440.3 m DSF), and overall recovery, using both APC and XCB coring systems, was $97 \%$. The drill string was pulled clear of the seafloor at $1400 \mathrm{~h}$ on 30 May, officially ending operations in Hole U1337C.

\section{Hole U1337D}

The plan for this hole was to duplicate recovery through those sections of the formation already recovered to provide additional sample material. In addition, the goal was to use a more focused coring approach to target once again the few remaining areas that had yet to be fully recovered. The most troublesome material was the large intervals of diatom mats and a porcellanite ("baby chert") layer. Hole U1338D was spudded at 1645 h on 30 May. Recovery of APC Core $1 \mathrm{H}$ placed the seafloor depth at $4476.5 \mathrm{~m}$ DRF. APC coring continued through Core $26 \mathrm{H}$ to $237.7 \mathrm{~m}$ DSF. Nonmagnetic core barrels were used through Core $20 \mathrm{H}$, and Core $21 \mathrm{H}$ was shot with the bit $4.5 \mathrm{~m}$ off bottom to set up the first target area of interest. The first XCB core (27X) was designed to only core through the hard $\sim 0.5 \mathrm{~m}$ thick porcellanite (baby chert) layer but not into the material below. The APC was once again deployed, and Cores $28 \mathrm{H}$ through $30 \mathrm{H}$ were cut to $267.0 \mathrm{~m}$ DSF. At this point the XCB coring system was once again deployed for Cores 31X through 49X to a total depth of $442.9 \mathrm{~m}$ DSF. The FlexIt core orientation system was deployed successfully with all APC cores, and all barrels were fully stroked except for Core $22 \mathrm{H}$. Total recovery for the APC in this hole was $103 \%$, and recovery with the XCB coring system was $90 \%$. Total recovery for the hole was $98 \%$. A much higher incidence of imploded or split liners plagued this hole, and we were unable to identify the reason. The drill string was recovered, the bottom-hole assembly was racked back in the derrick, and the rig floor was secured for transit. Once the bit cleared the seafloor the positioning beacon was recovered and thrusters and hydrophones were raised. At $1625 \mathrm{~h}$ on 2 June, control was switched from DP to cruise mode and the ship got underway for the next site.

\section{Lithostratigraphy}

Drilling at Site U1337 recovered a $\sim 450 \mathrm{~m}$ thick section of pelagic sediments overlying seafloor basalt (Fig. F5). The sedimentary sequence is divided into three major lithologic units (Fig. F5; Table T2). The upper part of the sedimentary sequence (Unit I; $\sim 90 \mathrm{CSF}$ ) is characterized by an alternating sequence of multicolored (including various hues of brown, gray, and green) nannofossil, diatom, and radiolarian oozes of latest Miocene to Pleistocene age. Unit II ( $125 \mathrm{~m} \mathrm{CSF})$ consists of gray and green biosiliceous (diatom and radiolarian) ooze with varying amounts of nannofossils. Unit III ( 230 m CSF) predominantly consists of white, yellow, green, brown, and gray nannofossil ooze and chalk of late Oligocene to early late Miocene age, with generally low but sometimes common abundances of siliceous microfossils. Unit IV is composed of aphanitic basalt of late Oligocene age.

Lithologic units and boundaries are defined by changes in lithology, physical properties, color reflectance, and calcium carbonate $\left(\mathrm{CaCO}_{3}\right)$ content. Lithologic differences, based on both visual core description and smear slide observations, are primarily attributable to varying distributions of biogenic components (nannofossils, diatoms, radiolarians, and foraminifers) (Fig. F6; see "Site U1337 smear slides" in "Core descriptions"). Lithologic descriptions are based primarily on sediments recovered in Hole U1337A and supplemented with observations from Holes U1337B, U1337C, and U1337D. 
See "Corrected core composite depth scale" in the "Methods" chapter for an explanation of the CCSF-B depth scale.

\section{Unit I}

Intervals: 321-U1337 A-1H-1, $0 \mathrm{~cm}$, through $11 \mathrm{H}-2$, $85 \mathrm{~cm}$; 321-U1337B-1H-1, $0 \mathrm{~cm}$, through $10 \mathrm{H}-5$, $56 \mathrm{~cm} ; 321-\mathrm{U} 1337 \mathrm{C}-1 \mathrm{H}-1,0 \mathrm{~cm}$, through at least $2 \mathrm{H}-\mathrm{CC}, 19 \mathrm{~cm}$; 321-U1337D-1H-1, $0 \mathrm{~cm}$, through $10 \mathrm{H}-4,106 \mathrm{~cm}$

Depths: Hole U1337A = 0-93.35 m CSF $(0-100.67$ $\mathrm{m}$ CCSF-A; 0-89.89 m CCSF-B); Hole U1337B = 0-93.06 m CSF (0-100.12 m CCSF-A; 0-89.40 m CCSF-B); Hole U1337C $=0$ to at least $11.59 \mathrm{~m}$ CSF ( 0 to at least $12.64 \mathrm{~m} \mathrm{CCSF-A;} 0$ to at least $11.29 \mathrm{~m}$ CCSF-B); Hole U1337D = 0-89.56 m CSF (0-100.49 m CCSF-A; 0-89.73 m CCSF-B)

Age: Pleistocene to latest Miocene

Lithology: nannofossil ooze, diatom nannofossil ooze, radiolarian nannofossil ooze, calcareous ooze, diatom calcareous ooze, diatom ooze, calcareous diatom ooze, radiolarian diatom ooze, nannofossil diatom ooze, and diatom radiolarian ooze

The major lithologies in Unit I are nannofossil ooze, diatom nannofossil ooze, radiolarian nannofossil ooze, calcareous ooze, diatom calcareous ooze, diatom ooze, calcareous diatom ooze, radiolarian diatom ooze, nannofossil diatom ooze, and diatom radiolarian ooze (Figs. F7, F8). Calcite grains are generally $<5 \mu \mathrm{m}$ and are most abundant in the top $20 \mathrm{~m}$. In Unit I they represent fragments of potentially reworked calcareous fossils, but below $300 \mathrm{~m}$, calcite grains are dominantly needlelike in shape, suggesting a diagenetic origin. Downsection the abundance of siliceous microfossils increases relative to nannofossils, which is consistent with a decreasing trend in $\mathrm{CaCO}_{3}$ weight percent.

Visual core descriptions and smear slide observations indicate that Unit I generally exhibits meter-scale cyclic alternations in color and lithology. Lighter colored sediments, such as white $(2.5 \mathrm{Y} 8 / 1)$, very pale hues of brown (e.g., 10YR 7/3), yellow (e.g., $5 \mathrm{Y}$ $8 / 3$ ), and light greenish gray (e.g., $10 \mathrm{Y} 8 / 1$ ), are richer in nannofossils. Darker colored sediments, such as slightly darker hues of brown (e.g., $2.5 \mathrm{Y} 3 / 3$ and 10YR 6/4 to 10YR 3/3) and gray (e.g., 5Y 6/1 and $5 Y$ 5/2), contain more siliceous microfossils, notably radiolarians (Fig. F7). Alternations in lithology covary with physical properties, including magnetic susceptibility and $b^{*}$ reflectance, as well as $\mathrm{CaCO}_{3}$ weight percent (Fig. F5). Magnetic susceptibility and $b^{*}$ reflectance show higher amplitude variability than in underlying units. Sediments are intensely bioturbated and mottled.
The transition to Unit II (Fig. F9) is defined by the last downcore occurrence of brown (e.g., 10YR 7/4, 10YR $8 / 2$, and $2.5 \mathrm{Y} 6 / 3$ ) sediments and the base of the interval of highly variable magnetic susceptibility and $b^{*}$ reflectance values.

\section{Unit II}

Intervals: $321-\mathrm{U} 1337 \mathrm{~A}-11 \mathrm{H}-2,85 \mathrm{~cm}$, through $24 \mathrm{X}-4,27 \mathrm{~cm}$; 321-U1337B-10H-5, $56 \mathrm{~cm}$, through $23 \mathrm{H}-4,4 \mathrm{~cm} ; 321-\mathrm{U} 1337 \mathrm{C}-4 \mathrm{H}-1,0 \mathrm{~cm}$, through $8 \mathrm{H}-7,55 \mathrm{~cm}$ (top of unit not recovered in Hole U1337C); 321-U1337D-10H-4, $106 \mathrm{~cm}$, through $24 \mathrm{H}$ (shattered liner)

Depth: Hole U1337A $=93.35-218.27 \mathrm{~m} \mathrm{CSF}$ (100.67-238.81 m CCSF-A; 89.89-213.23 m CCSF-B); Hole U1337B = 93.06-214.54 m CSF (100.12-238.83 m CCSF-A; 89.40-213.24 m CCSF-B); Hole U1337C = at least 192.65-211.85 $\mathrm{m}$ CSF (at least 192.96-237.65 m CCSF-A; at least 160.80-212.19 m CCSF-B); Hole U1337D = 89.56 to $\sim 216 \mathrm{~m} \mathrm{CSF}$ (100.49 to $\sim 243.25 \mathrm{~m}$ CCSF-A; 89.73 to $\sim 217.19$ m CCSF-B)

Age: latest Miocene to middle Miocene

Lithology: diatom ooze, radiolarian diatom ooze, nannofossil diatom ooze, radiolarian nannofossil diatom ooze, diatom radiolarian ooze, diatom nannofossil radiolarian ooze, nannofossil radiolarian diatom ooze, nannofossil ooze, diatom nannofossil ooze, and radiolarian nannofossil ooze

The major lithologies in Unit II are nannofossil ooze, diatom nannofossil ooze, radiolarian nannofossil ooze, diatom ooze, radiolarian diatom ooze, nannofossil diatom ooze, radiolarian nannofossil diatom ooze, diatom radiolarian ooze, diatom nannofossil radiolarian ooze, and nannofossil radiolarian diatom ooze (Figs. F7, F8). Even though nannofossils sometimes comprise the major sedimentary components, sediments in Unit II are generally composed of siliceous microfossils (i.e., diatoms and radiolarians with common silicoflagellates) (Figs. F5, F6). Unit II exhibits meterscale cyclic alternations in color and lithology.

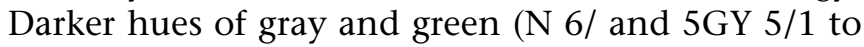
7.5Y 5/1) contain high abundances of siliceous microfossils (Fig. F7). Lighter colored intervals, such as white $(\mathrm{N} 8 /)$, pale yellow $(2.5 \mathrm{Y} 8 / 2$ to $2.5 \mathrm{Y} 7 / 3)$ and light greenish gray (5G $4 / 1$ to $10 \mathrm{Y} 7 / 1$ ), are richer in nannofossils. In fact, the entire unit is characterized by the occasional occurrence of 30$150 \mathrm{~cm}$ laminated diatom ooze that likely reflects diatom mat deposition, interbedded with nannofossil diatom ooze (Fig. F10). Both lithologies are overprinted with millimeter- and centimeterscale color banding with gray ( $\mathrm{N} 5 /$ to $\mathrm{N} \mathrm{6/)}$ ) and 
greenish gray (5G 4/1). Dolomite concretions (centimeter sized) commonly occur throughout Unit II. Laminated diatom ooze intervals contain abundant specimens of the diatom Thalassiothrix spp. and intercalate with very thin (millimeter scale) porcellanite layers (Fig. F10). Layers (millimeter and centimeter scale) and concretions of dolomite occur regularly throughout Unit II.

Magnetic susceptibility and $b^{*}$ color reflectance are extremely low in Unit II, except for an interval between $\sim 170$ and $190 \mathrm{~m}$ CSF (Hole U1337A). L* reflectance and $\mathrm{CaCO}_{3}$ content are highly variable throughout the unit (Fig. F5), reflecting decimeterto meter-scale alternations between nannofossil diatom ooze and diatom ooze. Note that the frequency of these alternations is higher than the shipboard $\mathrm{CaCO}_{3}$ sampling resolution in most of Unit II. Bioturbation is intense except in the laminated diatom mats.

The transition to Unit III is defined as the base of the interval in which siliceous microfossils are the dominant sedimentary component and coincides with a significant downhole increase in GRA density (Fig. F11) and a general increase in $\mathrm{CaCO}_{3}$ content (Fig. F5).

\section{Unit III}

Intervals: 321-U1337A-24X-4, $27 \mathrm{~cm}$, through 48X-CC, $21 \mathrm{~cm}$; 321-U1337B-23H-4, $4 \mathrm{~cm}$, through at least $27 \mathrm{H}-\mathrm{CC}, 25 \mathrm{~cm}$ (base of hole); $321-\mathrm{U} 1337 \mathrm{C}-8 \mathrm{H}-7,55 \mathrm{~cm}$, through $33 \mathrm{X}-4,1 \mathrm{~cm}$; 321-U1337D-24H (shattered liner) through 49X-3, $0 \mathrm{~cm}$

Depths: Hole U1337A = 218.27-448.04 m CSF (238.81-493.40 m CCSF-A; 213.23-440.53 m CCSF-B); Hole U1337B = 214.54-245.19 m CSF (238.83-268.52 m CCSF-A; 213.24-239.75 m CCSF-B); Hole U1337C $=211.85-439.77 \mathrm{~m} \mathrm{CSF}$ (237.65-494.47 m CCSF-A; 212.19- $441.49 \mathrm{~m}$ CCSF-B); Hole U1337D $=\sim 216-441.32 \mathrm{~m} \mathrm{CSF}$ ( 243-494.51 CCSF-A; 217-441.53 m CCSF-B)

Age: middle Miocene to latest Oligocene Lithology: nannofossil ooze, nannofossil chalk, diatom nannofossil ooze, radiolarian nannofossil chalk, diatom ooze, nannofossil diatom ooze, and nannofossil radiolarian ooze

The major lithologies in Unit III are nannofossil ooze, nannofossil chalk, diatom nannofossil ooze, radiolarian nannofossil chalk, diatom ooze, nannofossil diatom ooze, and nannofossil radiolarian ooze (Figs. F7, F8). Meter-scale lithologic alternations co-occur with color variations throughout the section: nannofossil oozes are white $(\mathrm{N} 8 /$ ) or light greenish gray (10G 7/1 and 10GY 8/1), whereas increased abundances of siliceous microfossils are generally slightly darker, with light greenish gray (10Y $8 / 1$ to $5 \mathrm{G} 6 / 1$ ) and sometimes light bluish gray (5PB 8/1) ooze (Fig. F6). Drilling breccia of chert and porcellanite was recovered in the lower part of Core 321-U1337C-11X (238.79238.91 m CSF; 267.65-267.77 m CCSF-A) and in Sections 321-U1337D-28H-1 and 28H-2 (242.63$243.37 \mathrm{~m}$ CSF; 270.14-270.88 m CCSF-A). This represents a chert layer, which may act as a barrier to flow of pore waters (see "Geochemistry"). The thickness of the chert layer is unclear from the cores because of poor recovery, but downhole logging indicates it is $\sim 40 \mathrm{~cm}$ (see "Downhole measurements"). The chert layer hampered core recovery across this interval in all holes, but correlation between density data from downhole logging and the cores indicates a gap in the composite section $<1 \mathrm{~m}$.

The transition from ooze to chalk occurs between Cores 321-U1337A-35X and 36X at $318 \mathrm{~m}$ CSF (and at equivalent depths at the other Site U1337 holes). Color banding of millimeter- to centimeter-scale is common in Unit III with light greenish gray (10Y 8/ $1)$, greenish gray $(5 G 6 / 1)$, grayish green $(5 G 4 / 2)$, and darker hues of gray ( $\mathrm{N} 4 /$ and $\mathrm{N} \mathrm{5/)}$. A $\sim 10 \mathrm{~m}$ thick interval around $340 \mathrm{~m}$ CSF (late early Miocene) is characterized by increased magnetic susceptibility; decreased L*, GRA density, and $\mathrm{CaCO}_{3}$ content; and the absence of planktonic foraminifers, suggesting carbonate dissolution. A sharp downcore transition from pale green to pale yellow sediments occurs at $412.36 \mathrm{~m}$ CSF in Hole U1337A (interval 321U1337A-44X-5, $146 \mathrm{~cm}$ ), at $396.56 \mathrm{~m}$ CSF in Hole U1337C (interval 321-U1337C-28X-2, $146 \mathrm{~cm}$ ), and at $396.25 \mathrm{~m}$ CSF in Hole U1337D (interval 321U1337D-44X-3, $106 \mathrm{~cm}$ ), below which nannofossil chalks are predominantly pale yellow (5Y 8/2) (Fig. F12). Lithologic accessories include regular millimeter-scale pumice, pyrite and manganese oxide grains (the latter are particularly abundant in the lower part of Unit III), porcellanite, and one vitric volcanic ash in Core 321-U1337A-34X. Bioturbation is intense throughout Unit III. The transition to Unit IV is defined at the base of the sediment column, overlying basement basalt.

\section{Unit IV}

Intervals: 321-U1337A-48X-CC, $21 \mathrm{~cm}$, through 48X-CC, $36 \mathrm{~cm}$; 321-U1337C-33X-4, $1 \mathrm{~cm}$, through 33X-4, $46 \mathrm{~cm}$; 321-U1337D-49X-3, 0 $\mathrm{cm}$, through $49 \mathrm{X}-3,32 \mathrm{~cm}$

Depths: Hole U1337A = 448.04-448.42 m CSF (493.40-493.78 m CCSF-A; 440.53-440.88 m CCSF-B); Hole U1337C $=439.77-440.23$ m CSF 
(494.47-494.93 m CCSF-A; 441.49-441.90 m CCSF-B); Hole U1337D = 441.32-441.64 m CSF (494.51-494.83 m CCSF-A; 441.53-441.81 m CCSF-B)

Age: latest Oligocene

Lithology: aphanitic basalt

Aphanitic basalt with calcite veins was recovered at the base of Holes U1337A, U1337C, and U1337D, indicating penetration into basement. The early-stage veins are cemented with microcrystalline white $(\mathrm{N} 8 /)$ calcite. Along the surface of partially open fractures are $2-3 \mathrm{~mm}$ euhedral crystals of bluish gray calcite. Unit III nannofossil chalks overlie the basalt.

\section{Discussion}

\section{Color changes, lithology, and redox state}

Smear slide analyses and visual core descriptions show that many of the meter-scale color variations in Units I and II to some extent relate to changes in lithology (Fig. F7). We suspect, however, that many of the color variations on centimeter to meter scale, notably the transitions between pale yellow and green lithologies, are controlled by sediment redox state, similar to those recorded at Sites U1331-U1336 and earlier work in the equatorial Pacific (e.g., cf. Lyle, 1983).

Magnetic susceptibility is relatively low in the light greenish gray intervals in Unit I and for all of Unit II. A significant decrease in the intensity of the magnetic signal in Unit II suggests dissolution of magnetite (see "Paleomagnetism") resulting from intensified microbial iron reduction. In the lower part of Unit III ( 410 $\mathrm{m} \mathrm{CSF})$ a sharp downcore transition from green to yellow is not associated with any lithologic change (Fig. F12). Although pore water iron concentrations reach 5-6 $\mu \mathrm{M}$ in the green interval, it is absent below the transition to yellow. Although some of this signal may be affected by seawater contamination during XCB drilling, all available information suggests that the lowermost color change represents a redox front.

\section{Diatom mat deposition}

Unit II at Site U1337 is mostly composed of biosiliceous lithologies, notably diatoms (Figs. F5, F6, F7). The abundance of diatoms in the middle and upper Miocene section at Site U1337 is much higher than encountered in any interval at Sites U1331-U1336. Several decimeter- to meter-scale intervals of diatom ooze are laminated, and smear slide analyses indicate that the diatom assemblage is composed primarily of pennate taxa with abundant needlelike Thalassiothrix spp., indicating diatom mat deposition (Fig. F10). The lowermost laminated diatom mat is in the upper portion of Unit III at 15 Ma. Much larger intervals are present in Unit II at $\sim 10 \mathrm{Ma}$ and shorter intervals at $\sim 4.5 \mathrm{Ma}$. The ages of laminated diatom mats at this site are similar to those found at Leg 138 sites farther to the east (Mayer, Pisias, Janecek, et al., 1992), which have been interpreted to reflect regional bursts of export silica production in the eastern equatorial Pacific (Kemp and Baldauf, 1993). No laminated diatom oozes were observed at Expedition 320 drill sites farther to the west; however, near 10 $\mathrm{Ma}$ at Site U1335, drilling recovered clayey diatom ooze and clayey radiolarian ooze containing no carbonate at all (Pälike et al., 2009) suggesting that dissolution may also play an important role in the deposition of laminated diatom mats.

\section{Oligocene-Miocene transition}

The Oligocene/Miocene boundary was recovered in Holes U1337A, U1337C, and U1337D (Fig. F5). In Hole U1337A, the Oligocene/Miocene boundary is estimated to fall between intervals 321-U1337A-48X2, 85-87 cm, and 48X-3, $55 \mathrm{~cm}(445.56-446.75 \mathrm{~m}$ CSF; 490.92-492.11 m CCSF-A) (see "Biostratigraphy"). It occurs in white (2.5Y 8/1) nannofossil chalk with foraminifers, interbedded and heavily mottled with pale yellow $(2.5 \mathrm{Y} 7 / 4)$ to very pale brown (10YR 7/4) nannofossil chalk. Abundant millimeter-scale dendritic manganese grains composed of manganese oxide occur throughout this interval. The lower $15 \mathrm{~cm}$ of the core catcher of this core represents basement. No prominent change in lithology, GRA bulk density, reflectance, or magnetic susceptibility is seen through the Oligocene-Miocene transition.

\section{Summary}

At Site U1337, latest Oligocene seafloor basalt is overlain by $\sim 450 \mathrm{~m}$ of nannofossil and biosiliceous oozes and nannofossil chalks that are divided into four lithologic units. Pleistocene through uppermost Miocene sediments of Unit I are characterized by multicolored (various hues of white, brown, green, and gray) nannofossil oozes, diatom oozes, and radiolarian oozes that alternate on a meter scale with a general downsection increase in siliceous microfossils relative to nannofossils. Green and gray biosiliceous lithologies, interbedded on a meter scale with white and light greenish gray nannofossil ooze comprise the dominant sedimentary constituents in the uppermost Miocene to middle Miocene Unit II, which includes regular diatom mat deposits. Meterscale color alternations in Units I and II are associated with variations in lithology and physical properties. However, similar to the common millimeter- and centimeter-scale color banding that 
does not mark compositional changes, they are likely associated with sediment redox conditions. White, pale yellow, and pale green nannofossil oozes and chalks dominate the sediments of middle Miocene to latest Oligocene age, although diatoms and radiolarians remain present in low abundances. Latest Oligocene seafloor basalt (Unit IV) was recovered at the base of the sedimentary section.

\section{Biostratigraphy}

A $450 \mathrm{~m}$ thick succession of Pleistocene to upper Oligocene sediment was recovered at Site U1337. Planktonic foraminifers are rare to abundant with poor to good preservation throughout most of the succession but are absent or extremely rare from Samples 321-U1337A-18H-CC through 24X-CC and 36X-4, 90-92 cm, through 37X-CC. Biozones PT1b to O6 are recognized, with the exception of Zones PL4, M12, and M3. Calcareous nannofossils at Site U1337 are moderately to poorly preserved, and some samples with high biosilica content are barren. Nannofossil Zones NN1 to NN21 are present, indicating an apparently complete sequence. The radiolarian stratigraphy at Site U1337 spans the interval from the uppermost part of Zone RN16-RN17 (upper Pleistocene) to RN1 (lower Miocene). The radiolarian assemblages of Pleistocene to upper Miocene tend to have good preservation, whereas middle to lower Miocene assemblages show moderate preservation. Below the uppermost portion of Zone RN1, sediments are barren of radiolarians. The high-resolution diatom stratigraphy at Site U1337 spans the interval from the Fragilariopsis doliolus Zone (upper Pleistocene) to the lowermost part of the C. elegans Zone (lower Miocene). The diatom assemblage is generally well to moderately preserved throughout the recovered section; however, there are several intervals in which valve preservation becomes moderate to poor. The nannofossil, foraminifer, radiolarian, and diatom datums and zonal schemes generally agree, though some discrepancies occur in the lowest part of the core. The integrated calcareous and siliceous microfossil biozonation is shown in Figure F13. An age-depth plot including biostratigraphic and paleomagnetic datums is shown in Figure F14. Benthic foraminifers occur continuously throughout the succession recovered in Hole U1337A and show good to moderate preservation. The overall assemblage composition indicates lower bathyal to abyssal paleodepths. Marked variations in downcore abundance and species distribution may reflect major changes in global climate linked to fluctuations in ice volume and reorganization of Pacific Ocean circulation during the Neogene.

\section{Calcareous nannofossils}

Calcareous nannofossil bioevents from all holes at Site U1337 are presented in Table T3. Most bioevents are determined to within a core section $(1.5 \mathrm{~m})$. Hereafter, all mention of nannofossil bioevents refers to this table. Qualitative estimates of assemblage preservation and relative abundances at the species level are presented in range chart format (Table T4). When subsampling split cores, the most biosilicarich layers were avoided, therefore implying that the abundances and preservation of samples shown in Table T4 are biased to reflect layers that are richer in calcareous fossils. Nannofossil bioevents from Holes U1337B-U1337D are listed in Table T3. The discussion below mainly refers to Hole U1337A.

Core 321-U1337A-1H consists only of the core catcher sample, containing a relatively diverse assemblage with abundant Gephyrocapsa oceanica and common Gephyrocapsa omega. This sample, and several samples below, contains abundant occurrences of small Gephyrocapsa $(<3 \mu \mathrm{m})$, which are here referred to as Gephyrocapsa ericsonii but likely represent more than one species. A few specimens of Emiliania huxleyi are observed in an assemblage dominated by abundant gephyrocapsids, placing this sample in Zone NN21. Rare reworked Miocene nannofossils include Discoaster bellus, Discoaster deflandrei, Reticulofenestra pseudoumbilicus, and Sphenolithus heteromorphus.

Small gephyrocapsids are dominant in Sample 321U1337A-2H-CC. The top of Pseudoemiliania lacunosa occurs in the lower part of Core 321-U1337A-2H. In Hole U1337B, this event occurs between Samples 321-U1337B-1H-4, $101 \mathrm{~cm}$, and 1H-CC. A major change in the abundance and preservation of calcareous nannofossils occurs between Samples 321U1337A-3H-5, 115-116 cm, and 3H-CC, progressing from abundant and moderately preserved assemblages in the upper sample to less abundant (common) and poorly preserved assemblages in the lower sample. Placoliths are strongly dissolved, resulting in disjointed shields and missing central areas. The appearance of common Reticulofenestra asanoi and the disappearance of large Gephyrocapsa $(>5.5 \mu \mathrm{m})$ occur in the lower part Core 321-U1337A-3H, indicating an approximate age of 1.1-1.3 Ma for this part of the core.

The Pliocene/Pleistocene boundary is placed in the middle part of Core 321-U1337A-4H, between the successive extinctions of Calcidiscus macintyrei (above) and Discoaster brouweri (below). Sample 321U1337A-4H-CC is characterized by an upper Pliocene assemblage including common $D$. brouweri and rare to few Discoaster triradiatus, placing it in Zone NN18. The proportion of these taxa implies that the 
deposited before the onset of the "acme" interval of the latter species in upper Zone NN18 (Fig. F2A in the "Methods" chapter). Other taxa in this sample are Calcidiscus leptoporus, Ceratolithus cristatus, Ceratolithus rugosus, Coccolithus pelagicus, Helicosphaera carteri, Helicosphaera sellii, Pontosphaera japonica, Pontosphaera multipora, P. lacunosa, small $(<5 \mu \mathrm{m})$ reticulofenestrids, and very small $(<3 \mu \mathrm{m})$ reticulofenestrid/dictyococcid placoliths. The tops of Zones NN17 (Discoaster pentaradiatus) and NN16 (Discoaster surculus) occur within Core 321-U1337A-5H. The diatom-rich Sample 321U1337A-5H-3, $96 \mathrm{~cm}$, lacked discoasters. The uppermost occurrence of Discoaster tamalis is recorded in a low-diversity assemblage within Sample U1337A-5HCC, impoverished by (selective) calcite dissolution. Rare occurrences of discoasters in the overlying diatomrich sediments in Core 321-U1337A-5H make it difficult to say whether or not the core catcher sample represents the true extinction of $D$. tamalis.

The lower/middle Pliocene boundary occurs in the upper part of Core 321-U1337A-7H, based on the extinction of $R$. pseudoumbilicus. Several biosilica-rich samples in the upper part Core 321-U1337A-7H are virtually barren of calcareous nannofossils. Early Pliocene assemblages are characterized by the presence of C. rugosus, $R$. pseudoumbilicus, Sphenolithus abies, and about a dozen other taxa, including tiny reticulofenestrids/dictyococcitids that are abundant or dominant in some samples. Furthermore, the distinct but rarely reported Discoaster altus is common in Sample 321-U1337A-8H-4, $10 \mathrm{~cm}$, the range of which appears to have biostratigraphic potential in the tropical Pacific Ocean. The Miocene/Pliocene boundary is well constrained in the lower part of Core 321-U1337A-10H, located above the first occurrence of Ceratolithus acutus. Zone NN12 is present in Cores 321-U1337A-10H and $11 \mathrm{H}$.

Nicklithus amplificus is observed in Cores 321U1337A-12H and $13 \mathrm{H}$, with a base occurrence in Section 321-U1337A-14H-1. It has a well-defined top and basal occurrence within Zone NN11 despite the poor to moderate preservation. The assemblages in these cores are characterized by abundant reticulofenestrids and, in Sample 321-U1337A-13H-CC, discoasters such as Discoaster berggrenii and Discoaster quinqueramus.

In Core 321-U1337A-14H the carbonate content increases and contains massive abundances of small placoliths representing a mixture of reticulofenestrid forms having either closed central areas (Dictyococcites) or minute pores/central openings (Reticulofenestra). The top of the paracme interval of $R$. pseudoumbilicus and the base of Amaurolithus spp. both occur in Core 321-U1337A-15H. The preservation deteriorates in Core 321-U1337A-16H, where the nannofossil assemblage shows low diversity and is characterized by robust placolith species and overgrown discoasters. The Zone NN11/NN10 boundary is observed in the lower part of Core 321-U1337A$17 \mathrm{H}$, defined by the base of $D$. berggrenii. Discoaster assemblages in samples from a few meters below the evolutionary appearance of $D$. berggrenii are characterized by abundant $D$. bellus as the dominant member of the genus. This composition changes upcore to a dominance of six-rayed forms belonging to the Discoaster variabilis group. D. berggrenii appears in this latter discoaster assemblage. The large $(>20 \mu \mathrm{m})$ Discoaster neorectus is common in several samples 3$4 \mathrm{~m}$ above the first occurrence of $D$. berggrenii. The bottom of the paracme interval of $R$. pseudoumbilicus occurs in a short interval characterized by a major change in preservation, from moderately preserved assemblages above to poorly preserved below in which most placoliths have been dissolved (see Core 321-U1337D-17H).

The core catcher samples of Cores 321-U1337A-18H and $19 \mathrm{H}$ contain well-preserved discoasters and poorly preserved placoliths, which are dissolved and fragmented. In Sample 321-U1337A-19H-CC, some of the larger Calcidiscus specimens are referred to Calcidiscus tropicus, which is slightly smaller than Calcidicus macintyrei and possesses a larger central pore or opening. The D. variabilis plexus shows much variability, including large forms such as Discoaster variabilis pansus.

Diatom mats composed of needle-shaped Thalassiothrix and Lioloma occur abundantly in Cores 321U1337A-20H through 24X. Calcareous nannofossil assemblages are often impoverished in terms of diversity and show poorly preserved assemblages in the most diatom-rich sediments. In terms of nannofossil biostratigraphy, diatom mats are concentrated in an interval from the upper half of Zone NN7 (below the top of Coccolithus miopelagicus but above the top of common D. kugleri) through lower Zone NN10 (shortly above the top of Discoaster hamatus). It is difficult to divide this interval rich in centimeter- to decimeter-thick diatom mats because of rare occurrences of $D$. hamatus and the Catinaster taxa, used for recognition of Zones NN9 and NN8.

C. miopelagicus, Catinaster coalitus, and D. hamatus provide a series of bioevents within $0.5 \mathrm{~m}$.y. in the early late Miocene based on the compilation by Lourens et al. (2004), which is adopted for the Neogene Pacific Equatorial Age Transect (Fig. F2B in the "Methods" chapter). The age estimates of these three taxa were derived from orbital tuning of ODP Leg 154 cores in the western equatorial Atlantic Ocean (see Raffi et al., 2006). In that region, the C. miopelagicus extinction occurs nearly $140 \mathrm{k} . \mathrm{y}$. prior to the 
Raffi et al. (2006) indicate a 0.4 m.y. younger age estimate $(10.60 \mathrm{Ma})$ for the extinction of $C$. miopelagicus from the eastern equatorial Pacific Ocean based on linear interpolation between geomagnetic reversal boundaries in Leg 138 sites, which is adopted here.

At Site U1337, C. miopelagicus has a range that extends into the range of $C$. coalitus. Primarily because of better core recovery, these taxa could be more tightly constrained in Holes U1337C and U1337D than in Hole U1337A (Table T3). In Hole U1337C, the $C$. miopelagicus and D. hamatus events occur within a $2.90 \mathrm{~m}$ (still unresolved) interval from Samples 321-U1337C-6H-CC to 7H-2, whereas in Hole U1337D, they occur within a $2.14 \mathrm{~m}$ interval (unresolved; Samples 321-U1337D-21H-CC to 22H-2) on the spliced depth scale (CCSF-A; see "Stratigraphic correlation and composite section"). A $2.14 \mathrm{~m}$ interval represents $<100 \mathrm{k} . \mathrm{y}$. in this part of the section. Raffi et al. (2006) estimated a 50 k.y. difference between these two events from Leg 138 Sites in the eastern equatorial Pacific Ocean, which is consistent with the observations made at Site U1337.

Sample 321-U1337A-22X-1, $53 \mathrm{~cm}$, contains rare Discoaster neohamatus, a six-rayed species present in upper Zone NN9 and in lower Zone NN10. Better preserved intervals from Cores 321-U1337B-19H and $20 \mathrm{H}$ have frequent occurrences of D. neohamatus. Despite the well-preserved and diverse discoaster assemblages in these intervals, Catinaster species are rare. This genus ranges throughout Zones NN8 and NN9. Sample 321-U1337A-24X-CC contains less biosilica and better preservation of calcareous nannofossil placolith taxa. Another sign of the improved calcareous preservation is that discoasters begin to be overgrown by secondary calcite, a typical phenomenon in carbonate-rich Miocene nannofossil oozes. Common D. kugleri are observed from the upper part of Core 321-U1337A-25X to upper 26X, marking the lower part of Zone NN7.

Core 321-U1337A-26X contains several bioevents which occur in upper Zone NN6, including the tops of Cyclicargolithus floridanus, Coronocyclus nitescens, and Calcidiscus premacintyrei in Sections 321U1337A-26X-3 to 26X-5. Of the three taxa, C. premacintyrei is the most abundant species, making it easier to recognize its uppermost occurrence. In contrast, C. floridanus and C. nitescens are rare in the upper parts of their ranges. In Cores 321-U1337A-27X through $30 \mathrm{X}$, preservation is predominantly poor but varies based upon the silica content in surrounding sediments. Only one section with alternating bands of diatom mats and more calcareous sediment from Core 321-U1337A-27X was recovered. The calcareous intervals contain some of the best preserved material from the Miocene, an example of which is a $22 \mu \mathrm{m}$ diameter $C$. miopelagicus coccosphere observed in Sample 321-U1337D-27X-1, $15 \mathrm{~cm}$. The assemblage in Sample 321-U1337A-27X-CC shows a dominance of small $(<3 \mu \mathrm{m})$ Dictyococcites spp., together with other placoliths and discoasters. The latter group displays little sign of overgrowth. This is in stark contrast to discoasters in Sample 321-U1337A29X-CC, most of which cannot be identified at the species level because of severe overgrowth. The top common occurrence of $C$. floridanus in lower Zone NN6 is placed at the base of Core 321-U1337A-30X. There is not a distinct change in the abundance of this species. Rather, the abundance gradually increases downcore, making this bioevent unreliable at this location.

Zone NN5 occurs in Cores 321-U1337A-31X through $34 \mathrm{X}$ as defined by the extinctions of $S$. heteromorphus (for top of zone) and Helicosphaera ampliaperta (for base of zone). This interval is moderately preserved and contains abundant, diverse nannofossils with common to abundant Sphenolithus, Reticulofenesta, and Coccolithus specimens. The amount of calcite overgrowth on the nannofossils in these samples increases with the elevated carbonate content of the sediments. $H$. ampliaperta is a distinct although rare species. Despite its low abundances, the highest occurrence could be placed between Sections 321U1337A-34X-4 and 34X-5.

Cores 321-U1337A-35X and 36X have similar assemblage compositions to those of Cores 31X and 34X, and preservation is moderate to poor. S. hetermorphus is abundant in this interval, and Sample 321U1337A-36X-CC shows unusually high abundances of Sphenolithus moriformis and S. heteromorphus. The top common occurrence of $D$. deflandrei is observed in Samples 321-U1337A-35X-3 through 35X-5. Reticulofenestra daviesii has its highest occurrence in the lower part of Core 321-U1337A-37X. This species may prove to be a useful biostratigraphic marker in this region because of its consistent presence from the upper Oligocene and distinct highest occurrence. Zone NN4 encompasses the interval between Sections 321-U1337A-34X-5 and 39X-2. The latter section marks the highest observed occurrence of Sphenolithus belemnos and hence the top of Zone NN3. The Zone NN3/NN2 boundary coincides with the Zone NN4/NN3 boundary between Samples 321U1337A-38X-CC and 39X-1, $40 \mathrm{~cm}$, because weakly birefringent specimens of Triquetrorhabdulus carinatus occur throughout Core 321-U1337A-39X. If assuming that these forms represent an indigenous presence, it follows that Zone NN3 does not exist in the paleoequatorial Pacific Ocean because of the nearsimultaneous disappearances of both $T$. carinatus and 
S. belemnos. This biostratigraphic order is not unique for Site U1337 because these events occur within $1.5 \mathrm{~m}$ at Site U1336 (see "Biostratigraphy" in the "Site U1336" chapter), suggesting that reworking of T. carinatus is probably not the cause as the two sites are located $360 \mathrm{nmi}$ apart. Rather, it appears as if the range of T. carinatus extends to the top of Zone NN3, implying that the nonexistent Zone NN3 at Sites U1336 and U1337 does not represent condensation and/or the presence of an erosional hiatus.

Sample 321-U1337A-39X-2, $40 \mathrm{~cm}$, shows the highest observed occurrence of a thickly calcified sphenolith species which is characterized also by its large size (7-18 $\mu \mathrm{m})$ and dark reddish, brownish, and blueish colors between crossed nicols. This morphovariant is considered to belong to the Sphenolithus moriformis group and is present from Core 321U1337A-39X to the sediment/basalt contact in Core $48 \mathrm{X}$. Its uppermost occurrence may have potential as a tropical Pacific Ocean biostratigraphic marker in the lower Miocene. A similar morphovariant has been described from the middle-upper Miocene (Zones NN7-NN11) in the South Atlantic (Haq and Berggren, 1978), termed Sphenolithus grandis. For the time being, we refer this large morphovariant from Site U1337 to the $S$. grandis concept. The largest specimens (up to $18 \mu \mathrm{m}$ ) are observed in the lower lower Miocene (Sample 321-U1337A-47X-1, $75 \mathrm{~cm}$ ). Sample 321-U1337A-39X-CC contains the highest observed occurrence of the large, albeit discontinuous and rare, Discoaster druggii, which occurs sporadically down to Sample 321-U1337A-47X-4, $80 \mathrm{~cm}$. This sample may thus be taken to mark the Zone NN1/ NN2 boundary.

Helicosphaerid abundance varies markedly in the sediments retrieved from Hole U1337A, although this group is consistently a minor component of the assemblages. The most abundant (1 specimen per 110 fields of view at $1000 \times$ ) helicosphaerid species in Sample 321-U1337A-43X-CC is Helicosphaera carteri, in contrast to the next core catcher sample (Sample 321-U1337A-44X-CC), where Helicosphaera euphratis is the most abundant representative of this genus. Investigation of a few samples within Core 321U1337A-44X did not provide statistically meaningful data about which of the two taxa was more abundant. We therefore place the crossover event of these two taxa between Samples 321-U1337A-43X-CC and 44X-CC.

Reticulofenestrids and $D$. deflandrei are common to abundant in Cores 321-U1337A-46X through 48X. Preservation is moderate and nannofossils are abundant. Top common $T$. carinatus occurs distinctly between Samples 321-U1337A-47X-2, $75 \mathrm{~cm}$, and $47 \mathrm{X}-3,75 \mathrm{~cm}$. The Oligocene/Miocene boundary
(23.03 Ma) is within Core 321-U1337A-48X, judging from the presence of Sphenolithus delphix in Samples 321-U1337A-48X-3, $55 \mathrm{~cm}$, to 48X-4, $15 \mathrm{~cm}$. The extinction of this short-ranged taxon has an age estimate of $\sim 23.1 \mathrm{Ma},<100 \mathrm{k} . \mathrm{y}$. prior to the Oligocene/ Miocene boundary. The sediment from the lowermost occurrence of $D$. druggii to the sediment/basalt contact belongs to Zone NN1, indicated by the presence of $S$. delphix shortly above the basalt and the absence of Sphenolithus ciperoensis. The chalk immediately in contact with the basalt contains poorly preserved nannofossils. A smear slide produced from a calcite vein toward the top of the basalt recovered from Hole U1337D shows rare, poorly preserved nannofossils, which evidently settled into the fissures of the basalt crust.

\section{Handling of the Reticulofenestra/Dictyococcites problem in Hole U1337A}

Reticulofenestra and Dictyococcites are two Cenozoic genera that belong to an extant evolutionary lineage. Other genera in this lineage are Pseudoemiliania, Gephyrocapsa, and Emiliania. These three genera, as well as Dictyococcites, all share the basic reticulofenestrid character, but each of them has a distinct morphologic quality that has rendered them their own taxonomic status at the generic level. In the case of Dictyococcites, this quality is its closed central area. Reticulofenestra has, per definition, a central area that is open (Hay et al., 1967). In a discussion of reticulofenestrid taxonomy, Young (1999) expressed the opinion that forms with closed central areas (Dictyococcites) are likely "ecophenotypes of no stratigraphic value (Young, 1990), so they are not recommended." That is, he discarded the genus Dictyococcites. However, this genus has several species, some of which are used biostratigraphically (e.g., Dictyococcites bisectus). Moreover, we do not consider potential biostratigraphic usage as a necessary prerequisite in calcareous nannofossil taxonomy. We therefore consider Dictyococcites to be a valid genus, no less valid than other genera in the reticulofenestrid lineage.

Members of both Dictyococcites and Reticulofenestra are common to abundant in most samples investigated at Site U1337. We distinguish five Reticulofenestra/ Dictyococcites morphotypes and/or morphotype groups. R. asanoi (circular to subcircular form having a restricted stratigraphic range within the Pleistocene) and $R$. pseudoumbilicus ( $\geq 7 \mu \mathrm{m}$, following Rio et al., 1990; includes the variant Reticulofenestra gelida, which has a small central opening) are recognized at the species level together with Dictyococcites antarcticus $(>3 \mu \mathrm{m})$. We group all medium-sized $(3-7 \mu \mathrm{m})$ reticulofenestrids into the Reticulofenestra haqii con- 
cept (includes the variant Reticulfenestra minutula, which has a large central opening). Most Neogene samples contain small $(\leq 3 \mu \mathrm{m})$ reticulofenestrid placoliths varying in abundance from rare to dominant. Most Pliocene-Pleistocene specimens of these minute placoliths have a small central opening, which make them referable to Reticulofenestra minuta. Many of the Miocene specimens, however, appear to have closed central areas or only a median slit in the closed central areas. These two morphotypes are difficult to distinguish from each other using light microscopy. We have therefore grouped all small $(\leq 3 \mu \mathrm{m})$ reticulofenestrid placoliths into the category "small Dictyococcites," both having closed and open central areas. At Site U1337, the open-center forms appear to be more common in the Pliocene-Pleistocene section, whereas the closed-center forms dominate in the Miocene. Scanning electron microscopy is required in order to reliably determine the Neogene distribution of these small reticulofenestrid placoliths, which likely contain at least two species.

Perch-Nielsen (1985) remarked that the "link(s) between the typical Eocene and Oligocene Reticulofenestra species and the species assigned to this genus in the Neogene have not been established satisfactorily." At Site U1337, however, we notice a short overlap in the stratigraphic ranges between the Paleogene species $R$. daviesii and the Neogene species $R$. pseudoumbilicus. Furthermore, as observed at Site $\mathrm{U} 1337$, if the central plug in $R$. daviesii is removed by an evolutionary development among the reticulofenestrids, the result will be $R$. pseudoumbilicus morphotypes. The relative abundance plot (Fig. F15) supports the idea that $R$. pseudoumbilicus evolved from $R$. daviesii, thereby establishing a link between the Paleogene and Neogene reticulofenestrid lineages. This transition occurred in Zone NN4.

\section{Radiolarians}

The radiolarian stratigraphy at Site U1337 (Table T5) spans the interval from the uppermost part of Zone RN16-RN17 (upper Pleistocene) to RN1 (lower Miocene), which generally agrees with planktonic foraminifer, calcareous nannofossil, diatom, and radiolarian biostratigraphies (Fig. F13). Below the uppermost portion of Zone RN1, the sediments are barren of radiolarians. The Pleistocene to upper Miocene radiolarian assemblages tend to have good preservation, whereas middle to lower Miocene assemblages show moderate preservation (Tables T6, T7, T8, T9). Reworked individuals from the lower to middle Miocene rarely occur in the upper Miocene to Pleistocene sediments.

The topmost part of Site U1337 corresponds to Pleistocene Zone RN16-RN17. The base of Zone RN16-
RN17 is placed between Samples 321U1337A-1H-CC and $2 \mathrm{H}-\mathrm{CC}$, as indicated by the top of Stylatractus universus. Core 321-U1337A-2H contains the base of Collosphaera tuberosa and the top of Anthocyrtidium angulae, which indicate the top of Zones RN14 and RN13, respectively. The top of $A$. angulae occurs between Samples 321-U1337B-1H-CC and 2H-CC and between Samples 321-U1337D-1H-CC and 2H-CC, marking the base of Zone RN14.

The base of Lamprocyrtis nigriniae is observed between Samples 321-U1337B-3H-CC and 4H-CC and between 321-U1337C-1H-CC and 2H-CC. This datum was not observed in Hole U1337A. The top of Theocyrtidium vetulum is between Samples 321U1337A-2H-CC and 3H-CC and Samples 321U1337B-1H-CC and 2H-CC. The base occurrences of Theocyrtidium tracherium and $A$. angulae are both distinguished between Samples 321-U1337A-3H-CC and $4 \mathrm{H}-\mathrm{CC}$ and between 321-U1337B-3H-CC and $4 \mathrm{H}-\mathrm{CC}$. The top of Pterocanium prismaticum also occurs in these samples in both holes and between Samples 321-U1337D-2H-CC and 3H-CC. This event defines the base of Zone RN13.

The top of Didymocyrtis avita and Stichocorys peregrina are observed between Samples 321-U1337A-4H-CC and 5H-CC and Samples 321-U1337B-4H-CC and $5 \mathrm{H}-\mathrm{CC}$. In Hole U1337D, the top of $S$. peregrina is recognized between Samples 321-U1337D-2H-CC and $3 \mathrm{H}-\mathrm{CC}$. The top of $S$. peregrina marks the boundary between Zones RN12 and RN11. Cycladophora davisiana is present in Zones RN12 to RN16-RN17 at Site U1337 but does not show enough abundance to confidently establish its base occurrence. The ranges of Lamprocyrtis neoheteroporus and Lamprocyrtis heteroporus are not determined because of their sporadic and discontinuous occurrences in Holes U1337A and U1337B.

The top of Phormostichoartus fistula is recognized in only Hole U1337B between Samples 321-U1337B$4 \mathrm{H}-\mathrm{CC}$ and 5H-CC. This datum defines the boundary between Subzones RN11b and RN11a. This datum is not observed in Hole U1337A. The top of Lychnodictyum audax is calibrated to Subzone RN11a. However, this species has its top occurrence in Zone RN9 at Site U1337.

The top of Phormostichoartus doliolum is found between Samples 321-U1337A-6H-CC and 7H-CC, Samples 321-U1337B-6H-CC and 7H-CC, and Samples 321-U1337D-6H-CC and 7H-CC. This species marks the top of Zone RN10. The base of Anphirhopalum ypsilon is observed between Samples 321-U1337A7H-CC and 8H-CC and Samples 321-U1337B-5H-CC and $6 \mathrm{H}-\mathrm{CC}$. 
The top of Zone RN9 is indicated by the base of Didymocyrtis penultima, which occurs between Samples 321-U1337A-8H-CC and 9H-CC and Samples 321-U1337B-7H-CC and 8H-CC. Nephrospyris renilla occurs in Zones RN9 to RN14 in both Holes U1337A and U1337B but not in sufficient abundance to establish its exact range. The tops of both Solenosphaera omnitubus and Spongaster berminghami are observed between Samples 321-U1337A-10H-CC and $11 \mathrm{H}-\mathrm{CC}$ and Samples 321-U1337B-9H-CC and 10HCC. The base of Didymocyrtis avita is between Samples 321-U1337A-11X-CC and 12H-CC and Samples 321-U1337B-12X-CC and 13H-CC. The top of Didymocyrtis antipenultima occurs between Samples 321-U1337A-12H-CC and 13H-CC, Samples 321U1337B-12H-CC and 13H-CC, and Samples 321U1337D-6H-CC and 7H-CC. The base of Didymocyrtis tetrathalamus and the top of Calocycletta caepa are between Samples 321-U1337A-13H-CC and 14H-CC and Samples 321-U1337B-13H-CC and 14H-CC. Stichocorys johnsoni is rare in Samples 321-U1337A$13 \mathrm{H}-\mathrm{CC}$ to $16 \mathrm{H}-\mathrm{CC}$ and $321-\mathrm{U} 1337 \mathrm{~B}-16 \mathrm{H}-\mathrm{CC}$. The abundance of this taxon was insufficient to determine its highest and lowest datums.

The evolutionary transition from Stichocorys delmontensis to $S$. peregrina, which defines the boundary between Zones RN9 and RN8, occurs between Samples 321-U1337A-13H-CC and 14H-CC, Samples 321U1337B-12H-CC and 13H-CC, and Samples 321U1337D-13H-CC and 14H-CC. The base occurrences of Theocyrtidium vetulum and Splenosphaera omnitubus are located between Samples 321-U1337A-14H-CC and $15 \mathrm{H}-\mathrm{CC}$ but are not clearly distinguished in Hole U1337B because of the rare occurrences of these two taxa.

The top of Diartus hughesi is between Samples 321-U1337A-15H-CC and 16H-CC, between 321U1337B-15H-CC and 16H-CC, and between 321U1337D-14H-CC and 15H-CC. The boundary between Zones RN8 and RN7 is distinguished in this level. The top of Didymocyrtis laticonus also occurs between Samples 321-U1337A-15H-CC and 16H-CC and between 321-U1337B-16H-CC and 17H-CC. The base of D. penultima is detected between Samples 321U1337A-16H-CC and 17H-CC and Samples 321U1337B-16H-CC and 17H-CC. The top of Botryostrobus miralestensis occurs between Samples 321-U1337A$17 \mathrm{H}-\mathrm{CC}$ and 18H-CC and Samples 321-U1337B-16H$\mathrm{CC}$ and $17 \mathrm{H}-\mathrm{CC}$. The base of $S$. berminghami could not be recognized because this species occurs so rarely in the lowermost part of its range.

The top of Zone RN6 is marked by the evolutionary transition of Diartus pettersoni to D. hughesi between Samples 321-U1337A-18H-CC and 19H-CC, Samples 321-U1337B-18H-CC and 19H-CC, and Samples 321-
U1337D-17H-CC and 18H-CC. The top of Stichocorys wolffii was not clearly found at Site U1337 because of its sparse presence. The base of $D$. antipenultima is found between Samples 321-U1337A-19H-CC and 20H-CC and Samples 321-U1337B-18H-CC and 19HCC. The top events of both Cyrtocapsera japonica and Carpocanopsis cristata are observed between Samples 321-U1337A-22X-CC and 23H-CC. In Hole U1337B, the top occurrence of $C$. japonica occurs between Samples 321-U1337B-19H-CC and 20H-CC, and the top of C. cristata is between Samples 321-U1337B$21 \mathrm{H}-\mathrm{CC}$ and 22H-CC. In Hole U1337C, the top of $C$. japonica occurs between Samples 321-U1337C-4H$\mathrm{CC}$ and $5 \mathrm{H}-\mathrm{CC}$. The top of C. cristata was not observed in Hole U1337C. Lithopera neotera occurs in Zones RN5 and RN6 in Holes U1337A and U1337B, but it is so rare that it is difficult to precisely decide the range of this species. The top occurrences of $C y r$ tocapsera cornuta and Cyrtocapsera tetrapera are located between Samples 321-U1337A-25X-CC and 26H-CC, Samples 321-U1337B-24H-CC and 25H-CC, and Samples 321-U1337C-10H-CC and 11X-CC.

The base of $D$. pettersoni occurs between Samples 321-U1337A-27X-CC and 28H-CC, Samples 321U1337C-11X-CC and 12X-CC, and Samples 321U1337D-27H-CC and 28H-CC, indicating the top of Zone RN5. Rare specimens of Lithopera renzae occur within Zone RN5 in Holes U1337A and U1337C, but it is not possible to delineate and occurs so rarely that we could not decide the range of this species. The top of Calocycletta robusta is between Samples 321-U1337A-29X-CC and 30H-CC and 321-U1337C15X-CC and 16X-CC. The top occurrences of Acrocubus octopyle and Liriospyris parkerae are between Samples 321-U1337A-30X-CC and 31H-CC. In Hole $\mathrm{U} 1337 \mathrm{~B}$, the top of $L$. parkerae was recognized between Samples 321-U1337C-15X-CC and 16X-CC, whereas the top of $A$. octopyle was not determined because of its rare occurrence. Between Samples 321U1337A-33X-CC and 34H-CC and Samples 321U1337C-17X-CC and 18X-CC, the top occurrences of Didymocyrtis violina, Calocycletta virginis, Calocycletta costata, and Dorcadospyris dentata are observed. The top events of Liriospyris stauropora and Didymocyrtis prismatica and the base of $L$. parkerae are detected between Samples 321-U1337A-33X-CC and 34H-CC and Samples 321-U1337C-19X-CC and 20XCC. Didymocyrtis mammifera and Dorcadospiris forcipata are present in Holes U1337A and U1337B, but they occur so rarely that their ranges could not be determined precisely.

The zonal boundary between Zones RN5 and RN4, defined by the evolutionary transition from $D$. dentata to Dorcadospyris alata, is difficult to recognize at Site U1337 because of the absence of D. alata. How- 
ever, the boundary between Zones RN5 and RN4 is considered to occur between Samples 321-U1337A33X-CC and 34X-CC and Samples 321-U1337C-11X$\mathrm{CC}$ and 12X-CC using secondary datums as follows. Samples 321-U1337A-33X-CC and 33X-CC and 321U1337D-33X-CC clearly belong to Zone RN5 because these samples did not contain Calocycletta costata, which disappears in the lowermost portion of Zone RN5. D. prismatica occurs in Samples 321-U1337A34X-CC, 321-U1337C-20X-CC, and 321-U1337D34X-CC and belongs to Zone RN4.

The top of Carpocanopsios cingulata is found between Samples 321-U1337A-35X-CC and 36X-CC. The base of Zone RN4 is identified by the base of C. costata. This event and the base of $D$. dentata were found between Samples 321-U1337A-38X-CC and 39X-CC and Samples 321-U1337C-23X-CC and 24X-CC. In Hole U1337D, the base of C. costata is recognized between Samples 321-U1337D-39X-CC and 40X-CC. Dorcadospuris forcipata is rare in Samples 321U1337A-39X-CC to 43X-CC.

The base of $S$. wolffii (base of Zone RN3) is observed between Samples 321-U1337A-40X-CC and 41H-CC, Samples 321-U1337C-25X-CC and 26X-CC, and Samples 321-U1337D-40X-CC and 41X-CC. The top of Dorcadospiris scambos is found between Samples 321-U1337A-40X-CC and 41H-CC but is not found in Hole U1337C. The base of $S$. delmontensis is between Samples 321-U1337A-44X-CC and 45X-CC and Samples 321-U1337C-29X-CC and 30X-CC. The top of Lophocyrtis delmontensis is constrained between Samples 321-U1337A-45X-CC and 46H-CC.

With the top of Theocyrtis anossa, the boundary between Zones RN2 and RN1 is recognized between Samples 321-U1337A-45X-CC and 46X-CC.

\section{Diatoms}

High-resolution biostratigraphy was performed on core catcher and additional samples (mostly two per core) from Hole U1337A. The diatom stratigraphy at Site U1337 (Fig. F13; Tables T10, T11) spans the interval from the $F$. doliolus Zone (upper Pleistocene) in Sample 321-U1337A-1H-CC to the lowermost part of the C. elegans Zone (lower Miocene) in Sample 43XCC (Fig. F13). The diatom assemblage is generally well to moderately preserved throughout the recovered section; however, there are several intervals in which valve preservation becomes moderate to poor. Intervals with moderate to poor diatom preservation are most commonly found between Samples 321U1337A-16H-CC and 18H-CC (middle upper Miocene); Samples 321-U1337A-29X-3, 44-45 cm, through 31X-2, 46-47 cm (middle Miocene); and Cores 321-U1337A-33X through 37X (lower Miocene to upper Miocene). This intermittent decrease in preservation is not clearly associated with the occurrence of turbidites or with reworking of older microfossils. The diverse diatom assemblage observed in samples from Site U1337 consists of species typical of the low-latitude eastern equatorial Pacific Ocean, including Actinocyclus ellipticus, several species of Azpeitia and Coscinodiscus, Hemidiscus cuneiformis, $F$. doliolus, Nitzschia fossilis, Fragilariopsis reinholdii, a few varieties of Thalassionema nitzschioides, and several species of Thalassiosira as well as Thalassiothrix spp. (Table T10).

The topmost Sample 321-U1337A-1H-CC and 2H-4, $121-122 \mathrm{~cm}$, are assigned to the Pleistocene $F$. doliolus Zone. Samples 321-U1337A-2H-6, 50-51 cm, through $4 \mathrm{H}-4,55-56 \mathrm{~cm}$, are within the $F$. reinholdii Zone. The majority of the Pliocene section of Hole U1337A is divided into the Rhizosolenia praebergonii and Nitzschia jouseae Zones (Fig. F13). The boundary between the $R$. praebergonii and $N$. jouseae Zones is tentatively located between Samples 321-U1337A$8 \mathrm{H}-\mathrm{CC}$ and $9 \mathrm{H}-1,60-70 \mathrm{~cm}$, because the base occurrence of $R$. praebergonii and the top occurrence of $A$. ellipticus f. lanceolata cannot be found. Similarly, it was not possible to fully subdivide the $R$. praebergonii Zone because of the absence of the age-diagnostic taxon Thalassiosira convexa within the high-resolution samples examined between Samples 321-U1337A$4 \mathrm{H}-\mathrm{CC}$ and $8 \mathrm{H}-\mathrm{CC}$.

Samples 321-U1337A-9H-1, 69-70 cm, through 10H$3,87-88 \mathrm{~cm}$, are assigned to the $N$. jouseae Zone. Stratigraphic events observed in this early Pliocene zone include the top occurrence of Fragilariopsis cylindrica (Sample 321-U1337A-10H-3, 87-88 cm) and the base occurrences of Thalassiosira lineata (Sample $10 \mathrm{H}-3,87-88 \mathrm{~cm}$ ) and Thalassiosira oestrupii var. venrickae (Sample 9H-CC). The base of the $N$. jouseae Zone is defined by the base occurrence of $N$. jouseae in Sample 321-U1337A-10H-3, 87-88 cm. For most of the Pliocene, diatom abundance is high and preservation varies from moderate to good.

In the expanded Miocene section, it becomes clear that he presence of some of the Miocene species used in the diatom stratigraphy is discontinuous (Table T10). This has been noticed in sediments of Miocene age recovered during Leg 138 (Baldauf and Iwai, 1995). The discontinuous occurrences may reflect large variations in the abundances of these species with time and changing ecologic conditions. However, there is also the possibility that some of these intermittent disappearances of a species may reflect genetic changes in the lineage that give rise to either "iterative evolution" or changing ecological preferences. These questions will be addressed during postcruise research. The upper boundary of the late Miocene $T$. convexa Zone is defined by base occur- 
rence of $N$. jouseae in Sample 321-U1337A-10H-3, $87-88 \mathrm{~cm}$. The base of the T. convexa Zone is given by the base occurrence of Thalassiosira miocenia in Sample 321-U1337A-14H-2, 58-59 cm. The lower boundary of the Nitzschia miocenica Zone is placed between Samples 321-U1337A-15H-4, 108-109 cm, and $15 \mathrm{H}-\mathrm{CC}$ on the base occurrence of $\mathrm{N}$. miocenica in Sample 15H-4, 108-109 cm. The base occurrence of Thalassiosira eccentrica occurs in Sample 321U1337A-14H-4, 90-91 cm.

Samples 321-U1337A-15H-CC through 17H-CC are placed in the Nitzschia porteri Zone based on the base occurrence of $N$. miocenica and the top occurrences of Thalassiosira grunowii and Thalassiosira yabei. Several secondary datum events, such as the top occurrences of Thalassiosira burckliana and Rosiella paleaceae, occur in the $N$. porteri Zone. The placement of Subzones A and B, defined by the top occurrence of Thalassiosira praeconvexa cannot be determined. The $N$. porteri/T. yabei Zone boundary occurs between Samples 321-U1337A-17H-CC and $18 \mathrm{H}-3,139-140 \mathrm{~cm}$. Similar to the $N$. porteri Zone, no exact placement of Subzones A and B within the $T$. yabei Zone can be determined. Given the absence of Actinocyclus moronensis, the top of the A. moronensis cannot be determined. The $A$. moronensis Zone is tentatively allocated to Sample 321-U1337A-23X-2, $124-125 \mathrm{~cm}$. The problematic differentiation of the A. moronensis Zone suggests the low biostratigraphic potential of this diatom. As a result, the exact position of some of the datums within the Craspedodiscus coscinodiscus Zone immediately below the A. moronensis Zone might be slightly biased.

The C. coscinodiscus and Coscinodiscus gigas var. diorama Zones are represented by the base occurrence of $N$. porteri in Sample 321-U1337A-26X-5, 37-38 cm, the base occurrence of $H$. cuneiformis in Sample 24X$\mathrm{CC}$, and the top occurrences of Crucidenticula nicobarica in Sample 25X-2, 42-43 cm, and Coscinodiscus lewisianus in Sample 26X-5, 37-38 cm. The C. gigas var. diorama Zone is tentatively assigned to Samples 321-U1337A-26X-CC and 27X-CC.

Samples 321-U1337A-28X-4, 75-75 cm, through $30 \mathrm{X}-\mathrm{CC}$ are tentatively assigned to the $C$. lewisianus Zone. Recognized in this zone are the base occurrences of Azpeitia apiculata, Thalassiosira tappanae, $T$. yabei, and Triceratium cinnamomeum. The Cestodiscus peplum Zone occurs between the base of the C. lewisianus Zone in Samples 321-U1337A-28X-4, 74-75 cm, and $35 \mathrm{X}-6,54-55 \mathrm{~cm}$, which is almost coincidental with the middle/lower Miocene boundary.

The boundary between the C. peplum and Crucidenticula nicobarica Zones is tentatively placed between Samples 321-U1337A-35X-CC and 36X-CC. The $C$. nicobarica Zone is characterized by several diatom events. Two base occurrences are observed: $C$. nicobarica in Sample 321-U1337A-38X-CC, and Raphidodiscus marylandicus in Sample 38X-2, 92-93 cm. The top occurrences of $R$. marylandicus and Coscinodiscus lewisianus var. similis are observed in Sample 321U1337A-37X-4, 88-89 cm. Diatom abundance is predominantly low through the $C$. nicobarica Zone, and valve preservation is moderate to poor.

The final two diatom zones found in Hole U1337A, Triceratium pileus and C. elegans, are weakly constrained, mainly because of low diatom abundance. Both zones are characterized by having the lowest diatom species diversity found in Hole U1337A. The boundary between the $T$. pileus and C. elegans Zones is tentatively located in Samples 321-U1337A-40XCC and 41X-CC. Similarly, the lower boundary of the C. elegans Zone cannot be identified, and this zonal placement is tentative. Diatoms are absent from the remainder of the samples examined from the lowermost portion of the recovered sequence (Cores 321-U1337A-44X through 47X).

The continuous occurrence of diatoms throughout the upper $410 \mathrm{~m}$ CSF makes Site U1337 an ideal type section for the description of stratigraphic events as well as hydrographic and climatic changes spanning from the early Miocene through the Pleistocene in the low-latitude Pacific Ocean. Although earlier authors took an expansive approach toward establishing ages for all of the diatom datums recovered at DSDP and ODP sites along the equatorial Pacific Ocean (e.g., Baldauf, 1985; Baldauf and Iwai, 1995; Barron, 1985a, 1985b, 2006; Barron et al., 2004), onboard analysis of Site U1337 samples shows that some of the diatom datums appear to be more reliable than others. In some cases, differences in the levels of the first or last appearance of a species may be caused by variation in taxonomic interpretation, but more often these variations are due either to real differences in the species ranges at different localities in the tropical Pacific Ocean or to extremely low species abundances at Site U1337.

\section{Occurrence of laminated diatom oozes}

A striking feature of sediments from Site U1337 is the occurrence of sequences of laminated diatom oozes (LDOs) intercalated with massive diatom oozes. The LDOs are mainly composed of a few species of the needle-shaped diatom Thalassiothrix. Entire valves are rarely seen, but fragments exceeding $0.5 \mathrm{~mm}$ are abundant and well preserved. Each lamination might represent a single productivity event but are not necessarily annual. Compared to laminated sediments from marginal marine basins (Kemp et al., 2006), the examined Site U1337 intervals lack significant terrigenous input and are almost entirely 
biogenic in origin. The preservation of undisturbed LDOs can be ascribed to the strength of the meshwork of entangled Thalassiothrix frustules. In earlier studies of similar laminated Thalassiothrix oozes from the equatorial Pacific Ocean (Kemp and Baldauf, 1993; Kemp et al., 1995), it was suggested that the frustule strength was sufficient to make the meshworks impenetrable for benthos and thus suppress sediment mixing by physical means. The appearance of LDOs in the open ocean requires conditions favorable for physical accumulation at the surface rather than high productivity (Yoder et al., 2002; Kemp et al., 1995). Grigorov et al. (2002), however, suggested that the contributions of both physical accumulation and enhanced productivity at the front zone might be equally important to the high densities of Thalassiothrix spp.

According to the model proposed by Goldman (1993), autumn/early winter deposition, coinciding with breakdown of summer stratification, is represented by lamina-forming species of Thalassiothrix, which grow at depth in low-light conditions. Both Yoder et al. (2002) and Kemp et al. (1995) argued that these Neogene mat deposits originated from the sinking of surface diatoms generated by tropical instability wave activity. At present, the ecology of Thalassiothrix spp. has not been well studied, either in the field or in culture.

\section{Planktonic foraminifers}

Planktonic foraminifer assemblages at Site U1337 are typical of tropical-subtropical eutrophic environments. Assemblages are highly variable with intervals barren of planktonic foraminifers, intervals of poor preservation dominated by the large dissolutionresistant forms (e.g., Sample 321-U1337A-36X-CC), and intervals with moderate to good preservation with diverse assemblages (e.g., Sample 43X-3, 79$82 \mathrm{~cm})$.

A high-resolution planktonic foraminifer biostratigraphy was generated at Site U1337 using core catchers and supplemented by additional samples (usually two per core) from Hole U1337A only. The sedimentary succession at this site ranges from Subzone PT1b (Pleistocene) to Zone O6 (upper Oligocene) (Fig. F13; Table T12), which generally agrees with calcareous nannofossil, diatom, and radiolarian biostratigraphies (Fig. F13). Preservation and abundance of planktonic foraminifers is extremely variable, ranging from poor to good preservation and specimens are commonly infilled. Planktonic foraminifer tests can account for $>95 \%$ of the total residue in each sample, but in some intervals planktonic foraminifers are rare or absent and assemblages are dominated by dissolution-resistant forms. In such cases it was not possible to identify the biozone. Taxon relative abundances and estimates of assemblage preservation are presented in range chart format (Table T13). A number of primary and secondary markers were absent in the Site U1337 samples or had insufficient abundances to provide robust stratigraphic control. These included Globorotalia birnageae, Globorotalia lenguaensis, Globorotalia (Hirsutella) cibaoensis, Globorotalia (Menardella) exilis, Globorotalia (Truncorotalia) truncatulinoides, Globoturborotalita decoraperta, and Turborotalita humilis.

The topmost part of Hole U1337A corresponds to Pleistocene Subzone PT1b. The youngest sample (321-U1337A-1H-CC) yields Globigerinoides ruber (pink); therefore, the top of the morphotype could be placed above the horizon. This bioevent has been determined at $0.12 \mathrm{Ma}$ in the Indian and Pacific Oceans by oxygen isotope stratigraphy (Thompson et al., 1979), and its converted age to the PEAT timescale is also $0.12 \mathrm{Ma}$. The top of G. (Truncorotalia) tosaensis is located between Samples 321-U1337A$2 \mathrm{H}-4,134-136 \mathrm{~cm}$, and $2 \mathrm{H}-6,64-66 \mathrm{~cm}$, defining the boundary between Subzones PT1b and PT1a. The top of Globigerinoides fistulosus occurs between Samples 321-U1337A-4H-3, 94-96 cm, and 4H-5, 9-11 cm, indicating the base of Subzone PT1a. Above the top of G. fistulosus, the change in dominant coiling direction of Pulleniatina spp. from sinistral to dextral is observed between Samples 321-U1337A-3H-5, 115$116 \mathrm{~cm}$, and $3 \mathrm{H}-\mathrm{CC}$. This group was mainly composed of dextrally coiled individuals throughout their stratigraphic range, with two significant intervals of sinistrally coiled population. The first interval was from the late Miocene to the early Pliocene and the second was the late Pliocene to the earliest Pleistocene (e.g., Bolli and Saunders, 1985). The latter coiling change from sinistral to dextral has been also recognized from sequences in the northwestern Pacific realm above the Olduvai Subchron (Oda, 1977) and is concordant with the present result. The late Miocene to the early Pliocene coiling change is discussed below. Globigerinoides extremus was sporadically present from Sample 321-U1337A-6H-2, 16-18 cm, through $15 \mathrm{H}-\mathrm{CC}$ but not in sufficient abundance to establish its top occurrence. The top occurrence of Globorotalia pseudomiocenica (indicating the base of Zone PL6) is between Samples 321-U1337A-4H-CC and $5 \mathrm{H}-2,111-113 \mathrm{~cm}$. The top of Globorotalia (Menardella) multicamerata also occurs at this level in Hole U1337A. The base of G. fistulosus is detected between Samples 321-U1337A-6H-2, 16-18 cm, and $6 \mathrm{H}-6,129-131 \mathrm{~cm}$. This bioevent has been correlated to the base of the Mammoth Subchron (Berggren et al., 1995). Globoturborotalita woodi was found intermittently in Samples 321-U1337A-15H-4, 104-106 cm, 
through 40X-2, 56-58 cm; however, the abundance of this taxon was insufficient to determine its top occurrence.

Dentoglobigerina altispira is found between Samples 321-U1337A-6H-2, 16-18 cm, and 39X-CC. The top horizons of $D$. altispira and Sphaeroidinellopsis seminulina are both found between Samples 321U1337A-6H-2, $16-18 \mathrm{~cm}$, and $6 \mathrm{H}-6,129-131 \mathrm{~cm}$, so we were unable to differentiate Zone PL4; further samples between Samples 321-U1337A-6H-2, 16$18 \mathrm{~cm}$, and $6 \mathrm{H}-6,129-131 \mathrm{~cm}$, are required to constrain this zone. The zonal boundary between Zones PL3 and PL2 is also hard to recognize because the index species Globorotalia (Hirsutella) margaritae occurs in only one sample $(321-\mathrm{U} 1337 \mathrm{~A}-7 \mathrm{H}-4,98-100 \mathrm{~cm})$ at the present site. The change in coiling direction from sinistral to dextral in Pulleniatina spp. occurs between Samples 321-U1337A-7H-CC and 8H-2, $119-121 \mathrm{~cm}$. This event can be correlated with the coiling change of the group with an astronomically tuned age of $4.08 \mathrm{Ma}$ within Zone PL2 (Lourens et al., 2004). Therefore, at least the latter sample can be assigned to Zone PL2.

Globoturborotalita nepenthes is rare in the assemblages, but the top occurrence is constrained between Samples 321-U1337A-10H-1, 26-28 cm, and $10 \mathrm{H}-3,82-84 \mathrm{~cm}$. We were unable to divide Subzones PL1a and PL1b because of the absence of Globorotalia (Hirsutella) cibaoensis. The base of Sphaeroidinella dehiscens sensu lato was found between Samples 321-U1337A-9H-CC and 10H-1, 26-28 cm. The base of Zone PL1, as indicated by the base of Globorotalia tumida, occurs between Samples 321U1337A-11H-2, 43-45 cm, and 11H-5, 144-146 cm. Below the base of G. tumida, the top of Globoquadrina dehiscens is observed between Samples 321-U1337A$12 \mathrm{H}-\mathrm{CC}$ and $13 \mathrm{H}-1,24-26 \mathrm{~cm}$. The numerical age of this datum has been reported as $5.8 \mathrm{Ma}$ (Berggren et al., 1995), with a recalibrated age to the PEAT timescale of $5.9 \mathrm{Ma}$, which demonstrates no discrepancy with the stratigraphy at Site U1337.

The base of Subzone M13b is well constrained by the base of Globorotalia plesiotumida between Samples $321-\mathrm{U} 1337 \mathrm{~A}-16 \mathrm{H}-2,32-34 \mathrm{~cm}$, and $16 \mathrm{H}-4,24-$ $26 \mathrm{~cm}$. However, Globorotalia lenguaensis was not observed in any of the samples, so we were unable to differentiate between Zone M14 and Subzone M13b.

Between Samples 321-U1337A-18H-5, 83-85 cm, and $24 \mathrm{X}-4,28-30 \mathrm{~cm}$, planktonic foraminifers are rare or absent, so we were unable to determine the base of Subzone M13a and Zone M12. Assemblages between Samples 321-U1337A-24X-CC and 5X-5, 36-38 cm, contain both Paragloborotalia mayeri and G. nepenthes, indicating Zone M11. The base of G. nepenthes and thus Zone M11 occurs between Samples 321-
U1337A-25X-5, 36-38 cm, and 25X-CC. The top of Globigerinoides subquadratus is placed between Samples 321-U1337A-25X-3, 35-37 cm, and 25X-5, 36$38 \mathrm{~cm}$. It is concordant with the astronomically tuned biohorizon (11.54 Ma) (Lourens et al., 2004).

Zone M10/N13 is represented between Samples 321U1337A-25X-CC and 26X-5, 40-42 cm, as indicated by the short stratigraphic interval between the base of G. nepenthes and the top of Globorotalia (Fohsella) fohsi sensu lato. The base of G. (Fohsella) fohsi sensu lato is between Samples 321-U1337A-28X-CC and $29 \mathrm{X}-3,38-40 \mathrm{~cm}$. The top of Zone N10/M7 is constrained between Samples 321-U1337A-31X-2, 49$51 \mathrm{~cm}$, and $31 \mathrm{X}-4,51-53 \mathrm{~cm}$. The base of this zone, as indicated by the base of Globorotalia (Fohsella) peripheroacuta, is between Samples 321-U1337A-33X-3, $39-41 \mathrm{~cm}$, and $33 X-5,39-41 \mathrm{~cm}$. The secondary marker subspecies Globorotalia (Fohsella) fohsi robusta was not detected in any of the samples. Clavatorella bermudezi is rare at Site U1337 but provides a good secondary marker for this interval with the top occurrence between Samples 321-U1337A-31X-4, 51$53 \mathrm{~cm}$, and 31X-CC and the base occurrence between Samples 321-U1337A-33X-CC and 34X-3, 63-65 cm.

The Praeorbulina-Orbulina lineage provides a number of biostratigraphic datums through the early middle Miocene. The base of Orbulina spp. (base of Zone M6/N9) is between Samples 321-U1337A-33X-CC and $34 \mathrm{X}-3,63-65 \mathrm{~cm}$. The base of Praeorbulina glomerosa allows differentiation of Subzones M5b and M5a and is placed between Samples 321-U1337A-34X-6, $63-65 \mathrm{~cm}$, and $34 \mathrm{X}-\mathrm{CC}$, although this species is rare. Praeorbulina sicana occurs in samples upsection from Sample 321-U1337A-36X-2, 90-92 cm; however, the interval immediately below is barren of planktonic foraminifers, so we are unable to constrain the base of Zone M5.

Paragloborotaliids are abundant and diverse in Hole U1337A. The coiling direction ratio of Paragloborotalia spp. changes from random to exclusively sinistral between Samples 321-U1337A-34X-3, 63-65 cm, and $34 \mathrm{X}-6,63-65 \mathrm{~cm}$. The coiling change in this group has been reported around the boundary of early and middle Miocene by several authors (Bolli and Saunders, 1985; Winter and Pearson, 2001; Abdul Aziz et al., 2007). Abdul Aziz et al. (2007) found that randomly coiled Paragloborotalia siakensis occur below the base of $P$. glomerosa, whereas sinistrally coiled $P$. siakensis dominate above that horizon. This suggests that the dominant coiling direction change of Paragloborotalia from random to sinistral can be placed around the boundary between Subzones M5a and M5b. Our results from Site U1337 are consistent with Abdul Aziz et al. (2007) and confirm the coiling change as a robust biostratigraphic event. 
The top of Catapsydrax dissimilis is constrained between Samples 321-U1337A-39X-CC and 40X-2, $56-58 \mathrm{~cm}$. This bioevent agrees well with the nannofossil, diatom, and radiolarian stratigraphies of this interval. Zone M4 is recognized as the interval between the top of $C$. dissimilis and the base of $P$. sicana. However, we are not able to constrain the base of Globigerinatella insueta and therefore can not recognize Zone M3. Catapsydrax unicavus is abundant from the base of the hole to Sample 321U1337A-36X-2, 90-92 cm, and then rare occurrences continue to Sample 31X-CC (Zone N10/M7). The abundance of this taxon in the lower part of the hole may in part reflect dissolution.

Globoquadrina binaiensis is found from the base of Hole U1337A to Sample 321-U1337A-43X-3, 79$82 \mathrm{~cm}$. However, in younger sediments we also find frequent to rare specimens resembling $G$. binaiensis with an inflated, arched, and cut-away final chamber and distinctly flattened apertural face but with four, rather than three, chambers in the final whorl. G. binaiensis specimens with four chambers have also been noted by Spezzaferri (1994). We follow the distinction used by Chaisson and Leckie (1993) and distinguish G. binaiensis sensu stricto as forms with three chambers in the final whorl. We refer to these four-chambered specimens as Globoquadrina cf. binaiensis. These specimens range into younger sediments (Sample 321-U1337A-36X-2, 90-92 cm; Subzone M5a). Specimens of $G$. binaiensis intergraded with $G$. dehiscens; however, our $G$. cf. binaiensis do not possess the quadrate, angular chambers that are distinctive in G. dehiscens (Bolli and Saunders, 1985).

There are discrepancies in the order of the biostratigraphic events at Site U1337 through the early Miocene, suggesting either reworking of marker taxa or contamination. The top of Subzone M1b is defined by the top of Paragloborotalia kugleri and is preceded over a short stratigraphic interval by the top of Paragloborotalia pseudokugleri. We apply a very restricted species concept for $P$. kugleri, including only forms with a pitched periphery, 7-8 chambers in the final whorl, and curved sutures on the spiral side. We find the top of $P$. kugleri between Samples 321-U1337A$45 \mathrm{X}-4,74-76 \mathrm{~cm}$, and $45 \mathrm{X}-\mathrm{CC}$ and the top of $P$. pseudokugleri between Samples 321-U1337A-44X-6, $0-2 \mathrm{~cm}$, and 44X-CC. This upper range of $P$. kugleri and $P$. pseudokugleri are at odds with Berggren et al. (1995), as we find the extinction of P. kugleri lower than the top of $P$. pseudokugleri and coincident with the base of $G$. dehiscens. Although the extinction of $P$. kugleri is considered a reliable biohorizon, several authors have commented on the sporadic occurrence and rarity of $P$. kugleri toward the top of its range (e.g., Mancin et al., 2003). Quantitative foraminifer analysis on a number of equatorial and northwest Pacific Ocean sites (DSDP Sites 55, 71, 77B, and 292) by Keller (1981) also previously revealed an abrupt decline in the abundance of $P$. kugleri concurrent with the base of $G$. dehiscens. Pearson and Wade (2009) note that the holotype of $P$. pseudokugleri is a highly developed specimen, with seven chambers in the final whorl. We also find rare and sporadic occurrences of Paragloborotalia cf. kugleri and Paragloborotalia cf. pseudokugleri, with the top of these taxa in Samples 321-U1337A-40X-4, 55-57 cm, and 39X-CC, respectively (higher than the top occurrence of $C$. dissimilis and $G$. binaiensis). These specimens have a more rounded periphery but do not fit into the taxonomic concepts of $P$. mayeri, $P$. siakensis, Globorotalia (Fohsella) peripheroronda, or Globorotalia birnageae. We were therefore unable to differentiate Subzone M1b, so we have assigned the interval from the base of $G$. dehiscens to the top of $G$. binaiensis sensu stricto as Subzone M1b-M2. The base of G. dehiscens, indicating the Subzone M1a/M1b boundary, is constrained between Samples 321-U1337A-45X-4, 74-76 cm, and 45X-CC.

The Oligocene/Miocene boundary occurs within the last core of Hole U1337A, just above basement. We record the base of Zone M1 by the lowest occurrence of P. kugleri between Samples 321-U1337A-48X-2, $85-87 \mathrm{~cm}$, and $48 \mathrm{X}-4,112-114 \mathrm{~cm}$. This is concurrent with the base of "Globigerina" primordius. The top of Globigerina ciperoensis is between Samples 321U1337A-47X-4, 100-102 cm, and 47X-CC.

The genus Globigerinoides is recognized by its sutural supplementary apertures of the spiral side of the test; the oldest taxon traditionally ascribed to this genus is Globigerinoides primordius. Consistent with the findings of Spezzaferri and Premoli Silva (1991), at Site U1337 there are forms that are identical in morphology to G. primordius but without supplementary apertures. Furthermore, detailed scanning electron microscope studies of well-preserved specimens from Trinidad (Pearson and Wade, 2009) show G. primordius to have a "bulloides-type" rather than a "sacculifer-type" wall typical of true Globigerinoides. We therefore refer to these specimens as "Globigerina" primordius pending further study.

Variations in assemblage composition are seen throughout the hole, reflecting both preservational and evolutionary changes and fluctuations in the water column structure (Fig. F16). Globoquadrinids and dentoglobigerinids dominate the assemblages from the base of the hole to Sample 321-U1337A24X-CC (Zones O6-M11). Globoquadrina venezuelana and Dentoglobigerina larmeui are prominent components of the assemblages from Samples 321U1337A$11 \mathrm{H}-2,43-45 \mathrm{~cm}$, and $32 \mathrm{X}-4,45-47 \mathrm{~cm}$, respectively, 
to the base of the hole. Dentoglobigerina tripartita sensu stricto is also very high in abundance from Zone $\mathrm{O} 6$ to the base of Zone N10/M7. Globigerinoides increase in abundance from Sample 321-U1337A$34 \mathrm{X}-\mathrm{CC}$, and keeled globorotaliids dominate the Pleistocene assemblages (Fig. F16). From Sample 321U1337A-19H-4, 95-97 cm, Globigerinoides sacculifer becomes a regular component of the assemblages. Peak abundances of Globigerinoides spp. occur within Subzone M13a, with abundant Globigerinoides immaturus, Globigerinoides obliquus, Globigerinoides quadrilobatus, G. sacculifer, and frequent Globigerinoides trilobus. Neogloboquadrina dutertrei is abundant from the top of the hole to Sample 321-U1337A-4H-3, 94$96 \mathrm{~cm}$. Paragloborotaliids are extremely abundant and diverse from the base of the hole to Sample 321U1337A-38X-CC (Zone M4). Taxa include Paragloborotalia continuosa, Paragloborotalia nana, Paragloborotalia pseudocontinuosa, Paragloborotalia semivera, P. mayeri, and $P$. siakensis. Above Sample 321-U1337A-35X-6, $50-52 \mathrm{~cm}$, to Sample $24 \mathrm{X}$-CC paragloborotaliids are restricted to three species: $P$. continuosa, $P$. mayeri, and $P$. siakensis. Tenuitellids including Teniutella angustiumbilicata, Teniutella gemma, and Teniutella praestainforthi are rare but recorded sporadically from Sample 321-U1337A-13H-1, 24-26 cm, to Sample $48 \mathrm{X}-\mathrm{CC}$, ranging from Zones M14-M13b to O6. The occurrences of T. gemma extend beyond Zone O6, as suggested by Huber et al. (2006), into Miocene Zone M4, which is consistent with the findings of Spezzaferri (1994).

\section{Benthic foraminifers}

Benthic foraminifers occur continuously throughout the $\sim 450 \mathrm{~m}$ thick Pleistocene to upper Oligocene succession recovered at Site U1337, although abundances vary markedly downcore depending on the silica-carbonate content of the sediment. Assemblages are predominantly composed of calcareous taxa, and agglutinated forms are rare. Benthic foraminifers were examined in core catcher samples from Hole U1337A, supplemented by samples from Hole U1337A sections (two per core) after cores were split. Mudline samples recovered in Holes U1337BU1337D were also investigated. Large samples with an average volume of $\sim 50 \mathrm{~cm}^{3}$ were processed from all core catchers to obtain quantitative estimates of benthic foraminifer distribution patterns downcore. Smaller $10 \mathrm{~cm}^{3}$ samples were additionally investigated from core sections to provide realistic estimates of species availability for shore-based geochemical and paleontological studies, although these small samples do not yield statistically significant numbers of specimens. Core catcher samples are overall more representative of lithologic variability, as they in- clude siliceous-rich layers. In contrast, core samples were preferentially selected from carbonate-rich intervals, thus introducing a certain amount of bias within the core sample data set, where siliceous intervals are underrepresented.

To assess assemblage composition and variability downhole, all specimens from the $>250 \mu \mathrm{m}$ fraction were picked from core catcher and core samples and mounted onto slides prior to identification and counting. The distribution of benthic foraminifers was additionally checked in the $150-250 \mu \mathrm{m}$ fraction to ensure that assemblages in the $>250 \mu \mathrm{m}$ fraction were representative and that small species such as phytodetritus feeders were not overlooked. A total of 92 benthic foraminifer taxa were identified. Census counts from core catcher and core section samples are presented in Table T14. Figure F17 summarizes the downcore distribution of the more common benthic foraminifer taxa in core catcher samples from Hole U1337A. Common taxa include Astrononion echolsi, Cibicidoides mundulus, Cibicidoides grimsdalei, Cibicidoides wuellerstorfi, Eggerella bradyi, Fissurina spp., Gyroidinoides soldanii, Laticarinina pauperata, Oridorsalis umbonatus, Pyrgo murrhina, Pyrgo serrata, Pullenia bulloides, and Siphonodosaria abyssorum. Preservation is good overall but deteriorates somewhat in the lower $\sim 100 \mathrm{~m}$ of Hole U1337A (below Core 321-U1337A-37X; 350 m CFS). Fish teeth and ostracodes are intermittently present throughout the succession. Composition of the upper Oligocene to Pleistocene benthic foraminifer assemblage at Site U1337 indicates lower bathyal to abyssal paleodepths. However, marked variations in the downcore distribution of benthic foraminifers probably relate to fundamental changes in global climate during the Neogene associated with major ice-volume fluctuations and reorganization of oceanic circulation.

Mudline samples from Holes U1337B-U1337D were gently washed in order to preserve fragile agglutinated specimens with extremely low fossilization potential. All mudline samples examined revealed a high degree of dissolution in the planktonic foraminifer assemblage, in particular among globorotalids. Rare benthic foraminifers are generally well preserved and consist predominantly of agglutinated forms. Calcareous taxa include C. wuellestorfi, Eobulimina exilis, Melonis sphaeroides, Osangularia plummerae, P. murrhina, and Fissurina spp. Agglutinated taxa are mainly tubular forms with organic cement, such as the branching species Rhizammina algaeformis, which typically agglutinates a variety of planktonic foraminifer tests. These highly fragile taxa occur in all mudline samples but are best preserved in Hole U1337B, suggesting sediment recov- 
ery close to the sediment/water interface. The finely agglutinated involute species Cyclammina pusilla, characteristic of lower bathyal to abyssal depths (Hess and Kuhnt, 2005), was also found in the mudline sample from Hole U1337A.

The Pleistocene to late Miocene assemblage within the biosiliceous-rich interval in the upper part of Hole U1337A (Cores 321-U1337A-1H through 12H; 0.14-110.40 m CSF) generally contain relatively low numbers of benthic foraminifers, except for Sample 321-U1337A-1H-CC (0.14 m CSF), which has a more diversified and abundant assemblage, suggesting improved ventilation and relatively high food influx at this abyssal seafloor location. The occurrence of the deep infaunal dweller Chilostomella oolina in Cores $321-\mathrm{U} 1337 \mathrm{~A}-1 \mathrm{H}$ and $4 \mathrm{H}(0.14-34.44 \mathrm{~m} \mathrm{CSF})$ is particularly striking, as this species is more typical of shallower settings with high organic export flux and/or restricted ventilation (Janninck et al., 1998; Jorissen and Rohling, 2000; W. Kuhnt, unpubl. data). In fact, marked variations in the abundance of organic flux-sensitive taxa such as C. oolina, G. subglosa, P. murrhina, and P. serrata suggest substantial changes in equatorial Pacific Ocean surface productivity throughout the Pleistocene to late Miocene, possibly associated with glacial-interglacial climate fluctuations. However, the low resolution of our shipboard benthic foraminifer data set prevents detection of variability on this scale.

A generally diversified and abundant assemblage is found in Cores 321-U1337A-13H through $17 \mathrm{H}$ (119.84-157.99 m CSF), coinciding with an interval of overall improved carbonate preservation (see "Geochemistry") and decreased biosiliceous sedimentation at $\sim 8-6 \mathrm{Ma}$. This assemblage is characterized by relatively high numbers of epifaunal or near-surface dwellers including C. mundulus, C. bradyi, L. pauperata, O. umbonatus, P. murrhina, P. serrata, and Quinqueloculina spp., which suggest a marked improvement in deep-ocean ventilation and relatively high export flux reaching the seafloor at this abyssal location. The lowest occurrence of Osangularia plummerae in Hole U1337A also occurs within this interval (Sample 321-U1337A-16X-CC; $148.52 \mathrm{~m} \mathrm{CSF).} \mathrm{This} \mathrm{inter-}$ val follows a prominent and extended period of low carbonate deposition in the eastern Pacific Ocean at 11-9 Ma in the early late Miocene, often referred to as the "carbonate crash" (Lyle et al., 1995; Farrell et al., 1995). This transition to higher carbonate deposition marks a fundamental change in Pacific Ocean circulation and productivity regime, possibly associated with changing rates of deepwater production and/or Northern Hemisphere ice development (Zachos et al., 2008).
Core catcher samples from Cores 321-U1337A-18H through 24X (167.50-218.98 m CSF), which are effectively barren of planktonic foraminifers, contain an impoverished benthic foraminifer assemblage. Abundances increase slightly in layers with higher carbonate content, which were selectively sampled for shipboard foraminifer investigation. However, the benthic to planktonic ratio remains at $~ 99 \%$ even in these enriched carbonate samples. Diatom mats with Thalassiothrix and Lioloma are abundant within this biosiliceous-rich interval, which corresponds to the early late Miocene carbonate crash in the eastern Pacific Ocean.

The late middle Miocene assemblage in Cores 321U1337A-25X through 30X (232.87-280.49 m CSF) is overall diverse and abundant, although marked fluctuations in abundance and composition are evident, which may reflect cyclic changes in surface productivity and circulation. This interval consists of alternating siliceous-rich laminated layers and more carbonate bands, which show some rhythmicity, although this is difficult to ascertain in Hole U1337A because of patchy core recovery. The benthic to planktonic ratio within this interval shows marked oscillations, suggesting substantial variations in carbonate preservation, which may be linked to changes in the CCD.

Cores 321-U1337A-31X through 34X (289.47$318.36 \mathrm{~m} \mathrm{CSF}$ ) contain the most diversified and abundant benthic foraminifer assemblage found in Hole U1337A. This middle Miocene assemblage is characterized by epifaunal species such as $C$. mundulus, C. wuellerstorfi, L. pauperata, and mobile, shallow infaunal dwellers living close to the sediment/water interface, such as Cibicidoides bradyi, C. grimsdalei, Cibicidoides robertsonianus, G. soldanii, G. subglobosa, O. umbonatus, and Pyrgo spp. The first common occurrence of $C$. wuellerstorfi occurs within this assemblage (Sample 321-U1337-34X-CC; $318.36 \mathrm{~m} \mathrm{CSF).}$ The relatively high numbers, high diversity, and low benthic to planktonic ratio indicate well-ventilated bottom water with enhanced carbonate preservation at the seafloor in agreement with $\mathrm{CaCO}_{3}$ values (see "Geochemistry"). An extended interval of enhanced $\mathrm{CaCO}_{3}$ deposition is widely recognized at $\sim 16-13 \mathrm{Ma}$ in the eastern equatorial Pacific Ocean (Lyle, 2003). Interestingly, most of this interval corresponds to the episode of major global cooling at $\sim 15-13 \mathrm{Ma}$, when ice sheets expanded in Antarctica toward the end of the "Monterey carbon isotope excursion." A substantial improvement in deepwater ventilation and deepening of the CCD was also recorded at ODP Site 1237 in the southeastern subtropical Pacific Ocean, implying widespread reorganization in South Pacific Ocean deepwater circulation following mid- 
dle Miocene ice growth (Holbourn et al., 2005; 2007).

The lower middle to upper lower Miocene assemblage in Cores 321-U1337A-35X through 37X (327.23$347.64 \mathrm{~m} \mathrm{CSF}$ ) exhibits marked changes in abundance and diversity. Sample 321-U1337A-37X-CC (347.64 m CSF), which corresponds to a siliceous-rich interval, contains only rare benthic foraminifers. In contrast, Sample 321-U1337A-36X-CC (338.15 $\mathrm{m}$ CSF) is characterized by high numbers of infaunal taxa $(>40 \%)$ including Siphodonosaria abyssorum and Siphodonosaria spp. and has a high benthic to planktonic ratio (99\%), suggesting somewhat reduced bottom water ventilation. The assemblage in Sample 321-U1337A-35X-CC (327.23 m CSF), which is more diversified with a benthic to planktonic ratio of $5 \%$, closely resembles the overlying middle Miocene assemblage in Cores 321-U1337A-31X through 34X (289.47-318.36 m CSF), although abundance is lower. This interval with highly variable benthic foraminifer distribution corresponds to a period of global warmth during the early part of the Monterey carbon isotope excursion, often referred to as the mid-Miocene climatic optimum.

The lower Miocene to uppermost Oligocene assemblage in Cores 321-U1337A-38X through 48X (352.65-449.32 m CSF) shows relatively low benthic to planktonic ratios and high diversity, although abundances are substantially lower than during peak carbonate preservation in the middle Miocene. Common taxa include C. mundulus, C. grimsdalei, $G$. soldanii, G. subglobosa, and O. umbonatus. The assemblage composition and overall higher $\mathrm{CaCO}_{3}$ values in this interval (see "Geochemistry") indicate relatively well ventilated bottom water and a deep CCD. However, higher resolution core samples reveal higher variability in assemblage composition and abundance, which may be related to fluctuations in the silica-carbonate content of the sediment and/or oceanographic changes. Shore-based studies will provide an opportunity to investigate these variations and unravel the links with global climatic events.

\section{Paleomagnetism}

Using the pass-through magnetometer, we measured the NRM of archive-half sections of 20 APC and 14 XCB cores from Hole U1337A, 27 APC cores from Hole U1337B, 8 APC cores from Hole U1337C, and 30 APC cores from Hole U1337D. Discrete samples, collected one per section from all APC cores of Hole U1337A and Cores 321-U1337B-22H through 26H, were also measured.

The primary objective of shipboard measurements is to determine magnetostratigraphy, thereby provid- ing chronostratigraphic constraints. To accomplish this, the standard protocol at Site U1337 was to measure the NRM of each section at $2.5 \mathrm{~cm}$ intervals before demagnetization and after demagnetization at peak AF of 10 and $20 \mathrm{mT}$. From Core 321-U1337B-5H to $27 \mathrm{H}$ and from Core $321-\mathrm{U} 1337 \mathrm{D}-3 \mathrm{H}$ to $30 \mathrm{H}$, only one demagnetization step $(20 \mathrm{mT})$ was carried out to save time and maintain laboratory core flow. Except for the uppermost two XCB cores in Hole U1337A (Cores 320-U1337A-23X and 24X), other XCB cores (Cores 321-U1337A-25X through 36X) were measured before demagnetization and after a single demagnetization step $(20 \mathrm{mT})$. During processing of the paleomagnetic data, we removed measurements within $7.5 \mathrm{~cm}$ of section ends to avoid section-end effects. Data from visibly disturbed intervals (see "Lithostratigraphy") were also removed.

The FlexIt core orientation tool was deployed in conjunction with all APC cores at Site U1337. The orientation angle (Table T15) was determined from the FlexIt software. The FlexIt tools were typically run for 12-14 h continuously, although battery life of each unit would allow them to run for up to $24 \mathrm{~h}$. The driller recorded the time on bottom (prior to APC firing) for each APC core. Arrival at the seafloor can also be determined by the temperature minimum (typically $2^{\circ}-3^{\circ} \mathrm{C}$ ) recorded by the FlexIt tool. The temperature minimum should be compatible with the drillers log and the time marker in the FlexIt software. The core barrel is held stationary by the driller for at least $5 \mathrm{~min}$ prior to APC firing and a period of steady FlexIt orientation should be recorded during this time interval. The orientation angle is the average angle recorded during this time interval, just prior to APC firing. The quality of the FlexIt orientation angle is a function of the uniformity of the angle during the $\sim 5 \mathrm{~min}$ that the tool and core barrel are held steady prior to firing. Data quality is partly represented by the standard deviation of the orientation angle (Table T15), although other factors such as the length of time over which the orientation angle is measured by the FlexIt tool should be taken into account. In addition, shattered/ split core liners are an indication that the orientation angle may not be reliable. It is noteworthy that the field intensity and inclination recorded by the FlexIt tool are larger than expected for the site location as a result, presumably, of the steeply dipping drill string magnetization. The field intensity can be as much as $50 \%$ greater than the geomagnetic field intensity expected at the site and the inclination several tens of degrees higher. We assume that the drill string does not affect the orientation angle significantly because at present it is difficult to correct for the effect. We account for the declination of the 
present geomagnetic field (the angle between true north and magnetic north) when applying the orientation angle to the remanence declinations.

At Site U1337, unlike most previous Expedition 320 sites, the FlexIt tool was deployed and its data applied throughout the APC sections. The results indicate that the FlexIt tool is far more reliable than its predecessor (the Tensor tool). There are 11 cores for which FlexIt data were inadvertently lost (Cores 321U1337A-19H through 21H; 321-U1337B-17H and $18 \mathrm{H}$; and $321-\mathrm{U} 1337 \mathrm{D}-25 \mathrm{H}, 26 \mathrm{H}$, and $28 \mathrm{H}$ through $30 \mathrm{H})$. The reasons for data loss are not fully understood, although on one occasion the computer was accidentally interrupted during the survey and on another occasion the $9 \mathrm{~V}$ battery in the radio transceiver that initializes the tool and downloads data from the tool abruptly failed at the time of download.

The remanence inclination is close to zero, as expected for a site close to the paleoequator, making inclination not diagnostic of polarity. In the absence of FlexIt core orientation data, resulting $180^{\circ}$ alternations in declination may be correlated to the GPTS as described in "Paleomagnetism" in the "Site U1331" chapter, although this was proved to be impractical at this site.

\section{Results}

Paleomagnetic data for Holes U1337A-U1337D are presented in Figures F18, F19, F20, and F21 together with whole-core magnetic susceptibility data measured on the WRMSL. Measurements of NRM above $93 \mathrm{~m}$ CSF indicate moderate magnetization intensities (on the order of $10^{-3} \mathrm{~A} / \mathrm{m}$ ) with a patchy but generally weak VRM or IRM coring overprint (see "Paleomagnetism" in the "Site U1331" chapter), and polarity reversal sequences are usually clearly recognizable. Agreement in declinations between archive-half sections and discrete samples taken from working halves (blue symbols in Fig. F18) indicate that the radial-inward drilling-induced remanence occasionally reported from previous ODP/IODP cores is not present in these cores.

Below $~ 93$ m CSF, remanence intensities after AF demagnetization at peak field of $20 \mathrm{mT}$ approach magnetometer noise level in the shipboard environment $\left(\sim 2 \times 10^{-5} \mathrm{~A} / \mathrm{m}\right)$. In this zone, sediment magnetizations have been partly overprinted during the coring process, and remanence inclinations are occasionally steep after AF demagnetization at a peak field of 20 $\mathrm{mT}$. Nonetheless, polarity reversals are apparently recorded, although the drilling-related magnetic overprint has not been effectively removed during shipboard demagnetization (Figs. F18, F19, F20, F21). Remanent magnetization intensities and mag- netic susceptibilities go hand in hand downcore with a notable recovery in remanence intensity and susceptibility in the 170-190 m CSF interval (Figs. F18, F19, F20, F21).

At depths where overpull was encountered during core recovery, cores were subsequently collected using a steel core barrel, in order not to endanger the more expensive nonmagnetic barrels. Steel core barrels were used for Cores 321-U1337A-21H and below, 321-U1337B-21H and below, 321-U1337C-4H and below, and 321-U1337D-21H and below. As can be seen from Figures F18, F19, F20, and F21, the magnetic polarity interpretation for these cores was hampered by enhanced magnetic overprint that could not be removed by AF demagnetization at a peak field of $20 \mathrm{mT}$. Particularly where steel core barrels were used, scattered inclinations remain markedly steeper than expected at the site latitude $\left(3^{\circ} 50^{\prime} \mathrm{N}\right)$, even after the demagnetization. It is also notable that remanence intensity tends to be highest near the top of some cores and gradually decreases toward the base, particularly for XCB cores and for APC cores utilizing steel core barrels (Figs. F19C, F20, F21C). Inclinations, although highly scattered, also show a tendency for upward increase within each core. This indicates that the upper parts of the cores are more strongly affected by steep drill stringrelated magnetizations, possibly indicating that the secondary magnetizations are a function not only of the magnetic field strength within the drill string but also by the level of drilling disturbance that is generally enhanced toward the core tops.

We measured the NRM of 14 XCB cores (321U1337A-23X through 36X). Declination changes appear to be random in the XCB cores (Fig. F18C). Inclinations are highly scattered and steeper than expected, on average, even after $20 \mathrm{mT}$ AF demagnetization, which indicates that magnetic overprint acquired during coring could not be removed by AF demagnetization (Fig. F18C). The unfavorable results are most likely caused by relative rotation of core pieces ("biscuits" or "protobiscuits") and remagnetization of fluidized mud filling gaps between biscuits and between a core liner and biscuits (matrix of biscuits) under a strong magnetic field produced by the drill string and the XCB core barrel. Although some of the XCB cores appear to be in excellent condition, showing no visible drilling disturbance, relative rotation of core pieces is apparent from the remanence data of all measured XCB cores.

\section{Magnetostratigraphy}

Our correlation of polarity zones with the GPTS is based on polarity zone pattern fit to the GPTS. Reversal depths are provided in Table T16 and the polarity 
interpretation is shown in Figure F22. All declinations are based on FlexIt orientation information apart from those cores for which the FlexIt data were lost during data acquisition or transfer (see above). There are two intervals of apparent inconsistency in declination (Fig. F22). The first involves the declinations of Core 321-U1337D-14H (137.86-147.36 m CCSF-A), which are nearly antipodal to those of the corresponding intervals in Cores 321-U1337A-15H and $321-\mathrm{U} 1337 \mathrm{~B}-14 \mathrm{H}$. The orientation of Core 321U1337D-14H with the FlexIt tool is uncertain because the stable interval before APC firing was short (Table T15). The other inconsistent interval is for Core 321-U1337D-18H (180.42-189.92 m CCSF-A). In this case, declinations in the upper part of the core contradict those in the corresponding interval of Core 321-U1337A-18H, and the declinations of the lower part of the core are opposite to those of Core 321-U1337B-19H. Because the latter core is consistent in declination with the declinations of Cores 321-U1337C-4H and 321-U1337D-19H in their common intervals, we consider the orientation of Core 321-U1337D-18H to be incorrect, although the core orientation data of the FlexIt tool for this core did not raise suspicion (Table T15).

The polarity interpretation is based on the declination record after demagnetization at a peak field of $20 \mathrm{mT}$ (Fig. F22). Interpretation is hampered by weak magnetization intensities that approach magnetometer noise level in some intervals, particularly below $\sim 100 \mathrm{~m}$ CCSF-A. In the lower part of the record, improved clarity of the declination record in the 190-200 m CCSF-A interval, where magnetization intensities briefly recover, illustrates that magnetization intensity is the principal control on the clarity of the directional NRM record. Without multiple holes and robust correlation among holes, using digital image scans and WRMSL data (see "Stratigraphic correlation and composite section"), a polarity interpretation at this site would be difficult or impossible. As it is, scattered data from one hole are often compensated by less scattered data from another hole, allowing the magnetostratigraphy to be pieced together. The polarity interpretation (Fig. F22), based on polarity zone pattern fit to the GPTS, should be considered tentative and provisional in some intervals, although it is consistent with site biostratigraphy and has been generated independent of it (see "Biostratigraphy"). Our conclusion from this site is that the FlexIt orientation data is generally reliable, although there is an apparent tendency for giving clockwise-deflected declinations to some extent, probably as a result of the effect of the magnetic field of the drill string. Without the FlexIt orientation data an interpretation independent of the biostratig- raphy would not have been possible. Sedimentation rates based on the polarity interpretation indicate a change in mean sedimentation rate at $\sim 3.3 \mathrm{Ma}(\sim 50 \mathrm{~m}$ CCSF-A) with mean sedimentation rates of $\sim 20 \mathrm{~m} / \mathrm{m}$.y. below this level and $\sim 15 \mathrm{~m} / \mathrm{m}$.y. above it (Fig. F23).

\section{Geochemistry}

Shipboard geochemical analyses of interstitial water and bulk sediment samples reflect large variations in sediment composition resulting from shifts in carbonate versus opal production. The large-scale redox state and diagenetic processes of the sediment column are related to overall changes in sediment composition. Interstitial water chemistry is also influenced by a chert layer forming a diffusive boundary at $\sim 240 \mathrm{~m} \mathrm{CSF}$ and seawater circulation in the basement. The basement itself appears to exert little influence on the geochemistry of the sediments and interstitial waters.

\section{Sediment gases sampling and analysis}

A total of 45 headspace gas samples were taken from Hole U1337A at a frequency of one sample per core as part of the routine environmental protection and safety monitoring program. The concentration of methane $\left(\mathrm{C}_{1}\right)$ in the samples ranged between 0.9 and 1.3 ppmv. No hydrocarbon gases higher than $C_{1}$ were detected.

\section{Interstitial water sampling and chemistry}

A total of 85 interstitial water samples were collected from Hole U1337A, 49 using the whole-round squeezing method across the entire hole and 36 in the upper $100 \mathrm{~m}$ CSF by Rhizon sampling (Table T17). Chemical constituents were determined according to the procedures outlined in "Geochemistry" in the "Methods" chapter. Rhizon samplers were inserted into the middle of the whole round through holes predrilled in the end cap at the bottom of sections. This allowed Rhizon samples to be taken adjacent to squeezed whole-round samples and facilitates direct comparison of the two interstitial water sampling techniques in the same hole. Analyses of squeezed and Rhizon-sampled interstitial waters were conducted during the same analytical sessions, and the data from adjacent Rhizon and squeeze samples agree, within the measurement uncertainties, for virtually all analytes (Table T17; Fig. F24). Notable exceptions are the $\mathrm{pH}$ values, which may have increased during the time Rhizon sample splits waited to be measured, and iron, which is higher in some squeezed samples. 
Chloride ion concentration (not corrected for $\mathrm{Br}^{-}$ contribution) varies slightly with depth and ranges from 554 to $566 \mathrm{mM}$ (Fig. F24). Chloride values increase from 554 to $565 \mathrm{mM}$ in the upper section with a peak between 50 and $100 \mathrm{~m} \mathrm{CSF}$, potentially reflecting the more saline bottom waters of the Last Glacial Maximum (e.g., Adkins and Schrag, 2003). However, the precision of the potassium chromate indicator technique is poor compared to the observed variation in chloride, and a potentiometric titration technique (Adkins and Schrag, 2003) would be required to reveal more detail. Alkalinity increases slightly downhole from $2.7 \mathrm{mM}$ in the upper $100 \mathrm{~m}$ CSF to values scattered around $3.8 \mathrm{mM}$ below $300 \mathrm{~m}$ CSF. Sulfate concentrations vary between 26 and $29 \mathrm{mM}$, with slightly decreasing values with depth. An enormous dissolved manganese peak of nearly $150 \mu \mathrm{M}$ at $13 \mathrm{~m}$ CSF is captured by the highresolution interstitial water sampling. Below this, manganese values remain very high at $\sim 100 \mu \mathrm{M}$ until $100 \mathrm{~m}$ CSF, where values decrease in a stepwise manner to barely detectable concentrations at $250 \mathrm{~m}$ CSF. Dissolved iron is sporadically detectable in the upper $200 \mathrm{~m}$ CSF and then increases to a peak of $\sim 5 \mu \mathrm{M}$ between 275 and $300 \mathrm{~m}$ CSF before becoming undetectable again below $400 \mathrm{~m}$ CSF. These variations in manganese and iron reflect changes in redox chemistry, which also manifest as changes in sediment color. For example, below $412 \mathrm{~m}$ CSF in Hole U1337A a sharp transition from pale green to yellow sediments occurs (see "Lithostratigraphy") and the dissolved iron concentration drops below detection. Such tandem changes in sediment color and interstitial water chemistry are well documented for the uppermost sediments where iron hosted in smectites is reduced (Lyle, 1983). However, to find such a redox front in a reversed position, extending from the basement upward, is surprising and suggests seawater has circulated through the basement for some time.

The silicic acid (dissolved silicate) content of the interstitial waters is substantially greater than that of bottom waters (e.g., Peng et al., 1993) and increases with depth from $\sim 700 \mu \mathrm{M}$ in the uppermost sediments to peak at $\sim 1200 \mu \mathrm{M}$ at $\sim 350 \mathrm{~m}$ CSF before decreasing to $\sim 900 \mu \mathrm{M}$ near the basaltic basement. This strong enrichment in silicic acid almost certainly originates from the dissolution and diagenesis of biogenic silica. Interestingly, the downcore pattern of silicic acid does not correspond directly with the occurrence of the biosiliceous sediments, which are mostly concentrated between 93.35 and $214 \mathrm{~m} \mathrm{CSF}$ in lithologic Unit II (see "Lithostratigraphy"). Furthermore, no change in silicic acid was found around the chert layer at $\sim 240 \mathrm{~m}$ CSF. Instead, the maximum silicic acid concentrations occur in the carbonate-rich sediments of lithologic Unit III below the ooze to chalk transition (see "Lithostratigraphy").

Calcium concentrations display very little variation downcore, with values increasing from a seawater value $(\sim 10.5 \mathrm{mM})$ to a maximum of $13 \mathrm{mM}$ between 300 and $350 \mathrm{~m}$ CSF before decreasing to seawater values in the bottom of the hole (Fig. F24). Magnesium and potassium concentrations deviate even less from seawater values, but a slight decrease with depth is evident. As the alteration of basaltic basement exchanges potassium and magnesium for calcium (e.g., Geiskes, 1981), the lack of strong gradients in these elements suggests the basement is no longer reactive at this site.

Lithium concentrations decrease from $\sim 26 \mu \mathrm{M}$ at the surface to $\sim 17 \mu \mathrm{M}$ at $150 \mathrm{~m}$ CSF. Below this, lithium values are relatively constant until $240 \mathrm{~m} \mathrm{CSF}$, where a dramatic decrease to $\sim 7 \mu \mathrm{M}$ is observed. From 250 to $340 \mathrm{~m}$ CSF lithium concentrations are low, fluctuating between 5 and $10 \mu \mathrm{M}$, but then increase with depth to almost seawater values near the basement. The interstitial water strontium profile is a mirror image to that of lithium with a slight increase with depth to $240 \mathrm{~m} \mathrm{CSF}$, where a sharp increase to $\sim 180 \mu \mathrm{M}$ occurs. This maximum in strontium extends for the next $\sim 100 \mathrm{~m}$ downhole before values decrease toward seawaterlike values near the basement. The lithium and strontium profiles reveal a strong barrier to diffusion at $240 \mathrm{~m}$ CSF where a chert/porcellanite layer was found (see "Lithostratigraphy" and "Downhole measurements"). A distinctive decrease in dissolved sulfate also occurs below this chert layer, whereas other tracers vary little across this physical boundary. Below the chert layer a source of strontium to the pore waters exists, which is most likely the dissolution and recrystallization of biogenic calcite (e.g., Baker et al., 1982). Conversely, there seems to be a sink for dissolved lithium below the chert layer, but the nature of this sink remains unknown. The lithium and strontium profiles, along with the calcium, magnesium, and silicic acid profiles, all indicate seawater circulation in the basement, as their values tend toward seawater values near the basement.

The concentration of barium is below the detection limit $(0.8 \mu \mathrm{M}$ in an undiluted sample) in all but four samples, which is not surprising given the high dissolved sulfate concentrations throughout the sediments. Boron concentrations range between 440 and $400 \mu \mathrm{M}$, showing a slight decrease from top to basement. 


\section{Bulk sediment geochemistry Major and minor elements}

At Site U1337, bulk sediment samples at a frequency of one per core were analyzed for sulfur, aluminum, iron, manganese, magnesium, calcium, sodium, potassium, titanium, phosphorus, barium, copper, chromium, scandium, strontium, vanadium, yttrium, and ziconium (Table T18).

The aluminum, magnesium, iron, and barium contents of the bulk sediment all follow a similar pattern, decreasing from a maximum in the upper $100 \mathrm{~m} \mathrm{CSF}$ to a low at $\sim 250 \mathrm{~m}$ CSF before a distinctive peak at $\sim 350 \mathrm{~m} \mathrm{CSF}$, followed by a further decrease toward the base of the sediment column. The calcium and strontium content of the bulk sediments effectively mirrors that of the aluminum group, indicating an important role played by dilution with carbonate. The $\mathrm{SiO}_{2}$ content of the bulk sediment is distinctive, with a broad peak between $40 \%$ to $50 \%$ in the uppermost $100 \mathrm{~m}$ CSF, a smaller second peak between 150 and $250 \mathrm{~m} \mathrm{CSF}$, and a third peak of $\sim 30 \% \mathrm{SiO}_{2}$ centered around $350 \mathrm{~m}$ CSF. Between 190 and $250 \mathrm{~m}$ CSF three samples have $\mathrm{SiO}_{2}$ contents $>50 \%$ and one sample is as $\mathrm{SiO}_{2}$ rich as 70\% (Fig. F25).

\section{Sedimentary inorganic and organic carbon}

Calcium carbonate and inorganic carbon concentrations were determined on 283 sediment samples from Hole U1337A and 28 from Hole U1337B (Table T19; Fig. F26). Cores 321-U1337A-22X through 25X were recovered by $\mathrm{XCB}$, and as discontinuity and core disturbance was expected in this interval, additional samples were taken from Hole U1337B. Calcium carbonate concentrations vary greatly in the upper two lithologic units (see "Lithostratigraphy"), from 30 to $90 \mathrm{wt} \%$, reflecting the alternation between calcite and opal. In lithologic Unit III, calcium carbonate contents are generally high, scattered around $80 \mathrm{wt} \%$, but a distinctive decrease is observed between 350 and 400 m CCSF-A.

The concentration of TOC was determined for 47 sediment samples from Holes U1337A and U1337B (Table T19; Fig. F26). In the upper 235 m CCSF-A, TOC content ranges between 0.10 and $0.34 \mathrm{wt} \%$, except for the high value of $0.72 \mathrm{wt} \%$ in the uppermost sample. TOC content increases at $44.00 \mathrm{~m}$ CCSF-A and in the interval from 87.28 to $108.59 \mathrm{~m}$ CCSF-A. Below $235 \mathrm{~m}$ CCSF-A, TOC values are generally $<0.10 \mathrm{wt} \%$; however, transient increases to 0.74 and $0.17 \mathrm{wt} \%$ are observed in samples from 267.46 and $441.08 \mathrm{~m}$ CCSF-A, respectively. Such downhole variability of TOC content is most likely related to lithology with higher TOC being found in the more siliceous rich intervals.

\section{Physical properties}

Physical properties at Site U1337 were measured on whole cores, split cores, and discrete samples. WRMSL measurements (GRA bulk density, magnetic susceptibility, and $P$-wave velocity), thermal conductivity, and NGR measurements comprised the wholecore measurements. Compressional wave velocity measurements on split cores and MAD analyses on discrete core samples were made at a frequency of one per undisturbed section in Hole U1337A and in Cores 321-U1337B-22H through 26H. The SHMSL was used to measure spectral reflectance on all archive-half sections.

\section{Density and porosity}

Two methods were used to determine bulk sediment properties at Site U1337, GRA for the bulk density of whole-round sections (Fig. F27A) and MAD analyses for wet bulk density, dry bulk density, grain density, water content, and porosity of discrete samples (Fig. F28; Table T20). MAD and GRA bulk density measurements display the same trends at Site U1337 (Fig. F28B), although in lithologic Unit I the wet bulk density from the MAD analyses averages $0.05 \mathrm{~g} / \mathrm{cm}^{3}$ less than the GRA bulk density. This difference most likely reflects the calibration of the GRA sensor with aluminum (density $=2.7 \mathrm{~g} / \mathrm{cm}^{3}$ ) and the abundant biogenic silica (grain density $=\sim 2.2 \mathrm{~g} / \mathrm{cm}^{3}$ ) in Unit I. Cross-plots of wet bulk density and dry bulk density versus interpolated GRA bulk density (Fig. F29) show excellent correlation between the MAD and GRA density data for both APC- and XCB-cored intervals.

Variation in wet bulk density corresponds to lithologic changes at Site U1337. Wet bulk density is low $\left(1.12-1.46 \mathrm{~g} / \mathrm{cm}^{3}\right)$ and variable in lithologic Unit I. Variations in the abundance of siliceous and calcareous components and clay are responsible for the differences in wet bulk density. Intervals rich in clay, diatoms, or radiolarians generally are less dense than the nannofossil-rich intervals. This pattern is reflected in a well-defined, direct relationship between carbonate content and wet bulk density at Site U1337 (Fig. F30). Wet bulk density increases slightly with depth in Unit II (Fig. F28B); however, this trend is reversed by a pronounced density minimum $\left(1.2 \mathrm{~g} / \mathrm{cm}^{3}\right)$ associated with a diatom-rich interval at $180 \mathrm{~m}$ CSF. At the boundary between lithologic Units II and III, wet bulk density increases sharply to $\sim 1.55 \mathrm{~g} / \mathrm{cm}^{3}$, reflecting the increase in calcareous components within the sediment. Density is more uniform in Unit III as a result of the uniformly high carbonate content of the nannofossil oozes of this unit (see "Geochemistry"). Wet bulk density generally increases with depth in Unit III; however, this 
trend is interrupted by a density minimum $\left(1.3 \mathrm{~g} / \mathrm{cm}^{3}\right)$ at $340 \mathrm{~m}$ CSF. Below this depth, the density gradient increases, accompanying the change from nannofossil ooze to nannofossil chalk. The bulk densities of the basal chalk at Site U1337 are the highest in the sediment column, $\sim 1.90$ to $1.95 \mathrm{~g} / \mathrm{cm}^{3}$.

Variations in grain density at Site U1337 follow the changes in lithology (Fig. F28C). The lithologically diverse Units I and II are characterized by a wide range in grain density $\left(2.17-2.85 \mathrm{~g} / \mathrm{cm}^{3}\right)$ and a low average grain density $\left(2.51 \mathrm{~g} / \mathrm{cm}^{3}\right)$. The more uniform and more calcareous nannofossil ooze of Unit III is characterized by less variable grain density $\left(2.30-2.82 \mathrm{~g} / \mathrm{cm}^{3}\right)$ and a higher average grain density $\left(2.67 \mathrm{~g} / \mathrm{cm}^{3}\right)$. The uniform trend in grain density in Unit III is interrupted by a minimum $\left(2.3 \mathrm{~g} / \mathrm{cm}^{3}\right)$ at $340 \mathrm{~m}$ CSF that is associated with a radiolarian-rich interval (see "Lithostratigraphy").

Porosity and water content vary inversely with wet bulk density (Fig. F28A). The highest porosities occur in Unit I, varying from $74 \%$ to $93 \%$. Porosities decrease slightly with depth in Unit II but remain high $(>80 \%)$. At the boundary between Units II and III porosity decreases sharply to 55\% (Fig. F28A). Below this depth, the trend in decreasing porosity with depth is marked by a maximum (81\%) in the radiolarian-rich interval at $340 \mathrm{~m}$ CSF and a change in gradient below this depth associated with the transition to nannofossil chalk. The porosity of the chalk immediately above the basement at Site U1337 is $\sim 47 \%$.

\section{Magnetic susceptibility}

Whole-core magnetic susceptibility measurements correlate well with the major differences in lithology at Site U1337 (Fig. F27B). Susceptibility is highest in lithologic Unit I and shows high-amplitude and high-frequency variations from $4 \times 10^{-5}$ to $18 \times 10^{-5}$ SI. These variations are characterized by low values in more calcareous intervals and higher values in more siliceous intervals. Across the boundary between Units I and II, susceptibility decreases from $\sim 14 \times 10^{-5}$ to near $2 \times 10^{-5} \mathrm{SI}$ and remains low for the remainder of the section. Magnetic susceptibility increases in Unit II from $\sim 2 \times 10^{-5}$ to $\sim 15 \times 10^{-5}$ SI at $180 \mathrm{~m}$ CSF associated with the diatom-rich interval at this depth. Below $180 \mathrm{~m}$ CSF, susceptibility drops back to $2 \times 10^{-5}$ SI for the remainder of Unit II. In Unit III, a similar increase from $\sim 2 \times 10^{-5}$ to $\sim 13 \times 10^{-5}$ SI at $340 \mathrm{~m}$ CSF is associated with a radiolarian-rich interval. An abrupt increase in magnetic susceptibility from $\sim 2 \times 10^{-5}$ to $\sim 10 \times 10^{-5} \mathrm{SI}$ is present at the base of Unit III.

\section{Compressional wave velocity}

$P$-wave logger (PWL) velocity measurements from whole-round sections and discrete velocity measurements made on split cores follow similar trends at Site U1337. Velocity fluctuates around $1500 \mathrm{~m} / \mathrm{s}$ for lithologic Units I and II. In Unit III, velocities begin to increase with depth relating to increased compaction (Fig. F31). A similar increase in velocity is present in the well log data (see "Downhole measurements").

During the initial sampling of Hole U1337A it was observed that $x$-directed velocities were consistently higher than the other velocity measurements. Measurements of the velocity of water using the contact probe ( $x$-direction) were higher $(\sim 1540 \mathrm{~m} / \mathrm{s})$ than the known velocity of water at room temperature (1485$1490 \mathrm{~m} / \mathrm{s}$ ), probably as a result of incorrect calibration parameters (liner thickness $=3.2 \mathrm{~mm}$; system delay $=20.61 \mu \mathrm{s}$; liner delay $=1.5 \mu \mathrm{s}$ ). After recalibrating the contact probe by measuring the velocity of water at room temperature and varying the distance between the $x$-axis transducers, new calibration parameters were determined (liner thickness = $2.7 \mathrm{~mm}$; system delay $=19.811 \mu \mathrm{s}$; liner delay $=$ $1.26 \mu \mathrm{s})$. These new parameters yield a reasonable velocity of water $(\sim 1495 \mathrm{~m} / \mathrm{s})$ at room temperature. The velocity of water obtained from the PWL was consistently low $(\sim 1450 \mathrm{~m} / \mathrm{s})$ for the quality assurance/ quality control liner. Therefore, it was decided to add a constant shift of $40 \mathrm{~m} / \mathrm{s}$ to the velocity derived from the PWL. After the correction, PWL results are in excellent agreement with discrete sample velocity measurements (Table T21; Fig. F31). Differences between whole-core and split-core measurements possibly reflect the presence of water in the space between the core liner and sediment in the whole cores and the slight compaction of the sediment in the contact probe technique. No $y$ - or $z$-axis measurements were taken below $287 \mathrm{~m} \mathrm{CSF}$, as the XCBcored sediment was hard and fractured easily with insertion of the transducers. Beginning with Core 321-U1337A-37X (340 m CSF), discrete samples were cut from the biscuits to measure velocity along the $z$-axis using the $x$-axis measurement systems. The effect of liner correction was removed to obtain the correct velocity.

Velocity at Site U1337 displays high-frequency fluctuations between 1490 to $1530 \mathrm{~m} / \mathrm{s}$ in lithologic Unit I and between 1490 and $1510 \mathrm{~m} / \mathrm{s}$ in Unit II. An increase in velocity from 1510 to $1560 \mathrm{~m} / \mathrm{s}$ occurs at $\sim 200 \mathrm{~m} \mathrm{CSF}$ at the base of Unit II. This increase is probably related to the presence of a diatom mat interval. At $\sim 340 \mathrm{~m}$ CSF, velocities begin to increase rapidly in Unit III, from 1510 to $\sim 1800 \mathrm{~m} / \mathrm{s}$ at the base of Unit III (Figs. F27C, F31). The velocity of the 
basalt basement was determined for one sample to be $6212 \mathrm{~m} / \mathrm{s}$.

\section{Natural gamma radiation}

NGR was measured on cores from all holes drilled at Site U1337. The highest counts per second are present in the upper $10 \mathrm{~m}$ of the sediment column, with values of $\sim 65$ cps near the seafloor (Fig. F27D). Below $10 \mathrm{~m}$ CSF, the NGR signal is characterized by small variations centered around $4 \mathrm{cps}$. From lithologic Unit II to Unit III, the strength of the NGR signal decreases further with most of the variation centered around 2 cps. Although NGR counts are low in Unit III, variations are associated with significant changes in sediment composition. Examples of these variations are shown in the $\sim 8$ cps increase in NGR centered on the chert rubble interval in Core 321U1337D-28H (Fig. F32A) and the color change from greenish gray to pale yellow in Core 321-U1337A$44 \mathrm{X}$ (Fig. F32B). Both of these intervals display peaks in uranium abundance, as indicated in borehole spectral gamma logs (see "Downhole measurements"). In the chert rubble it is assumed that the uranium is associated with organic matter. The color change from green to yellow represents a redox boundary along which uranium is concentrated. Comparison of results of carbon analyses and NGR records for Hole U1337A suggests a correlation between the weight percent TOC and NGR counts for TOC values $<0.4 \mathrm{wt} \%$. (Fig. F33). Samples with TOC values $>0.7 \mathrm{wt} \%$ do not fit the trend of the correlation. These samples include a near-surface sample with an NGR value of $\sim 40 \mathrm{cps}$ and a sample from 243.1 m CSF in Hole U1337A, close to the interval of the prominent chert layer in Unit III.

\section{Thermal conductivity}

Thermal conductivity was measured on the third section of each core from Hole U1337A that contained at least three sections (Table T22). Thermal conductivity increases gradually with depth at Site U1337 from a conductivity of $0.75 \mathrm{~W} /(\mathrm{m} \cdot \mathrm{K})$ at $9.25 \mathrm{~m} \mathrm{CSF}$ to $1.64 \mathrm{~W} /(\mathrm{m} \cdot \mathrm{K})$ at $446.95 \mathrm{~m} \mathrm{CSF}$ (Fig. F34). A local maxima in thermal conductivity occurs at $370.55 \mathrm{~m}$ CSF where the conductivity is $1.76 \mathrm{~W} /(\mathrm{m} \cdot \mathrm{K})$. The amplitude of conductivity variations increases below $220 \mathrm{~m} \mathrm{CSF}$, coinciding with the XCB-cored section of Hole U1337A, and possibly reflects differences among intact and disturbed intervals in the cores. Thermal conductivity at Site U1337 is inversely correlated to porosity (Fig. F35). Lower conductivity occurs with higher porosity, as increased interstitial spacing attenuates the applied current from the probe.

\section{Reflectance spectroscopy}

Spectral reflectance was measured on the archive-half sections from all holes at Site U1337 using the SHMSL. The three color parameters, $\mathrm{L}^{*}, \mathrm{a}^{*}$, and $\mathrm{b}^{*}$, show a systematic variation among the lithologic units (Fig. F36). Unit I is characterized by dark colors (low $\mathrm{L}^{*}$ ) dominated by a mix of yellow (positive $a^{\star}$ ) and red (positive $b^{*}$ ). High-amplitude changes in the color parameters reflect the mix of lithologic components within the unit. At the boundary between lithologic Units I and II, $\mathrm{a}^{*}$ and $\mathrm{b}^{*}$ decrease sharply indicating an increase in blue and green components as the sediment takes on the greenish gray coloring of the nannofossil ooze. Luminance $\left(\mathrm{L}^{*}\right)$ increases toward the base of Unit I, and overall Unit II is characterized by a higher luminance than that of Unit I. Values of $a^{*}$ and $b^{*}$ are similar for lithologic Units II and III. The main difference in the color of the two units is the lighter color (more positive $\mathrm{L}^{*}$ ) of Unit III. Below $410 \mathrm{~m}$ CSF in Unit III, $\mathrm{a}^{*}$ and $\mathrm{b}^{*}$ increase sharply as the nannofossil ooze changes from greenish gray to pale yellow. Near the base of the sediment column at Site U1337, the increase in $\mathrm{a}^{*}$ values and the decrease in luminance represent the change from pale yellow to pale brown nannofossil ooze.

\section{Stratigraphic correlation and composite section}

Special Task Multisensor Logger data were collected at $5 \mathrm{~cm}$ intervals from Holes U1337B-U1337D and compared to the Whole-Round Multisensor Track (WRMST) data obtained at $2.5 \mathrm{~cm}$ resolution from Hole U1337A. In this way drilling was monitored in holes after Hole U1337A in real time to maximize the opportunity for the recovery and construction of a stratigraphically complete composite section. Cores from Holes U1337B to U1337D were measured on the WRMST for final correlation. After the cores were split and described, a composite section and spliced sequence were constructed.

Magnetic susceptibility, NGR, GRA bulk density, light reflectance $\left(\mathrm{L}^{*}\right)$, and scanned images all contributed to correlation between holes at Site U1337. GRA and magnetic susceptibility are illustrated in Figures F37 and F38. Features between all records are well aligned to $\sim 220 \mathrm{~m}$ CCSF-A. Offsets and composite depths are listed in Table T23.

Below 220 m CCSF-A, a confused interval of $\sim 50 \mathrm{~m}$ was characterized by incomplete recovery in all holes (Fig. F39). A short gap may persist at $220 \mathrm{~m}$ CCSF-A and Core 321-U1337C-9H has been appended to the bottom of Core 321-U1337C-8H, suggesting another short break in recovery. At 265 m CCSF-A a definite 
break occurs apparently caused by poor recovery of a hard chert layer. Comparison of GRA records with downhole density logs (see "Downhole measurements") indicate that most of the section is represented in the cored material. Between 265 and $440 \mathrm{~m}$ CCSF-A a continuous correlation can be made although the amplitude of the variations in properties are such that there may be some incorrect tie points. A major gap occurs at $440 \mathrm{~m}$ CCSF-A where Core 321-U1337A-44X is appended to Core 321-U1337A43X. Particularly puzzling is the large gap seen in Holes U1337C and U1337D at the same level. This "void" is the result of forcing the color change at $\sim 445 \mathrm{~m}$ CCSF-A to the same level at all holes. It may be that this color change occurs higher in the section at the latter two holes than in Hole U1337A. This question is not resolvable using data available. Splice tie points are listed in Table T24.

A growth factor of 1.12 is calculated by linear regression of CSF versus CCSF-A for all Site U1337 cores, indicating a $12 \%$ increase in CCSF-A relative to CSF depth (Fig. F14). We used this value to calculate the CCSF-B scale presented in Table T23 to aid in the calculation of sedimentation and mass accumulation rates.

\section{Sedimentation rates}

All principal biostratigraphic datums and a set of 26 tentatively interpreted paleomagnetic reversals (restricted to the APC-cored sections) (Table T25; see also "Biostratigraphy" and "Paleomagnetism") were used in establishing age control (Fig. F40). The linear sedimentation rate at Site U1337 decreases from $21 \mathrm{~m} / \mathrm{m} . \mathrm{y}$. in the middle Miocene to $17 \mathrm{~m} / \mathrm{m}$.y. in the late Miocene and stays relatively constant in the remainder of the section (Fig. F40).

\section{Downhole measurements}

\section{Logging operations}

Downhole logging of Hole U1337A started after APC/XCB coring to a total depth of $449.8 \mathrm{~m}$ DSF ended on 23 May 2009 at 0245 h (all times are U.S. Pacific Daylight Savings Time; UTC $-7 \mathrm{~h}$ ). While drilling the last three cores, the hole was checked for fill at the bottom and no fill was detected. In preparation for logging, the hole was flushed with a $\sim 50 \mathrm{bbl}$ sweep of sepiolite/attapulgite mud ( 9 ppg) followed by a wiper trip up to $80 \mathrm{~m}$ DSF and down to the bottom. No tight spots were encountered during the reaming, and no fill was noted at the bottom. A go-devil was then pumped through the drill string to open and lock the lockable flapper valve located above the bit. Finally, the hole was displaced with barite/attapulgite mud ( 10 ppg) and the bit was raised to the final logging depth of $83.3 \mathrm{~m}$ DSF.

We deployed three downhole tool strings in Hole U1337A: (1) a modified triple combo that did not include a neutron porosity measurement, (2) an FMS-sonic combination, and (3) a VSI tool with a Scintillation Gamma Ray (SGT-N) sonde. For tool and measurement acronyms, see "Downhole measurements" in the "Methods" chapter.

The modified triple combo was lowered into the hole at $1410 \mathrm{~h}$ on $23 \mathrm{May}$, and after some testing and adjustment of the WHC the tool string, reached the bottom of the hole (4885 m wireline log depth below rig floor [WRF]). A first uphole logging pass started at 2020 h (Fig. F41). The tool string was lowered back to the bottom of the hole and a second uphole pass started at $2248 \mathrm{~h}$. This second run ended when the tool string crossed the seafloor, marked by a peak in natural radioactivity clearly visible in the Hostile Environment Natural Gamma Ray Sonde (HNGS) measurement. The seafloor was detected at $4442.5 \mathrm{~m}$ WRF, which is significantly different from the drillers seafloor of $4472 \mathrm{~m}$ DRF. This discrepancy is mostly due to a wheel axle breaking in the depth measuring mechanism on the wireline winch. This failure occurred and was repaired while the tool was above the open hole interval; therefore, it does not affect the accuracy of the wireline depths relative to the seafloor. The modified triple combo reached the rig floor and was rigged down at $0421 \mathrm{~h}$ on 24 May.

The planned VSP at Site U1337 was shot during the daylight hours of 24 May in order to maintain a watch for the presence of marine mammals. The VSI tool was deployed in the second tool string together with a SGT-N tool to detect the seafloor. While the VSI/SGT-N combination was being lowered in the hole, the marine mammal watch started at $0645 \mathrm{~h}$ and the air guns began ramping up the shooting a half-hour later. The first VSI station was taken at $1010 \mathrm{~h}$ immediately above the base of the hole (4912.8 m WRF). We took as many as five shot records at each station for stacking and moved the tool string uphole by $15 \mathrm{~m}$ between stations. VSP operations were interrupted at $1213 \mathrm{~h}$ when a hydraulic hose failed on the WHC. Given that the ship's heave was no more than $1 \mathrm{~m}$ peak to trough and that a delay would have required cutting short the VSP experiment at sundown, we decided to continue acquiring data and to repair the WHC during the rig-up of the third tool string. We acquired 16 successful VSP stations up to $4688.1 \mathrm{~m} \mathrm{WRF}$; three shallower stations were attempted, but the VSI tool could not be coupled to the borehole wall because of an enlarged hole and the soft formation. At $1515 \mathrm{~h}$ we decided to end VSP operations and started logging with the SGT-N 
tool, detecting the seafloor at $4474 \mathrm{~m}$ WRF. Rigdown was completed at $1820 \mathrm{~h}$.

The third and final wireline tool string deployed in Hole U1337A was the FMS-sonic combination (Fig. F42). The FMS-sonic tool string was lowered in the hole at $2005 \mathrm{~h}$, and after some testing of the WHC it reached the bottom of the hole at $4914.3 \mathrm{~m}$ WRF. The first uphole logging pass started at $0125 \mathrm{~h}$ on 25 May and ended at $0235 \mathrm{~h}$. After returning to the bottom of the hole, the second pass started at $0310 \mathrm{~h}$ and ended after reaching the seafloor at $4467 \mathrm{~m}$ WRF. Rig-down was completed at $0838 \mathrm{~h}$.

\section{Downhole log data quality}

Figures F4 and F43 show a summary of the downhole log data acquired in Hole U1337A. These data were processed to convert to depth below seafloor and to match depths between different logging runs, resulting in the WMSF depth scale (see "Downhole measurements" in the "Methods" chapter).

The overall quality of the logging data can be assessed from the repeatability of measurements acquired in different passes and by comparing downhole $\log$ data to core measurements. In general, downhole log data acquired in Hole U1337A show excellent repeatability between passes (Figs. F4, F43). A key factor that influences downhole log data quality is the size and irregularity of the borehole, especially for measurements that require a good contact with the borehole wall (e.g., density measured by the Hostile Environment Litho-Density Sonde [HLDS] and resistivity images obtained by the FMS tool). The "hole diameter" track in Figure F4 is measured by a caliper arm on the HNGS and shows a hole generally well above the bit diameter (11.4375 inches), with values greater than the maximum measurable range ( 18 inches) above $210 \mathrm{~m}$ WMSF. Despite the occasionally large hole, HLDS density data are of high quality, as shown by their close correlation with MAD core measurements on discrete core samples and with the electrical resistivity logs, which are relatively insensitive to hole size. There is only one interval where the densities logged in the two passes differ significantly, between 110 and $140 \mathrm{~m}$ WMSF (Fig. F4). This difference is most likely due to poor contact with the formation in the second logging pass, which resulted in anomalously low density measurements; the higher densities measured in the first pass are the more reliable values.

Resistivities obtained by the electrode spherically focused resistivity (SFLU) measurement were lower than those obtained in induction measurements (e.g., medium induction phasor-processed resistivity in Fig. F4), probably because of current loss at the electrodes. The higher induction resistivities are closer to values typically measured in deep-sea sediments, and we applied a simple empirical correction to the SFLU data by multiplying them by a constant factor of 1.6. This correction brings the overall measured resistivity values in close agreement.

$P$-wave velocities measured by the Dipole Sonic Imager (DSI) in the two logging passes closely agree in the lower part of Hole U1337A, below $230 \mathrm{~m}$ WMSF (Fig. F4). Above this depth, the processing of the sonic log waveforms was unable to distinguish the formation velocities from those of the fluid circulating in the hole $(\sim 1500 \mathrm{~m} / \mathrm{s})$. Core measurements (see "Physical properties") and results of the VSP experiment (see below) also indicate velocities near or just above $1500 \mathrm{~m} / \mathrm{s}$ in the top $200 \mathrm{~m}$ of the hole.

Figure F43 compares spectral gamma ray logs acquired by the HNGS in the triple combo and FMSsonic tool strings. The gamma ray measurement is highly attenuated when the tool is inside the bottom hole assembly and the drill pipe (above $77 \mathrm{~m}$ WMSF in Hole U1337A), and data in this interval should only be used qualitatively. The total gamma ray log is very similar in the two passes illustrated in Figure F43; in the spectral data, some features are repeatable (e.g., the uranium peaks around $240 \mathrm{~m}$ WMSF and at the seafloor), whereas others are less so (e.g., in the thorium log). Spectral gamma ray features that are not repeatable in different passes may not be reliable.

In Hole U1337A, we also acquired FMS electrical resistivity images. The quality of these measurements depends on close contact between the measuring pads on the tool and the borehole wall. The FMS borehole images are of high quality between $\sim 200 \mathrm{~m}$ WMSF and the base of the logged interval, where they accurately reproduce sediment layers. Above $200 \mathrm{~m}$ WMSF, the hole is significantly enlarged and the images are marred by low-resistivity swaths, which are likely caused by poor contact between the tool pads and the borehole wall.

Finally, hole diameters measured by the HLDS caliper arm (Fig. F4) and by the FMS tool (not shown) were not consistent, with the HLDS caliper, measuring a 3-4 inch larger diameter. The tool calipers were recalibrated after logging Hole U1337A; although the recalibration reduced the differences in the hole diameters, the two measurements are still not the same. This difference may be due to the different shape of the pads at the end of the caliper arms. The larger FMS pads may smooth out small-scale irregularities in the borehole wall and thus measure a smaller hole diameter. 


\section{Logging units}

Downhole log measurements of bulk density, electrical resistivity, and $P$-wave velocity in Hole U1337A correlate very well (Fig. F4). The likely reason is that variations in sediment composition result in variations of porosity, and changes in porosity affect similarly bulk density, resistivity, and $P$-wave velocity. High porosities obviously result in low bulk densities. Also, resistivity variations in water-saturated sediments are controlled by variations in their content of pore water, which is the component of bulk sediment that conducts electricity. Finally, laboratory measurements and rock-physics models show that $P$-wave velocities in sediments decrease with increasing porosity. Details on these fundamental relationships between porosity and logged properties are given by Hearst and Nelson (1985) and Ellis and Singer (2007).

The downhole logs of gamma ray radioactivity (Fig. F43) are controlled by the sediment content of naturally occurring radioactive elements (potassium, uranium, and thorium) and do not closely depend on porosity. The most significant features in the gamma ray logs are the peaks in uranium content at the seafloor and $240 \mathrm{~m}$ WMSF. The seafloor peak is notably large, as it is attenuated because the tool is measuring through the drill pipe (see above) and it matches a peak in natural gamma ray counts made on the cores immediately below the seafloor (see "Physical properties"). The uranium peak at $240 \mathrm{~m}$ WMSF corresponds to a chert layer that was only recovered in fragments and that is clearly seen in the FMS images as a $\sim 40 \mathrm{~cm}$ thick high-resistivity layer (see next section and Fig. F44).

We divided the logged section into three units on the basis of the overall variation of density, resistivity, and $P$-wave velocity. Logging Unit 1 (from the base of the drill pipe at $77 \mathrm{~m}$ WMSF to $212 \mathrm{~m}$ WMSF) has low densities and resistivities that are variable but show no trend with depth and mostly corresponds to lithologic Unit II (see "Lithostratigraphy"). The transition between logging Units 1 and 2 is marked by a distinct increase in logged densities and resistivities and corresponds to the transition between lithologic Units II and III. Whereas density and resistivity do not show a trend with depth in logging Unit 2, Unit 3 (from $339 \mathrm{~m}$ WMSF to the base of the logged interval) displays a clear increase with depth of density, resistivity, and $P$-wave velocity. This increase is probably due to lithification of the pelagic carbonate oozes in lithologic Unit III, which turn in to chalk at the base of the sediment column of Site U1337 (see "Lithostratigraphy").

\section{Core-log correlation}

By comparing the continuous wireline logging data to measurements taken on the core we can start piecing together a more complete recovery story and identify where there may be gaps in the core record for Site U1337. Additionally, the logs provide in situ physical property measurement of formations downhole. Here we make a first attempt to correlate core photographs and GRA density data from the core with the continuous downhole logging density measurements (Fig. F44). We focus on an interval of interest where core recovery was particularly poor to determine the amount of core missing between 230 and $250 \mathrm{~m}$ WMSF. At $240 \mathrm{~m}$ WMSF, a layer showing very high resistivity is observed in the FMS images (Fig. F44C). Above and below this band are contrastingly conductive layers. The resistive layer corresponds to a $40 \mathrm{~cm}$ thick chert, which is only recovered in the core as rubble, whereas the enveloping conductive layers are two diatom mat units $(160 \mathrm{~cm}$ thick above the chert layer and $60 \mathrm{~cm}$ thick below). The presence of these two markedly different formations in the FMS images is complemented by the wireline HLDS density measurement, which shows a decrease in density to $\sim 1.4 \mathrm{~g} / \mathrm{cm}^{3}$ where the conductive layers (diatom mats) are observed and a peak in density at $\sim 1.8 \mathrm{~g} / \mathrm{cm}^{3}$ at the chert unit (Fig. F44B). In contrast, the HNGS (spectral gamma ray) logging data shows a peak of $\sim 15$ gAPI at the chert unit (previously discussed) and very little variability either side (Fig. F44A).

We used the location of the top and base of the diatom mats surrounding the chert to line up the core photographs and their associated GRA density measurements with the FMS images. It must be noted that none of the core image/measurements have been distorted from the original to better fit the wireline data; therefore, the fit of the logging and core data sets is by no means perfect. We did not consider changes in original in situ formation thickness caused by expansion and contraction of the core following recovery. In the correlation process we matched broad patterns and changes in density curves rather than small-scale variations.

The core GRA density data fit fairly well to the HLDS density above the chert layer and show intermediateto high-density values dropping to much lower values in the diatom mat unit (Fig. F44D-F44G). In Hole U1337A, there is a large gap in core recovery below $240 \mathrm{~m}$ WMSF, beneath the chert layer; Hole U1337B was terminated at this depth because of a stuck core barrel. However, some remnants of the chert in the form of chert rubble are seen in Cores 321-U1337C-11X and 321-U1337D-27X. The chert layer has likely been fragmented by the drilling pro- 
cess, resulting in disturbed core sections and chert rubble forced further downsection. The chert rubble has elevated the GRA density values taken in the upper part of Core 321-U1337D-27X, so that the data are no longer representative of the formation at this level (Fig. F44G). Additionally, as previously mentioned, diatom mats have been used as "line-up" markers, but in Hole U1337D much lighter colored sediment (not visible in Fig. F44) occurs above the identified diatom mat in Core 321-U1337D-28H, suggesting that the core should perhaps reside lower on the depth scale (see gray dashed lines in Fig. F44). However, even if Core 321-U1337D-28H were moved, there is only $\sim \mathrm{m}$ of section missing from Site U1337. The best fit of the GRA density measurements to the logged density below the chert layer is seen in Core 321-U1337C-12X, in which the close correspondence of the curves gives some confidence on the core location on the WMSF depth scale. Additionally, in the CSF depth scale the base of Core 321$\mathrm{U} 1337 \mathrm{C}-11 \mathrm{X}$ is at $238.96 \mathrm{~m} \mathrm{CSF}$ and the top of Core $321-\mathrm{U} 1337 \mathrm{C}-12 \mathrm{X}$ is at $240.50 \mathrm{~m} \mathrm{CSF}, 1.54 \mathrm{~m}$ apart. This is similar to the distance between the images of these cores in our correlation (Fig. F44F). More detailed postexpedition work will refine these core-log correlations.

\section{Vertical seismic profile}

Figure F45A shows the stacked waveforms measured at 16 stations (214.1-438.4 m WSF) by the vertical direction geophone in the VSI. The waveforms show two clear events: a direct arrival, where the arrival times (red dots) increase with increasing receiver depths, and a later event with smaller amplitude and opposite polarity that instead arrives earlier at deeper receivers. The latter event is a strong reflection from the top of the basaltic oceanic basement. The basement reflection converges with the first arrival at the base of Hole U1337A, which reaches the top of the basalt.

Table T26 lists the values of the measured and corrected one-way arrival times from VSP in Hole U1337A. The measured traveltimes are the differences between the arrival of the acoustic pulse at a hydrophone located immediately below the air gun source and the arrival at the borehole receiver. The corrected traveltimes are the traveltimes from the sea surface to the borehole receiver and account for the depth of the air guns (7 mbsl) and for the depth of the hydrophone below the air guns $(2 \mathrm{~m})$. More details on the VSP measurement procedure are in "Downhole measurements" in the "Methods" chapter.

Figure F45B shows the relationship between depth below seafloor in Hole U1337A and the TWT, which is the traveltime to reflectors in surface seismic sections. To construct this relationship, we start from the TWT from sea level to the seafloor (5.9444 s), computed from the uncorrected seafloor depth measured by the ship's echo sounder $(4458.3 \mathrm{~m})$. The difference between this time and the arrival time to the shallowest receiver in the VSP gives an average $P$ wave velocity of $1514 \mathrm{~m} / \mathrm{s}$ between the seafloor and $214.1 \mathrm{~m}$ WSF. At first approximation, the traveltimedepth relationship in Figure F45 assumes a constant velocity in the interval 0-214.1 $\mathrm{m}$ WSF. The dependence of the arrival times on depth in the VSP receiver array can be fit very closely by a second degree polynomial:

$$
t(z)=5.9414+\left(1.4378 \times 10^{-3}\right) z-\left(4.8984 \times 10^{-7}\right) z^{2},
$$

where $t$ is TWT (s) and $z$ is depth below seafloor (214.1 $\leq z \leq 438.8 \mathrm{~m}$ WSF). The maximum residual on this fit is $0.45 \mathrm{~ms}$ and the root-mean-square residual $0.23 \mathrm{~ms}$.

The variation of $P$-wave velocity in the depth interval spanned by the VSP receiver array can be obtained from the derivative of the time-depth relationship above, which gives

$$
V(z)=\left[\left(0.7189 \times 10^{-3}\right)-\left(4.8984 \times 10^{-7}\right) z\right]^{-1},
$$

where $V$ is $P$-wave velocity $(\mathrm{m} / \mathrm{s})$ and $z$ is depth (214.1 $\leq z \leq 438.8 \mathrm{~m}$ WSF). This relationship is compared to the velocities measured by acoustic logging with the DSI in Figure F4. The acoustic log measures small-scale details in the velocity structure that cannot be resolved by the VSP arrival time data, yet both estimates of velocity give the same trend of increase in velocity with depth.

The traveltime-depth relationship allows for correlating stratigraphic events in Site U1337 to reflections in the surface seismic data. In Figure F46, we correlate the downhole logging results in Hole U1337A to seismic reflection Line 4 of the AMAT-03 site survey in the proposed Site PEAT-7C area, which crosses the location of Site U1337 at Shotpoint 1756. To make an accurate correlation, the TWTs in the seismic reflection line were shifted so that the seafloor reflection time (originally at $5.989 \mathrm{~s}$ ) matched the more accurate TWT to the seafloor measured by the JOIDES Resolution echo sounder (5.9444 s; see above). Reflections in the seismic line correspond to fluctuations in bulk density and velocity; for example, the increase in density between logging Units 1 and 2 at $212 \mathrm{~m}$ WMSF (corresponding to the boundary between lithologic Units II and III) matches a cluster of reflection events at $6.2 \mathrm{~s}$ TWT. This preliminary well to seismic correlation demonstrates that the Site 
U1337 results can be used to construct an up to date, age-calibrated interpretation of seismic stratigraphy and Neogene sedimentation history in the equatorial Pacific (e.g., Mayer et al., 1985; Mitchell et al., 2003).

\section{Heat flow}

Downhole temperature measurements at Site U1337 included eight APCT-3 measurements in Holes U1337A and U1337B and a SET measurement in Hole U1337C (Table T27). Measured temperatures ranged from $3.14^{\circ} \mathrm{C}$ at $43.5 \mathrm{~m}$ DSF to $11.24^{\circ} \mathrm{C}$ at $298.1 \mathrm{~m}$ DSF and closely fit a linear geothermal gradient of $32.4^{\circ} \mathrm{C} / \mathrm{km}$ (Fig. F47). Temperature at the seafloor was $1.634^{\circ} \mathrm{C}$, based on the average of the measurements at the mudline in the nine temperature profiles. The thermal conductivity under in situ conditions was estimated from the laboratorydetermined thermal conductivity using the method of Hyndman et al. (1974). The estimated in situ thermal conductivities in Figure F47 are as much as $2.3 \%$ below the measured laboratory values.

A simple estimate of the heat flow can be obtained from the product of the geothermal gradient times the average in situ thermal conductivity $(0.89 \mathrm{~W} /[\mathrm{m} \cdot \mathrm{K}])$, which gives a value of $29.1 \mathrm{~mW} / \mathrm{m}^{2}$. However, thermal conductivity increases with depth, hence a more accurate heat flow value can be obtained from the slope of the temperature measurements plotted versus thermal resistance as in the Bullard method (see Pribnow et al., 2000). The variation of thermal conductivity with depth was estimated by fitting a linear trend, and thermal resistance was calculated as the integral in depth of the inverse thermal conductivity (Pribnow et al., 2000). The fit between temperature and thermal resistance gives a slightly lower heat flow of $28.4 \mathrm{~mW} / \mathrm{m}^{2}$, which is similar to values of nearby sites in the global heat flow database (Pollack et al., 1993).

\section{References}

Abdul Aziz, H., Di Stefano, A., Foresi, L.M., Hilgen, F.J., Iaccarino, S.M., Kuiper, K.F., Lirer, F., Salvatorini, G., and Turco, E., 2007. Integrated stratigraphy and ${ }^{40} \mathrm{Ar} /{ }^{39} \mathrm{Ar}$ chronology of early Middle Miocene sediments from DSDP Leg 42A, Site 372 (Western Mediterranean). Palaeogeogr., Palaeoclimatol., Palaeoecol., 257(1-2):123138. doi:10.1016/j.palaeo.2007.09.013

Adkins, J.F., and Schrag, D.P., 2003. Reconstructing Last Glacial Maximum bottom water salinities from deep-sea sediment pore fluid profiles. Earth Planet Sci. Lett., 216:109-123. doi:10.1016/S0012-821X(03)00502-8

Baker, P.A., Gieskes, J.M., and Elderfield, H., 1982. Diagenesis of carbonates in deep-sea sediments-evidence from $\mathrm{Sr}^{2+} / \mathrm{Ca}^{2+}$ ratios and interstitial dissolved $\mathrm{Sr}^{2+}$ data. J. Sediment. Petrol., 52:71-82.
Baldauf, J.G., 1985. A high resolution late Miocene-Pliocene diatom biostratigraphy for the eastern equatorial Pacific. In Mayer, L., Theyer, F., Thomas, E., et al., Init. Repts. DSDP, 85: Washington, DC (U.S. Govt. Printing Office), 457-475. doi:10.2973/dsdp.proc.85.109.1985

Baldauf, J.G., and Iwai, M., 1995. Neogene diatom biostratigraphy for the eastern equatorial Pacific Ocean, Leg 138. In Pisias, N.G., Mayer, L.A., Janecek, T.R., PalmerJulson, A., and van Andel, T.H. (Eds.), Proc. ODP, Sci. Results, 138: College Station, TX (Ocean Drilling Program), 105-128. doi:10.2973/ odp.proc.sr.138.107.1995

Barker, P.F., 2001. Scotia Sea regional tectonic evolution: implications for mantle flow and palaeocirculation. Earth-Sci. Rev., 55(1-2):1-39. doi:10.1016/S00128252(01)00055-1

Barron, J.A., 1985a. Late Eocene to Holocene diatom biostratigraphy of the equatorial Pacific Ocean, Deep Sea Drilling Project Leg 85. In Mayer, L., Theyer, F., Thomas, E., et al., Init. Repts. DSDP, 85: Washington, DC (U.S. Govt. Printing Office), 413-456. doi:10.2973/ dsdp.proc.85.108.1985

Barron, J.A., 1985b. Miocene to Holocene planktic diatoms. In Bolli, H.M., Saunders, J.B., and Perch-Nielsen, K. (Eds.), Plankton Stratigraphy: Cambridge (Cambridge Univ. Press), 763-809.

Barron, J.A. 2006. Diatom biochronology for the early Miocene of the equatorial Pacific. Stratigraphy, 2(4):281-30.

Barron, J.A., and Baldauf, J.G., 1989. Tertiary cooling steps and paleoproductivity as reflected by diatoms and biosiliceous sediments. In Berger, W.H., Smetacek, V.S., and Wefer, G. (Eds.), Productivity of the Ocean: Present and Past: Berlin (Springer), 341-354.

Barron, J.A., Fourtanier, E., and Bohaty, S.M., 2004. Oligocene and earliest Miocene diatom biostratigraphy of ODP Leg 199 Site 1220, equatorial Pacific. In Wilson, P.A., Lyle, M., Janecek, T.R., and Firth, J.V. (Eds.), Proc. ODP, Sci. Results, 199: College Station (Ocean Drilling Program), 1-25. doi:10.2973/ odp.proc.sr.199.204.2004

Berggren, W.A., Kent, D.V., Swisher, C.C., III, and Aubry, M.-P., 1995. A revised Cenozoic geochronology and chronostratigraphy. In Berggren, W.A., Kent, D.V., Aubry, M.-P., and Hardenbol, J. (Eds.), Geochronology, Time Scales and Global Stratigraphic Correlation. Spec. Publ._SEPM (Soc. Sediment. Geol.), 54:129-212.

Bolli, H.M., and Saunders, J.B., 1985. Oligocene to Holocene low latitude planktic foraminifera. In Bolli, H.M., Saunders, J.B., and Perch-Nielsen, K. (Eds.), Plankton Stratigraphy: Cambridge (Cambridge Univ. Press), 155262.

Cande, S.C., LaBrecque, J.L., Larson, R.L., Pitmann, W.C., III, Golovchenko, X., and Haxby, W.F., 1989. Magnetic Lineations of the World's Ocean Basins. AAPG Map Ser., 13.

Chaisson, W.P., and Leckie, R.M., 1993. High-resolution Neogene planktonic foraminifer biostratigraphy of Site 806, Ontong Java Plateau (western equatorial Pacific). In Berger, W.H., Kroenke, L.W., Mayer, L.A., et al., Proc. ODP, Sci. Results, 130: College Station, TX (Ocean Drill- 
ing Program), 137-178. doi:10.2973/

odp.proc.sr.130.010.1993

Ellis, D.V., and Singer, J.M., 2007. Well Logging for Earth Scientists (2nd ed.): Dordrecht, The Netherlands (Springer).

Farrell, J.W., Raffi, I., Janecek, T.R., Murray, D.W., Levitan, M., Dadey, K.A., Emeis, K.-C., Lyle, M., Flores, J.-A., and Hovan, S., 1995. Late Neogene sedimentation patterns in the eastern equatorial Pacific Ocean. In Pisias, N.G., Mayer, L.A., Janecek, T.R., Palmer-Julson, A., and van Andel, T.H. (Eds.), Proc. ODP, Sci. Results, 138: College Station, TX (Ocean Drilling Program), 717-756. doi:10.2973/odp.proc.sr.138.143.1995

Goldman, J.C., 1993. Potential role of large oceanic diatoms in new primary production. Deep-Sea Res., Part I, 40(1):159-168. doi:10.1016/0967-0637(93)90059-C

Grigorov, I., Pearce, R.B., and Kemp, A.E.S., 2002. Southern Ocean laminated diatom ooze: mat deposits and potential for palaeo-flux studies, ODP Leg 177, Site 1093. Deep-Sea Res., Part II, 49(16):3391-3407. doi:10.1016/ S0967-0645(02)00089-9

Haq, B.U., and Berggren, W. A., 1978. Late Neogene calcareous nannoplankton biogeography of the Rio Grande Rise (South Atlantic Ocean). J. Paleontol., 52:1167-1194.

Hay, W.W., Mohler, H.P., Roth, P.H., Schmidt, R.R., and Boudreaux, J.E., 1967. Calcareous nannoplankton zonation of the Cenozoic of the Gulf Coast and CaribbeanAntillean area and transoceanic correlation. Trans. Gulf Coast Assoc. Geol. Soc., 17:428-480.

Hess, S., and Kuhnt, W., 2005. Neogene and Quaternary paleoceanographic changes in the southern South China Sea (Site 1143): the benthic foraminiferal record. In Wang, P., and Lipps, J. (Eds.), Marine Micropaleonotology of the South China Sea. Mar. Micropaleontol., 54(12):63-87. doi:10.1016/j.marmicro.2004.09.004

Hearst, J.R., and Nelson, P.H., 1985. Well Logging for Physical Properties: New York (McGraw-Hill).

Holbourn, A., Kuhnt, W., Schulz, M., and Erlenkeuser, H., 2005. Impacts of orbital forcing and atmospheric $\mathrm{CO}_{2}$ on Miocene ice-sheet expansion. Nature (London, U.K.), 438(7067):483-487. doi:10.1038/nature04123

Holbourn, A., Kuhnt, W., Schulz, M., Flores, J.-A., Andersen, N., 2007. Orbitally-paced climate evolution during the middle Miocene "Monterey" carbon-isotope excursion. Earth Planet. Sci. Lett., 261(3-4):534-550. doi:10.1016/j.epsl.2007.07.026

Horner-Johnson, B.C., and Gordon, R.G., 2003. Equatorial Pacific magnetic anomalies identified from vector aeromagnetic data. Geophys. J. Int., 155(2):547-556. doi:10.1046/j.1365-246X.2003.02065.X

Huber, B.T., Olsson, R.K., and Pearson, P.N., 2006. Taxonomy, biostratigraphy and phylogeny of Eocene microperforate planktonic foraminifera (Jenkinsina, Cassigerinelloita, Chiloguembelina, Streptochilus, Zeauvigerina, Tenuitella, and Cassigerinella) and problematica (Dipsidripella). In Pearson, P.N., Olsson, R.K., Huber, B.T., Hemleben, C., and Berggren, W.A. (Eds.), Atlas of Eocene Planktonic Foraminifera. Spec. Publ.-Cushman Found. Foraminiferal Res., 41:461-508.

Hyndman, R.D., Erickson, A.J., and Von Herzen, R.P., 1974. Geothermal measurements on DSDP Leg 26. In Davies,
T.A., Luyendyk, B.P., et al., Init. Repts. DSDP, 26: Washington, DC (U.S. Govt. Printing Office), 451-463. doi:10.2973/dsdp.proc.26.113.1974

Jannink, N.T., Zachariasse, W.J., and Van der Zwaan, G.J., 1998. Living (Rose Bengal stained) benthic foraminifers from the Pakistan continental margin (northern Arabian Sea). Deep-Sea Res., Part I, 45(9):1483-1513. doi:10.1016/S0967-0637(98)00027-2

Jorissen, F.J., and Rohling, E.J. (Eds.), 2000. Foraminiferal proxies of paleoproductivity. Spec. Issue Mar. Micropaleontol., 40:131-344.

Keller, G., 1981. Miocene biochronology and paleoceanography of the North Pacific. Marine Micropal., 6(5-6):535551. doi:10.1016/0377-8398(81)90020-7

Kemp, A.E.S., and Baldauf, J.G., 1993. Vast Neogene laminated diatom mat deposits from the eastern equatorial Pacific Ocean. Nature (London, U. K.), 362(6416):141144. doi:10.1038/362141a0

Kemp, A.E.S., Baldauf, J.G., and Pearce, R.B., 1995. Origins and paleoceanographic significance of laminated diatom ooze from the eastern equatorial Pacific Ocean. In Pisias, N.G., Mayer, L.A., Janecek, T.R., Palmer-Julson, A., and van Andel, T.H. (Eds.), Proc. ODP, Sci. Results, 138: College Station, TX (Ocean Drilling Program), 641645. doi:10.2973/odp.proc.sr.138.134.1995

Kemp, A.E.S., Pearce, R.B., Grigorov, I.,Rance, J., Lange, C.B., Quilty, P., and Salter, I., 2006. Production of giant marine diatoms and their export at oceanic frontal zones: implications for $\mathrm{Si}$ and $\mathrm{C}$ flux from stratified oceans. Global Biogeochem. Cycles, 20(4):GB4S04. doi:10.1029/2006GB002698

Lawver, L.A., and Gahagan, L.M., 2003. Evolution of Cenozoic seaways in the circum-Antarctic region. Palaeogeogr., Palaeoclimatol., Palaeoecol., 198(1-2):11-37. doi:10.1016/S0031-0182(03)00392-4

Lourens, L.J., Hilgen, F.J., Laskar, J., Shackleton, N.J., and Wilson, D., 2004. The Neogene period. In Gradstein, F.M., Ogg, J., et al. (Eds.), A Geologic Time Scale 2004: Cambridge (Cambridge Univ. Press), 409-440.

Lyle, M., 1983. The brown-green color transition in marine sediments: a marker of the Fe(III)-Fe(II) redox boundary. Limnol. Oceanogr., 28:1026-1033.

Lyle, M., 2003. Neogene carbonate burial in the Pacific Ocean. Paleoceanography, 18(3):1059. doi:10.1029/ 2002PA000777

Lyle, M., Dadey, K.A., and Farrell, J.W., 1995. The late Miocene (11-8 Ma) eastern Pacific carbonate crash: evidence for reorganization of deep-water circulation by the closure of the Panama gateway. In Pisias, N.G., Mayer, L.A., Janecek, T.R., Palmer-Julson, A., and van Andel, T.H. (Eds.), Proc. ODP, Sci. Results, 138: College Station, TX (Ocean Drilling Program), 821-838. doi:10.2973/odp.proc.sr.138.157.1995

Lyle, M., Gibbs, S., Moore, T.C., and Rea, D.K., 2007. Late Oligocene initiation of the Antarctic Circumpolar Current: evidence from the South Pacific. Geology, 35(8):691-694. doi:10.1130/G23806A.1

Mancin, N., Pirini, C., Bicchi, E., Ferrero, E., and Valleri, G., 2003. Middle Eocene to middle Miocene planktonic foraminifer biostratigraphy for internal basins (Monfer- 
rato and northern Appennines, Italy). Micropaleontol., 49(4):341-358. doi:10.2113/49.4.341

Mayer, L., Pisias, N., Janecek, T., et al., 1992. Proc. ODP, Init. Repts., 138: College Station, TX (Ocean Drilling Program). doi:10.2973/odp.proc.sr.138.1995

Mayer, L.A., Shipley, T.H., Theyer, F., Wilkens, R.H., and Winterer, E.L., 1985. Seismic modeling and paleoceanography at Deep Sea Drilling Project Site 574. In Mayer, L., Theyer, F., Thomas, E., et al., Init. Repts. DSDP, 85: Washington, DC (U.S. Govt. Printing Office), 947-970. doi:10.2973/dsdp.proc.85.132.1985

Mitchell, N.C., Lyle, M.W., Knappenberger, M.B., and Liberty, L.M., 2003. Lower Miocene to present stratigraphy of the equatorial Pacific sediment bulge and carbonate dissolution anomalies. Paleoceanography, 18(2):1038. doi:10.1029/2002PA000828

Oda, M., 1977. Planktonic foraminiferal biostratigraphy of the late Cenozoic sedimentary sequence, central Honshu, Japan. Sci. Repts. Tohoku Univ., 2nd Ser. (Geol.), 48:176.

Pagani, M., Arthur, M.A., and Freeman, K.H., 1999. Miocene evolution of atmospheric carbon dioxide. Paleoceanography, 14(3):273-292. doi:10.1029/ 1999PA900006

Pälike, H., Nishi, H., Lyle, M., Raffi, I., Klaus, A., Gamage, K., and the Expedition 320/321 Scientists, 2009. Pacific Equatorial Transect. IODP Prel. Rept., 320. doi:10.2204/ iodp.pr.320.2009

Pearson, P.N., and Wade, B.S., 2009. Taxonomy and stable isotope paleoecology of well-preserved planktonic foraminifera from the uppermost Oligocene of Trinidad. J. Foraminifer. Res., 39(3):191-217. doi:10.2113/ gsjfr.39.3.191

Peng, T.-H., Maier-Reimer, E., and Broecker, W.S. 1993. Distribution of ${ }^{32} \mathrm{Si}$ in the world ocean: model compared to observation. Global Biogeochem. Cycles, 7(2):463-474. doi:10.1029/93GB00686

Perch-Nielsen, K., 1985. Cenozoic calcareous nannofossils. In Bolli, H.M., Saunders, J.B., and Perch-Nielsen, K. (Eds.), Plankton Stratigraphy: Cambridge (Cambridge Univ. Press), 427-554.

Pollack, H.N., Hurter, S.J., and Johnson, J.R., 1993. Heat flow from the earth's interior: analysis of the global data set. Rev. Geophys., 31(3):267-280. doi:10.1029/ 93RG01249

Pribnow, D.F.C., Kinoshita, M., and Stein, C.A., 2000. Thermal Data Collection and Heat Flow Recalculations for ODP Legs 101-180: Hanover, Germany (Inst. Joint Geosci. Res., Inst. Geowiss. Gemeinschaftsauf. [GGA]). http:// www-odp.tamu.edu/publications/heatflow/ ODPReprt.pdf
Raffi, I., Backman, J., Fornaciari, E., Pälike, H., Rio, D., Lourens, L., and Hilgen, F., 2006. A review of calcareous nannofossil astrobiochronology encompassing the past 25 million years. Quat. Sci. Rev., 25(23-24):3113-3137. doi:10.1016/j.quascirev.2006.07.007

Rio, D., Raffi, I., and Villa, G., 1990. Pliocene-Pleistocene calcareous nannofossil distribution patterns in the western Mediterranean. In Kastens, K.A., Mascle, J., et al., Proc. ODP, Sci. Results, 107: College Station, TX (Ocean Drilling Program), 513-533. doi:10.2973/ odp.proc.sr.107.164.1990

Scher, H.D., and Martin, E.E., 2006. Timing and climatic consequences of the opening of Drake Passage. Science, 312(5772):428-430. doi:10.1126/science.1120044

Spezzaferri, S., 1994. Planktonic foraminiferal biostratigraphy and taxonomy of the Oligocene and lower Miocene in the oceanic record: an overview. Palaeontographica Ital., 81:1-187.

Spezzaferri, S., and Premoli Silva, I., 1991. Oligocene planktonic foraminiferal biostratigraphy and paleoclimatic interpretation from Hole 538A, DSDP Leg 77, Gulf of Mexico. Palaeogeogr., Palaeoclimatol., Palaeoecol., 83(1-3):217-263. doi:10.1016/0031-0182(91)90080-B

Thompson, P.R., Bé, A.W.H., Duplessy, J.-C., and Shackleton, N.J., 1979. Disappearance of pink-pigmented Globigerinoides ruber at 120,000 yr BP in the Indian and Pacific oceans. Nature (London, U. K.), 280(5723):554558. doi:10.1038/280554a0

Winter, C.J., and Pearson, P.N., 2001. Coiling directions in some Miocene planktonic foraminifera. Jour. Micropalaeontol., 20(1):29-30.

Yoder, J.A., Ackleson, S.G., Barber, R.T., Flamant, P., and Balch, W.M., 2002. A line in the sea. Nature (London, $U$. K.), 371:689-692. doi:10.1038/371689a0

Young, J.R., 1990. Size variation of Neogene Reticulofenestra coccoliths from Indian Ocean DSDP cores. J. Micropaleontol., 9:71-85.

Young, J.R., 1999. Neogene. In Bown, P.R. (Ed.), Calcareous Nannofossil Biostratigraphy: Dordrecht, The Netherlands (Kluwer Academic Publ.), 225-265.

Zachos, J.C., Dickens, G.R., and Zeebe, R.E., 2008. An early Cenozoic perspective on greenhouse warming and carbon-cycle dynamics. Nature (London, U. K.), 451(7176):279-283. doi:10.1038/nature06588

Publication: 30 October 2010 MS 320321-109 
Figure F1. A. Site U1337 and PEAT program drill sites. F.Z. = fracture zone. B. Swath bathymetry from AMAT03 site survey, Site U1337 region.
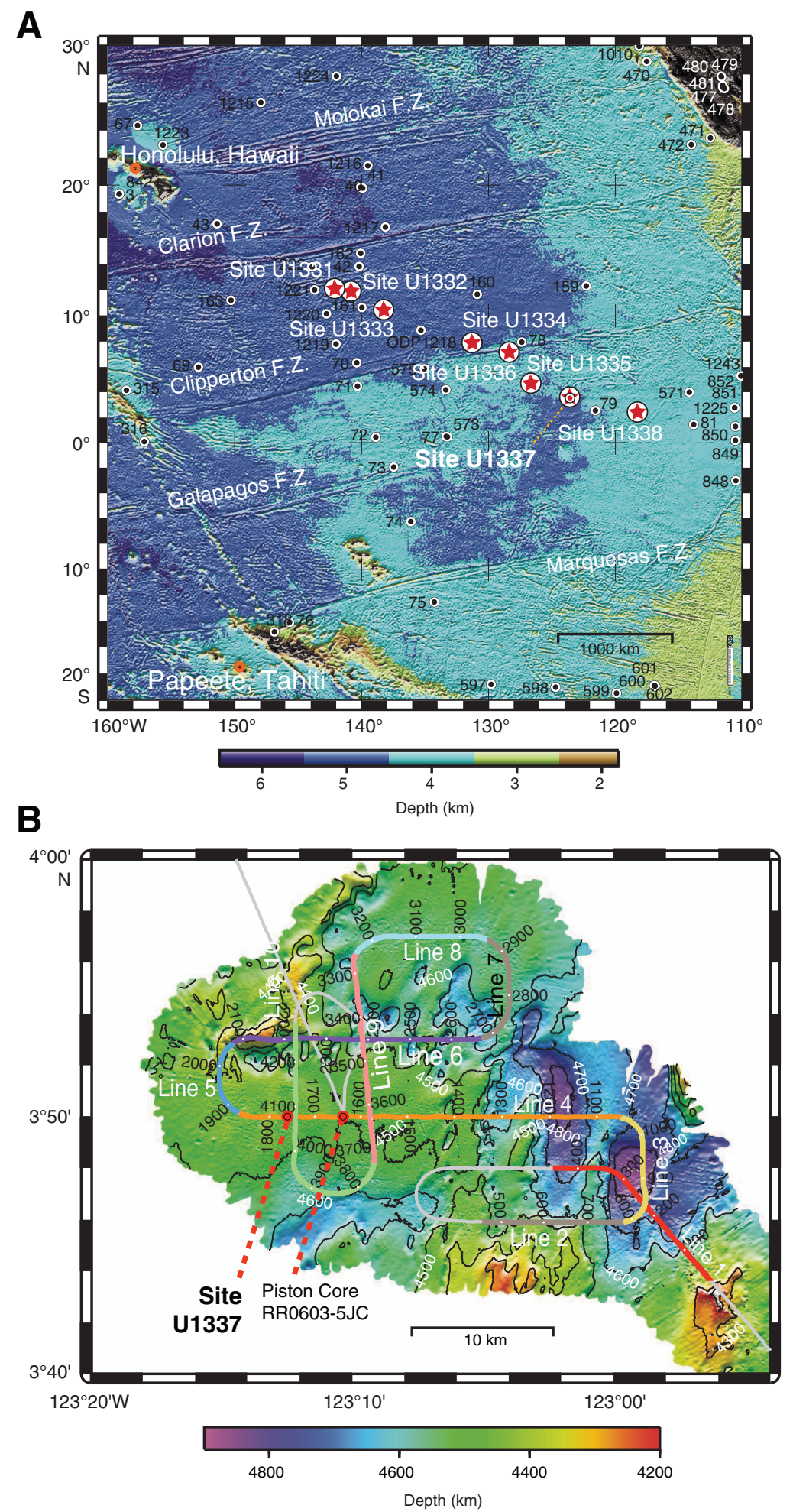

seismic source.

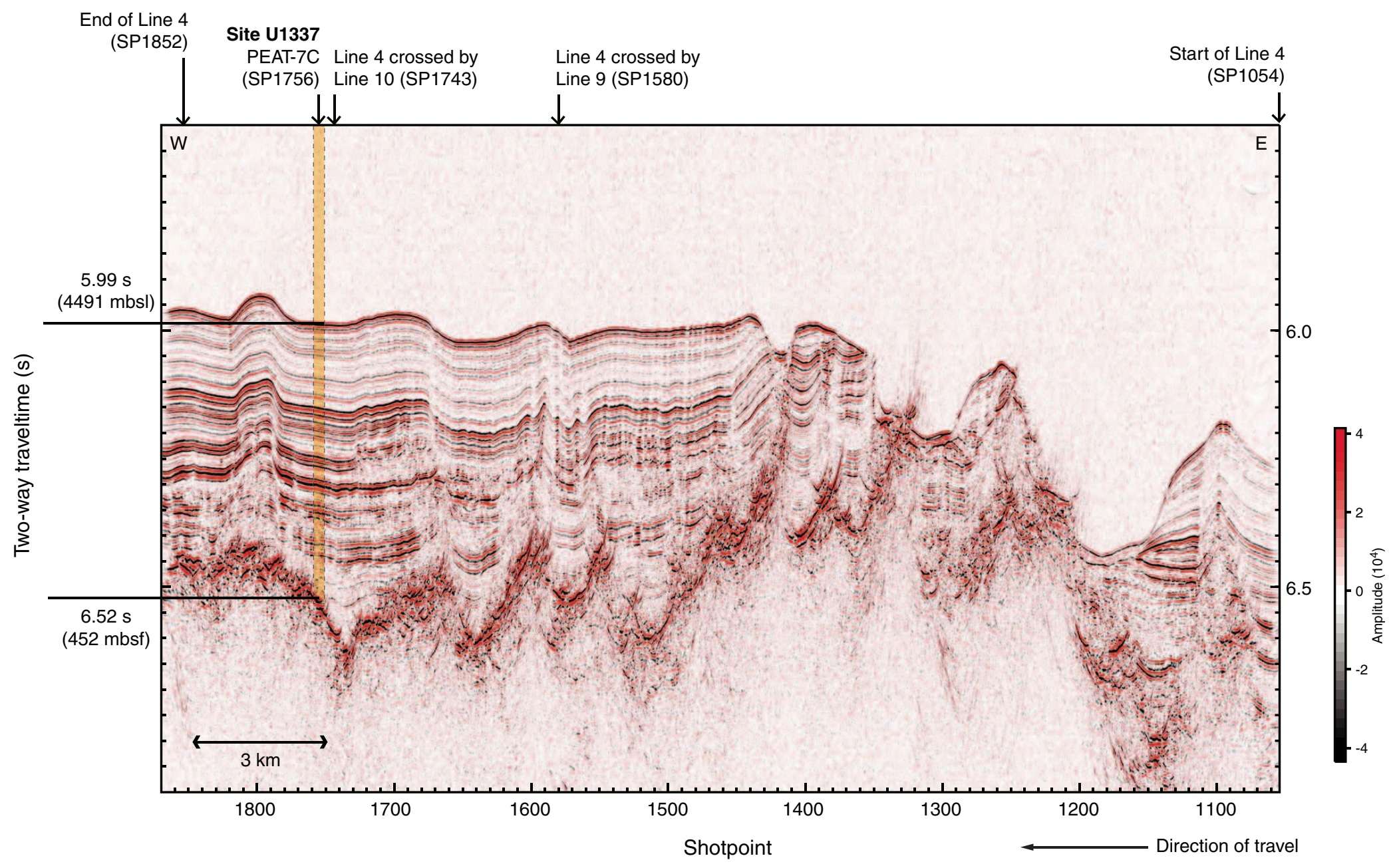


Figure F3. Site U1337 summary. Light green circles $=\mathrm{CaCO}_{3}$ contents from Hole U1337B. Diatom mat intervals are from Hole U1337D. Core depth below seafloor for Holes U1337D and U1337B were converted to core depth below seafloor for Hole U1337A. Magnetic stratigraphy represents a spliced record from all holes and is plotted relative to corrected core composite depth below seafloor.

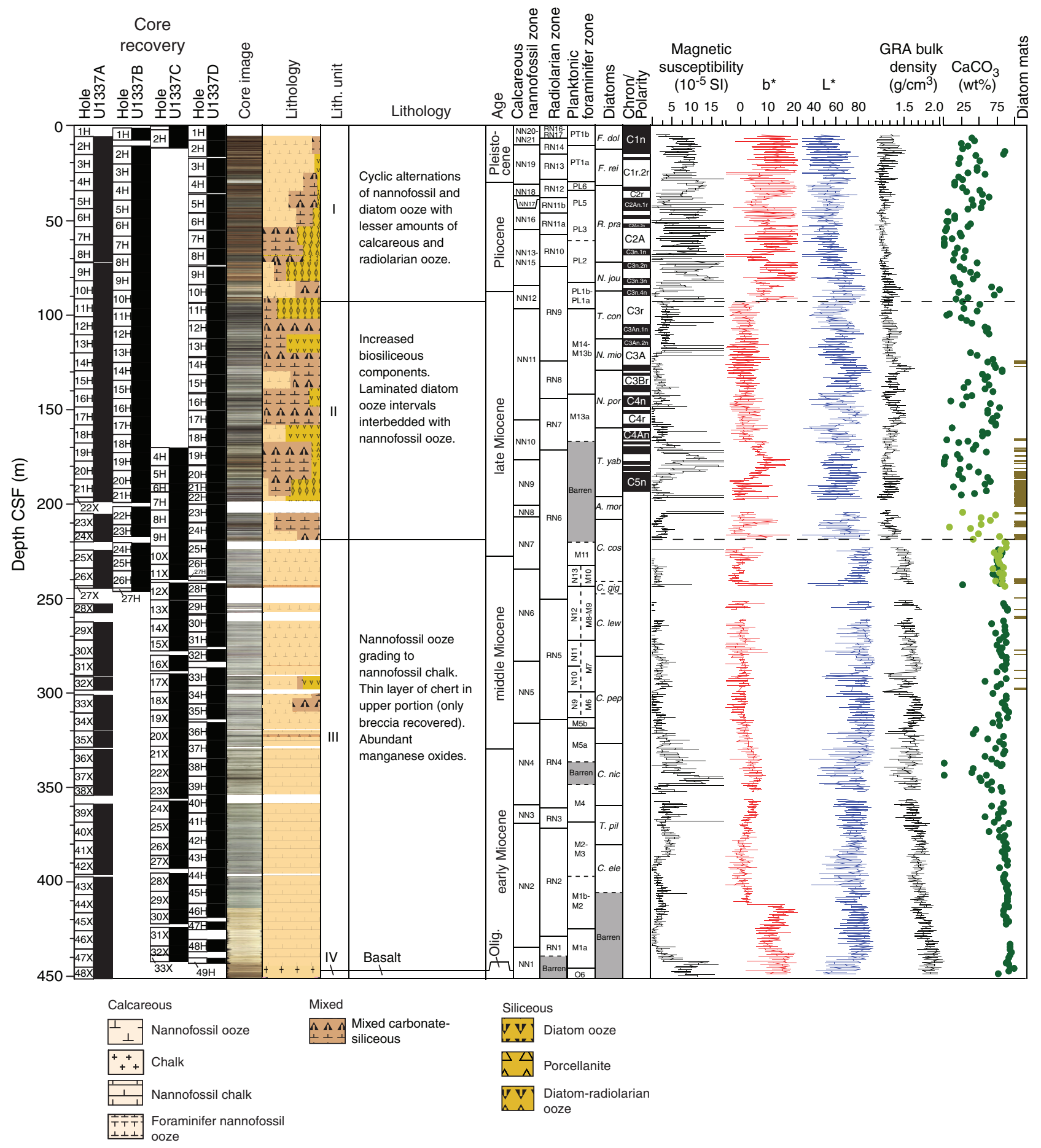


Figure F4. Downhole log measurement summary, Hole U1337A. p1 = uplog Pass $1, \mathrm{p} 2=\operatorname{uplog}$ Pass 2, MAD = moisture and density, IMPH = medium induction phasor-processed resistivity, SFLU = spherically focused resistivity, VSP = vertical seismic profile.

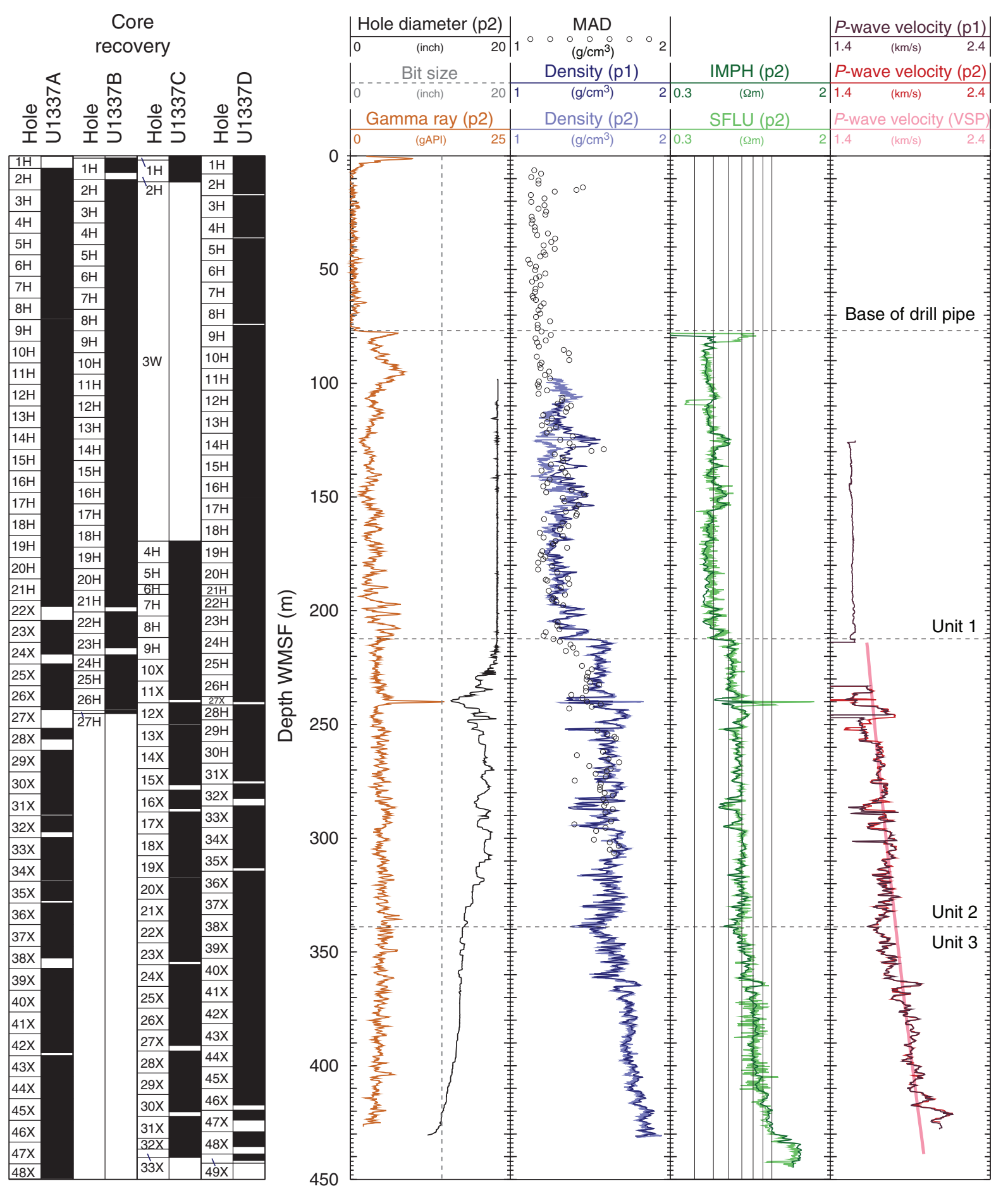


Figure F5. Lithostratigraphy summary, Site U1337. $\mathrm{CaCO}_{3}$ content: light green circles = Hole U1337B, dark green circles $=$ Hole U1337A. Diatom mat intervals from Hole U1337D. All other measurements from Hole U1337A. Core depth below seafloor for Holes U1337D and U1337B were converted to core depth below seafloor for Hole U1337A using adjustments from Table T23. Magnetic stratigraphy represents a spliced record from all holes and is plotted relative to corrected core composite depth below seafloor. See "Biostratigraphy" for clarification of zones. $\mathrm{L}^{*}, \mathrm{~b}^{*}=$ reflectance value of sediment as defined in the LAB color model, GRA = gamma ray attenuation.

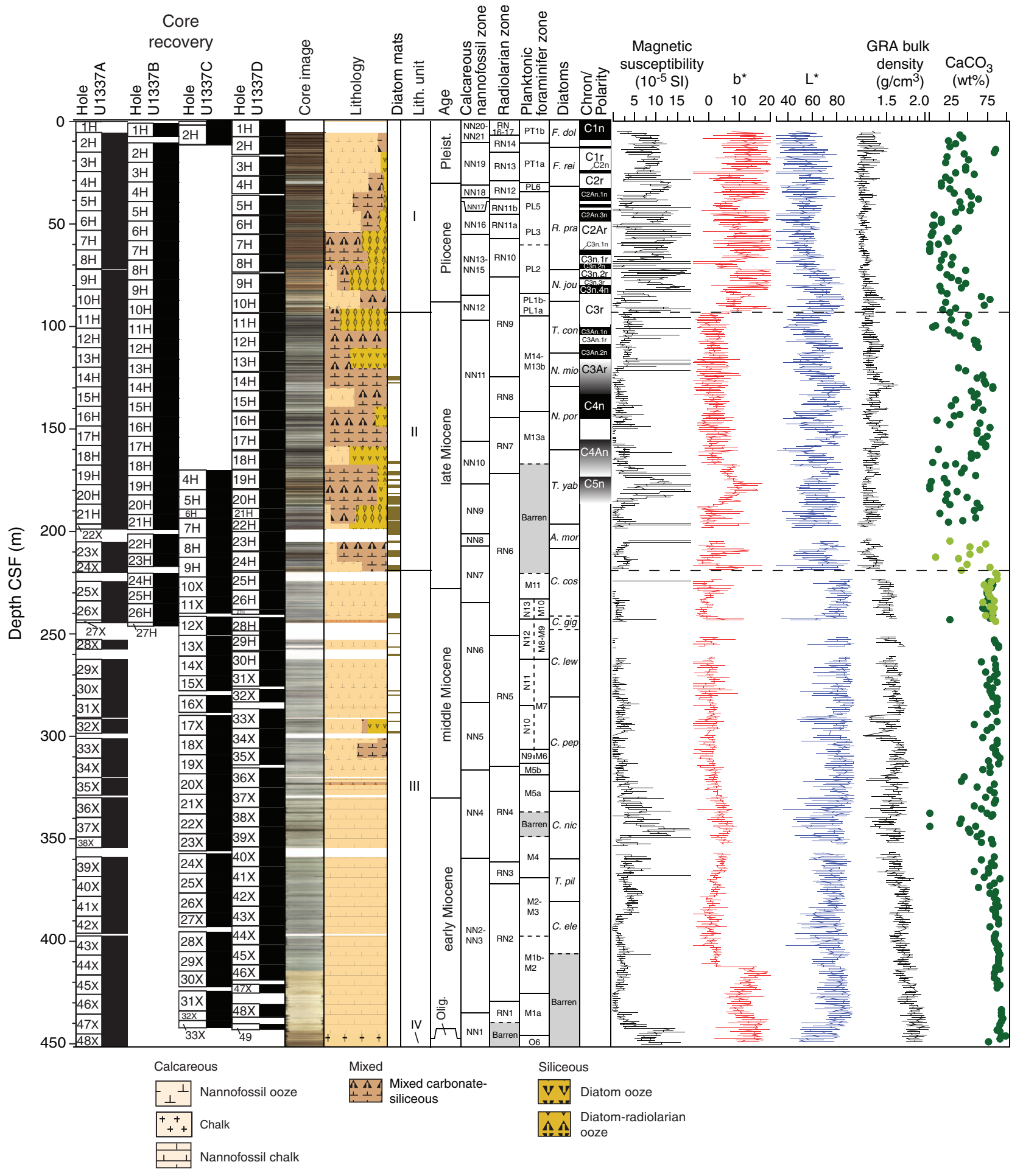


Figure F6. Smear slide results, Site U1337.

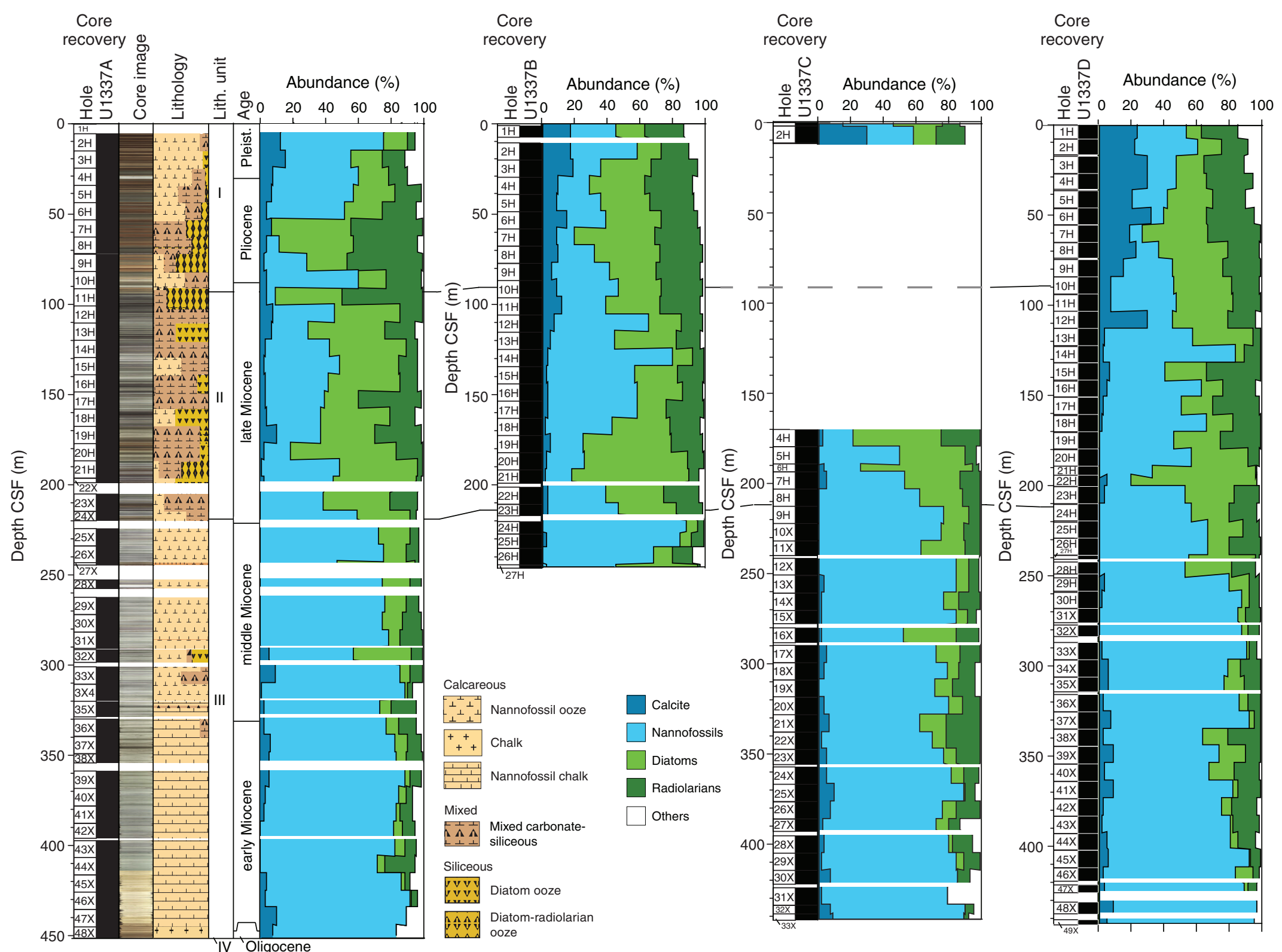


Figure F7. Line scan images and smear slide data from intervals characteristic of Units I and II.

Hole U1337A
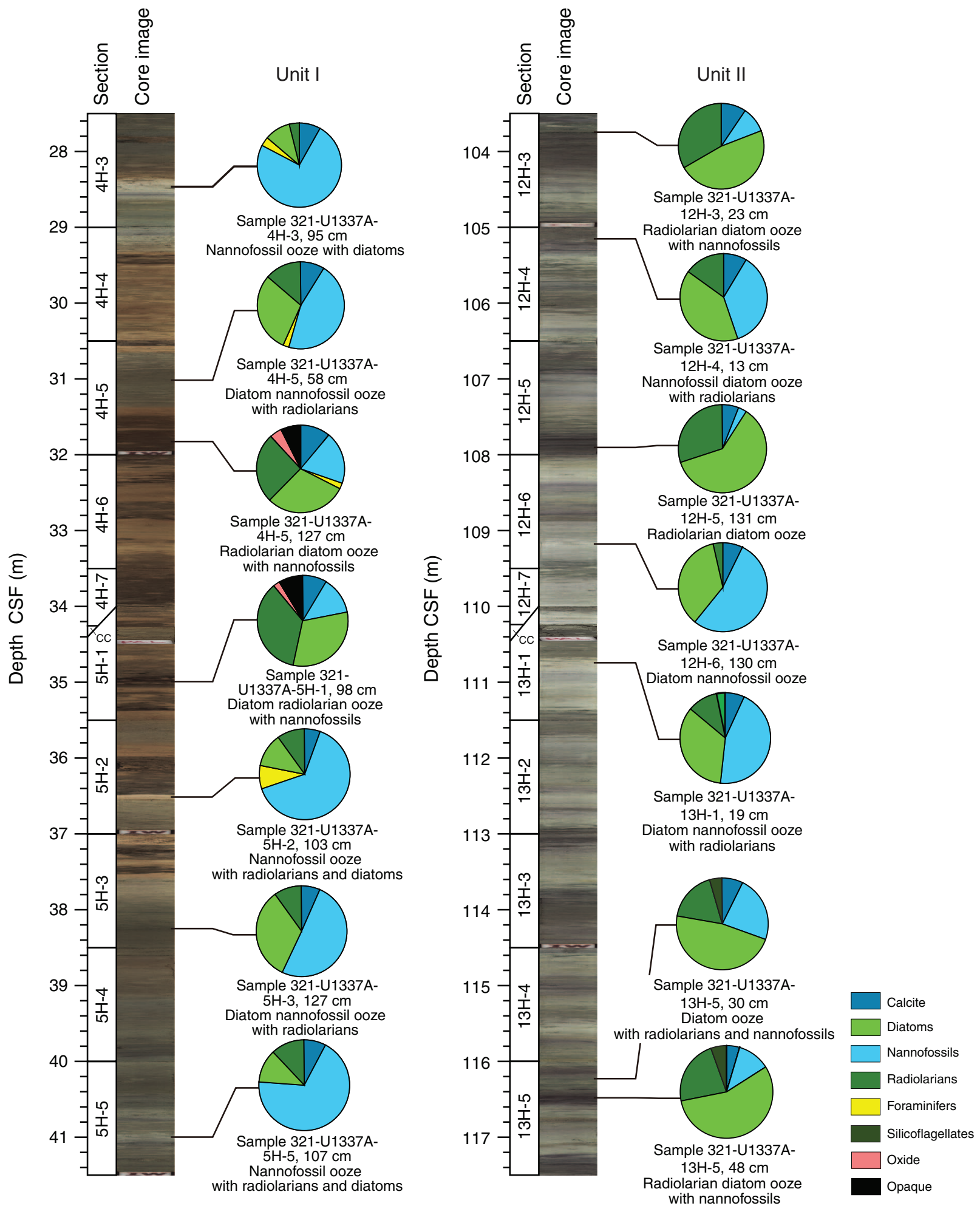
Figure F8. Light microscope photographs of smear slides indicating the dominant lithologies of Units I-III. Left image $=$ plane-polarized light, right image $=$ cross-polarized light. A. Nannofossil ooze with diatoms, Unit I (Sample 321-U1337A-4H-3, $95 \mathrm{~cm}$ ). B. Diatom radiolarian ooze with nannofossils, Unit 1 (Sample 321-U1337A5H-1, $98 \mathrm{~cm}$ ). C. Diatom nannofossil ooze with radiolarians, Unit 1 (Sample 321-U1337A-5H-3, 127cm). D. Radiolarian diatom ooze, Unit II (Sample 321-U1337A-12H-5, $131 \mathrm{~cm}$ ). (Continued on next page.)
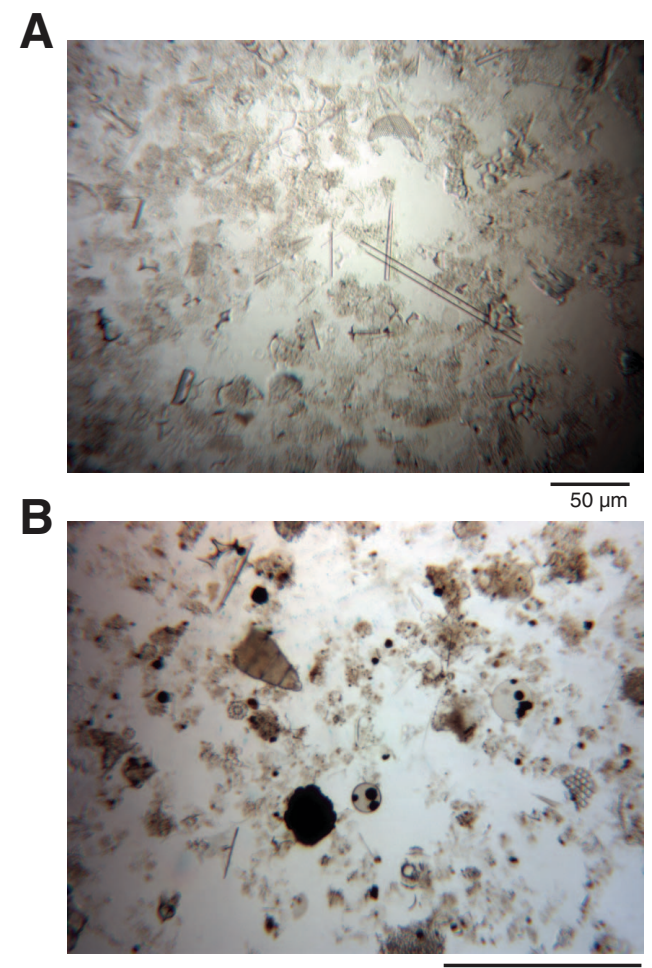

C

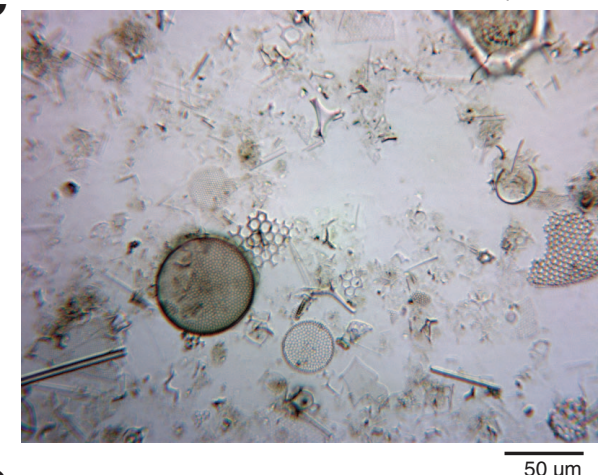

$\mathbf{D}$

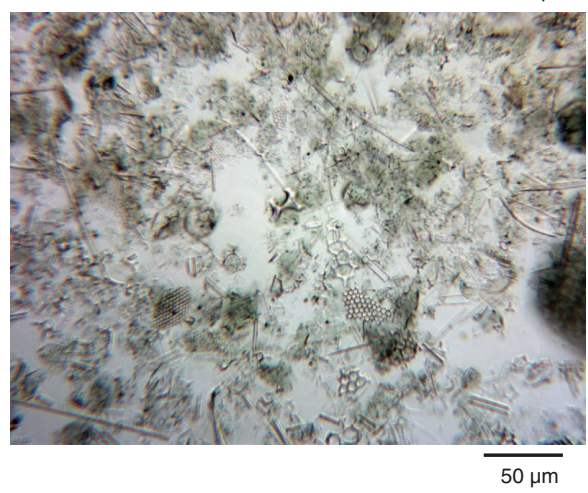

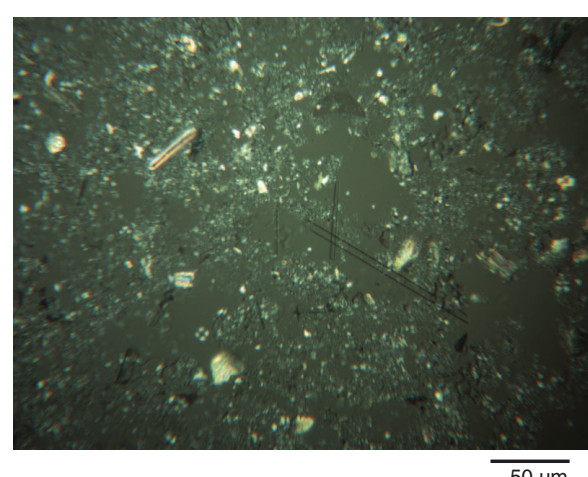

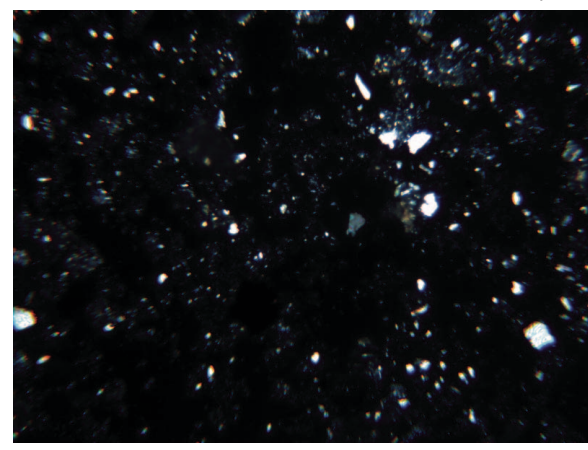

$50 \mu \mathrm{m}$
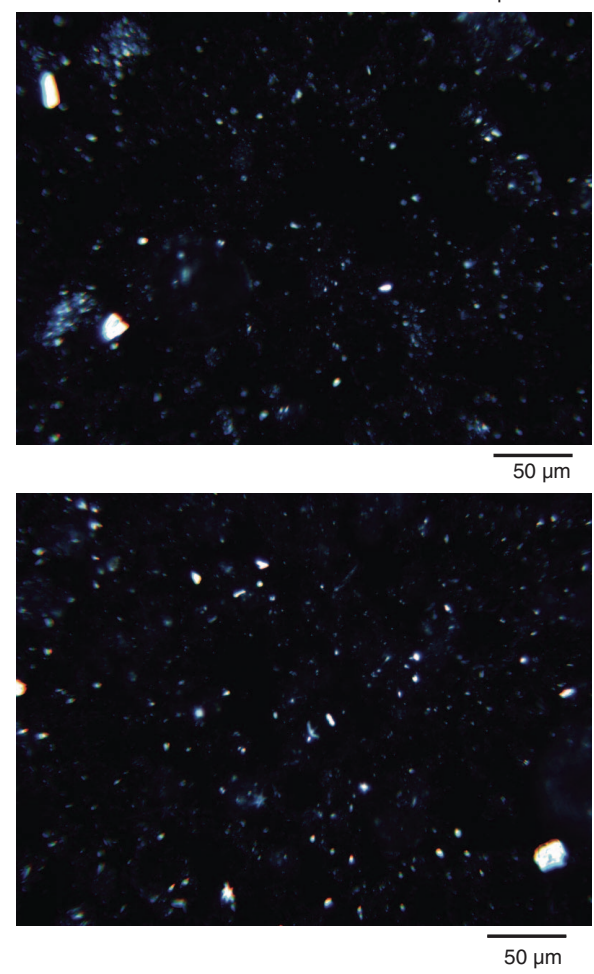
Figure F8 (continued). E. Diatom nannofossil ooze with radiolarians, Unit II (Sample 321-U1337A-13H-1, 19 $\mathrm{cm})$. F. Diatom ooze with radiolarians and nannofossils, Unit II (Sample 321-U1337A-13H-5, $30 \mathrm{~cm}$ ). G. Nannofossil ooze, Unit III (Sample 321-U1337A-29X-3, 12 cm). H. Nannofossil chalk, Unit III (Sample 321-U1337A$36 \mathrm{X}-3,80 \mathrm{~cm})$.
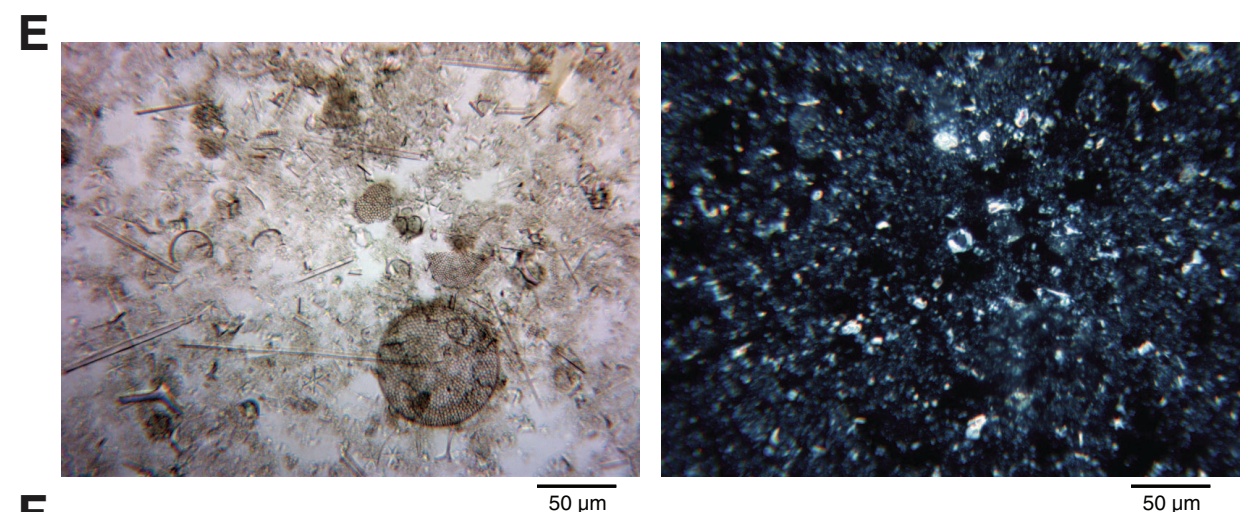

$\mathbf{F}$
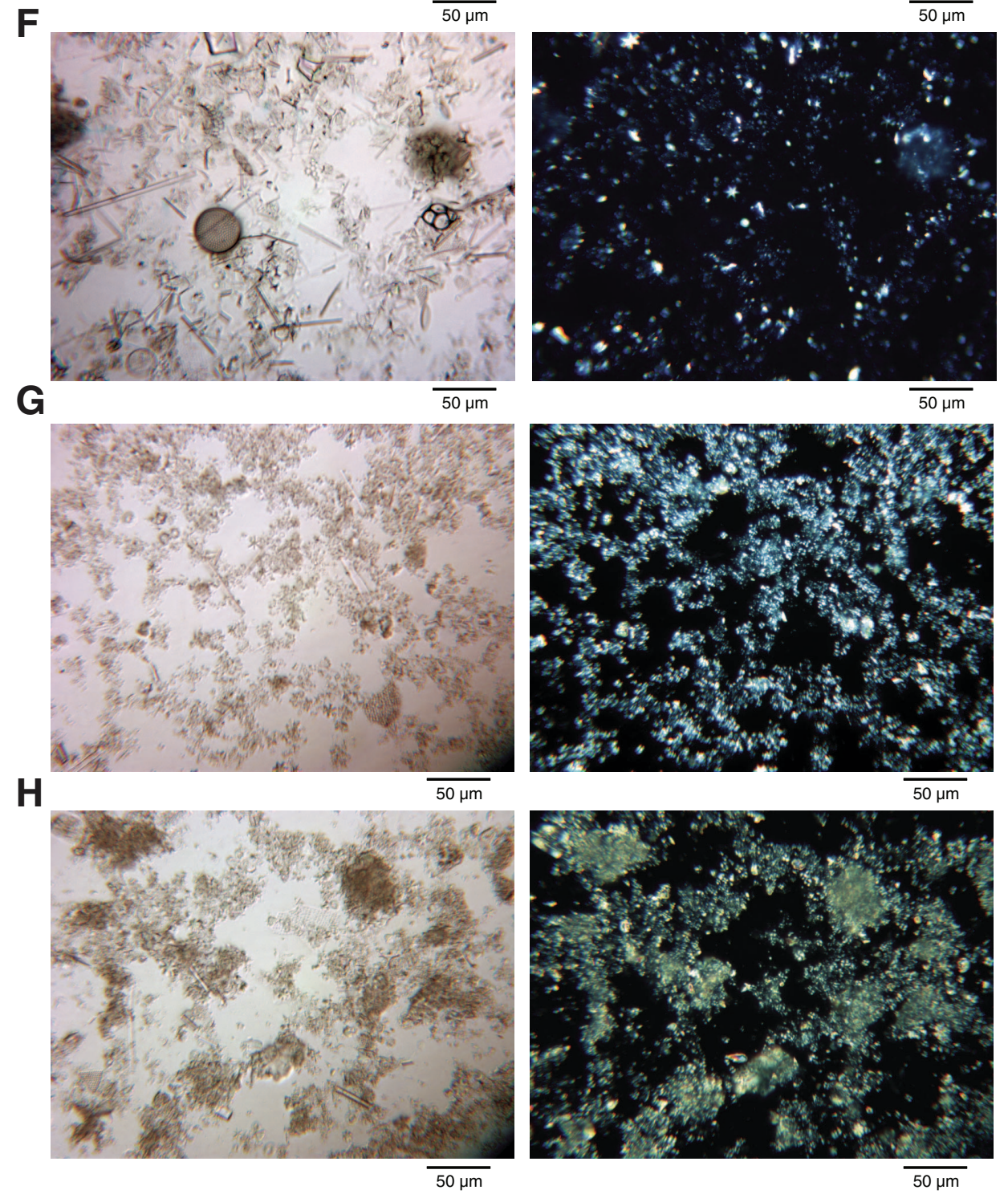
Figure F9. Unit I-II transition (Cores 321-U1337A-10H and 11H). GRA = gamma ray attenuation, $\mathrm{L}^{*}, \mathrm{a}^{*}, \mathrm{~b}^{*}=$ reflectance values of sediment as defined in the LAB color model.

Hole U1337A

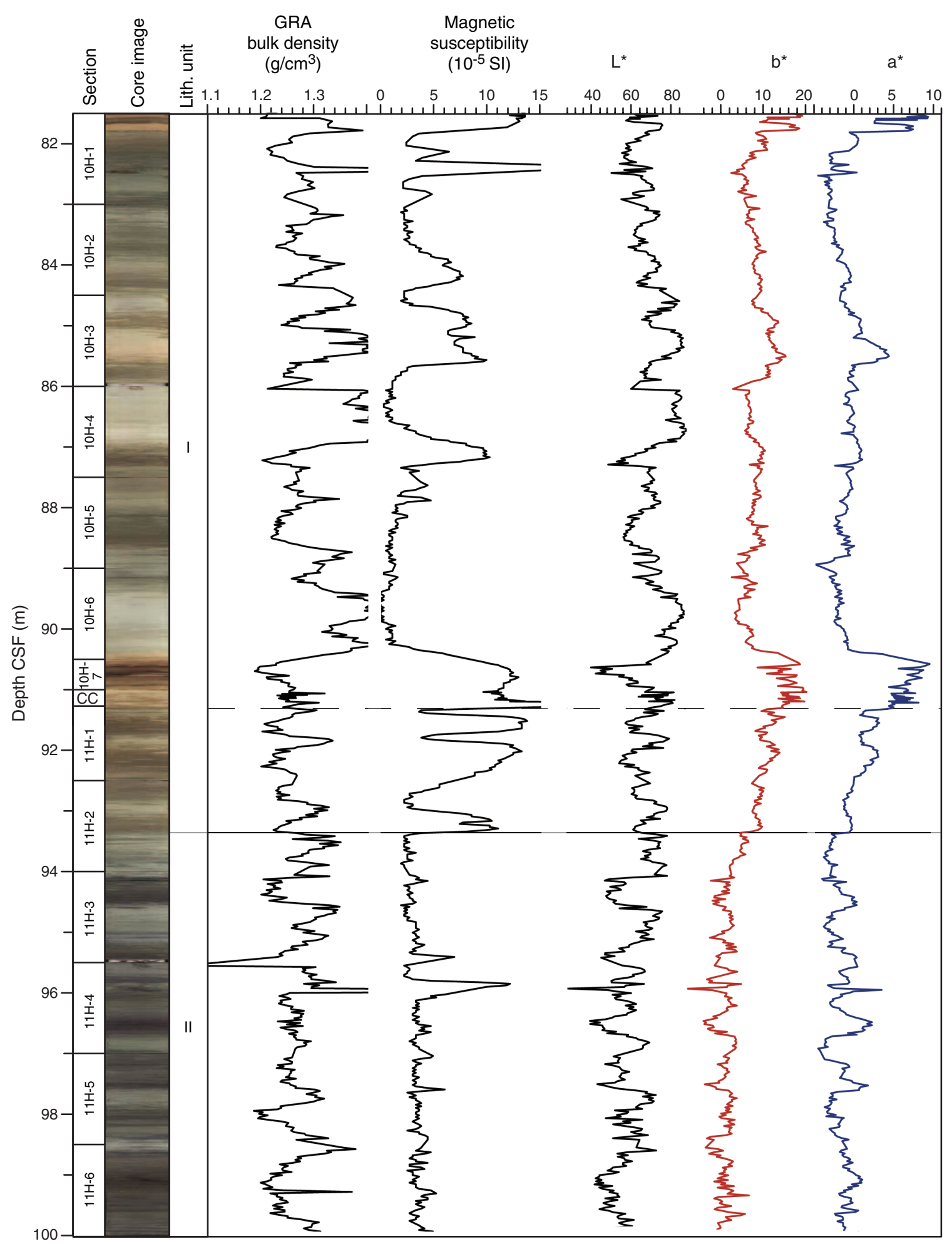


Figure F10. A. Line scan image of diatom mat (Section 321-U1337C-6H-2). B. Transmitted light microscope photograph of smear slide of Thalassiothrix diatom mat.
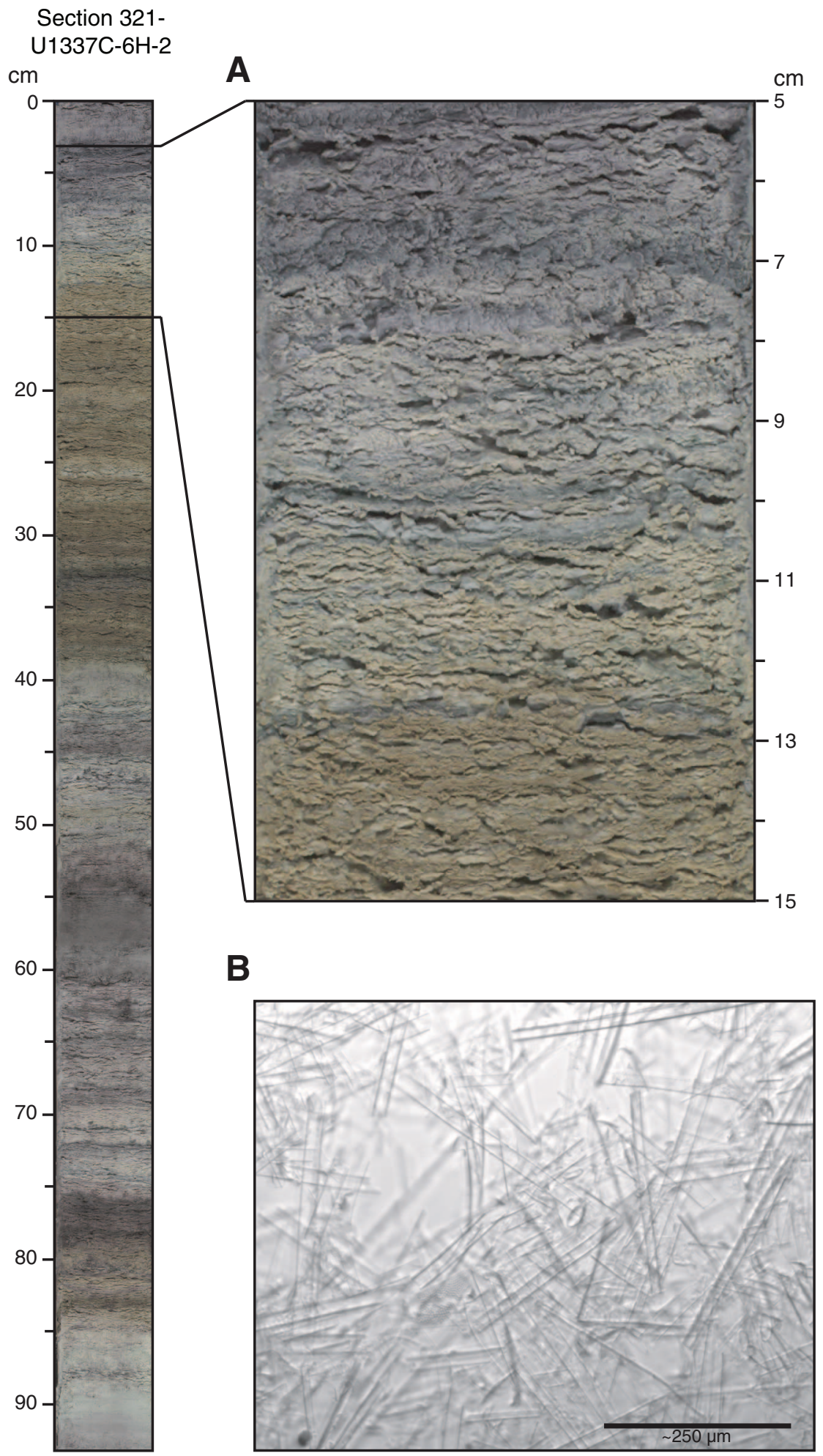
Figure F11. Unit II-III transition (Core 321-U1337B-23H). GRA = gamma ray attenuation, $\mathrm{L}^{*}, \mathrm{~b}^{*}=$ reflectance values of sediment as defined in the LAB color model.

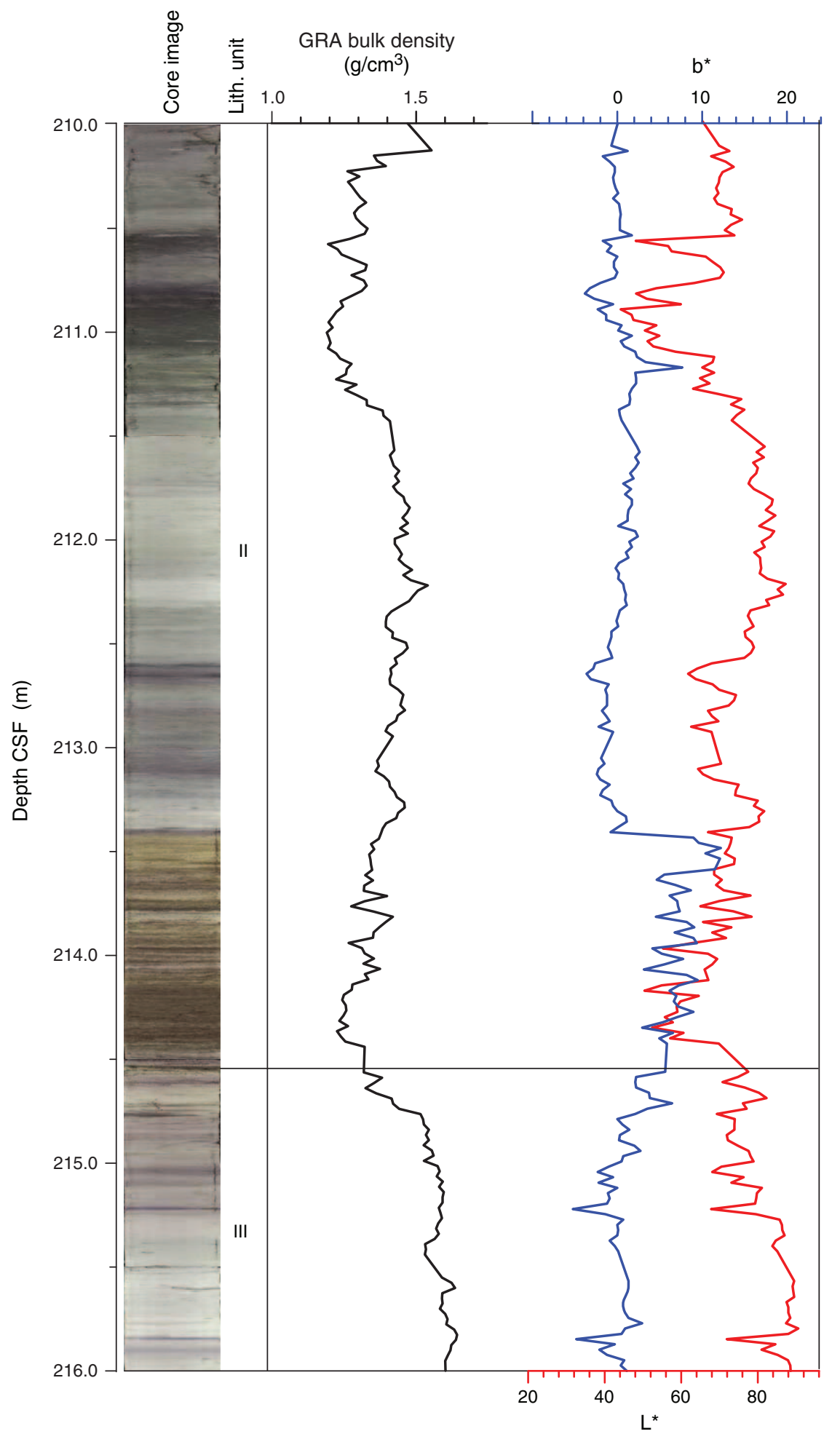


Figure F12. Line scan image and $b^{*}$ color reflectance across the green to yellow transition in the lower part of Unit III (interval 321-U1337A-44X-5, $126 \mathrm{~cm}$, through 44X-6, $16 \mathrm{~cm}$ ).

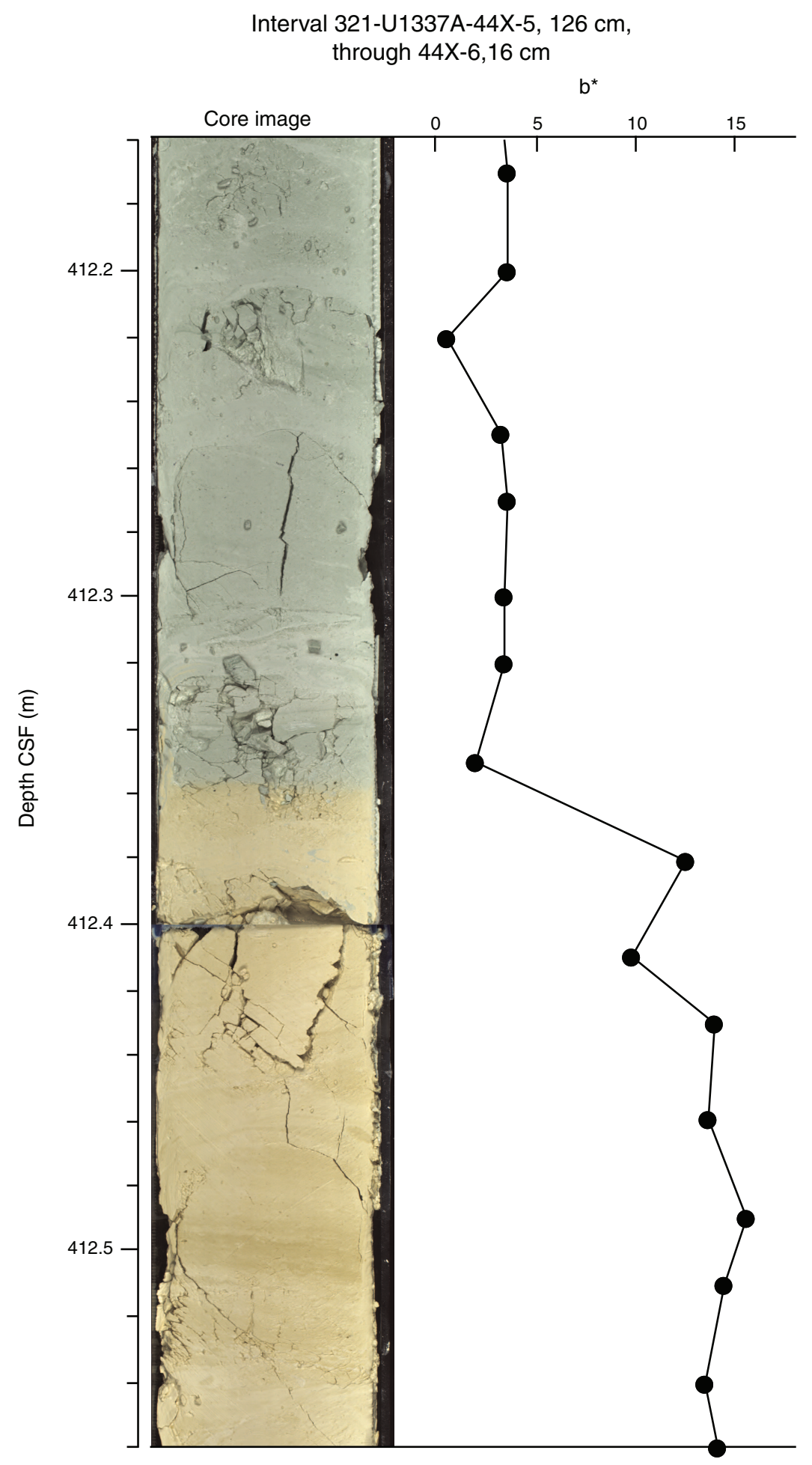


Figure F13. Integrated calcareous and siliceous microfossil biozonation, Site U1337.

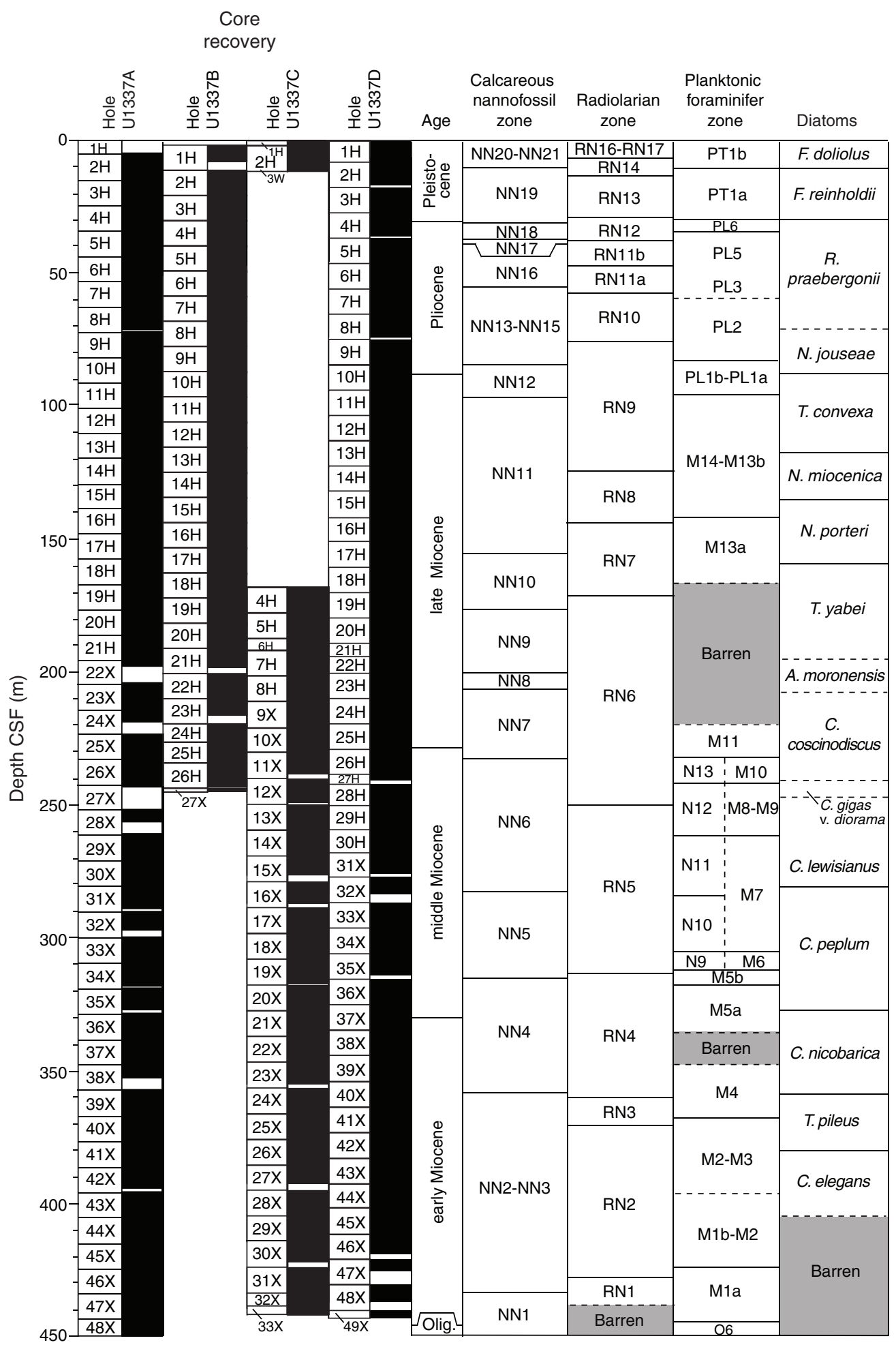


Figure F14. Core depth below seafloor vs. core composite depth below seafloor for tops of cores, Site U1337. Growth factor is slope of the regression line. On average, the core composite depth below seafloor of the spliced section is $12 \%$ greater than the core depth below seafloor.

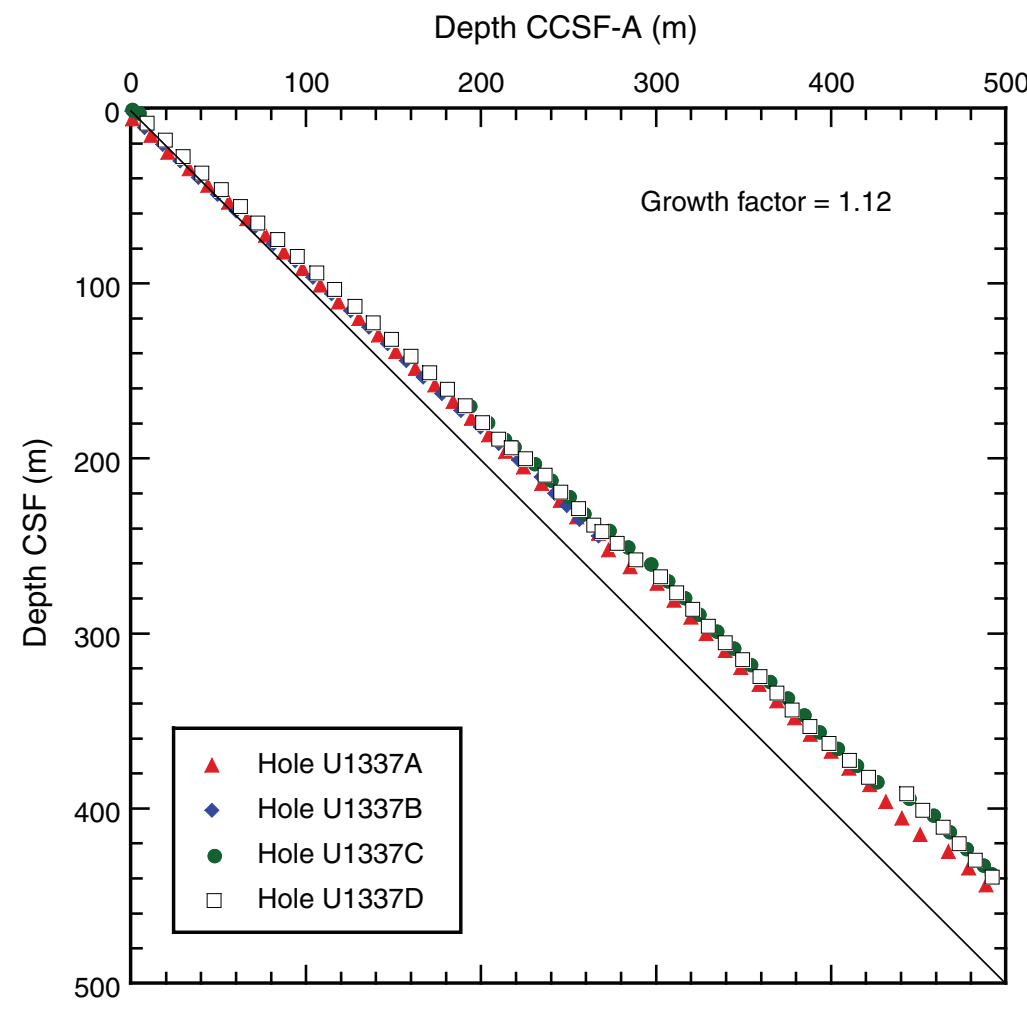


Figure F15. Biostratigraphic relationship between two early Miocene reticulofenestrid taxa suggesting an ancestor-descendant relationship. Qualitative estimates of relative abundances derived from Table T4. Abundance: 5 = dominant, 4 = abundant, 3 = common, $2=$ frequent, $1=$ rare, $0=$ absent.

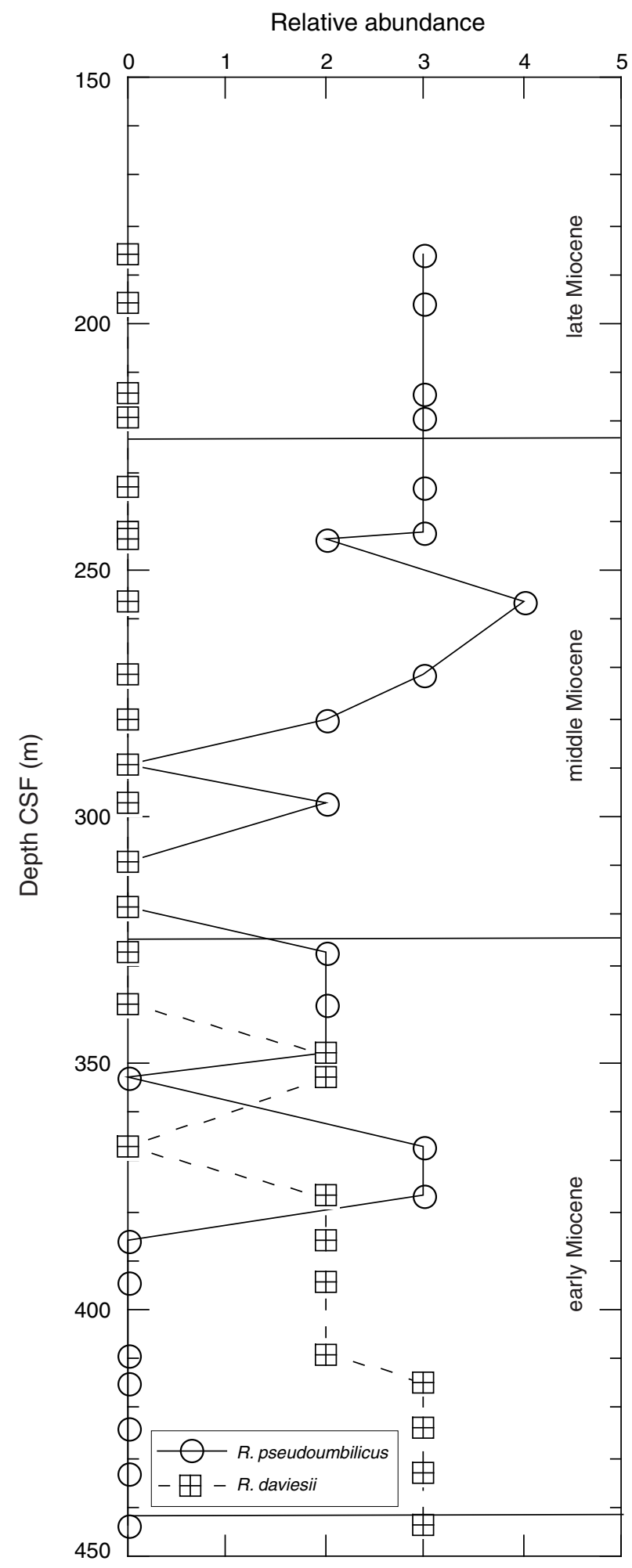


Figure F16. Planktonic foraminifer abundance and assemblage changes, Site U1337. Red line $=$ three-point moving average.
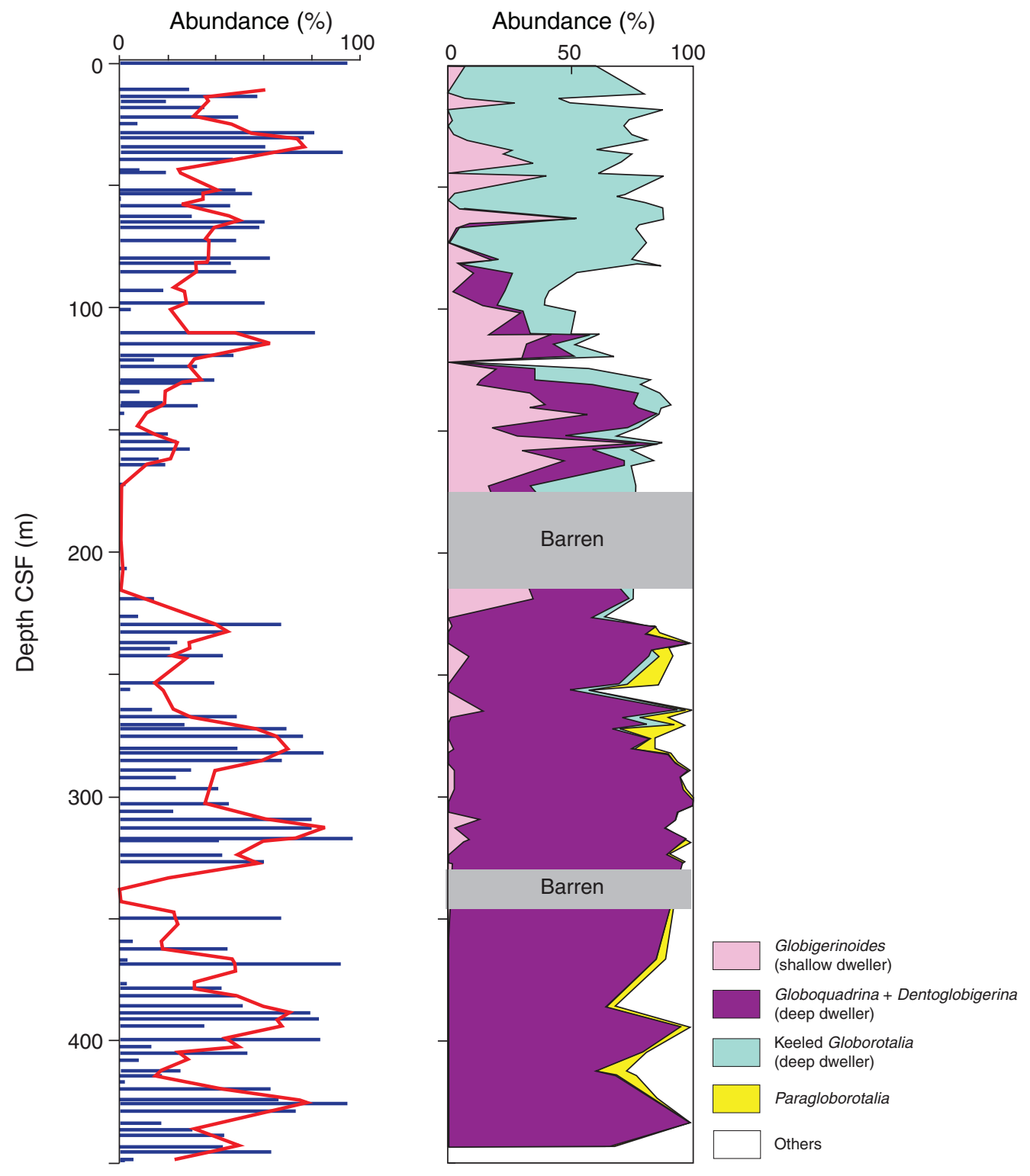
Figure F17. Distribution of common benthic foraminifer taxa in core catcher samples, Hole U1337A. Marked variations in downcore abundance and species distribution may reflect major changes in global climate during the Neogene. $\mathrm{CCD}=$ calcium carbonate compensation depth, $\mathrm{BF}=$ benthic foraminifers.

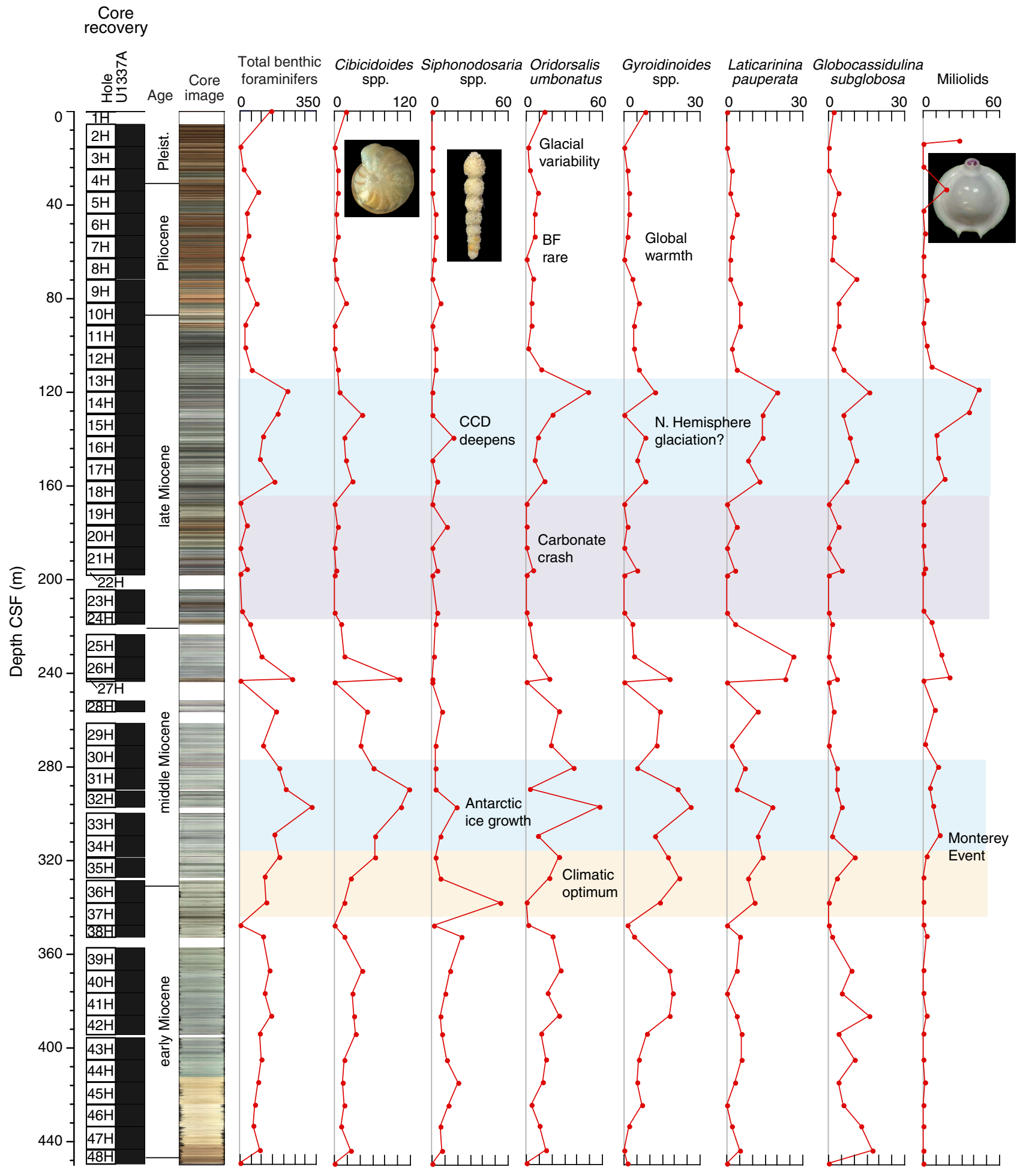


Figure F18. Magnetic susceptibility and paleomagnetic summary, Hole U1337A. Declinations are raw data before FlexIt tool orientation. Gray lines = measurements before demagnetization, red lines = measurements after $20 \mathrm{mT}$ alternating-field demagnetization step, blue squares = discrete sample data. A. 0-100 m CSF. (Continued on next two pages.)

A

Magnetic susceptibility $\left(10^{-5} \mathrm{SI}\right)$

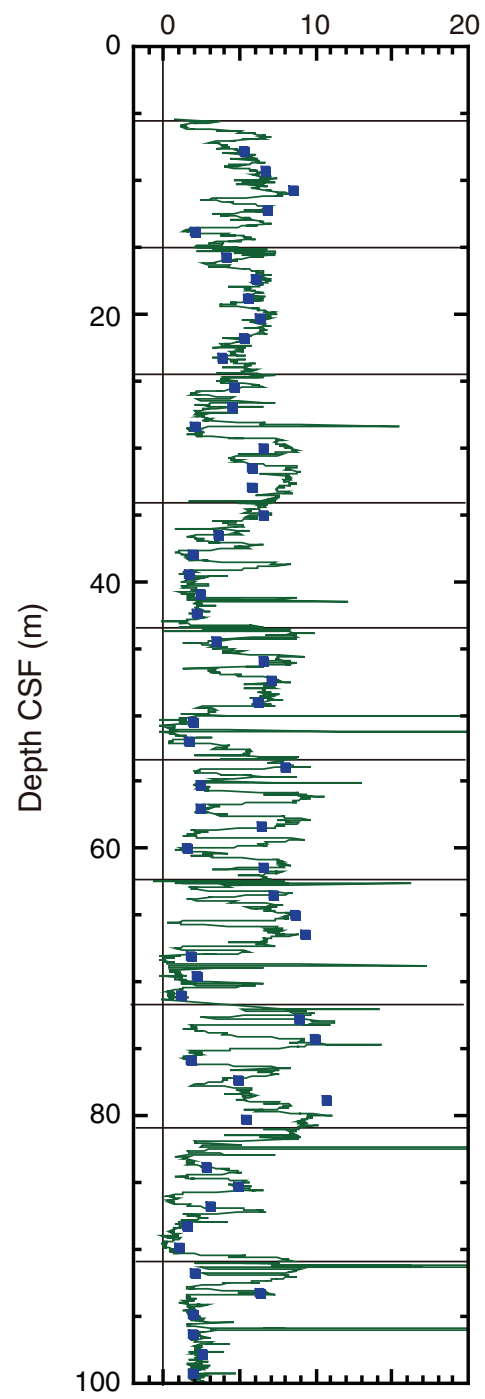

Hole U1337A

Intensity

$(\mathrm{A} / \mathrm{m})$

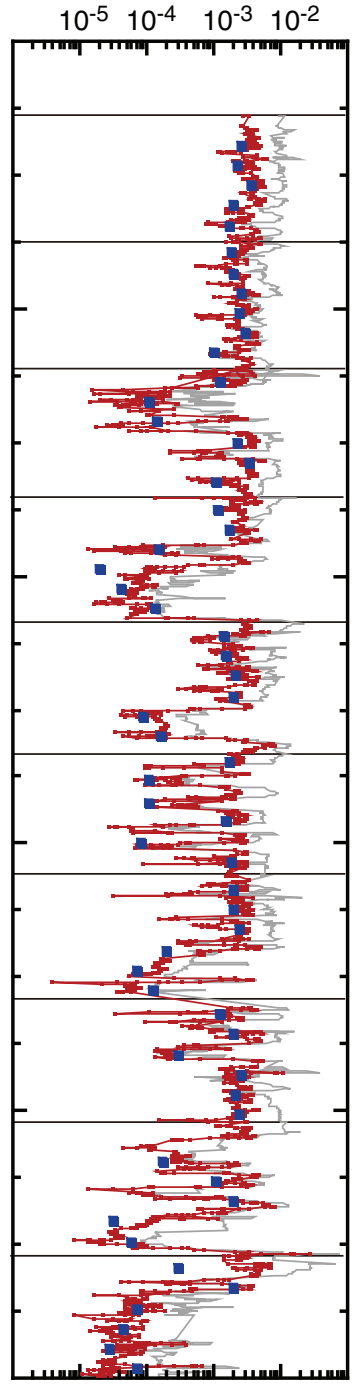

Inclination

$\left(^{\circ}\right)$
Declination

$\left.{ }^{\circ}\right)$

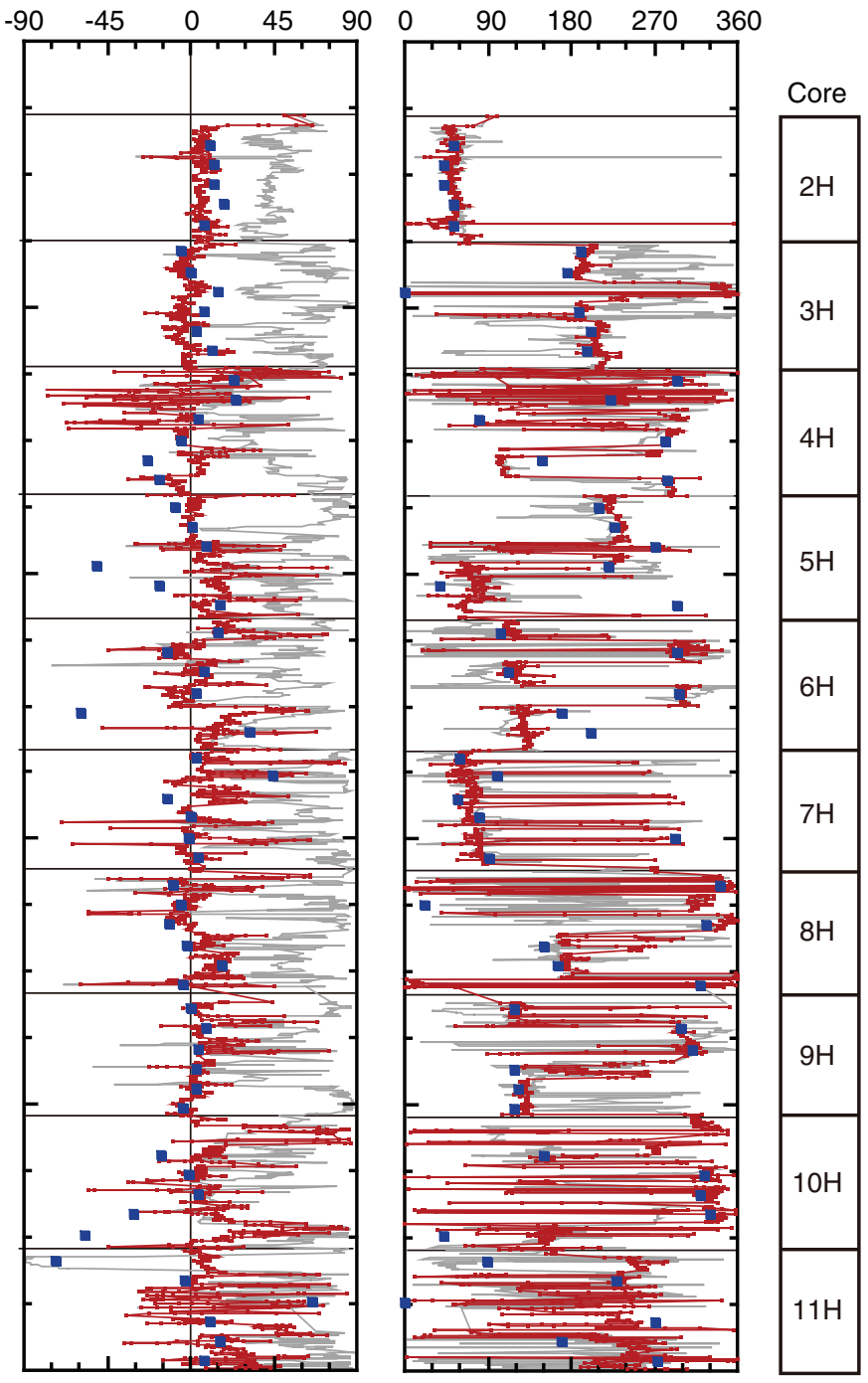


Figure F18 (continued). B. 100-200 m CSF. (Continued on next page.)

B Magnetic susceptibility $\left(10^{-5} \mathrm{SI}\right)$

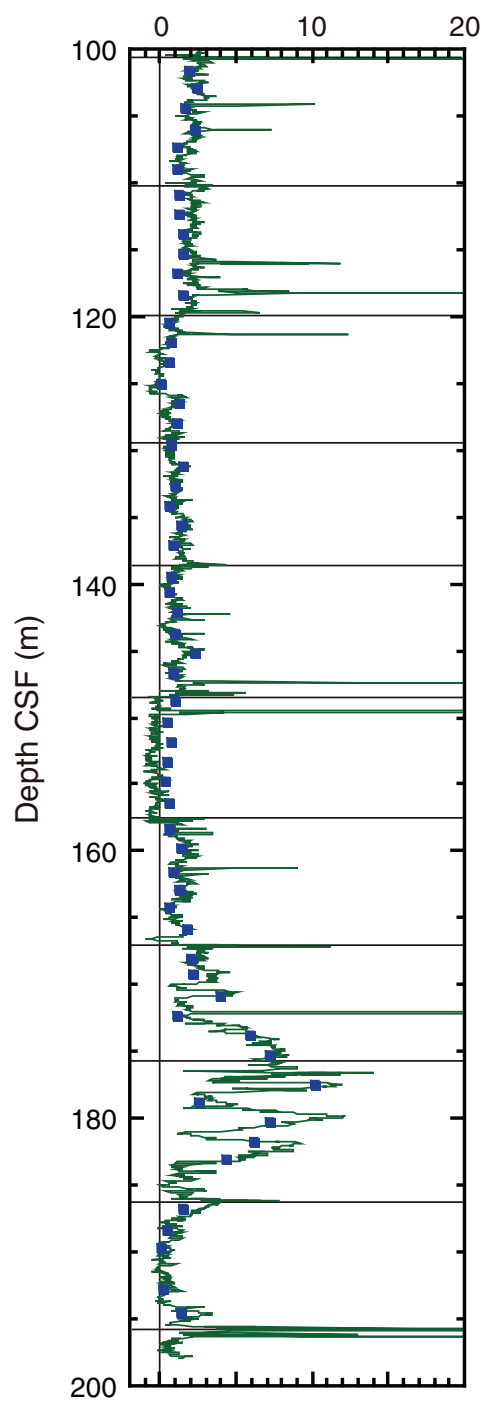

Hole U1337A

Intensity

$(\mathrm{A} / \mathrm{m})$

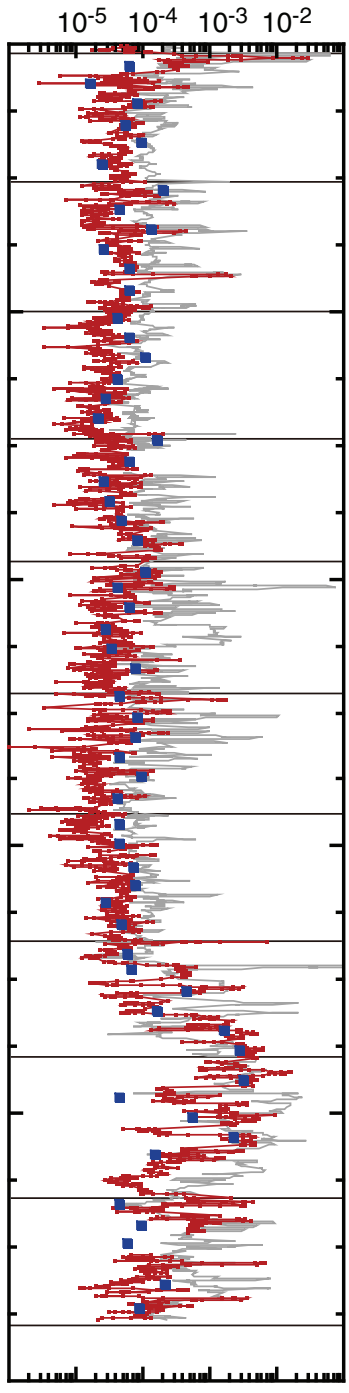

Inclination

$\left(^{\circ}\right)$

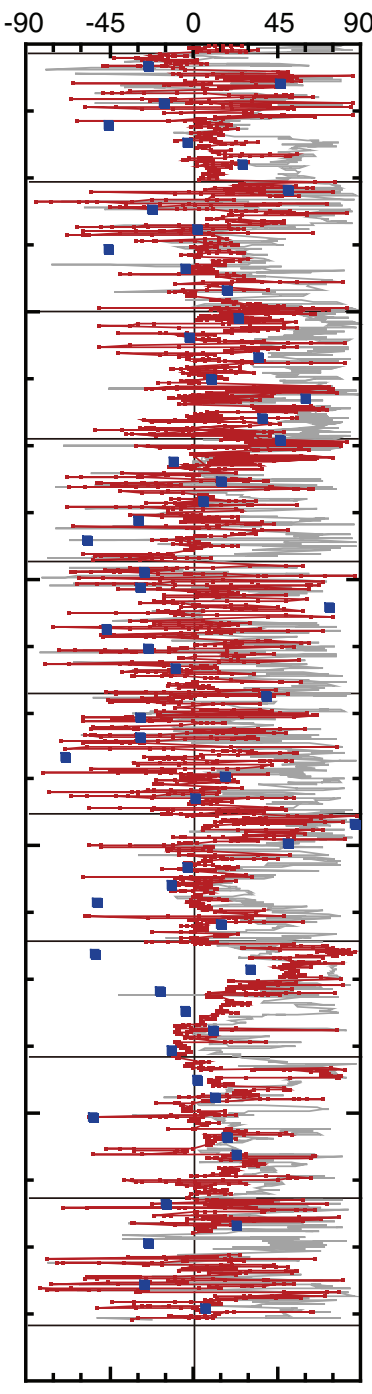

Declination

$\left.{ }^{\circ}\right)$

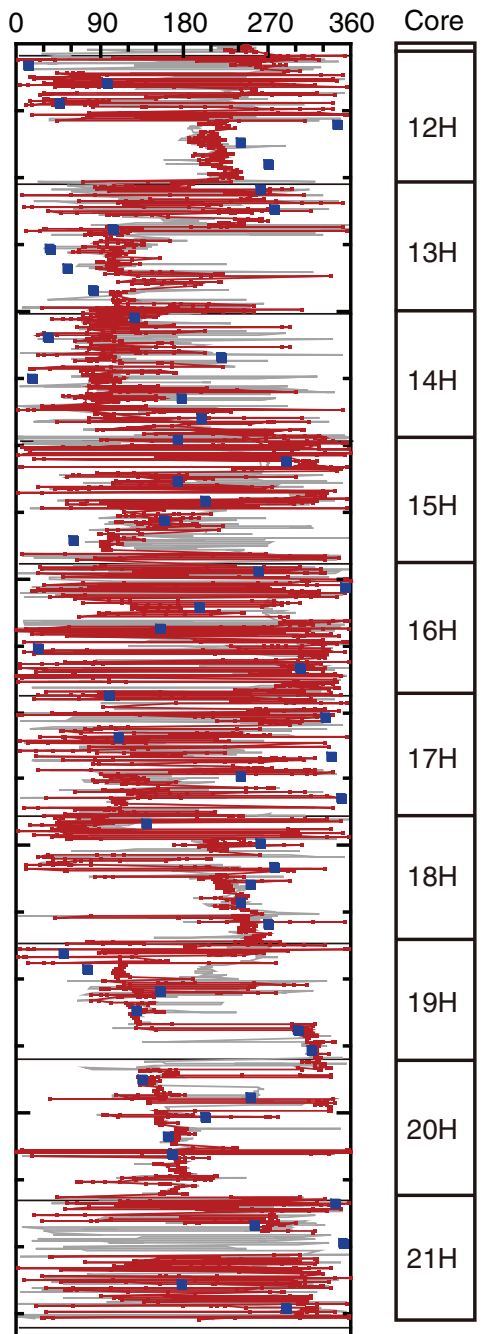


Figure F18 (continued). C. 200-335 m CSF.

C

Hole U1337A

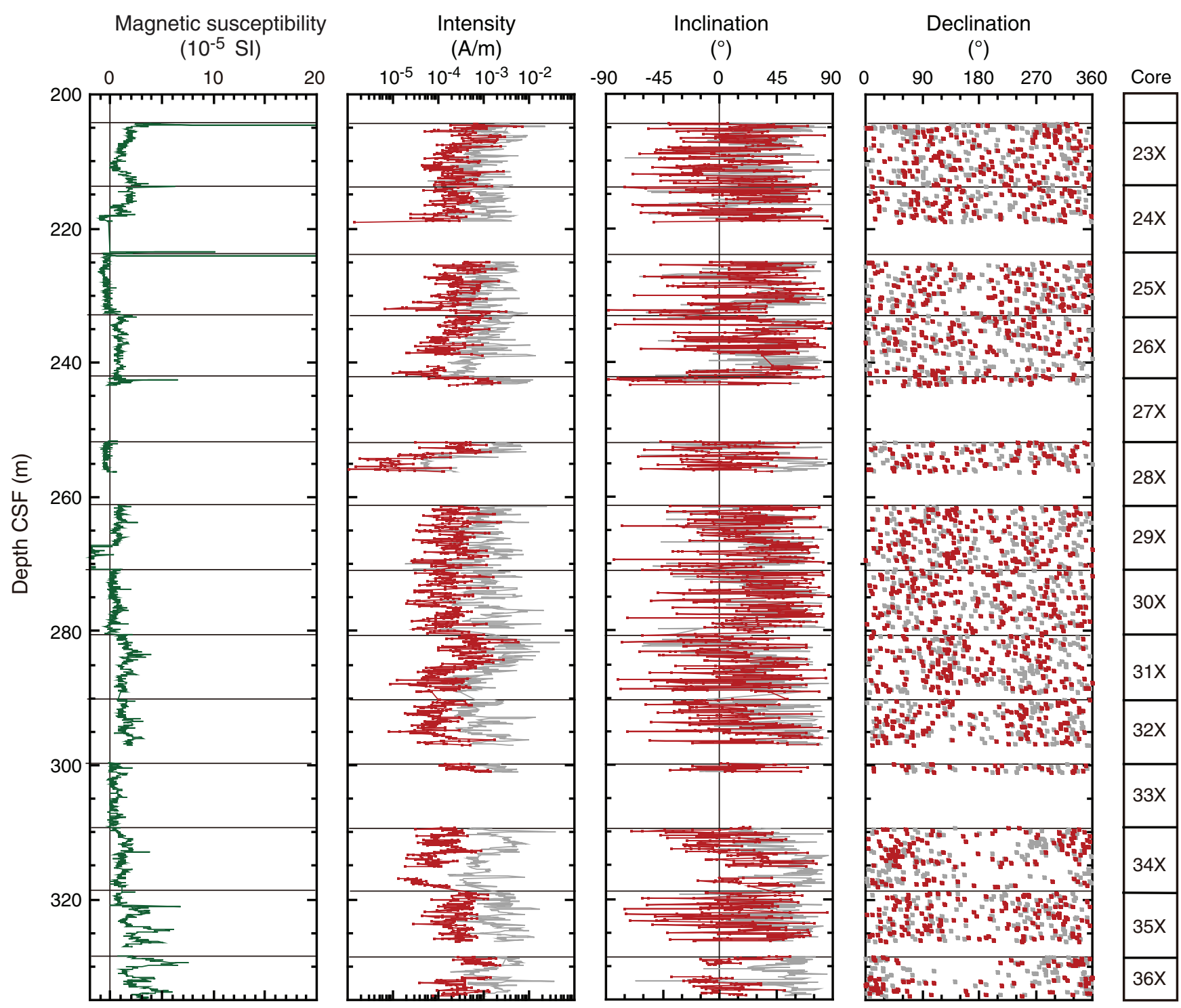


Figure F19. Magnetic susceptibility and paleomagnetic summary, Hole U1337B. Declinations are raw data before FlexIt tool orientation. Gray lines = measurements before demagnetization, red lines = measurements after $20 \mathrm{mT}$ alternating-field demagnetization step. A. 0-100 m CSF. (Continued on next two pages.)

A Hole U1337B

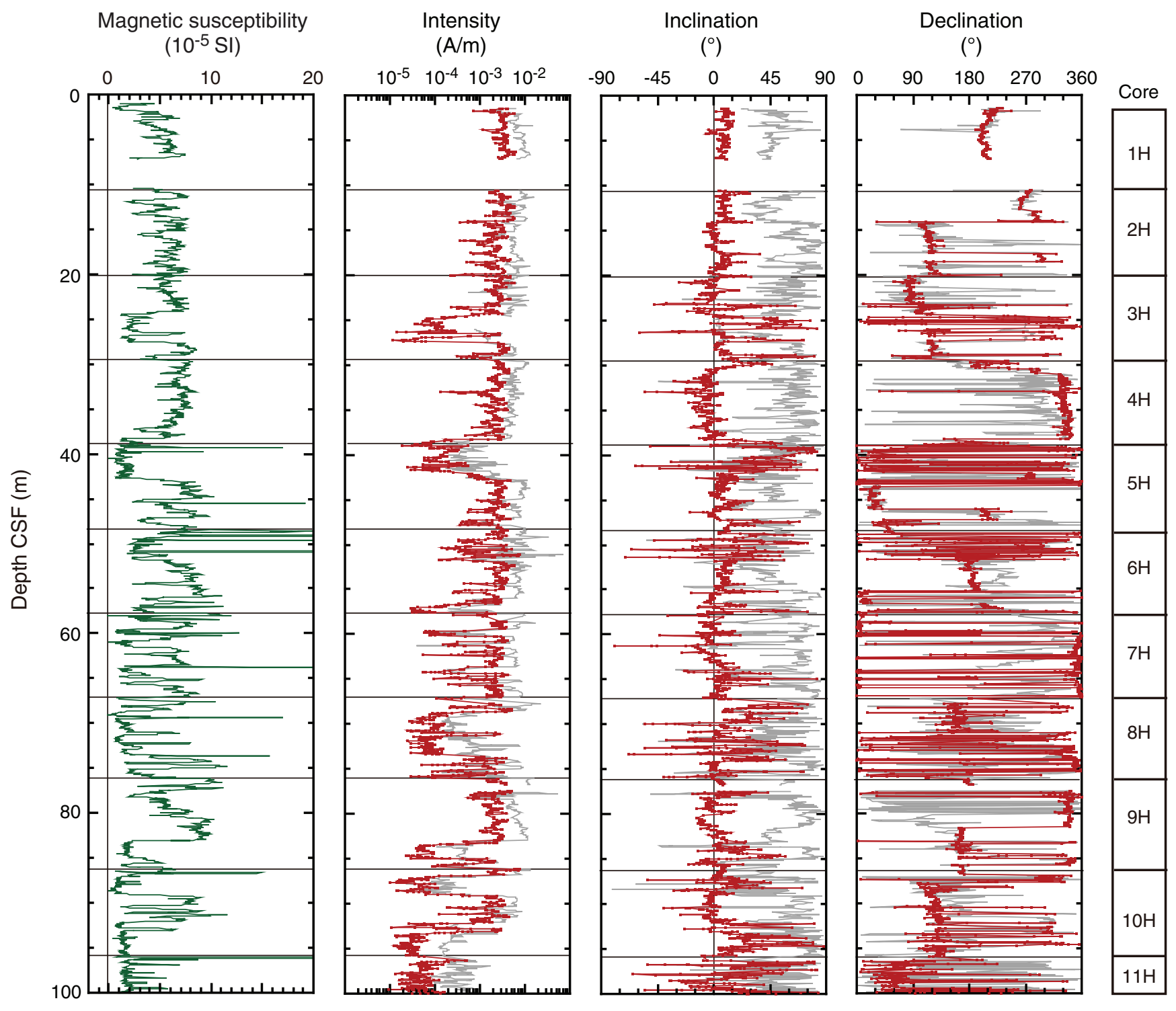


Figure F19 (continued). B. 100-200 m CSF. (Continued on next page.)

B

Magnetic susceptibility $\left(10^{-5} \mathrm{SI}\right)$

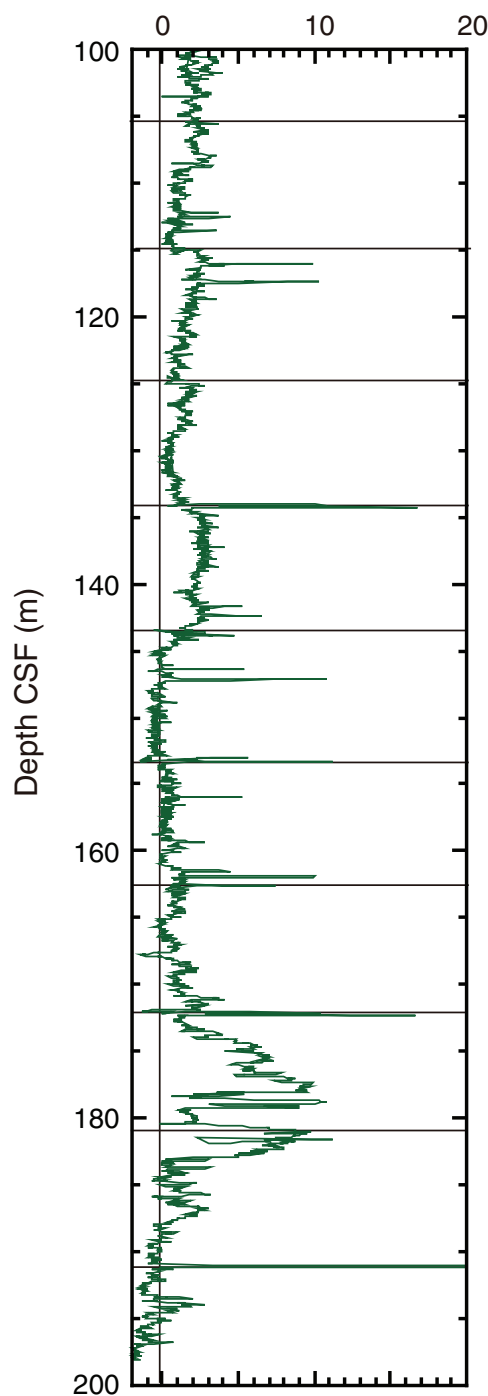

Hole U1337B

Intensity

$(\mathrm{A} / \mathrm{m})$

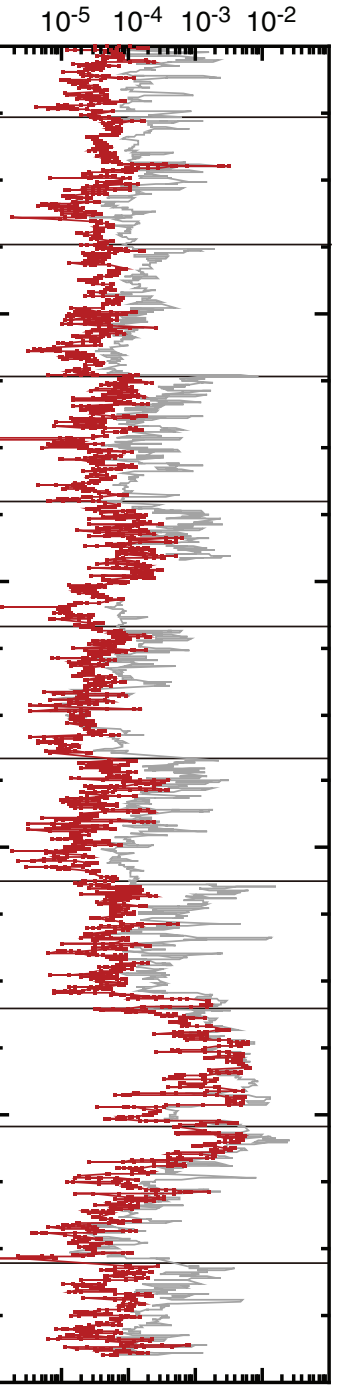

Inclination

$\left(^{\circ}\right)$

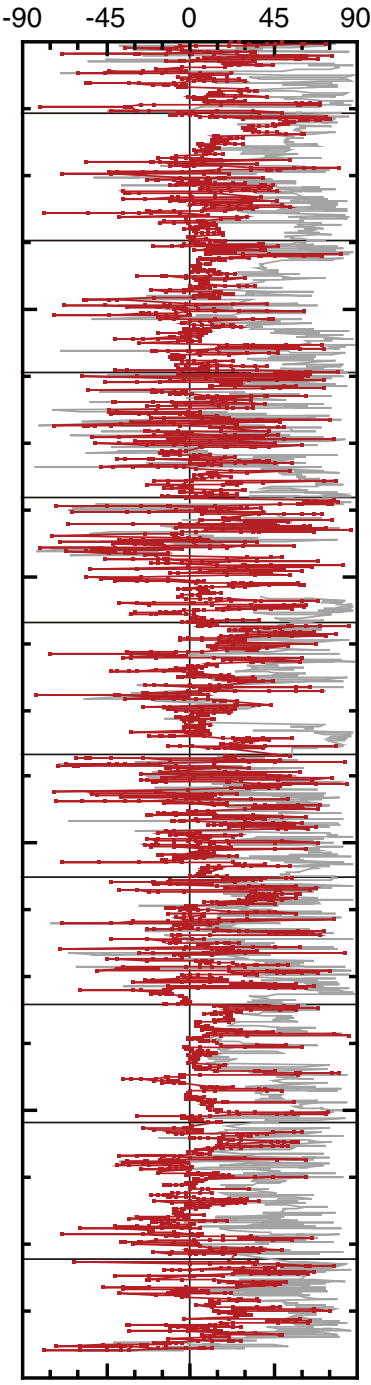

Declination

$\left({ }^{\circ}\right)$

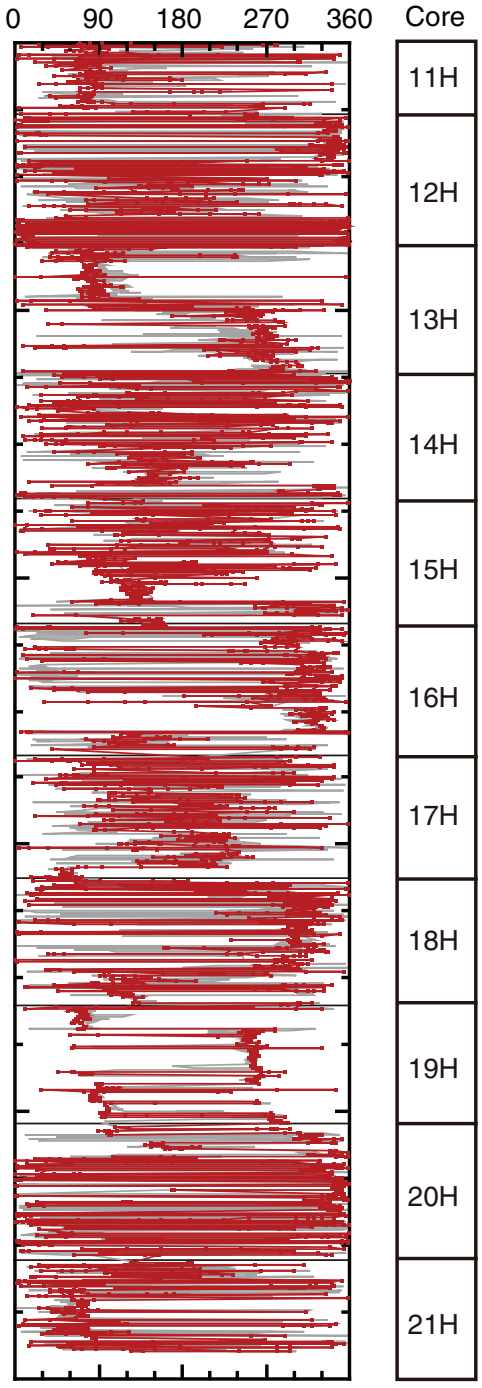


C

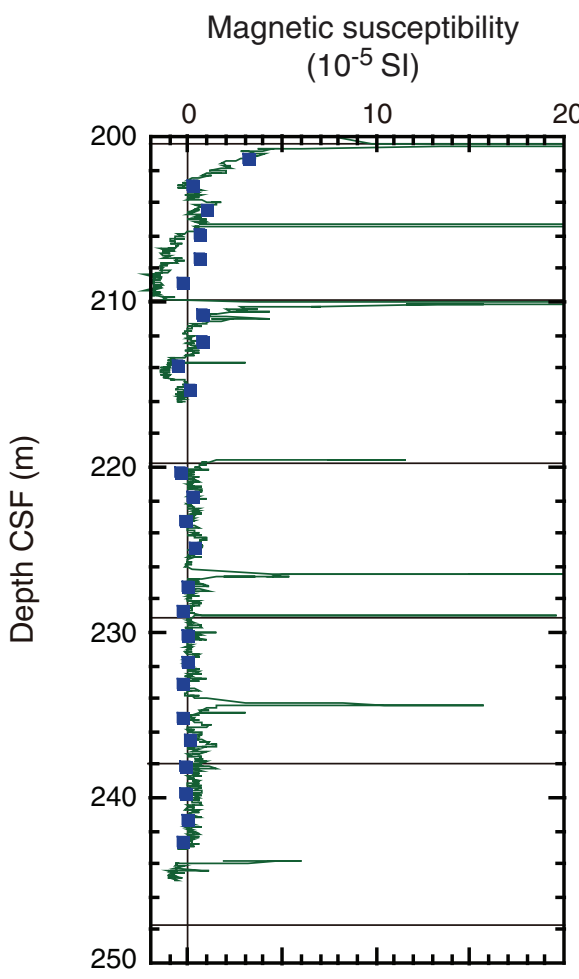

Hole U1337B

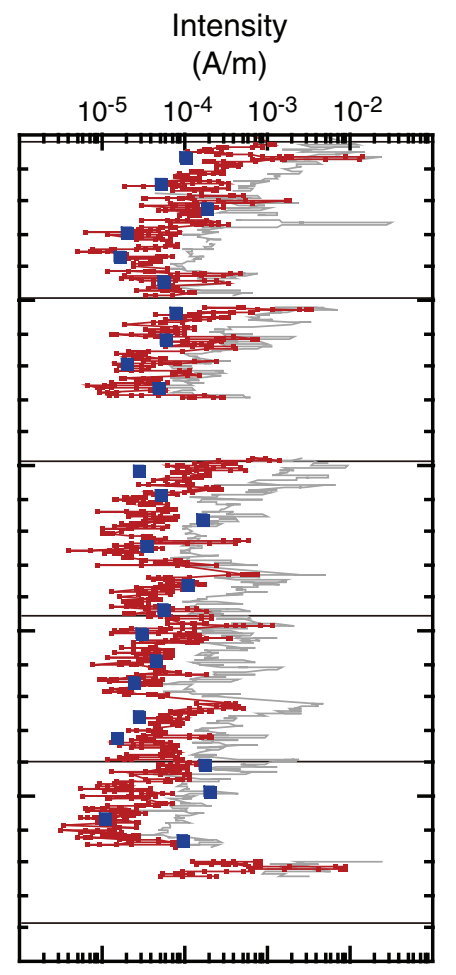

Inclination

$\left({ }^{\circ}\right)$
Declination

$$
\left({ }^{\circ}\right)
$$

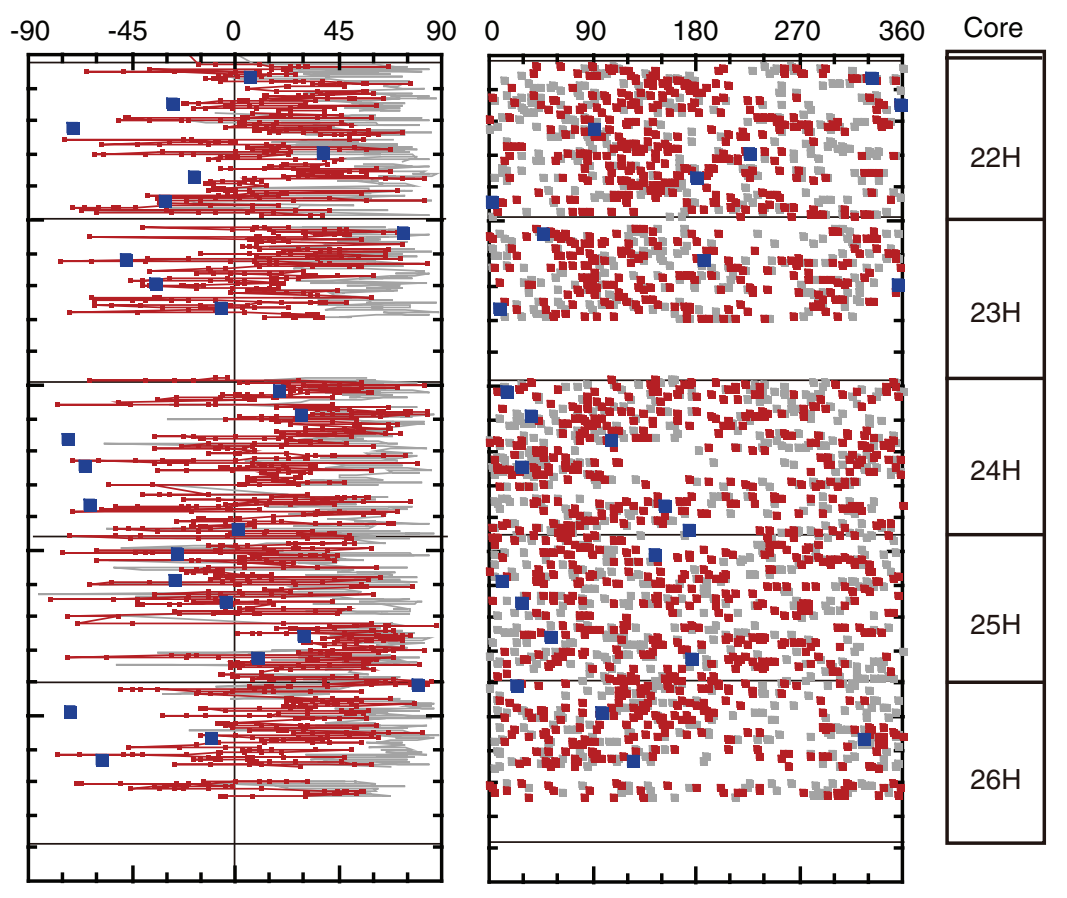


Figure F20. Magnetic susceptibility and paleomagnetic summary, Hole U1337C. Declinations are raw data before FlexIt tool orientation. Gray lines = measurements before demagnetization, red lines = measurements after $20 \mathrm{mT}$ alternating-field demagnetization step.

Hole U1337C

Magnetic susceptibility

$\left(10^{-5} \mathrm{SI}\right)$
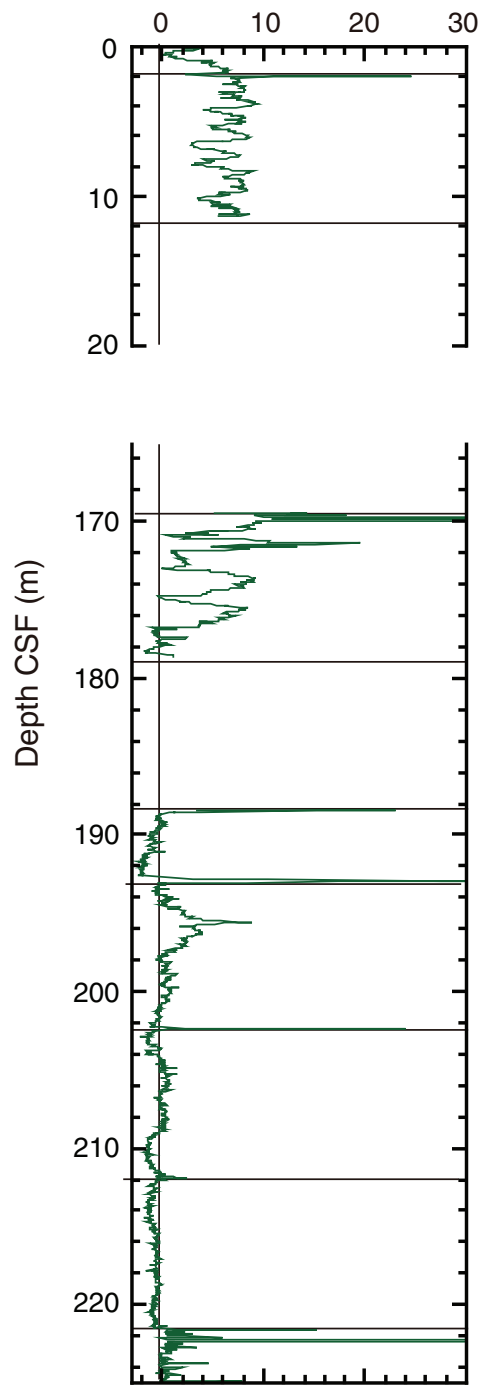

Intensity

$(\mathrm{A} / \mathrm{m})$
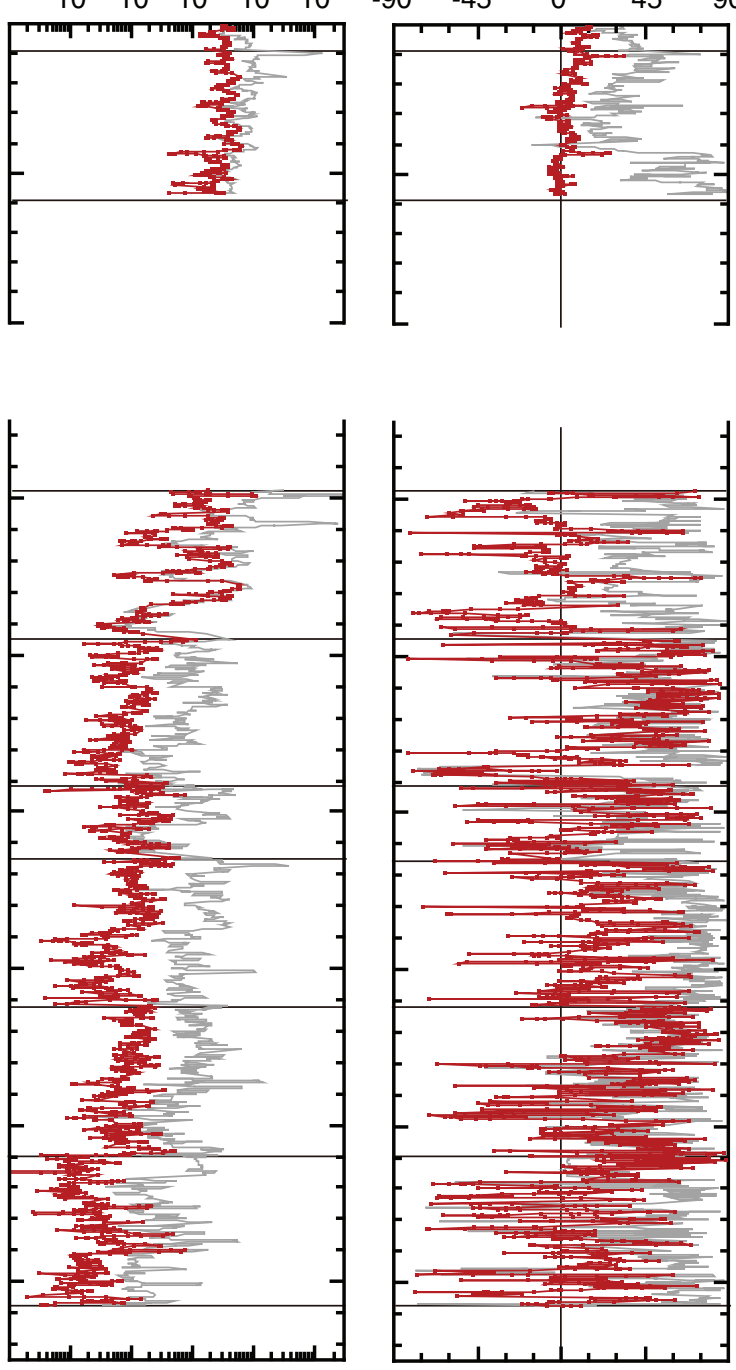

Inclination

$\left({ }^{\circ}\right)$

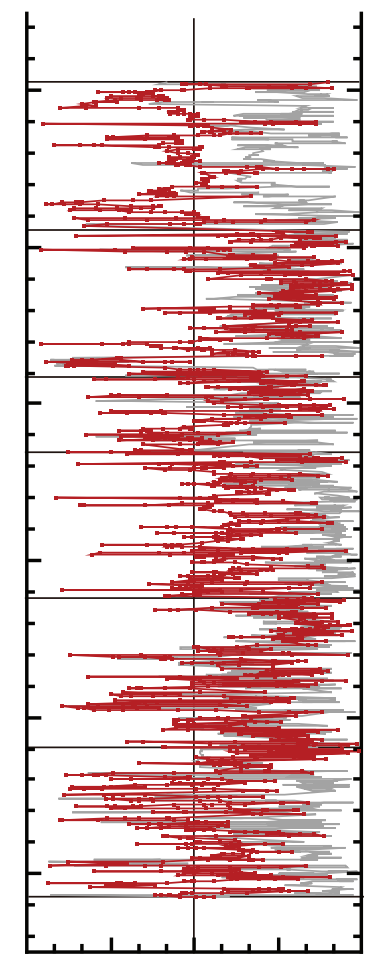

Declination

$\left(^{\circ}\right)$
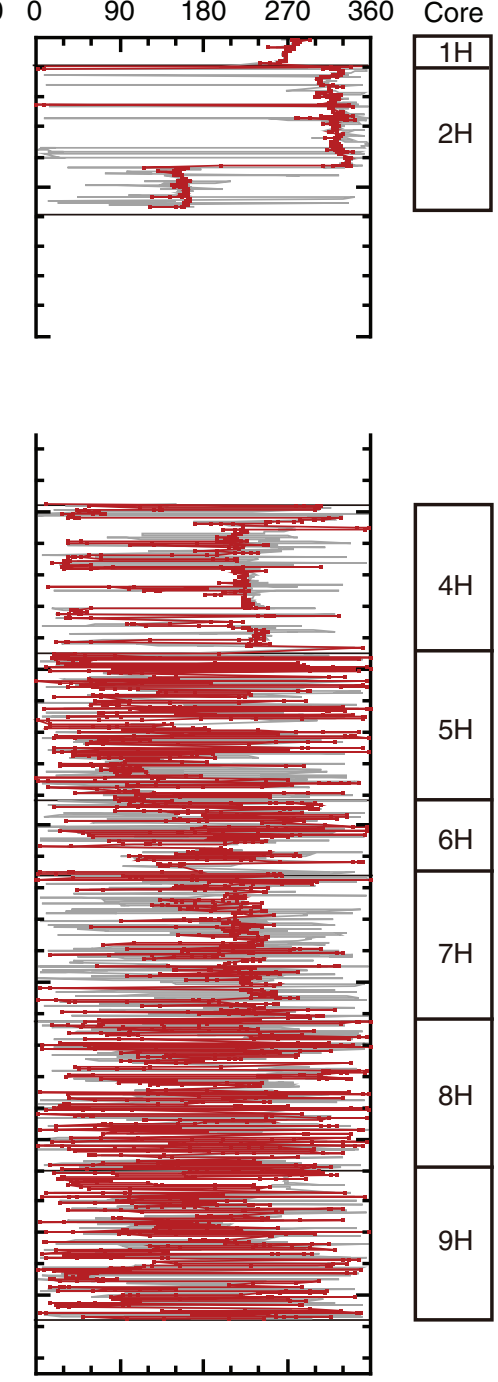

\begin{tabular}{|l|}
\hline $4 \mathrm{H}$ \\
\hline $5 \mathrm{H}$ \\
\hline $6 \mathrm{H}$ \\
\hline $7 \mathrm{H}$ \\
\hline $8 \mathrm{H}$ \\
\hline $9 \mathrm{H}$ \\
\hline
\end{tabular} 
Figure F21. Magnetic susceptibility and paleomagnetic summary, Hole U1337D. Declinations are raw data before FlexIt tool orientation. Gray lines = measurements before demagnetization, red lines = measurements after $20 \mathrm{mT}$ alternating-field demagnetization step. A. 0-100 m CSF. (Continued on next two pages.)

A

Hole U1337D

Magnetic susceptibility $\left(10^{-5} \mathrm{SI}\right)$

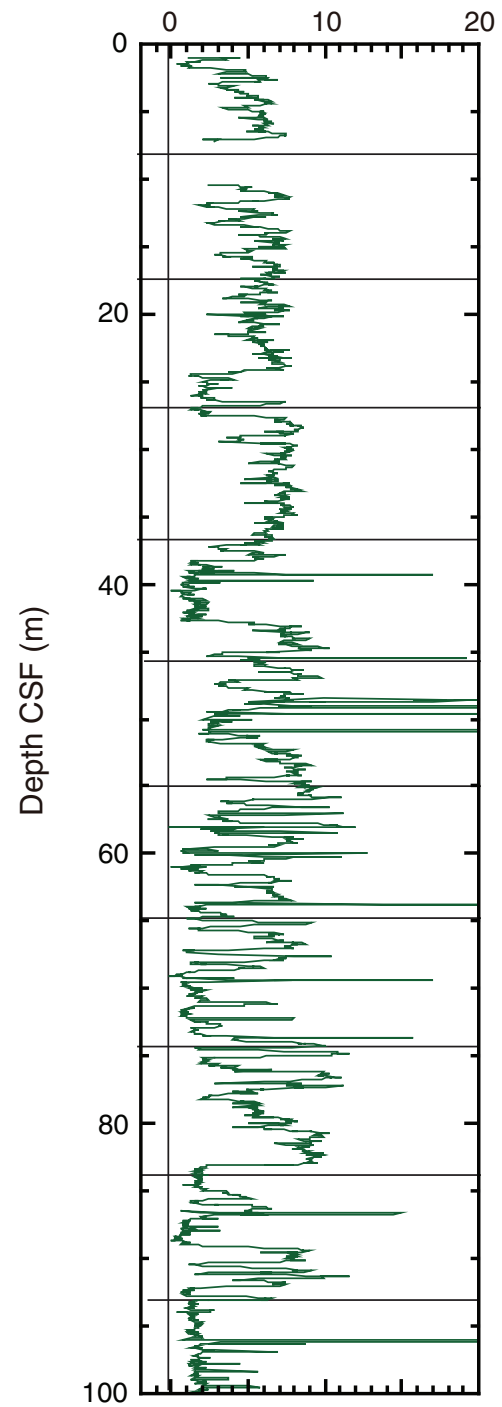

Intensity

$(\mathrm{A} / \mathrm{m})$

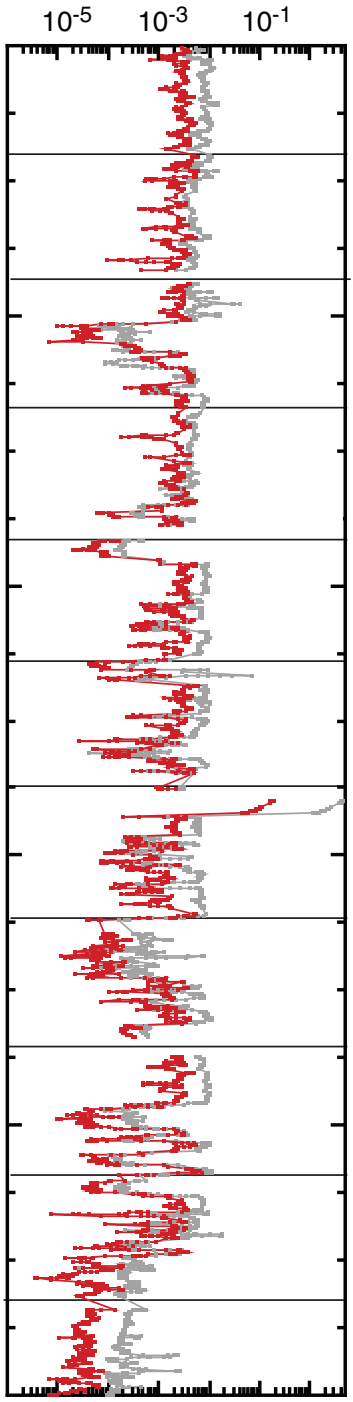

Inclination

$\left.{ }^{\circ}\right)$

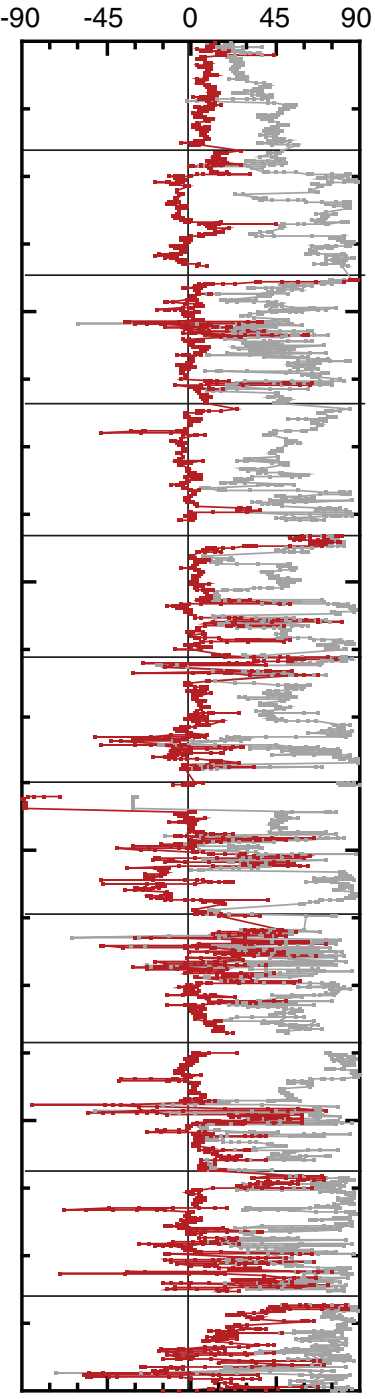

Declination

$\left(^{\circ}\right)$

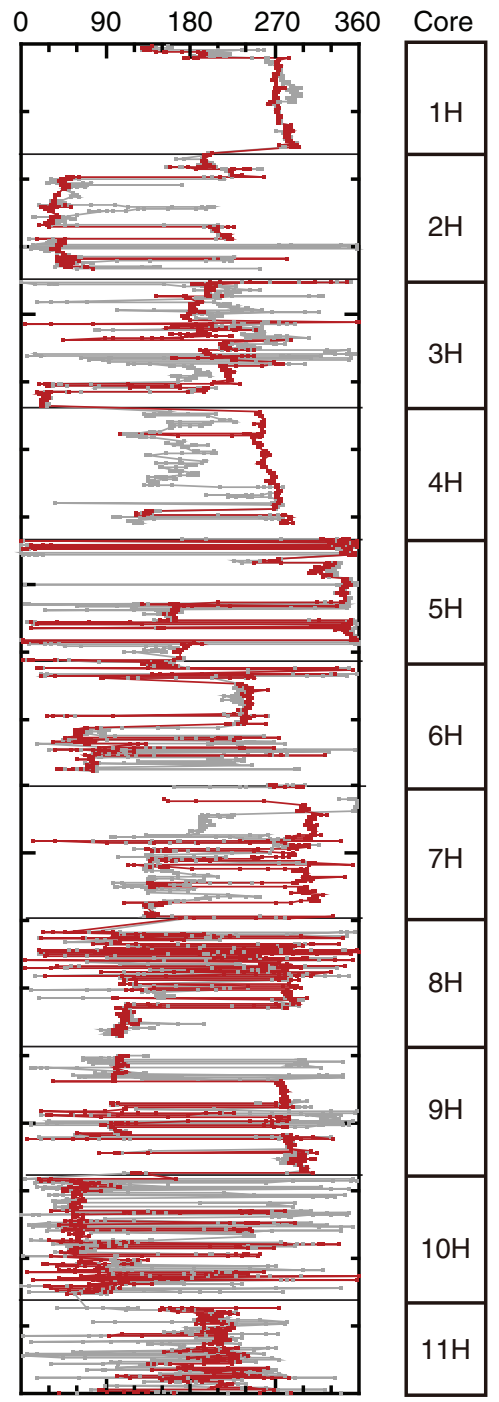


Figure F21 (continued) B. 100-200 m CSF. (Continued on next page.)

B

Magnetic susceptibility $\left(10^{-5} \mathrm{SI}\right)$

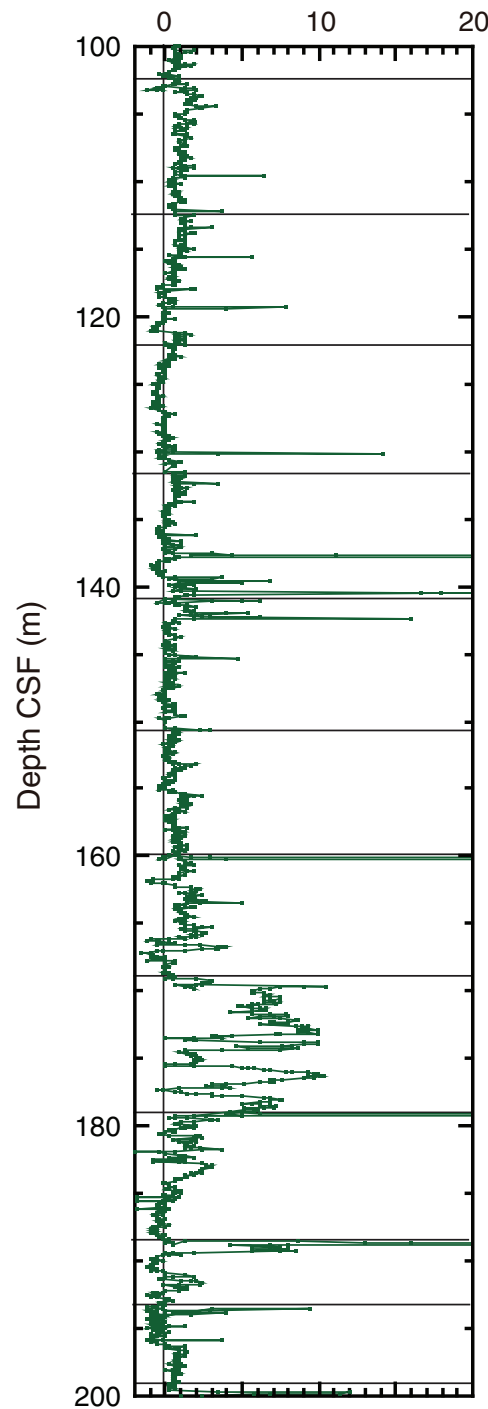

Hole U1337D

Intensity

$(\mathrm{A} / \mathrm{m})$

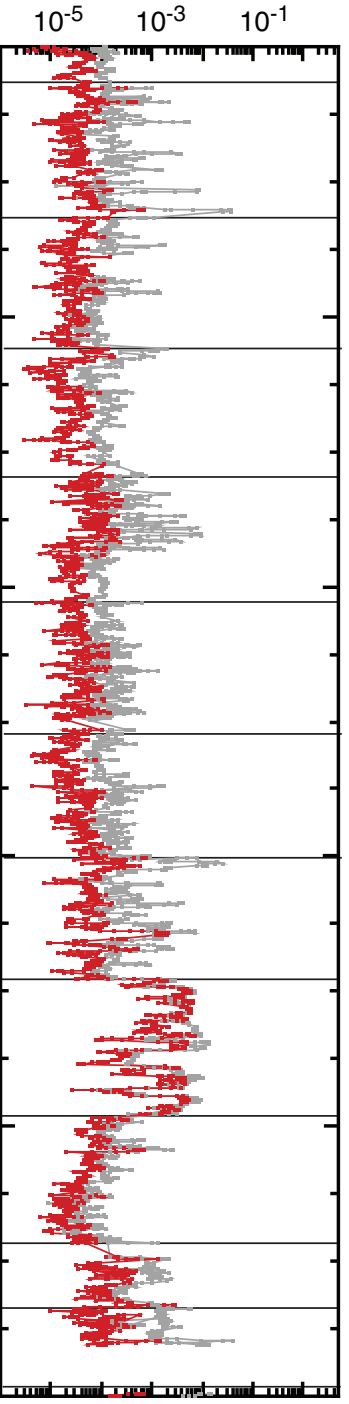

Inclination

( )

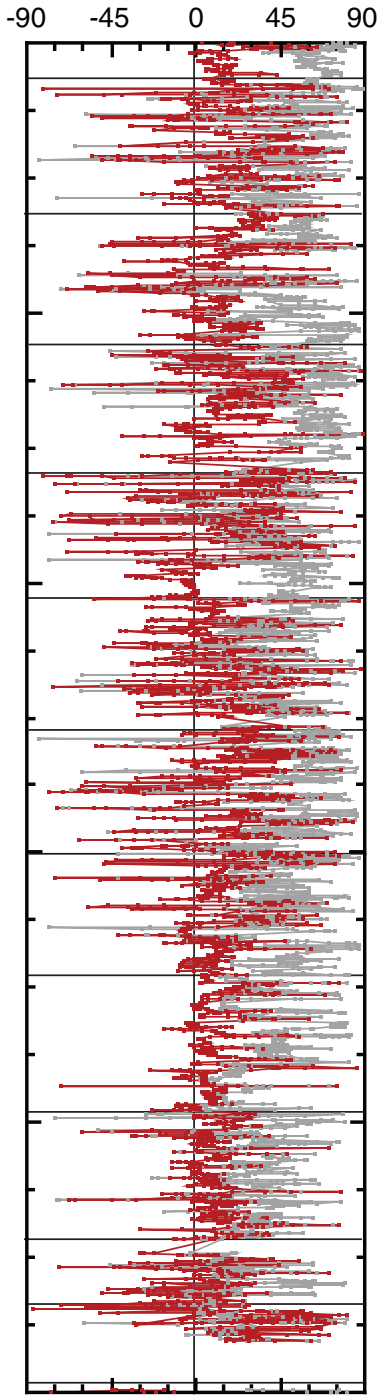

Declination

$\left({ }^{\circ}\right)$

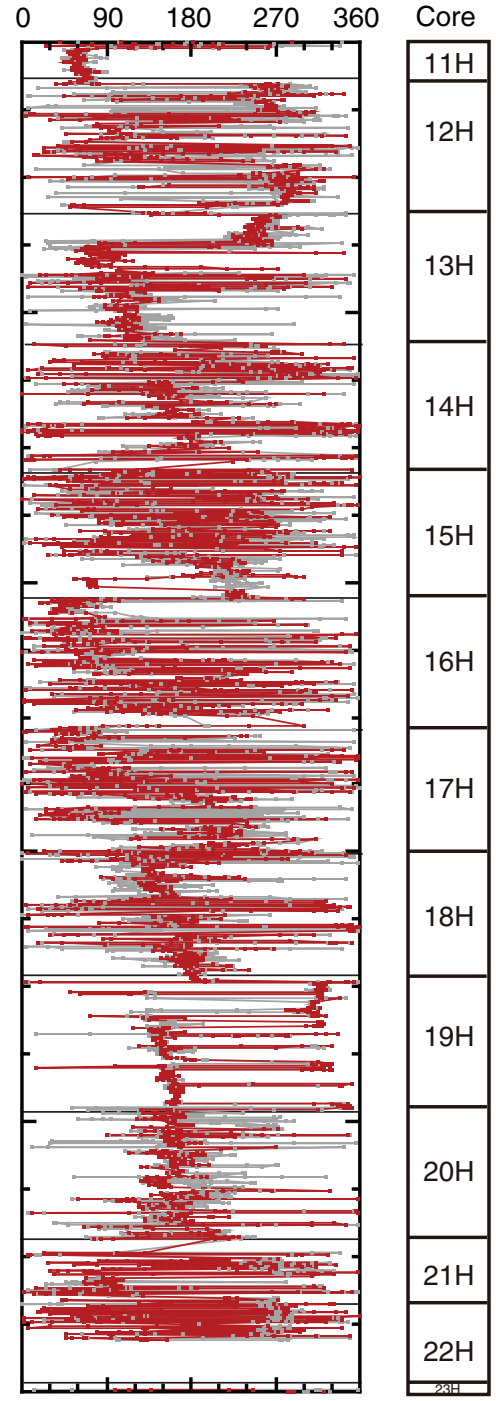


Figure F21 (continued). C. 200-270 m CSF.

C Hole U1337D
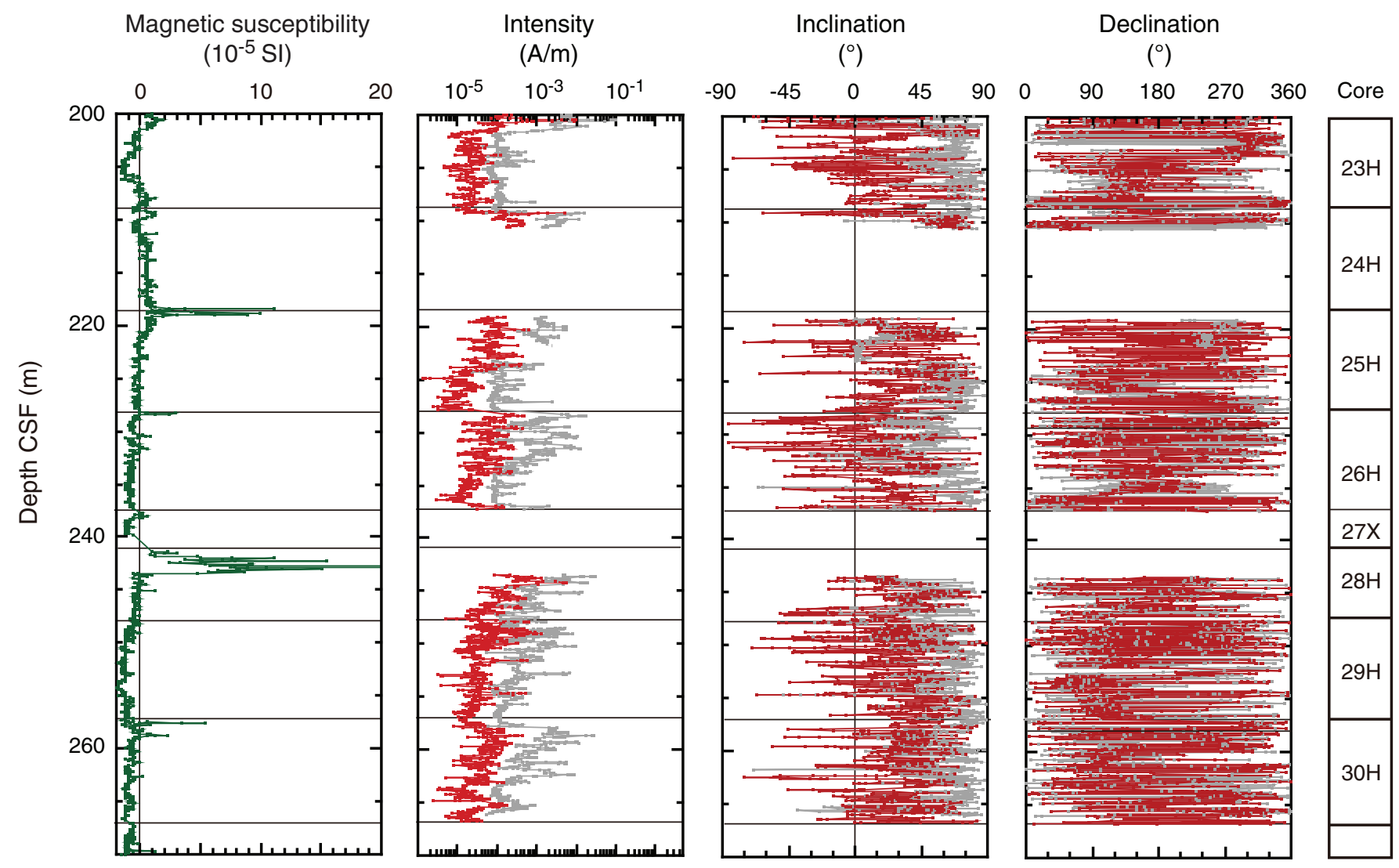
Figure F22. Declination of magnetic remanence after applying orientation using the FlexIt tool and $20 \mathrm{mT}$ peak alternating-field demagnetization. Interpretations are hampered by weak magnetization intensities and scattered directional data in some intervals. Core composite depths below seafloor were determined independent of the polarity record. See Table T16. GPTS = geomagnetic polarity timescale. A. 0-110 m CCSF-A. (Continued on next page.)

A

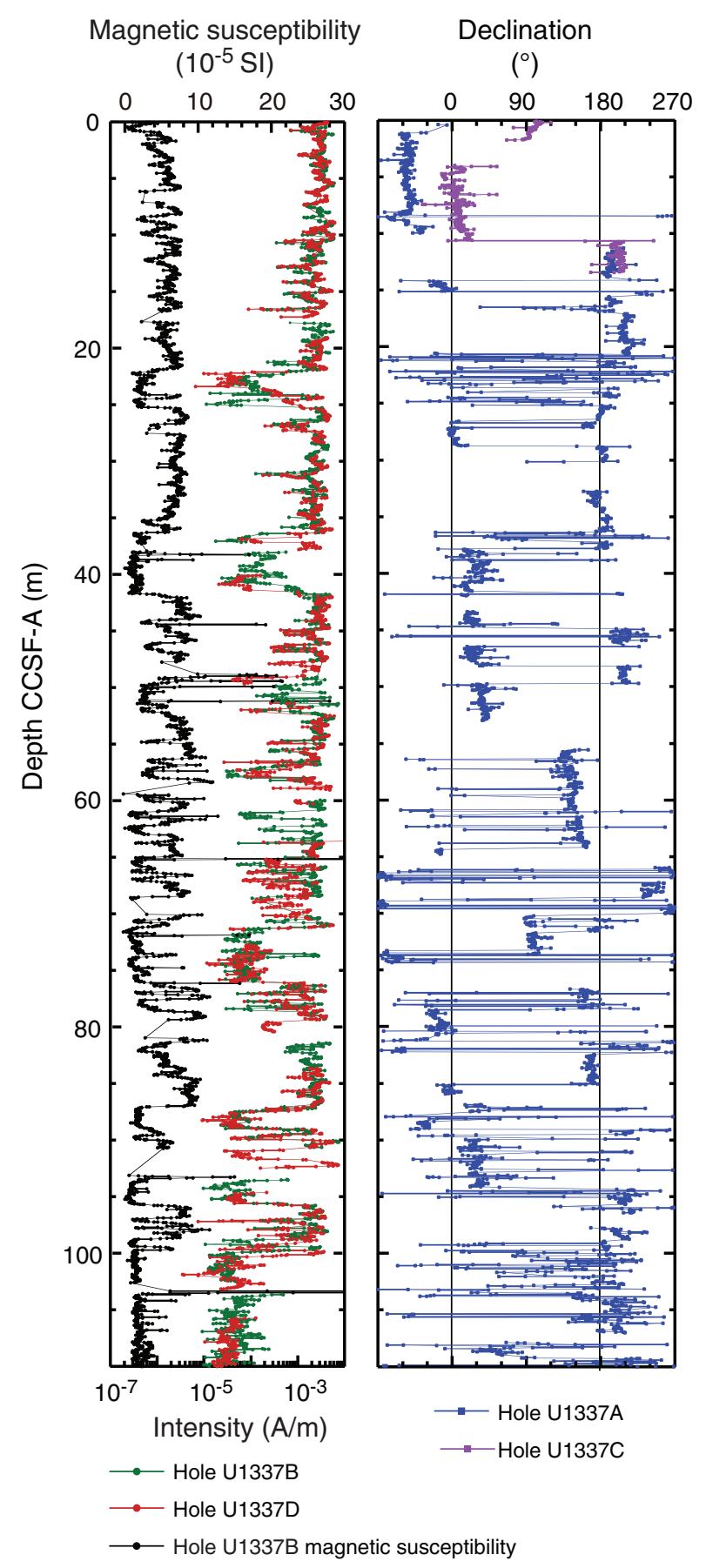

Holes U1337B

and U1337D

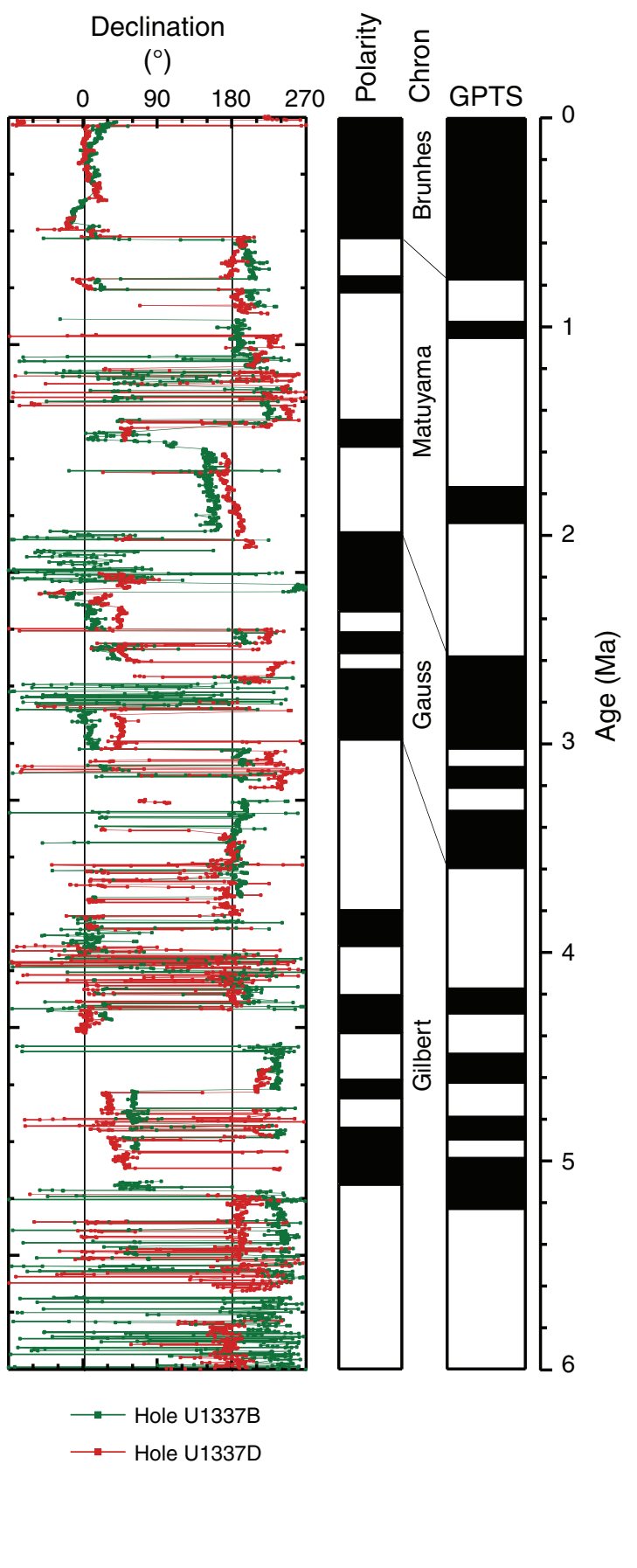


Figure F22 (continued). B. 110-220 m CCSF-A.

B

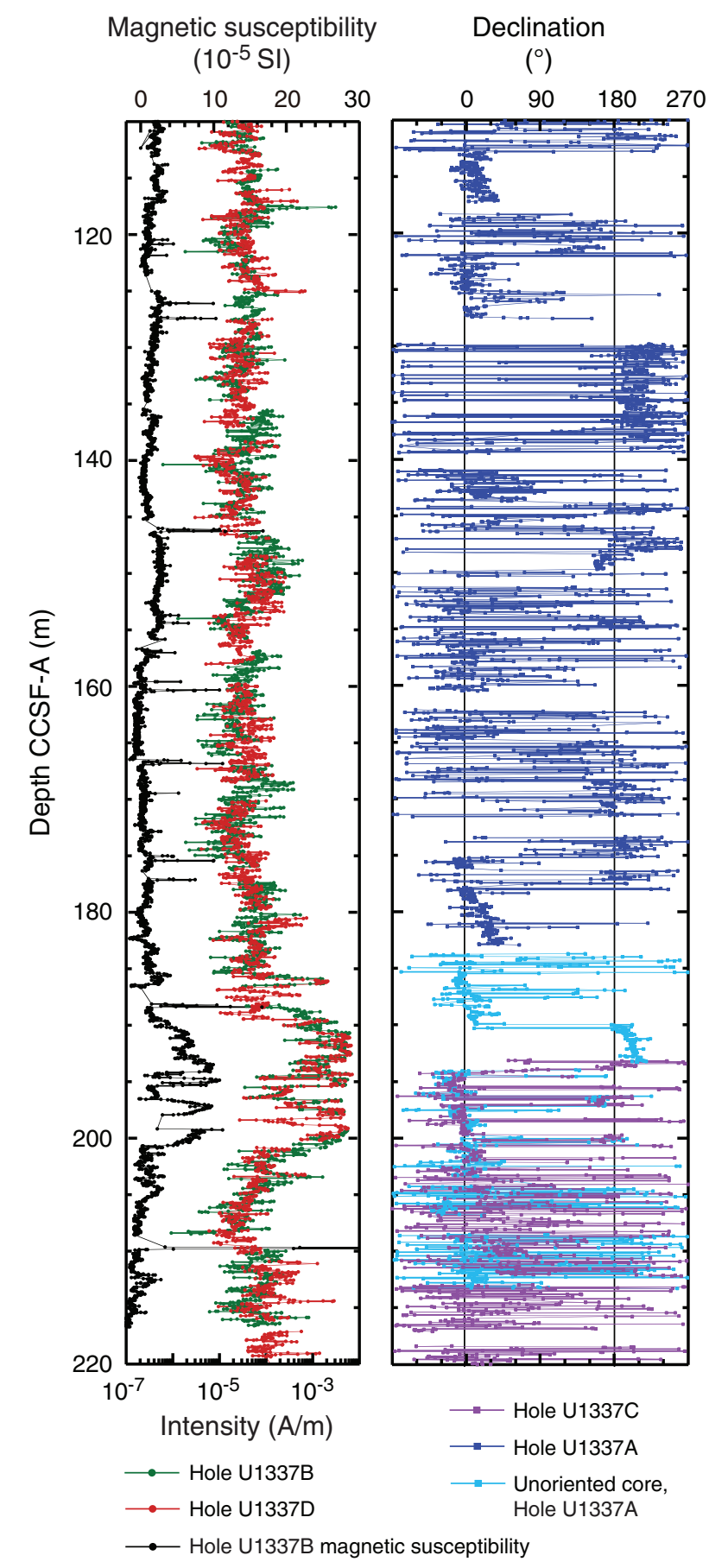

Holes U1337B

and U1337D

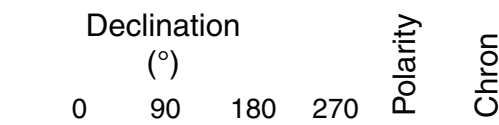
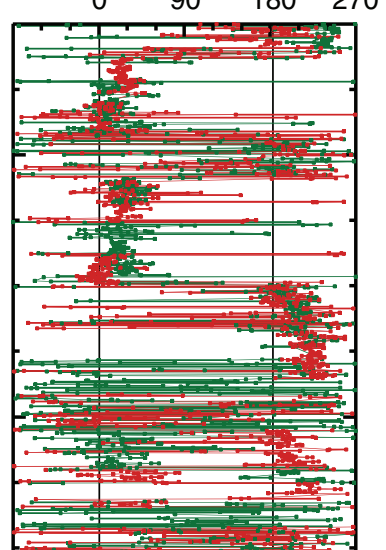

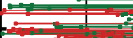

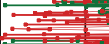

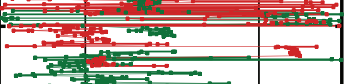

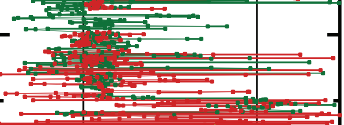

$\Rightarrow$

$\therefore \quad-3=$

$=10$

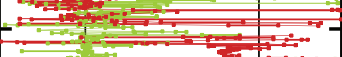

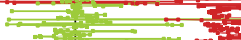

$=$

.

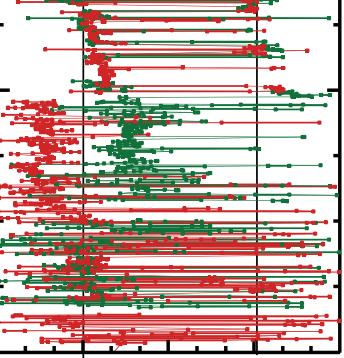

— Hole U1337B

—- Hole U1337D

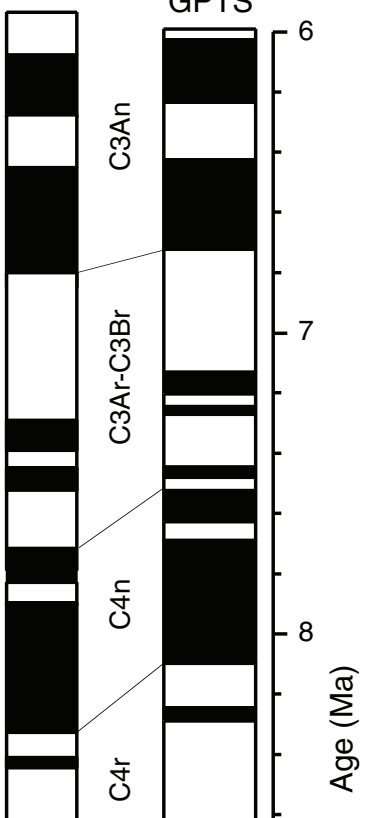

—Unoriented core,

Hole U1337B 
Figure F23. Depth-age plot based on polarity interpretation indicating a change in mean sedimentation rate at $\sim 3.3 \mathrm{Ma}$ ( 50 m CCSF-A), Holes U1337A-U1337D.

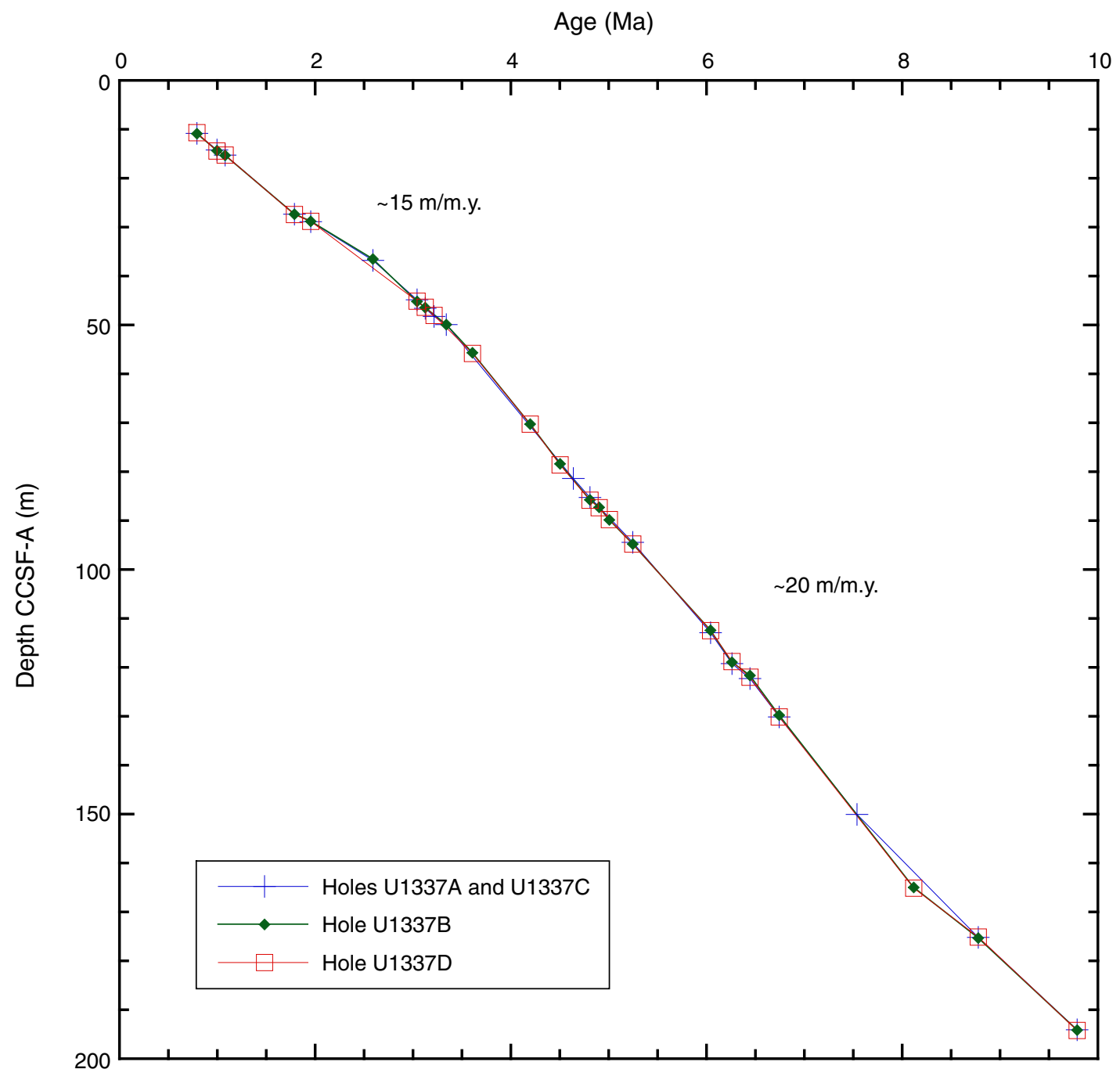


Figure F24. Interstitial water chemistry, Hole U1337A. Open circles = Rhizon samples, solid circles = squeezed samples. See the "Methods" chapter for uncertainty estimates. Values below detection limit (see Table T17) are plotted as zero.
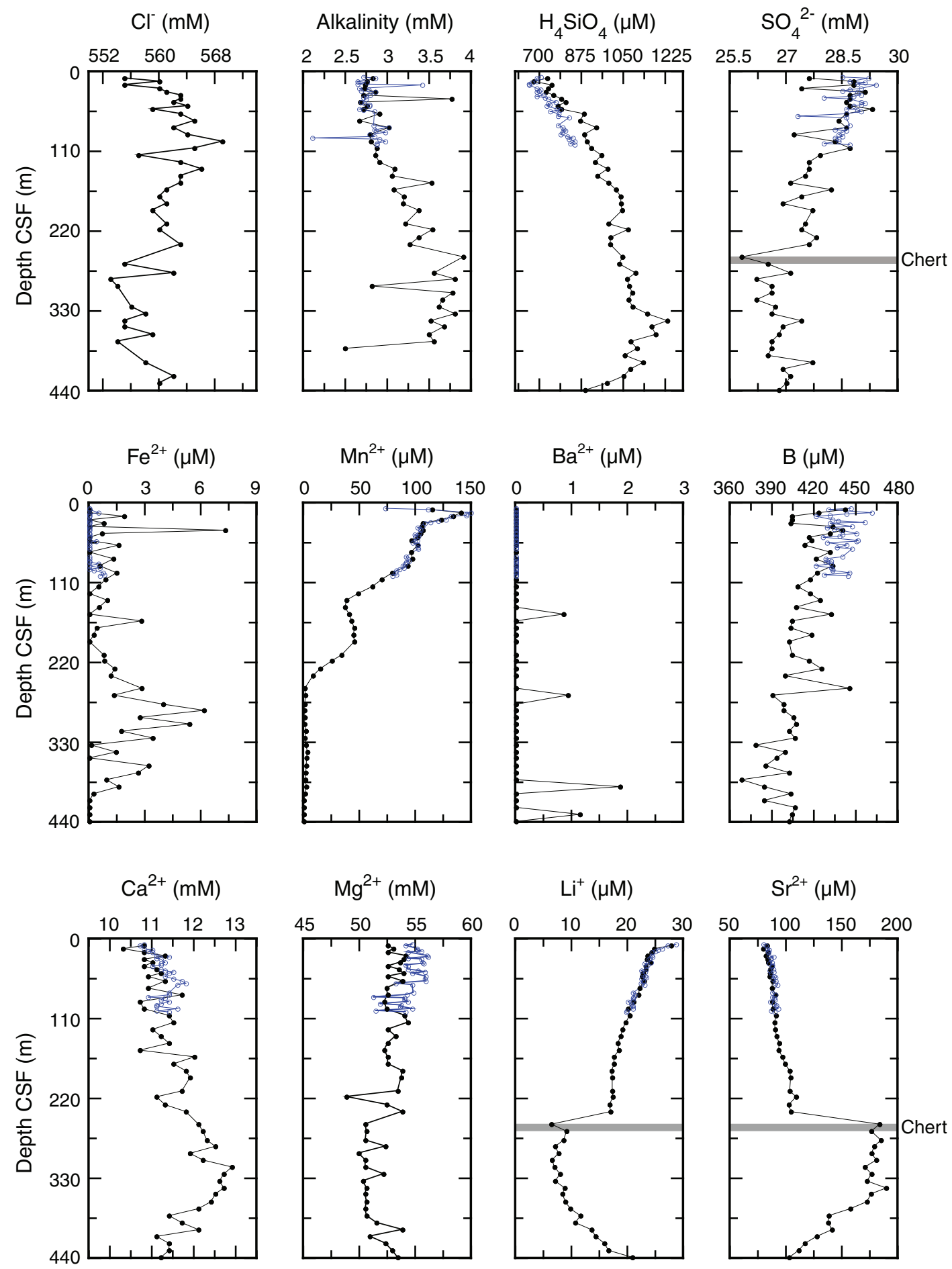
Figure F25. Selected bulk sediment geochemistry, Hole U1337A.

Bulk sediment (wt\%)

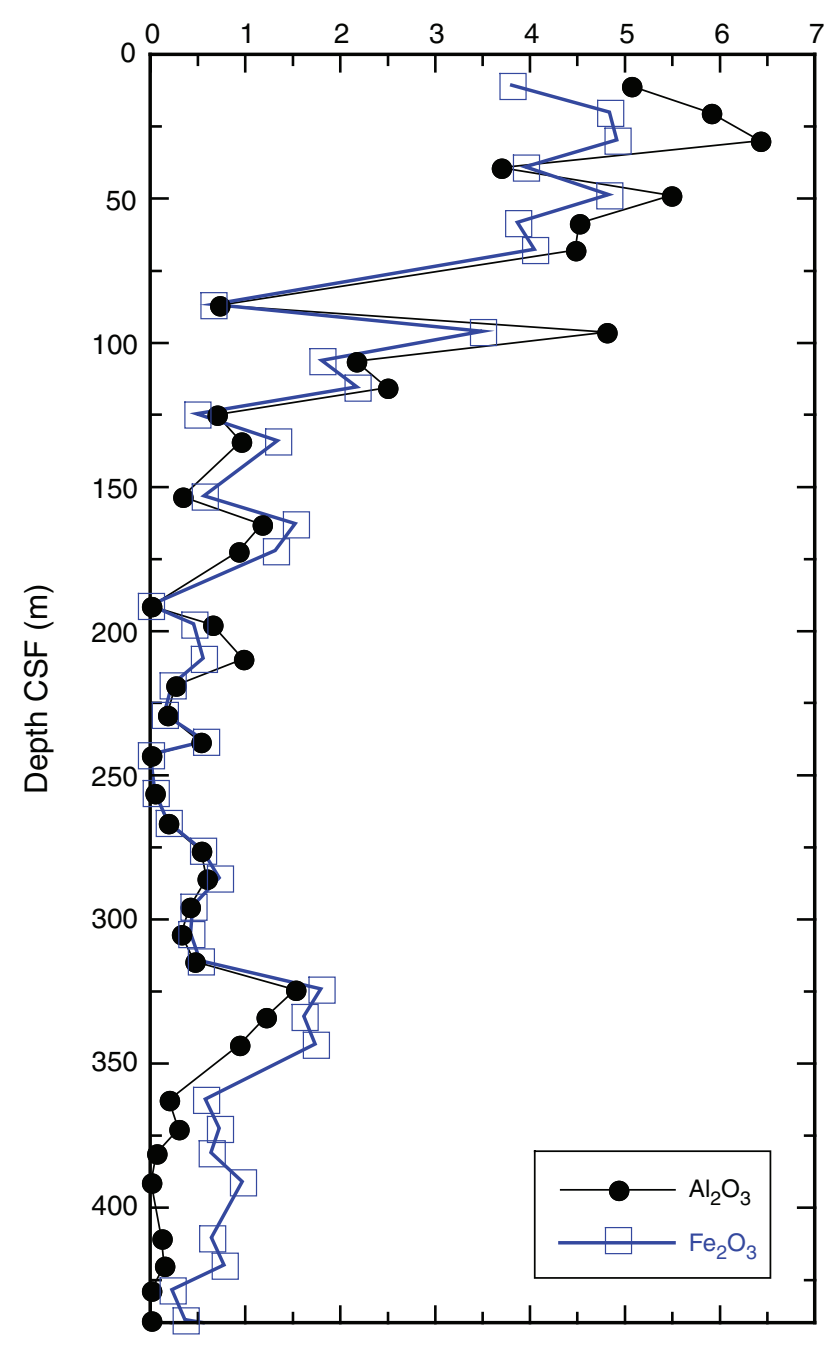

Bulk sediment (wt\%)

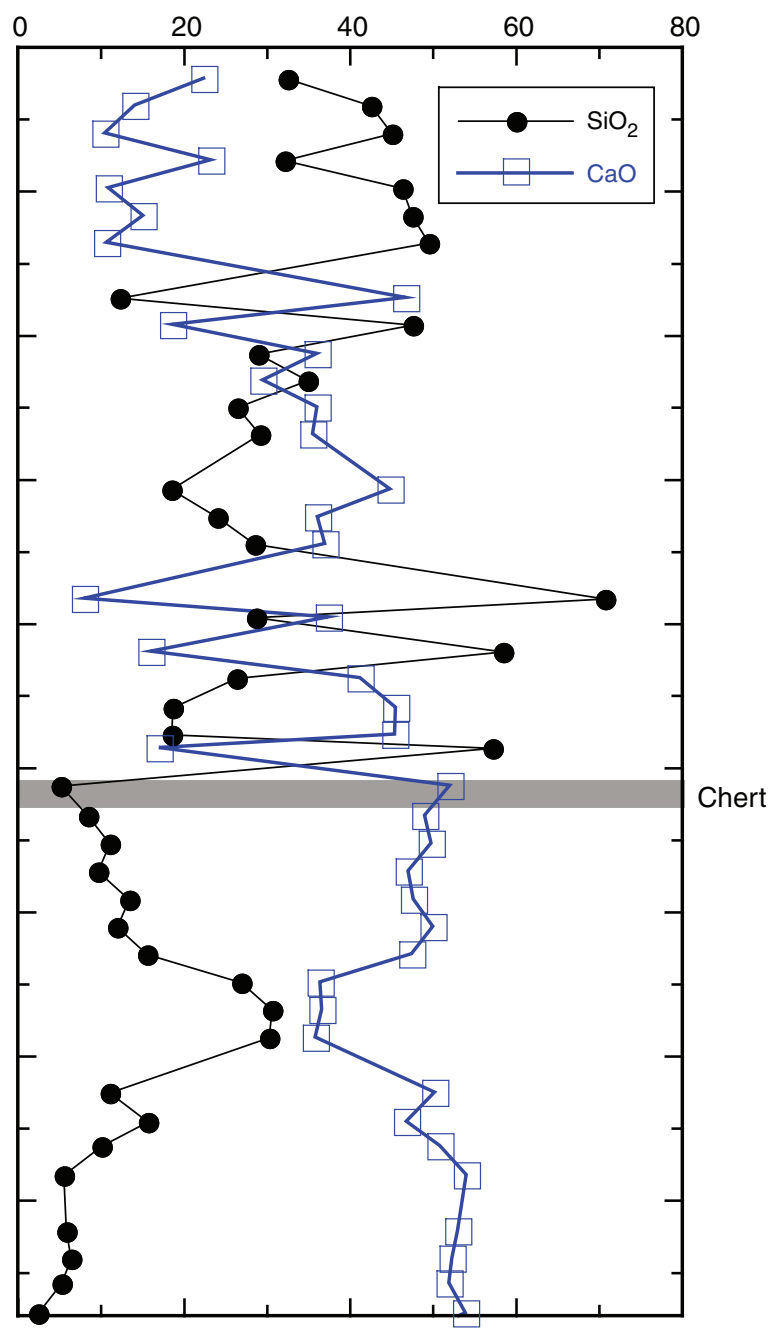


Figure F26. Sediment calcium carbonate $\left(\mathrm{CaCO}_{3}\right)$ and total organic carbon (TOC) concentrations, Holes U1337A and U1337B.
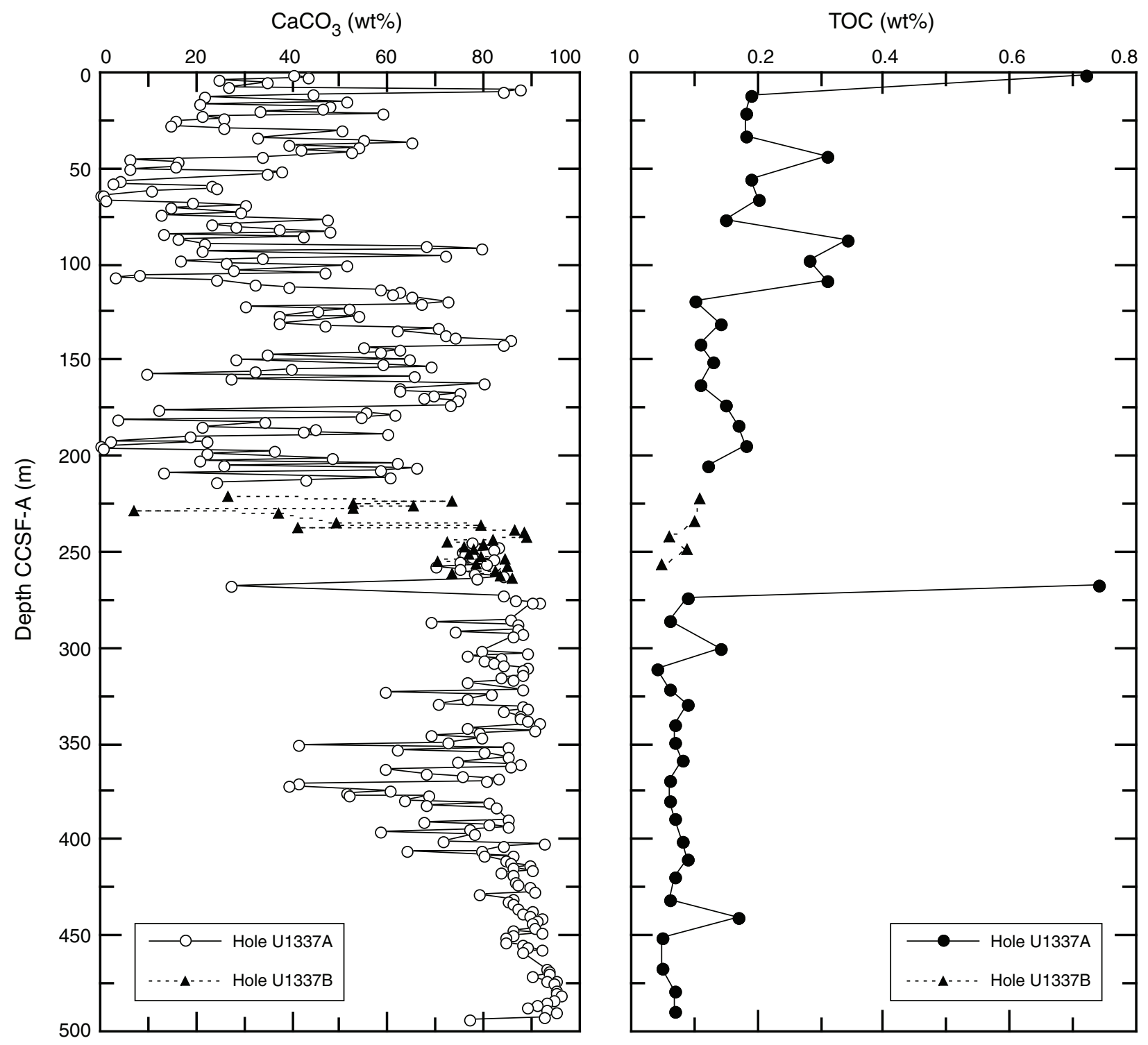
Figure F27. Whole-round measurements, Holes U1337A (black) and U1337C (red). Note scale change for natural gamma radiation at 16 cps. A. Bulk density. B. Magnetic susceptibility. C. $P$-wave velocity. D. Natural gamma radiation.

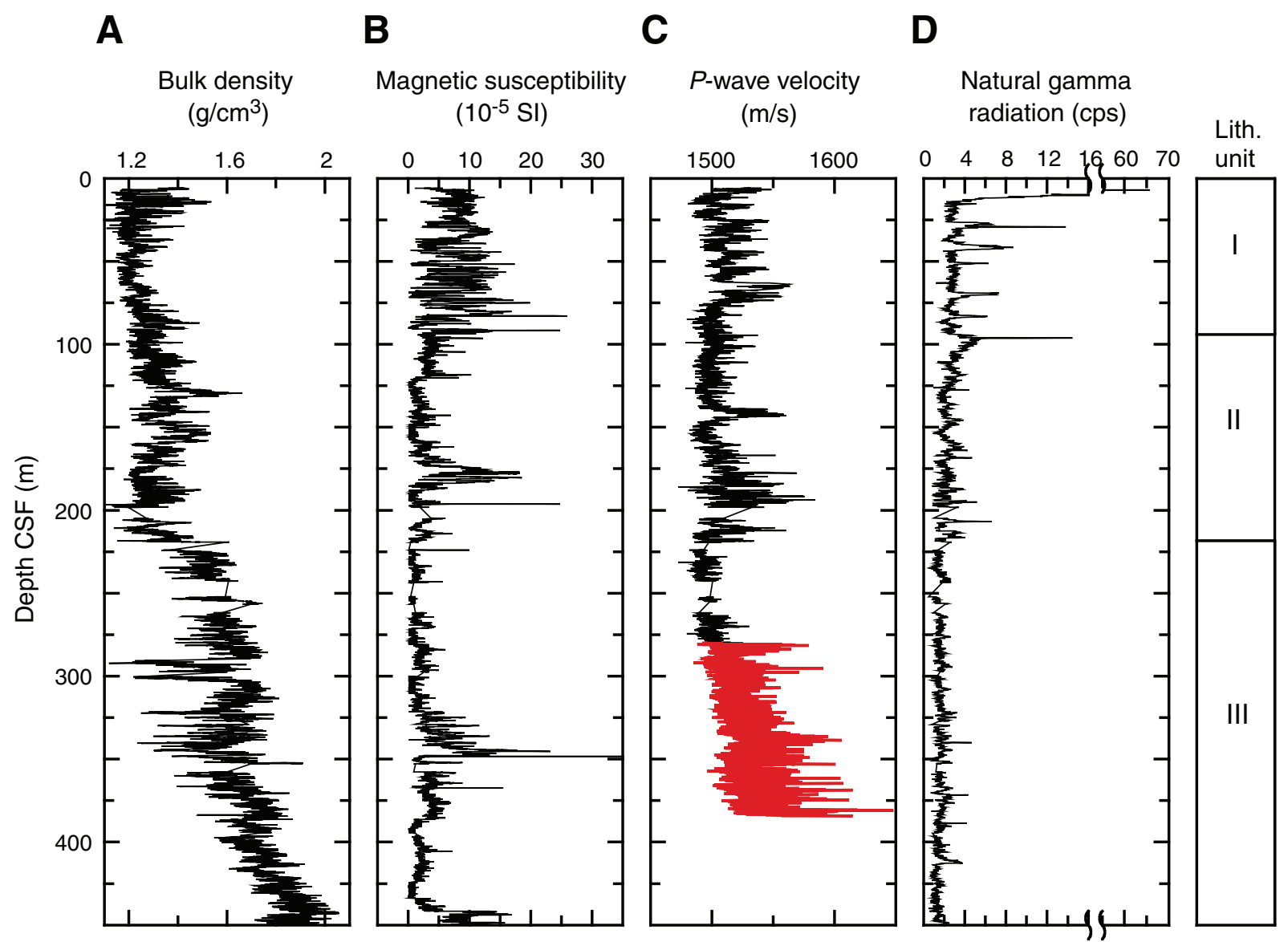


Figure F28. MAD measurements, Holes U1337A (black) and U1337B (red). Depths for Hole U1337B measurements are plotted in meters core depth below seafloor in Hole U1337A. A. Porosity (solid circles) and water content (open circles). B. Discrete sample wet bulk density and GRA bulk density (gray line). C. Grain density.

A

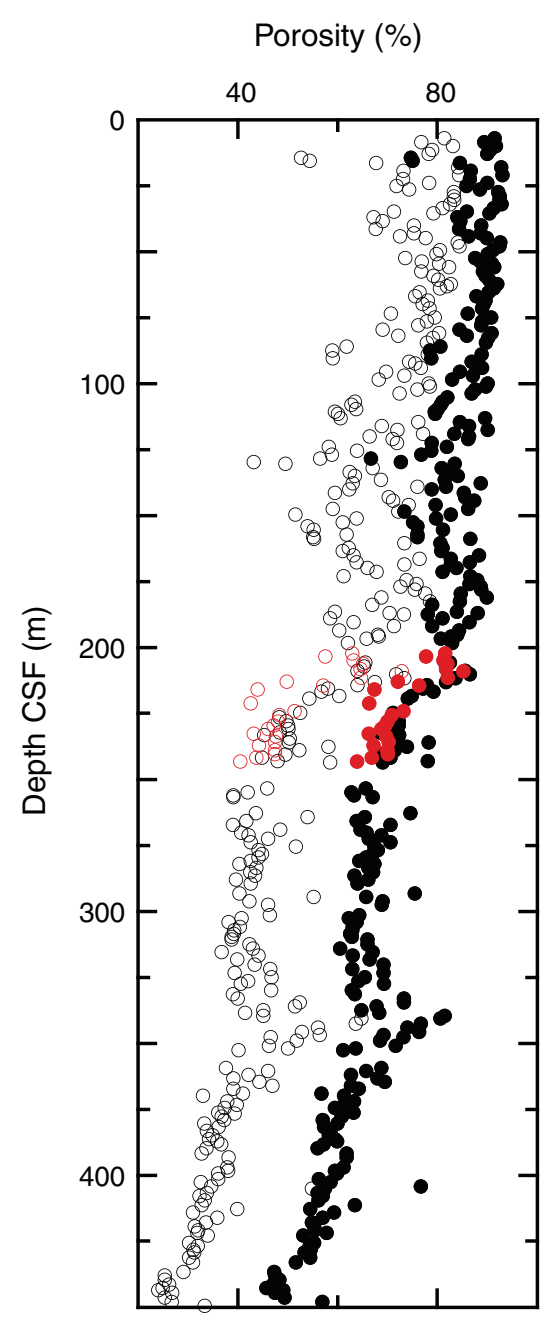

B Bulk density $\left(\mathrm{g} / \mathrm{cm}^{3}\right)$

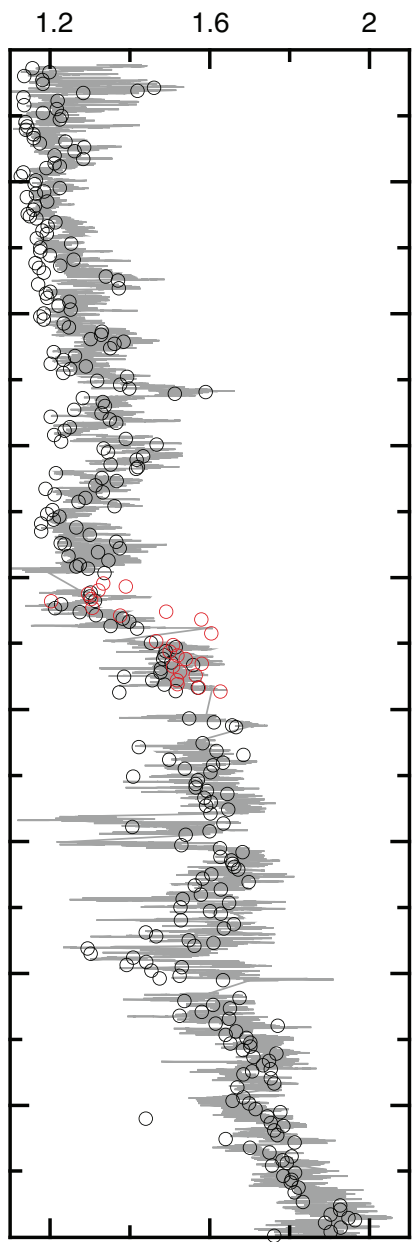

C Grain density $\left(\mathrm{g} / \mathrm{cm}^{3}\right)$

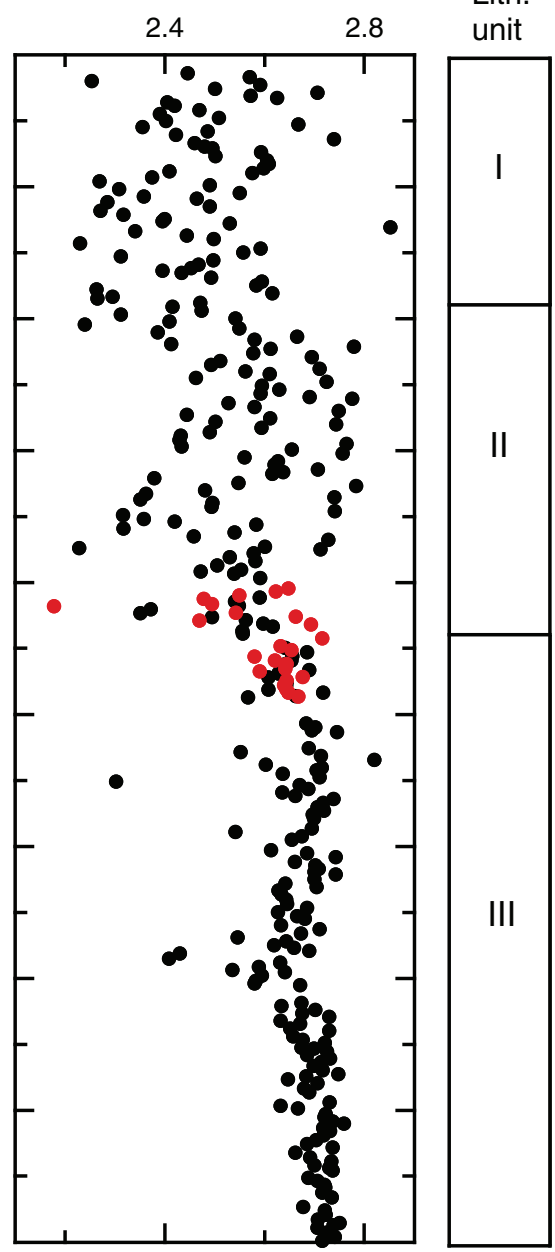

Water content (\%) 
Figure F29. (A) Wet and (B) dry bulk density from MAD analysis of discrete samples from Hole U1337A with gamma ray attenuation (GRA) bulk density interpolated with a $20 \mathrm{~cm}$ wide Gaussian window. Solid circles = APC-cored intervals, open circles $=\mathrm{XCB}$-cored intervals.
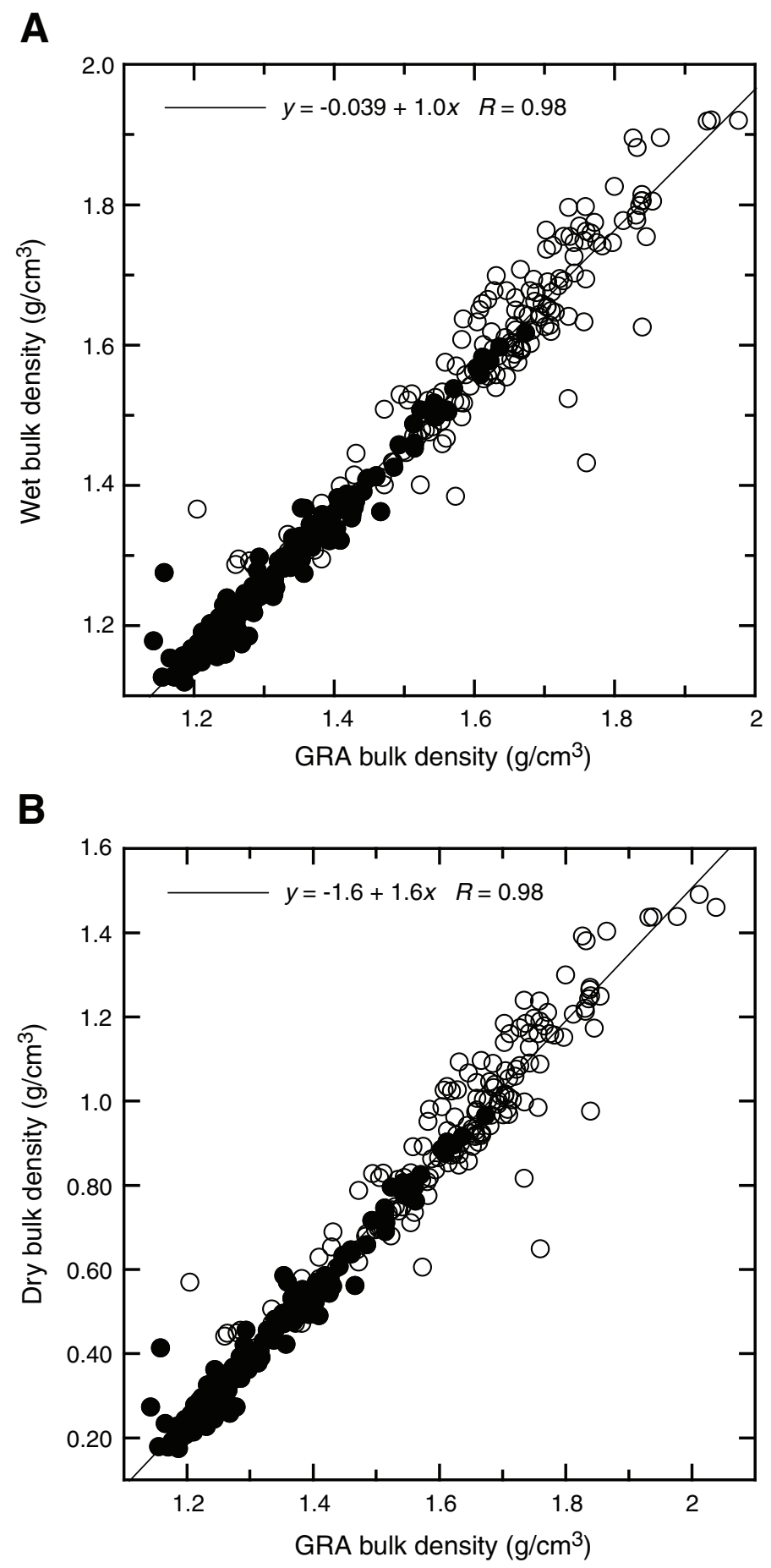
Figure F30. Wet bulk density vs. $\mathrm{CaCO}_{3}$.

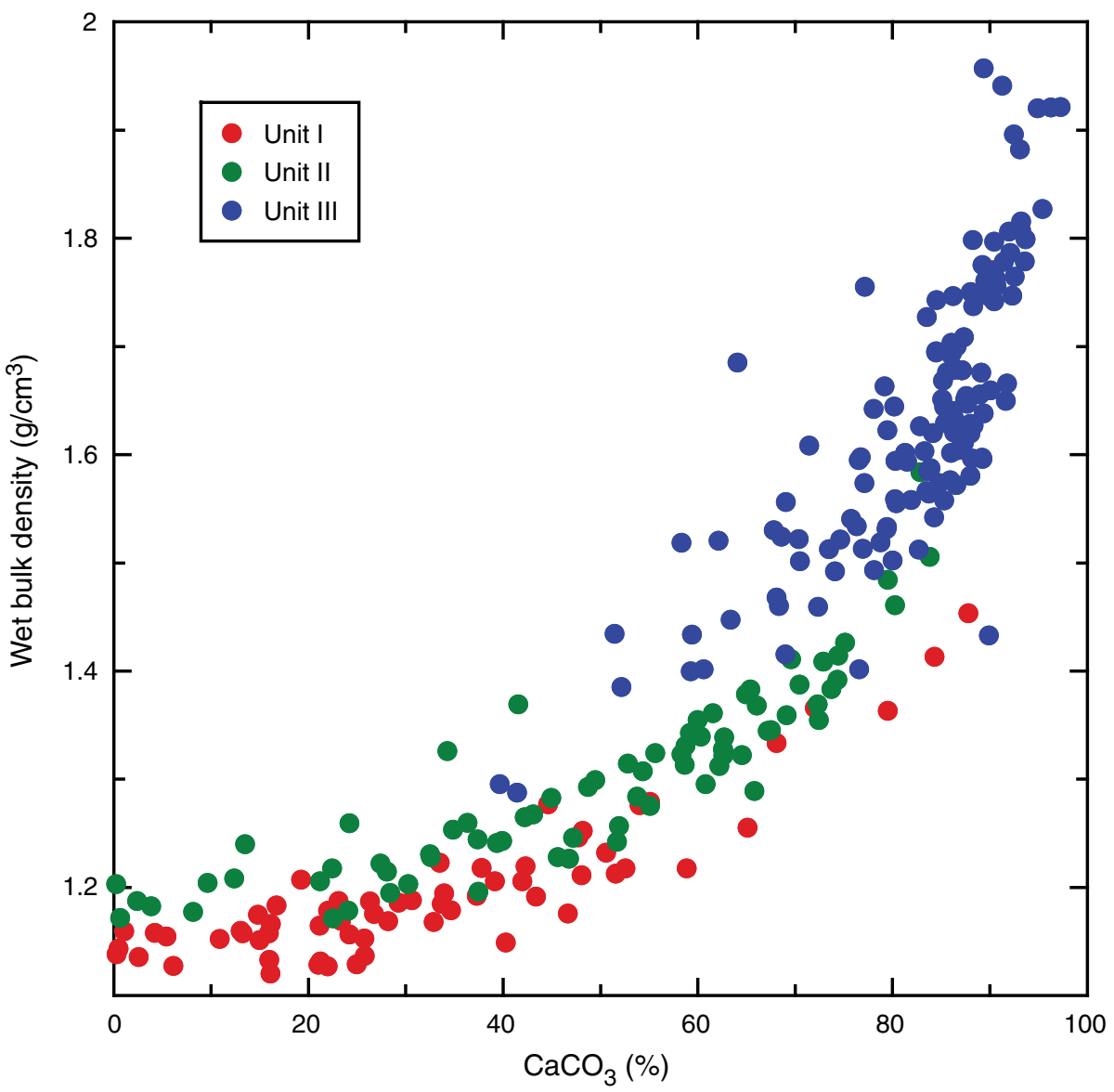


Figure F31. Compressional wave velocity from the PWL (gray lines) and discrete velocity measurements on split core using the contact probe for $x$-axis measurements and $z$-axis measurements below $330 \mathrm{~m}$ CSF, and using insertion probes for $y$-axis measurements and $z$-axis measurements above $330 \mathrm{~m}$ CSF. Black circles $=$ Hole U1337A, red circles $=$ Hole U1337B.

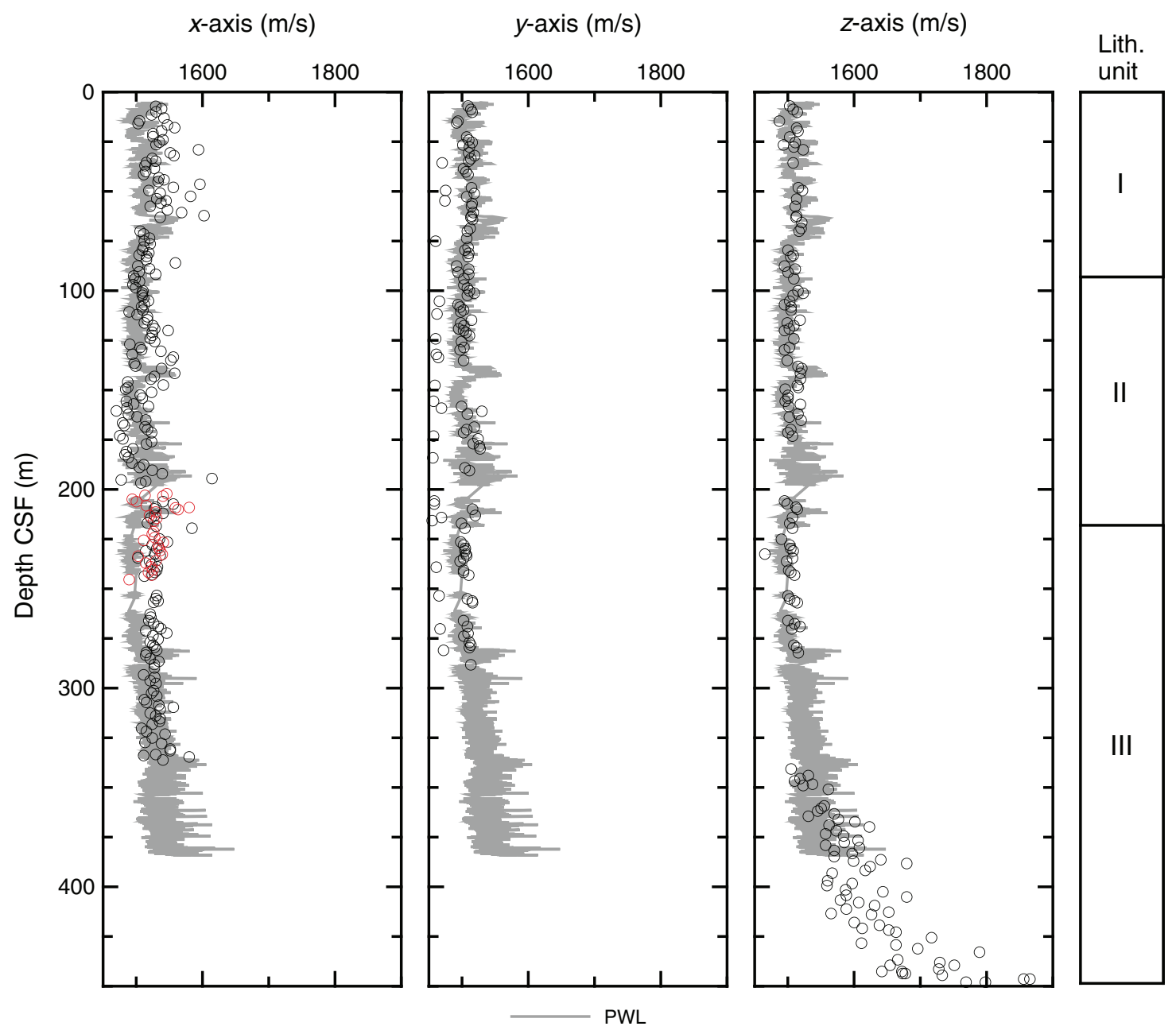


Figure F32. Natural gamma radiation records compared with core images. A. Natural gamma peak associated with chert rubble interval (Core 321-U1337D-28H). B. Natural gamma peak at greenish gray to pale yellow color change (Core 321-U1337A-44X).

A

Natural gamma radiation

(cps)

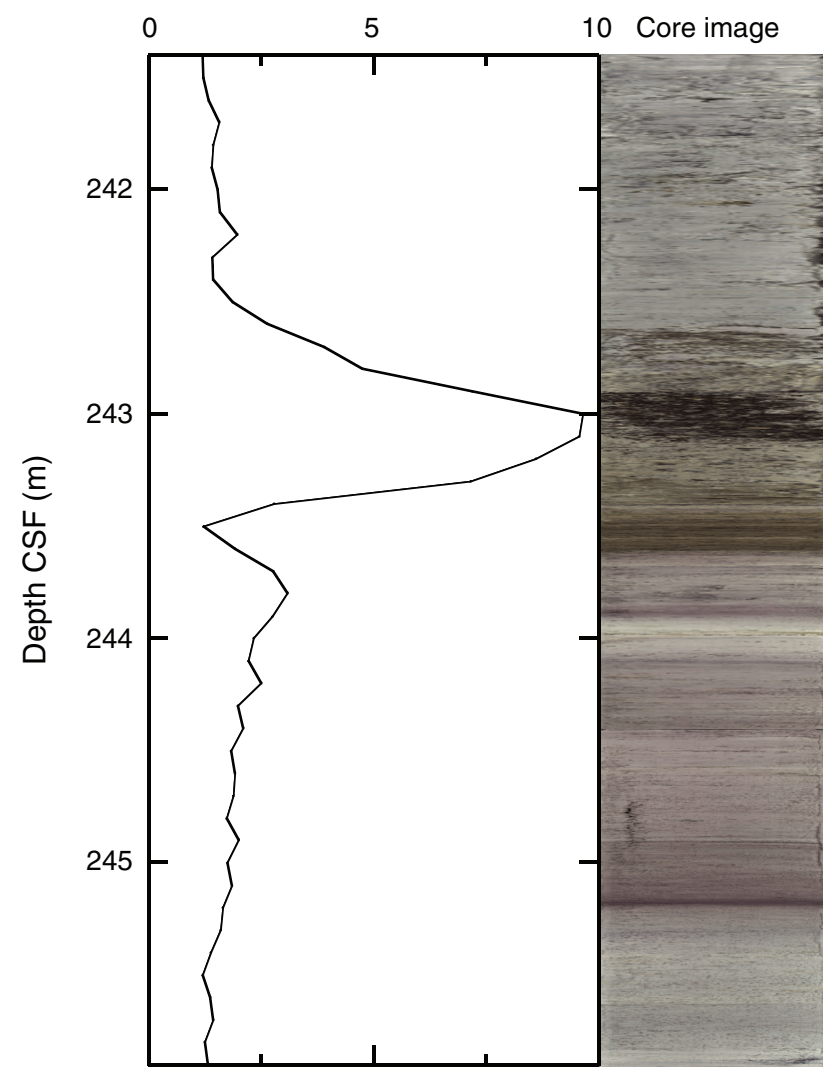

B Natural gamma radiation

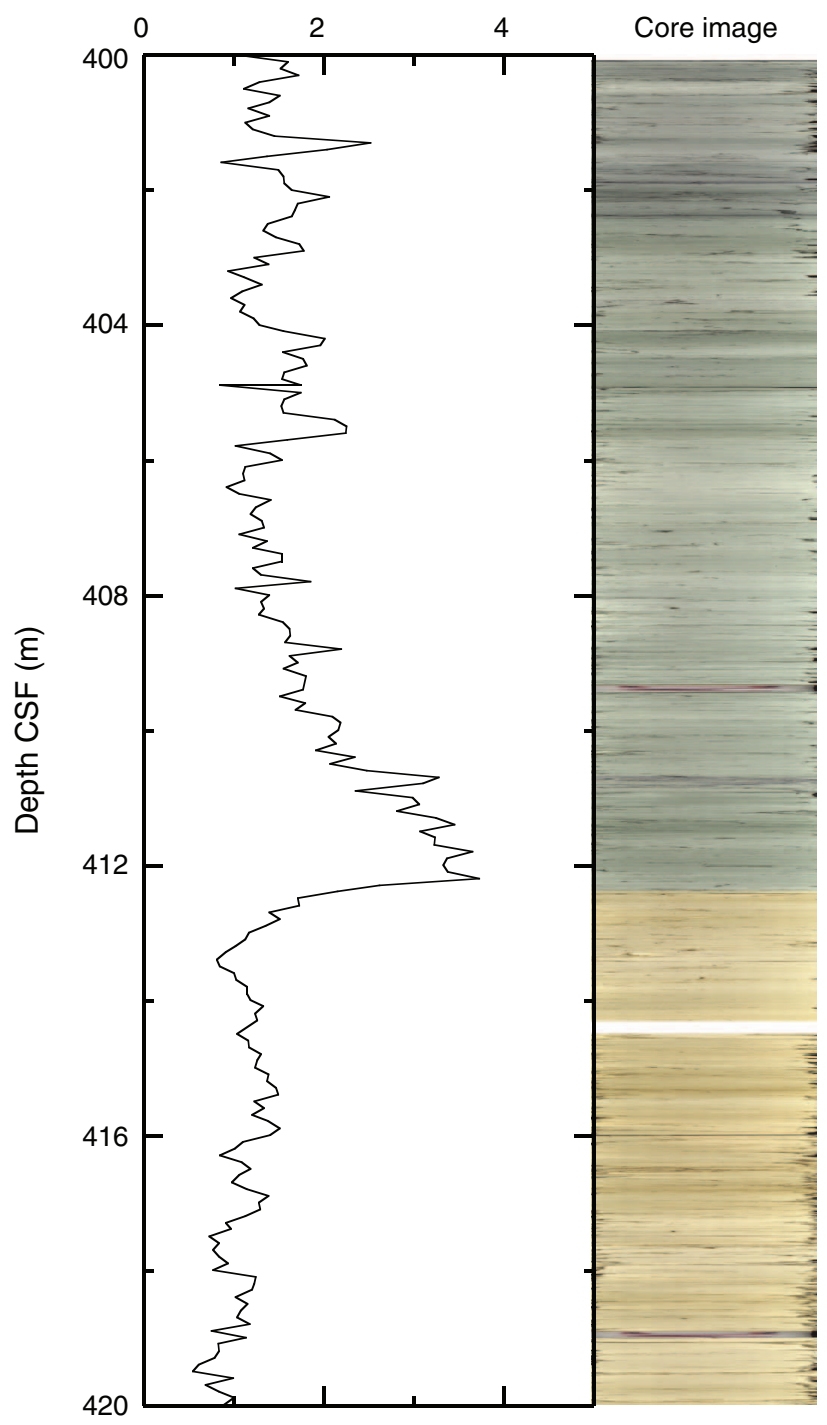


Figure F33. Natural gamma radiation vs. total organic carbon, Hole U1337A. Red circles = data not used in the regression of natural gamma radiation with total organic carbon.

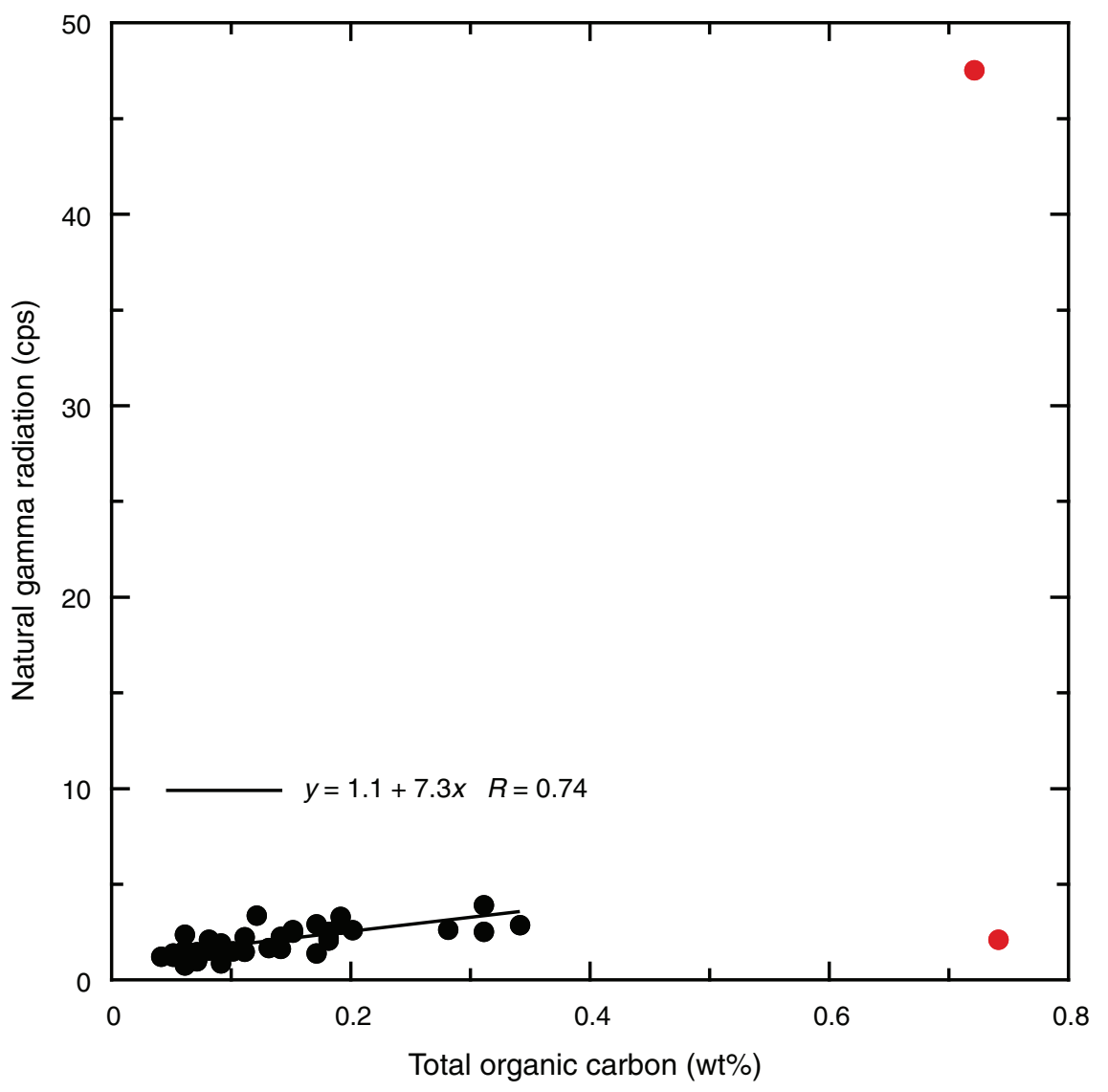


Figure F34. Thermal conductivity vs. depth, Hole U1337A.

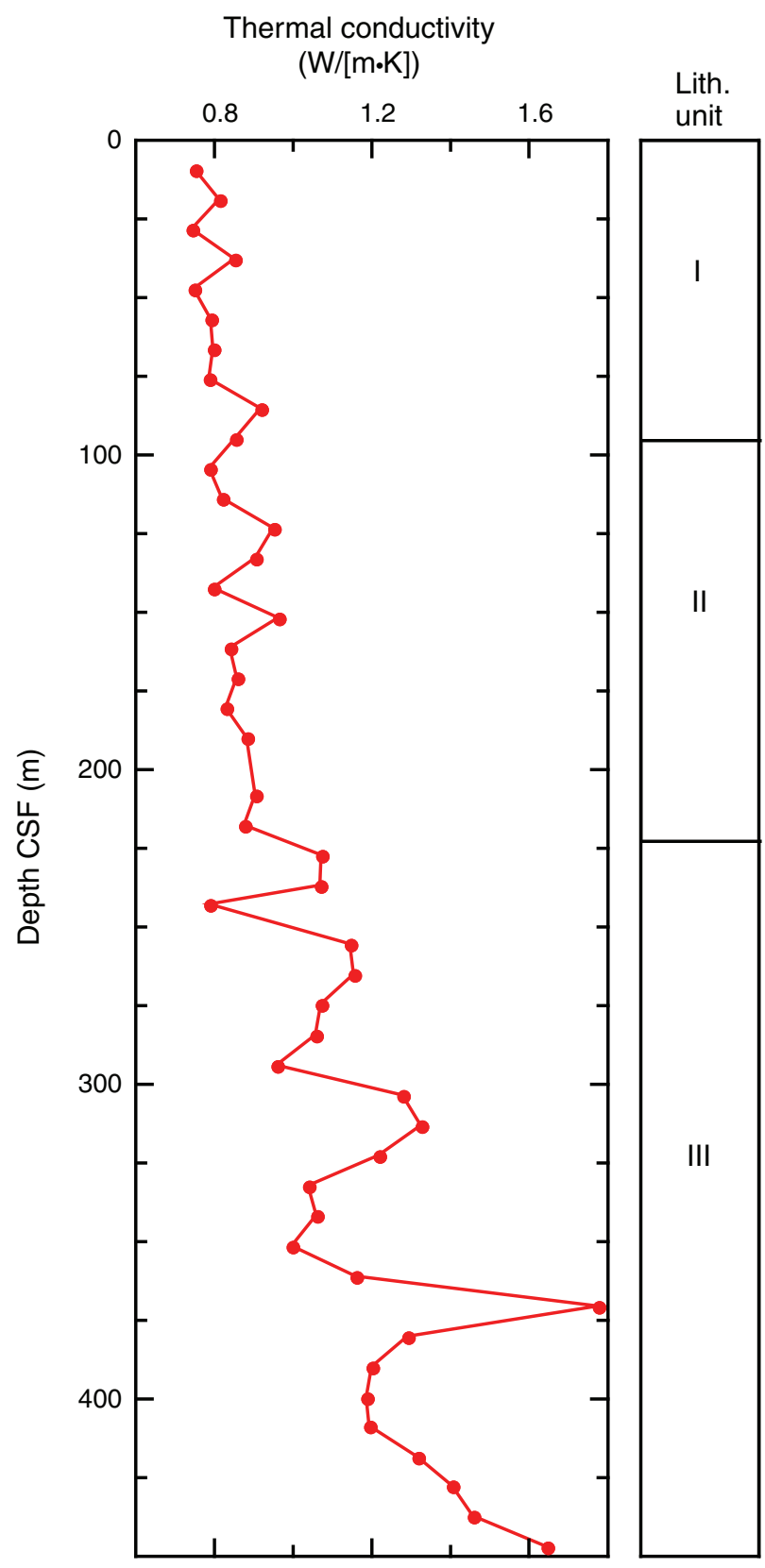


Figure F35. Thermal conductivity vs. porosity from MAD analysis of discrete samples, Hole U1337A.

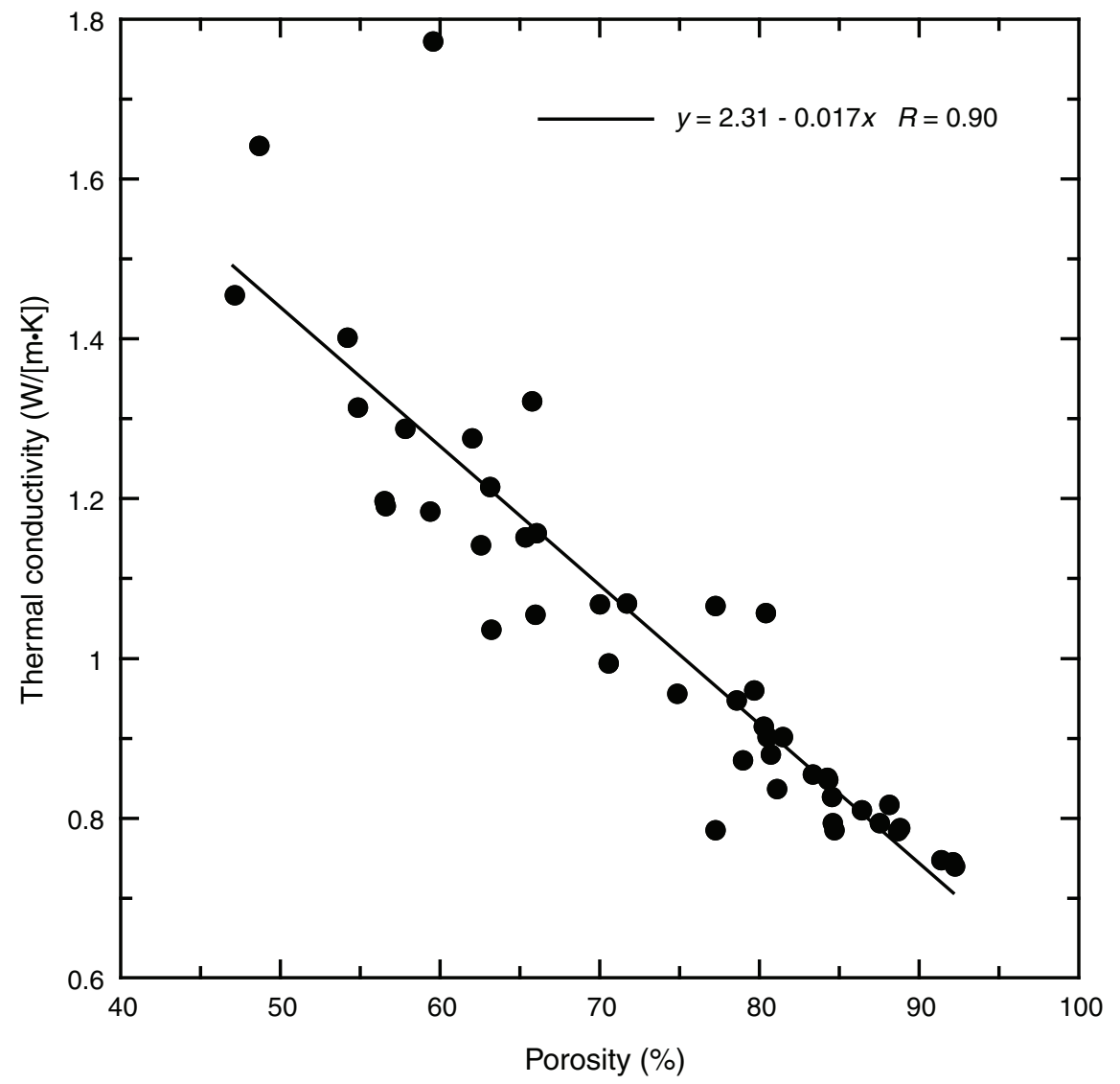


Figure F36. Reflectance spectroscopy, Hole U1337A. $\mathrm{L}^{*}=$ luminance, $\mathrm{a}^{*}=$ blue-yellow, $\mathrm{b}^{*}=$ green-red.

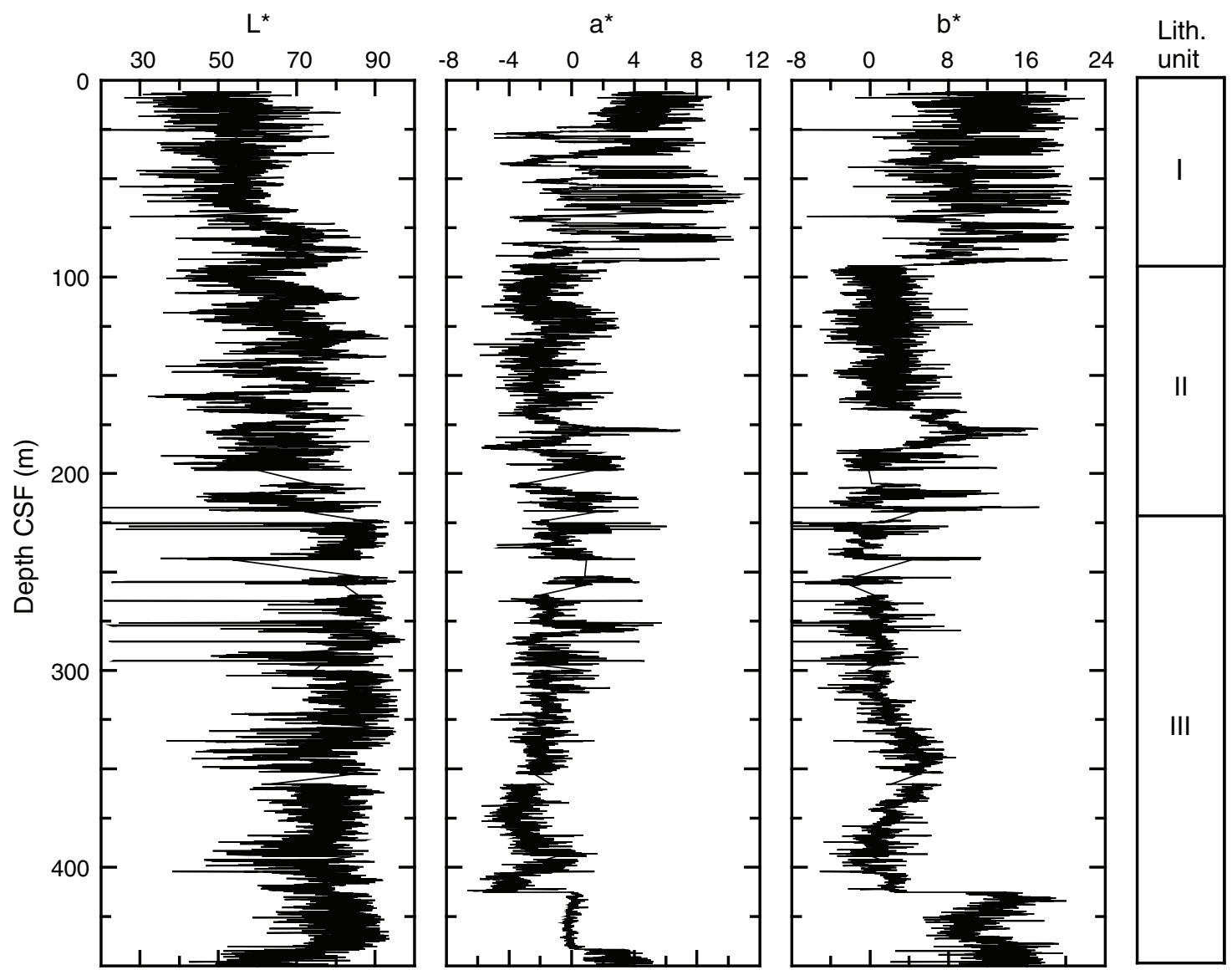


Figure F37. Magnetic susceptibility data, Site U1337. Red = Hole U1337A; blue = Hole U1337B, offset by 10 SI units; green $=$ Hole U1337C, offset by 20 SI units; pink = Hole U1337D, offset by 30 SI units. A. 0-50 m CCSFA. (Continued on next nine pages.)
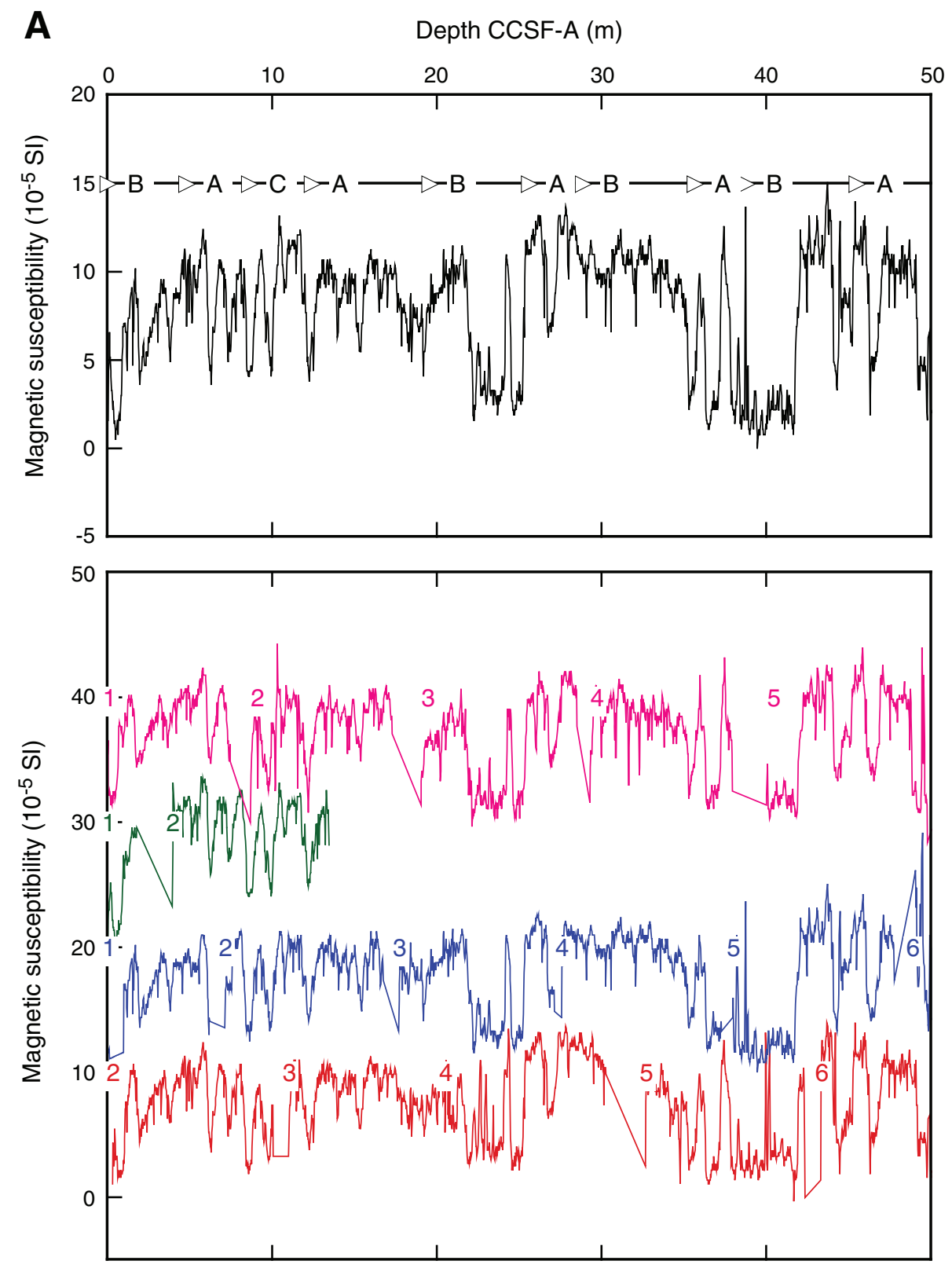
Figure F37 (continued). B. 50-100 m CCSF-A. (Continued on next page.)

B Depth CCSF-A (m)
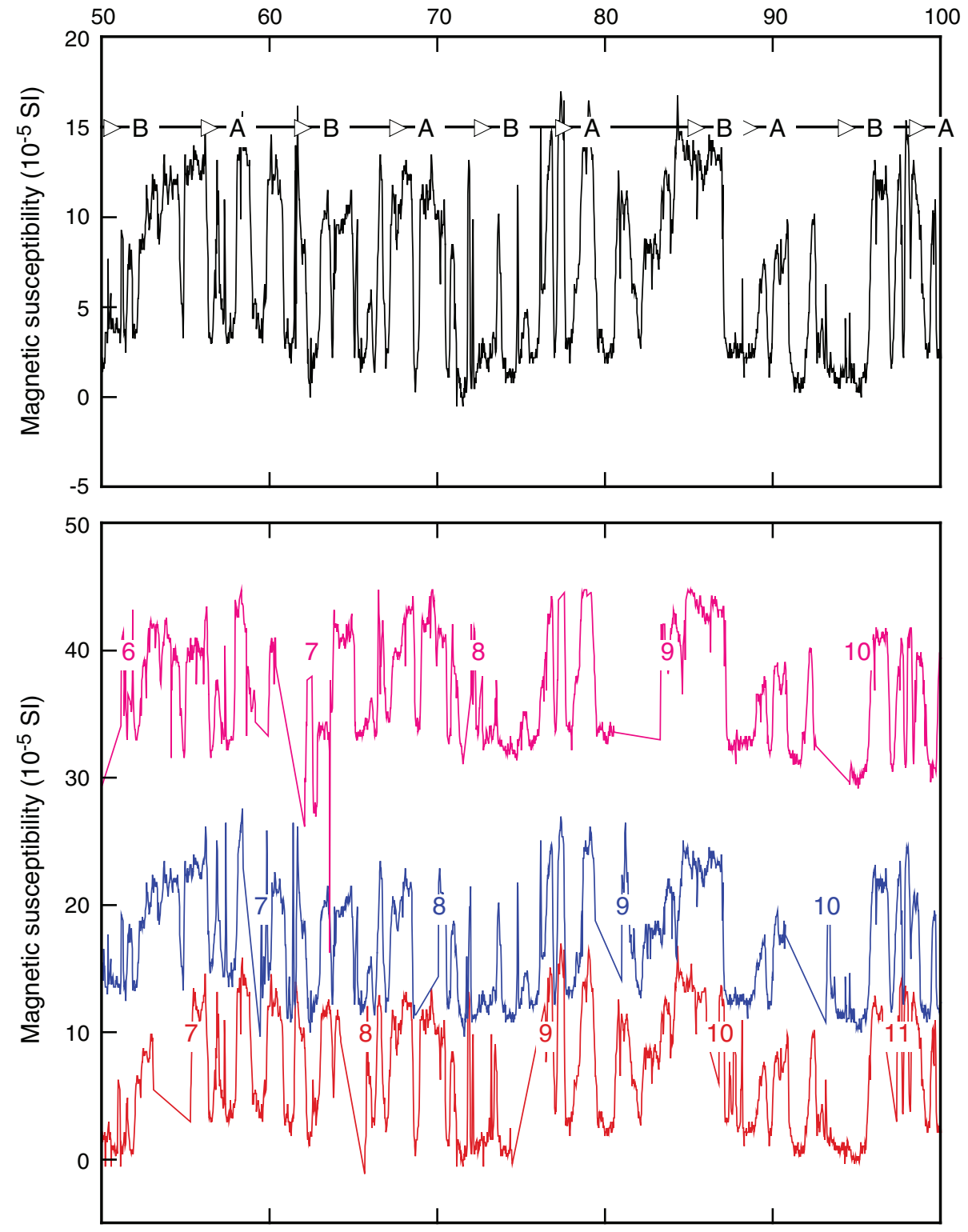
Figure F37 (continued). C. 100-150 m CCSF-A. (Continued on next page.)
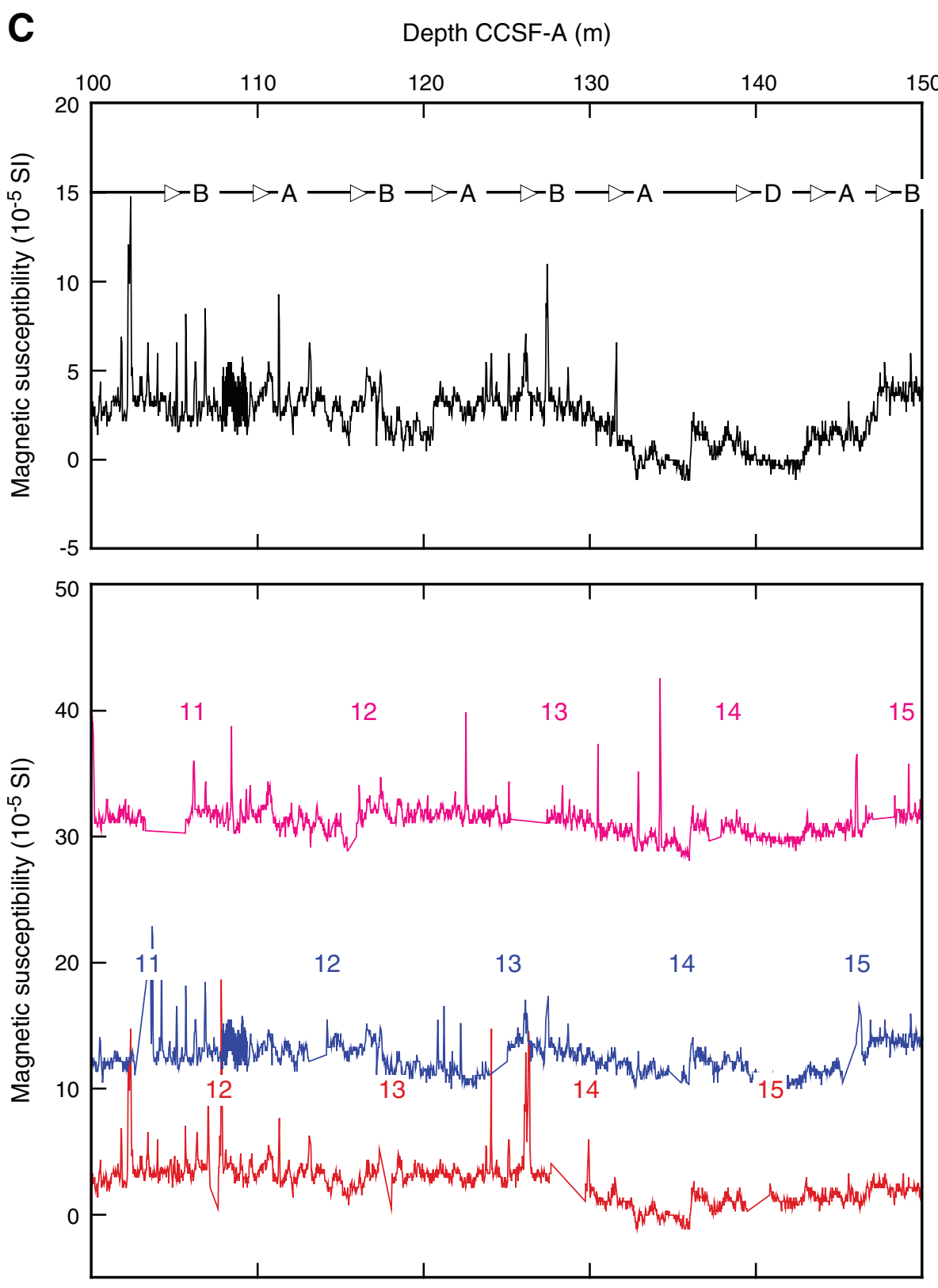
Figure F37 (continued). D. 150-200 m CCSF-A. (Continued on next page.)
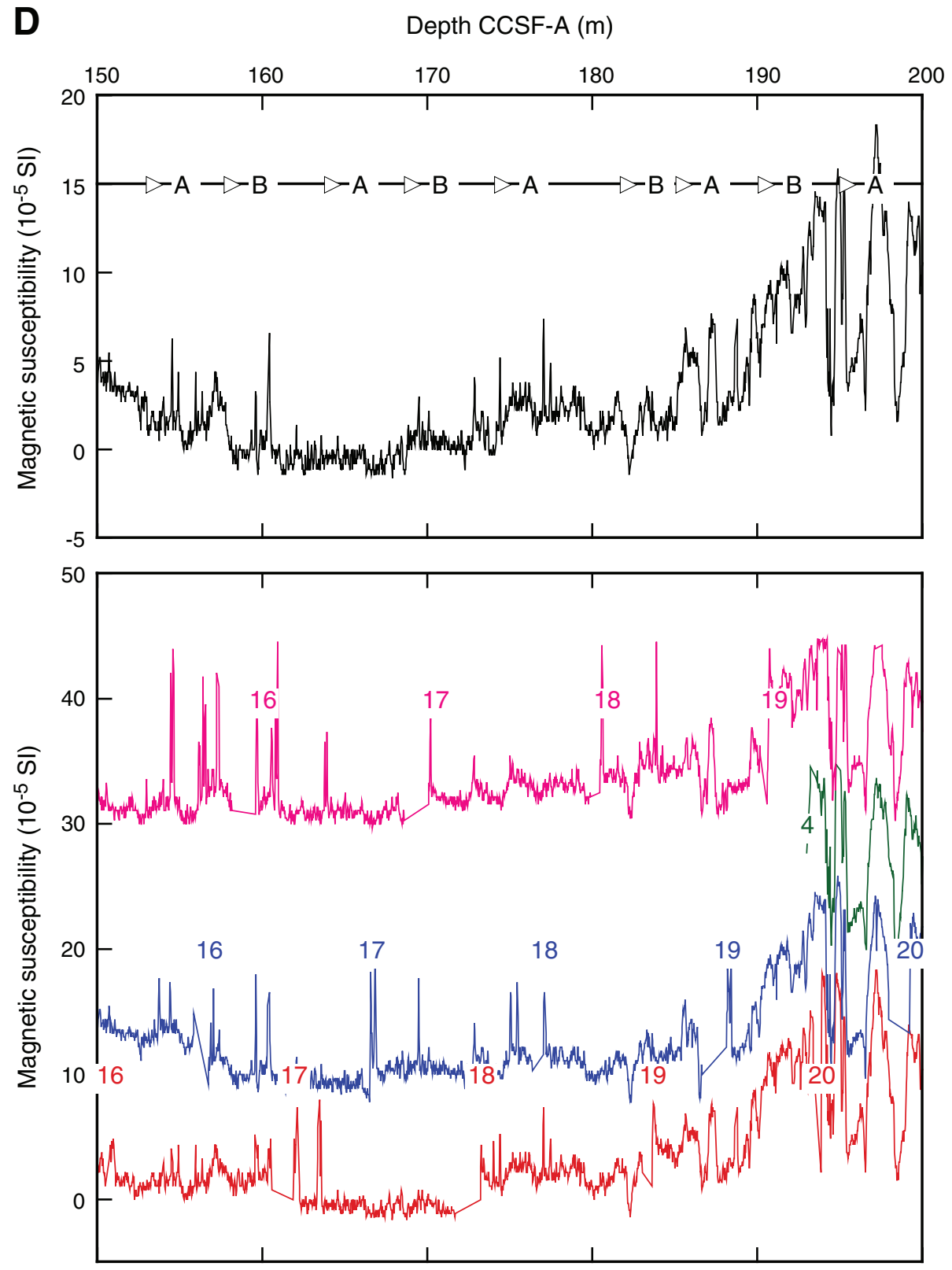
Figure F37 (continued). E. 200-250 m CCSF-A. (Continued on next page.)

E

Depth CCSF-A (m)
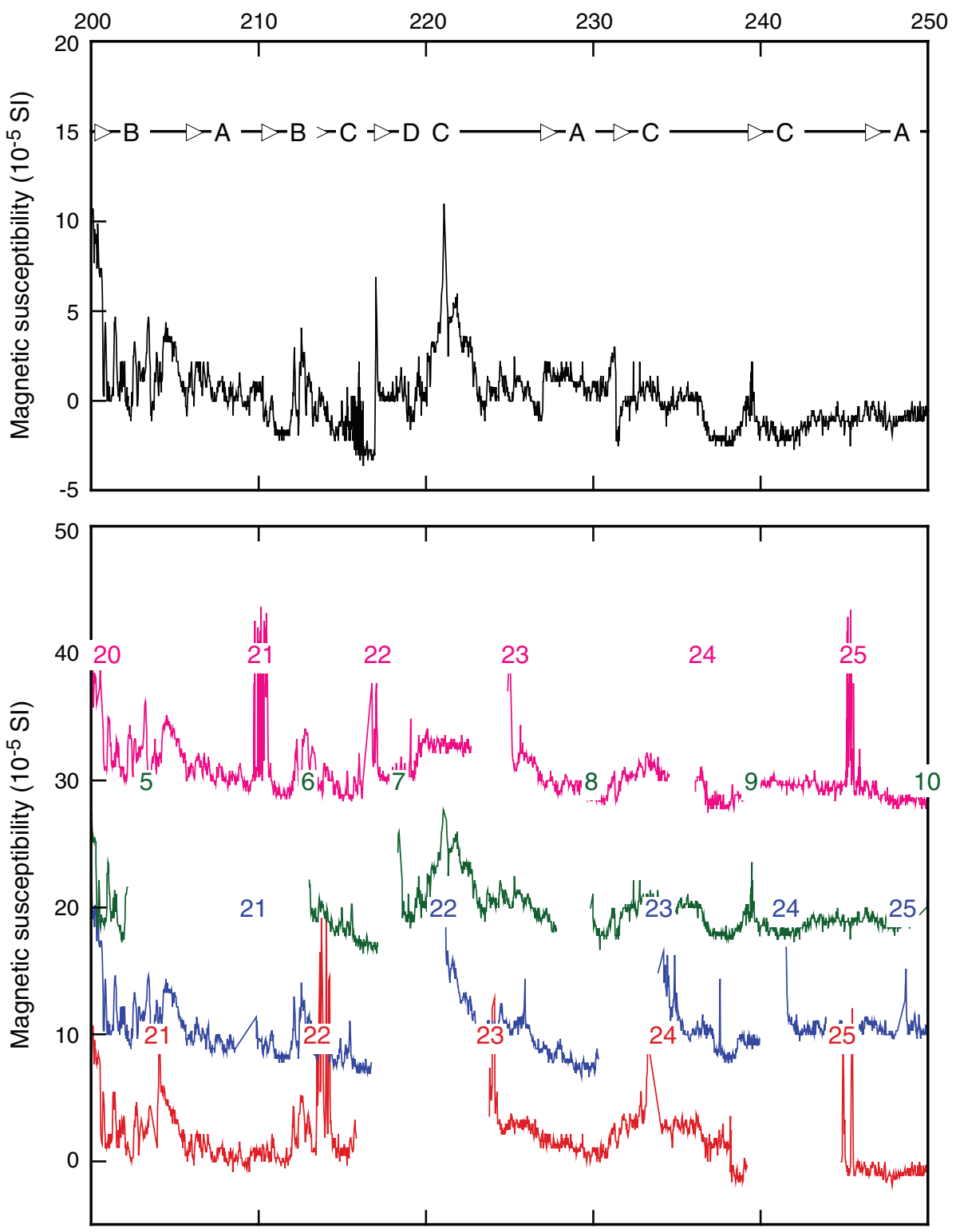
Figure F37 (continued). F. 250-300 m CCSF-A. (Continued on next page.)
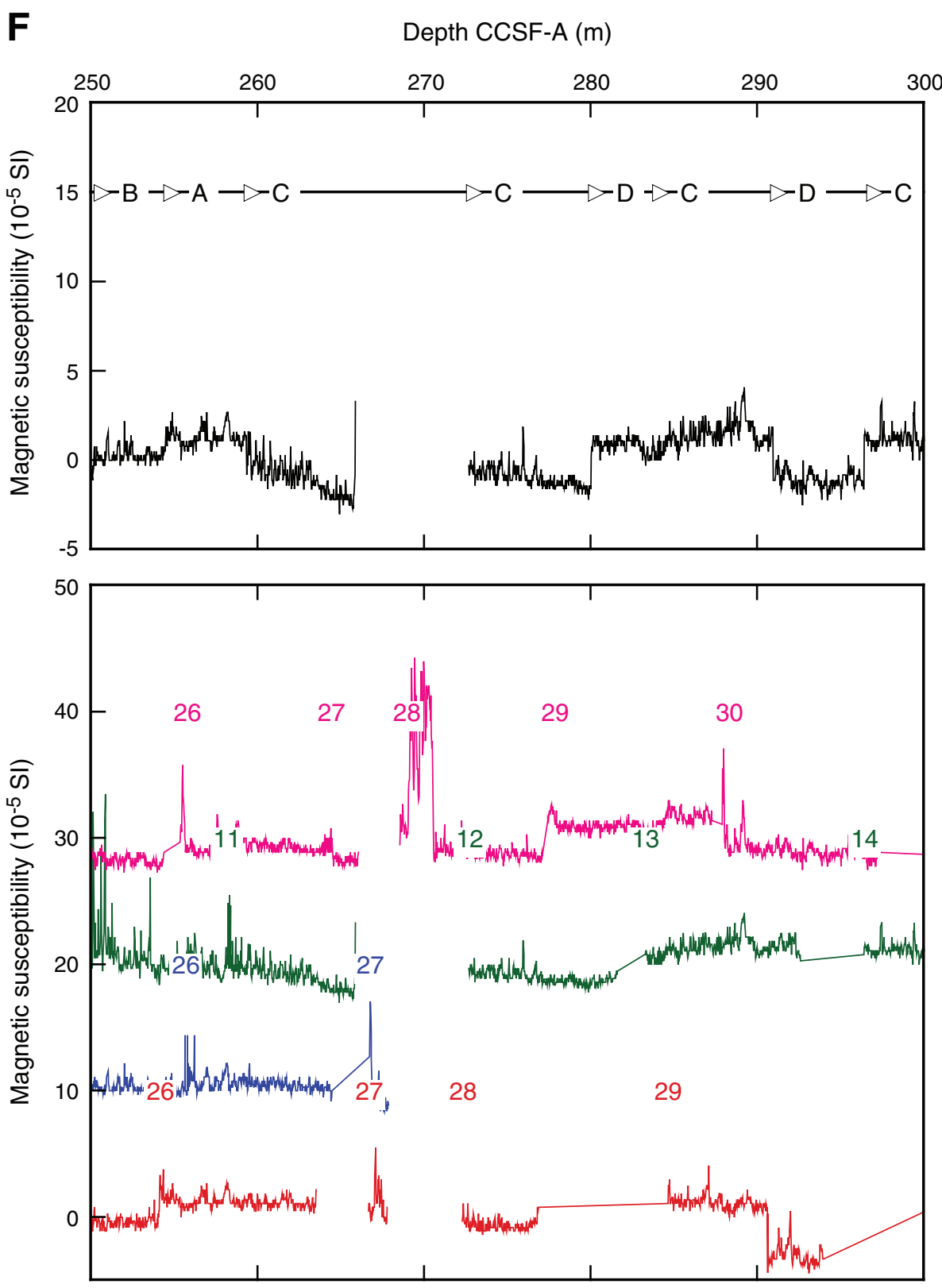
Figure F37 (continued). G. 300-350 m CCSF-A. (Continued on next page.)
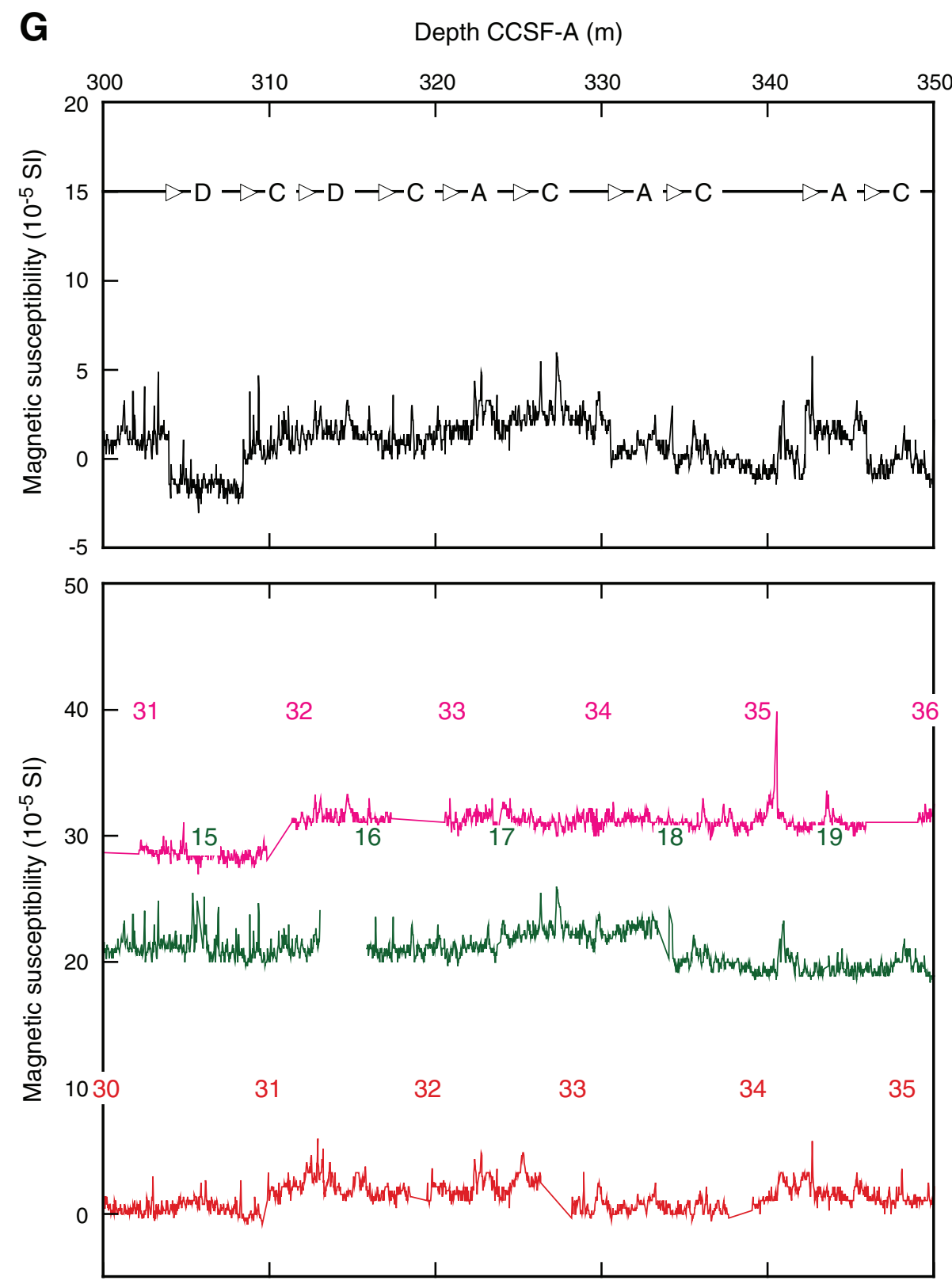
Figure F37 (continued). H. 350-400 m CCSF-A. (Continued on next page.)
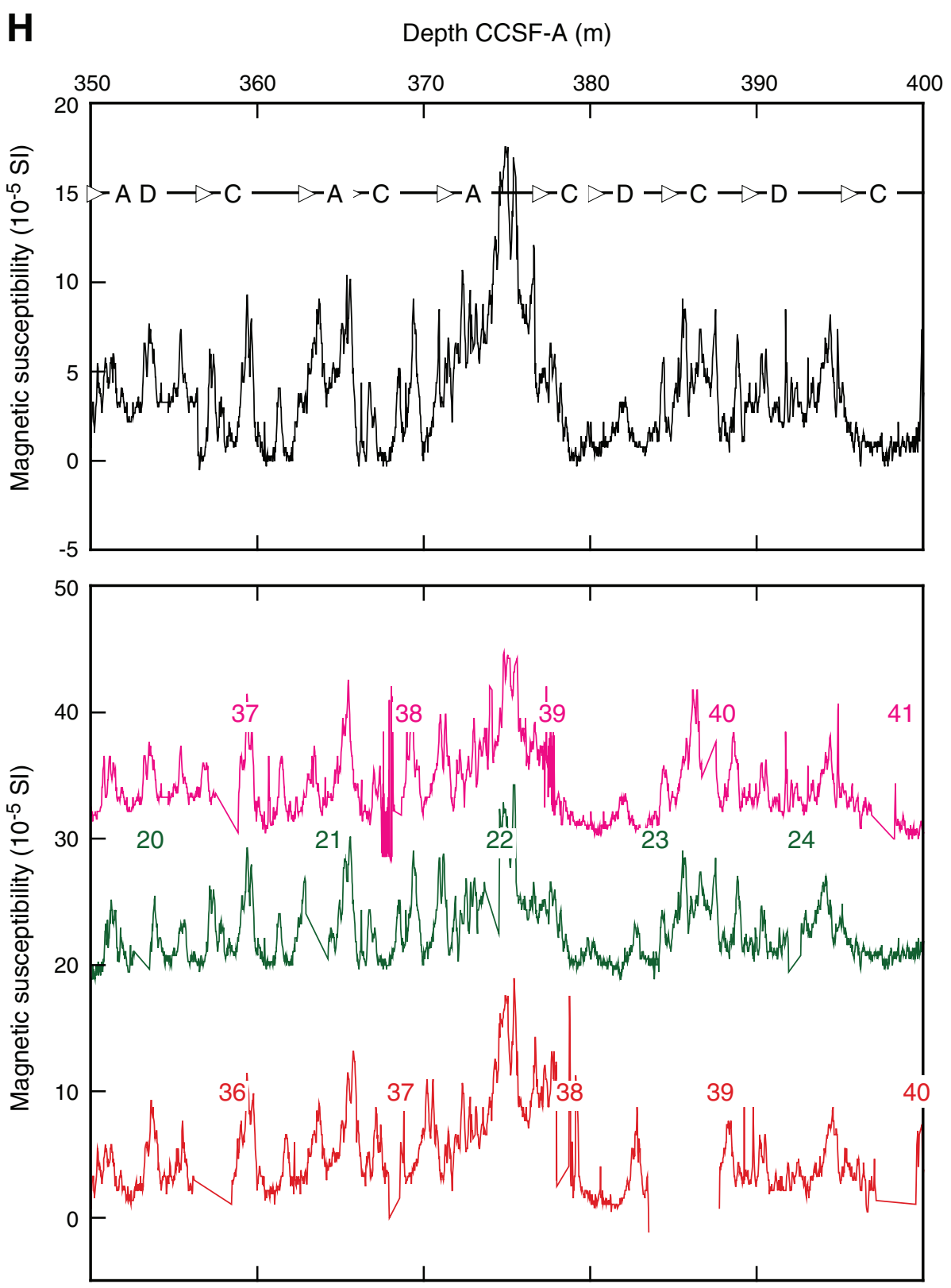
Figure F37 (continued). I. 400-450 m CCSF-A. (Continued on next page.)
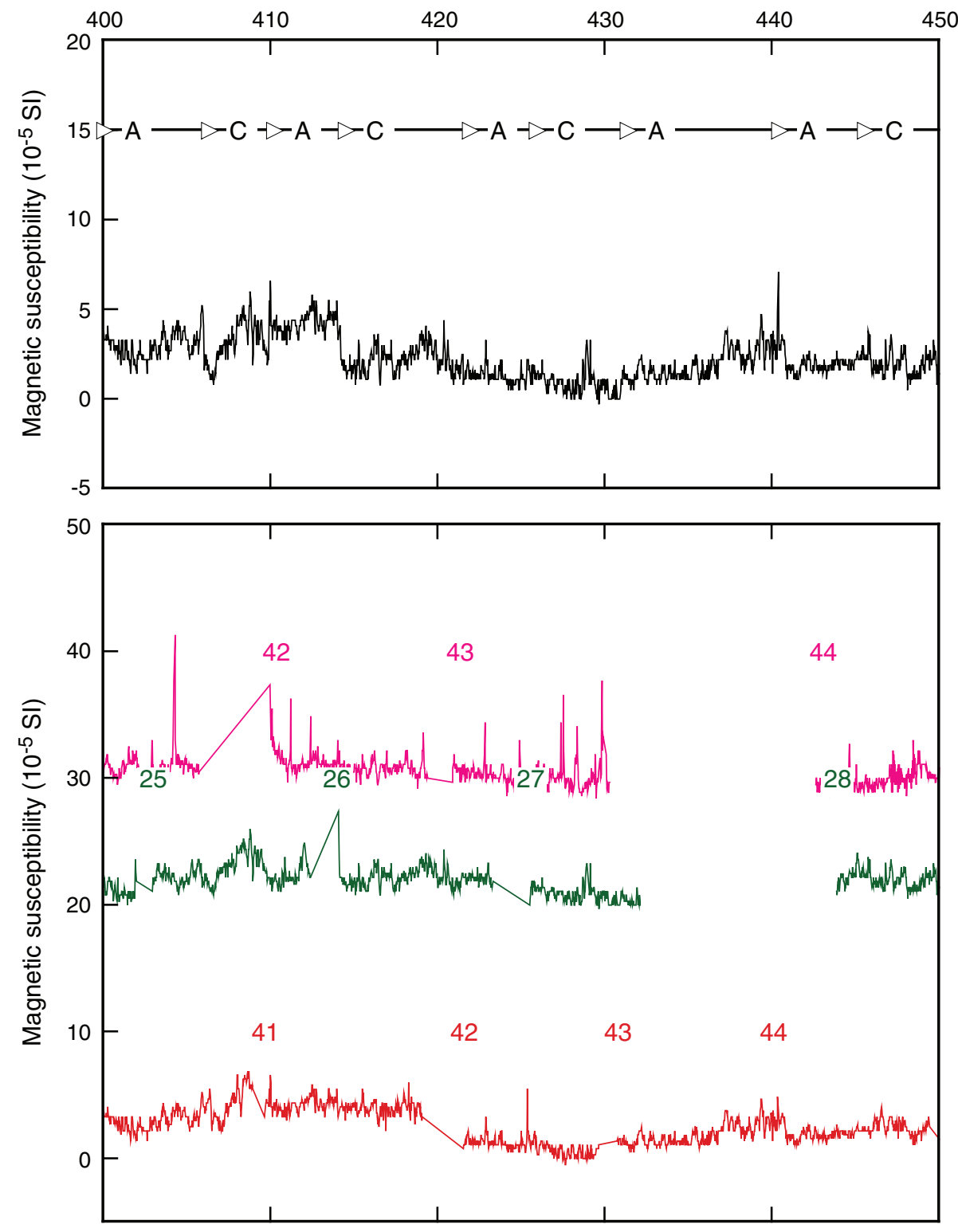
Figure F37 (continued). J. 450-500 m CCSF-A.
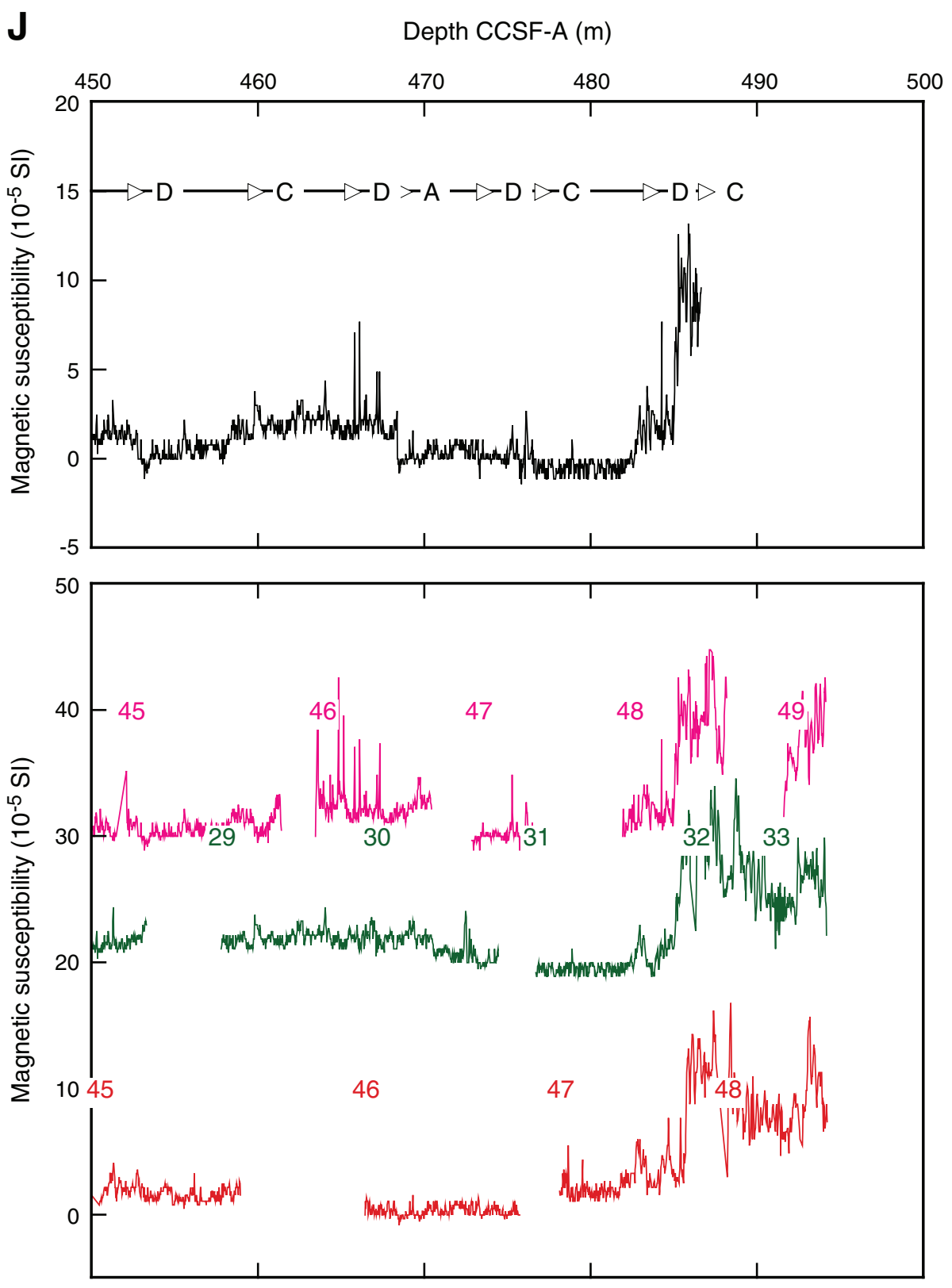
Figure F38. Gamma ray attenuation (GRA) density data, Site U1337. Red = Hole U1337A; blue = Hole U1337B, offset by $0.5 \mathrm{~g} / \mathrm{cm}^{3}$; green = Hole U1337C, offset by $1.0 \mathrm{~g} / \mathrm{cm}^{3}$; pink = Hole U1337D, offset by $1.5 \mathrm{~g} / \mathrm{cm}^{3}$. A. $0-$ 50 m CCSF-A. (Continued on next nine pages.)

\section{A}
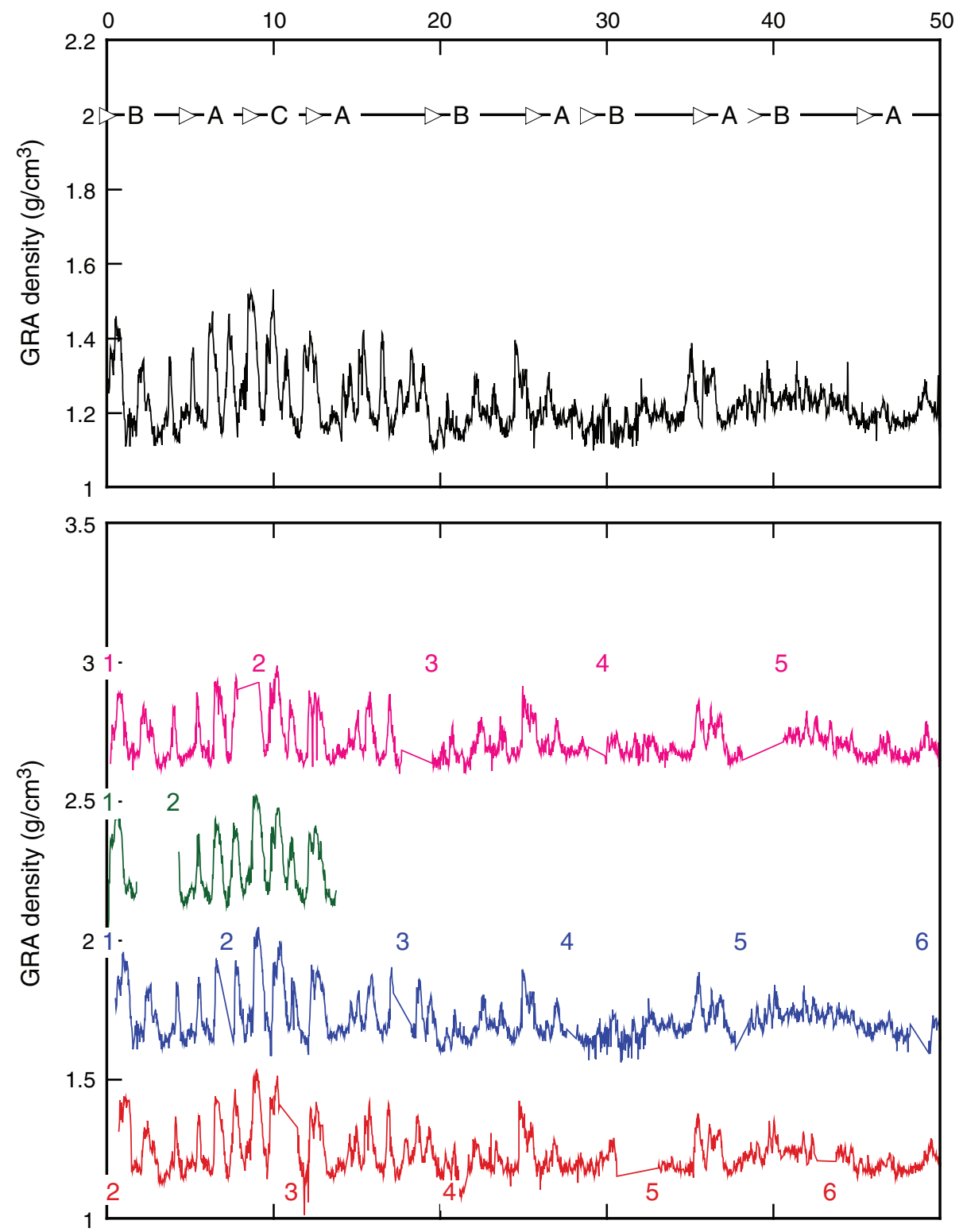
Figure F38 (continued). B. 50-100 m CCSF-A. (Continued on next page.)

B Depth CCSF-A (m)
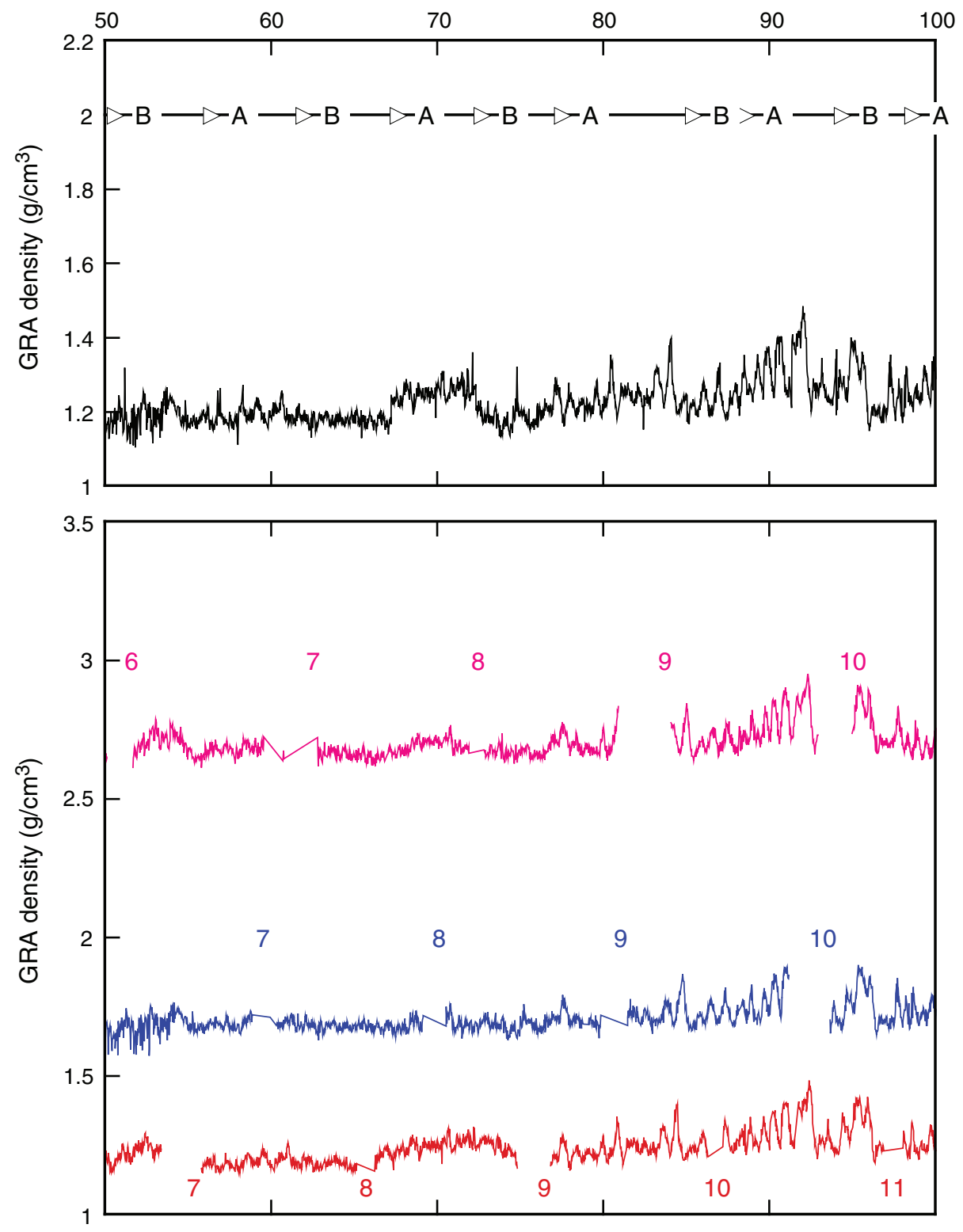
Figure F38 (continued). C. 100-150 m CCSF-A. (Continued on next page.)
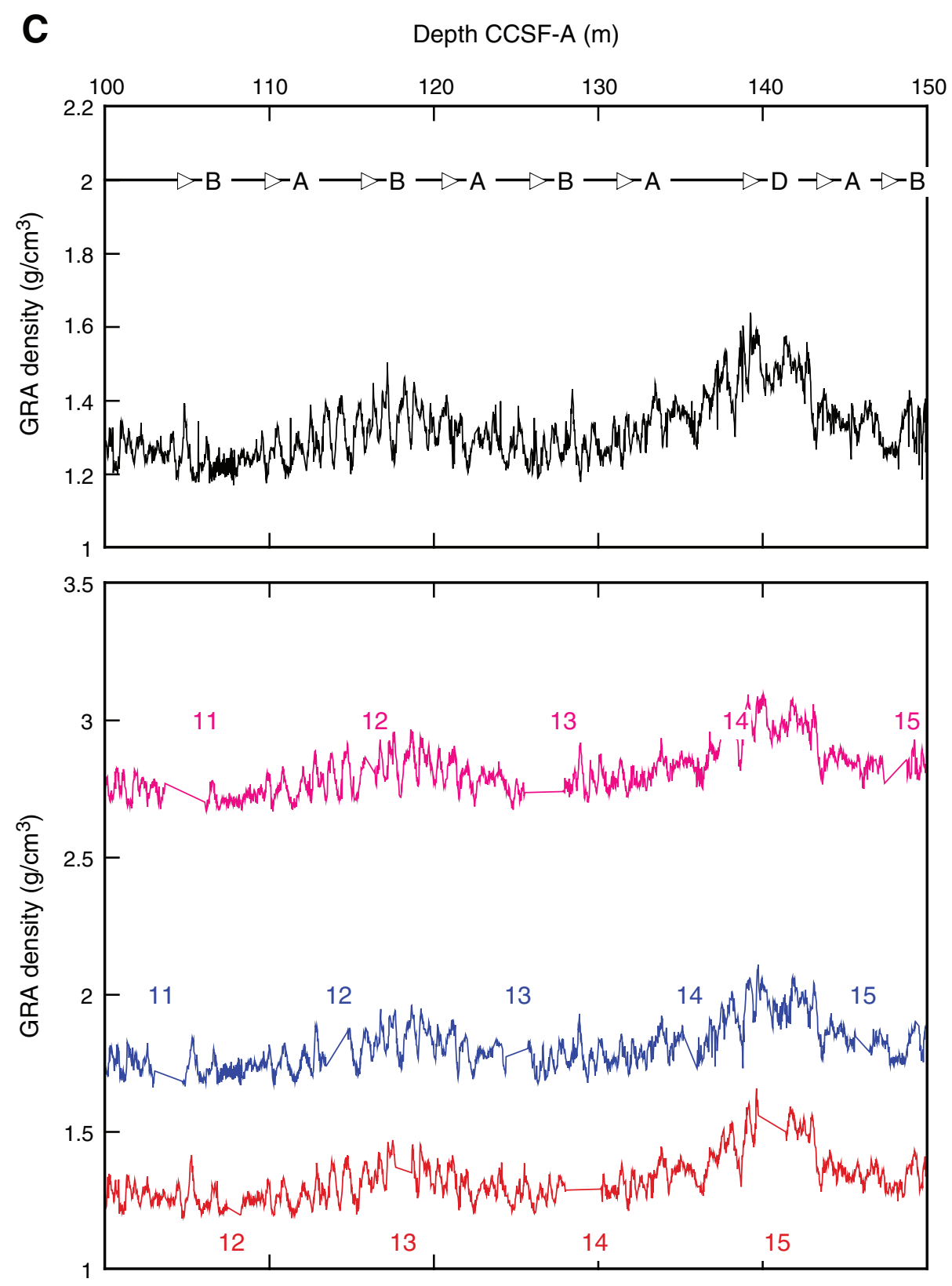
Figure F38 (continued). D. 150-200 m CCSF-A. (Continued on next page.)
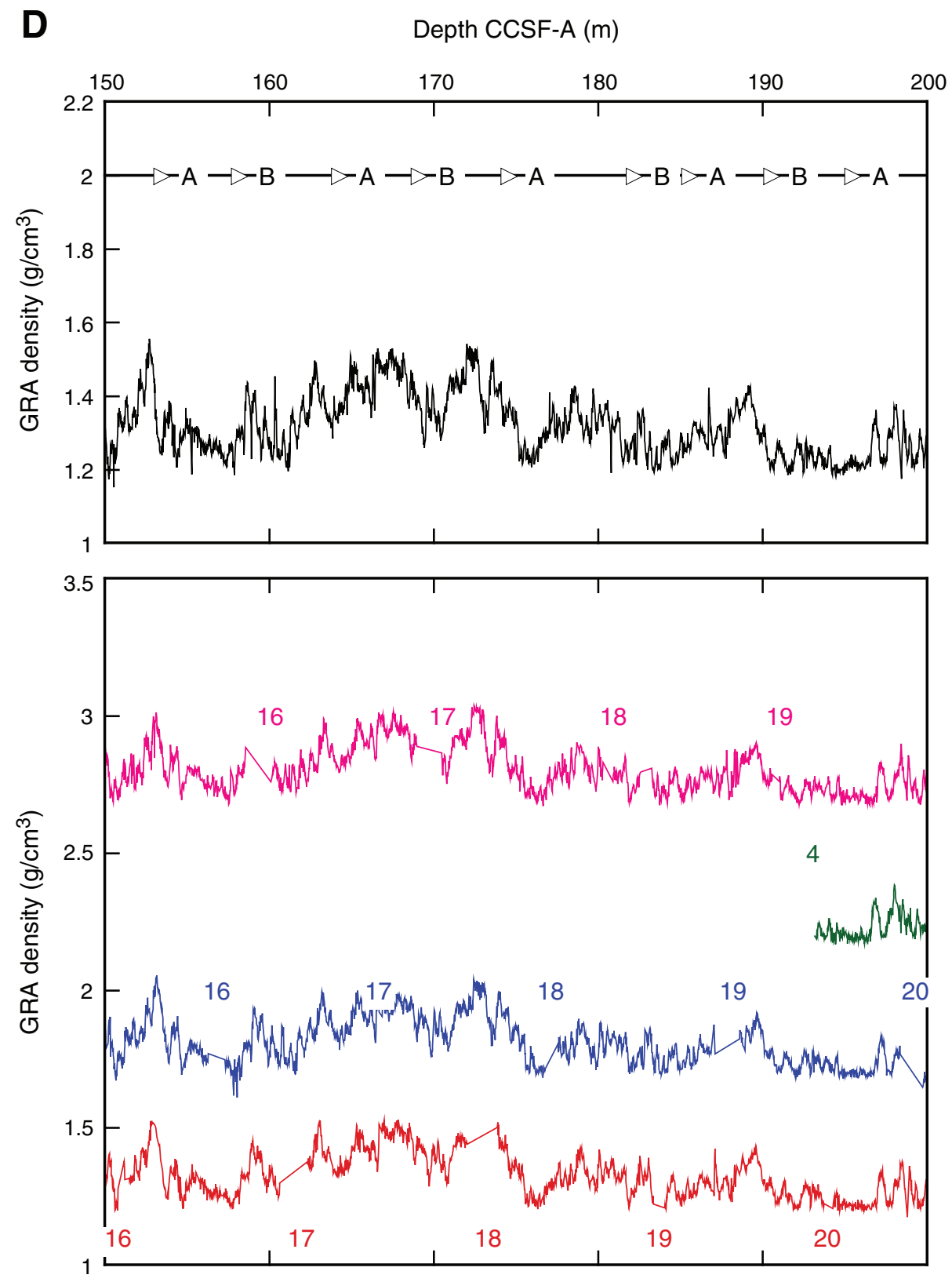
Figure F38 (continued). E. 200-250 m CCSF-A. (Continued on next page.)

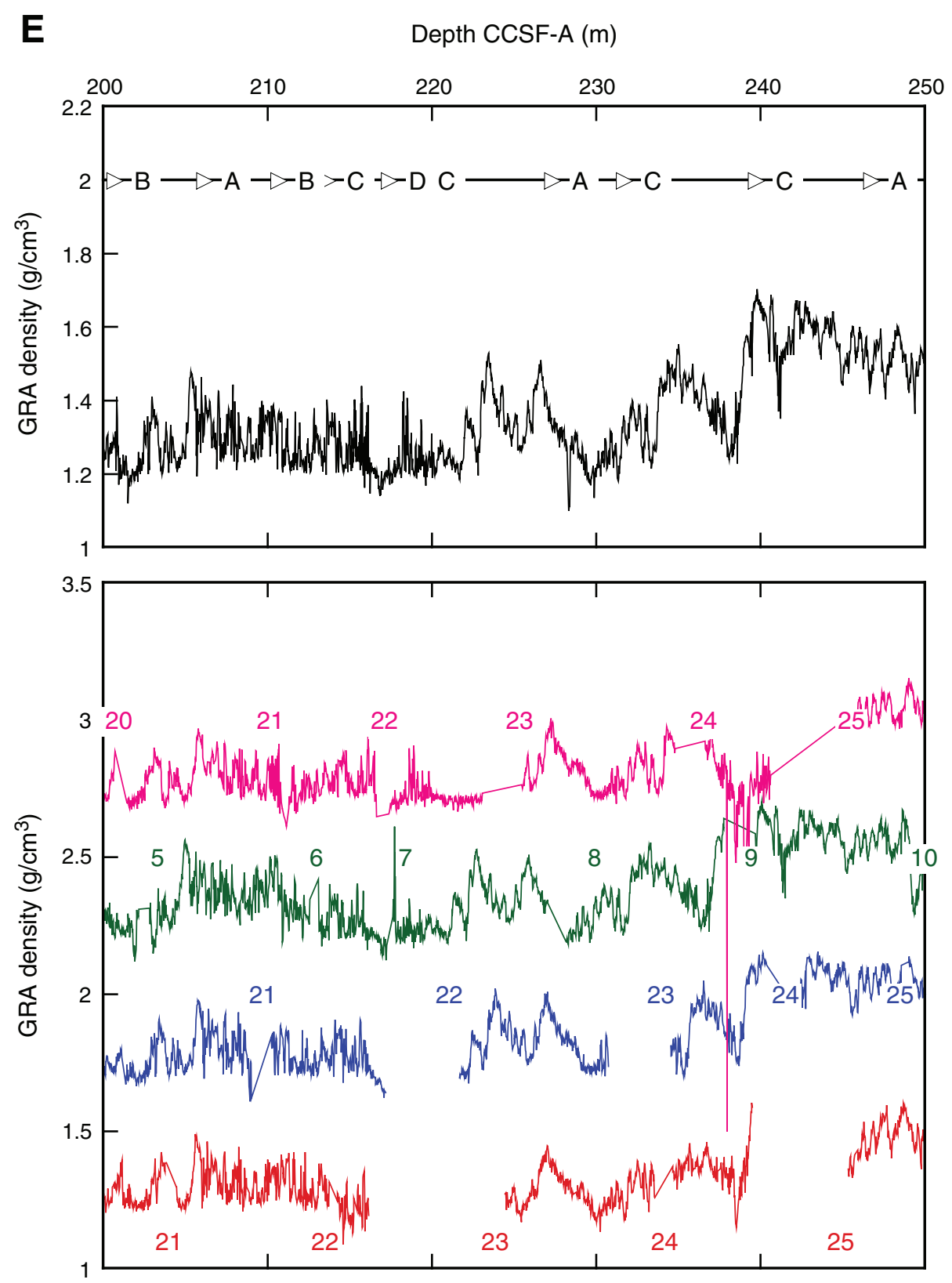


Figure F38 (continued). F. 250-300 m CCSF-A. (Continued on next page.)
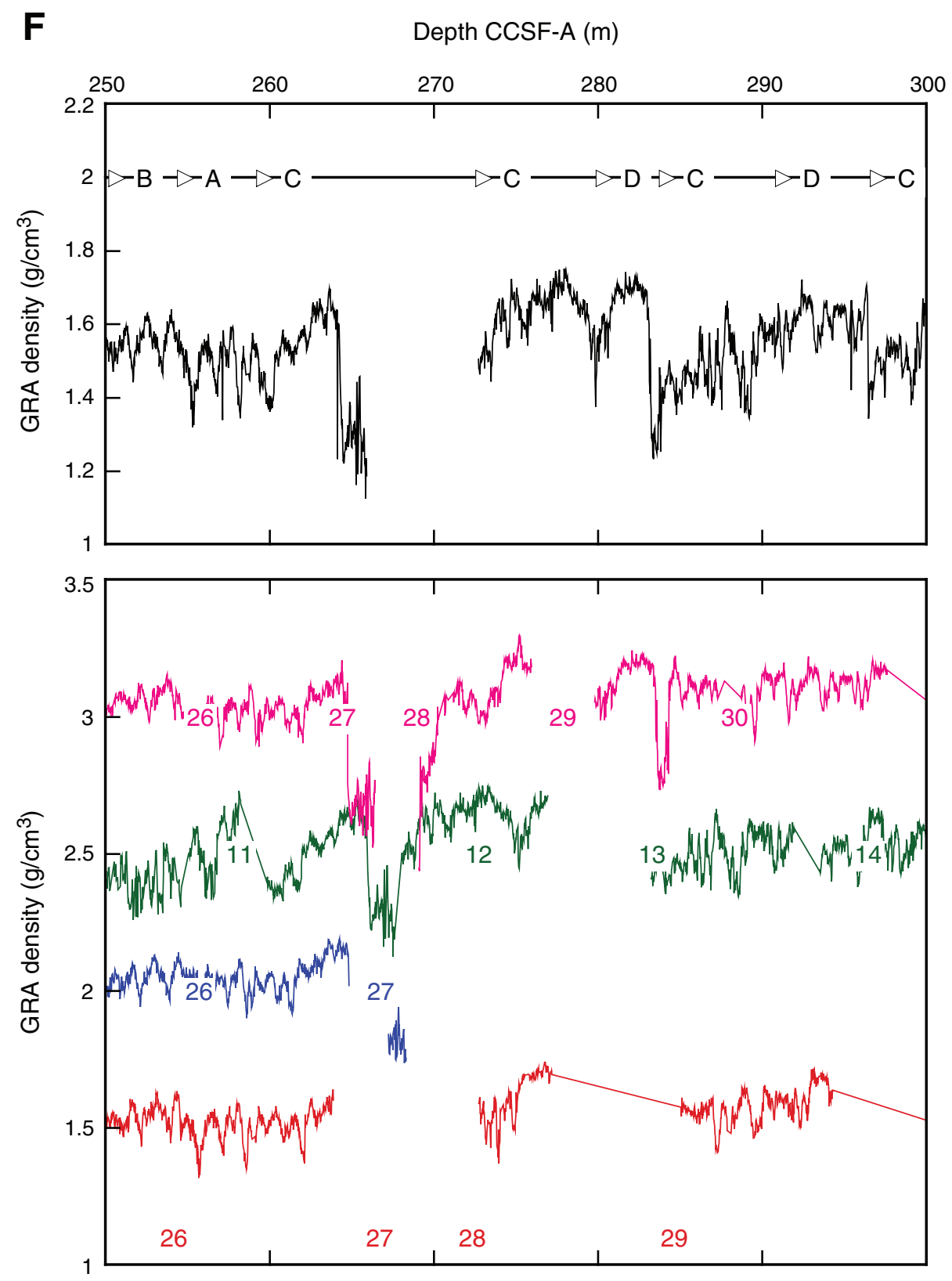
Figure F38 (continued). G. 300-350 m CCSF-A. (Continued on next page.)

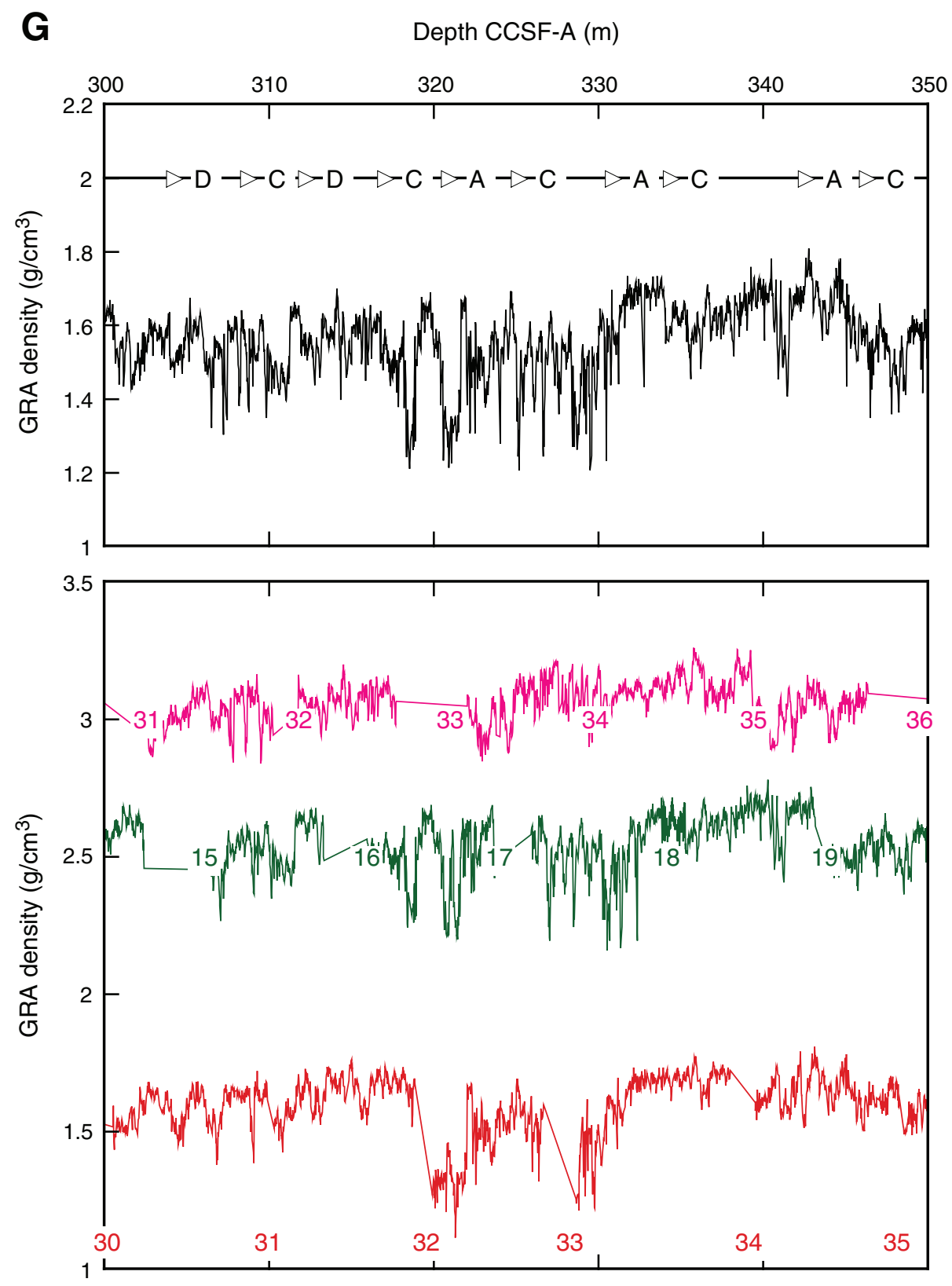


Figure F38 (continued). H. 350-400 m CCSF-A. (Continued on next page.)

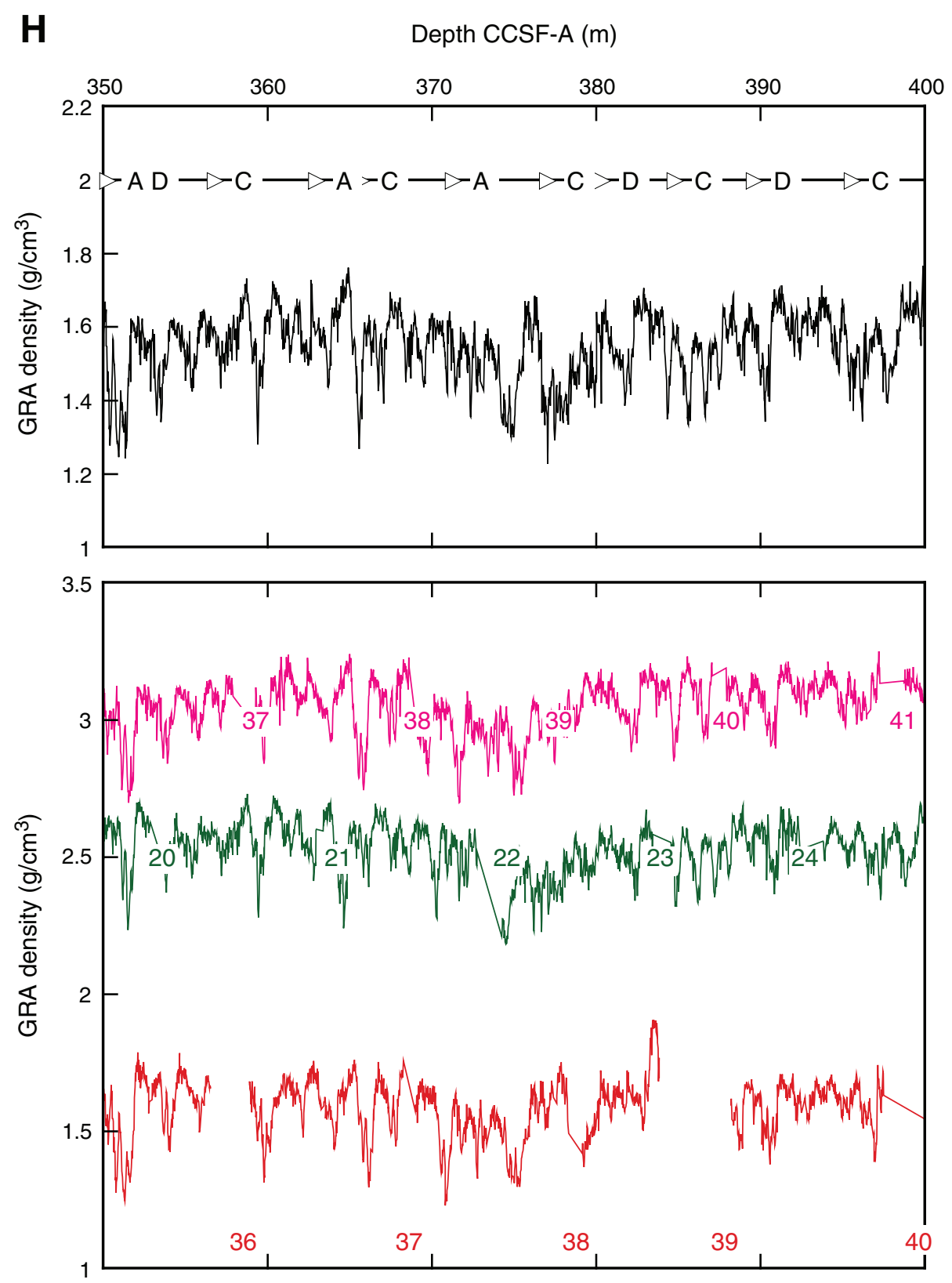


Figure F38 (continued). I. 400-450 m CCSF-A. (Continued on next page.)

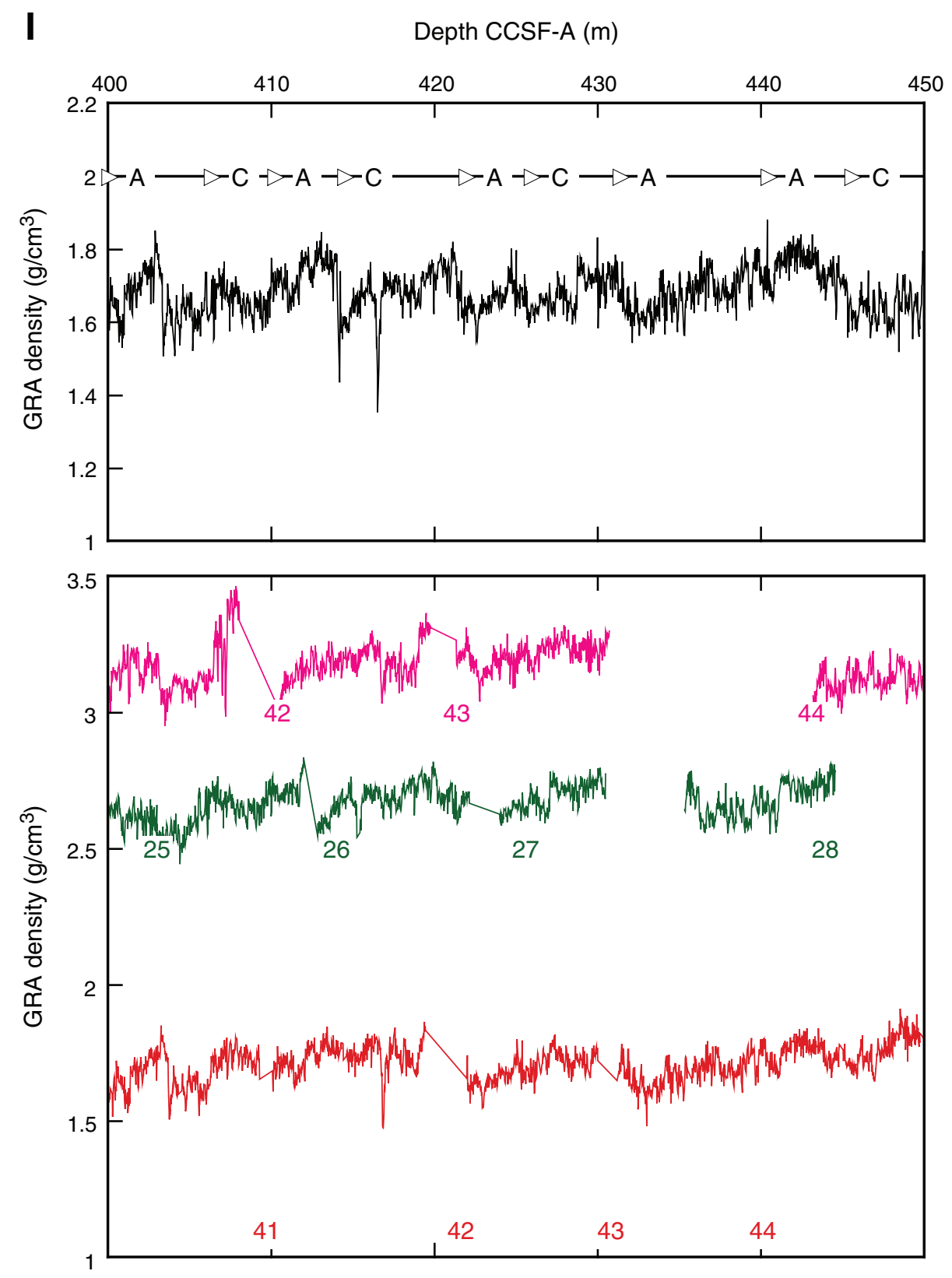


Figure F38 (continued). J. 450-500 m CCSF-A.

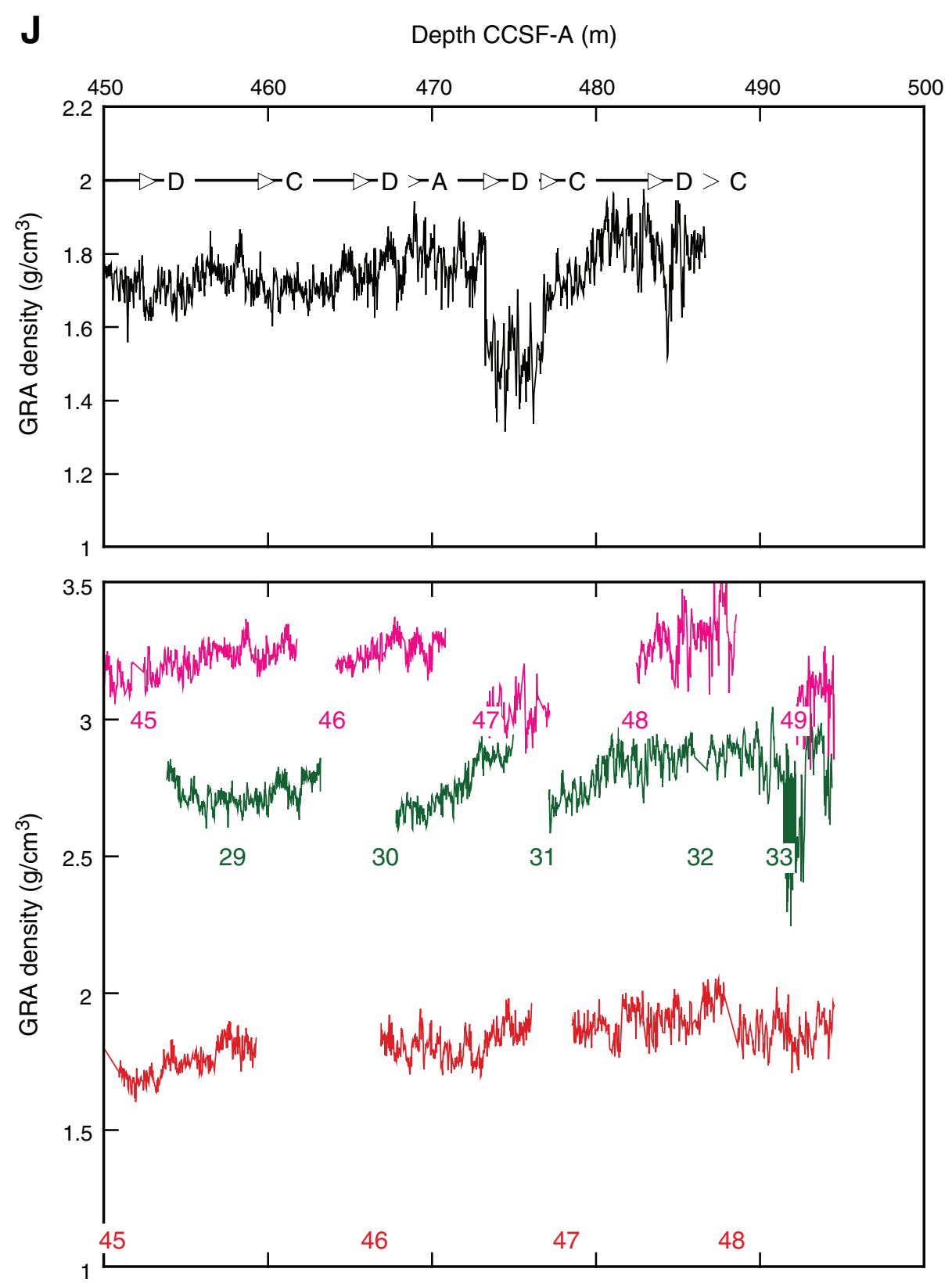


Figure F39. Core images, Holes U1337A-U1337D. Broken pieces of hard chert layer (see text) were recovered from the top of Core 321-U1337D$28 X$.

Hole U1337D
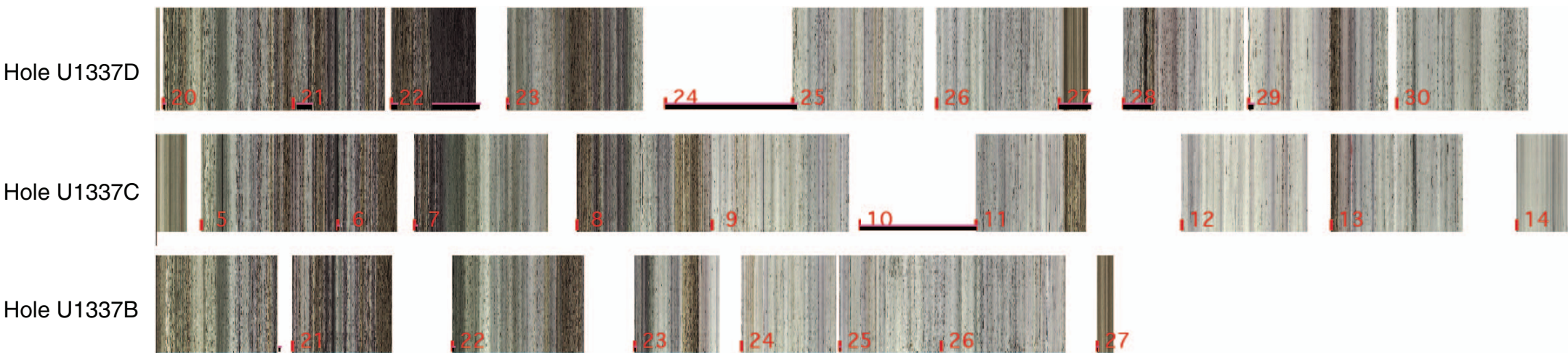

$\theta$

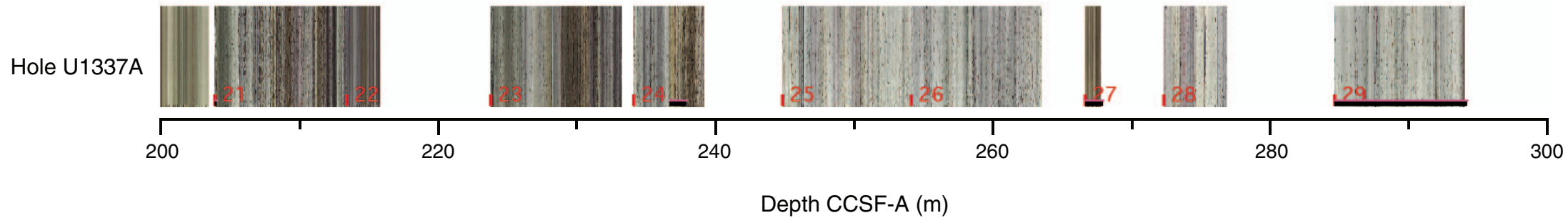


Figure F40. Linear sedimentation rates and chronostratigraphic markers, Site U1337.

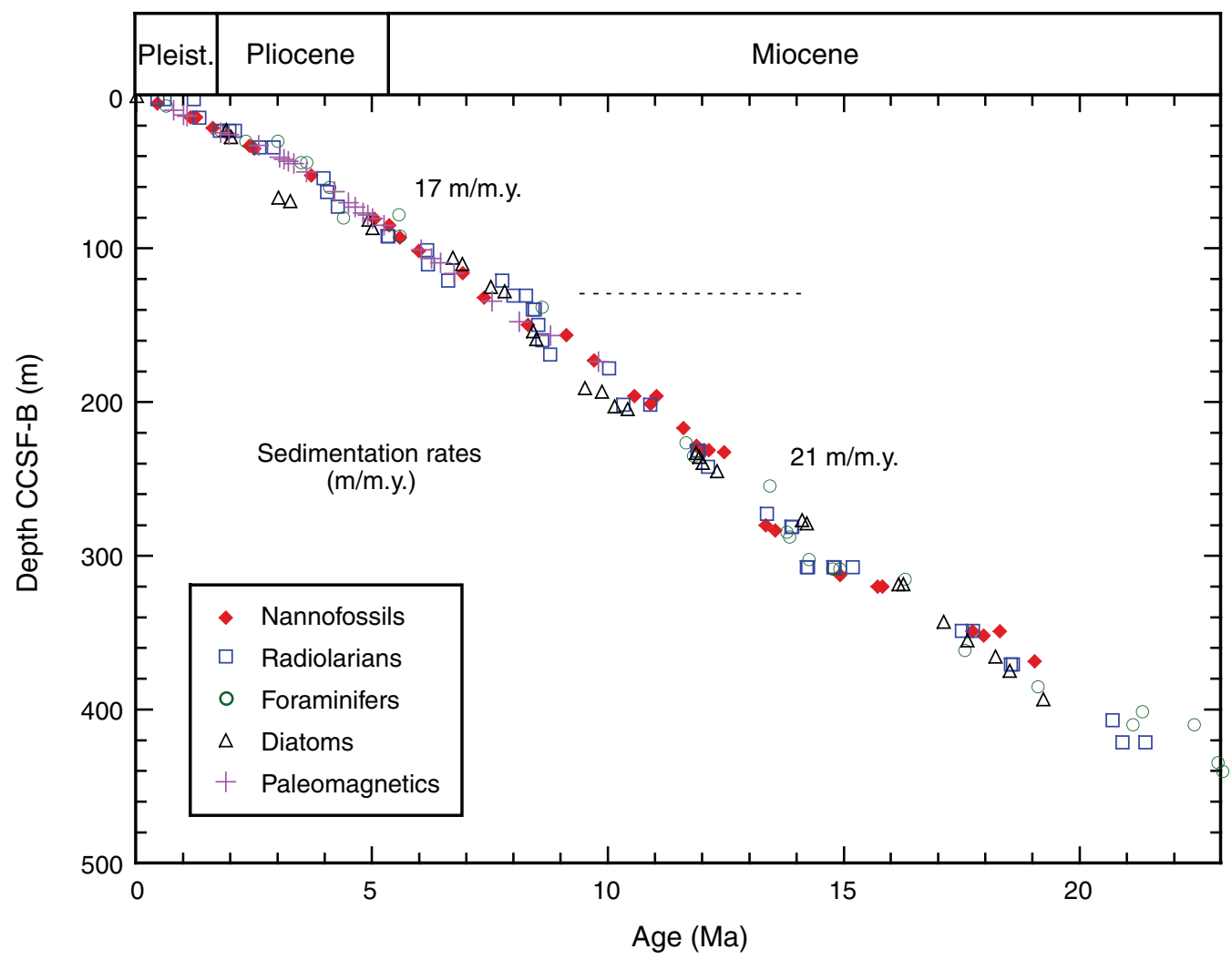


Figure F41. A. Modified triple combination tool string. HNGS = Hostile Environment Natural Gamma Ray Sonde, HLDS $=$ Hostile Environment Litho-Density Sonde, GPIT = General Purpose Inclinometer Tool, DIT = Dual Induction Tool, SFLU = spherically focused resistivity. B. Logging pass schematic, Hole U1337A.

A

Modified triple combination

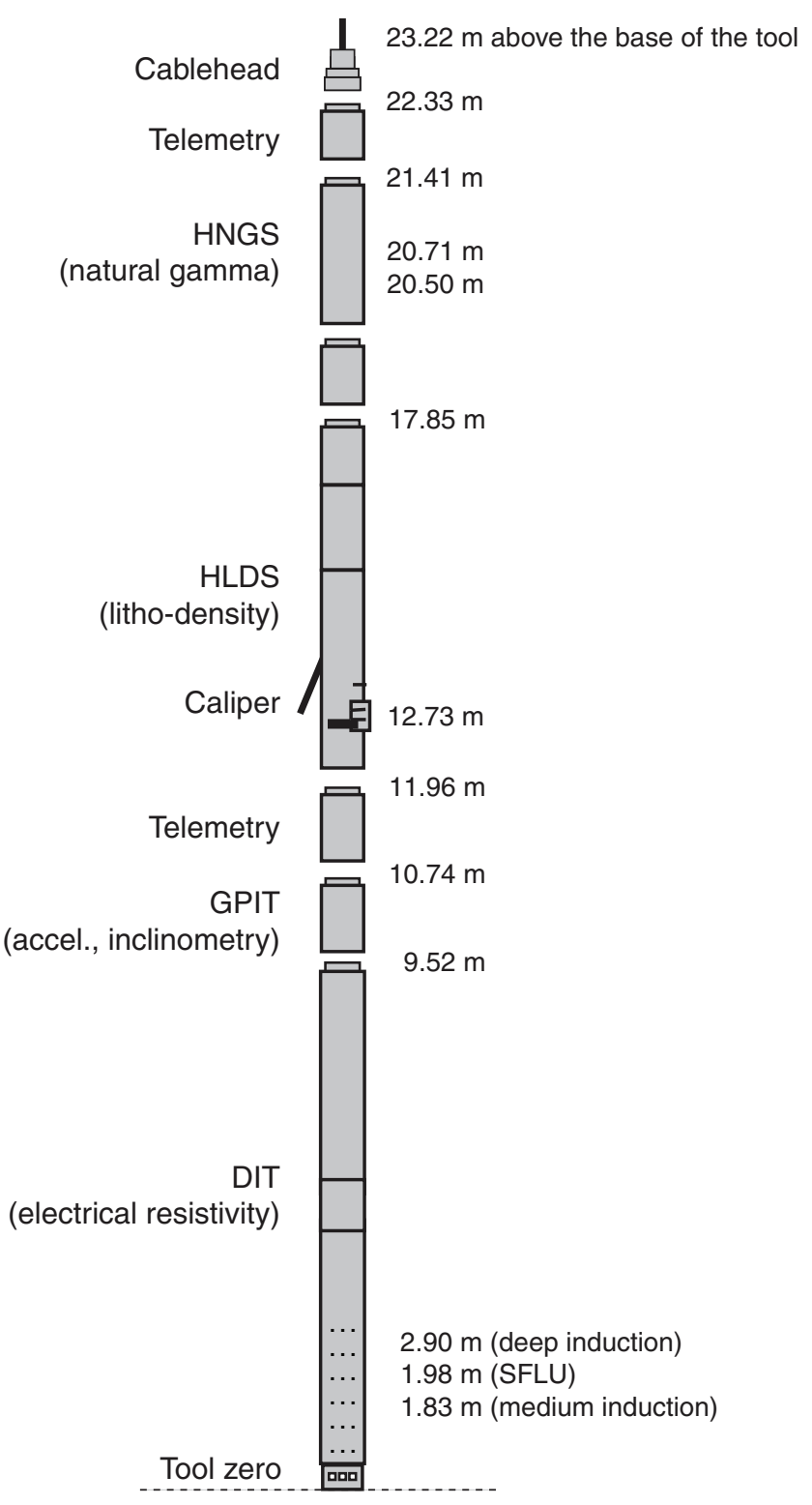

B

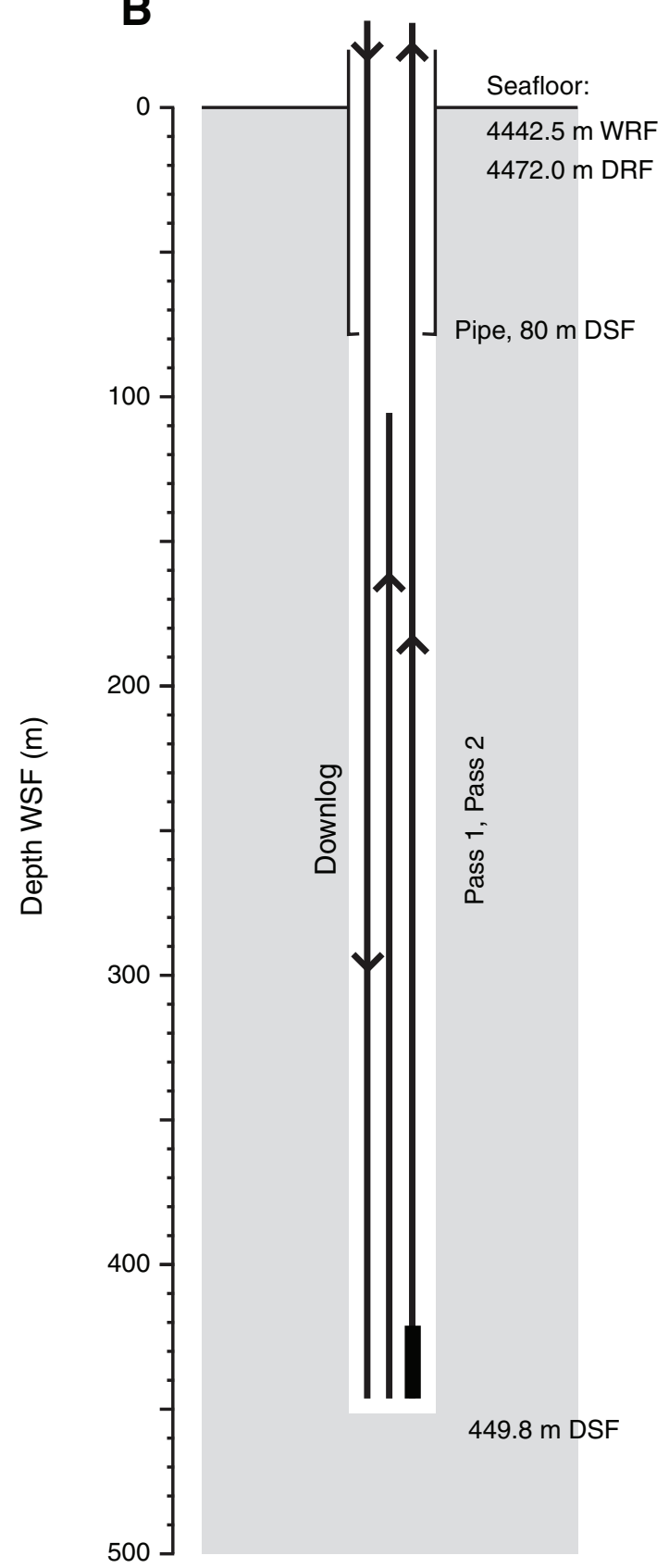


Figure F42. A. Formation MicroScanner-sonic tool string. HNGS = Hostile Environment Natural Gamma Ray Sonde, DSI = Dipole Sonic Imager, GPIT = General Purpose Inclinometer Tool, FMS = Formation MicroScanner. B. Logging pass schematic, Hole U1337A.

A Formation MicroScanner-sonic

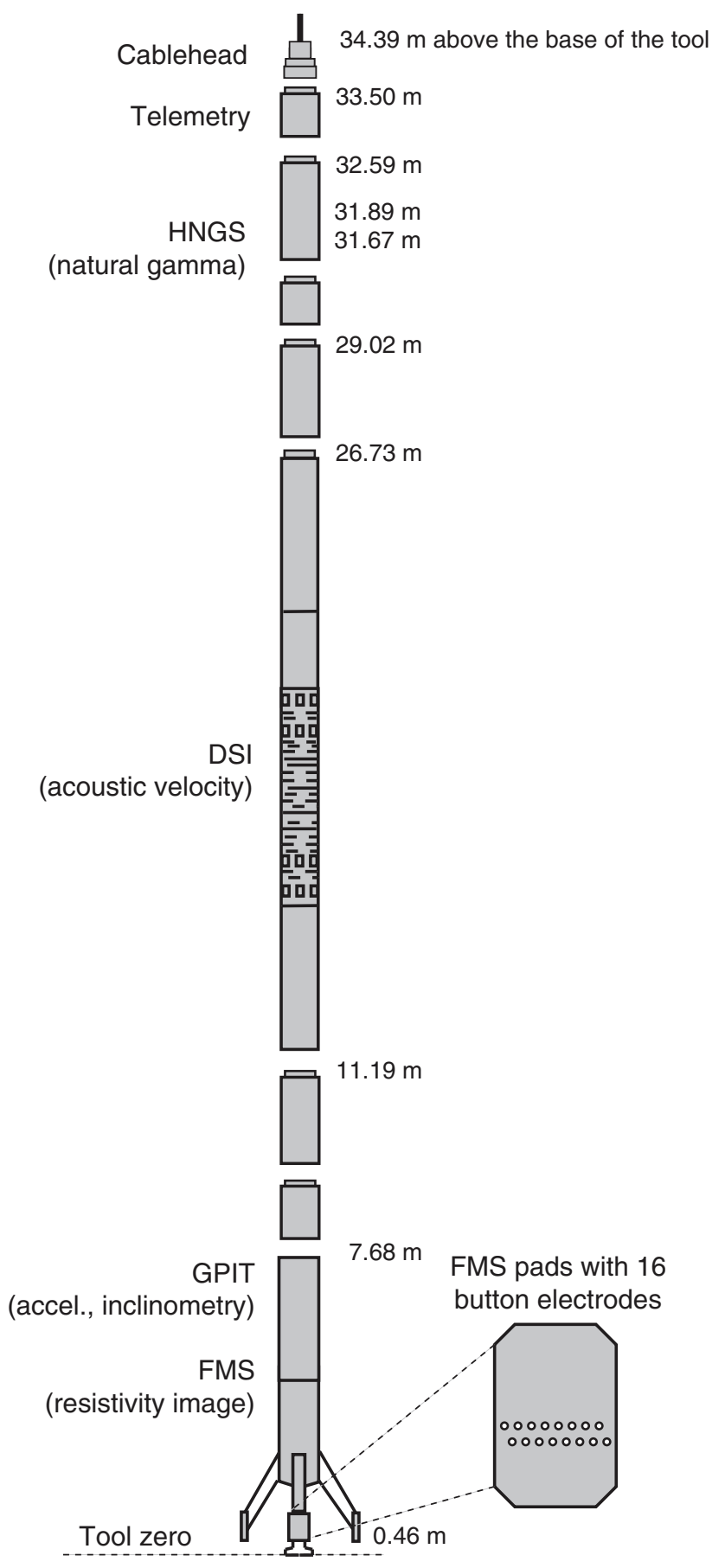

B

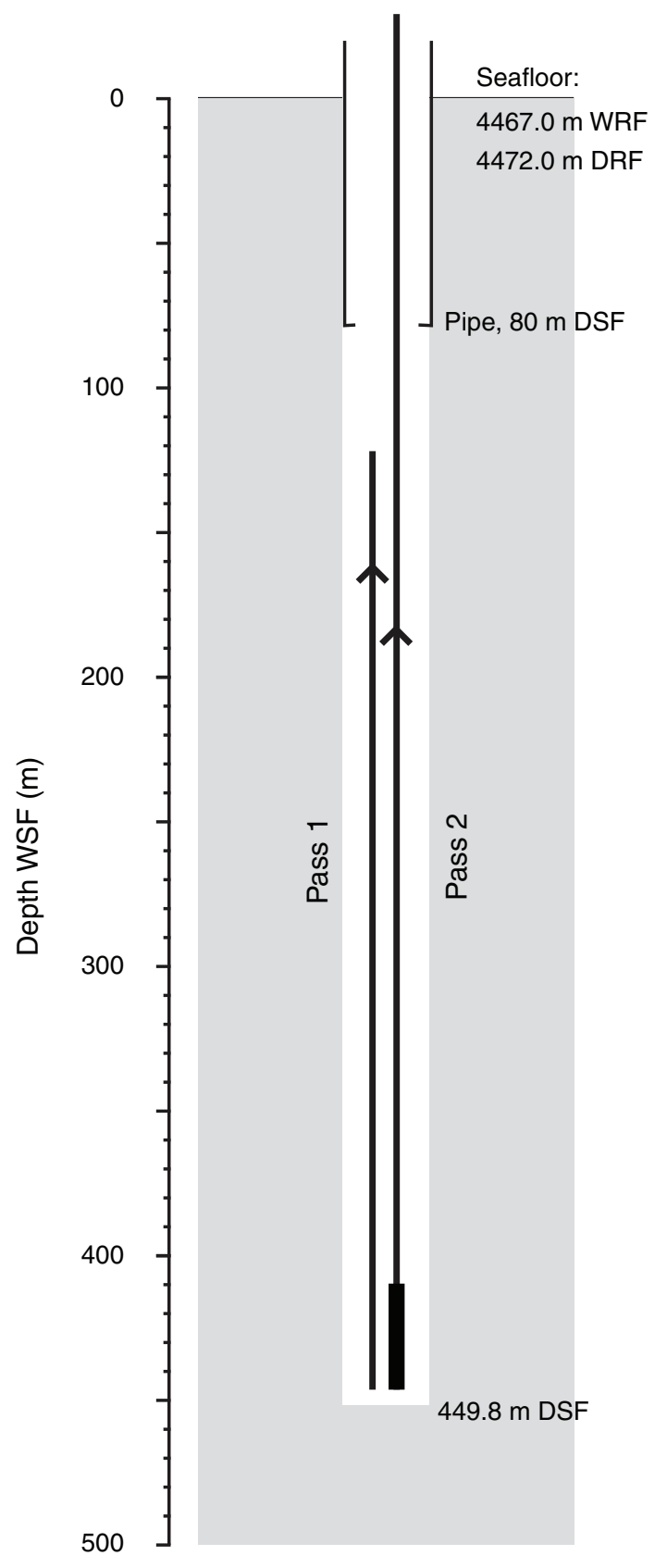


Figure F43. Natural gamma ray log measurement summary, Hole U1337A. FMS = Formation MicroScanner, TC $=$ triple combination tool string.

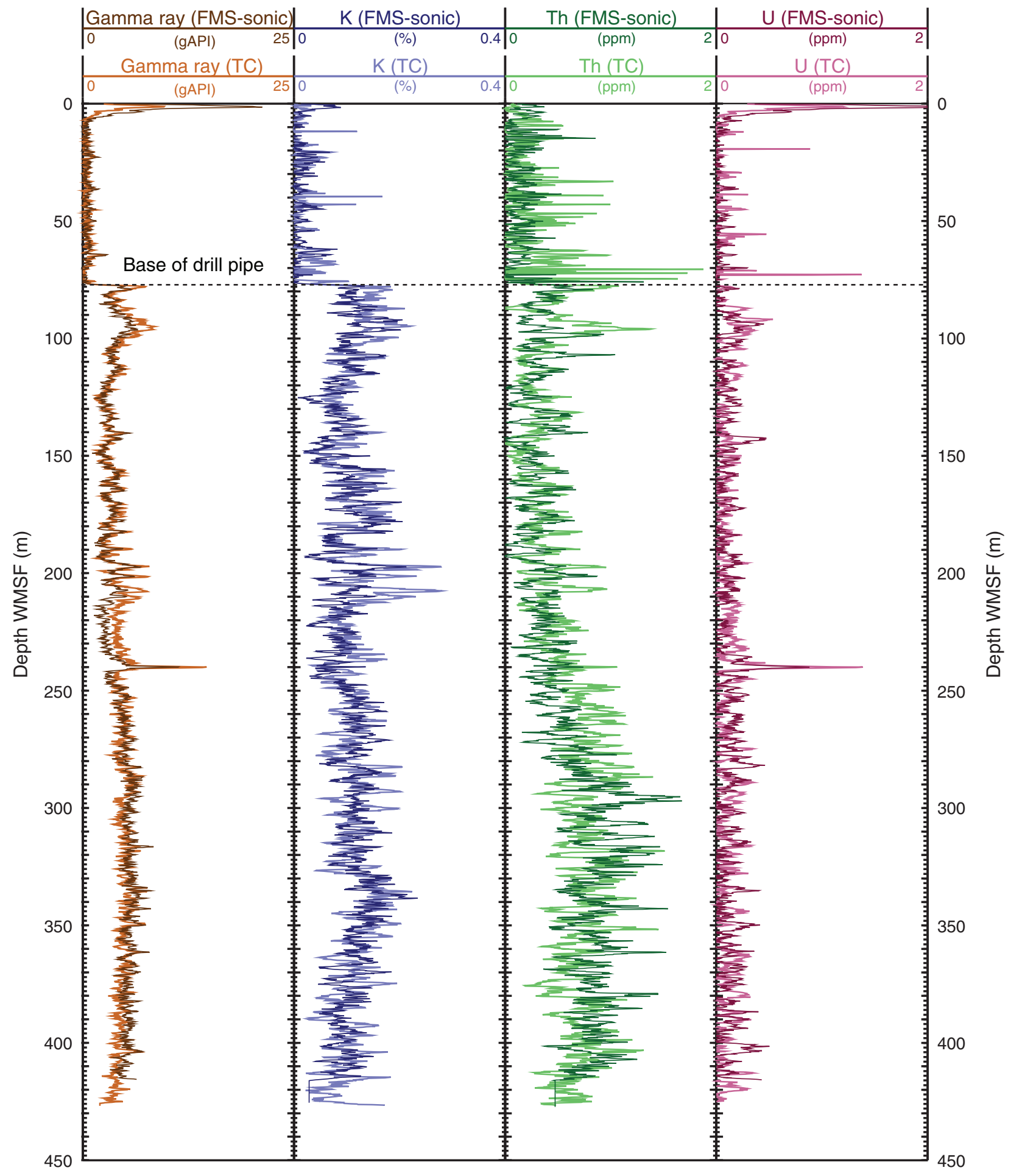


Figure F44. Downhole log curves showing (A) HNGS total gamma radiation, (B) HLDS bulk density, and (C) Formation MicroScanner (FMS) fourpad downhole resistivity image for Hole U1337A. Note the highly resistive layer $(\sim 40 \mathrm{~cm})$ at $240 \mathrm{~m}$ WMSF. Also shown are core images and gamma ray attenuation (GRA) density for Holes (D) U1337A, (E) U1337B, (F) U1337C, and (G) U1337D. White = core numbers, gray dashed lines $=$ another possible match for core density data.

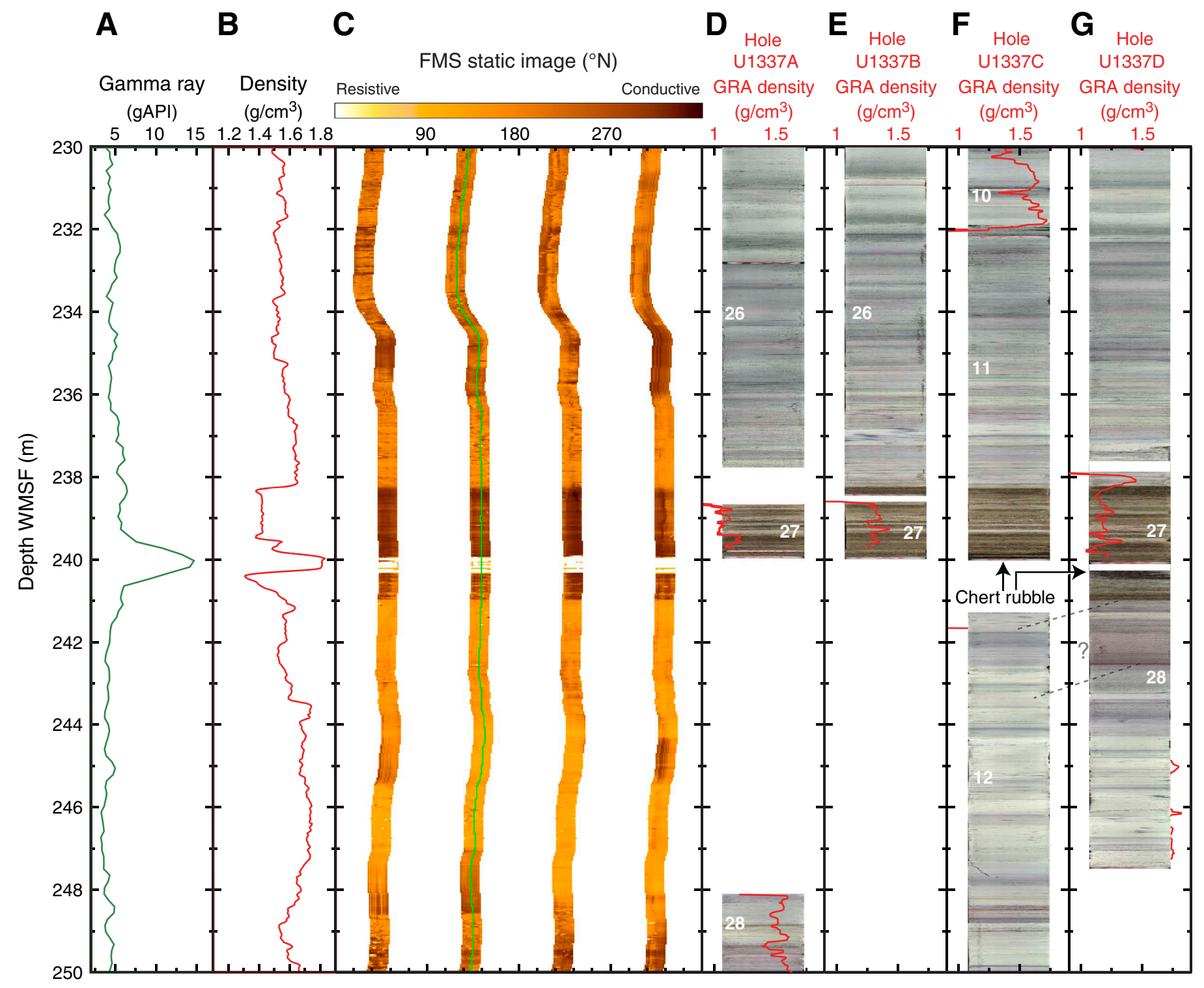


Figure F45. A. Vertical seismic profile (VSP) waveforms, Hole U1337A. B. Interpolation of the VSP direct arrival times defines a relationship between two-way traveltime (TWT) in seismic records and depth at Site U1337.

A

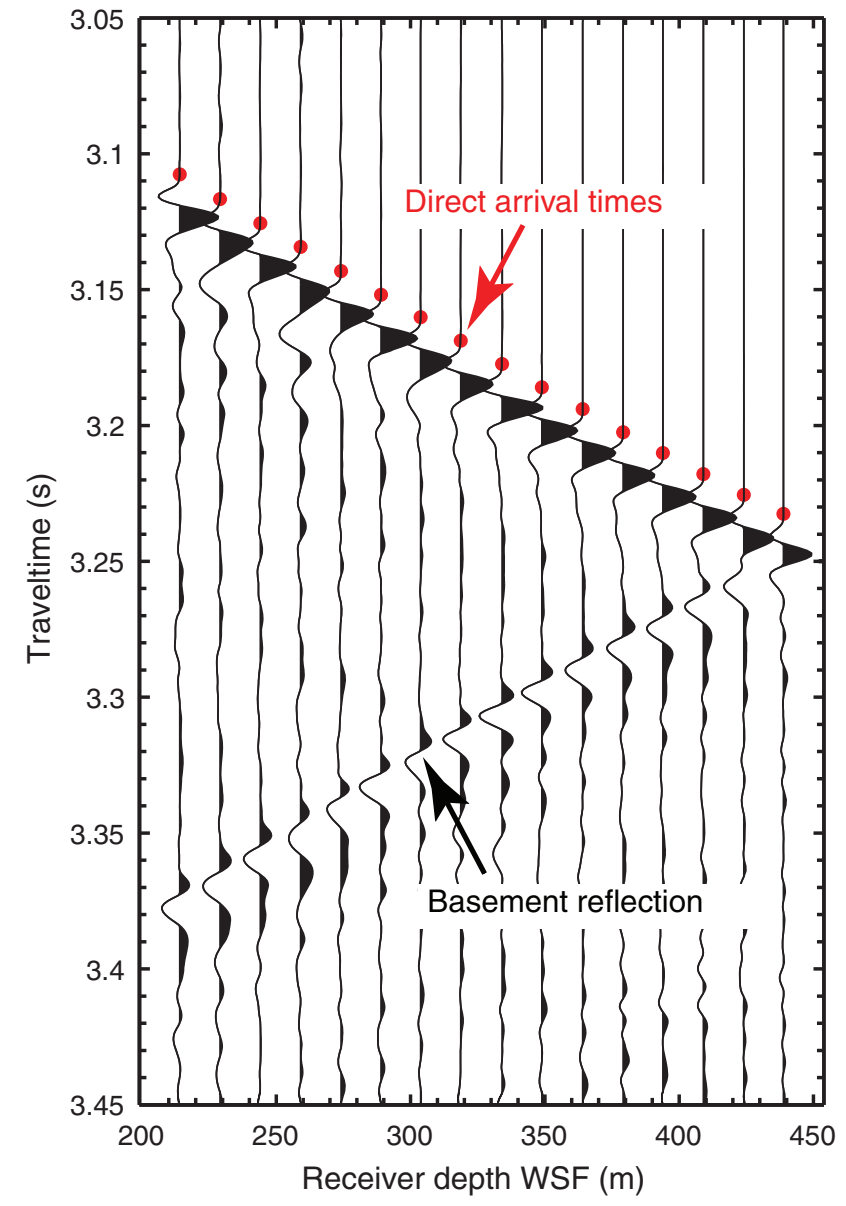

B

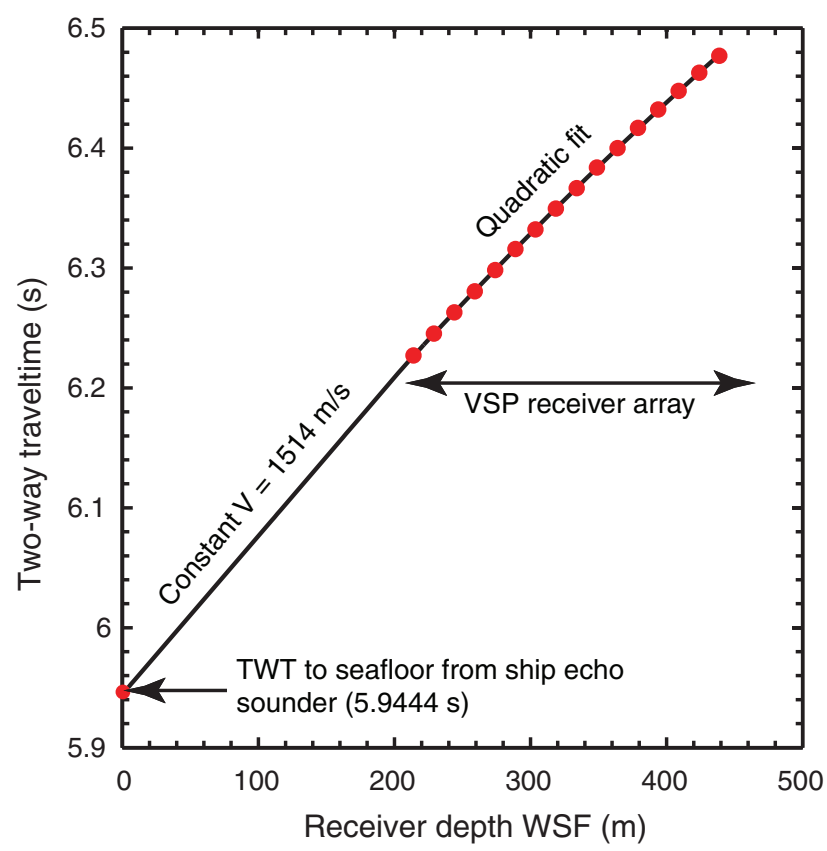


Figure F46. Correlation between seismic reflection record at Site U1337 (AMAT-03 site survey) and depth in Hole U1337A. Transition between low-density logging Unit 1 and higher density logging Unit 2 is marked by a cluster of reflectors at $6.2 \mathrm{~s}$ two-way traveltime. p1 $=$ uplog Pass $1, \mathrm{p} 2=$ uplog Pass $2, \mathrm{MAD}=$ moisture and density, IMPH = medium induction phasor-processed resistivity, SFLU = spherically focused resistivity, VSP = vertical seismic profile.

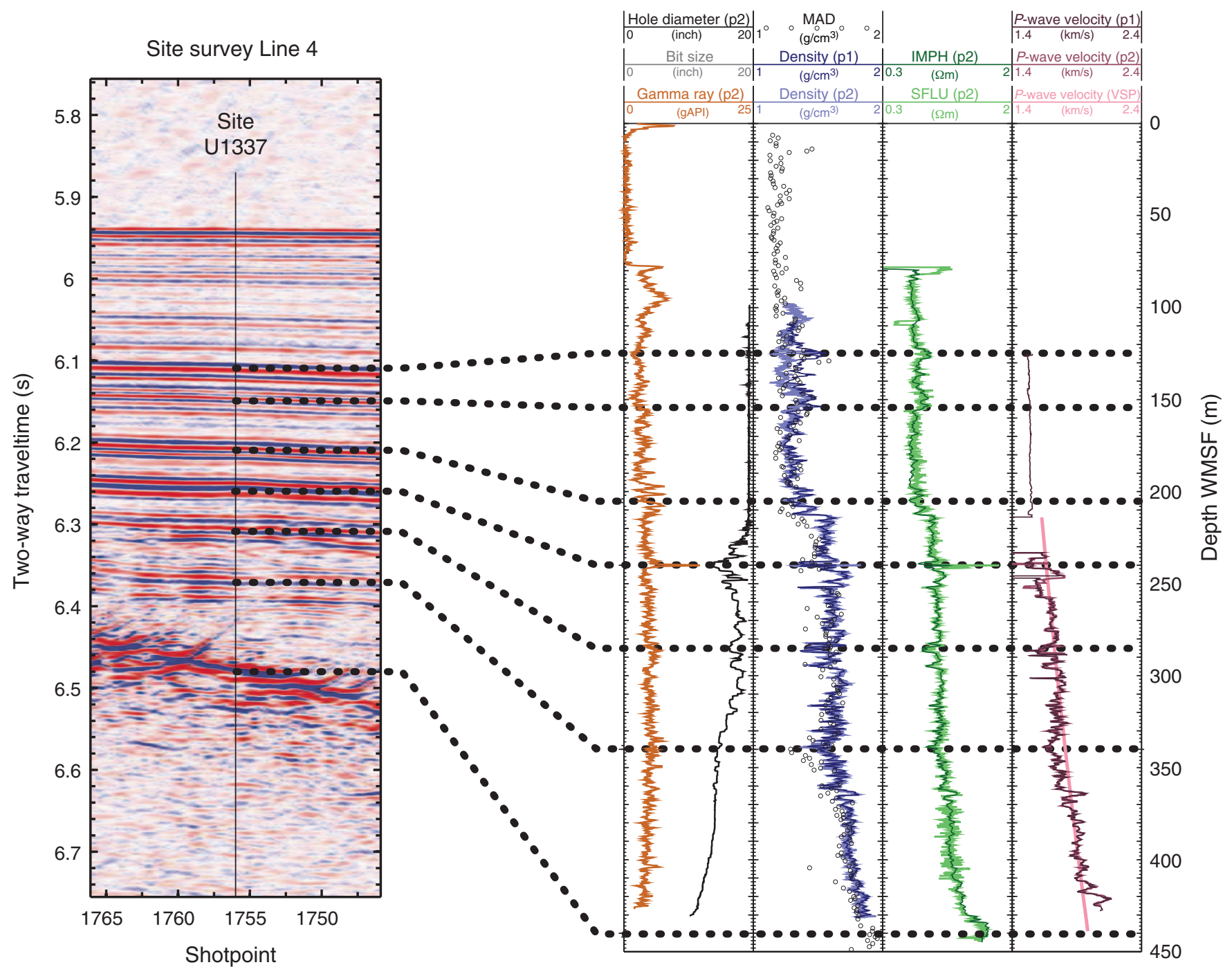


Figure F47. Geothermal gradient, in situ thermal conductivities, and temperature vs. thermal resistance, Hole U1337A. Heat flow is determined from the slope of a line fitted to the relationship between temperature and thermal resistance.

Site U1337

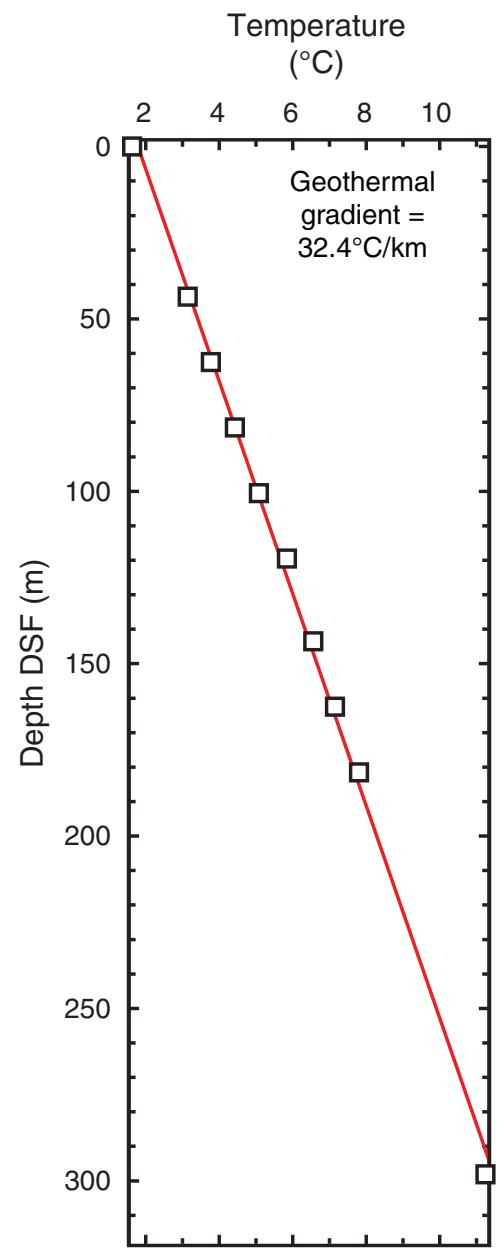

Thermal conductivity

$(\mathrm{W} /[\mathrm{m} \cdot \mathrm{K}])$

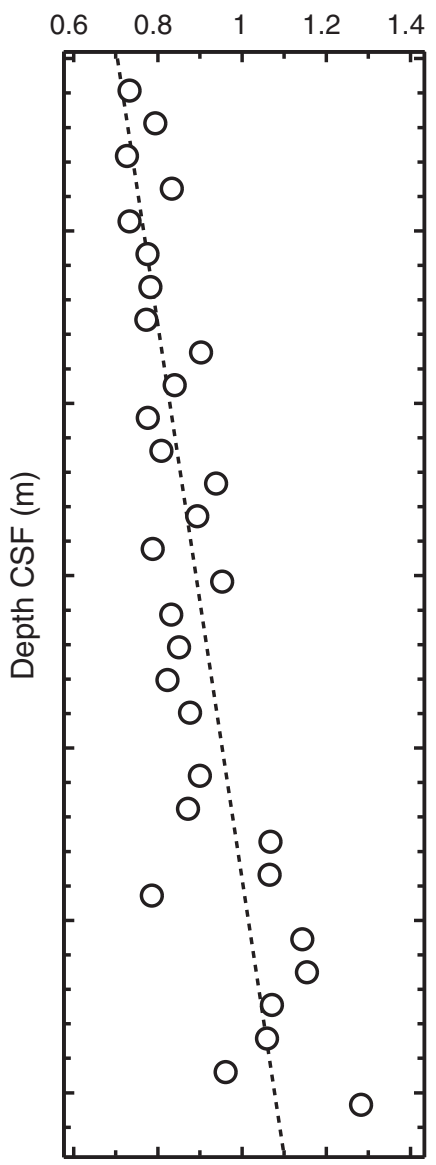

Temperature

$\left({ }^{\circ} \mathrm{C}\right)$

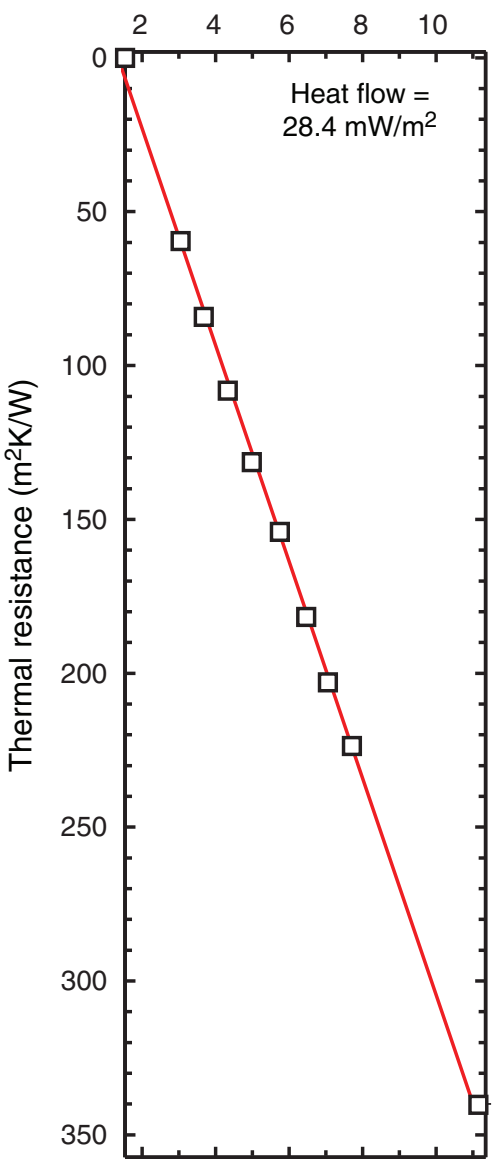


Table T1. Coring summary, Site U1337. (See table notes.) (Continued on next three pages.)

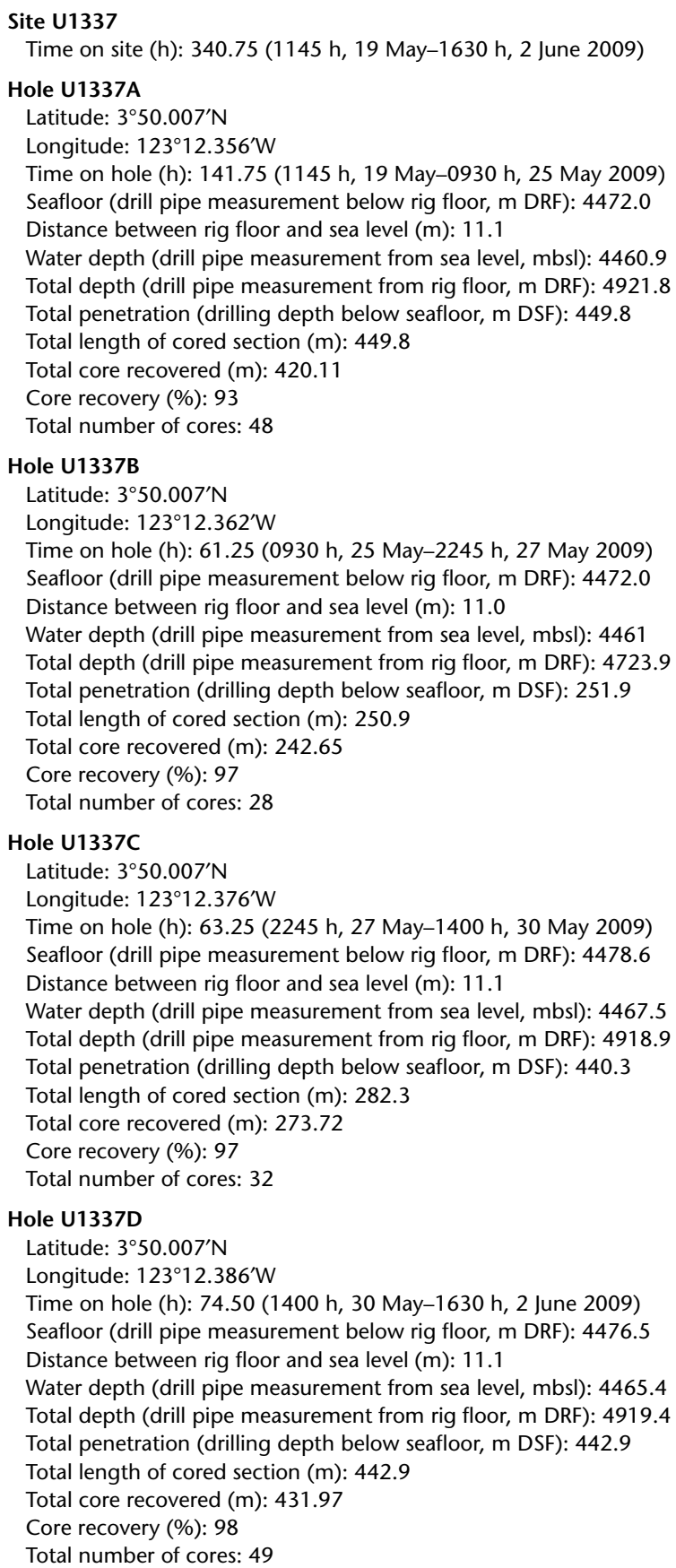

\begin{tabular}{|c|c|c|c|c|c|c|c|c|c|}
\hline \multirow[b]{2}{*}{ Core } & \multirow[b]{2}{*}{$\begin{array}{c}\text { Date } \\
(2009)\end{array}$} & \multirow[b]{2}{*}{$\begin{array}{l}\text { Local time } \\
\text { (h) }\end{array}$} & \multicolumn{2}{|c|}{ Depth DSF (m) } & \multirow[b]{2}{*}{$\begin{array}{l}\text { Interval } \\
\text { advanced } \\
(\mathrm{m})\end{array}$} & \multicolumn{2}{|c|}{ Depth CSF (m) } & \multirow[b]{2}{*}{$\begin{array}{l}\text { Length of core } \\
\text { recovered } \\
(\mathrm{m})\end{array}$} & \multirow[b]{2}{*}{$\begin{array}{c}\text { Recovery } \\
\text { (\%) }\end{array}$} \\
\hline & & & $\begin{array}{l}\text { Top of } \\
\text { cored } \\
\text { interval }\end{array}$ & $\begin{array}{l}\text { Bottom of } \\
\text { cored } \\
\text { interval }\end{array}$ & & $\begin{array}{l}\text { Top of } \\
\text { cored } \\
\text { interval }\end{array}$ & $\begin{array}{l}\text { Bottom of } \\
\text { cored } \\
\text { interval }\end{array}$ & & \\
\hline \multicolumn{10}{|c|}{ 321-U1337A- } \\
\hline $1 \mathrm{H}$ & 20 May & 1150 & 0.00 & 5.50 & 5.5 & 0.00 & 0.19 & 0.20 & 4 \\
\hline $2 \mathrm{H}$ & 20 May & 1335 & 5.50 & 15.00 & 9.5 & 5.50 & 15.49 & 10.00 & 105 \\
\hline $3 \mathrm{H}$ & 20 May & 1455 & 15.00 & 24.50 & 9.5 & 15.00 & 24.96 & 10.00 & 105 \\
\hline $4 \mathrm{H}$ & 20 May & 1620 & 24.50 & 34.00 & 9.5 & 24.50 & 34.49 & 10.00 & 105 \\
\hline $5 \mathrm{H}$ & 20 May & 1755 & 34.00 & 43.50 & 9.5 & 34.00 & 43.85 & 9.85 & 104 \\
\hline $6 \mathrm{H}$ & 20 May & 1925 & 43.50 & 53.00 & 9.5 & 43.50 & 53.50 & 10.00 & 105 \\
\hline $7 \mathrm{H}$ & 20 May & 2100 & 53.00 & 62.50 & 9.5 & 53.00 & 62.91 & 9.91 & 104 \\
\hline $8 \mathrm{H}$ & 20 May & 2220 & 62.50 & 72.00 & 9.5 & 62.50 & 71.60 & 9.10 & 96 \\
\hline
\end{tabular}


Table T1 (continued). (Continued on next page.)

\begin{tabular}{|c|c|c|c|c|c|c|c|c|c|}
\hline \multirow[b]{2}{*}{ Core } & \multirow[b]{2}{*}{$\begin{array}{l}\text { Date } \\
(2009)\end{array}$} & \multirow[b]{2}{*}{$\begin{array}{l}\text { Local time } \\
\text { (h) }\end{array}$} & \multicolumn{2}{|c|}{ Depth DSF (m) } & \multirow[b]{2}{*}{$\begin{array}{l}\text { Interval } \\
\text { advanced } \\
\text { (m) }\end{array}$} & \multicolumn{2}{|c|}{ Depth CSF (m) } & \multirow[b]{2}{*}{$\begin{array}{l}\text { Length of core } \\
\text { recovered } \\
(\mathrm{m})\end{array}$} & \multirow[b]{2}{*}{$\begin{array}{l}\text { Recovery } \\
(\%)\end{array}$} \\
\hline & & & $\begin{array}{l}\text { Top of } \\
\text { cored } \\
\text { interval }\end{array}$ & $\begin{array}{l}\text { Bottom of } \\
\text { cored } \\
\text { interval }\end{array}$ & & $\begin{array}{l}\text { Top of } \\
\text { cored } \\
\text { interval }\end{array}$ & $\begin{array}{l}\text { Bottom of } \\
\text { cored } \\
\text { interval }\end{array}$ & & \\
\hline $9 \mathrm{H}$ & 21 May & 0000 & 72.00 & 81.50 & 9.5 & 72.00 & 81.99 & 9.99 & 105 \\
\hline $10 \mathrm{H}$ & 21 May & 0120 & 81.50 & 91.00 & 9.5 & 81.50 & 91.58 & 10.08 & 106 \\
\hline $11 \mathrm{H}$ & 21 May & 0245 & 91.00 & 100.50 & 9.5 & 91.00 & 101.05 & 11.26 & 119 \\
\hline $12 \mathrm{H}$ & 21 May & 0400 & 100.50 & 110.00 & 9.5 & 100.50 & 110.45 & 9.95 & 105 \\
\hline $13 \mathrm{H}$ & 21 May & 0530 & 110.00 & 119.50 & 9.5 & 110.00 & 119.89 & 9.89 & 104 \\
\hline $14 \mathrm{H}$ & 21 May & 0650 & 119.50 & 129.00 & 9.5 & 119.50 & 129.45 & 9.95 & 105 \\
\hline $15 \mathrm{H}$ & 22 May & 0815 & 129.00 & 138.50 & 9.5 & 129.00 & 138.87 & 9.87 & 104 \\
\hline $16 \mathrm{H}$ & 22 May & 0925 & 138.50 & 148.00 & 9.5 & 138.50 & 148.58 & 10.08 & 106 \\
\hline $17 \mathrm{H}$ & 22 May & 1030 & 148.00 & 157.50 & 9.5 & 148.00 & 158.04 & 10.04 & 106 \\
\hline $18 \mathrm{H}$ & 22 May & 1145 & 157.50 & 167.00 & 9.5 & 157.50 & 167.55 & 10.05 & 106 \\
\hline $19 \mathrm{H}$ & 22 May & 1300 & 167.00 & 176.50 & 9.5 & 167.00 & 177.05 & 10.05 & 106 \\
\hline $20 \mathrm{H}$ & 22 May & 1430 & 176.50 & 186.00 & 9.5 & 176.50 & 186.43 & 9.93 & 105 \\
\hline $21 \mathrm{H}$ & 22 May & 1605 & 186.00 & 195.50 & 9.5 & 186.00 & 195.67 & 9.67 & 102 \\
\hline $22 x$ & 21 May & 1745 & 195.50 & 204.30 & 8.8 & 195.50 & 198.09 & 2.59 & 29 \\
\hline $23 x$ & 21 May & 1900 & 204.30 & 213.90 & 9.6 & 204.30 & 213.92 & 9.62 & 100 \\
\hline $24 X$ & 21 May & 2020 & 213.90 & 223.40 & 9.5 & 213.90 & 219.05 & 5.15 & 54 \\
\hline $25 X$ & 21 May & 2130 & 223.40 & 233.00 & 9.6 & 223.40 & 232.92 & 9.52 & 99 \\
\hline $26 x$ & 21 May & 2245 & 233.00 & 242.20 & 9.2 & 233.00 & 242.49 & 9.49 & 103 \\
\hline $27 X$ & 22 May & 0015 & 242.20 & 251.70 & 9.5 & 242.20 & 243.51 & 1.31 & 14 \\
\hline $28 \mathrm{X}$ & 22 May & 0120 & 251.70 & 261.30 & 9.6 & 251.70 & 256.42 & 4.72 & 49 \\
\hline $29 X$ & 22 May & 0235 & 261.30 & 270.80 & 9.5 & 261.30 & 270.85 & 9.55 & 101 \\
\hline $30 x$ & 22 May & 0345 & 270.80 & 280.50 & 9.7 & 270.80 & 280.54 & 9.74 & 100 \\
\hline $31 x$ & 22 May & 0500 & 280.50 & 290.20 & 9.7 & 280.50 & 289.52 & 9.02 & 93 \\
\hline $32 x$ & 22 May & 0615 & 290.20 & 299.70 & 9.5 & 290.20 & 297.22 & 7.02 & 74 \\
\hline $33 x$ & 22 May & 0730 & 299.70 & 309.30 & 9.6 & 299.70 & 309.30 & 9.60 & 100 \\
\hline $34 X$ & 22 May & 0845 & 309.30 & 318.90 & 9.6 & 309.30 & 318.41 & 9.11 & 95 \\
\hline $35 X$ & 22 May & 0950 & 318.90 & 328.50 & 9.6 & 318.90 & 327.28 & 8.38 & 87 \\
\hline $36 \mathrm{X}$ & 22 May & 1105 & 328.50 & 338.00 & 9.5 & 328.50 & 338.20 & 9.70 & 102 \\
\hline $37 X$ & 22 May & 1225 & 338.00 & 347.60 & 9.6 & 338.00 & 347.69 & 9.69 & 101 \\
\hline $38 \mathrm{X}$ & 22 May & 1340 & 347.60 & 357.20 & 9.6 & 347.60 & 352.70 & 5.10 & 53 \\
\hline $39 x$ & 22 May & 1455 & 357.20 & 366.80 & 9.6 & 357.20 & 366.90 & 9.70 & 101 \\
\hline $40 x$ & 22 May & 1620 & 366.80 & 376.40 & 9.6 & 366.80 & 376.52 & 9.72 & 101 \\
\hline $41 X$ & 22 May & 1735 & 376.40 & 386.00 & 9.6 & 376.40 & 386.11 & 9.71 & 101 \\
\hline $42 X$ & 22 May & 1855 & 386.00 & 395.60 & 9.6 & 386.00 & 394.28 & 8.28 & 86 \\
\hline $43 x$ & 22 May & 2000 & 395.60 & 404.90 & 9.3 & 395.60 & 405.19 & 9.59 & 103 \\
\hline $44 X$ & 22 May & 2120 & 404.90 & 414.50 & 9.6 & 404.90 & 414.59 & 9.69 & 101 \\
\hline $45 x$ & 22 May & 2240 & 414.50 & 424.00 & 9.5 & 414.50 & 424.24 & 9.74 & 103 \\
\hline $46 X$ & 22 May & 2355 & 424.00 & 433.60 & 9.6 & 424.00 & 433.54 & 9.54 & 99 \\
\hline $47 X$ & 23 May & 0100 & 433.60 & 443.20 & 9.6 & 433.60 & 443.50 & 9.90 & 103 \\
\hline \multirow[t]{3}{*}{$48 \mathrm{X}$} & 23 May & 0225 & 443.20 & 449.80 & 6.6 & 443.20 & 449.54 & 6.34 & 96 \\
\hline & & & \multirow{2}{*}{\multicolumn{2}{|c|}{$\begin{array}{l}\text { Advanced total: } \\
\text { Total interval cored: }\end{array}$}} & 449.8 & & & 421.39 & 94 \\
\hline & & & & & 449.8 & & & & \\
\hline $321-U$ & $37 \mathrm{~B}-$ & & & & & & & & \\
\hline $1 \mathrm{H}$ & 24 May & 1245 & 1.00 & 10.50 & 9.5 & 1.00 & 7.41 & 6.41 & 67 \\
\hline $2 \mathrm{H}$ & 25 May & 1355 & 10.50 & 20.00 & 9.5 & 10.50 & 20.30 & 9.80 & 103 \\
\hline $3 \mathrm{H}$ & 25 May & 1505 & 20.00 & 29.50 & 9.5 & 20.00 & 29.72 & 9.72 & 102 \\
\hline $4 \mathrm{H}$ & 25 May & 1610 & 29.50 & 39.00 & 9.5 & 29.50 & 39.44 & 9.94 & 105 \\
\hline $5 \mathrm{H}$ & 24 May & 1720 & 39.00 & 48.50 & 9.5 & 39.00 & 49.01 & 10.01 & 105 \\
\hline $6 \mathrm{H}$ & 24 May & 1855 & 48.50 & 58.00 & 9.5 & 48.50 & 58.35 & 9.85 & 104 \\
\hline $7 \mathrm{H}$ & 24 May & 2025 & 58.00 & 67.50 & 9.5 & 58.00 & 67.51 & 9.51 & 100 \\
\hline $8 \mathrm{H}$ & 24 May & 2135 & 67.50 & 77.00 & 9.5 & 67.50 & 77.04 & 9.54 & 100 \\
\hline $9 \mathrm{H}$ & 24 May & 2245 & 77.00 & 86.50 & 9.5 & 77.00 & 87.00 & 10.00 & 105 \\
\hline $10 \mathrm{H}$ & 24 May & 2355 & 86.50 & 96.00 & 9.5 & 86.50 & 96.22 & 9.72 & 102 \\
\hline $11 \mathrm{H}$ & 25 May & 0055 & 96.00 & 105.50 & 9.5 & 96.00 & 106.04 & 10.04 & 106 \\
\hline $12 \mathrm{H}$ & 25 May & 0155 & 105.50 & 115.00 & 9.5 & 105.50 & 115.57 & 10.07 & 106 \\
\hline $13 \mathrm{H}$ & 25 May & 0300 & 115.00 & 124.50 & 9.5 & 115.00 & 125.11 & 10.00 & 105 \\
\hline $14 \mathrm{H}$ & 25 May & 0355 & 124.50 & 134.00 & 9.5 & 124.50 & 134.41 & 9.72 & 102 \\
\hline $15 \mathrm{H}$ & 25 May & 0515 & 134.00 & 143.50 & 9.5 & 134.00 & 143.82 & 9.82 & 103 \\
\hline $16 \mathrm{H}$ & 25 May & 0625 & 143.50 & 153.00 & 9.5 & 143.50 & 153.48 & 9.98 & 105 \\
\hline $17 \mathrm{H}$ & 25 May & 0750 & 153.00 & 162.50 & 9.5 & 153.00 & 163.16 & 10.16 & 107 \\
\hline $18 \mathrm{H}$ & 25 May & 0850 & 162.50 & 172.00 & 9.5 & 162.50 & 172.41 & 9.91 & 104 \\
\hline $19 \mathrm{H}$ & 25 May & 1015 & 172.00 & 181.50 & 9.5 & 172.00 & 182.27 & 10.27 & 108 \\
\hline $20 \mathrm{H}$ & 25 May & 1120 & 181.50 & 191.00 & 9.5 & 181.50 & 191.08 & 9.58 & 101 \\
\hline $21 \mathrm{H}$ & 25 May & 1250 & 191.00 & 200.50 & 9.5 & 191.00 & 198.30 & 7.30 & 77 \\
\hline $22 \mathrm{H}$ & 25 May & 1355 & 200.50 & 210.00 & 9.5 & 200.50 & 210.00 & 9.50 & 100 \\
\hline $23 \mathrm{H}$ & 25 May & 1515 & 210.00 & 219.50 & 9.5 & 210.00 & 216.27 & 6.27 & 66 \\
\hline $24 \mathrm{H}$ & 25 May & 1640 & 219.50 & 226.40 & 6.9 & 219.50 & 226.38 & 6.88 & 100 \\
\hline
\end{tabular}


Table T1 (continued). (Continued on next page.)

\begin{tabular}{|c|c|c|c|c|c|c|c|c|c|}
\hline \multirow[b]{2}{*}{ Core } & \multirow[b]{2}{*}{$\begin{array}{l}\text { Date } \\
\text { (2009) }\end{array}$} & \multirow[b]{2}{*}{$\begin{array}{l}\text { Local time } \\
\text { (h) }\end{array}$} & \multicolumn{2}{|c|}{ Depth DSF (m) } & \multirow[b]{2}{*}{$\begin{array}{l}\text { Interval } \\
\text { advanced } \\
\text { (m) }\end{array}$} & \multicolumn{2}{|c|}{ Depth CSF (m) } & \multirow[b]{2}{*}{$\begin{array}{l}\text { Length of core } \\
\text { recovered } \\
\text { (m) }\end{array}$} & \multirow[b]{2}{*}{$\begin{array}{c}\text { Recovery } \\
\text { (\%) }\end{array}$} \\
\hline & & & $\begin{array}{l}\text { Top of } \\
\text { cored } \\
\text { interval }\end{array}$ & $\begin{array}{c}\text { Bottom of } \\
\text { cored } \\
\text { interval }\end{array}$ & & $\begin{array}{c}\text { Top of } \\
\text { cored } \\
\text { interval }\end{array}$ & $\begin{array}{c}\text { Bottom of } \\
\text { cored } \\
\text { interval }\end{array}$ & & \\
\hline $25 \mathrm{H}$ & 25 May & 1800 & 226.40 & 234.30 & 7.9 & 226.40 & 234.33 & 7.93 & 100 \\
\hline $26 \mathrm{H}$ & 25 May & 1925 & 234.30 & 243.80 & 9.5 & 234.30 & 243.33 & 9.08 & 96 \\
\hline $27 \mathrm{H}$ & 25 May & 2030 & 243.80 & 245.20 & 1.4 & 243.80 & 245.19 & 1.39 & 99 \\
\hline \multirow[t]{2}{*}{$28 x$} & 25 May & 2245 & 245.50 & 251.90 & 6.4 & 245.50 & 245.50 & 0.00 & 0 \\
\hline & & & \multicolumn{2}{|c|}{ Advanced total: } & 250.6 & & & 242.40 & 97 \\
\hline
\end{tabular}

321-U1337C

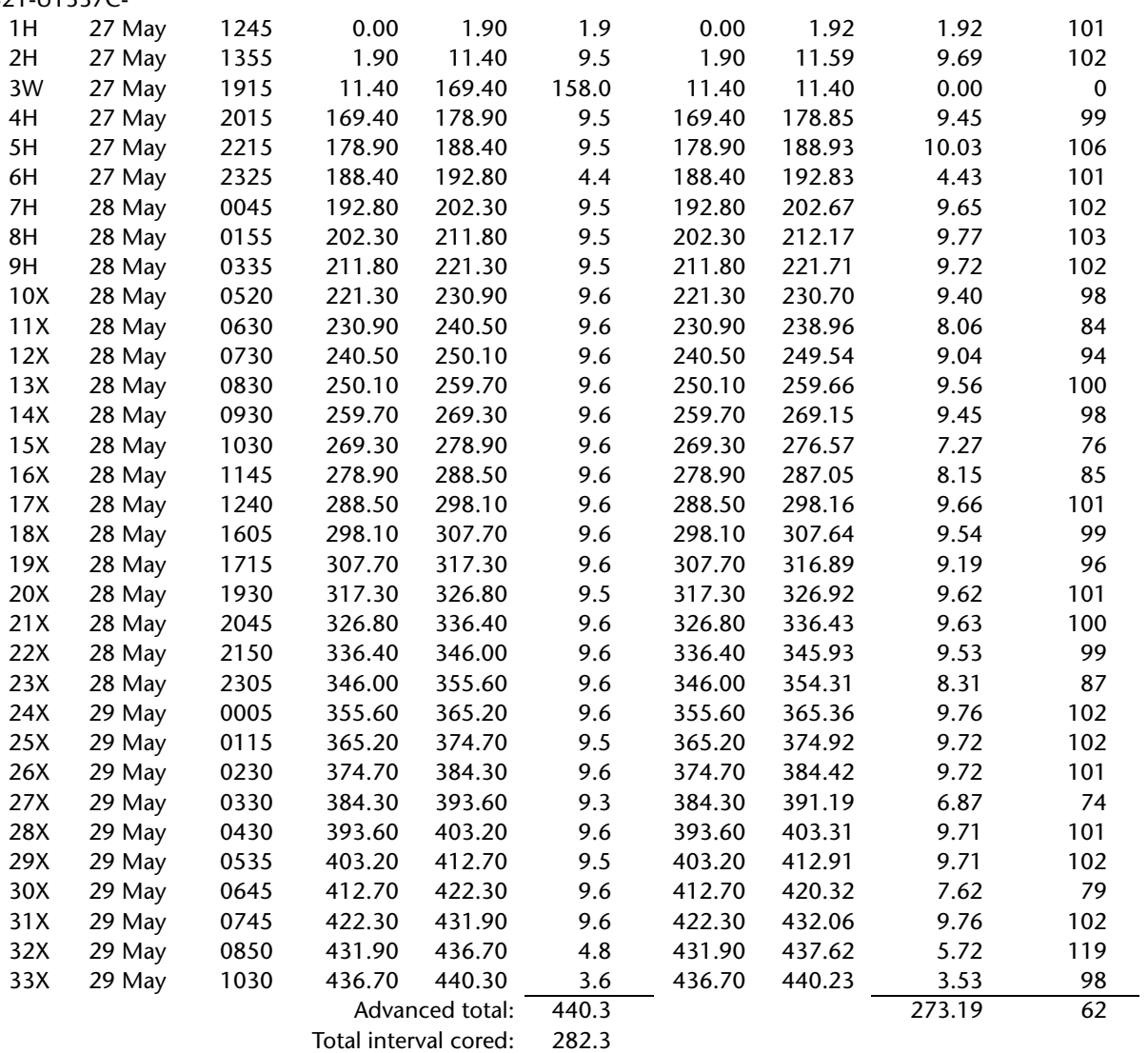

321-U1337D-

$\begin{array}{llrrr}1 \mathrm{H} & 29 \text { May } & 1710 & 0.00 & 8.00 \\ 2 \mathrm{H} & 29 \text { May } & 1830 & 8.00 & 17.50 \\ 3 \mathrm{H} & 29 \text { May } & 1935 & 17.50 & 27.00 \\ 4 \mathrm{H} & 29 \text { May } & 2040 & 27.00 & 36.50 \\ 5 \mathrm{H} & 29 \text { May } & 2150 & 36.50 & 46.00 \\ 6 \mathrm{H} & 29 \text { May } & 2250 & 46.00 & 55.50 \\ 7 \mathrm{H} & 29 \text { May } & 2355 & 55.50 & 65.00 \\ 8 \mathrm{H} & 30 \text { May } & 0100 & 65.00 & 74.50 \\ 9 \mathrm{H} & 30 \text { May } & 0200 & 74.50 & 84.00 \\ 10 \mathrm{H} & 30 \text { May } & 0300 & 84.00 & 93.50 \\ 11 \mathrm{H} & 30 \text { May } & 0355 & 93.50 & 103.00 \\ 12 \mathrm{H} & 30 \text { May } & 0503 & 103.00 & 112.50 \\ 13 \mathrm{H} & 30 \text { May } & 0559 & 112.50 & 122.00 \\ 14 \mathrm{H} & 30 \text { May } & 0715 & 122.00 & 131.50 \\ 15 \mathrm{H} & 30 \text { May } & 0845 & 131.50 & 141.00 \\ 16 \mathrm{H} & 30 \text { May } & 0945 & 141.00 & 150.50 \\ 17 \mathrm{H} & 30 \text { May } & 1045 & 150.50 & 160.00 \\ 18 \mathrm{H} & 30 \text { May } & 1145 & 160.00 & 169.50 \\ 19 \mathrm{H} & 30 \text { May } & 1320 & 169.50 & 179.00 \\ 20 \mathrm{H} & 30 \text { May } & 1425 & 179.00 & 188.50 \\ 21 \mathrm{H} & 30 \text { May } & 1540 & 188.50 & 193.50 \\ 22 \mathrm{H} & 30 \text { May } & 1640 & 193.50 & 199.70 \\ 23 \mathrm{H} & 30 \text { May } & 1805 & 199.70 & 209.20\end{array}$

$\begin{array}{rrrrr}8.0 & 0.00 & 7.98 & 7.98 & 100 \\ 9.5 & 8.00 & 16.68 & 8.68 & 91 \\ 9.5 & 17.50 & 27.24 & 9.74 & 103 \\ 9.5 & 27.00 & 35.70 & 8.70 & 92 \\ 9.5 & 36.50 & 46.44 & 9.94 & 105 \\ 9.5 & 46.00 & 55.28 & 9.28 & 98 \\ 9.5 & 55.50 & 65.19 & 9.69 & 102 \\ 9.5 & 65.00 & 73.71 & 8.71 & 92 \\ 9.5 & 74.50 & 84.11 & 9.61 & 101 \\ 9.5 & 84.00 & 93.84 & 9.84 & 104 \\ 9.5 & 93.50 & 103.55 & 10.05 & 106 \\ 9.5 & 103.00 & 112.48 & 9.48 & 100 \\ 9.5 & 112.50 & 122.50 & 10.00 & 105 \\ 9.5 & 122.00 & 131.35 & 9.35 & 98 \\ 9.5 & 131.50 & 141.58 & 10.08 & 106 \\ 9.5 & 141.00 & 150.30 & 9.30 & 98 \\ 9.5 & 150.50 & 160.56 & 10.06 & 106 \\ 9.5 & 160.00 & 169.97 & 9.97 & 105 \\ 9.5 & 169.50 & 179.45 & 9.95 & 105 \\ 9.5 & 179.00 & 189.06 & 10.06 & 106 \\ 5.0 & 188.50 & 195.21 & 6.71 & 134 \\ 6.2 & 193.50 & 199.76 & 6.26 & 101 \\ 9.5 & 199.70 & 209.59 & 9.89 & 104\end{array}$


Table T1 (continued).

\begin{tabular}{|c|c|c|c|c|c|c|c|c|c|}
\hline \multirow[b]{2}{*}{ Core } & \multirow[b]{2}{*}{$\begin{array}{l}\text { Date } \\
(2009)\end{array}$} & \multirow[b]{2}{*}{$\begin{array}{l}\text { Local time } \\
\text { (h) }\end{array}$} & \multicolumn{2}{|c|}{ Depth DSF (m) } & \multirow[b]{2}{*}{$\begin{array}{l}\text { Interval } \\
\text { advanced } \\
(\mathrm{m})\end{array}$} & \multicolumn{2}{|c|}{ Depth CSF (m) } & \multirow[b]{2}{*}{$\begin{array}{l}\text { Length of core } \\
\text { recovered } \\
(\mathrm{m})\end{array}$} & \multirow[b]{2}{*}{$\begin{array}{l}\text { Recovery } \\
\text { (\%) }\end{array}$} \\
\hline & & & $\begin{array}{l}\text { Top of } \\
\text { cored } \\
\text { interval }\end{array}$ & $\begin{array}{l}\text { Bottom of } \\
\text { cored } \\
\text { interval }\end{array}$ & & $\begin{array}{l}\text { Top of } \\
\text { cored } \\
\text { interval }\end{array}$ & $\begin{array}{l}\text { Bottom of } \\
\text { cored } \\
\text { interval }\end{array}$ & & \\
\hline $24 \mathrm{H}$ & 30 May & 1910 & 209.20 & 218.70 & 9.5 & 209.20 & 219.45 & 10.25 & 108 \\
\hline $25 \mathrm{H}$ & 30 May & 2115 & 218.70 & 228.20 & 9.5 & 218.70 & 228.29 & 10.08 & 106 \\
\hline $26 \mathrm{H}$ & 30 May & 2220 & 228.20 & 237.70 & 9.5 & 228.20 & 237.61 & 9.41 & 99 \\
\hline $27 X$ & 30 May & 2355 & 237.70 & 241.40 & 3.7 & 237.70 & 239.93 & 2.26 & 61 \\
\hline $28 \mathrm{H}$ & 31 May & 0100 & 241.40 & 248.00 & 6.6 & 241.40 & 250.14 & 8.74 & 132 \\
\hline $29 \mathrm{H}$ & 31 May & 0200 & 248.00 & 257.50 & 9.5 & 248.00 & 258.12 & 10.09 & 106 \\
\hline $30 \mathrm{H}$ & 31 May & 0315 & 257.50 & 267.00 & 9.5 & 257.50 & 267.09 & 9.54 & 100 \\
\hline $31 x$ & 31 May & 0435 & 267.00 & 276.20 & 9.2 & 267.00 & 274.88 & 7.88 & 86 \\
\hline $32 x$ & 31 May & 0540 & 276.20 & 285.80 & 9.6 & 276.20 & 282.52 & 6.32 & 66 \\
\hline $33 x$ & 31 May & 0645 & 285.80 & 295.30 & 9.5 & 285.80 & 295.49 & 9.69 & 102 \\
\hline $34 \mathrm{X}$ & 31 May & 0745 & 295.30 & 304.90 & 9.6 & 295.30 & 304.99 & 9.69 & 101 \\
\hline $35 X$ & 31 May & 0850 & 304.90 & 314.50 & 9.6 & 304.90 & 313.02 & 8.12 & 85 \\
\hline $36 \mathrm{X}$ & 31 May & 1000 & 314.50 & 324.10 & 9.6 & 314.50 & 324.05 & 9.55 & 99 \\
\hline $37 X$ & 31 May & 1115 & 324.10 & 333.60 & 9.5 & 324.10 & 333.67 & 9.57 & 101 \\
\hline $38 x$ & 31 May & 1225 & 333.60 & 343.20 & 9.6 & 333.60 & 343.07 & 9.47 & 99 \\
\hline $39 x$ & 31 May & 1625 & 343.20 & 352.80 & 9.6 & 343.20 & 352.95 & 9.75 & 102 \\
\hline $40 x$ & 31 May & 1745 & 352.80 & 362.40 & 9.6 & 352.80 & 362.53 & 9.73 & 101 \\
\hline $41 x$ & 31 May & 1850 & 362.40 & 372.00 & 9.6 & 362.40 & 372.06 & 9.66 & 101 \\
\hline $42 X$ & 31 May & 2000 & 372.00 & 381.60 & 9.6 & 372.00 & 381.73 & 9.73 & 101 \\
\hline $43 x$ & 31 May & 2110 & 381.60 & 391.20 & 9.6 & 381.60 & 391.31 & 9.71 & 101 \\
\hline $44 X$ & 31 May & 2215 & 391.20 & 400.50 & 9.3 & 391.20 & 400.27 & 9.07 & 98 \\
\hline $45 x$ & 31 May & 2330 & 400.50 & 410.10 & 9.6 & 400.50 & 410.24 & 9.74 & 101 \\
\hline $46 \mathrm{X}$ & 1 Jun & 0050 & 410.10 & 419.60 & 9.5 & 410.10 & 417.56 & 7.21 & 76 \\
\hline $47 X$ & 1 Jun & 0210 & 419.60 & 429.10 & 9.5 & 419.60 & 423.89 & 4.31 & 45 \\
\hline $48 \mathrm{X}$ & 1 Jun & 0340 & 429.10 & 438.80 & 9.7 & 429.10 & 435.54 & 6.44 & 66 \\
\hline \multirow[t]{2}{*}{$49 \mathrm{X}$} & 1 Jun & 0525 & 438.80 & 442.90 & 4.1 & 438.80 & 441.64 & 2.84 & 69 \\
\hline & & & \multicolumn{2}{|c|}{ Advanced total: } & 442.9 & & & 432.18 & 98 \\
\hline
\end{tabular}

Notes: DRF = drilling depth below rig floor determined by length of mudline core unless otherwise noted, DSF = drilling depth below seafloor, CSF $=$ core depth below seafloor. For Hole U1337B, DSF depth was determined by tagging seafloor; for Holes U1337C and U1337D, DSF depth from Hole U1337A was used. $\mathrm{H}=\mathrm{APC}$ core, $\mathrm{X}=\mathrm{XCB}$ core, $\mathrm{W}=$ washed interval. Local time $=\mathrm{UTC}-7 \mathrm{~h}$.

Table T2. Lithologic unit boundaries, Site U1337.

\begin{tabular}{|c|c|c|c|c|}
\hline \multirow[b]{2}{*}{ Unit } & \multirow{2}{*}{$\begin{array}{l}\text { Core, section, } \\
\text { interval }(\mathrm{cm})\end{array}$} & \multicolumn{3}{|c|}{ Depth $(m)$} \\
\hline & & CSF & CCSF-A & CCSF-B \\
\hline & 321-U1337A- & & & \\
\hline I/II & $11 \mathrm{H}-2,145$ & 93.95 & 100.67 & 89.89 \\
\hline$\| / I I I$ & $24 X-4,27$ & 218.27 & 238.81 & 213.23 \\
\hline III/IV & $48 \mathrm{X}-\mathrm{CC}, 21$ & 448.04 & 493.40 & 440.53 \\
\hline & 321-U1337B- & & & \\
\hline I/II & $10 \mathrm{H}-5,56$ & 93.06 & 100.12 & 89.40 \\
\hline II/III & $23 \mathrm{H}-4,4$ & 214.54 & 238.83 & 213.24 \\
\hline & 321-U1337C- & & & \\
\hline II/III & $8 \mathrm{H}-7,55$ & 211.85 & 237.65 & 212.19 \\
\hline III/IV & $33 X-4,0$ & 439.77 & 494.47 & 441.49 \\
\hline & 321-U1337D- & & & \\
\hline I/II & $10 \mathrm{H}-4,106$ & 89.56 & 100.49 & 89.73 \\
\hline II/III & $24 \mathrm{H}$, shattered liner & $\sim 216$ & $\sim 243.25$ & $\sim 217.19$ \\
\hline III/IV & $49 \mathrm{X}-3,0$ & 441.32 & 494.51 & 441.53 \\
\hline
\end{tabular}


Table T3. Calcareous nannofossil bioevents, Site U1337. (See table note.) (Continued on next two pages.)

\begin{tabular}{|c|c|c|c|c|c|c|c|c|c|}
\hline \multicolumn{2}{|c|}{ Core, section, interval $(\mathrm{cm})$} & \multirow[b]{2}{*}{ Marker species (base zone) } & \multirow{2}{*}{$\begin{array}{l}\text { Age } \\
(\mathrm{Ma})\end{array}$} & \multicolumn{4}{|c|}{ Depth CSF (m) } & \multicolumn{2}{|c|}{ Depth $(\mathrm{m})$} \\
\hline Top & Bottom & & & Top & Bottom & Midpoint & \pm & CCSF-A & CCSF-B \\
\hline 321-U1337A- & 321-U1337A- & & & & & & & & \\
\hline $2 \mathrm{H}-4,35$ & 2H-5, 19 & T Pseudoemiliania lacunosa (NN20) & 0.44 & 10.35 & 11.69 & 11.02 & 0.67 & 6.17 & 5.51 \\
\hline $3 \mathrm{H}-3,10$ & $3 \mathrm{H}-5,115$ & Bc Reticulofenestra asanoi & 1.14 & 18.10 & 22.15 & 20.13 & 2.03 & 16.48 & 14.71 \\
\hline $3 \mathrm{H}-3,10$ & $3 \mathrm{H}-5,115$ & T Gephyrocapsa (>5.5 $\mu \mathrm{m})$ & 1.26 & 18.10 & 22.15 & 20.13 & 2.03 & 16.48 & 14.71 \\
\hline \multirow[t]{2}{*}{$4 \mathrm{H}-2,97$} & $4 \mathrm{H}-3,94-96$ & T Calcidiscus macintyrei & 1.61 & 26.97 & 28.45 & 27.71 & 0.74 & 24.06 & 21.48 \\
\hline & & Pliocene/Pleistocene boundary & 1.81 & & & & & & \\
\hline $4 \mathrm{H}-5,9-11$ & $4 \mathrm{H}-6,126$ & T Discoaster brouweri (NN19) & 1.93 & 30.60 & 33.26 & 31.93 & 1.33 & 28.28 & 25.25 \\
\hline $5 \mathrm{H}-2,111-113$ & $5 \mathrm{H}-4,111-113$ & T Discoaster pentaradiatus (NN18) & 2.39 & 36.62 & 39.62 & 38.12 & 1.50 & 37.14 & 33.16 \\
\hline $5 \mathrm{H}-4,111-113$ & $5 \mathrm{H}-5,6$ & T Discoaster surculus (NN17) & 2.49 & 39.62 & 40.06 & 39.84 & 0.22 & 38.86 & 34.70 \\
\hline 7H-1, 99 & $7 \mathrm{H}-4,90$ & T Reticulofenestra pseudoumbilicus (NN16) & 3.70 & 53.99 & 58.40 & 56.20 & 2.21 & 58.83 & 52.52 \\
\hline \multirow[t]{2}{*}{$10 \mathrm{H}-2,100$} & $10 \mathrm{H}-3,90$ & T Ceratolithus acutus & 5.04 & 84.00 & 85.40 & 84.70 & 0.70 & 90.33 & 80.65 \\
\hline & & Miocene/Pliocene boundary & 5.33 & & & & & & \\
\hline $10 \mathrm{H}-5,80$ & $10 \mathrm{H}-6,138$ & B Ceratolithus acutus & 5.35 & 88.30 & 90.38 & 89.34 & 1.04 & 94.97 & 84.79 \\
\hline $11 \mathrm{H}-3,65$ & $11 \mathrm{H}-6,147$ & T Discoaster quinqueramus (NN12) & 5.58 & 94.65 & 99.97 & 97.31 & 2.66 & 104.03 & 92.88 \\
\hline $12 \mathrm{H}-4,40$ & $12 \mathrm{H}-5,60$ & T Nicklithus amplificus & 5.98 & 105.40 & 107.10 & 106.25 & 0.85 & 113.71 & 101.53 \\
\hline $13 \mathrm{H}-\mathrm{CC}$ & $14 \mathrm{H}-1,129$ & B Nicklithus amplificus & 6.91 & 119.86 & 120.79 & 120.33 & 0.47 & 129.82 & 115.91 \\
\hline $14 \mathrm{H}-\mathrm{CC}$ & $15 \mathrm{H}-1,67$ & TP Reticulofenestra pseudoumbilicus & 7.07 & 129.40 & 129.67 & 129.54 & 0.13 & 140.91 & 125.81 \\
\hline $15 \mathrm{H}-5,15$ & $15 \mathrm{H}-6,34$ & B Amaurolithus spp. & 7.36 & 135.15 & 135.84 & 135.50 & 0.34 & 347.66 & 310.41 \\
\hline $17 \mathrm{H}-3,69-70$ & $17 \mathrm{H}-5,85-86$ & B Discoaster berggrenii (NN11) & 8.29 & 151.70 & 154.86 & 153.28 & 1.58 & 167.50 & 149.55 \\
\hline $18 \mathrm{H}-1,75$ & $18 \mathrm{H}-2,80$ & BP Reticulofenestra pseudoumbilicus & 9.10 & 158.25 & 159.80 & 159.03 & 0.78 & 175.09 & 156.33 \\
\hline $19 \mathrm{H}-6,110$ & $19 \mathrm{H}-\mathrm{CC}$ & T Discoaster hamatus (NN10) & 9.69 & 175.60 & 177.00 & 176.30 & 0.70 & 193.26 & 172.55 \\
\hline $22 X-1,53$ & $23 X-1,40$ & B Discoaster hamatus (NN9) & 10.55 & 196.03 & 204.70 & 200.37 & 4.33 & 219.42 & 195.91 \\
\hline $22 X-1,53$ & $23 X-1,40$ & T Coccolithus miopelagicus & 10.60 & 196.03 & 204.70 & 200.37 & 4.33 & 219.42 & 195.91 \\
\hline $23 X-1,40$ & $23 X-2,40$ & B Catinaster coalitus (NN8) & 10.89 & 204.70 & 206.20 & 205.45 & 0.75 & 225.28 & 201.14 \\
\hline $24 X-C C$ & $25 X-1,88$ & Tc Discoaster kugleri & 11.58 & 219.00 & 224.28 & 221.64 & 2.64 & 242.79 & 216.78 \\
\hline $26 X-1,45$ & $26 X-2,45$ & Bc Discoaster kugleri (NN7) & 11.86 & 233.45 & 234.95 & 234.20 & 0.75 & 255.67 & 228.28 \\
\hline $26 X-3,45$ & $26 X-4,45$ & T Cyclicargolithus floridanus & 12.03 & 236.45 & 237.95 & 237.20 & 0.75 & 258.67 & 230.96 \\
\hline $26 X-3,45$ & $26 X-4,45$ & T Coronocyclus nitescens & 12.12 & 236.45 & 237.95 & 237.20 & 0.75 & 258.67 & 230.96 \\
\hline $26 X-4,45$ & $26 X-5,45$ & T Calcidiscus premacintyrei & 12.45 & 237.95 & 239.45 & 238.70 & 0.75 & 260.17 & 232.29 \\
\hline $30 X-6,30$ & $30 X-C C$ & Tc Cyclicargolithus floridanus & 13.33 & 278.60 & 280.50 & 279.55 & 0.95 & 309.20 & 276.07 \\
\hline $31 X-2,20$ & $31 X-3,20$ & T Sphenolithus heteromorphus (NN6) & 13.53 & 282.20 & 283.70 & 282.95 & 0.75 & 312.68 & 279.18 \\
\hline $34 X-4,70$ & $34 X-5,70$ & T Helicosphaera ampliaperta (NN5) & 14.91 & 314.50 & 316.00 & 315.25 & 0.75 & 345.35 & 308.35 \\
\hline $35 X-3,75$ & $35 X-5,75$ & Tc Discoaster deflandrei & 15.66 & 322.65 & 325.65 & 324.15 & 1.50 & 353.64 & 315.75 \\
\hline $35 X-3,75$ & $35 X-5,75$ & B Discoaster petaliformis & 15.70 & 322.65 & 325.65 & 324.15 & 1.50 & 353.64 & 315.75 \\
\hline $38 \mathrm{X}-\mathrm{CC}$ & $39 X-1,40$ & Bc Sphenolithus heteromorphus & 17.71 & 352.65 & 357.50 & 355.08 & 2.43 & 386.26 & 344.87 \\
\hline $39 X-1,40$ & $39 X-2,40$ & Tc Sphenolithus belemnos (NN4) & 17.95 & 357.50 & 359.10 & 358.30 & 0.80 & 389.19 & 347.49 \\
\hline $38 \mathrm{X}-\mathrm{CC}$ & $39 X-1,40$ & T Triquetrorhabdulus carinatus (NN3) & 18.29 & 352.65 & 357.50 & 355.08 & 2.43 & 386.26 & 344.87 \\
\hline $40 X-5,65$ & $40 \mathrm{X}-\mathrm{CC}$ & B Sphenolithus belemnos & 19.03 & 373.45 & 376.52 & 374.99 & 1.54 & 408.08 & 364.35 \\
\hline $43 \mathrm{X}-\mathrm{CC}$ & $44 \mathrm{X}-\mathrm{CC}$ & X Helicosphaera euphratis/Helicosphaera carteri & 20.90 & 409.19 & 414.59 & 411.89 & 2.70 & 447.39 & 399.46 \\
\hline \multirow[t]{3}{*}{$47 X-2,75$} & $47 X-3,75$ & Tc Triquetrorhabdulus carinatus & 22.10 & 435.85 & 437.40 & 436.63 & 0.77 & 481.51 & 429.92 \\
\hline & $47 X-4,80$ & Lowermost observed Discoaster druggii (NN2) & $\leq 22.41$ & & 438.90 & & & & \\
\hline & & Oligocene/Miocene boundary & 23.03 & & & & & & \\
\hline $48 X-2,100$ & $48 X-3,55$ & T Sphenolithus delphix & 23.1 & 445.70 & 446.75 & 446.23 & 0.53 & 491.59 & 438.92 \\
\hline $48 X-4,15$ & $48 X-4,55$ & B Sphenolithus delphix & 23.2 & 447.85 & 448.25 & 448.05 & 0.20 & 493.41 & 440.54 \\
\hline 321-U1337B- & 321-U1337B- & & & & & & & & \\
\hline $1 \mathrm{H}-5,67$ & $1 \mathrm{H}-\mathrm{CC}$ & T Pseudoemiliania lacunosa (NN20) & 0.44 & 7.17 & 7.41 & 7.29 & 0.12 & 6.75 & 6.03 \\
\hline $1 \mathrm{H}-\mathrm{CC}$ & $2 \mathrm{H}-\mathrm{CC}$ & Bc Reticulofenestra asanoi & 1.14 & 7.41 & 20.30 & 13.86 & 6.45 & 12.11 & 10.81 \\
\hline $2 \mathrm{H}-\mathrm{CC}$ & $3 \mathrm{H}-\mathrm{CC}$ & T Gephyrocapsa (>5.5 $\mu \mathrm{m})$ & 1.26 & 20.30 & 29.72 & 25.01 & 4.71 & 22.58 & 20.16 \\
\hline \multirow[t]{2}{*}{$2 \mathrm{H}-\mathrm{CC}$} & $3 \mathrm{H}-\mathrm{CC}$ & T Calcidiscus macintyrei & 1.61 & 20.30 & 29.72 & 25.01 & 4.71 & 22.58 & 20.16 \\
\hline & & Pliocene/Pleistocene boundary & 1.81 & & & & & & \\
\hline $2 \mathrm{H}-\mathrm{CC}$ & $3 \mathrm{H}-\mathrm{CC}$ & T Discoaster brouweri (NN19) & 1.93 & 20.30 & 29.72 & 25.01 & 4.71 & 22.58 & 20.16 \\
\hline $4 \mathrm{H}-\mathrm{CC}$ & $5 \mathrm{H}-\mathrm{CC}$ & T Discoaster surculus (NN17) & 2.49 & 39.44 & 49.01 & 44.23 & 4.79 & 43.16 & 38.53 \\
\hline $5 \mathrm{H}-\mathrm{CC}$ & $6 \mathrm{H}-\mathrm{CC}$ & T Reticulofenestra pseudoumbilicus (NN16) & 3.70 & 49.01 & 58.35 & 53.68 & 4.67 & 53.75 & 47.99 \\
\hline \multirow[t]{2}{*}{$8 \mathrm{H}-\mathrm{CC}$} & $9 \mathrm{H}-\mathrm{CC}$ & T Ceratolithus acutus & 5.04 & 77.04 & 87.00 & 82.02 & 4.98 & 85.71 & 76.52 \\
\hline & & Miocene/Pliocene boundary & 5.33 & & & & & & \\
\hline 9H-CC & $10 \mathrm{H}-\mathrm{CC}$ & B Ceratolithus acutus & 5.35 & 87.00 & 96.22 & 91.61 & 4.61 & 97.34 & 86.91 \\
\hline $10 \mathrm{H}-\mathrm{CC}$ & $11 \mathrm{H}-\mathrm{CC}$ & T Discoaster quinqueramus (NN12) & 5.58 & 96.22 & 106.04 & 101.13 & 4.91 & 108.55 & 96.92 \\
\hline $10 \mathrm{H}-\mathrm{CC}$ & $11 \mathrm{H}-\mathrm{CC}$ & T Nicklithus amplificus & 5.98 & 96.22 & 106.04 & 101.13 & 4.91 & 108.55 & 96.92 \\
\hline $12 \mathrm{H}-\mathrm{CC}$ & $13 \mathrm{H}-\mathrm{CC}$ & B Nicklithus amplificus & 6.91 & 115.57 & 125.11 & 120.34 & 4.77 & 130.09 & 116.15 \\
\hline $13 \mathrm{H}-\mathrm{CC}$ & $14 \mathrm{H}-\mathrm{CC}$ & TP Reticulofenestra pseudoumbilicus & 7.07 & 125.11 & 134.41 & 129.76 & 4.65 & 140.68 & 125.61 \\
\hline $14 \mathrm{H}-\mathrm{CC}$ & $15 \mathrm{H}-\mathrm{CC}$ & B Amaurolithus spp. & 7.36 & 134.41 & 143.82 & 139.12 & 4.71 & 151.04 & 134.85 \\
\hline $16 \mathrm{H}-\mathrm{CC}$ & $17 \mathrm{H}-\mathrm{CC}$ & B Discoaster berggrenii (NN11) & 8.29 & 153.48 & 163.16 & 158.32 & 4.84 & 172.12 & 153.67 \\
\hline $17 \mathrm{H}-\mathrm{CC}$ & $18 \mathrm{H}-\mathrm{CC}$ & BP Reticulofenestra pseudoumbilicus & 9.10 & 163.16 & 172.41 & 167.79 & 4.63 & 182.24 & 162.71 \\
\hline $18 \mathrm{H}-\mathrm{CC}$ & $19 \mathrm{H}-\mathrm{CC}$ & T Discoaster hamatus (NN10) & 9.69 & 172.41 & 182.27 & 177.34 & 4.93 & 181.03 & 161.63 \\
\hline
\end{tabular}


Table T3 (continued). (Continued on next page.)

\begin{tabular}{|c|c|c|c|c|c|c|c|c|c|}
\hline \multicolumn{2}{|c|}{ Core, section, interval $(\mathrm{cm})$} & \multirow[b]{2}{*}{ Marker species (base zone) } & \multirow{2}{*}{$\begin{array}{l}\text { Age } \\
\text { (Ma) }\end{array}$} & \multicolumn{4}{|c|}{ Depth CSF (m) } & \multicolumn{2}{|c|}{ Depth $(\mathrm{m})$} \\
\hline Top & Bottom & & & Top & Bottom & Midpoint & \pm & CCSF-A & CCSF-B \\
\hline $21 \mathrm{H}-4,105$ & $22 \mathrm{H}-1,100$ & B Discoaster hamatus (NN9) & 10.55 & 196.55 & 201.50 & 199.03 & 2.47 & 219.02 & 195.55 \\
\hline $22 \mathrm{H}-1,100$ & $22 \mathrm{H}-2,75$ & T Coccolithus miopelagicus & 10.60 & 201.50 & 202.75 & 202.13 & 0.63 & 223.05 & 199.15 \\
\hline $22 \mathrm{H}-2,75$ & $22 \mathrm{H}-3,75$ & B Catinaster coalitus & 10.89 & 202.75 & 204.25 & 203.50 & 0.75 & 224.42 & 200.38 \\
\hline $24 \mathrm{H}-1,75$ & $24 \mathrm{H}-2,75$ & Tc Discoaster kugleri & 11.58 & 220.25 & 221.75 & 221.00 & 0.75 & 243.38 & 217.30 \\
\hline $25 \mathrm{H}-5,75$ & $25 \mathrm{H}-\mathrm{CC}$ & Bc Discoaster kugleri (NN7) & 11.86 & 233.15 & 234.33 & 233.74 & 0.59 & 256.18 & 228.73 \\
\hline 321-U1337C- & 321-U1337C- & & & & & & & & \\
\hline $1 \mathrm{H}-\mathrm{CC}$ & $2 \mathrm{H}-\mathrm{CC}$ & T Pseudoemiliania lacunosa & 0.44 & 1.92 & 11.59 & 6.76 & 4.84 & 4.84 & \\
\hline \multicolumn{2}{|c|}{$3 W(11.4-169.4 \mathrm{~m})$} & \multicolumn{2}{|c|}{ Pliocene/Pleistocene and Miocene/Pliocene boundaries } & & & & & & \\
\hline & $4 \mathrm{H}-1,40$ & Within range of $D$. hamatus & $>9.69$ & & 169.80 & & & & \\
\hline $6 \mathrm{H}-\mathrm{CC}$ & $7 \mathrm{H}-2,74$ & B Discoaster hamatus (NN9) & 10.55 & 192.83 & 194.70 & 193.77 & 0.93 & 218.46 & 195.05 \\
\hline $6 \mathrm{H}-\mathrm{CC}$ & $7 \mathrm{H}-2,74$ & T Coccolithus miopelagicus & 10.60 & 192.83 & 194.70 & 193.77 & 0.93 & 218.46 & 195.05 \\
\hline $7 \mathrm{H}-3,100$ & $7 \mathrm{H}-4,50$ & B Catinaster coalitus (NN8) & 10.89 & 196.80 & 197.80 & 197.30 & 0.50 & 222.07 & 198.28 \\
\hline $9 \mathrm{H}-3,75$ & $9 \mathrm{H}-4,75$ & Tc Discoaster kugleri & 11.58 & 215.55 & 217.05 & 216.30 & 0.75 & 244.12 & 217.96 \\
\hline $10 \mathrm{X}-\mathrm{CC}$ & $11 \mathrm{X}-\mathrm{CC}$ & Bc Discoaster kugleri (NN7) & 11.86 & 230.70 & 238.96 & 234.83 & 4.13 & 263.19 & 234.99 \\
\hline $10 \mathrm{X}-\mathrm{CC}$ & $11 \mathrm{X}-\mathrm{CC}$ & T Cyclicargolithus floridanus & 12.03 & 230.70 & 238.96 & 234.83 & 4.13 & 263.19 & 234.99 \\
\hline $10 \mathrm{X}-\mathrm{CC}$ & $11 \mathrm{X}-\mathrm{CC}$ & T Coronocyclus nitescens & 12.12 & 230.70 & 238.96 & 234.83 & 4.13 & 263.19 & 234.99 \\
\hline $10 \mathrm{X}-\mathrm{CC}$ & $11 \mathrm{X}-\mathrm{CC}$ & T Calcidiscus premacintyrei & 12.45 & 230.70 & 238.96 & 234.83 & 4.13 & 263.19 & 234.99 \\
\hline $15 X-5,30$ & $15 \mathrm{X}-\mathrm{CC}$ & T Sphenolithus heteromorphus (NN6) & 13.53 & 275.60 & 276.57 & 276.09 & 0.48 & 313.08 & 279.53 \\
\hline $18 X-5,31$ & $18 \mathrm{X}-\mathrm{CC}$ & T Helicosphaera ampliaperta (NN5) & 14.91 & 304.41 & 307.60 & 306.01 & 1.60 & 341.72 & 305.10 \\
\hline $21 X-1,65$ & $21 X-2,75$ & Tc Discoaster deflandrei & 15.66 & 315.80 & 316.89 & 316.35 & 0.54 & 352.86 & 315.05 \\
\hline $23 X-2,80$ & $23 X-2,145$ & Bc Sphenolithus heteromorphus & 17.71 & 348.30 & 348.95 & 348.63 & 0.32 & 387.03 & 345.56 \\
\hline $23 X-3,145$ & $23 X-4,80$ & Tc Sphenolithus belemnos (NN4) & 17.95 & 350.45 & 351.30 & 350.88 & 0.43 & 389.28 & 347.57 \\
\hline $23 X-3,145$ & $23 X-5,80$ & T Triquerorhabdulus carinatus (NN3) & 18.28 & 350.45 & 352.80 & 351.63 & 1.18 & 390.03 & 348.24 \\
\hline $25 X-3,60$ & $25 X-4,60$ & B Sphenolithus belemnos & 19.03 & 368.80 & 370.30 & 369.55 & 0.75 & 406.88 & 363.29 \\
\hline \multirow[t]{2}{*}{$30 X-C C$} & $31 X-1,60$ & Tc Triquerorhabdulus carinatus & 22.09 & 437.20 & 437.62 & 437.41 & 0.21 & 492.21 & 439.47 \\
\hline & & Oligocene/Miocene boundary & 23.03 & & & & & & \\
\hline $32 X-4,80$ & $32 \mathrm{X}-\mathrm{CC}$ & T Sphenolithus delphix & 23.1 & 432.06 & 440.23 & 436.15 & 4.09 & 490.85 & 438.25 \\
\hline $33 X-1,100$ & $33 X-2,4$ & B Sphenolithus delphix & 23.2 & 437.70 & 438.24 & 437.97 & 0.27 & 492.67 & 439.88 \\
\hline 321-U1337D- & 321-U1337D- & & & & & & & & \\
\hline $1 \mathrm{H}-5,40$ & $1 \mathrm{H}-5,75$ & T Pseudoemiliania lacunosa (NN20) & 0.44 & 6.40 & 6.75 & 6.58 & 0.18 & 6.63 & 5.92 \\
\hline $2 \mathrm{H}-2,60$ & $2 \mathrm{H}-3,40$ & Tc Reticulofenestra asanoi & 0.91 & 10.10 & 11.40 & 10.75 & 0.65 & 11.80 & 10.54 \\
\hline \multirow[t]{2}{*}{$3 \mathrm{H}-3,135$} & $3 \mathrm{H}-4,105$ & T Calcidiscus macintyrei & 1.61 & 21.85 & 23.05 & 22.45 & 0.60 & 24.35 & 21.74 \\
\hline & & Pliocene/Pleistocene boundary & 1.81 & & & & & & \\
\hline $3 \mathrm{H}-\mathrm{CC}$ & $4 \mathrm{H}-1,100$ & T Discoaster brouweri (NN19) & 1.93 & 27.24 & 28.00 & 27.62 & 0.38 & 29.90 & 26.70 \\
\hline $4 \mathrm{H}-1,100$ & $4 \mathrm{H}-2,70$ & Bc Discoaster triradiatus & 2.14 & 28.00 & 29.20 & 28.60 & 0.60 & 31.26 & 27.91 \\
\hline $5 \mathrm{H}-1,90$ & $5 \mathrm{H}-3,90$ & T Discoaster pentaradiatus (NN18) & 2.39 & 37.40 & 40.40 & 38.90 & 1.50 & 42.77 & 38.19 \\
\hline $5 \mathrm{H}-1,90$ & $5 \mathrm{H}-3,90$ & T Discoaster surculus (NN17) & 2.49 & 37.40 & 40.40 & 38.90 & 1.50 & 42.77 & 38.19 \\
\hline $6 \mathrm{H}-4,50$ & $6 \mathrm{H}-\mathrm{CC}$ & T Reticulofenestra pseudoumbilicus (NN16) & 3.70 & 51.00 & 55.25 & 53.13 & 2.13 & 58.64 & 52.35 \\
\hline \multirow[t]{2}{*}{$9 \mathrm{H}-4,50$} & $9 \mathrm{H}-5,50$ & T Ceratolithus acutus & 5.04 & 79.50 & 81.00 & 80.25 & 0.75 & 89.40 & 79.82 \\
\hline & & Miocene/Pliocene boundary & 5.33 & & & & & & \\
\hline $10 \mathrm{H}-1,50$ & $10 \mathrm{H}-2,130$ & B Ceratolithus acutus & 5.35 & 84.50 & 86.80 & 85.65 & 1.15 & 96.58 & 86.23 \\
\hline $10 \mathrm{H}-6,50$ & $11 \mathrm{H}-1,70$ & T Discoaster quinqueramus (NN12) & 5.58 & 92.00 & 102.00 & 97.00 & 5.00 & 108.73 & 97.08 \\
\hline $11 \mathrm{H}-5,76$ & $11 \mathrm{H}-6,100$ & T Nicklithus amplificus & 5.98 & 100.26 & 102.00 & 101.13 & 0.87 & 113.66 & 101.48 \\
\hline $13 \mathrm{H}-2,80$ & $13 \mathrm{H}-3,80$ & B Nicklithus amplificus & 6.91 & 114.80 & 116.30 & 115.55 & 0.75 & 130.82 & 116.80 \\
\hline $14 \mathrm{H}-5,70$ & $14 \mathrm{H}-6,70$ & TP Reticulofenestra pseudoumbilicus & 7.07 & 128.70 & 130.20 & 129.45 & 0.75 & 145.70 & 130.09 \\
\hline $14 \mathrm{H}-\mathrm{CC}$ & $15 \mathrm{H}-1,50$ & B Amaurolithus spp. & 7.36 & 131.35 & 132.00 & 131.68 & 0.33 & 148.40 & 132.50 \\
\hline $16 \mathrm{H}-6,60$ & $17 \mathrm{H}-1,80$ & B Discoaster berggrenii (NN11) & 8.29 & 149.10 & 151.30 & 150.20 & 1.10 & 169.65 & 151.47 \\
\hline $17 \mathrm{H}-3,80$ & $17 \mathrm{H}-4,40$ & BP Reticulofenestra pseudoumbilicus & 9.10 & 154.30 & 155.40 & 154.85 & 0.55 & 174.78 & 156.05 \\
\hline $18 \mathrm{H}-\mathrm{CC}$ & $19 \mathrm{H}-1,60$ & T Discoaster hamatus (NN10) & 9.69 & 169.97 & 170.10 & 170.04 & 0.06 & 191.17 & 170.68 \\
\hline $21 \mathrm{H}-\mathrm{CC}$ & $22 \mathrm{H}-2,32$ & B Discoaster hamatus (NN9) & 10.55 & 195.17 & 195.32 & 195.25 & 0.08 & 217.81 & 194.47 \\
\hline $21 \mathrm{H}-\mathrm{CC}$ & $22 \mathrm{H}-2,33$ & T Coccolithus miopelagicus & 10.60 & 195.17 & 195.32 & 195.25 & 0.08 & 217.81 & 194.47 \\
\hline $23 \mathrm{H}-1,50$ & $23 \mathrm{H}-2,50$ & B Catinaster coalitus (NN8) & 10.89 & 200.20 & 201.70 & 200.95 & 0.75 & 226.50 & 202.23 \\
\hline $24 \mathrm{H}-\mathrm{CC}$ & $25 \mathrm{H}-1,60$ & Tc Discoaster kugleri & 11.58 & 219.45 & 219.30 & 219.38 & -0.07 & 246.38 & 219.98 \\
\hline $26 \mathrm{H}-5,50$ & $26 \mathrm{H}-6,50$ & Bc Discoaster kugleri (NN7) & 11.86 & 234.70 & 236.20 & 235.45 & 0.75 & 262.96 & 234.79 \\
\hline $27 X-1,15$ & $27 X-2,40$ & T Cyclicargolithus floridanus & 12.03 & 237.85 & 239.35 & 238.60 & 0.75 & 265.27 & 236.85 \\
\hline $27 X-1,15$ & $27 X-2,40$ & T Coronocyclus nitescens & 12.12 & 237.85 & 239.35 & 238.60 & 0.75 & 265.27 & 236.85 \\
\hline $27 X-1,15$ & $27 X-2,40$ & T Calcidiscus premacintyrei & 12.45 & 237.85 & 239.35 & 238.60 & 0.75 & 265.27 & 236.85 \\
\hline $32 X-2,5$ & $32 X-2,70$ & T Sphenolithus heteromorphus (NN6) & 13.53 & 277.75 & 278.40 & 278.08 & 0.32 & 313.59 & 279.99 \\
\hline $35 X-4,96$ & $35 X-5,80$ & T Helicosphaera ampliaperta (NN5) & 14.91 & 310.36 & 311.70 & 311.03 & 0.67 & 345.47 & 308.46 \\
\hline $36 X-1,72$ & $36 \mathrm{X}-2,80$ & Tc Discoaster deflandrei & 15.66 & 315.22 & 316.80 & 316.01 & 0.79 & 350.92 & 313.32 \\
\hline $39 X-6,70$ & $39 X-C C$ & Bc Sphenolithus heteromorphus & 17.71 & 351.40 & 352.90 & 352.15 & 0.75 & 386.59 & 345.17 \\
\hline $40 x-1,60$ & $40 x-2,60$ & Tc Sphenolithus belemnos (NN4) & 17.95 & 353.40 & 354.90 & 354.15 & 0.75 & 389.19 & 347.49 \\
\hline $42 X-2,60$ & $42 X-3,60$ & B Sphenolithus belemnos & 19.03 & 374.10 & 375.60 & 374.85 & 0.75 & 413.16 & 368.89 \\
\hline $47 X-C C$ & $48 X-1,80$ & Tc Triquerorhabdulus carinatus & 22.09 & 423.89 & 429.90 & 426.90 & 3.01 & 480.30 & 428.84 \\
\hline
\end{tabular}


Table T3 (continued).

Note: $\mathrm{T}=$ top, $\mathrm{BC}=$ bottom common, $\mathrm{B}=$ bottom, $\mathrm{TP}=$ top paracme, $\mathrm{BP}=$ bottom paracme, $\mathrm{Tc}=$ top common, $\mathrm{X}=$ abundance $\mathrm{crossover}$.

Table T4. Preservation and estimated abundances of calcareous nannofossils, Hole U1337A. This table is available in an oversized format.

Table T5. Radiolarian datums, Site U1337. (See table note.) (Continued on next page.)

\begin{tabular}{|c|c|c|c|c|c|c|c|}
\hline \multicolumn{2}{|c|}{ Core, section } & \multirow[b]{2}{*}{ Marker species } & \multirow{2}{*}{$\begin{array}{l}\text { Age } \\
\text { (Ma) }\end{array}$} & \multicolumn{4}{|c|}{ Depth CSF (m) } \\
\hline Top & Bottom & & & Top & Bottom & Midpoint & \pm \\
\hline 321-U1337A- & 321-U1337A- & & & & & & \\
\hline $1 \mathrm{H}-\mathrm{CC}$ & $2 \mathrm{H}-\mathrm{CC}$ & T Stylatractus universus & 0.44 & 0.19 & 15.44 & 7.82 & 7.63 \\
\hline $1 \mathrm{H}-\mathrm{CC}$ & $2 \mathrm{H}-\mathrm{CC}$ & B Collosphaera tuberosa & 0.59 & 0.19 & 15.44 & 7.82 & 7.63 \\
\hline $1 \mathrm{H}-\mathrm{CC}$ & $2 \mathrm{H}-\mathrm{CC}$ & $\mathrm{T}$ Anthocyrtidium angulare & 1.21 & 0.19 & 15.44 & 7.82 & 7.63 \\
\hline $2 \mathrm{H}-\mathrm{CC}$ & $3 \mathrm{H}-\mathrm{CC}$ & T Theocorythium vetulum & 1.33 & 15.49 & 24.91 & 20.20 & 4.71 \\
\hline $3 \mathrm{H}-\mathrm{CC}$ & $4 \mathrm{H}-\mathrm{CC}$ & B Theocorythium trachelium & 1.76 & 24.96 & 34.44 & 29.70 & 4.74 \\
\hline $3 \mathrm{H}-\mathrm{CC}$ & $4 \mathrm{H}-\mathrm{CC}$ & B Anthocyrtidium angulare & 1.97 & 24.96 & 34.44 & 29.70 & 4.74 \\
\hline $3 \mathrm{H}-\mathrm{CC}$ & $4 \mathrm{H}-\mathrm{CC}$ & T Pterocanium prismatium & 2.08 & 24.96 & 34.44 & 29.70 & 4.74 \\
\hline $4 \mathrm{H}-\mathrm{CC}$ & $5 \mathrm{H}-\mathrm{CC}$ & T Didymocyrtis avita & 2.60 & 34.49 & 43.80 & 39.15 & 4.65 \\
\hline $4 \mathrm{H}-\mathrm{CC}$ & $5 \mathrm{H}-\mathrm{CC}$ & T Stichocorys pergrina & 2.90 & 34.49 & 43.80 & 39.15 & 4.65 \\
\hline $6 \mathrm{H}-\mathrm{CC}$ & $7 \mathrm{H}-\mathrm{CC}$ & T Phormostichoartus doliolum & 3.96 & 53.50 & 62.86 & 58.18 & 4.68 \\
\hline $7 \mathrm{H}-\mathrm{CC}$ & $8 \mathrm{H}-\mathrm{CC}$ & B Amphirhopalum ypsilon & 4.03 & 62.91 & 71.55 & 67.23 & 4.32 \\
\hline $8 \mathrm{H}-\mathrm{CC}$ & $9 \mathrm{H}-\mathrm{CC}$ & T Didymocyrtis penultima & 4.26 & 71.60 & 81.94 & 76.77 & 5.17 \\
\hline $10 \mathrm{H}-\mathrm{CC}$ & $11 \mathrm{H}-\mathrm{CC}$ & T Solenosphaera omnitubus & 5.32 & 91.58 & 101.00 & 96.29 & 4.71 \\
\hline $10 \mathrm{H}-\mathrm{CC}$ & $11 \mathrm{H}-\mathrm{CC}$ & T Spongaster berminghami & 5.33 & 91.58 & 101.00 & 96.29 & 4.71 \\
\hline $11 \mathrm{H}-\mathrm{CC}$ & $12 \mathrm{H}-\mathrm{CC}$ & B Didymocyrtis avita & 6.15 & 101.05 & 110.40 & 105.73 & 4.68 \\
\hline $12 \mathrm{H}-\mathrm{CC}$ & $13 \mathrm{H}-\mathrm{CC}$ & T Didymocyrtis antepenultima & 6.17 & 110.45 & 119.84 & 115.15 & 4.70 \\
\hline $13 \mathrm{H}-\mathrm{CC}$ & $14 \mathrm{H}-\mathrm{CC}$ & B Didymocyrtis tetrathalamus & 6.60 & 119.89 & 129.37 & 124.63 & 4.74 \\
\hline $13 \mathrm{H}-\mathrm{CC}$ & $14 \mathrm{H}-\mathrm{CC}$ & T Calocycletta caepa & 6.60 & 119.89 & 129.37 & 124.63 & 4.74 \\
\hline $13 \mathrm{H}-\mathrm{CC}$ & $14 \mathrm{H}-\mathrm{CC}$ & S. delmontensis > S. pergrina & 7.75 & 119.89 & 129.37 & 124.63 & 4.74 \\
\hline $14 \mathrm{H}-\mathrm{CC}$ & $15 \mathrm{H}-\mathrm{CC}$ & B Theocorythium vetulum & 7.98 & 129.45 & 138.82 & 134.14 & 4.69 \\
\hline $14 \mathrm{H}-\mathrm{CC}$ & $15 \mathrm{H}-\mathrm{CC}$ & B Solenosphaera omnitubus & 8.25 & 129.45 & 138.82 & 134.14 & 4.69 \\
\hline $15 \mathrm{H}-\mathrm{CC}$ & $16 \mathrm{H}-\mathrm{CC}$ & T Diartus hughesi & 8.39 & 138.87 & 148.52 & 143.70 & 4.82 \\
\hline $15 \mathrm{H}-\mathrm{CC}$ & $16 \mathrm{H}-\mathrm{CC}$ & T Didymocyrtis laticonus & 8.43 & 138.87 & 148.52 & 143.70 & 4.82 \\
\hline $16 \mathrm{H}-\mathrm{CC}$ & $17 \mathrm{H}-\mathrm{CC}$ & B Didymocyrtis penultima & 8.51 & 148.58 & 157.99 & 153.29 & 4.71 \\
\hline $17 \mathrm{H}-\mathrm{CC}$ & $18 \mathrm{H}-\mathrm{CC}$ & T Botryostrobus miralestensis & 8.59 & 158.04 & 167.50 & 162.77 & 4.73 \\
\hline $18 \mathrm{H}-\mathrm{CC}$ & 19H-CC & D. pettersoni $>$ D. hughesi & 8.76 & 167.55 & 177.00 & 172.28 & 4.72 \\
\hline $19 \mathrm{H}-\mathrm{CC}$ & $20 \mathrm{H}-\mathrm{CC}$ & B Didymocyrtis antepenultima & 10.01 & 177.05 & 186.38 & 181.72 & 4.66 \\
\hline $22 \mathrm{X}-\mathrm{CC}$ & $23 X-C C$ & T Cyrtocapsera japonica & 10.31 & 198.09 & 213.87 & 205.98 & 7.89 \\
\hline $22 \mathrm{X}-\mathrm{CC}$ & $23 X-C C$ & T Carpocanopsis cristata & 10.88 & 198.09 & 213.87 & 205.98 & 7.89 \\
\hline $25 X-C C$ & $26 \mathrm{X}-\mathrm{CC}$ & T Cyrtocapsera cornuta & 11.88 & 232.92 & 242.42 & 237.67 & 4.75 \\
\hline $25 \mathrm{X}-\mathrm{CC}$ & $26 \mathrm{X}-\mathrm{CC}$ & T Cyrtocapsera tetrapera & 11.91 & 232.92 & 242.42 & 237.67 & 4.75 \\
\hline $27 \mathrm{X}-\mathrm{CC}$ & $28 \mathrm{X}-\mathrm{CC}$ & B Diartus pettersoni & 12.11 & 243.51 & 256.37 & 249.94 & 6.43 \\
\hline $29 X-C C$ & $30 X-C C$ & T Calocycletta robusta & 13.35 & 270.85 & 280.49 & 275.67 & 4.82 \\
\hline $30 \mathrm{X}-\mathrm{CC}$ & $31 X-C C$ & T Acrocubus octopyle & 13.88 & 280.54 & 289.47 & 285.01 & 4.46 \\
\hline $30 \mathrm{X}-\mathrm{CC}$ & $31 \mathrm{X}-\mathrm{CC}$ & T Liriospyris parkerae & 13.89 & 280.54 & 289.47 & 285.01 & 4.46 \\
\hline $33 \mathrm{X}-\mathrm{CC}$ & $34 \mathrm{X}-\mathrm{CC}$ & T Didymocyrtis violina & 14.20 & 309.30 & 318.36 & 313.83 & 4.53 \\
\hline $33 \mathrm{X}-\mathrm{CC}$ & $34 \mathrm{X}-\mathrm{CC}$ & T Calocycletta virginis & 14.23 & 309.30 & 318.36 & 313.83 & 4.53 \\
\hline $33 \mathrm{X}-\mathrm{CC}$ & $34 \mathrm{X}-\mathrm{CC}$ & T Calocycletta costata & 14.23 & 309.30 & 318.36 & 313.83 & 4.53 \\
\hline $33 \mathrm{X}-\mathrm{CC}$ & $34 \mathrm{X}-\mathrm{CC}$ & T Dorcadospyris dentata & 14.76 & 309.30 & 318.36 & 313.83 & 4.53 \\
\hline $33 \mathrm{X}-\mathrm{CC}$ & $34 \mathrm{X}-\mathrm{CC}$ & T Liriospyris stauropora & $14.78-14.83$ & 309.30 & 318.36 & 313.83 & 4.53 \\
\hline $33 \mathrm{X}-\mathrm{CC}$ & $34 \mathrm{X}-\mathrm{CC}$ & B Liriospyris parkerae & $14.79-15.03$ & 309.30 & 318.36 & 313.83 & 4.53 \\
\hline $33 \mathrm{X}-\mathrm{CC}$ & $34 \mathrm{X}-\mathrm{CC}$ & T Didymocyrtis prismatica & 15.17 & 309.30 & 318.36 & 313.83 & 4.53 \\
\hline $38 \mathrm{X}-\mathrm{CC}$ & $39 X-C C$ & B Calocycletta costata & 17.49 & 352.70 & 366.85 & 359.78 & 7.07 \\
\hline $38 \mathrm{X}-\mathrm{CC}$ & $39 X-C C$ & B Dorcadospyris dentata & 17.72 & 352.70 & 366.85 & 359.78 & 7.07 \\
\hline $40 \mathrm{X}-\mathrm{CC}$ & $41 \mathrm{X}-\mathrm{CC}$ & T Dorcadospyris scambos & 18.53 & 376.52 & 386.06 & 381.29 & 4.77 \\
\hline $40 \mathrm{X}-\mathrm{CC}$ & $41 \mathrm{X}-\mathrm{CC}$ & B Stichocorys wolffii & 18.57 & 376.52 & 386.06 & 381.29 & 4.77 \\
\hline $44 \mathrm{X}-\mathrm{CC}$ & $45 \mathrm{X}-\mathrm{CC}$ & B Stichocorys delmontensis & 20.68 & 414.59 & 424.19 & 419.39 & 4.80 \\
\hline $45 \mathrm{X}-\mathrm{CC}$ & $46 \mathrm{X}-\mathrm{CC}$ & T Lophocyrtis pegetrum & 20.89 & 424.24 & 433.49 & 428.87 & 4.63 \\
\hline $45 \mathrm{X}-\mathrm{CC}$ & $46 \mathrm{X}-\mathrm{CC}$ & $\mathrm{T}$ Theocyrtis anossa & 21.38 & 424.24 & 433.49 & 428.87 & 4.63 \\
\hline 321-U1337B- & 321-U1337B- & & & & & & \\
\hline $1 \mathrm{H}-\mathrm{CC}$ & $2 \mathrm{H}-\mathrm{CC}$ & T Anthocyrtidium angulare & 1.21 & 7.41 & 20.26 & 13.84 & 6.43 \\
\hline $1 \mathrm{H}-\mathrm{CC}$ & $2 \mathrm{H}-\mathrm{CC}$ & T Theocorythium vetulum & 1.33 & 7.41 & 20.26 & 13.84 & 6.43 \\
\hline $2 \mathrm{H}-\mathrm{CC}$ & $3 \mathrm{H}-\mathrm{CC}$ & B Lamprocyrtis nigriniae & 1.31 & 20.30 & 29.69 & 25.00 & 4.70 \\
\hline $2 \mathrm{H}-\mathrm{CC}$ & $3 \mathrm{H}-\mathrm{CC}$ & B Theocorythium trachelium & 1.76 & 20.30 & 29.69 & 25.00 & 4.70 \\
\hline $2 \mathrm{H}-\mathrm{CC}$ & $3 \mathrm{H}-\mathrm{CC}$ & B Anthocyrtidium angulare & 1.97 & 20.30 & 29.69 & 25.00 & 4.70 \\
\hline $2 \mathrm{H}-\mathrm{CC}$ & $3 \mathrm{H}-\mathrm{CC}$ & T Pterocanium prismatium & 2.08 & 20.30 & 29.69 & 25.00 & 4.70 \\
\hline
\end{tabular}


Table T5 (continued).

\begin{tabular}{|c|c|c|c|c|c|c|c|}
\hline \multicolumn{2}{|c|}{ Core, section } & \multirow[b]{2}{*}{ Marker species } & \multirow{2}{*}{$\begin{array}{l}\text { Age } \\
\text { (Ma) }\end{array}$} & \multicolumn{4}{|c|}{ Depth CSF (m) } \\
\hline Top & Bottom & & & Top & Bottom & Midpoint & \pm \\
\hline $3 \mathrm{H}-\mathrm{CC}$ & $4 \mathrm{H}-\mathrm{CC}$ & T Didymocyrtis avita & 2.60 & 29.72 & 39.39 & 34.56 & 4.84 \\
\hline $3 \mathrm{H}-\mathrm{CC}$ & $4 \mathrm{H}-\mathrm{CC}$ & T Stichocorys pergrina & 2.90 & 29.72 & 39.39 & 34.56 & 4.84 \\
\hline $4 \mathrm{H}-\mathrm{CC}$ & $5 \mathrm{H}-\mathrm{CC}$ & T Phormostichoartus fistula & 3.52 & 39.44 & 48.96 & 44.20 & 4.76 \\
\hline $5 \mathrm{H}-\mathrm{CC}$ & $6 \mathrm{H}-\mathrm{CC}$ & B Amphirhopalum ypsilon & 4.03 & 49.01 & 58.3 & 53.66 & 4.65 \\
\hline $6 \mathrm{H}-\mathrm{CC}$ & 7H-CC & T Phormostichoartus doliolum & 3.96 & 58.35 & 67.46 & 62.91 & 4.56 \\
\hline 7H-CC & $8 \mathrm{H}-\mathrm{CC}$ & T Didymocyrtis penultima & 4.26 & 67.51 & 76.99 & 72.25 & 4.74 \\
\hline $9 \mathrm{H}-\mathrm{CC}$ & $10 \mathrm{H}-\mathrm{CC}$ & T Solenosphaera omnitubus & 5.32 & 87.00 & 96.17 & 91.59 & 4.59 \\
\hline 9H-CC & $10 \mathrm{H}-\mathrm{CC}$ & T Spongaster berminghami & 5.33 & 87.00 & 96.17 & 91.59 & 4.59 \\
\hline $12 \mathrm{H}-\mathrm{CC}$ & $13 \mathrm{H}-\mathrm{CC}$ & B Didymocyrtis avita & 6.15 & 115.57 & 125.06 & 120.32 & 4.75 \\
\hline $12 \mathrm{H}-\mathrm{CC}$ & $13 \mathrm{H}-\mathrm{CC}$ & T Didymocyrtis antepenultima & 6.17 & 115.57 & 125.06 & 120.32 & 4.75 \\
\hline $12 \mathrm{H}-\mathrm{CC}$ & $13 \mathrm{H}-\mathrm{CC}$ & B Didymocyrtis tetrathalamus & 6.60 & 115.57 & 125.06 & 120.32 & 4.75 \\
\hline $12 \mathrm{H}-\mathrm{CC}$ & $13 \mathrm{H}-\mathrm{CC}$ & T Calocycletta caepa & 6.60 & 115.57 & 125.06 & 120.32 & 4.75 \\
\hline $12 \mathrm{H}-\mathrm{CC}$ & $13 \mathrm{H}-\mathrm{CC}$ & S. delmontensis $>$ S. pergrina & 7.75 & 115.57 & 125.06 & 120.32 & 4.75 \\
\hline $15 \mathrm{H}-\mathrm{CC}$ & $16 \mathrm{H}-\mathrm{CC}$ & T Diartus hughesi & 8.39 & 144.24 & 153.32 & 148.78 & 4.54 \\
\hline $16 \mathrm{H}-\mathrm{CC}$ & $17 \mathrm{H}-\mathrm{CC}$ & T Didymocyrtis laticonus & 8.43 & 153.37 & 162.82 & 158.10 & 4.72 \\
\hline $16 \mathrm{H}-\mathrm{CC}$ & $17 \mathrm{H}-\mathrm{CC}$ & B Didymocyrtis penultima & 8.51 & 153.37 & 162.82 & 158.10 & 4.72 \\
\hline $16 \mathrm{H}-\mathrm{CC}$ & $17 \mathrm{H}-\mathrm{CC}$ & T Botryostrobus miralestensis & 8.59 & 153.37 & 162.82 & 158.10 & 4.72 \\
\hline $18 \mathrm{H}-\mathrm{CC}$ & $19 \mathrm{H}-\mathrm{CC}$ & D. pettersoni $>$ D. hughesi & 8.76 & 172.36 & 181.92 & 177.14 & 4.78 \\
\hline $18 \mathrm{H}-\mathrm{CC}$ & $19 \mathrm{H}-\mathrm{CC}$ & B Didymocyrtis antepenultima & 10.01 & 172.36 & 181.92 & 177.14 & 4.78 \\
\hline $19 \mathrm{H}-\mathrm{CC}$ & $20 \mathrm{H}-\mathrm{CC}$ & T Cyrtocapsera japonica & 10.31 & 181.97 & 191.03 & 186.50 & 4.53 \\
\hline $21 \mathrm{H}-\mathrm{CC}$ & $22 \mathrm{H}-\mathrm{CC}$ & T Carpocanopsis cristata & 10.88 & 198.3 & 209.95 & 204.13 & 5.82 \\
\hline $24 \mathrm{H}-\mathrm{CC}$ & $25 \mathrm{H}-\mathrm{CC}$ & T Cyrtocapsera cornuta & 11.88 & 226.38 & 234.28 & 230.33 & 3.95 \\
\hline $24 \mathrm{H}-\mathrm{CC}$ & $25 \mathrm{H}-\mathrm{CC}$ & T Cyrtocapsera tetrapera & 11.91 & 226.38 & 234.28 & 230.33 & 3.95 \\
\hline \multicolumn{8}{|c|}{ 321-U1337C- 321-U1337C- } \\
\hline $1 \mathrm{H}-\mathrm{CC}$ & $2 \mathrm{H}-\mathrm{CC}$ & B Lamprocyrtis nigriniae & 1.31 & 1.92 & 11.54 & 6.73 & 4.81 \\
\hline $4 \mathrm{H}-\mathrm{CC}$ & $5 \mathrm{H}-\mathrm{CC}$ & T Cyrtocapsera japonica & 10.31 & 178.85 & 188.88 & 183.87 & 5.02 \\
\hline $10 \mathrm{X}-\mathrm{CC}$ & $11 \mathrm{X}-\mathrm{CC}$ & T Cyrtocapsera cornuta & 11.88 & 230.70 & 238.91 & 234.81 & 4.11 \\
\hline $10 \mathrm{X}-\mathrm{CC}$ & $11 \mathrm{X}-\mathrm{CC}$ & T Cyrtocapsera tetrapera & 11.91 & 230.7 & 238.91 & 234.81 & 4.11 \\
\hline $11 \mathrm{X}-\mathrm{CC}$ & $12 \mathrm{X}-\mathrm{CC}$ & B Diartus pettersoni & 12.11 & 238.96 & 249.49 & 244.23 & 5.27 \\
\hline $15 \mathrm{X}-\mathrm{CC}$ & $16 \mathrm{X}-\mathrm{CC}$ & T Calocycletta robusta & 13.35 & 276.57 & 287 & 281.79 & 5.21 \\
\hline $15 \mathrm{X}-\mathrm{CC}$ & $16 \mathrm{X}-\mathrm{CC}$ & T Liriospyris parkerae & 13.89 & 276.57 & 287 & 281.79 & 5.21 \\
\hline $17 \mathrm{X}-\mathrm{CC}$ & $18 \mathrm{X}-\mathrm{CC}$ & T Didymocyrtis violina & 14.20 & 298.16 & 307.59 & 302.88 & 4.71 \\
\hline $17 \mathrm{X}-\mathrm{CC}$ & $18 \mathrm{X}-\mathrm{CC}$ & T Calocycletta virginis & 14.23 & 298.16 & 307.59 & 302.88 & 4.71 \\
\hline $17 \mathrm{X}-\mathrm{CC}$ & $18 \mathrm{X}-\mathrm{CC}$ & T Calocycletta costata & 14.23 & 298.16 & 307.59 & 302.88 & 4.71 \\
\hline $17 \mathrm{X}-\mathrm{CC}$ & $18 \mathrm{X}-\mathrm{CC}$ & T Dorcadospyris dentata & 14.76 & 298.16 & 307.59 & 302.88 & 4.71 \\
\hline $19 \mathrm{X}-\mathrm{CC}$ & $20 \mathrm{X}-\mathrm{CC}$ & T Liriospyris stauropora & $14.78-14.83$ & 316.89 & 326.92 & 321.91 & 5.01 \\
\hline $19 \mathrm{X}-\mathrm{CC}$ & $20 \mathrm{X}-\mathrm{CC}$ & B Liriospyris parkerae & $14.79-15.03$ & 316.89 & 326.92 & 321.91 & 5.01 \\
\hline $19 \mathrm{X}-\mathrm{CC}$ & $20 \mathrm{X}-\mathrm{CC}$ & $\mathrm{T}$ Didymocyrtis prismatica & 15.17 & 316.89 & 326.92 & 321.91 & 5.01 \\
\hline $23 \mathrm{X}-\mathrm{CC}$ & $24 X-C C$ & B Calocycletta costata & 17.49 & 354.31 & 365.31 & 359.81 & 5.50 \\
\hline $23 \mathrm{X}-\mathrm{CC}$ & $24 X-C C$ & B Dorcadospyris dentata & 17.72 & 354.31 & 365.31 & 359.81 & 5.50 \\
\hline $25 \mathrm{X}-\mathrm{CC}$ & $26 \mathrm{X}-\mathrm{CC}$ & B Stichocorys wolffii & 18.57 & 374.87 & 384.37 & 379.62 & 4.75 \\
\hline $29 X-C C$ & $30 X-C C$ & B Stichocorys delmontensis & 20.68 & 412.86 & 420.27 & 416.57 & 3.70 \\
\hline \multicolumn{8}{|c|}{ 321-U1337D- 321-U1337D- } \\
\hline $1 \mathrm{H}-\mathrm{CC}$ & $2 \mathrm{H}-\mathrm{CC}$ & T Anthocyrtidium angulare & 1.21 & 7.98 & 16.6 & 12.29 & 4.31 \\
\hline $2 \mathrm{H}-\mathrm{CC}$ & $3 \mathrm{H}-\mathrm{CC}$ & T Pterocanium prismatium & 2.08 & 16.68 & 27.19 & 21.94 & 5.26 \\
\hline $4 \mathrm{H}-\mathrm{CC}$ & $5 \mathrm{H}-\mathrm{CC}$ & T Stichocorys pergrina & 2.90 & 35.7 & 46.39 & 41.05 & 5.35 \\
\hline $6 \mathrm{H}-\mathrm{CC}$ & 7H-CC & T Phormostichoartus doliolum & 3.96 & 55.28 & 65.14 & 60.21 & 4.93 \\
\hline 7H-CC & $8 \mathrm{H}-\mathrm{CC}$ & T Didymocyrtis penultima & 4.26 & 65.19 & 73.66 & 69.43 & 4.24 \\
\hline $13 \mathrm{H}-\mathrm{CC}$ & $14 \mathrm{H}-\mathrm{CC}$ & S. delmontensis $>$ S. pergrina & 7.75 & 122.50 & 131.35 & 126.93 & 4.43 \\
\hline $14 \mathrm{H}-\mathrm{CC}$ & $15 \mathrm{H}-\mathrm{CC}$ & T Diartus hughesi & 8.39 & 131.35 & 141.53 & 136.44 & 5.09 \\
\hline $17 \mathrm{H}-\mathrm{CC}$ & $18 \mathrm{H}-\mathrm{CC}$ & D. pettersoni $>$ D. hughesi & 8.76 & 160.56 & 169.90 & 165.23 & 4.67 \\
\hline $27 \mathrm{H}-\mathrm{CC}$ & $28 \mathrm{H}-\mathrm{CC}$ & B Diartus pettersoni & 12.11 & 239.93 & 250.09 & 245.01 & 5.08 \\
\hline $33 \mathrm{X}-\mathrm{CC}$ & $34 \mathrm{X}-\mathrm{CC}$ & T Calocycletta costata & 14.23 & 295.49 & 304.94 & 300.22 & 4.73 \\
\hline $34 \mathrm{X}-\mathrm{CC}$ & $35 \mathrm{X}-\mathrm{CC}$ & T Didymocyrtis prismatica & 15.17 & 304.99 & 312.97 & 308.98 & 3.99 \\
\hline $39 X-C C$ & $40 \mathrm{X}-\mathrm{CC}$ & B Calocycletta costata & 17.49 & 352.95 & 362.48 & 357.72 & 4.77 \\
\hline $40 X-C C$ & $41 X-C C$ & B Stichocorys wolffii & 18.57 & 362.53 & 372.01 & 367.27 & 4.74 \\
\hline
\end{tabular}

Note: $\mathrm{T}=$ top, $\mathrm{B}=$ bottom. 
Table T6. Preservation and relative abundance of radiolarians, Hole U1337A. (See table notes.)

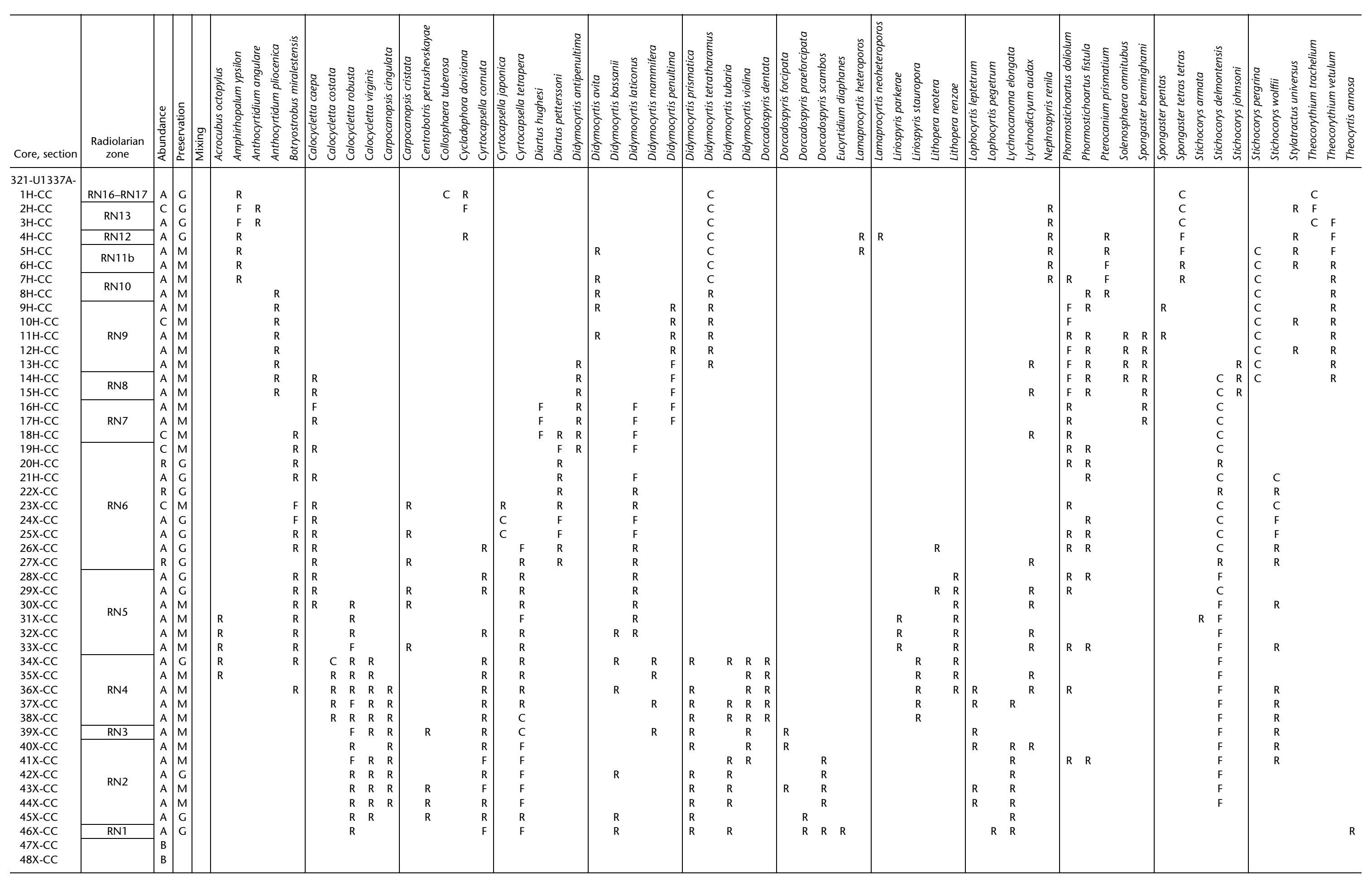

Notes: Abundance: $\mathrm{A}=$ abundant, $\mathrm{C}=$ common, $\mathrm{F}=$ few, $\mathrm{R}=$ rare, $\mathrm{B}=$ barren. Preservation: $\mathrm{G}=$ good, $\mathrm{M}=$ moderate. Mixing: blank = no mixing of older specimens detected. 


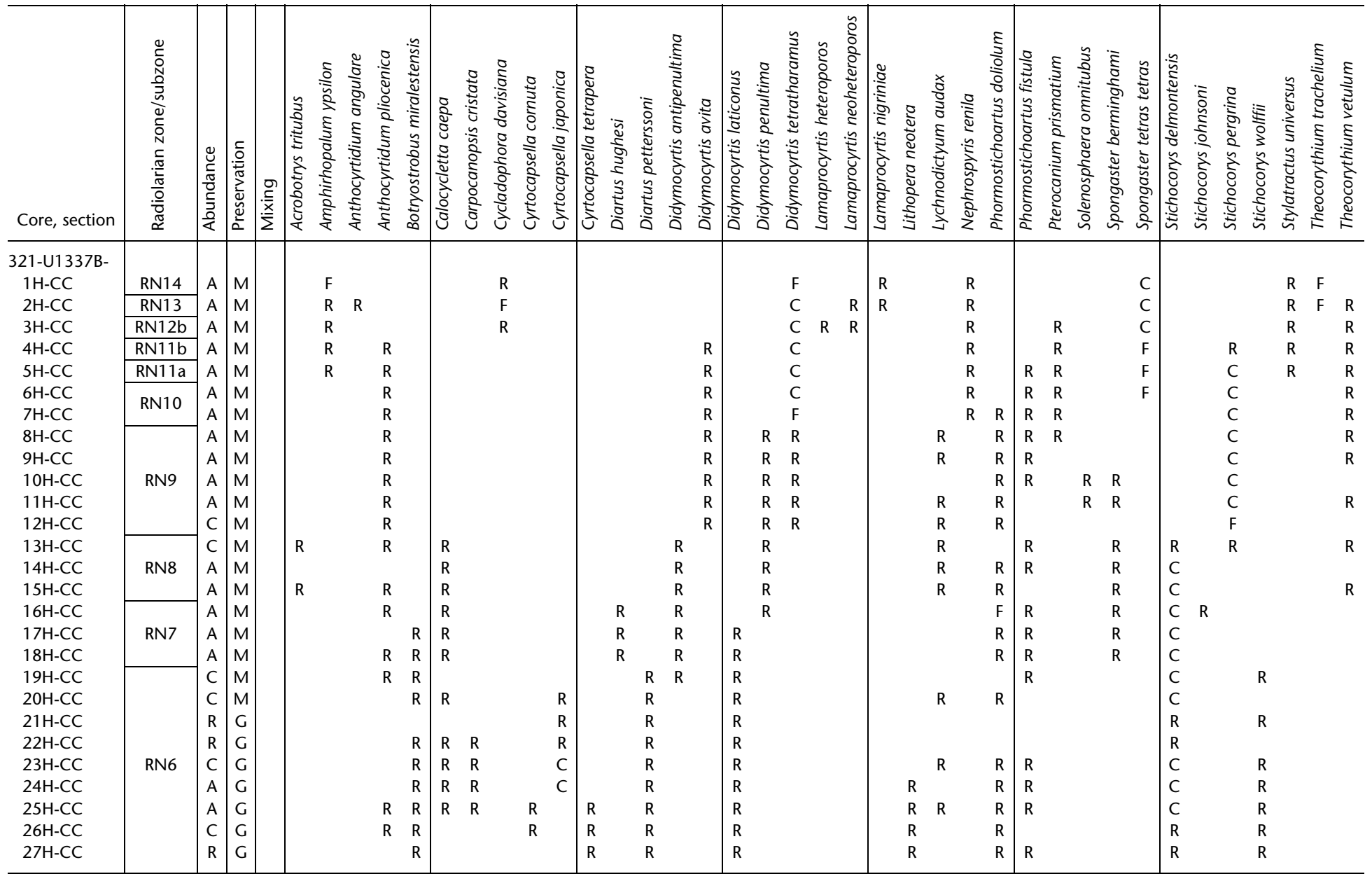

Notes: Abundance: $\mathrm{A}=$ abundant, $\mathrm{C}=$ common, $\mathrm{F}=\mathrm{few}, \mathrm{R}=$ rare. Preservation: $\mathrm{G}=$ good, $\mathrm{M}=$ moderate. Mixing: blank $=$ no mixing of older specimens detected. 
Notes: Abundance: $\mathrm{A}=$ abundant, $\mathrm{C}=$ common, $\mathrm{F}=$ few, $\mathrm{R}=$ rare, $\mathrm{B}=$ barren. Preservation: $\mathrm{G}=$ good, $\mathrm{M}=$ moderate. Mixing: blank $=$ no mixing of older specimens detected. 

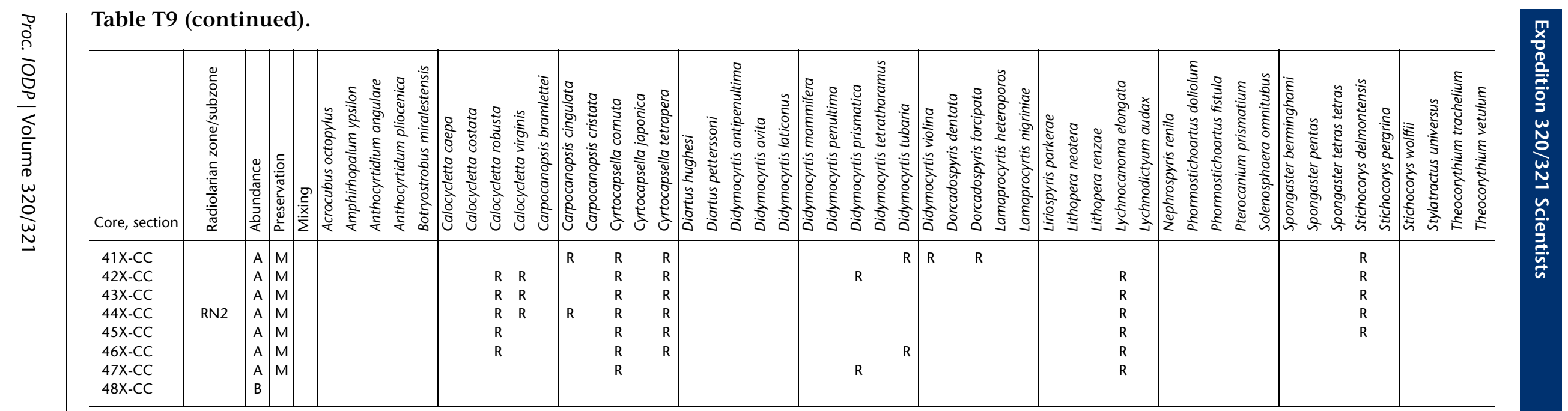

Notes: Abundance: $\mathrm{A}=$ abundant, $\mathrm{C}=$ common, $\mathrm{F}=$ few, $\mathrm{R}=$ rare, $\mathrm{B}=$ barren. Preservation: $\mathrm{G}=$ good, $\mathrm{M}=$ moderate. Mixing: blank $=$ no mixing of older specimens detected. 
Table T10. Diatom datums, Site U1337. (See table note.)

\begin{tabular}{|c|c|c|c|c|c|c|}
\hline \multicolumn{2}{|c|}{ Core, section, interval $(\mathrm{cm})$} & \multirow[b]{2}{*}{ Marker species } & \multirow{2}{*}{$\begin{array}{l}\text { Age } \\
(\mathrm{Ma})\end{array}$} & \multicolumn{3}{|c|}{ Depth CSF (m) } \\
\hline Top & Base & & & Top & Bottom & Mean \\
\hline 321-U1337A- & 321-U1337A- & & & & & \\
\hline $9 \mathrm{H}-6,8-9$ & $9 \mathrm{H}-\mathrm{CC}$ & T Thalassiosira oestrupii var. venrickae & 4.00 & 79.58 & 81.65 & 80.62 \\
\hline $10 \mathrm{H}-1,23-24$ & $10 \mathrm{H}-3,87-88$ & T Fragilariopsis cylindrica & 4.69 & 81.73 & 85.37 & 83.55 \\
\hline $10 \mathrm{H}-1,23-24$ & $10 \mathrm{H}-3,87-88$ & T Thalassiosira lineata & 4.92 & 81.73 & 85.37 & 83.55 \\
\hline $10 \mathrm{H}-1,23-24$ & $10 \mathrm{H}-3,87-88$ & B Nitzschia jouseae & 4.92 & 81.73 & 85.37 & 83.55 \\
\hline $11 \mathrm{H}-2,46-47$ & $11 \mathrm{H}-5,140-141$ & $\mathrm{~T}$ Thalassiosira miocenica & 5.10 & 92.96 & 98.40 & 95.68 \\
\hline $11 \mathrm{H}-2,46-47$ & $11 \mathrm{H}-5,140-141$ & T Thalassiosira oestrupii var. oestrupii & 5.10 & 98.40 & 92.96 & 95.68 \\
\hline $14 \mathrm{H}-2,58-59$ & $14 \mathrm{H}-4,90-91$ & B Nitzschia miocenica & 6.86 & 124.90 & 121.28 & 123.09 \\
\hline $15 \mathrm{H}-2,33-34$ & $15 \mathrm{H}-4,108-109$ & B Thalassiosira eccentrica & 7.58 & 130.83 & 134.58 & 132.71 \\
\hline $16 \mathrm{H}-\mathrm{CC}$ & $17 \mathrm{H}-3,69-70$ & T Rossiella paleaceae & 7.64 & 148.34 & 151.59 & 149.97 \\
\hline $17 \mathrm{H}-3,69-70$ & $17 \mathrm{H}-5,85-86$ & T Thalassiosira burckliana & 7.86 & 151.69 & 154.85 & 153.27 \\
\hline $17 \mathrm{H}-5,85-86$ & $17 \mathrm{H}-\mathrm{CC}$ & T Thalassiosira grunowii & 7.40 & 154.85 & 157.82 & 156.34 \\
\hline $17 \mathrm{H}-5,85-86$ & $17 \mathrm{H}-\mathrm{CC}$ & T Thalassiosira yabei & 8.44 & 154.85 & 157.82 & 156.34 \\
\hline $24 \mathrm{H}-4,21-22$ & $24 \mathrm{H}-\mathrm{CC}$ & B Hemidiscus cuneiformis & 11.24 & 218.21 & 218.98 & 218.60 \\
\hline $24 \mathrm{H}-\mathrm{CC}$ & $25 X-2,42-43$ & T Crucidenticula nicobarica & 12.50 & 218.98 & 225.32 & 222.15 \\
\hline $26 X-3,112-113$ & $26 X-5,37-38$ & T Coscinodiscus lewisianus & 12.99 & 269.00 & 278.50 & 273.75 \\
\hline $25 \mathrm{H}-\mathrm{CC}$ & $26 X-3,112-113$ & B Thalassiosira brunii & 11.50 & 225.32 & 237.12 & 231.22 \\
\hline $25 \mathrm{H}-\mathrm{CC}$ & $26 \mathrm{X}-3,112-113$ & B Thalassiosira grunowii & 13.75 & 225.32 & 237.12 & 231.22 \\
\hline $26 X-3,112-113$ & $26 X-5,37-38$ & B Nitzschia porteri & 12.11 & 269.00 & 278.50 & 273.75 \\
\hline $29 X-C C$ & $30 X-2,19-20$ & $\mathrm{~T}$ Thalassiosira tappanae & 13.37 & 270.65 & 272.49 & 271.57 \\
\hline $28 \mathrm{H}-\mathrm{CC}$ & $29 X-3,44-45$ & B Azpeitia apiculata & 13.50 & 256.25 & 264.74 & 260.50 \\
\hline $29 \mathrm{H}-5,36-37$ & $29 X-C C$ & B Thalassiosira yabei & 13.50 & 270.65 & 303.00 & 286.83 \\
\hline $29 \mathrm{H}-5,36-37$ & $29 X-C C$ & B Triceratium cinnamomeum & 13.52 & 270.65 & 303.00 & 286.83 \\
\hline $35 X-6,54-55$ & $35 X-C C$ & B Actinocyclus ingens & 15.25 & 326.94 & 327.07 & 327.01 \\
\hline $37 X-2,51-52$ & $37 X-4,88-89$ & T Coscinodiscus lewisianus var. similis & 15.35 & 340.01 & 343.38 & 341.70 \\
\hline $37 X-2,51-52$ & $37 X-4,88-89$ & T Raphidodiscus marylandicus & 16.49 & 340.01 & 343.38 & 341.70 \\
\hline $37 \mathrm{X}-\mathrm{CC}$ & $38 \mathrm{X}-2,92-93$ & B Raphidodiscus marylandicus & 16.75 & 347.44 & 350.02 & 348.73 \\
\hline $38 X-2,92-93$ & $38 \mathrm{X}-\mathrm{CC}$ & B Crucidenticula nicobarica & 17.49 & 350.02 & 353.39 & 351.71 \\
\hline
\end{tabular}

Note: $\mathrm{T}=$ top, $\mathrm{B}=$ bottom.

Table T11. Preservation and estimated abundances of diatoms, Site U1337. This table is available in an oversized format. 
Table T12. Planktonic foraminifer datums, Site U1337. (See table note.)

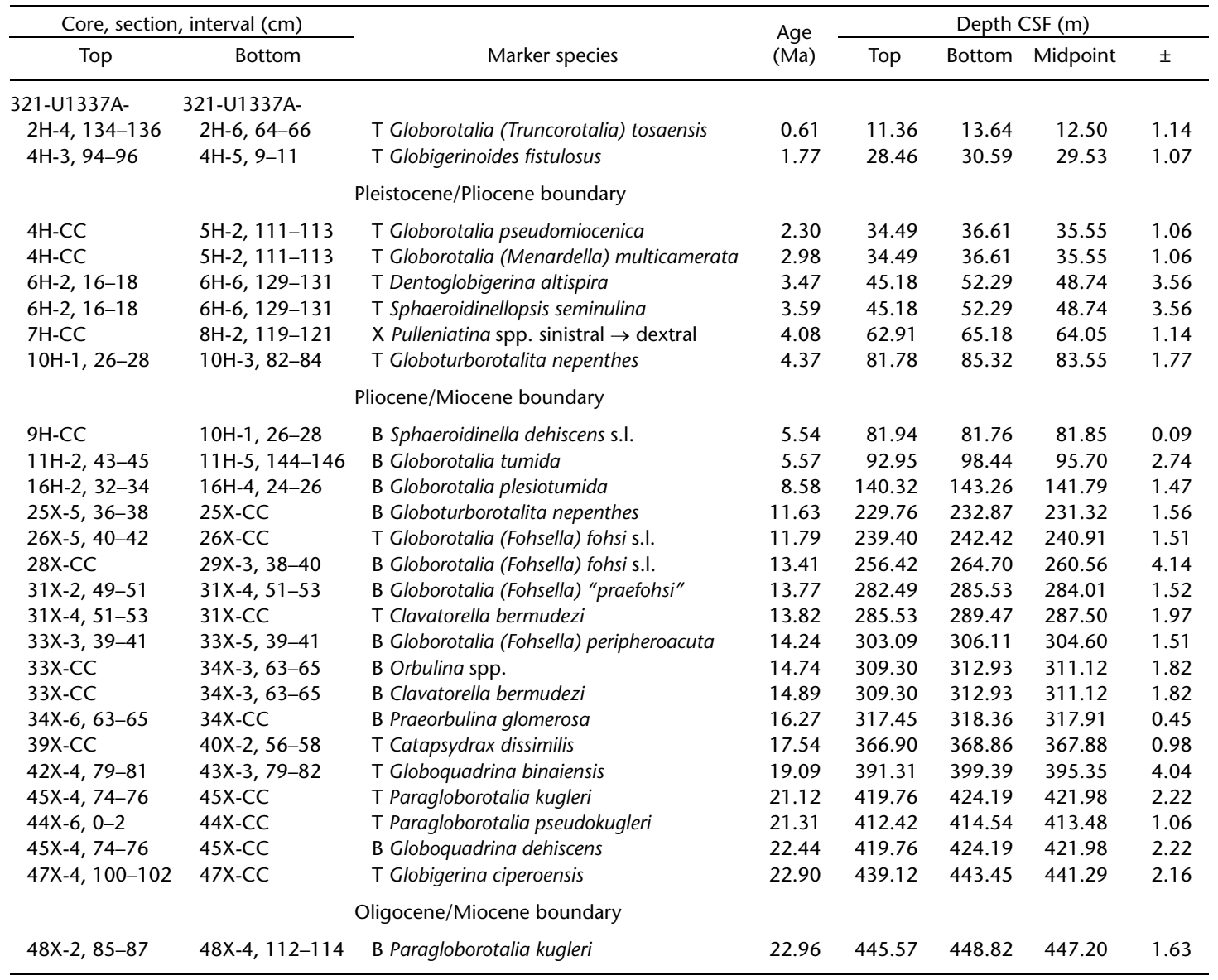

Note: $\mathrm{T}=$ top, $\mathrm{X}=$ abundance crossover, $\mathrm{B}=$ bottom.

Table T13. Preservation and estimated abundances of planktonic foraminifers, Site U1337. This table is available in an oversized format.

Table T14. Distribution of benthic foraminifers, Hole U1337A. This table is available in an oversized format. 
Table T15. FlexIt tool core orientation summary, Site U1337. (See table note.) (Continued on next page.)

\begin{tabular}{|c|c|c|c|c|}
\hline Core & $\begin{array}{l}\text { Orientation } \\
\text { angle }\left({ }^{\circ}\right)\end{array}$ & $\begin{array}{l}\text { Standard } \\
\text { deviation }\end{array}$ & $\begin{array}{c}\text { Tool } \\
\text { number }\end{array}$ & Remarks \\
\hline \multicolumn{5}{|c|}{ 321-U1337A- } \\
\hline $2 \mathrm{H}$ & 244.3 & 4.77 & 936 & \\
\hline $3 \mathrm{H}$ & 350.7 & 4.59 & 936 & \\
\hline $4 \mathrm{H}$ & 246.6 & 3.29 & 936 & \\
\hline $5 \mathrm{H}$ & 303.0 & 4.10 & 936 & \\
\hline $6 \mathrm{H}$ & 258.0 & 1.78 & 936 & \\
\hline $7 \mathrm{H}$ & 64.5 & 2.35 & 937 & Suspect \\
\hline $8 \mathrm{H}$ & 272.8 & 3.37 & 937 & Split core liner \\
\hline 9H & 29.5 & 8.12 & 937 & Suspect; rotation \\
\hline $10 \mathrm{H}$ & 47.0 & 3.84 & 937 & \\
\hline $11 \mathrm{H}$ & 301.9 & 2.35 & 937 & \\
\hline $12 \mathrm{H}$ & 146.4 & 5.15 & 937 & \\
\hline $13 \mathrm{H}$ & 246.8 & 1.68 & 937 & \\
\hline $14 \mathrm{H}$ & 104.8 & 7.83 & 937 & \\
\hline $15 \mathrm{H}$ & 55.5 & 8.85 & 937 & \\
\hline $16 \mathrm{H}$ & 27.9 & 3.96 & 937 & \\
\hline $17 \mathrm{H}$ & 52.8 & 6.47 & 937 & \\
\hline $18 \mathrm{H}$ & 131.0 & 1.70 & 937 & Suspect; very short usable orientations \\
\hline $19 \mathrm{H}$ & NA & NA & 936 & \\
\hline $20 \mathrm{H}$ & NA & NA & 936 & \\
\hline $21 \mathrm{H}$ & NA & NA & 936 & \\
\hline \multicolumn{5}{|c|}{ 321-U1337B- } \\
\hline $1 \mathrm{H}$ & 157.4 & 3.98 & 937 & \\
\hline $2 \mathrm{H}$ & 75.7 & 1.89 & 937 & \\
\hline $3 \mathrm{H}$ & 93.1 & 4.40 & 937 & \\
\hline $4 \mathrm{H}$ & 171.5 & 3.41 & 937 & \\
\hline $5 \mathrm{H}$ & 335.2 & 2.40 & 937 & \\
\hline $6 \mathrm{H}$ & 172.8 & 2.21 & 937 & \\
\hline $7 \mathrm{H}$ & 182.3 & 1.93 & 936 & \\
\hline $8 \mathrm{H}$ & 198.8 & 3.98 & 936 & \\
\hline $9 \mathrm{H}$ & 245.8 & 3.41 & 936 & \\
\hline $10 \mathrm{H}$ & 102.6 & 3.98 & 936 & \\
\hline $11 \mathrm{H}$ & 150.1 & 1.94 & 936 & \\
\hline $12 \mathrm{H}$ & 19.5 & 9.95 & 936 & \\
\hline $13 \mathrm{H}$ & 290.8 & 27.40 & 936 & Suspect; rotation \\
\hline $14 \mathrm{H}$ & 216.2 & 6.95 & 936 & \\
\hline $15 \mathrm{H}$ & 282.2 & 2.69 & 936 & \\
\hline $16 \mathrm{H}$ & 47.2 & 2.64 & 936 & \\
\hline $17 \mathrm{H}$ & NA & NA & 937 & Data lost \\
\hline $18 \mathrm{H}$ & NA & NA & 937 & Data lost \\
\hline $19 \mathrm{H}$ & 264.7 & 3.05 & 937 & \\
\hline $20 \mathrm{H}$ & 51.0 & 19.32 & 937 & Suspect; rotation \\
\hline $21 \mathrm{H}$ & 284.3 & 1.31 & 937 & \\
\hline $22 \mathrm{H}$ & 222.6 & 3.65 & 937 & \\
\hline $23 \mathrm{H}$ & 29.4 & 1.79 & 937 & \\
\hline $24 \mathrm{H}$ & 49.7 & 1.86 & 937 & \\
\hline $25 \mathrm{H}$ & 13.8 & 0.86 & 937 & \\
\hline $26 \mathrm{H}$ & 248.7 & 2.04 & 937 & \\
\hline $27 \mathrm{H}$ & 114.3 & 1.49 & 937 & \\
\hline \multicolumn{5}{|c|}{ 321-U1337C- } \\
\hline $1 \mathrm{H}$ & 175.3 & 2.91 & 936 & \\
\hline $2 \mathrm{H}$ & 35.7 & 2.72 & 936 & \\
\hline $4 \mathrm{H}$ & 121.6 & 1.17 & 937 & Suspect; rotation period prior to shot \\
\hline $5 \mathrm{H}$ & 304.2 & 3.41 & 937 & Shattered core liner \\
\hline $6 \mathrm{H}$ & 155.3 & 1.80 & 937 & \\
\hline $7 \mathrm{H}$ & 155.0 & 1.60 & 937 & \\
\hline $8 \mathrm{H}$ & 42.4 & 0.84 & 937 & \\
\hline $9 \mathrm{H}$ & 337.7 & 6.95 & 937 & Suspect; slow rotation during orientation \\
\hline \multicolumn{5}{|c|}{ 321-U1337D- } \\
\hline $1 \mathrm{H}$ & 82.0 & 4.07 & 937 & \\
\hline $2 \mathrm{H}$ & 136.8 & 3.73 & 937 & \\
\hline $3 \mathrm{H}$ & 18.5 & 3.32 & 937 & \\
\hline $4 \mathrm{H}$ & 268.5 & 2.95 & 937 & \\
\hline $5 \mathrm{H}$ & 51.0 & 3.04 & 937 & \\
\hline $6 \mathrm{H}$ & 155.1 & 2.91 & 937 & \\
\hline $7 \mathrm{H}$ & 221.0 & 4.43 & 937 & \\
\hline $8 \mathrm{H}$ & 246.2 & 1.69 & 937 & \\
\hline
\end{tabular}


Table T15 (continued).

\begin{tabular}{lcccl}
\hline Core & $\begin{array}{c}\text { Orientation } \\
\text { angle }\left({ }^{\circ}\right)\end{array}$ & $\begin{array}{c}\text { Standard } \\
\text { deviation }\end{array}$ & $\begin{array}{c}\text { Tool } \\
\text { number }\end{array}$ & Remarks \\
\hline $9 \mathrm{H}$ & 102.0 & 1.86 & 937 & \\
$10 \mathrm{H}$ & 121.6 & 3.00 & 937 & \\
$11 \mathrm{H}$ & 315.8 & 2.60 & 937 & Suspect; very short usable orientations \\
$12 \mathrm{H}$ & 90.6 & 2.80 & 937 & \\
$13 \mathrm{H}$ & 103.1 & 2.81 & 937 & Suspect; very short usable orientations \\
$14 \mathrm{H}$ & 32.1 & 1.10 & 936 & Suspect; very short usable orientations \\
$15 \mathrm{H}$ & 135.5 & 5.17 & 936 & Suspect; very short usable orientations \\
$16 \mathrm{H}$ & 309.9 & 1.99 & 936 & \\
$17 \mathrm{H}$ & 134.1 & 1.63 & 936 & Suspect; very short usable orientations \\
$18 \mathrm{H}$ & 2.6 & 4.73 & 936 & \\
$19 \mathrm{H}$ & 210.6 & 5.03 & 936 & \\
$20 \mathrm{H}$ & 148.8 & 3.84 & 936 & Some rotation early on \\
$21 \mathrm{H}$ & 268.2 & 3.27 & 936 & \\
$22 \mathrm{H}$ & 260.6 & 0.93 & 936 & \\
$23 \mathrm{H}$ & 78.6 & 5.89 & 936 & \\
$24 \mathrm{H}$ & 248.4 & 9.45 & 936 & \\
$25 \mathrm{H}$ & $\mathrm{NA}$ & $\mathrm{NA}$ & 936 & Data lost \\
$26 \mathrm{H}$ & $\mathrm{NA}$ & $\mathrm{NA}$ & 936 & Data lost \\
$28 \mathrm{H}$ & $\mathrm{NA}$ & $\mathrm{NA}$ & 936 & Data lost \\
$29 \mathrm{H}$ & $\mathrm{NA}$ & $\mathrm{NA}$ & 936 & Data lost \\
$30 \mathrm{H}$ & $\mathrm{NA}$ & $\mathrm{NA}$ & 936 & Data lost \\
& & & & \\
& & & & \\
& & & & \\
& & & & \\
& & &
\end{tabular}

Note: NA = not available.

Table T16. Interpretation of polarity stratigraphy, Site U1337. (See table note.)

\begin{tabular}{|c|c|c|c|c|c|c|c|}
\hline \multirow[b]{2}{*}{ Chron } & \multirow[b]{2}{*}{$\begin{array}{l}\text { Age } \\
\text { (Ma) }\end{array}$} & \multicolumn{2}{|c|}{ Hole U1337A } & \multicolumn{2}{|c|}{ Hole U1337B } & \multicolumn{2}{|c|}{ Hole U1337D } \\
\hline & & $\begin{array}{l}\text { Core, section, } \\
\text { interval }(\mathrm{cm})\end{array}$ & $\begin{array}{c}\text { Depth } \\
\text { CCSF-A (m) }\end{array}$ & $\begin{array}{l}\text { Core, section, } \\
\text { interval }(\mathrm{cm})\end{array}$ & $\begin{array}{l}\text { Depth } \\
\text { CCSF-A (m) }\end{array}$ & $\begin{array}{l}\text { Core, section, } \\
\text { interval }(\mathrm{cm})\end{array}$ & $\begin{array}{c}\text { Depth } \\
\text { CCSF-A (m) }\end{array}$ \\
\hline $\mathrm{C} 1 \mathrm{n} / \mathrm{C} 1 \mathrm{r} .1 \mathrm{r}$ & 0.781 & $3 \mathrm{H}-1,0$ & 10.69 & $2 \mathrm{H}-3,62$ & 10.74 & $2 \mathrm{H}-2,35$ & 10.51 \\
\hline $\mathrm{C} 1 \mathrm{r} .1 \mathrm{r} / \mathrm{C} 1 \mathrm{r} .1 \mathrm{n}$ & 0.988 & $3 \mathrm{H}-3,15$ & 14.09 & $2 \mathrm{H}-5,112$ & 14.24 & $2 \mathrm{H}-4,110$ & 14.25 \\
\hline $\mathrm{C} 1 \mathrm{r} .1 \mathrm{n} / \mathrm{C} 1 \mathrm{r} .2 \mathrm{r}$ & 1.072 & $3 \mathrm{H}-3,112$ & 15.11 & $2 \mathrm{H}-6,55$ & 15.16 & $2 \mathrm{H}-5,42$ & 15.06 \\
\hline $\mathrm{C} 1 \mathrm{r} / \mathrm{C} 2 \mathrm{n}$ & 1.778 & $4 \mathrm{H}-5,62$ & 27.14 & $4 \mathrm{H}-1,0$ & 27.21 & $3 \mathrm{H}-6,75$ & 27.26 \\
\hline $\mathrm{C} 2 \mathrm{n} / \mathrm{C} 2 \mathrm{r} \cdot 1 \mathrm{r}$ & 1.945 & $4 \mathrm{H}-6,75$ & 28.73 & $4 \mathrm{H}-1,110$ & 28.65 & $4 \mathrm{H}-1,0$ & 28.68 \\
\hline $\mathrm{C} 2 \mathrm{r} / \mathrm{C} 2 \mathrm{An} .1 \mathrm{n}$ & 2.581 & $5 \mathrm{H}-3,97$ & 36.62 & $4 \mathrm{H}-6,130$ & 36.34 & & \\
\hline C2An.1n/C2An.1r & 3.032 & $6 \mathrm{H}-1,140$ & 44.69 & $5 \mathrm{H}-5,107$ & 45.00 & $5 \mathrm{H}-4,45$ & 44.92 \\
\hline C2An.1r/C2An.2n & 3.116 & $6 \mathrm{H}-3,15$ & 46.42 & $5 \mathrm{H}-6,82$ & 46.27 & $5 \mathrm{H}-5,22$ & 46.21 \\
\hline C2An.2n/C2An.2r & 3.207 & $6 \mathrm{H}-4,32$ & 48.11 & & & $5 \mathrm{H}-6,40$ & 47.87 \\
\hline C2An.2r/C2An.3 & 3.330 & $6 \mathrm{H}-5,42$ & 49.73 & $6 \mathrm{H}-1,95$ & 49.77 & & \\
\hline C2An.3/C2Ar & 3.596 & & & $6 \mathrm{H}-5,70$ & 55.51 & $6 \mathrm{H}-4,0$ & 55.62 \\
\hline $\mathrm{C} 2 \mathrm{Ar} / \mathrm{C} 3 \mathrm{n} \cdot 1 \mathrm{n}$ & 4.187 & & & $8 \mathrm{H}-1,20$ & 70.14 & $7 \mathrm{H}-6,57$ & 70.15 \\
\hline C $3 n .1 n / C 3 n .1 r$ & 4.300 & & & & & & \\
\hline C $3 n .1 r / C 3 n .2 n$ & 4.493 & & & $8 \mathrm{H}-6,65$ & 78.21 & $8 \mathrm{H}-5,42$ & 78.42 \\
\hline C $3 n .2 n / C 3 n .2 r$ & 4.631 & $9 \mathrm{H}-4,37$ & 81.26 & & & & \\
\hline C $3 n .2 r / C 3 n .3 n$ & 4.799 & $9 \mathrm{H}-6,125$ & 85.10 & $9 \mathrm{H}-4,10$ & 85.57 & $9 \mathrm{H}-2,95$ & 85.70 \\
\hline C $3 n .3 n / C 3 n .3 r$ & 4.896 & & & $9 \mathrm{H}-5,12$ & 87.10 & $9 \mathrm{H}-3,97$ & 87.22 \\
\hline C $3 n .3 r / C 3 n .4 n$ & 4.997 & & & $9 \mathrm{H}-6,117$ & 89.65 & $9 \mathrm{H}-5,35$ & 89.60 \\
\hline$C 3 n .4 n / C 3 r$ & 5.235 & $10 \mathrm{H}-6,0$ & 94.28 & $10 \mathrm{H}-2,0$ & 94.60 & $10 \mathrm{H}-1,0$ & 94.60 \\
\hline C $3 r / C 3 A n .1 n$ & 6.033 & $12 \mathrm{H}-4,62$ & 112.72 & $11 \mathrm{H}-6,140$ & 112.23 & $11 \mathrm{H}-5,75$ & 112.30 \\
\hline C3An.1n/C3An.1r & 6.252 & $13 \mathrm{H}-1,102$ & 119.07 & $12 \mathrm{H}-4,12$ & 118.75 & $12 \mathrm{H}-2,120$ & 118.62 \\
\hline C3An.1r/C3An.2n & 6.436 & $13 \mathrm{H}-3,100$ & 122.08 & $12 \mathrm{H}-5,135$ & 121.50 & $12 \mathrm{H}-4,140$ & 121.82 \\
\hline C3An.2n/C3Ar & 6.733 & $14 \mathrm{H}-1,20$ & 129.92 & $13 \mathrm{H}-4,0$ & 129.60 & $13 \mathrm{H}-2,102$ & 129.90 \\
\hline $\mathrm{C} 3 \mathrm{Ar} / \mathrm{C} 3 \mathrm{Bn}$ & 7.140 & & & & & & \\
\hline $\mathrm{C} 3 \mathrm{Br} / \mathrm{C} 4 \mathrm{n}$ & 7.528 & $15 \mathrm{H}-7,0$ & 149.85 & & & & \\
\hline $\mathrm{C} 4 \mathrm{n} / \mathrm{C} 4 \mathrm{r}$ & 8.108 & & & $16 \mathrm{H}-6,62$ & 164.82 & $16 \mathrm{H}-4,90$ & 164.97 \\
\hline C4r/C4An & 8.769 & $18 \mathrm{H}-2,30$ & 175.00 & $17 \mathrm{H}-6,117$ & 175.20 & $17 \mathrm{H}-4,35$ & 174.90 \\
\hline C4An/C4Ar & 9.098 & & & & & & \\
\hline C4Ar/C5n & 9.779 & $20 \mathrm{H}-1,0$ & 193.90 & $19 \mathrm{H}-4,117$ & 193.95 & $19 \mathrm{H}-3,47$ & 194.05 \\
\hline
\end{tabular}

Note: See Figure F22. 
Table T17. Interstitial water data from squeezed whole-round and Rhizon samples, Hole U1337A. (See table notes.)

\begin{tabular}{|c|c|c|c|c|c|c|c|c|c|c|}
\hline & & Depth & $\operatorname{CSF}(\mathrm{m})$ & & & & & & & \\
\hline & & Top & Bottom & $\mathrm{pH}$ & & Salinity & & & & \\
\hline 321-U1337A- & & & & & & & & & & \\
\hline $2 \mathrm{H}-2,145-150$ & IW & 8.45 & 8.50 & 7.70 & 2.82 & 34.0 & 555 & 480 & 27.6 & ND \\
\hline $2 \mathrm{H}-5,145-150$ & IW & 12.95 & 13.00 & 7.64 & 2.75 & 34.1 & 560 & 488 & 28.8 & ND \\
\hline $3 \mathrm{H}-2,145-150$ & IW & 17.95 & 18.00 & 7.63 & 2.73 & 34.0 & 555 & 483 & 28.8 & ND \\
\hline $3 \mathrm{H}-5,145-150$ & IW & 22.45 & 22.50 & 7.62 & 2.72 & ND & 560 & 480 & 27.4 & ND \\
\hline $4 \mathrm{H}-2,145-150$ & IW & 27.45 & 27.50 & 7.69 & 2.85 & ND & 561 & 486 & 29.1 & ND \\
\hline $4 \mathrm{H}-5,145-150$ & IW & 31.95 & 32.00 & 7.66 & 2.71 & ND & 563 & 487 & 28.7 & ND \\
\hline $5 \mathrm{H}-2,145-150$ & IW & 36.95 & 37.00 & 7.65 & 3.76 & 34.0 & 563 & 490 & 28.7 & ND \\
\hline $5 \mathrm{H}-5,145-150$ & IW & 41.45 & 41.50 & 7.65 & 2.67 & 34.0 & 562 & 486 & 28.6 & ND \\
\hline $6 \mathrm{H}-2,145-$ & IW & 46.45 & 46.50 & 7.65 & 2.75 & 34.0 & 564 & 487 & 28.7 & ND \\
\hline $6 \mathrm{H}-5,145-150$ & IW & 50.95 & 51.00 & 7.70 & 2.71 & 34.0 & 559 & 487 & 29.3 & ND \\
\hline $7 \mathrm{H}-3,145-150$ & IW & 57.45 & 57.50 & 7.68 & 2.90 & 34.0 & 563 & 486 & 28.6 & ND \\
\hline $8 \mathrm{H}-3,145-150$ & IW & 66.95 & 67.00 & 7.59 & 2.66 & 34.0 & 565 & 491 & 28.4 & ND \\
\hline $9 \mathrm{H}-3,145-150$ & IW & 76.45 & 76.50 & 7.69 & 3.01 & 34.0 & 562 & 487 & 28.6 & ND \\
\hline $10 \mathrm{H}-3,145-150$ & IW & 85.95 & 86.00 & 7.58 & 2.79 & 34.0 & 564 & 489 & 27.2 & ND \\
\hline $11 \mathrm{H}-3,145-150$ & IW & 95.45 & 95.50 & 7.63 & 2.80 & 34.0 & 569 & 496 & 28.3 & ND \\
\hline $12 \mathrm{H}-3,1$ & IW & 104.95 & 105.00 & 7.65 & 2.8 & 34.0 & 56 & 488 & 28.7 & ND \\
\hline $13 \mathrm{H}-3,145-150$ & IW & 114.45 & 114.50 & 7.57 & 2.85 & 34.0 & 557 & 477 & 27.9 & ND \\
\hline $14 \mathrm{H}-3,150-155$ & IW & 123.95 & 124.00 & 7.60 & 2.90 & 34.1 & 563 & 488 & 27.6 & ND \\
\hline $15 \mathrm{H}-3,145-150$ & IW & 133.45 & 133.50 & 7.59 & 3.08 & 34.0 & 56 & 489 & 27.6 & ND \\
\hline $16 \mathrm{H}-3,1$ & IW & 142.95 & 143.00 & 7.57 & 3.05 & 34.0 & 563 & 487 & 27.5 & ND \\
\hline $17 \mathrm{H}-3,145-150$ & IW & 152.45 & 152.50 & 7.58 & 3.52 & 34.0 & 563 & 488 & 27.1 & ND \\
\hline $18 \mathrm{H}-3,147-152$ & IW & 161.99 & 162.04 & 7.62 & 3.07 & 34.0 & 561 & 485 & 28.2 & ND \\
\hline $19 \mathrm{H}-3$, & IW & 171.45 & 171.50 & 7.62 & 3.1 & 340 & 56 & 484 & 27.4 & \\
\hline $20 \mathrm{H}-3,145-150$ & IW & 180.95 & 181.00 & 7.64 & 3.18 & 34.0 & 561 & 480 & 26.9 & ND \\
\hline $21 \mathrm{H}-3,145-150$ & IW & 190.45 & 190.50 & 7.61 & 3.37 & 34.0 & 559 & 480 & 27.7 & ND \\
\hline $23 \mathrm{X}-3,145-150$ & IW & 208.75 & 208.80 & 7.58 & 3.21 & 34.0 & 561 & 483 & 27.5 & ND \\
\hline 24$\rangle$ & IW & 216.85 & 216.90 & & & 35.0 & 56 & 49 & 27.4 & ND \\
\hline $25 \mathrm{X}-3,145-150$ & IW & 227.85 & 227.90 & 7.63 & 3.37 & 3 & ND & ND & 27.8 & $\mathrm{~N}$ \\
\hline $26 \mathrm{X}-3,145-150$ & IW & 237.45 & 237.50 & 7.61 & 3.26 & 34.0 & 563 & 484 & 27.6 & ND \\
\hline $28 \mathrm{X}-2,140-150$ & IW & 254.60 & 254.70 & 7.49 & 3.90 & 35.0 & ND & ND & 25.8 & ND \\
\hline 29 & IW & 2 & $26433 \Rightarrow$ & 7.52 & 3.36 & 340 & 55 & 479 & 26.5 & $N 1$ \\
\hline $30 \mathrm{X}-4,140-150$ & IW & 276.70 & 276.80 & 7.65 & 3.55 & 34.0 & 562 & 489 & 27.1 & $\mathrm{~N}$ \\
\hline $31 X-3,140-150$ & IW & 284.90 & 285.00 & 7.55 & 3.80 & 34.0 & 553 & 473 & 26.2 & ND \\
\hline $32 X-3$, & IW & 294.60 & 294.70 & 7.57 & 2.81 & 34.0 & 55 & 481 & 26.6 & N \\
\hline 33 & IW & 3 & 304 & 7.50 & 3. & & $\mathrm{~N}$ & ND & 26.6 & \\
\hline $34 \mathrm{X}-3,140-150$ & IW & 313.70 & 313.80 & 7.53 & 3.65 & 35.0 & ND & ND & 26.2 & $\mathrm{~N}$ \\
\hline $35 \mathrm{X}-3,140-150$ & IW & 323.30 & 323.40 & 7.52 & 3.61 & 35.0 & 556 & 477 & 26.7 & ND \\
\hline & IV & .90 & 333.00 & 7.57 & & 36.0 & & 483 & 26.6 & ND \\
\hline 37 & IV & & 34 & 7.5 & 3. & 3 & 5 & 48 & 27.4 & \\
\hline $38 \mathrm{X}-2,140-150$ & IW & 350.50 & 350.60 & 7.55 & 3.67 & 34.0 & 555 & 480 & 26.9 & ND \\
\hline $39 \times-3,140-150$ & IW & 361.60 & 361.70 & 7.57 & 3.49 & 35.0 & 559 & 484 & 26.8 & ND \\
\hline & IV & & 371 & 7.5 & & & 5 & $4 \varepsilon$ & 26 & \\
\hline $41 \mathrm{X}-3$ & IW & & 38 & 7.68 & & $N$ & $\mathrm{~N}$ & $\mathrm{~N}$ & 26 & \\
\hline $42 \mathrm{X}-3,140-150$ & IW & 390.40 & 390.50 & ND & ND & 34.0 & ND & ND & 26.5 & ND \\
\hline $43 \mathrm{X}-3,140-150$ & IW & 400.00 & 400.10 & 7.68 & 2.98 & ND & 558 & 479 & 27.7 & ND \\
\hline & IW & & 409. & 7.5 & & & & $\Lambda$ & & \\
\hline $45 X-3,1$ & IW & 418.90 & 419.00 & 7.61 & & 3. & 56 & 48 & 27 & $N$ \\
\hline $46 \mathrm{X}-3,140-150$ & IW & 428.40 & 428.50 & 7.60 & 3. & 34.0 & 560 & 483 & 27.0 & ND \\
\hline $47 X-3,140-150$ & IW & 438.00 & 438.10 & 7.60 & 3.02 & 34.0 & ND & $\mathrm{NL}$ & 26.8 & N \\
\hline & & & & & & & & & & \\
\hline $2 \mathrm{H}-2,140-145$ & $\mathrm{RI}$ & & & 1.15 & & & $\mathrm{~N}$ & $\mathrm{~N}$ & 29 & ND \\
\hline $2 \mathrm{H}-5,140-145$ & Rhizor & 12.90 & 12.9 & 7.65 & 2. & ND & 553 & 475 & 28 & ND \\
\hline $2 \mathrm{H}-6,145-150$ & $\mathrm{R}$ & 14.45 & 14 & 7.70 & 2. & $T$ & ND & ND & 29.1 & $\mathrm{~N}$ \\
\hline & & & & 7. & & & a & 40 & & \\
\hline $3 \mathrm{H}-2,140-145$ & $\mathrm{Rl}$ & 17 & 17 & 7.73 & & & $\mathrm{NL}$ & ND & 29 & N \\
\hline $3 \mathrm{H}-5,140-145$ & $\mathrm{Rl}$ & 22 & 22 & 7.73 & 2. & ND & ND & ND & 28 & N \\
\hline $3 \mathrm{H}-6,14$ & & 23 & 24 & 7.7 & 2. & ND & $\mathrm{N}$ & $\mathrm{N}$ & 28 & $\mathrm{~N}$ \\
\hline & & & & & & & $N$ & $N$ & & \\
\hline $2,140-145$ & $\mathrm{R}$ & 2 & & 7. & & & $\mathrm{~N}$ & $\mathrm{~N}$ & 28 & $\mathrm{~N}$ \\
\hline $4 \mathrm{H}-5,140-145$ & & & & 7.6 & & $\mathrm{~N}$ & N & N & & $N$ \\
\hline 6,1 & & & 33. & 7.7 & 2. & ND & $\mathrm{N}$ & $\mathrm{N}$ & $2 \varepsilon$ & $\mathrm{N}$ \\
\hline $5 \mathrm{H}-1,1$ & & & & 7. & & & $\mathrm{~N}$ & & & \\
\hline $5 \mathrm{H}-2,1$ & & 36 & 3 & 7. & & & NL & $\mathrm{N}$ & 28 & \\
\hline $5 t$ & & & & 7 & & & & & & \\
\hline $5 \mathrm{H}-6,14$ & & 42 & $43 . c$ & 7.7 & 2. & & $\mathrm{~N}$ & $\mathrm{~N}$ & 29.1 & $\mathrm{~N}$ \\
\hline $6 \mathrm{H}-1,14$ & & & & 7. & & & $N$ & N & & \\
\hline $6 \mathrm{H}-2 \quad 140-1$ & & & 46 & 7.7 & & & $N$ & $1 T$ & & \\
\hline & & & & & & & & & & \\
\hline $6 \mathrm{H}-6,145-15$ & Rhizc & 52.4 & 52.50 & 7.7 & 2.7 & & $\mathrm{~N}$ & $\mathrm{~N}$ & 28.9 & $\mathrm{~N}$ \\
\hline $7 \mathrm{H}-1,1$ & & & & 7.7 & & & $N$ & $N$ & & \\
\hline & & & & $78-3$ & & & & & & \\
\hline 가 & & & & 7. & & & & & & \\
\hline $7 \mathrm{H}-7$, & $\mathrm{R}$ & 62.53 & 62.5 & 7.7 & 2.8 & N & $\mathrm{N}$ & N & 28 & $\mathrm{~N}$ \\
\hline & & & & 7.7 & & & & & & \\
\hline & & & & & & & & & & \\
\hline & & & 79 & 7. & 2. & & 56 & $4 \varepsilon$ & & 10 \\
\hline $9 \mathrm{H}-6$ & $\mathrm{R}$ & 80 & 81 & 7.7 & 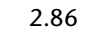 & & ND & ND & 28.6 & $N D$ \\
\hline & & & & 7 & & & & 48 & & \\
\hline & & & & & & & & & & \\
\hline $10 \mathrm{H}$ & & & 89 & 7.7 & 2.8 & & $\mathrm{~N}$ & ND & & ND \\
\hline & R & 0 & 8 & $77-3+3$ & $17+2$ & & 56 & 485 & 28. & $\mathrm{~N}$ \\
\hline & & & & & & & & 15 & & \\
\hline & & & & 1.2 & & & $\mathrm{~N}$ & N & & \\
\hline & & 98 & 98 & 7.9 & 2.8 & ND & ND & ND & 28.0 & ND \\
\hline 50 & izon & 95 & 100.00 & 8.01 & .87 & $\Lambda$ & 566 & 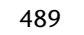 & 8.7 & N \\
\hline
\end{tabular}

Notes: $\mathrm{IW}=$ squeezed whole-round sample. $\mathrm{ND}=$ not determined. $\mathrm{BDL}=$ below detection limit (average blank plus three times the standard deviation of multiple blank measurements; $\mathrm{Li}+=0.1$ $\left.\mu \mathrm{M}, \mathrm{B}=0.2 \mu \mathrm{M}, \mathrm{Mn}^{2+}=0.09 \mu \mathrm{M}, \mathrm{Fe}^{2+}=0.03 \mu \mathrm{M}, \mathrm{Sr}^{2+}=1 \mu \mathrm{M}, \mathrm{Ba}^{2+}=0.08 \mu \mathrm{M}\right) . \mathrm{H}_{4} \mathrm{SiO}_{4}$ values measured by different techniques during Expeditions 320 and 321 disagree significantly, especially for low values. Therefore, caution should be
uncertainty estimates and assessment of accuracy. 
Table T18. Inorganic geochemistry of solid samples, Site U1337. (See table notes.)

\begin{tabular}{|c|c|c|c|c|c|c|c|c|c|c|c|c|c|c|c|}
\hline \multirow{2}{*}{$\begin{array}{l}\text { Core, section, } \\
\text { interval }(\mathrm{cm})\end{array}$} & \multirow{2}{*}{$\begin{array}{l}\text { Top depth. } \\
\text { CSF }(m)\end{array}$} & \multicolumn{10}{|c|}{ Major element oxides (wt\%) } & \multicolumn{4}{|c|}{ Trace elements (ppm) } \\
\hline & & $\mathrm{SiO}_{2}$ & $\mathrm{Al}_{2} \mathrm{O}_{3}$ & $\mathrm{Fe}_{2} \mathrm{O}_{3} \mathrm{~T}$ & $\mathrm{MnO}$ & $\mathrm{MgO}$ & $\mathrm{CaO}$ & $\mathrm{Na}_{2} \mathrm{O}$ & $\mathrm{K}_{2} \mathrm{O}$ & $\mathrm{TiO}_{2}$ & $\mathrm{P}_{2} \mathrm{O}_{5}$ & $\mathrm{Ba}$ & $\mathrm{Sr}$ & $\mathrm{V}$ & $\mathrm{Zr}$ \\
\hline \multicolumn{16}{|l|}{ 321-U1337A- } \\
\hline $2 \mathrm{H}-4,72-73$ & 10.72 & 32.43 & 5.06 & 3.81 & 0.315 & 1.996 & 22.4 & 10.66 & 1.132 & 0.160 & 0.557 & 5652 & 794 & 53.1 & 75.1 \\
\hline $3 \mathrm{H}-4,70-71$ & 20.20 & 42.43 & 5.90 & 4.84 & 0.456 & 2.725 & 14.1 & 13.99 & 1.285 & 0.195 & 0.809 & 6956 & 588 & 51.3 & 109.4 \\
\hline $4 \mathrm{H}-4,70-71$ & 29.70 & 44.95 & 6.42 & 4.92 & 0.770 & 2.882 & 10.5 & 13.27 & 1.459 & 0.240 & 1.020 & 9520 & 656 & 41.0 & 107.5 \\
\hline $5 \mathrm{H}-4,71-72$ & 39.21 & 32.07 & 3.69 & 3.95 & 0.612 & 2.565 & 23.2 & 8.49 & 0.957 & 0.118 & 1.536 & 6566 & 783 & 24.5 & 67.8 \\
\hline $6 \mathrm{H}-4,71-72$ & 48.71 & 46.25 & 5.48 & 4.83 & 1.873 & 3.178 & 10.9 & 11.33 & 1.220 & 0.195 & 1.615 & 8016 & 512 & 39.0 & 108.9 \\
\hline 7H-4, 92-93 & 58.42 & 47.42 & 4.51 & 3.87 & 3.149 & 2.844 & 15.1 & 11.09 & 0.854 & 0.191 & 2.590 & 8678 & 733 & 35.5 & 96.8 \\
\hline $8 \mathrm{H}-4,72-73$ & 67.72 & 49.44 & 4.47 & 4.05 & 0.762 & 2.764 & 10.7 & 10.12 & 1.049 & 0.154 & 0.694 & 8571 & 599 & 30.4 & 82.2 \\
\hline $10 \mathrm{H}-4,72-73$ & 86.72 & 12.22 & 0.72 & 0.66 & 0.649 & 0.709 & 46.7 & 4.14 & 0.205 & $\mathrm{BDL}$ & 0.167 & 2382 & 1528 & $\mathrm{BDL}$ & $\mathrm{BDL}$ \\
\hline $11 \mathrm{H}-4,72-73$ & 96.22 & 47.47 & 4.80 & 3.50 & 0.377 & 2.708 & 18.6 & 10.67 & 1.016 & 0.177 & 0.830 & 9281 & 853 & 34.6 & 97.5 \\
\hline $12 \mathrm{H}-4,120-121$ & 106.20 & 28.88 & 2.16 & 1.81 & 0.793 & 1.557 & 36.0 & 6.37 & 0.392 & 0.057 & 0.414 & 5185 & 1295 & 25.6 & 52.9 \\
\hline $13 \mathrm{H}-4,94-95$ & 115.44 & 34.79 & 2.49 & 2.18 & 0.432 & 1.883 & 29.5 & 7.92 & 0.471 & 0.063 & 0.521 & 5924 & 1117 & 27.6 & 56.3 \\
\hline $14 \mathrm{H}-4,65-66$ & 124.70 & 26.38 & 0.69 & 0.49 & 0.278 & 0.679 & 36.0 & 4.85 & 0.230 & $\mathrm{BDL}$ & 0.177 & 3023 & 1226 & 17.7 & BDL \\
\hline $15 \mathrm{H}-4,71-72$ & 134.21 & 29.06 & 0.95 & 1.34 & 0.331 & 1.252 & 35.5 & 5.72 & 0.273 & 0.014 & 0.279 & 4192 & 1216 & 21.5 & 33.1 \\
\hline $17 \mathrm{H}-4,71-72$ & 153.21 & 18.39 & 0.33 & 0.57 & 0.478 & 0.628 & 44.8 & 4.00 & 0.172 & $\mathrm{BDL}$ & 0.192 & 3181 & 1507 & 16.4 & $\mathrm{BDL}$ \\
\hline $18 \mathrm{H}-4,72-73$ & 162.76 & 23.94 & 1.17 & 1.53 & 0.509 & 1.105 & 36.1 & 4.92 & 0.306 & 0.021 & 0.356 & 5689 & 1392 & 17.3 & 39.0 \\
\hline $19 \mathrm{H}-4,72-73$ & 172.22 & 28.45 & 0.92 & 1.32 & 0.475 & 1.014 & 37.0 & 5.33 & 0.240 & $\mathrm{BDL}$ & 0.248 & 3755 & 1391 & 17.9 & 41.0 \\
\hline $21 \mathrm{H}-4,73-74$ & 191.23 & 70.63 & 0.00 & 0.00 & 0.048 & 0.601 & 8.0 & 7.62 & 0.185 & $\mathrm{BDL}$ & 0.093 & 788 & 342 & $\mathrm{BDL}$ & BDL \\
\hline $22 X-2,55-56$ & 197.55 & 28.57 & 0.65 & 0.46 & 0.262 & 0.659 & 37.4 & 6.13 & 0.191 & $\mathrm{BDL}$ & 0.190 & 3248 & 1409 & 12.5 & 31.4 \\
\hline $23 X-4,67-68$ & 209.47 & 58.36 & 0.97 & 0.56 & 0.066 & 0.934 & 16.0 & 7.81 & 0.268 & $\mathrm{BDL}$ & 0.318 & 4351 & 710 & 61.6 & 34.3 \\
\hline $24 X-4,72-73$ & 218.72 & 26.23 & 0.26 & 0.23 & 0.227 & 0.407 & 41.2 & 4.38 & 0.164 & $\mathrm{BDL}$ & 0.127 & 2135 & 1494 & $\mathrm{BDL}$ & $\mathrm{BDL}$ \\
\hline $25 X-4,106-107$ & 228.96 & 18.57 & 0.17 & 0.15 & 0.149 & 0.373 & 45.5 & 3.34 & 0.162 & $\mathrm{BDL}$ & 0.148 & 2413 & 1469 & 12.0 & $\mathrm{BDL}$ \\
\hline $26 X-4,70-71$ & 238.20 & 18.49 & 0.52 & 0.58 & 0.129 & 0.610 & 45.4 & 3.74 & 0.184 & $\mathrm{BDL}$ & 0.190 & 3123 & 1422 & 17.4 & $\mathrm{BDL}$ \\
\hline $27 X-1,81-82$ & 243.01 & 57.10 & $\mathrm{BDL}$ & $\mathrm{BDL}$ & 0.024 & 0.586 & 17.0 & 7.39 & 0.178 & $\mathrm{BDL}$ & 0.078 & 853 & 626 & $\mathrm{BDL}$ & BDL \\
\hline $28 X-4,36-37$ & 256.06 & 5.09 & 0.04 & 0.05 & 0.108 & 0.234 & 52.0 & 1.77 & 0.162 & $\mathrm{BDL}$ & 0.080 & 1884 & 1483 & 12.8 & $\mathrm{BDL}$ \\
\hline $29 X-4,74-75$ & 266.54 & 8.39 & 0.18 & 0.19 & 0.129 & 0.315 & 49.0 & 2.31 & 0.167 & $\mathrm{BDL}$ & 0.108 & 2274 & 1492 & 15.5 & $\mathrm{BDL}$ \\
\hline $30 X-4,72-73$ & 276.02 & 11.01 & 0.53 & 0.55 & 0.142 & 0.482 & 49.8 & 2.79 & 0.188 & $\mathrm{BDL}$ & 0.287 & 3695 & 1538 & 13.1 & $\mathrm{BDL}$ \\
\hline $31 X-4,72-73$ & 285.72 & 9.58 & 0.59 & 0.73 & 0.102 & 0.502 & 47.0 & 2.51 & 0.204 & $\mathrm{BDL}$ & 0.194 & 3213 & 1416 & $\mathrm{BDL}$ & $\mathrm{BDL}$ \\
\hline $32 X-4,76-77$ & 295.46 & 13.34 & 0.41 & 0.45 & 0.143 & 0.465 & 47.6 & 2.74 & 0.180 & $\mathrm{BDL}$ & 0.187 & 2851 & 1264 & 19.5 & BDL \\
\hline $33 X-4,82-83$ & 305.02 & 11.89 & 0.32 & 0.43 & 0.120 & 0.409 & 50.0 & 2.39 & 0.167 & $\mathrm{BDL}$ & 0.123 & 3632 & 1410 & 12.6 & $\mathrm{BDL}$ \\
\hline $34 X-4,71-72$ & 314.51 & 15.51 & 0.46 & 0.53 & 0.078 & 0.447 & 47.4 & 2.70 & 0.174 & $\mathrm{BDL}$ & 0.285 & 3893 & 1426 & $\mathrm{BDL}$ & $\mathrm{BDL}$ \\
\hline $35 X-4,81-82$ & 324.21 & 26.84 & 1.52 & 1.80 & 0.104 & 1.039 & 36.4 & 3.99 & 0.335 & 0.023 & 0.320 & 6355 & 1283 & 21.0 & $\mathrm{BDL}$ \\
\hline $36 X-4,81-82$ & 333.81 & 30.52 & 1.21 & 1.62 & 0.121 & 1.010 & 36.6 & 5.15 & 0.258 & 0.013 & 0.291 & 5100 & 1273 & 19.5 & 41.6 \\
\hline $37 X-4,81-82$ & 343.31 & 30.15 & 0.93 & 1.74 & 0.193 & 0.977 & 35.8 & 4.49 & 0.223 & $\mathrm{BDL}$ & 0.259 & 5077 & 1276 & 17.3 & 34.4 \\
\hline $39 X-4,82-83$ & 362.52 & 11.02 & 0.19 & 0.58 & 0.260 & 0.510 & 50.2 & 2.70 & 0.143 & $\mathrm{BDL}$ & 0.104 & 2434 & 1274 & 15.8 & $\mathrm{BDL}$ \\
\hline $40 X-4,128-129$ & 372.58 & 15.62 & 0.29 & 0.73 & 0.169 & 0.596 & 46.8 & 3.04 & 0.168 & $\mathrm{BDL}$ & 0.152 & 3073 & 1364 & 16.8 & $\mathrm{BDL}$ \\
\hline $41 X-4,13-14$ & 381.03 & 10.02 & 0.06 & 0.64 & 0.147 & 0.479 & 50.8 & 1.69 & 0.164 & $\mathrm{BDL}$ & 0.157 & 2297 & 1439 & $\mathrm{BDL}$ & $\mathrm{BDL}$ \\
\hline $42 X-4,60-61$ & 391.10 & 5.46 & 0.00 & 0.97 & 0.124 & 0.393 & 54.0 & 1.55 & 0.143 & $\mathrm{BDL}$ & 0.149 & 1664 & 1410 & 17.3 & $\mathrm{BDL}$ \\
\hline $44 X-4,114-115$ & 410.54 & 5.74 & 0.11 & 0.65 & 0.116 & 0.482 & 53.0 & 1.59 & 0.143 & $\mathrm{BDL}$ & 0.129 & 2291 & 1622 & 17.0 & $\mathrm{BDL}$ \\
\hline $45 X-4,109-110$ & 420.09 & 6.38 & 0.14 & 0.78 & 0.101 & 0.595 & 52.3 & 1.47 & 0.159 & $\mathrm{BDL}$ & 0.114 & 2967 & 1515 & 18.7 & $\mathrm{BDL}$ \\
\hline $46 X-4,5-6$ & 428.55 & 5.18 & 0.00 & 0.23 & 0.069 & 0.399 & 51.9 & 1.45 & 0.143 & BDL & 0.102 & 2135 & 1238 & 11.9 & $\mathrm{BDL}$ \\
\hline $47 X-4,74-75$ & 438.84 & 2.36 & 0.00 & 0.37 & 0.044 & 0.670 & 53.9 & 1.12 & 0.143 & $\mathrm{BDL}$ & 0.108 & 1869 & 1330 & 15.8 & $\mathrm{BDL}$ \\
\hline $48 X-4,109-110$ & 448.79 & 12.89 & 2.02 & 2.18 & 0.298 & 2.557 & 46.2 & 2.39 & 0.229 & 0.143 & 0.268 & 849 & 1105 & 21.0 & BDL \\
\hline
\end{tabular}

Notes: $\mathrm{BDL}=$ below detection limit $\left(\mathrm{Al}_{2} \mathrm{O}_{3}=0.015 \%, \mathrm{Fe}_{2} \mathrm{O}_{3}=0.0024 \%, \mathrm{TiO}_{2}=0.085 \%, \mathrm{~V}=7.25 \mathrm{ppm}, \mathrm{Zr}=26.8 \mathrm{ppm}\right)$. Values for Sr and $\mathrm{Ba}$ are well above calibration range ( $\mathrm{Sr}<700 \mathrm{ppm}, \mathrm{Ba}<570 \mathrm{ppm})$. See "Geochemistry" in the "Methods" chapter for uncertainty estimates and assessment of accuracy. 
Table T19. Carbon concentrations, Site U1337. (See table notes.) (Continued on next two pages.)

\begin{tabular}{|c|c|c|c|c|c|c|}
\hline \multirow{2}{*}{$\begin{array}{l}\text { Core, section, } \\
\text { interval }(\mathrm{cm})\end{array}$} & \multicolumn{2}{|c|}{ Depth $(m)$} & \multicolumn{4}{|c|}{ Carbon (wt\%) } \\
\hline & CSF & CCSF-A & $\mathrm{CaCO}_{3}$ & IC & TC & TOC \\
\hline \multicolumn{7}{|l|}{ 321-U1337A- } \\
\hline $2 \mathrm{H}-1,78-79$ & 6.28 & 1.07 & 40.1 & 4.8 & 5.15 & 0.72 \\
\hline $2 \mathrm{H}-2,72-73$ & 7.72 & 2.51 & 43.2 & 5.2 & ND & ND \\
\hline $2 \mathrm{H}-3,71-72$ & 9.21 & 4.00 & 24.7 & 3.0 & ND & ND \\
\hline $2 \mathrm{H}-4,72-73$ & 10.72 & 5.51 & 34.8 & 4.2 & ND & ND \\
\hline $2 \mathrm{H}-5,68-69$ & 12.18 & 6.97 & 26.6 & 3.2 & ND & ND \\
\hline $2 \mathrm{H}-6,70-71$ & 13.70 & 8.49 & 87.6 & 10.5 & ND & ND \\
\hline $2 \mathrm{H}-7,44-45$ & 14.94 & 9.73 & 84.1 & 10.1 & ND & ND \\
\hline $3 \mathrm{H}-1,77-78$ & 15.77 & 11.75 & 44.4 & 5.3 & 5.64 & 0.19 \\
\hline $3 \mathrm{H}-2,72-73$ & 17.22 & 13.20 & 21.8 & 2.6 & ND & ND \\
\hline $3 \mathrm{H}-3,72-73$ & 18.72 & 14.70 & 51.4 & 6.2 & ND & ND \\
\hline $3 \mathrm{H}-4,70-71$ & 20.20 & 16.18 & 20.8 & 2.5 & ND & ND \\
\hline $3 \mathrm{H}-5,73-74$ & 21.73 & 17.71 & 47.9 & 5.7 & ND & ND \\
\hline $3 \mathrm{H}-6,72-73$ & 23.22 & 19.20 & 46.5 & 5.6 & ND & ND \\
\hline $3 \mathrm{H}-7,61-62$ & 24.61 & 20.59 & 33.3 & 4.0 & ND & ND \\
\hline $4 \mathrm{H}-1,126-127$ & 25.76 & 21.74 & 58.7 & 7.0 & 7.15 & 0.18 \\
\hline $4 \mathrm{H}-2,70-71$ & 26.70 & 22.68 & 21.0 & 2.5 & ND & ND \\
\hline $4 \mathrm{H}-3,70-71$ & 28.20 & 24.18 & 25.6 & 3.1 & ND & ND \\
\hline $4 \mathrm{H}-4,70-71$ & 29.70 & 25.68 & 15.8 & 1.9 & ND & ND \\
\hline $4 \mathrm{H}-5,70-71$ & 31.20 & 27.18 & 14.8 & 1.8 & ND & ND \\
\hline $4 \mathrm{H}-6,70-71$ & 32.70 & 28.68 & 25.5 & 3.1 & ND & ND \\
\hline $4 \mathrm{H}-7,50-51$ & 34.00 & 29.98 & 50.4 & 6.1 & ND & ND \\
\hline $5 \mathrm{H}-1,71-72$ & 34.71 & 33.36 & 32.7 & 3.9 & 4.11 & 0.18 \\
\hline $5 \mathrm{H}-2,71-72$ & 36.21 & 34.86 & 54.9 & 6.6 & ND & ND \\
\hline $5 \mathrm{H}-3,71-72$ & 37.71 & 36.36 & 64.9 & 7.8 & ND & ND \\
\hline $5 \mathrm{H}-4,71-72$ & 39.21 & 37.86 & 39.0 & 4.7 & ND & ND \\
\hline $5 \mathrm{H}-5,71-72$ & 40.71 & 39.36 & 53.8 & 6.5 & ND & ND \\
\hline $5 \mathrm{H}-6,71-72$ & 42.21 & 40.86 & 41.8 & 5.0 & ND & ND \\
\hline $5 \mathrm{H}-7,42-43$ & 43.42 & 42.07 & 52.4 & 6.3 & ND & ND \\
\hline $6 \mathrm{H}-1,71-72$ & 44.21 & 44.00 & 33.5 & 4.0 & 4.29 & 0.31 \\
\hline $6 \mathrm{H}-2,71-72$ & 45.71 & 45.50 & 6.0 & 0.7 & ND & ND \\
\hline $6 \mathrm{H}-3,79-80$ & 47.29 & 47.08 & 15.9 & 1.9 & ND & ND \\
\hline $6 \mathrm{H}-4,71-72$ & 48.71 & 48.50 & 15.7 & 1.9 & ND & ND \\
\hline $6 \mathrm{H}-5,71-72$ & 50.21 & 50.00 & 6.0 & 0.7 & ND & ND \\
\hline $6 \mathrm{H}-6,71-72$ & 51.71 & 51.50 & 37.6 & 4.5 & ND & ND \\
\hline $6 \mathrm{H}-7,51-52$ & 53.01 & 52.80 & 34.5 & 4.1 & ND & ND \\
\hline 7H-1, 78-79 & 53.78 & 56.04 & 4.2 & 0.5 & 1.00 & 0.19 \\
\hline 7H-2, 70-71 & 55.20 & 57.46 & 2.7 & 0.3 & ND & ND \\
\hline 7H-3, 71-72 & 56.71 & 58.97 & 22.9 & 2.8 & ND & ND \\
\hline $7 \mathrm{H}-4,92-93$ & 58.42 & 60.68 & 24.0 & 2.9 & ND & ND \\
\hline $7 \mathrm{H}-5,85-86$ & 59.85 & 62.11 & 10.6 & 1.3 & ND & ND \\
\hline 7H-6, 101-102 & 61.51 & 63.77 & 0.1 & 0.0 & ND & ND \\
\hline 7H-7, 33-34 & 62.33 & 64.59 & 0.3 & 0.0 & ND & ND \\
\hline $8 \mathrm{H}-1,72-73$ & 63.22 & 66.37 & 0.9 & 0.1 & 1.93 & 0.20 \\
\hline $8 \mathrm{H}-2,72-73$ & 64.72 & 67.87 & 19.0 & 2.3 & ND & ND \\
\hline $8 \mathrm{H}-3,72-73$ & 66.22 & 69.37 & 30.4 & 3.7 & ND & ND \\
\hline $8 \mathrm{H}-4,72-73$ & 67.72 & 70.87 & 14.6 & 1.8 & ND & ND \\
\hline $8 \mathrm{H}-5,72-73$ & 69.22 & 72.37 & 29.1 & 3.5 & ND & ND \\
\hline $8 \mathrm{H}-6,72-73$ & 70.72 & 73.87 & 12.8 & 1.5 & ND & ND \\
\hline $9 \mathrm{H}-1,72-73$ & 72.72 & 77.10 & 47.5 & 5.7 & 5.92 & 0.15 \\
\hline $9 \mathrm{H}-2,72-73$ & 74.22 & 78.60 & 23.2 & 2.8 & ND & ND \\
\hline $9 \mathrm{H}-3,72-73$ & 75.72 & 80.10 & 28.0 & 3.4 & ND & ND \\
\hline $9 \mathrm{H}-4,72-73$ & 77.22 & 81.60 & 37.1 & 4.5 & ND & ND \\
\hline $9 \mathrm{H}-5,72-73$ & 78.72 & 83.10 & 48.0 & 5.8 & ND & ND \\
\hline $9 \mathrm{H}-6,72-73$ & 80.22 & 84.60 & 13.1 & 1.6 & ND & ND \\
\hline $9 \mathrm{H}-7,17-18$ & 81.17 & 85.55 & 42.1 & 5.1 & ND & ND \\
\hline $10 \mathrm{H}-1,52-53$ & 82.02 & 87.28 & 16.0 & 1.9 & 2.18 & 0.34 \\
\hline $10 \mathrm{H}-2,72-73$ & 83.72 & 88.98 & 21.8 & 2.6 & ND & ND \\
\hline $10 \mathrm{H}-3,72-73$ & 85.22 & 90.48 & 67.9 & 8.1 & ND & ND \\
\hline $10 \mathrm{H}-4,72-73$ & 86.72 & 91.98 & 79.3 & 9.5 & ND & ND \\
\hline $10 \mathrm{H}-5,72-73$ & 88.22 & 93.48 & 21.0 & 2.5 & ND & ND \\
\hline $10 \mathrm{H}-6,72-73$ & 89.72 & 94.98 & 71.8 & 8.6 & ND & ND \\
\hline $10 \mathrm{H}-7,42-43$ & 90.92 & 96.18 & 33.7 & 4.0 & ND & ND \\
\hline $11 \mathrm{H}-1,72-73$ & 91.72 & 98.07 & 16.5 & 2.0 & 2.26 & 0.28 \\
\hline $11 \mathrm{H}-2,72-73$ & 93.22 & 99.57 & 26.1 & 3.1 & ND & ND \\
\hline $11 \mathrm{H}-3,72-73$ & 94.72 & 101.07 & 51.5 & 6.2 & ND & ND \\
\hline $11 \mathrm{H}-4,72-73$ & 96.22 & 102.57 & 27.9 & 3.3 & ND & ND \\
\hline $11 \mathrm{H}-5,72-73$ & 97.72 & 104.07 & 47.0 & 5.6 & ND & ND \\
\hline
\end{tabular}

\begin{tabular}{|c|c|c|c|c|c|c|}
\hline \multirow{2}{*}{$\begin{array}{l}\text { Core, section, } \\
\text { interval }(\mathrm{cm})\end{array}$} & \multicolumn{2}{|c|}{ Depth $(m)$} & \multicolumn{4}{|c|}{ Carbon (wt\%) } \\
\hline & CSF & CCSF-A & $\mathrm{CaCO}_{3}$ & IC & TC & TOC \\
\hline $11 \mathrm{H}-6,70-71$ & 99.20 & 105.55 & 8.0 & 1.0 & ND & ND \\
\hline $11 \mathrm{H}-7,41-42$ & 100.41 & 106.76 & 3.0 & 0.4 & ND & ND \\
\hline $12 \mathrm{H}-1,100-101$ & 101.50 & 108.59 & 23.9 & 2.9 & 3.17 & 0.31 \\
\hline $12 \mathrm{H}-2,106-107$ & 103.06 & 110.15 & 32.4 & 3.9 & ND & ND \\
\hline $12 \mathrm{H}-3,97-98$ & 104.47 & 111.56 & 39.2 & 4.7 & ND & ND \\
\hline $12 \mathrm{H}-4,120-121$ & 106.20 & 113.29 & 58.1 & 7.0 & ND & ND \\
\hline $12 \mathrm{H}-5,83-84$ & 107.33 & 114.42 & 62.4 & 7.5 & ND & ND \\
\hline $12 \mathrm{H}-6,95-96$ & 108.95 & 116.04 & 60.6 & 7.3 & ND & ND \\
\hline $12 \mathrm{H}-7,34-35$ & 109.84 & 116.93 & 64.7 & 7.8 & ND & ND \\
\hline $13 \mathrm{H}-1,89-90$ & 110.89 & 118.93 & 72.2 & 8.7 & 8.29 & 0.10 \\
\hline $13 \mathrm{H}-2,94-95$ & 112.44 & 120.48 & 67.0 & 8.0 & ND & ND \\
\hline $13 \mathrm{H}-3,94-95$ & 113.94 & 121.98 & 30.0 & 3.6 & ND & ND \\
\hline $13 \mathrm{H}-4,94-95$ & 115.44 & 123.48 & 51.7 & 6.2 & ND & ND \\
\hline $13 \mathrm{H}-5,88-89$ & 116.88 & 124.92 & 45.4 & 5.5 & ND & ND \\
\hline $13 \mathrm{H}-6,94-95$ & 118.44 & 126.48 & 37.2 & 4.5 & ND & ND \\
\hline $13 \mathrm{H}-7,28-29$ & 119.28 & 127.32 & 53.6 & 6.4 & ND & ND \\
\hline $14 \mathrm{H}-1,70-71$ & 120.20 & 130.41 & 37.2 & 4.5 & 4.58 & 0.14 \\
\hline $14 \mathrm{H}-2,67-68$ & 121.67 & 131.88 & 46.6 & 5.6 & ND & ND \\
\hline $14 \mathrm{H}-3,70-71$ & 123.20 & 133.41 & 70.3 & 8.4 & ND & ND \\
\hline $14 \mathrm{H}-4,65-66$ & 124.70 & 134.91 & 62.0 & 7.4 & ND & ND \\
\hline $14 \mathrm{H}-5,70-71$ & 126.20 & 136.41 & 72.1 & 8.7 & ND & ND \\
\hline $14 \mathrm{H}-6,70-71$ & 127.70 & 137.91 & 74.1 & 8.9 & ND & ND \\
\hline $14 \mathrm{H}-7,45-46$ & 128.95 & 139.16 & 85.2 & 10.2 & ND & ND \\
\hline $15 \mathrm{H}-1,71-72$ & 129.71 & 141.51 & 83.7 & 10.0 & 10.01 & 0.11 \\
\hline $15 \mathrm{H}-2,71-72$ & 131.21 & 143.01 & 54.9 & 6.6 & ND & ND \\
\hline $15 \mathrm{H}-3,71-72$ & 132.71 & 144.51 & 62.5 & 7.5 & ND & ND \\
\hline $15 \mathrm{H}-4,71-72$ & 134.21 & 146.01 & 58.5 & 7.0 & ND & ND \\
\hline $15 \mathrm{H}-5,71-72$ & 135.71 & 147.51 & 34.7 & 4.2 & ND & ND \\
\hline $15 \mathrm{H}-6,67-68$ & 137.17 & 148.97 & 64.3 & 7.7 & ND & ND \\
\hline $15 \mathrm{H}-7,37-38$ & 138.37 & 150.17 & 28.2 & 3.4 & ND & ND \\
\hline $16 \mathrm{H}-1,72-73$ & 139.22 & 151.44 & 59.0 & 7.1 & 7.17 & 0.13 \\
\hline $16 \mathrm{H}-2,72-73$ & 140.72 & 152.94 & 69.0 & 8.3 & ND & ND \\
\hline $16 \mathrm{H}-3,82-83$ & 142.32 & 154.54 & 39.7 & 4.8 & ND & ND \\
\hline $16 \mathrm{H}-4,71-72$ & 143.71 & 155.93 & 32.3 & 3.9 & ND & ND \\
\hline $16 \mathrm{H}-5,71-72$ & 145.21 & 157.43 & 9.5 & 1.1 & ND & ND \\
\hline $16 \mathrm{H}-6,71-72$ & 146.71 & 158.93 & 65.2 & 7.8 & ND & ND \\
\hline $16 \mathrm{H}-7,32-33$ & 147.82 & 160.04 & 27.2 & 3.3 & ND & ND \\
\hline $17 \mathrm{H}-1,81-82$ & 148.81 & 162.66 & 80.0 & 9.6 & 9.58 & 0.11 \\
\hline $17 \mathrm{H}-2,88-89$ & 150.38 & 164.23 & 62.4 & 7.5 & ND & ND \\
\hline $17 \mathrm{H}-3,81-82$ & 151.81 & 165.66 & 62.5 & 7.5 & ND & ND \\
\hline $17 \mathrm{H}-4,71-72$ & 153.21 & 167.06 & 74.9 & 9.0 & ND & ND \\
\hline $17 \mathrm{H}-5,71-72$ & 154.71 & 168.56 & 69.4 & 8.3 & ND & ND \\
\hline $17 \mathrm{H}-6,81-82$ & 156.31 & 170.16 & 67.3 & 8.1 & ND & ND \\
\hline $17 \mathrm{H}-7,42-43$ & 157.42 & 171.27 & 74.3 & 8.9 & ND & ND \\
\hline $18 \mathrm{H}-1,70-71$ & 158.20 & 173.90 & 72.7 & 8.7 & 8.79 & 0.15 \\
\hline $18 \mathrm{H}-2,71-72$ & 159.71 & 175.41 & 12.2 & 1.5 & ND & ND \\
\hline $18 \mathrm{H}-3,96-97$ & 161.48 & 177.18 & 55.4 & 6.7 & ND & ND \\
\hline $18 \mathrm{H}-4,72-73$ & 162.76 & 178.46 & 61.4 & 7.4 & ND & ND \\
\hline $18 \mathrm{H}-5,77-78$ & 164.31 & 180.01 & 54.2 & 6.5 & ND & ND \\
\hline $18 \mathrm{H}-6,77-78$ & 165.81 & 181.51 & 3.7 & 0.4 & ND & ND \\
\hline $18 \mathrm{H}-7,55-56$ & 167.09 & 182.79 & 34.1 & 4.1 & ND & ND \\
\hline $19 \mathrm{H}-1,72-73$ & 167.72 & 184.31 & 21.0 & 2.5 & 2.71 & 0.17 \\
\hline $19 \mathrm{H}-2,72-73$ & 169.22 & 185.81 & 44.7 & 5.4 & ND & ND \\
\hline $19 \mathrm{H}-3,72-73$ & 170.72 & 187.31 & 42.0 & 5.0 & ND & ND \\
\hline $19 \mathrm{H}-4,72-73$ & 172.22 & 188.81 & 59.8 & 7.2 & ND & ND \\
\hline $19 \mathrm{H}-5,72-73$ & 173.72 & 190.31 & 18.4 & 2.2 & ND & ND \\
\hline $19 \mathrm{H}-6,72-73$ & 175.22 & 191.81 & 2.2 & 0.3 & ND & ND \\
\hline $19 \mathrm{H}-7,22-23$ & 176.22 & 192.81 & 22.3 & 2.7 & ND & ND \\
\hline $20 \mathrm{H}-1,75-76$ & 177.25 & 194.58 & 0.1 & 0.0 & 0.16 & 0.18 \\
\hline $20 \mathrm{H}-2,72-73$ & 178.72 & 196.05 & 0.5 & 0.1 & ND & ND \\
\hline $20 \mathrm{H}-3,72-73$ & 180.22 & 197.55 & 36.2 & 4.3 & ND & ND \\
\hline $20 \mathrm{H}-4,72-73$ & 181.72 & 199.05 & 22.3 & 2.7 & ND & ND \\
\hline $20 \mathrm{H}-5,67-68$ & 183.17 & 200.50 & 48.5 & 5.8 & ND & ND \\
\hline $2 \mathrm{OH}-6,68-69$ & 184.68 & 202.01 & 20.8 & 2.5 & ND & ND \\
\hline $20 \mathrm{H}-7,45-46$ & 185.95 & 203.28 & 61.9 & 7.4 & ND & ND \\
\hline $21 \mathrm{H}-1,72-73$ & 186.72 & 204.64 & 25.7 & 3.1 & 3.08 & 0.12 \\
\hline $21 \mathrm{H}-2,71-72$ & 188.21 & 206.13 & 65.9 & 7.9 & ND & ND \\
\hline $21 \mathrm{H}-3,71-72$ & 189.71 & 207.63 & 58.5 & .0 & D & ND \\
\hline
\end{tabular}


Table T19 (continued). (Continued on next page.)

\begin{tabular}{|c|c|c|c|c|c|c|}
\hline \multirow{2}{*}{$\begin{array}{l}\text { Core, section, } \\
\text { interval }(\mathrm{cm})\end{array}$} & \multicolumn{2}{|c|}{ Depth (m) } & \multicolumn{4}{|c|}{ Carbon (wt\%) } \\
\hline & CSF & CCSF-A & $\mathrm{CaCO}_{3}$ & IC & $\mathrm{TC}$ & TOC \\
\hline $21 \mathrm{H}-4,73-74$ & 191.23 & 209.15 & 13.3 & 1.6 & ND & ND \\
\hline $21 \mathrm{H}-5,85-86$ & 192.86 & 210.78 & 60.1 & 7.2 & ND & ND \\
\hline $21 \mathrm{H}-6,88-89$ & 194.41 & 212.33 & 42.9 & 5.1 & ND & ND \\
\hline $21 \mathrm{H}-7,18-19$ & 195.11 & 213.03 & 24.0 & 2.9 & ND & ND \\
\hline $25 X-1,77-78$ & 224.17 & 245.56 & 77.2 & 9.3 & ND & ND \\
\hline $25 X-2,76-77$ & 225.66 & 247.05 & 82.7 & 9.9 & ND & ND \\
\hline $25 X-3,81-82$ & 227.21 & 248.60 & 81.8 & 9.8 & ND & ND \\
\hline $25 X-4,106-107$ & 228.96 & 250.35 & 75.6 & 9.1 & ND & ND \\
\hline $25 X-5,77-78$ & 230.17 & 251.56 & 75.8 & 9.1 & ND & ND \\
\hline $25 X-6,69-70$ & 231.59 & 252.98 & 77.6 & 9.3 & ND & ND \\
\hline $25 X-7,61-62$ & 232.51 & 253.90 & 81.9 & 9.8 & ND & ND \\
\hline $26 X-1,71-72$ & 233.71 & 254.81 & 74.9 & 9.0 & ND & ND \\
\hline $26 X-2,71-72$ & 235.21 & 256.31 & 80.4 & 9.6 & ND & ND \\
\hline $26 X-3,72-73$ & 236.72 & 257.82 & 70.1 & 8.4 & ND & ND \\
\hline $26 X-4,70-71$ & 238.20 & 259.30 & 74.9 & 9.0 & ND & ND \\
\hline $26 X-5,86-87$ & 239.86 & 260.96 & 77.8 & 9.3 & ND & ND \\
\hline $26 X-6,47-48$ & 240.97 & 262.07 & 83.9 & 10.1 & ND & ND \\
\hline $26 X-7,70-71$ & 242.20 & 263.30 & 78.4 & 9.4 & ND & ND \\
\hline $27 X-1,81-82$ & 243.01 & 267.46 & 27.2 & 3.3 & 3.82 & 0.74 \\
\hline $28 X-1,96-97$ & 252.66 & 273.25 & 84.1 & 10.1 & 9.99 & 0.09 \\
\hline $28 X-2,96-97$ & 254.16 & 274.75 & 86.6 & 10.4 & ND & ND \\
\hline $28 X-3,56-57$ & 255.26 & 275.85 & 91.4 & 11.0 & ND & ND \\
\hline $28 X-4,36-37$ & 256.06 & 276.65 & 89.9 & 10.8 & ND & ND \\
\hline $29 X-1,71-72$ & 262.01 & 285.31 & 85.7 & 10.3 & 10.26 & 0.06 \\
\hline $29 X-2,72-73$ & 263.52 & 286.82 & 68.8 & 8.3 & ND & ND \\
\hline $29 X-3,74-75$ & 265.04 & 288.34 & 87.1 & 10.5 & ND & ND \\
\hline $29 X-4,74-75$ & 266.54 & 289.84 & 86.9 & 10.4 & ND & ND \\
\hline $29 X-5,86-87$ & 268.16 & 291.46 & 73.9 & 8.9 & ND & ND \\
\hline $29 X-6,56-57$ & 269.36 & 292.66 & 88.1 & 10.6 & ND & ND \\
\hline $29 X-7,51-52$ & 270.31 & 293.61 & 85.8 & 10.3 & ND & ND \\
\hline $30 X-1,86-87$ & 271.66 & 300.94 & 79.2 & 9.5 & 9.56 & 0.14 \\
\hline $30 \times-2,69-70$ & 272.99 & 302.27 & 89.0 & 10.7 & ND & ND \\
\hline $30 \times-3,85-86$ & 274.65 & 303.93 & 76.4 & 9.2 & ND & ND \\
\hline $30 \times-4,72-73$ & 276.02 & 305.30 & 83.6 & 10.0 & ND & ND \\
\hline $30 \times-5,69-70$ & 277.49 & 306.77 & 80.1 & 9.6 & ND & ND \\
\hline $30 X-6,40-41$ & 278.70 & 307.98 & 81.7 & 9.8 & ND & ND \\
\hline $30 x-7,26-27$ & 280.06 & 309.34 & 83.7 & 10.0 & ND & ND \\
\hline $31 X-1,74-75$ & 281.24 & 310.60 & 89.2 & 10.7 & 10.63 & 0.04 \\
\hline $31 X-2,70-71$ & 282.70 & 312.06 & 87.8 & 10.5 & ND & ND \\
\hline $31 X-3,86-87$ & 284.36 & 313.72 & 88.0 & 10.6 & ND & ND \\
\hline $31 X-4,72-73$ & 285.72 & 315.08 & 83.5 & 10.0 & ND & ND \\
\hline $31 X-5,72-73$ & 287.22 & 316.58 & 86.0 & 10.3 & ND & ND \\
\hline $31 X-6,72-73$ & 288.72 & 318.08 & 76.3 & 9.2 & ND & ND \\
\hline $32 X-2,90-91$ & 292.60 & 321.87 & 87.8 & 10.5 & 10.37 & 0.06 \\
\hline $32 X-3,71-72$ & 293.91 & 323.18 & 59.1 & 7.1 & ND & ND \\
\hline $32 X-4,76-77$ & 295.46 & 324.73 & 81.3 & 9.8 & ND & ND \\
\hline $32 X-5,66-67$ & 296.86 & 326.13 & 76.2 & 9.1 & ND & ND \\
\hline $33 X-1,89-90$ & 300.59 & 329.07 & 70.2 & 8.4 & 8.39 & 0.09 \\
\hline $33 \times-2,70-71$ & 301.90 & 330.38 & 87.8 & 10.5 & ND & ND \\
\hline $33 X-3,67-68$ & 303.37 & 331.85 & 88.9 & 10.7 & ND & ND \\
\hline $33 X-4,82-83$ & 305.02 & 333.50 & 83.9 & 10.1 & ND & ND \\
\hline $33 X-5,82-83$ & 306.52 & 335.00 & 87.5 & 10.5 & ND & ND \\
\hline $33 X-6,69-70$ & 307.89 & 336.37 & 87.3 & 10.5 & ND & ND \\
\hline $33 X-7,56-57$ & 308.96 & 337.44 & 88.8 & 10.7 & ND & ND \\
\hline $34 X-1,54-55$ & 309.84 & 339.58 & 91.6 & 11.0 & 10.79 & 0.07 \\
\hline $34 X-2,71-72$ & 311.51 & 341.25 & 76.5 & 9.2 & ND & ND \\
\hline $34 X-3,71-72$ & 313.01 & 342.75 & 90.3 & 10.8 & ND & ND \\
\hline $34 X-4,71-72$ & 314.51 & 344.25 & 79.0 & 9.5 & ND & ND \\
\hline $34 X-5,71-72$ & 316.01 & 345.75 & 68.9 & 8.3 & ND & ND \\
\hline $34 X-6,75-76$ & 317.55 & 347.29 & 79.3 & 9.5 & ND & ND \\
\hline $35 X-1,81-82$ & 319.71 & 348.83 & 72.3 & 8.7 & 8.53 & 0.07 \\
\hline $35 X-2,81-82$ & 321.21 & 350.33 & 41.3 & 5.0 & ND & ND \\
\hline $35 X-3,81-82$ & 322.71 & 351.83 & 84.9 & 10.2 & ND & ND \\
\hline $35 X-4,81-82$ & 324.21 & 353.33 & 61.9 & 7.4 & ND & ND \\
\hline $35 X-5,81-82$ & 325.71 & 354.83 & 80.1 & 9.6 & ND & ND \\
\hline $35 X-6,81-82$ & 327.21 & 356.33 & 84.8 & 10.2 & ND & ND \\
\hline $36 X-1,64-65$ & 329.14 & 359.08 & 74.4 & 8.9 & 8.89 & 0.08 \\
\hline $36 X-2,64-65$ & 330.64 & 360.58 & 87.4 & 10.5 & ND & ND \\
\hline $36 X-3,72-73$ & 332.22 & 362.16 & 85.2 & 10.2 & ND & ND \\
\hline
\end{tabular}

\begin{tabular}{|c|c|c|c|c|c|c|}
\hline \multirow{2}{*}{$\begin{array}{l}\text { Core, section, } \\
\text { interval }(\mathrm{cm})\end{array}$} & \multicolumn{2}{|c|}{ Depth (m) } & \multicolumn{4}{|c|}{ Carbon (wt\%) } \\
\hline & CSF & CCSF-A & $\mathrm{CaCO}_{3}$ & IC & $\mathrm{TC}$ & TOC \\
\hline $36 X-4,81-82$ & 333.81 & 363.75 & 59.2 & 7.1 & ND & ND \\
\hline $36 X-5,80-81$ & 335.30 & 365.24 & 68.1 & 8.2 & ND & ND \\
\hline $36 X-6,81-82$ & 336.81 & 366.75 & 75.5 & 9.1 & ND & ND \\
\hline $36 X-7,36-37$ & 337.76 & 367.70 & 83.1 & 10.0 & ND & ND \\
\hline $37 X-1,77-78$ & 338.77 & 369.31 & 80.2 & 9.6 & 9.50 & 0.06 \\
\hline $37 X-2,38-39$ & 339.88 & 370.42 & 41.3 & 5.0 & ND & ND \\
\hline $37 X-3,77-78$ & 341.77 & 372.31 & 39.4 & 4.7 & ND & ND \\
\hline $37 X-4,81-82$ & 343.31 & 373.85 & 60.1 & 7.2 & ND & ND \\
\hline $37 X-5,85-86$ & 344.85 & 375.39 & 51.2 & 6.2 & ND & ND \\
\hline $37 X-6,59-60$ & 346.09 & 376.63 & 52.0 & 6.2 & ND & ND \\
\hline $37 X-7,37-38$ & 346.87 & 377.41 & 68.4 & 8.2 & ND & ND \\
\hline $38 X-1,60-61$ & 348.20 & 379.30 & 63.2 & 7.6 & 7.50 & 0.06 \\
\hline $38 X-2,60-61$ & 349.70 & 380.80 & 81.0 & 9.7 & ND & ND \\
\hline $38 X-3,65-66$ & 351.25 & 382.35 & 67.9 & 8.2 & ND & ND \\
\hline $38 X-4,29-30$ & 351.89 & 382.99 & 82.6 & 9.9 & ND & ND \\
\hline $39 X-1,144-145$ & 358.64 & 389.17 & 85.0 & 10.2 & 10.10 & 0.07 \\
\hline $39 X-2,101-102$ & 359.71 & 390.24 & 67.6 & 8.1 & ND & ND \\
\hline $39 X-3,99-100$ & 361.19 & 391.72 & 81.1 & 9.7 & ND & ND \\
\hline $39 X-4,82-83$ & 362.52 & 393.05 & 85.1 & 10.2 & ND & ND \\
\hline $39 X-5,59-60$ & 363.79 & 394.32 & 76.9 & 9.2 & ND & ND \\
\hline $39 X-6,60-61$ & 365.30 & 395.83 & 58.2 & 7.0 & ND & ND \\
\hline $39 X-7,60-61$ & 366.50 & 397.03 & 77.9 & 9.4 & ND & ND \\
\hline $40 X-1,138-139$ & 368.18 & 400.91 & 71.2 & 8.6 & 8.50 & 0.08 \\
\hline $40 X-2,81-82$ & 369.11 & 401.84 & 92.3 & 11.1 & ND & ND \\
\hline $40 X-3,134-135$ & 371.14 & 403.87 & 84.0 & 10.1 & ND & ND \\
\hline $40 X-4,128-129$ & 372.58 & 405.31 & 79.2 & 9.5 & ND & ND \\
\hline $40 X-5,88-89$ & 373.68 & 406.41 & 63.9 & 7.7 & ND & ND \\
\hline $40 X-6,115-116$ & 375.45 & 408.18 & 86.0 & 10.3 & ND & ND \\
\hline $40 x-7,36-37$ & 375.86 & 408.59 & 80.0 & 9.6 & ND & ND \\
\hline $41 X-1,62-63$ & 377.02 & 410.25 & 84.3 & 10.1 & 10.14 & 0.09 \\
\hline $41 X-2,38-39$ & 378.28 & 411.51 & 85.4 & 10.3 & ND & ND \\
\hline $41 X-3,14-15$ & 379.54 & 412.77 & 89.3 & 10.7 & ND & ND \\
\hline $41 X-4,13-14$ & 381.03 & 414.26 & 85.9 & 10.3 & ND & ND \\
\hline $41 X-5,12-13$ & 382.52 & 415.75 & 90.2 & 10.8 & ND & ND \\
\hline $41 X-6,28-29$ & 384.18 & 417.41 & 83.3 & 10.0 & ND & ND \\
\hline $41 X-7,53-54$ & 385.63 & 418.86 & 86.0 & 10.3 & 10.33 & 0.07 \\
\hline $42 X-1,37-38$ & 386.37 & 421.90 & 86.4 & 10.4 & ND & ND \\
\hline $42 X-2,3-4$ & 387.53 & 423.06 & 86.9 & 10.4 & ND & ND \\
\hline $42 X-3,0-1$ & 389.00 & 424.53 & 89.7 & 10.8 & ND & ND \\
\hline $42 X-4,60-61$ & 391.10 & 426.63 & 90.5 & 10.9 & ND & ND \\
\hline $42 X-5,48-49$ & 392.48 & 428.01 & 79.0 & 9.5 & ND & ND \\
\hline $43 X-1,64-65$ & 396.24 & 431.37 & 86.2 & 10.3 & 10.24 & 0.06 \\
\hline $43 X-2,58-59$ & 397.68 & 432.81 & 84.9 & 10.2 & ND & ND \\
\hline $43 X-3,7-8$ & 398.67 & 433.80 & 85.8 & 10.3 & ND & ND \\
\hline $43 X-4,56-57$ & 400.66 & 435.79 & 87.1 & 10.5 & ND & ND \\
\hline $43 X-5,24-25$ & 401.84 & 436.97 & 90.2 & 10.8 & ND & ND \\
\hline $43 X-6,40-41$ & 403.50 & 438.63 & 88.1 & 10.6 & ND & ND \\
\hline $43 X-7,29-30$ & 404.39 & 439.52 & 89.7 & 10.8 & ND & ND \\
\hline $44 X-1,105-106$ & 405.95 & 441.08 & 92.1 & 11.1 & 11.00 & 0.17 \\
\hline $44 X-2,75-76$ & 407.15 & 442.28 & 91.2 & 11.0 & ND & ND \\
\hline $44 X-3,85-86$ & 408.75 & 443.88 & 90.1 & 10.8 & ND & ND \\
\hline $44 X-4,114-115$ & 410.54 & 445.67 & 90.4 & 10.9 & ND & ND \\
\hline $44 X-5,113-114$ & 412.03 & 447.16 & 86.1 & 10.3 & ND & ND \\
\hline $44 X-6,89-90$ & 413.29 & 448.42 & 91.8 & 11.0 & ND & ND \\
\hline $44 X-7,70-71$ & 414.10 & 449.23 & 86.2 & 10.3 & ND & ND \\
\hline $45 X-1,92-93$ & 415.42 & 451.36 & 84.3 & 10.1 & 10.04 & 0.05 \\
\hline $45 X-2,118-119$ & 417.18 & 453.12 & 84.3 & 10.1 & ND & ND \\
\hline $45 X-3,105-106$ & 418.55 & 454.49 & 88.1 & 10.6 & ND & ND \\
\hline $45 X-4,109-110$ & 420.09 & 456.03 & 89.0 & 10.7 & ND & ND \\
\hline $45 X-5,61-62$ & 421.11 & 457.05 & 91.9 & 11.0 & ND & ND \\
\hline $45 X-6,11-12$ & 422.11 & 458.05 & 87.9 & 10.5 & ND & ND \\
\hline $46 X-1,78-79$ & 424.78 & 467.19 & 93.0 & 11.2 & 11.17 & 0.05 \\
\hline $46 X-2,57-58$ & 426.07 & 468.48 & 93.4 & 11.2 & ND & ND \\
\hline $46 X-3,56-57$ & 427.56 & 469.97 & 93.5 & 11.2 & ND & ND \\
\hline $46 X-4,5-6$ & 428.55 & 470.96 & 90.2 & 10.8 & ND & ND \\
\hline $46 X-5,65-66$ & 430.65 & 473.06 & 93.0 & 11.2 & ND & ND \\
\hline $46 X-6,34-35$ & 431.84 & 474.25 & 94.9 & 11.4 & ND & ND \\
\hline $46 X-7,45-46$ & 433.05 & 475.46 & 94.6 & 11.4 & ND & ND \\
\hline $47 X-1,56-57$ & 434.16 & 478.67 & 95.0 & 11.4 & 11.28 & 0.07 \\
\hline
\end{tabular}


Table T19 (continued).

\begin{tabular}{|c|c|c|c|c|c|c|}
\hline \multirow{2}{*}{$\begin{array}{l}\text { Core, section, } \\
\text { interval }(\mathrm{cm})\end{array}$} & \multicolumn{2}{|c|}{ Depth $(\mathrm{m})$} & \multicolumn{4}{|c|}{ Carbon (wt\%) } \\
\hline & CSF & CCSF-A & $\mathrm{CaCO}_{3}$ & IC & TC & TOC \\
\hline $47 X-2,90-91$ & 436.00 & 480.51 & 95.2 & 11.4 & ND & ND \\
\hline $47 X-3,64-65$ & 437.24 & 481.75 & 96.1 & 11.5 & ND & ND \\
\hline $47 X-4,74-75$ & 438.84 & 483.35 & 94.7 & 11.4 & ND & ND \\
\hline $47 X-5,50-51$ & 440.10 & 484.61 & 93.0 & 11.2 & ND & ND \\
\hline $47 X-6,85-86$ & 441.95 & 486.46 & 91.1 & 10.9 & ND & ND \\
\hline $47 X-7,54-55$ & 442.86 & 487.37 & 89.2 & 10.7 & ND & ND \\
\hline $48 X-1,65-66$ & 443.85 & 488.84 & 92.9 & 11.2 & 10.98 & 0.07 \\
\hline $48 X-2,91-92$ & 445.61 & 490.60 & 94.9 & 11.4 & ND & ND \\
\hline $48 X-3,109-110$ & 447.29 & 492.28 & 92.3 & 11.1 & ND & ND \\
\hline $48 X-4,109-110$ & 448.79 & 493.78 & 76.9 & 9.2 & ND & ND \\
\hline \multicolumn{7}{|l|}{ 321-U1337B- } \\
\hline $22 \mathrm{H}-1,71-72$ & 201.21 & 221.69 & 26.7 & 3.2 & 3.25 & 0.11 \\
\hline $22 \mathrm{H}-2,73-74$ & 202.73 & 223.21 & 73.5 & 8.8 & ND & ND \\
\hline $22 \mathrm{H}-3,71-72$ & 204.21 & 224.69 & 52.6 & 6.3 & ND & ND \\
\hline $22 \mathrm{H}-4,71-72$ & 205.71 & 226.19 & 65.6 & 7.9 & ND & ND \\
\hline $22 \mathrm{H}-5,71-72$ & 207.21 & 227 & 52.6 & 6.3 & ND & ND \\
\hline $22 \mathrm{H}-6,71-72$ & 208.71 & 229 & 6. & 0.8 & ND & ND \\
\hline $22 \mathrm{H}-7,71-72$ & 209.71 & 230.19 & 37.0 & 4.4 & ND & ND \\
\hline $23 \mathrm{H}-1,71-72$ & 210.71 & 234.56 & 49.2 & 5.9 & 5.97 & 0.10 \\
\hline $23 \mathrm{H}-2,71-72$ & 212.21 & 236.06 & 79.3 & 9.5 & ND & ND \\
\hline 231 & 2 & 237 & 41.4 & 5.0 & ND & ND \\
\hline $23 \mathrm{H}-4,71-72$ & 215.21 & 239.06 & 86.3 & 10.4 & ND & ND \\
\hline $23 \mathrm{H}-5,40-41$ & 215.90 & 239.75 & 88.5 & 10.6 & ND & ND \\
\hline $24 \mathrm{H}-1,106-107$ & 220.56 & 242.51 & 89.0 & 10.7 & 10.63 & 0.06 \\
\hline $24 \mathrm{H}-2,82-83$ & 221.82 & 243.77 & 81.8 & 9.8 & ND & ND \\
\hline $24 \mathrm{H}-3,82-83$ & 223.32 & 245 & 72.2 & 8.7 & ND & ND \\
\hline $24 \mathrm{H}-4,86-87$ & 224.86 & 246.81 & 79.8 & 9.6 & ND & ND \\
\hline $24 \mathrm{H}-5,9-10$ & 225.59 & 247.54 & 76.0 & 9.1 & ND & ND \\
\hline $25 \mathrm{H}-1,94-95$ & 227.34 & 249.35 & 77.9 & 9.4 & 9.36 & 0.09 \\
\hline $25 \mathrm{H}-2,98-99$ & 228.88 & 250 & 76.7 & 9.2 & ND & ND \\
\hline $25 \mathrm{H}-3,77-78$ & 230.17 & 252 & 79.2 & 9.5 & ND & ND \\
\hline $25 \mathrm{H}-4,108-109$ & 231.98 & 253.99 & 84.6 & 10.2 & ND & ND \\
\hline $25 \mathrm{H}-5,57-58$ & 232.97 & 254.98 & 70.3 & 8.4 & ND & ND \\
\hline $26 \mathrm{H}-1,82-83$ & 235.12 & 256.45 & 78.6 & 9.4 & 9.35 & 0.05 \\
\hline $26 \mathrm{H}-2,63-64$ & 236.43 & 257.76 & 85.1 & 10.2 & ND & ND \\
\hline $26 \mathrm{H}-3,91-92$ & 238.21 & 259.54 & 82.5 & 9.9 & ND & ND \\
\hline $26 \mathrm{H}-4,88-89$ & 239.68 & 261.01 & 73.3 & 8.8 & ND & ND \\
\hline $26 \mathrm{H}-5,83-84$ & 241.13 & 262.46 & 83.3 & 10.0 & ND & ND \\
\hline $26 \mathrm{H}-6,73-74$ & 242.53 & 263.86 & 86.2 & 10.3 & ND & ND \\
\hline
\end{tabular}

Notes: IC = inorganic carbon, $\mathrm{TC}=$ total carbon, $\mathrm{TOC}=$ total organic carbon determined by acidification method. ND = not determined. Bold $=$ averaged values of replicated measurements. 
Table T20. Moisture and density measurements, Site U1337. (Continued on next two pages.)

\begin{tabular}{|c|c|c|c|c|c|c|}
\hline \multirow[b]{2}{*}{$\begin{array}{l}\text { Core, section, } \\
\text { interval }(\mathrm{cm})\end{array}$} & \multirow[b]{2}{*}{$\begin{array}{l}\text { Depth } \\
\text { CSF (m) }\end{array}$} & \multirow{2}{*}{$\begin{array}{l}\text { Water } \\
\text { content } \\
\text { (wt\%) }\end{array}$} & \multicolumn{3}{|c|}{ Density $\left(\mathrm{g} / \mathrm{cm}^{3}\right)$} & \multirow[b]{2}{*}{$\begin{array}{l}\text { Porosity } \\
\text { (\%) }\end{array}$} \\
\hline & & & $\begin{array}{l}\text { Wet } \\
\text { bulk }\end{array}$ & $\begin{array}{l}\text { Dry } \\
\text { bulk }\end{array}$ & Grain & \\
\hline \multicolumn{7}{|l|}{ 321-U1337A- } \\
\hline $2 \mathrm{H}-1,80-82$ & 6.31 & 81.0 & 1.15 & 0.22 & 2.44 & 91.0 \\
\hline $2 \mathrm{H}-2,76-78$ & 7.77 & 76.4 & 1.19 & 0.28 & 2.57 & 89.0 \\
\hline $2 \mathrm{H}-3,74-76$ & 9.25 & 82.7 & 1.13 & 0.20 & 2.25 & 91.3 \\
\hline $2 \mathrm{H}-4,74-76$ & 10.75 & 78.6 & 1.18 & 0.25 & 2.59 & 90.3 \\
\hline $2 \mathrm{H}-5,72-74$ & 12.23 & 77.9 & 1.18 & 0.26 & 2.50 & 89.6 \\
\hline $2 \mathrm{H}-6,74-76$ & 13.75 & 52.3 & 1.46 & 0.69 & 2.70 & 74.3 \\
\hline $2 \mathrm{H}-7,45-47$ & 14.96 & 54.0 & 1.42 & 0.65 & 2.57 & 74.7 \\
\hline $3 \mathrm{H}-1,74-76$ & 15.75 & 67.3 & 1.28 & 0.42 & 2.62 & 84.1 \\
\hline $3 \mathrm{H}-2,74-76$ & 17.25 & 83.8 & 1.13 & 0.18 & 2.40 & 92.4 \\
\hline $3 \mathrm{H}-3,74-76$ & 18.75 & 72.8 & 1.21 & 0.33 & 2.42 & 86.3 \\
\hline $3 \mathrm{H}-4,72-74$ & 20.23 & 83.9 & 1.13 & 0.18 & 2.47 & 92.6 \\
\hline $3 \mathrm{H}-5,70-72$ & 21.71 & 72.7 & 1.21 & 0.33 & 2.39 & 86.1 \\
\hline $3 \mathrm{H}-6,74-76$ & 23.25 & 77.9 & 1.18 & 0.26 & 2.50 & 89.6 \\
\hline $3 \mathrm{H}-7,45-47$ & 24.46 & 71.4 & 1.22 & 0.35 & 2.40 & 85.4 \\
\hline $4 \mathrm{H}-1,129-131$ & 25.80 & 74.0 & 1.22 & 0.32 & 2.66 & 88.1 \\
\hline $4 \mathrm{H}-2,74-76$ & 26.75 & 82.9 & 1.13 & 0.19 & 2.35 & 91.8 \\
\hline $4 \mathrm{H}-3,74-76$ & 28.25 & 82.9 & 1.14 & 0.19 & 2.48 & 92.1 \\
\hline $4 \mathrm{H}-4,74-76$ & 29.75 & 83.0 & 1.13 & 0.19 & 2.42 & 92.0 \\
\hline $4 \mathrm{H}-5,74-76$ & 31.25 & 82.1 & 1.15 & 0.21 & 2.73 & 92.5 \\
\hline $4 \mathrm{H}-6,74-76$ & 32.75 & 80.6 & 1.15 & 0.22 & 2.46 & 90.9 \\
\hline $4 \mathrm{H}-7,54-56$ & 34.05 & 71.0 & 1.23 & 0.36 & 2.48 & 85.5 \\
\hline $5 \mathrm{H}-1,74-76$ & 34.75 & 78.8 & 1.17 & 0.25 & 2.49 & 90.1 \\
\hline $5 \mathrm{H}-2,74-76$ & 36.25 & 66.8 & 1.28 & 0.42 & 2.59 & 83.6 \\
\hline $5 \mathrm{H}-3,74-76$ & 37.75 & 68.6 & 1.26 & 0.39 & 2.50 & 84.2 \\
\hline $5 \mathrm{H}-4,74-76$ & 39.25 & 75.0 & 1.21 & 0.30 & 2.60 & 88.4 \\
\hline $5 \mathrm{H}-5,74-76$ & 40.75 & 67.3 & 1.28 & 0.42 & 2.60 & 83.9 \\
\hline $5 \mathrm{H}-6,74-76$ & 42.25 & 74.9 & 1.21 & 0.30 & 2.59 & 88.3 \\
\hline $5 \mathrm{H}-7,45-47$ & 43.46 & 72.1 & 1.22 & 0.34 & 2.41 & 85.9 \\
\hline $6 \mathrm{H}-1,74-76$ & 44.25 & 77.2 & 1.19 & 0.27 & 2.57 & 89.5 \\
\hline $6 \mathrm{H}-2,74-76$ & 45.75 & 83.6 & 1.13 & 0.18 & 2.37 & 92.2 \\
\hline $6 \mathrm{H}-3,82-84$ & 47.33 & 84.0 & 1.12 & 0.18 & 2.27 & 92.1 \\
\hline $6 \mathrm{H}-4,75-77$ & 48.76 & 80.1 & 1.16 & 0.23 & 2.49 & 90.7 \\
\hline $6 \mathrm{H}-5,74-76$ & 50.25 & 79.4 & 1.16 & 0.24 & 2.30 & 89.7 \\
\hline $6 \mathrm{H}-6,74-76$ & 51.75 & 73.2 & 1.22 & 0.33 & 2.55 & 87.1 \\
\hline $6 \mathrm{H}-7,54-56$ & 53.05 & 76.5 & 1.18 & 0.28 & 2.35 & 88.2 \\
\hline $7 \mathrm{H}-1,74-76$ & 53.75 & 80.0 & 1.16 & 0.23 & 2.46 & 90.6 \\
\hline 7H-2, 74-76 & 55.25 & 81.9 & 1.14 & 0.21 & 2.28 & 91.0 \\
\hline $7 \mathrm{H}-3,74-76$ & 56.75 & 76.4 & 1.19 & 0.28 & 2.49 & 88.7 \\
\hline 7H-4, 94-96 & 58.45 & 78.8 & 1.16 & 0.25 & 2.27 & 89.2 \\
\hline $7 \mathrm{H}-5,81-83$ & 59.82 & 79.8 & 1.15 & 0.23 & 2.31 & 89.9 \\
\hline 7H-6, 104-106 & 61.55 & 82.2 & 1.14 & 0.20 & 2.40 & 91.6 \\
\hline 7H-7, 34-36 & 62.35 & 81.5 & 1.14 & 0.21 & 2.39 & 91.2 \\
\hline $8 \mathrm{H}-1,74-76$ & 63.25 & 80.1 & 1.16 & 0.23 & 2.53 & 90.8 \\
\hline $8 \mathrm{H}-2,74-76$ & 64.75 & 76.1 & 1.21 & 0.29 & 2.85 & 89.9 \\
\hline $8 \mathrm{H}-3,69-71$ & 66.20 & 75.2 & 1.19 & 0.30 & 2.34 & 87.4 \\
\hline $8 \mathrm{H}-4,74-76$ & 67.75 & 77.7 & 1.18 & 0.26 & 2.44 & 89.2 \\
\hline $8 \mathrm{H}-5,74-76$ & 69.25 & 76.6 & 1.19 & 0.28 & 2.49 & 88.9 \\
\hline $8 \mathrm{H}-6,74-76$ & 70.75 & 78.1 & 1.16 & 0.25 & 2.23 & 88.6 \\
\hline $9 \mathrm{H}-1,74-76$ & 72.75 & 70.3 & 1.25 & 0.37 & 2.59 & 85.7 \\
\hline $9 \mathrm{H}-2,74-76$ & 74.25 & 79.1 & 1.17 & 0.25 & 2.55 & 90.4 \\
\hline $9 \mathrm{H}-3,74-76$ & 75.75 & 77.5 & 1.17 & 0.26 & 2.31 & 88.6 \\
\hline $9 \mathrm{H}-4,74-76$ & 77.25 & 75.8 & 1.19 & 0.29 & 2.49 & 88.4 \\
\hline $9 \mathrm{H}-5,74-76$ & 78.75 & 68.6 & 1.25 & 0.39 & 2.46 & 84.0 \\
\hline $9 \mathrm{H}-6,74-76$ & 80.25 & 79.9 & 1.16 & 0.23 & 2.45 & 90.5 \\
\hline $9 \mathrm{H}-7,19-21$ & 81.20 & 71.8 & 1.22 & 0.35 & 2.39 & 85.6 \\
\hline $10 \mathrm{H}-1,54-56$ & 82.05 & 78.7 & 1.17 & 0.25 & 2.43 & 89.8 \\
\hline $10 \mathrm{H}-2,74-76$ & 83.75 & 77.5 & 1.18 & 0.27 & 2.49 & 89.3 \\
\hline $10 \mathrm{H}-3,74-76$ & 85.25 & 61.5 & 1.34 & 0.51 & 2.59 & 80.2 \\
\hline $10 \mathrm{H}-4,74-76$ & 86.75 & 58.6 & 1.37 & 0.57 & 2.58 & 78.1 \\
\hline $10 \mathrm{H}-5,74-76$ & 88.25 & 77.7 & 1.17 & 0.26 & 2.26 & 88.5 \\
\hline $10 \mathrm{H}-6,74-76$ & 89.75 & 58.7 & 1.37 & 0.57 & 2.61 & 78.4 \\
\hline $10 \mathrm{H}-7,44-46$ & 90.95 & 74.0 & 1.20 & 0.31 & 2.29 & 86.4 \\
\hline $11 \mathrm{H}-1,74-76$ & 91.75 & 75.2 & 1.18 & 0.29 & 2.26 & 87.0 \\
\hline $11 \mathrm{H}-2,74-76$ & 93.25 & 76.3 & 1.19 & 0.28 & 2.47 & 88.6 \\
\hline $11 \mathrm{H}-3,74-76$ & 94.75 & 69.3 & 1.24 & 0.38 & 2.41 & 84.2 \\
\hline $11 \mathrm{H}-4,74-76$ & 96.25 & 73.0 & 1.22 & 0.33 & 2.47 & 86.7 \\
\hline $11 \mathrm{H}-5,74-76$ & 97.75 & 67.8 & 1.25 & 0.40 & 2.31 & 82.6 \\
\hline
\end{tabular}

\begin{tabular}{|c|c|c|c|c|c|c|}
\hline \multirow[b]{2}{*}{$\begin{array}{l}\text { Core, section, } \\
\text { interval }(\mathrm{cm})\end{array}$} & \multirow[b]{2}{*}{$\begin{array}{l}\text { Depth } \\
\text { CSF (m) }\end{array}$} & \multirow{2}{*}{$\begin{array}{l}\text { Water } \\
\text { content } \\
(\text { wt } \%)\end{array}$} & \multicolumn{3}{|c|}{ Density $\left(\mathrm{g} / \mathrm{cm}^{3}\right)$} & \multirow[b]{2}{*}{$\begin{array}{l}\text { Porosity } \\
\text { (\%) }\end{array}$} \\
\hline & & & $\begin{array}{l}\text { Wet } \\
\text { bulk }\end{array}$ & $\begin{array}{l}\text { Dry } \\
\text { bulk }\end{array}$ & Grain & \\
\hline $11 \mathrm{H}-6,72-74$ & 99.23 & 77.9 & 1.18 & 0.26 & 2.54 & 89.7 \\
\hline $11 \mathrm{H}-7,43-45$ & 100.44 & 78.1 & 1.17 & 0.26 & 2.41 & 89.4 \\
\hline $12 \mathrm{H}-1,109-111$ & 101.60 & 75.6 & 1.18 & 0.29 & 2.24 & 87.1 \\
\hline $12 \mathrm{H}-2,103-105$ & 103.04 & 72.0 & 1.23 & 0.34 & 2.55 & 86.5 \\
\hline $12 \mathrm{H}-3,99-101$ & 104.50 & 69.1 & 1.24 & 0.38 & 2.38 & 83.9 \\
\hline $12 \mathrm{H}-4,121-123$ & 106.22 & 63.1 & 1.32 & 0.49 & 2.66 & 81.6 \\
\hline $12 \mathrm{H}-5,84-86$ & 107.35 & 62.4 & 1.32 & 0.50 & 2.58 & 80.7 \\
\hline $12 \mathrm{H}-6,94-96$ & 108.95 & 63.4 & 1.30 & 0.48 & 2.41 & 80.3 \\
\hline $12 \mathrm{H}-7,31-33$ & 109.82 & 59.1 & 1.38 & 0.56 & 2.78 & 79.7 \\
\hline $13 \mathrm{H}-1,86-88$ & 110.87 & 59.7 & 1.36 & 0.55 & 2.61 & 79.0 \\
\hline $13 \mathrm{H}-2,91-93$ & 112.42 & 60.2 & 1.35 & 0.54 & 2.57 & 79.2 \\
\hline $13 \mathrm{H}-3,91-93$ & 113.92 & 75.8 & 1.20 & 0.29 & 2.69 & 89.2 \\
\hline $13 \mathrm{H}-4,91-93$ & 115.42 & 68.5 & 1.26 & 0.40 & 2.51 & 84.2 \\
\hline $13 \mathrm{H}-5,86-88$ & 116.87 & 71.5 & 1.23 & 0.35 & 2.49 & 85.9 \\
\hline $13 \mathrm{H}-6,92-94$ & 118.43 & 76.7 & 1.20 & 0.28 & 2.71 & 89.7 \\
\hline $13 \mathrm{H}-7,26-28$ & 119.27 & 66.1 & 1.29 & 0.44 & 2.56 & 82.9 \\
\hline $14 \mathrm{H}-1,76-78$ & 120.27 & 70.6 & 1.25 & 0.37 & 2.61 & 86.0 \\
\hline $14 \mathrm{H}-2,71-73$ & 121.72 & 71.5 & 1.23 & 0.35 & 2.46 & 85.8 \\
\hline $14 \mathrm{H}-3,74-76$ & 123.25 & 57.8 & 1.39 & 0.59 & 2.72 & 78.5 \\
\hline $14 \mathrm{H}-4,74-76$ & 124.75 & 63.5 & 1.31 & 0.48 & 2.59 & 81.5 \\
\hline $14 \mathrm{H}-5,74-76$ & 126.25 & 58.5 & 1.37 & 0.57 & 2.62 & 78.3 \\
\hline $14 \mathrm{H}-6,74-76$ & 127.75 & 56.1 & 1.39 & 0.61 & 2.59 & 76.4 \\
\hline $14 \mathrm{H}-7,50-52$ & 129.01 & 42.8 & 1.59 & 0.91 & 2.69 & 66.2 \\
\hline $15 \mathrm{H}-1,74-76$ & 129.75 & 49.1 & 1.51 & 0.77 & 2.77 & 72.3 \\
\hline $15 \mathrm{H}-2,74-76$ & 131.25 & 66.6 & 1.28 & 0.43 & 2.52 & 83.1 \\
\hline $15 \mathrm{H}-3,74-76$ & 132.75 & 62.0 & 1.33 & 0.50 & 2.58 & 80.4 \\
\hline $15 \mathrm{H}-4,74-76$ & 134.25 & 63.1 & 1.33 & 0.49 & 2.74 & 82.1 \\
\hline $15 \mathrm{H}-5,74-76$ & 135.75 & 68.3 & 1.26 & 0.40 & 2.44 & 83.7 \\
\hline $15 \mathrm{H}-6,69-71$ & 137.20 & 62.7 & 1.32 & 0.49 & 2.61 & 81.0 \\
\hline $15 \mathrm{H}-7,39-41$ & 138.40 & 75.6 & 1.20 & 0.29 & 2.50 & 88.3 \\
\hline $16 \mathrm{H}-1,74-76$ & 139.25 & 61.9 & 1.34 & 0.51 & 2.74 & 81.3 \\
\hline $16 \mathrm{H}-2,74-76$ & 140.75 & 59.0 & 1.36 & 0.56 & 2.59 & 78.5 \\
\hline $16 \mathrm{H}-3,84-86$ & 142.35 & 69.8 & 1.24 & 0.38 & 2.49 & 84.9 \\
\hline $16 \mathrm{H}-4,74-76$ & 143.75 & 70.8 & 1.23 & 0.36 & 2.43 & 85.2 \\
\hline $16 \mathrm{H}-5,74-76$ & 145.25 & 73.9 & 1.21 & 0.32 & 2.43 & 87.0 \\
\hline $16 \mathrm{H}-6,74-76$ & 146.75 & 58.6 & 1.38 & 0.57 & 2.76 & 79.2 \\
\hline $16 \mathrm{H}-7,34-36$ & 147.85 & 71.8 & 1.22 & 0.35 & 2.43 & 85.8 \\
\hline $17 \mathrm{H}-1,84-86$ & 148.85 & 51.1 & 1.46 & 0.71 & 2.65 & 73.0 \\
\hline $17 \mathrm{H}-2,91-93$ & 150.42 & 63.4 & 1.33 & 0.49 & 2.75 & 82.3 \\
\hline $17 \mathrm{H}-3,84-86$ & 151.85 & 60.6 & 1.34 & 0.53 & 2.56 & 79.3 \\
\hline $17 \mathrm{H}-4,74-76$ & 153.25 & 53.6 & 1.43 & 0.66 & 2.62 & 74.7 \\
\hline $17 \mathrm{H}-5,74-76$ & 154.75 & 54.8 & 1.41 & 0.64 & 2.62 & 75.6 \\
\hline $17 \mathrm{H}-6,84-86$ & 156.35 & 61.4 & 1.35 & 0.52 & 2.70 & 80.8 \\
\hline $17 \mathrm{H}-7,44-46$ & 157.45 & 54.7 & 1.42 & 0.64 & 2.63 & 75.6 \\
\hline $18 \mathrm{H}-1,74-76$ & 158.25 & 54.9 & 1.41 & 0.64 & 2.61 & 75.6 \\
\hline $18 \mathrm{H}-2,74-76$ & 159.75 & 73.0 & 1.21 & 0.33 & 2.37 & 86.2 \\
\hline $18 \mathrm{H}-3,99-101$ & 161.52 & 61.9 & 1.33 & 0.51 & 2.54 & 80.1 \\
\hline $18 \mathrm{H}-4,74-76$ & 162.79 & 60.6 & 1.36 & 0.54 & 2.78 & 80.7 \\
\hline $18 \mathrm{H}-5,74-76$ & 164.29 & 62.9 & 1.31 & 0.49 & 2.48 & 80.4 \\
\hline $18 \mathrm{H}-6,74-76$ & 165.79 & 76.1 & 1.18 & 0.28 & 2.36 & 88.0 \\
\hline $18 \mathrm{H}-7,51-53$ & 167.06 & 63.4 & 1.33 & 0.49 & 2.74 & 82.3 \\
\hline $19 \mathrm{H}-1,74-76$ & 167.75 & 73.1 & 1.21 & 0.33 & 2.35 & 86.1 \\
\hline $19 \mathrm{H}-2,74-76$ & 169.25 & 65.6 & 1.28 & 0.44 & 2.49 & 82.3 \\
\hline $19 \mathrm{H}-3,64-66$ & 170.65 & 67.4 & 1.27 & 0.41 & 2.49 & 83.4 \\
\hline $19 \mathrm{H}-4,74-76$ & 172.25 & 60.8 & 1.36 & 0.53 & 2.74 & 80.6 \\
\hline $19 \mathrm{H}-5,74-76$ & 173.75 & 73.4 & 1.20 & 0.32 & 2.31 & 86.2 \\
\hline $19 \mathrm{H}-6,74-76$ & 175.25 & 75.4 & 1.19 & 0.29 & 2.35 & 87.6 \\
\hline $19 \mathrm{H}-7,24-26$ & 176.25 & 72.2 & 1.22 & 0.34 & 2.42 & 86.0 \\
\hline $20 \mathrm{H}-1,79-81$ & 177.30 & 75.1 & 1.21 & 0.30 & 2.58 & 88.4 \\
\hline $20 \mathrm{H}-2,79-81$ & 178.80 & 77.2 & 1.17 & 0.27 & 2.31 & 88.4 \\
\hline $20 \mathrm{H}-3,79-81$ & 180.30 & 68.4 & 1.26 & 0.40 & 2.54 & 84.3 \\
\hline $20 \mathrm{H}-4,79-81$ & 181.80 & 78.2 & 1.17 & 0.26 & 2.45 & 89.6 \\
\hline $20 \mathrm{H}-5,64-66$ & 183.15 & 66.5 & 1.29 & 0.43 & 2.72 & 84.1 \\
\hline $20 \mathrm{H}-7,27-29$ & 185.78 & 59.1 & 1.36 & 0.56 & 2.60 & 78.6 \\
\hline $20 \mathrm{H}-\mathrm{CC}, 17-19$ & 186.35 & 70.0 & 1.22 & 0.37 & 2.22 & 83.5 \\
\hline $21 \mathrm{H}-1,74-76$ & 186.75 & 72.9 & 1.23 & 0.33 & 2.71 & 87.7 \\
\hline $21 \mathrm{H}-2,74-76$ & 188.25 & 58.1 & 1.37 & 0.57 & 2.57 & 77.7 \\
\hline $21 \mathrm{H}-3,74-76$ & 189.75 & 62.8 & 1.32 & 0.49 & 2.53 & 80.6 \\
\hline
\end{tabular}


Table T20 (continued). (Continued on next page.)

\begin{tabular}{|c|c|c|c|c|c|c|}
\hline \multirow[b]{2}{*}{$\begin{array}{l}\text { Core, section, } \\
\text { interval }(\mathrm{cm})\end{array}$} & \multirow[b]{2}{*}{$\begin{array}{l}\text { Depth } \\
\text { CSF }(m)\end{array}$} & \multirow{2}{*}{$\begin{array}{c}\text { Water } \\
\text { content } \\
\text { (wt\%) }\end{array}$} & \multicolumn{3}{|c|}{ Density $\left(\mathrm{g} / \mathrm{cm}^{3}\right)$} & \multirow[b]{2}{*}{$\begin{array}{c}\text { Porosity } \\
\text { (\%) }\end{array}$} \\
\hline & & & $\begin{array}{l}\text { Wet } \\
\text { bulk }\end{array}$ & $\begin{array}{l}\text { Dry } \\
\text { bulk }\end{array}$ & Grain & \\
\hline $21 \mathrm{H}-4,76-78$ & 191.27 & 70.9 & 1.24 & 0.36 & 2.58 & 86.0 \\
\hline $21 \mathrm{H}-5,88-90$ & 192.90 & 59.9 & 1.34 & 0.54 & 2.50 & 78.5 \\
\hline $21 \mathrm{H}-6,91-93$ & 194.45 & 67.7 & 1.27 & 0.41 & 2.55 & 83.9 \\
\hline $21 \mathrm{H}-7,20-22$ & 195.14 & 67.9 & 1.26 & 0.41 & 2.47 & 83.6 \\
\hline $22 X-1,52-54$ & 196.03 & 65.4 & 1.29 & 0.45 & 2.53 & 82.4 \\
\hline $22 X-2,52-54$ & 197.53 & 61.7 & 1.33 & 0.51 & 2.59 & 80.3 \\
\hline $23 X-1,70-72$ & 205.01 & 65.1 & 1.30 & 0.45 & 2.59 & 82.5 \\
\hline $23 X-2,72-74$ & 206.53 & 64.9 & 1.29 & 0.45 & 2.54 & 82.1 \\
\hline $23 X-3,72-74$ & 208.03 & 63.6 & 1.31 & 0.48 & 2.54 & 81.3 \\
\hline $23 X-4,62-64$ & 209.43 & 71.3 & 1.22 & 0.35 & 2.37 & 85.2 \\
\hline $23 X-5,63-65$ & 210.94 & 73.0 & 1.21 & 0.33 & 2.35 & 86.1 \\
\hline $23 X-6,64-66$ & 212.45 & 67.1 & 1.27 & 0.42 & 2.49 & 83.2 \\
\hline $23 X-7,64-66$ & 213.55 & 63.6 & 1.31 & 0.48 & 2.56 & 81.4 \\
\hline $24 X-1,94-96$ & 214.85 & 57.7 & 1.38 & 0.58 & 2.59 & 77.5 \\
\hline $24 X-2,74-76$ & 216.15 & 56.4 & 1.39 & 0.61 & 2.61 & 76.7 \\
\hline $24 X-3,74-76$ & 217.65 & 59.9 & 1.35 & 0.54 & 2.55 & 78.8 \\
\hline $24 X-4,74-76$ & 218.75 & 54.0 & 1.41 & 0.65 & 2.55 & 74.5 \\
\hline $25 X-1,74-76$ & 224.15 & 52.1 & 1.45 & 0.69 & 2.64 & 73.7 \\
\hline $25 X-2,74-76$ & 225.65 & 47.9 & 1.51 & 0.79 & 2.68 & 70.7 \\
\hline $25 X-3,79-81$ & 227.20 & 49.4 & 1.49 & 0.75 & 2.65 & 71.6 \\
\hline $25 X-4,104-106$ & 228.95 & 49.7 & 1.48 & 0.75 & 2.65 & 71.9 \\
\hline $25 X-5,74-76$ & 230.15 & 49.8 & 1.48 & 0.74 & 2.64 & 71.8 \\
\hline $25 X-6,66-68$ & 231.57 & 48.0 & 1.50 & 0.78 & 2.63 & 70.4 \\
\hline $25 X-7,58-60$ & 232.49 & 44.9 & 1.55 & 0.86 & 2.69 & 68.1 \\
\hline $26 X-1,74-76$ & 233.75 & 50.0 & 1.47 & 0.74 & 2.62 & 71.9 \\
\hline $26 X-2,74-76$ & 235.25 & 49.9 & 1.47 & 0.74 & 2.60 & 71.7 \\
\hline $26 X-3,95-97$ & 236.96 & 57.8 & 1.38 & 0.58 & 2.64 & 77.9 \\
\hline $26 X-4,74-76$ & 238.25 & 51.9 & 1.45 & 0.70 & 2.64 & 73.5 \\
\hline $26 X-5,91-93$ & 239.92 & 49.1 & 1.48 & 0.75 & 2.60 & 71.1 \\
\hline $26 X-6,52-54$ & 241.03 & 44.4 & 1.57 & 0.87 & 2.71 & 67.9 \\
\hline $26 X-7,74-76$ & 242.25 & 47.6 & 1.51 & 0.79 & 2.66 & 70.2 \\
\hline $27 X-1,65-67$ & 242.86 & 58.1 & 1.37 & 0.57 & 2.56 & 77.6 \\
\hline 28X-1, 99-101 & 252.70 & 45.5 & 1.54 & 0.84 & 2.68 & 68.6 \\
\hline 28X-2, 99-101 & 254.20 & 41.6 & 1.61 & 0.94 & 2.70 & 65.2 \\
\hline $28 X-3,59-61$ & 255.30 & 38.7 & 1.65 & 1.01 & 2.69 & 62.4 \\
\hline $28 X-4,39-41$ & 256.10 & 38.8 & 1.66 & 1.02 & 2.74 & 62.9 \\
\hline $29 X-1,74-76$ & 262.05 & 43.2 & 1.58 & 0.90 & 2.68 & 66.6 \\
\hline $29 X-2,74-76$ & 263.55 & 53.6 & 1.42 & 0.66 & 2.55 & 74.2 \\
\hline $29 \times-3,77-79$ & 265.08 & 41.3 & 1.61 & 0.95 & 2.71 & 65.1 \\
\hline $29 X-4,78-80$ & 266.59 & 38.6 & 1.68 & 1.03 & 2.82 & 63.4 \\
\hline $29 X-5,89-91$ & 268.20 & 48.1 & 1.49 & 0.78 & 2.60 & 70.2 \\
\hline $29 X-6,59-61$ & 269.40 & 40.3 & 1.63 & 0.97 & 2.71 & 64.2 \\
\hline $29 X-7,54-56$ & 270.35 & 41.8 & 1.60 & 0.93 & 2.70 & 65.5 \\
\hline $30 X-1,87-89$ & 271.68 & 45.7 & 1.53 & 0.83 & 2.63 & 68.4 \\
\hline $30 x-2,71-73$ & 273.02 & 42.2 & 1.60 & 0.92 & 2.71 & 65.9 \\
\hline $30 X-3,87-89$ & 274.68 & 51.3 & 1.40 & 0.68 & 2.30 & 70.2 \\
\hline $30 \times-4,74-76$ & 276.05 & 43.8 & 1.57 & 0.88 & 2.67 & 67.0 \\
\hline $30 \times-5,71-73$ & 277.52 & 44.4 & 1.56 & 0.87 & 2.68 & 67.7 \\
\hline $30 \times-6,42-44$ & 278.73 & 43.8 & 1.56 & 0.88 & 2.63 & 66.7 \\
\hline $30 X-7,28-30$ & 280.09 & 42.1 & 1.59 & 0.92 & 2.66 & 65.4 \\
\hline $31 X-1,77-79$ & 281.28 & 40.0 & 1.64 & 0.98 & 2.73 & 64.0 \\
\hline $31 X-2,74-76$ & 282.75 & 43.3 & 1.58 & 0.90 & 2.71 & 67.0 \\
\hline $31 X-3,89-91$ & 284.40 & 42.1 & 1.60 & 0.93 & 2.70 & 65.8 \\
\hline $31 X-4,74-76$ & 285.75 & 43.1 & 1.59 & 0.90 & 2.72 & 66.7 \\
\hline $31 X-5,74-76$ & 287.25 & 39.3 & 1.64 & 1.00 & 2.69 & 63.0 \\
\hline $31 X-6,74-76$ & 288.75 & 42.2 & 1.60 & 0.92 & 2.70 & 65.7 \\
\hline $32 X-2,87-89$ & 292.58 & 40.0 & 1.63 & 0.98 & 2.69 & 63.6 \\
\hline $32 X-3,69-71$ & 293.90 & 54.8 & 1.40 & 0.63 & 2.54 & 75.1 \\
\hline $32 X-4,74-76$ & 295.45 & 41.9 & 1.60 & 0.93 & 2.67 & 65.3 \\
\hline $32 X-5,64-66$ & 296.85 & 45.7 & 1.54 & 0.83 & 2.65 & 68.6 \\
\hline $33 X-1,92-94$ & 300.63 & 46.0 & 1.52 & 0.82 & 2.61 & 68.5 \\
\hline $33 X-2,66-68$ & 301.87 & 40.4 & 1.62 & 0.97 & 2.68 & 64.0 \\
\hline $33 X-3,70-72$ & 303.41 & 37.8 & 1.68 & 1.04 & 2.74 & 61.9 \\
\hline $33 X-4,84-86$ & 305.05 & 40.0 & 1.62 & 0.97 & 2.66 & 63.4 \\
\hline $33 X-5,79-81$ & 306.50 & 38.9 & 1.65 & 1.01 & 2.70 & 62.7 \\
\hline $33 X-6,66-68$ & 307.87 & 38.8 & 1.65 & 1.01 & 2.70 & 62.6 \\
\hline $33 X-7,52-54$ & 308.93 & 38.4 & 1.66 & 1.02 & 2.70 & 62.1 \\
\hline $34 X-1,58-60$ & 309.89 & 38.4 & 1.67 & 1.03 & 2.74 & 62.5 \\
\hline
\end{tabular}

\begin{tabular}{|c|c|c|c|c|c|c|}
\hline \multirow[b]{2}{*}{$\begin{array}{l}\text { Core, section, } \\
\text { interval }(\mathrm{cm})\end{array}$} & \multirow[b]{2}{*}{$\begin{array}{l}\text { Depth } \\
\text { CSF (m) }\end{array}$} & \multirow{2}{*}{$\begin{array}{c}\text { Water } \\
\text { content } \\
\text { (wt\%) }\end{array}$} & \multicolumn{3}{|c|}{ Density $\left(\mathrm{g} / \mathrm{cm}^{3}\right)$} & \multirow[b]{2}{*}{$\begin{array}{c}\text { Porosity } \\
\text { (\%) }\end{array}$} \\
\hline & & & $\begin{array}{l}\text { Wet } \\
\text { bulk }\end{array}$ & $\begin{array}{l}\text { Dry } \\
\text { bulk }\end{array}$ & Grain & \\
\hline $34 X-2,97-99$ & 311.78 & 42.0 & 1.60 & 0.93 & 2.70 & 65.6 \\
\hline $34 X-3,99-101$ & 313.30 & 42.6 & 1.58 & 0.91 & 2.64 & 65.7 \\
\hline $34 X-4,96-98$ & 314.77 & 36.4 & 1.69 & 1.08 & 2.70 & 60.1 \\
\hline $34 X-5,78-80$ & 316.09 & 43.8 & 1.56 & 0.88 & 2.62 & 66.6 \\
\hline $34 X-6,69-71$ & 317.50 & 39.5 & 1.62 & 0.98 & 2.63 & 62.6 \\
\hline $35 X-1,57-59$ & 319.48 & 43.0 & 1.57 & 0.90 & 2.64 & 66.0 \\
\hline $35 X-2,69-71$ & 321.10 & 46.2 & 1.53 & 0.82 & 2.64 & 68.9 \\
\hline $35 X-3,62-64$ & 322.53 & 39.0 & 1.64 & 1.00 & 2.68 & 62.6 \\
\hline $35 X-4,87-89$ & 324.28 & 46.3 & 1.52 & 0.82 & 2.62 & 68.8 \\
\hline $35 X-5,74-76$ & 325.65 & 41.7 & 1.60 & 0.93 & 2.66 & 65.1 \\
\hline $35 X-6,32-34$ & 326.73 & 40.2 & 1.62 & 0.97 & 2.68 & 63.8 \\
\hline $36 X-1,66-68$ & 329.17 & 46.3 & 1.52 & 0.82 & 2.63 & 68.9 \\
\hline $36 X-2,66-68$ & 330.67 & 38.6 & 1.66 & 1.02 & 2.71 & 62.4 \\
\hline $36 X-3,74-76$ & 332.25 & 39.6 & 1.63 & 0.98 & 2.67 & 63.1 \\
\hline $36 X-4,81-83$ & 333.82 & 52.0 & 1.44 & 0.69 & 2.54 & 72.9 \\
\hline $36 X-5,78-80$ & 335.29 & 51.1 & 1.46 & 0.72 & 2.64 & 72.9 \\
\hline $36 X-6,78-80$ & 336.79 & 44.8 & 1.54 & 0.85 & 2.61 & 67.4 \\
\hline $36 X-7,32-34$ & 337.73 & 41.1 & 1.60 & 0.95 & 2.66 & 64.4 \\
\hline $37 X-1,83-85$ & 338.84 & 44.7 & 1.56 & 0.86 & 2.69 & 67.9 \\
\hline $37 X-2,42-44$ & 339.93 & 64.4 & 1.29 & 0.46 & 2.43 & 81.1 \\
\hline $37 X-3,80-82$ & 341.81 & 63.3 & 1.30 & 0.48 & 2.40 & 80.2 \\
\hline $37 X-4,86-88$ & 343.37 & 55.7 & 1.40 & 0.62 & 2.63 & 76.3 \\
\hline $37 X-5,88-90$ & 344.89 & 52.5 & 1.44 & 0.68 & 2.58 & 73.6 \\
\hline $37 X-6,64-66$ & 346.15 & 56.0 & 1.39 & 0.61 & 2.53 & 75.9 \\
\hline $37 X-7,41-43$ & 346.92 & 46.2 & 1.53 & 0.82 & 2.64 & 68.9 \\
\hline $38 X-1,64-66$ & 348.25 & 51.5 & 1.45 & 0.70 & 2.59 & 72.9 \\
\hline $38 X-2,115-117$ & 350.26 & 45.9 & 1.52 & 0.82 & 2.58 & 68.1 \\
\hline $38 X-3,68-70$ & 351.29 & 49.7 & 1.47 & 0.74 & 2.58 & 71.3 \\
\hline $38 X-4,26-28$ & 351.87 & 39.8 & 1.63 & 0.98 & 2.67 & 63.2 \\
\hline $39 X-1,146-148$ & 358.67 & 37.2 & 1.67 & 1.05 & 2.67 & 60.7 \\
\hline $39 X-2,107-109$ & 359.78 & 45.7 & 1.53 & 0.83 & 2.63 & 68.4 \\
\hline $39 X-3,101-103$ & 361.22 & 41.8 & 1.60 & 0.93 & 2.70 & 65.4 \\
\hline $39 X-4,86-88$ & 362.57 & 38.7 & 1.65 & 1.01 & 2.67 & 62.2 \\
\hline $39 X-5,64-66$ & 363.85 & 43.9 & 1.58 & 0.88 & 2.73 & 67.6 \\
\hline $39 X-6,64-66$ & 365.35 & 46.5 & 1.52 & 0.81 & 2.63 & 69.1 \\
\hline $39 X-7,61-63$ & 366.52 & 38.8 & 1.64 & 1.01 & 2.67 & 62.3 \\
\hline $40 X-1,141-143$ & 368.22 & 40.6 & 1.61 & 0.96 & 2.65 & 63.9 \\
\hline $40 X-2,84-86$ & 369.15 & 32.7 & 1.77 & 1.19 & 2.73 & 56.4 \\
\hline $40 x-3,138-140$ & 371.19 & 37.5 & 1.66 & 1.04 & 2.65 & 60.9 \\
\hline $40 X-4,131-133$ & 372.62 & 39.4 & 1.64 & 0.99 & 2.67 & 62.9 \\
\hline $40 X-5,89-91$ & 373.70 & 37.0 & 1.69 & 1.06 & 2.72 & 60.9 \\
\hline $40 X-6,118-120$ & 375.49 & 35.7 & 1.70 & 1.09 & 2.67 & 59.1 \\
\hline $40 x-7,40-42$ & 375.91 & 39.0 & 1.65 & 1.00 & 2.70 & 62.8 \\
\hline $41 X-1,61-63$ & 377.02 & 36.4 & 1.70 & 1.08 & 2.72 & 60.3 \\
\hline $41 X-2,39-41$ & 378.30 & 36.9 & 1.68 & 1.06 & 2.68 & 60.5 \\
\hline $41 X-3,15-17$ & 379.56 & 32.9 & 1.76 & 1.18 & 2.73 & 56.7 \\
\hline $41 X-4,15-17$ & 381.06 & 35.8 & 1.71 & 1.09 & 2.71 & 59.6 \\
\hline $41 X-5,13-15$ & 382.54 & 33.4 & 1.74 & 1.16 & 2.69 & 56.9 \\
\hline $41 X-6,29-31$ & 384.20 & 34.5 & 1.73 & 1.13 & 2.71 & 58.2 \\
\hline $41 X-7,54-56$ & 385.65 & 33.9 & 1.75 & 1.16 & 2.74 & 57.9 \\
\hline $42 X-1,37-39$ & 386.38 & 35.5 & 1.70 & 1.10 & 2.68 & 59.1 \\
\hline $42 X-2,2-4$ & 387.53 & 36.3 & 1.68 & 1.07 & 2.64 & 59.5 \\
\hline $42 X-3,2-4$ & 389.03 & 33.3 & 1.75 & 1.17 & 2.70 & 56.8 \\
\hline $42 X-4,61-63$ & 391.12 & 32.4 & 1.76 & 1.19 & 2.68 & 55.6 \\
\hline $42 X-5,50-52$ & 392.51 & 37.8 & 1.67 & 1.04 & 2.69 & 61.4 \\
\hline $43 X-1,65-67$ & 396.26 & 37.5 & 1.68 & 1.05 & 2.73 & 61.5 \\
\hline $43 X-2,59-61$ & 397.70 & 37.7 & 1.65 & 1.03 & 2.63 & 60.8 \\
\hline $43 X-3,8-10$ & 398.69 & 35.7 & 1.69 & 1.09 & 2.66 & 59.1 \\
\hline $43 X-4,58-60$ & 400.69 & 35.6 & 1.71 & 1.10 & 2.72 & 59.5 \\
\hline $43 X-5,25-27$ & 401.86 & 32.2 & 1.77 & 1.20 & 2.72 & 55.8 \\
\hline $43 X-6,41-43$ & 403.52 & 34.2 & 1.74 & 1.14 & 2.73 & 58.2 \\
\hline $43 X-7,30-32$ & 404.41 & 54.4 & 1.43 & 0.65 & 2.75 & 76.3 \\
\hline $44 X-1,106-108$ & 405.97 & 33.4 & 1.75 & 1.16 & 2.71 & 57.1 \\
\hline $44 X-2,76-78$ & 407.17 & 32.0 & 1.78 & 1.21 & 2.73 & 55.6 \\
\hline $44 X-3,86-88$ & 408.77 & 33.0 & 1.76 & 1.18 & 2.71 & 56.6 \\
\hline $44 X-4,115-117$ & 410.56 & 32.4 & 1.76 & 1.19 & 2.70 & 55.8 \\
\hline $44 X-5,114-116$ & 412.05 & 39.5 & 1.64 & 0.99 & 2.68 & 63.1 \\
\hline $44 X-6,90-92$ & 413.31 & 30.6 & 1.81 & 1.25 & 2.73 & 54.1 \\
\hline
\end{tabular}


Table T20 (continued).

\begin{tabular}{|c|c|c|c|c|c|c|}
\hline \multirow[b]{2}{*}{$\begin{array}{l}\text { Core, section, } \\
\text { interval }(\mathrm{cm})\end{array}$} & \multirow[b]{2}{*}{$\begin{array}{l}\text { Depth } \\
\operatorname{CSF}(\mathrm{m})\end{array}$} & \multirow{2}{*}{$\begin{array}{c}\text { Water } \\
\text { content } \\
\text { (wt\%) }\end{array}$} & \multicolumn{3}{|c|}{ Density $\left(\mathrm{g} / \mathrm{cm}^{3}\right)$} & \multirow[b]{2}{*}{$\begin{array}{l}\text { Porosity } \\
\text { (\%) }\end{array}$} \\
\hline & & & $\begin{array}{l}\text { Wet } \\
\text { bulk }\end{array}$ & $\begin{array}{l}\text { Dry } \\
\text { bulk }\end{array}$ & Grain & \\
\hline $45 X-1,93-95$ & 415.44 & 35.5 & 1.70 & 1.09 & 2.66 & 58.9 \\
\hline $45 X-2,119-121$ & 417.20 & 33.3 & 1.74 & 1.16 & 2.69 & 56.7 \\
\hline $45 X-3,105-107$ & 418.56 & 31.0 & 1.80 & 1.24 & 2.73 & 54.5 \\
\hline $45 X-4,110-112$ & 420.11 & 31.7 & 1.78 & 1.21 & 2.70 & 55.0 \\
\hline $45 X-5,62-64$ & 421.13 & 31.5 & 1.79 & 1.22 & 2.72 & 55.1 \\
\hline $45 X-6,9-11$ & 422.10 & 33.5 & 1.75 & 1.16 & 2.73 & 57.4 \\
\hline $46 \times-1,77-79$ & 424.78 & 29.9 & 1.81 & 1.27 & 2.68 & 52.7 \\
\hline $46 \times-2,57-59$ & 426.08 & 31.6 & 1.78 & 1.22 & 2.70 & 54.9 \\
\hline $46 \times-3,53-55$ & 427.54 & 30.7 & 1.80 & 1.25 & 2.72 & 54.1 \\
\hline $46 X-4,6-8$ & 428.57 & 30.9 & 1.80 & 1.24 & 2.72 & 54.3 \\
\hline $46 \times-5,45-47$ & 430.46 & 29.9 & 1.82 & 1.27 & 2.71 & 53.0 \\
\hline $46 \mathrm{X}-6,79-81$ & 432.30 & 30.6 & 1.81 & 1.25 & 2.73 & 54.1 \\
\hline $47 X-2,85-87$ & 435.96 & 28.7 & 1.83 & 1.30 & 2.67 & 51.2 \\
\hline $47 X-3,65-67$ & 437.26 & 25.0 & 1.92 & 1.44 & 2.72 & 46.9 \\
\hline $47 X-4,76-78$ & 438.87 & 25.1 & 1.92 & 1.44 & 2.72 & 47.0 \\
\hline $47 X-5,112-114$ & 440.73 & 25.9 & 1.90 & 1.41 & 2.70 & 47.9 \\
\hline $47 X-6,82-84$ & 441.93 & 24.6 & 1.94 & 1.46 & 2.75 & 46.7 \\
\hline $47 X-7,55-57$ & 442.88 & 23.7 & 1.96 & 1.49 & 2.73 & 45.3 \\
\hline $48 X-1,65-67$ & 443.86 & 26.5 & 1.88 & 1.38 & 2.70 & 48.8 \\
\hline $48 X-2,91-93$ & 445.62 & 25.0 & 1.92 & 1.44 & 2.72 & 47.0 \\
\hline $48 X-3,109-111$ & 447.30 & 26.4 & 1.90 & 1.40 & 2.74 & 49.0 \\
\hline $48 X-4,109-111$ & 448.80 & 33.0 & 1.76 & 1.18 & 2.71 & 56.6 \\
\hline \multicolumn{7}{|l|}{ 321-U1337B- } \\
\hline $22 \mathrm{H}-1,99-101$ & 201.50 & 62.5 & 1.33 & 0.50 & 2.64 & 81.2 \\
\hline $22 \mathrm{H}-2,69-71$ & 202.70 & 57.2 & 1.39 & 0.59 & 2.62 & 77.3 \\
\hline $22 \mathrm{H}-4,64-66$ & 204.15 & 62.8 & 1.32 & 0.49 & 2.55 & 80.8 \\
\hline $22 \mathrm{H}-3,52-54$ & 205.53 & 64.7 & 1.29 & 0.46 & 2.47 & 81.6 \\
\hline $22 \mathrm{H}-5,99-101$ & 207.50 & 64.2 & 1.30 & 0.46 & 2.49 & 81.3 \\
\hline $22 \mathrm{H}-6,34-36$ & 208.35 & 72.5 & 1.20 & 0.33 & 2.17 & 84.8 \\
\hline $23 \mathrm{H}-1,64-66$ & 210.65 & 64.3 & 1.30 & 0.46 & 2.54 & 81.7 \\
\hline $23 \mathrm{H}-2,74-76$ & 212.25 & 49.4 & 1.49 & 0.75 & 2.66 & 71.7 \\
\hline $23 \mathrm{H}-3,71-73$ & 213.72 & 56.7 & 1.37 & 0.59 & 2.47 & 75.9 \\
\hline $23 \mathrm{H}-4,64-66$ & 215.15 & 43.6 & 1.57 & 0.89 & 2.69 & 67.0 \\
\hline $24 \mathrm{H}-1,102-104$ & 220.53 & 42.2 & 1.60 & 0.92 & 2.71 & 65.9 \\
\hline $24 \mathrm{H}-3,92-94$ & 223.43 & 51.0 & 1.46 & 0.72 & 2.63 & 72.7 \\
\hline $24 \mathrm{H}-4,83-85$ & 224.84 & 48.0 & 1.50 & 0.78 & 2.65 & 70.5 \\
\hline $25 \mathrm{H}-1,90-92$ & 227.31 & 47.7 & 1.50 & 0.78 & 2.58 & 69.6 \\
\hline $25 \mathrm{H}-2,94-96$ & 228.85 & 46.8 & 1.51 & 0.81 & 2.62 & 69.2 \\
\hline $25 \mathrm{H}-3,73-75$ & 230.14 & 45.6 & 1.54 & 0.83 & 2.64 & 68.4 \\
\hline $25 \mathrm{H}-4,105-107$ & 231.96 & 42.8 & 1.58 & 0.90 & 2.64 & 65.8 \\
\hline $25 \mathrm{H}-5,54-56$ & 232.95 & 47.2 & 1.50 & 0.79 & 2.59 & 69.3 \\
\hline $26 \mathrm{H}-1,84-86$ & 235.15 & 47.0 & 1.52 & 0.81 & 2.67 & 69.9 \\
\hline $26 \mathrm{H}-2,60-62$ & 236.41 & 43.9 & 1.56 & 0.88 & 2.64 & 66.9 \\
\hline $26 \mathrm{H}-3,89-91$ & 238.20 & 47.1 & 1.51 & 0.80 & 2.63 & 69.6 \\
\hline $26 \mathrm{H}-4,90-92$ & 239.71 & 47.1 & 1.51 & 0.80 & 2.64 & 69.6 \\
\hline $26 \mathrm{H}-5,81-83$ & 241.12 & 43.4 & 1.57 & 0.89 & 2.64 & 66.4 \\
\hline $26 \mathrm{H}-6,70-72$ & 242.51 & 40.1 & 1.62 & 0.97 & 2.66 & 63.5 \\
\hline
\end{tabular}


Table T21. Split-core $P$-wave velocity measurements, Site U1337. (Continued on next two pages.)

\begin{tabular}{|c|c|c|c|c|}
\hline \multirow{2}{*}{$\begin{array}{c}\text { Core, } \\
\text { section }\end{array}$} & \multirow{2}{*}{$\begin{array}{l}\text { Depth } \\
\text { CSF }(m)\end{array}$} & \multicolumn{3}{|c|}{ Velocity $(\mathrm{m} / \mathrm{s})$} \\
\hline & & $x$-axis & $y$-axis & $z$-axis \\
\hline \multicolumn{5}{|c|}{ 321-U1337A- } \\
\hline $2 \mathrm{H}-1$ & 6.41 & & 1507 & 1501 \\
\hline $2 \mathrm{H}-1$ & 6.49 & 1527 & & \\
\hline $2 \mathrm{H}-2$ & 7.81 & 1536 & & \\
\hline $2 \mathrm{H}-2$ & 7.98 & & 1511 & 1506 \\
\hline $2 \mathrm{H}-3$ & 9.30 & 1528 & & \\
\hline $2 \mathrm{H}-3$ & 9.41 & & 1513 & 1512 \\
\hline $2 \mathrm{H}-4$ & 10.80 & 1521 & & \\
\hline $2 \mathrm{H}-5$ & 12.31 & 1540 & & \\
\hline $2 \mathrm{H}-6$ & 13.79 & 1503 & & \\
\hline $2 \mathrm{H}-6$ & 13.90 & & 1492 & 1485 \\
\hline $2 \mathrm{H}-7$ & 14.89 & & 1490 & \\
\hline $2 \mathrm{H}-7$ & 15.13 & 1501 & & \\
\hline $3 \mathrm{H}-1$ & 15.79 & 1545 & & \\
\hline $3 \mathrm{H}-2$ & 17.26 & 1556 & & \\
\hline $3 \mathrm{H}-2$ & 17.40 & & & 1511 \\
\hline $3 \mathrm{H}-3$ & 18.80 & 1536 & & \\
\hline $3 \mathrm{H}-3$ & 18.97 & & & 1513 \\
\hline $3 \mathrm{H}-4$ & 20.30 & 1523 & & \\
\hline $3 \mathrm{H}-5$ & 21.75 & 1523 & & \\
\hline $3 \mathrm{H}-5$ & 21.85 & & 1505 & 1501 \\
\hline $3 \mathrm{H}-6$ & 23.30 & 1538 & & \\
\hline $3 \mathrm{H}-6$ & 23.40 & & 1508 & \\
\hline $3 \mathrm{H}-7$ & 24.60 & 1533 & & \\
\hline $3 \mathrm{H}-7$ & 24.70 & & 1513 & 1509 \\
\hline $4 \mathrm{H}-1$ & 25.84 & 1528 & & \\
\hline $4 \mathrm{H}-1$ & 25.94 & & 1499 & 1491 \\
\hline $4 \mathrm{H}-2$ & 26.90 & & 1509 & 1507 \\
\hline $4 \mathrm{H}-3$ & 28.30 & 1592 & & \\
\hline $4 \mathrm{H}-3$ & 28.40 & & & 1521 \\
\hline $4 \mathrm{H}-4$ & 29.80 & 1549 & & \\
\hline $4 \mathrm{H}-4$ & 29.90 & & 1508 & 1422 \\
\hline $4 \mathrm{H}-5$ & 31.30 & 1555 & & \\
\hline $4 \mathrm{H}-5$ & 31.40 & & 1517 & 1426 \\
\hline $4 \mathrm{H}-6$ & 32.80 & 1522 & & \\
\hline $4 \mathrm{H}-6$ & 32.90 & & 1511 & \\
\hline $4 \mathrm{H}-7$ & 34.10 & 1527 & & \\
\hline $4 \mathrm{H}-7$ & 34.20 & & 1508 & \\
\hline $5 \mathrm{H}-1$ & 34.80 & 1513 & & \\
\hline $5 \mathrm{H}-1$ & 34.90 & & 1468 & 1506 \\
\hline $5 \mathrm{H}-2$ & 36.30 & 1511 & & \\
\hline $5 \mathrm{H}-3$ & 37.80 & 1525 & & \\
\hline $5 \mathrm{H}-3$ & 37.90 & & 1500 & 1402 \\
\hline $5 \mathrm{H}-4$ & 39.30 & 1512 & & \\
\hline $5 \mathrm{H}-4$ & 39.40 & & 1504 & \\
\hline $5 \mathrm{H}-5$ & 40.80 & 1509 & & \\
\hline $5 \mathrm{H}-5$ & 40.90 & & 1507 & \\
\hline $5 \mathrm{H}-6$ & 42.30 & 1532 & & \\
\hline $5 \mathrm{H}-6$ & 42.40 & & & 1420 \\
\hline $5 \mathrm{H}-7$ & 43.46 & 1540 & & \\
\hline $6 \mathrm{H}-1$ & 44.30 & 1531 & & \\
\hline $6 \mathrm{H}-1$ & 44.40 & & & 1407 \\
\hline $6 \mathrm{H}-2$ & 45.80 & 1594 & & \\
\hline $6 \mathrm{H}-3$ & 47.30 & 1554 & & \\
\hline $6 \mathrm{H}-3$ & 47.40 & & 1512 & 1514 \\
\hline $6 \mathrm{H}-4$ & 48.80 & 1517 & & \\
\hline $6 \mathrm{H}-4$ & 48.90 & & 1473 & 1520 \\
\hline $6 \mathrm{H}-5$ & 50.30 & 1534 & & \\
\hline $6 \mathrm{H}-5$ & 50.40 & & 1516 & 1408 \\
\hline $6 \mathrm{H}-6$ & 51.80 & 1580 & & \\
\hline $6 \mathrm{H}-6$ & 51.90 & & 1505 & \\
\hline $6 \mathrm{H}-7$ & 53.08 & 1529 & & \\
\hline $6 \mathrm{H}-7$ & 53.18 & & 1434 & 1511 \\
\hline 7H-1 & 53.99 & 1543 & & \\
\hline 7H-1 & 54.07 & & 1472 & \\
\hline $7 \mathrm{H}-2$ & 55.30 & 1535 & & \\
\hline $7 \mathrm{H}-2$ & 55.40 & & 1513 & \\
\hline $7 \mathrm{H}-3$ & 56.75 & 1519 & & \\
\hline
\end{tabular}

\begin{tabular}{|c|c|c|c|c|}
\hline \multirow{2}{*}{$\begin{array}{l}\text { Core, } \\
\text { section }\end{array}$} & \multirow{2}{*}{$\begin{array}{l}\text { Depth } \\
\text { CSF }(\mathrm{m})\end{array}$} & \multicolumn{3}{|c|}{ Velocity $(\mathrm{m} / \mathrm{s})$} \\
\hline & & $x$-axis & $y$-axis & $z$-axis \\
\hline $7 \mathrm{H}-3$ & 56.85 & & 1512 & 1509 \\
\hline $7 \mathrm{H}-4$ & 58.49 & 1545 & & \\
\hline $7 \mathrm{H}-5$ & 59.85 & 1566 & & \\
\hline $7 \mathrm{H}-5$ & 59.95 & & 1515 & \\
\hline $7 \mathrm{H}-6$ & 61.58 & 1600 & & \\
\hline $7 \mathrm{H}-6$ & 61.67 & & 1512 & 1511 \\
\hline $7 \mathrm{H}-7$ & 62.35 & 1534 & & \\
\hline $7 \mathrm{H}-7$ & 62.45 & & 1511 & 1510 \\
\hline $8 \mathrm{H}-1$ & 63.40 & & 1514 & \\
\hline $8 \mathrm{H}-2$ & 64.90 & & & 1519 \\
\hline $8 \mathrm{H}-3$ & 66.31 & & & 1436 \\
\hline $8 \mathrm{H}-4$ & 67.90 & & 1510 & 1518 \\
\hline $8 \mathrm{H}-5$ & 69.30 & 1504 & & \\
\hline $8 \mathrm{H}-5$ & 69.40 & & 1506 & 1515 \\
\hline $8 \mathrm{H}-6$ & 70.80 & 1509 & & \\
\hline $8 \mathrm{H}-6$ & 70.90 & & & 1410 \\
\hline $9 \mathrm{H}-1$ & 72.79 & 1518 & & \\
\hline $9 \mathrm{H}-1$ & 72.89 & & 1505 & \\
\hline $9 \mathrm{H}-2$ & 74.30 & 1510 & & \\
\hline $9 \mathrm{H}-2$ & 74.40 & & 1458 & 1401 \\
\hline $9 \mathrm{H}-3$ & 75.80 & 1519 & & \\
\hline $9 \mathrm{H}-3$ & 75.90 & & & 1402 \\
\hline $9 \mathrm{H}-4$ & 77.30 & 1509 & & \\
\hline $9 \mathrm{H}-4$ & 77.40 & & 1507 & \\
\hline $9 \mathrm{H}-5$ & 78.80 & 1507 & & \\
\hline $9 \mathrm{H}-5$ & 78.90 & & 1502 & 1498 \\
\hline $9 \mathrm{H}-6$ & 80.30 & 1517 & & \\
\hline $9 \mathrm{H}-6$ & 80.40 & & 1508 & 1403 \\
\hline $9 \mathrm{H}-7$ & 81.19 & 1502 & & \\
\hline $9 \mathrm{H}-7$ & 81.56 & & & 1506 \\
\hline $10 \mathrm{H}-1$ & 82.06 & 1514 & & \\
\hline $10 \mathrm{H}-1$ & 82.19 & & 1507 & 1502 \\
\hline $10 \mathrm{H}-2$ & 83.79 & 1513 & & \\
\hline $10 \mathrm{H}-3$ & 85.30 & 1557 & & \\
\hline $10 \mathrm{H}-3$ & 85.40 & & 1425 & \\
\hline $10 \mathrm{H}-4$ & 86.80 & 1500 & & \\
\hline $10 \mathrm{H}-4$ & 86.90 & & 1490 & 1493 \\
\hline $10 \mathrm{H}-5$ & 88.30 & 1518 & & \\
\hline $10 \mathrm{H}-5$ & 88.40 & & 1508 & 1509 \\
\hline $10 \mathrm{H}-6$ & 89.80 & 1502 & & \\
\hline $10 \mathrm{H}-6$ & 89.90 & & 1492 & 1498 \\
\hline $10 \mathrm{H}-7$ & 90.98 & 1527 & & \\
\hline $10 \mathrm{H}-7$ & 91.07 & & 1508 & 1405 \\
\hline $11 \mathrm{H}-1$ & 91.81 & 1494 & & \\
\hline $11 \mathrm{H}-2$ & 93.29 & 1496 & & \\
\hline $11 \mathrm{H}-2$ & 93.41 & & 1501 & 1507 \\
\hline $11 \mathrm{H}-3$ & 94.79 & 1503 & & \\
\hline $11 \mathrm{H}-4$ & 96.30 & 1493 & & \\
\hline $11 \mathrm{H}-4$ & 96.39 & & 1501 & \\
\hline $11 \mathrm{H}-5$ & 97.80 & 1497 & & \\
\hline $11 \mathrm{H}-5$ & 97.90 & & 1506 & 1406 \\
\hline $11 \mathrm{H}-6$ & 99.31 & 1508 & & \\
\hline $11 \mathrm{H}-6$ & 99.40 & & 1509 & 1513 \\
\hline $11 \mathrm{H}-7$ & 100.40 & 1507 & & \\
\hline $11 \mathrm{H}-7$ & 100.52 & & 1516 & 1521 \\
\hline $12 \mathrm{H}-1$ & 101.65 & 1507 & & \\
\hline $12 \mathrm{H}-1$ & 101.75 & & 1506 & 1506 \\
\hline $12 \mathrm{H}-2$ & 103.08 & 1509 & & \\
\hline $12 \mathrm{H}-3$ & 104.53 & 1516 & & \\
\hline $12 \mathrm{H}-3$ & 104.62 & & 1464 & 1501 \\
\hline $12 \mathrm{H}-4$ & 106.22 & 1510 & & \\
\hline $12 \mathrm{H}-4$ & 106.30 & & 1492 & 1493 \\
\hline $12 \mathrm{H}-5$ & 107.40 & 1506 & & \\
\hline $12 \mathrm{H}-5$ & 107.48 & & 1495 & 1503 \\
\hline $12 \mathrm{H}-6$ & 108.99 & 1508 & & \\
\hline $12 \mathrm{H}-6$ & 109.07 & & 1500 & 1503 \\
\hline $12 \mathrm{H}-7$ & 109.86 & 1487 & & \\
\hline $12 \mathrm{H}-7$ & 109.95 & & 1496 & \\
\hline
\end{tabular}

\begin{tabular}{|c|c|c|c|c|}
\hline \multirow{2}{*}{$\begin{array}{l}\text { Core, } \\
\text { section }\end{array}$} & \multirow{2}{*}{$\begin{array}{c}\text { Depth } \\
\operatorname{CSF}(\mathrm{m})\end{array}$} & \multicolumn{3}{|c|}{ Velocity $(\mathrm{m} / \mathrm{s})$} \\
\hline & & $x$-axis & $y$-axis & $z$-axis \\
\hline $13 \mathrm{H}-1$ & 111.00 & & 1460 & \\
\hline $13 \mathrm{H}-1$ & 111.27 & 1499 & & \\
\hline $13 \mathrm{H}-2$ & 112.46 & 1515 & & \\
\hline $13 \mathrm{H}-3$ & 113.96 & 1515 & & \\
\hline $13 \mathrm{H}-3$ & 114.05 & & 1512 & 1516 \\
\hline $13 \mathrm{H}-4$ & 115.46 & 1510 & & \\
\hline $13 \mathrm{H}-4$ & 115.56 & & 1496 & 1497 \\
\hline $13 \mathrm{H}-5$ & 116.91 & 1523 & & \\
\hline $13 \mathrm{H}-5$ & 117.00 & & 1501 & 1507 \\
\hline $13 \mathrm{H}-6$ & 118.46 & 1526 & & \\
\hline $13 \mathrm{H}-6$ & 118.55 & & 1493 & 1500 \\
\hline $13 \mathrm{H}-7$ & 119.29 & 1546 & & \\
\hline $13 \mathrm{H}-7$ & 119.37 & & 1500 & 1493 \\
\hline $14 \mathrm{H}-1$ & 120.30 & 1522 & & \\
\hline $14 \mathrm{H}-1$ & 120.40 & & 1504 & \\
\hline $14 \mathrm{H}-2$ & 121.77 & 1522 & & \\
\hline $14 \mathrm{H}-2$ & 121.85 & & 1509 & \\
\hline $14 \mathrm{H}-3$ & 123.30 & 1519 & & \\
\hline $14 \mathrm{H}-3$ & 123.40 & & 1458 & 1507 \\
\hline $14 \mathrm{H}-4$ & 124.84 & 1526 & & \\
\hline $14 \mathrm{H}-4$ & 124.93 & & 1497 & \\
\hline $14 \mathrm{H}-5$ & 126.30 & 1488 & & \\
\hline $14 \mathrm{H}-6$ & 127.82 & 1504 & & \\
\hline $14 \mathrm{H}-6$ & 127.90 & & 1501 & 1500 \\
\hline $14 \mathrm{H}-7$ & 129.06 & 1506 & & \\
\hline $14 \mathrm{H}-7$ & 129.15 & & 1495 & 1493 \\
\hline $15 \mathrm{H}-1$ & 129.75 & 1535 & & \\
\hline $15 \mathrm{H}-1$ & 129.85 & & 1449 & \\
\hline $15 \mathrm{H}-2$ & 131.30 & 1492 & & \\
\hline $15 \mathrm{H}-2$ & 131.40 & & 1459 & \\
\hline $15 \mathrm{H}-3$ & 132.80 & 1554 & & \\
\hline $15 \mathrm{H}-3$ & 132.90 & & 1462 & 1402 \\
\hline $15 \mathrm{H}-4$ & 134.30 & 1550 & & \\
\hline $15 \mathrm{H}-4$ & 134.40 & & 1500 & 1497 \\
\hline $15 \mathrm{H}-5$ & 135.80 & 1495 & & \\
\hline $15 \mathrm{H}-6$ & 137.21 & 1497 & & \\
\hline $15 \mathrm{H}-6$ & 137.30 & & & 1513 \\
\hline $15 \mathrm{H}-7$ & 138.41 & 1536 & & \\
\hline $15 \mathrm{H}-7$ & 138.49 & & & 1519 \\
\hline $16 \mathrm{H}-2$ & 140.80 & 1556 & & \\
\hline $16 \mathrm{H}-2$ & 140.90 & & & 1517 \\
\hline $16 \mathrm{H}-3$ & 142.40 & 1525 & & \\
\hline $16 \mathrm{H}-3$ & 142.50 & & & 1428 \\
\hline $16 \mathrm{H}-4$ & 143.81 & 1520 & & \\
\hline $16 \mathrm{H}-4$ & 143.90 & & & 1517 \\
\hline $16 \mathrm{H}-5$ & 145.32 & 1485 & & \\
\hline $16 \mathrm{H}-6$ & 146.81 & 1539 & & \\
\hline $16 \mathrm{H}-6$ & 146.90 & & 1457 & 1512 \\
\hline $16 \mathrm{H}-7$ & 147.86 & 1485 & & \\
\hline $16 \mathrm{H}-7$ & 147.95 & & & 1514 \\
\hline $17 \mathrm{H}-1$ & 148.85 & 1482 & & \\
\hline $17 \mathrm{H}-1$ & 148.95 & & & 1494 \\
\hline $17 \mathrm{H}-2$ & 150.42 & 1521 & & \\
\hline $17 \mathrm{H}-3$ & 151.85 & 1504 & & \\
\hline $17 \mathrm{H}-3$ & 151.95 & & & 1498 \\
\hline $17 \mathrm{H}-4$ & 153.30 & 1507 & & \\
\hline $17 \mathrm{H}-4$ & 153.38 & & & 1498 \\
\hline $17 \mathrm{H}-5$ & 154.82 & 1483 & & \\
\hline $17 \mathrm{H}-5$ & 154.91 & & 1455 & 1494 \\
\hline $17 \mathrm{H}-6$ & 156.39 & 1494 & & \\
\hline $17 \mathrm{H}-6$ & 156.47 & & & 1517 \\
\hline $17 \mathrm{H}-7$ & 157.47 & 1516 & & \\
\hline $17 \mathrm{H}-7$ & 157.55 & & 1497 & 1499 \\
\hline $18 \mathrm{H}-1$ & 158.30 & 1484 & & \\
\hline $18 \mathrm{H}-1$ & 158.40 & & 1467 & \\
\hline $18 \mathrm{H}-2$ & 159.79 & 1468 & & \\
\hline $18 \mathrm{H}-2$ & 159.90 & & 1528 & \\
\hline $18 \mathrm{H}-3$ & 161.43 & & 1506 & 1513 \\
\hline
\end{tabular}


Table T21 (continued). (Continued on next page.)

\begin{tabular}{|c|c|c|c|c|c|c|c|c|c|c|c|c|c|c|}
\hline \multirow{2}{*}{$\begin{array}{l}\text { Core, } \\
\text { section }\end{array}$} & \multirow{2}{*}{$\begin{array}{l}\text { Depth } \\
\text { CSF }(m)\end{array}$} & \multicolumn{3}{|c|}{ Velocity $(\mathrm{m} / \mathrm{s})$} & \multirow{2}{*}{$\begin{array}{l}\text { Core, } \\
\text { section }\end{array}$} & \multirow{2}{*}{$\begin{array}{l}\text { Depth } \\
\text { CSF (m) }\end{array}$} & \multicolumn{3}{|c|}{ Velocity $(\mathrm{m} / \mathrm{s})$} & & epth & & ocity (m & \\
\hline & & $x$-axis & $y$-axis & $z$-axis & & & $x$-axis & $y$-axis & $z$-axis & section & $\operatorname{CSF}(m)$ & $x$-axis & $y$-axis & $z$-axis \\
\hline $18 \mathrm{H}-3$ & 161.53 & 1486 & & & $25 X-6$ & 231.61 & 1526 & & & $33 X-4$ & 305.09 & 1510 & & \\
\hline $18 \mathrm{H}-4$ & 162.84 & 1499 & & & $25 X-6$ & 231.71 & & 1504 & 1463 & $33 X-5$ & 306.52 & 1513 & & \\
\hline $18 \mathrm{H}-4$ & 162.94 & & & 1500 & $25 X-7$ & 232.54 & 1534 & & & $33 X-6$ & 307.87 & 1532 & & \\
\hline $18 \mathrm{H}-5$ & 164.35 & 1512 & & & $25 X-7$ & 232.63 & & 1505 & & $33 X-7$ & 308.94 & 1554 & & \\
\hline $18 \mathrm{H}-5$ & 164.44 & & & 1518 & $26 \mathrm{X}-1$ & 233.80 & 1500 & & & $34 X-1$ & 309.90 & 1534 & & \\
\hline $18 \mathrm{H}-6$ & 165.84 & 1477 & & & $26 \mathrm{X}-1$ & 233.90 & & 1500 & 1505 & $34 X-2$ & 311.77 & 1519 & & \\
\hline $18 \mathrm{H}-6$ & 165.96 & & & 1423 & $26 X-2$ & 235.30 & 1518 & & & $34 X-3$ & 313.30 & 1527 & & \\
\hline $18 \mathrm{H}-7$ & 166.99 & & 1449 & 1415 & $26 \mathrm{X}-2$ & 235.40 & & 1495 & 1496 & $34 X-4$ & 314.77 & 1534 & & \\
\hline $18 \mathrm{H}-7$ & 167.07 & 1480 & & & $26 X-3$ & 237.00 & 1521 & & & $34 X-5$ & 316.10 & 1533 & & \\
\hline $19 \mathrm{H}-1$ & 167.80 & 1511 & & & $26 X-3$ & 237.09 & & 1448 & & $34 X-6$ & 317.50 & 1522 & & \\
\hline $19 \mathrm{H}-1$ & 167.90 & & 1516 & 1403 & $26 \mathrm{X}-4$ & 238.30 & 1530 & & & $35 X-1$ & 319.50 & 1506 & & \\
\hline $19 \mathrm{H}-2$ & 169.10 & & 1505 & 1502 & $26 X-4$ & 238.40 & & 1459 & 1390 & $35 X-2$ & 321.10 & 1513 & & \\
\hline $19 \mathrm{H}-2$ & 169.19 & 1515 & & & $26 \mathrm{X}-5$ & 239.92 & 1529 & & & $35 X-3$ & 322.54 & 1541 & & \\
\hline $19 \mathrm{H}-3$ & 170.67 & 1521 & & & $26 X-5$ & 240.00 & & 1500 & 1499 & $35 X-4$ & 324.29 & 1522 & & \\
\hline $19 \mathrm{H}-3$ & 170.75 & & 1500 & 1498 & $26 \mathrm{X}-6$ & 241.06 & 1526 & & & $35 X-6$ & 326.73 & 1511 & & \\
\hline $19 \mathrm{H}-4$ & 172.31 & 1473 & & & $26 X-6$ & 241.15 & & 1500 & 1502 & $35 X-5$ & 327.25 & 1536 & & \\
\hline $19 \mathrm{H}-4$ & 172.40 & & 1455 & 1505 & $26 X-7$ & 242.25 & 1522 & & & $36 X-1$ & 329.81 & 1549 & & \\
\hline $19 \mathrm{H}-5$ & 173.80 & 1478 & & & $26 X-7$ & 242.33 & & 1508 & 1508 & $36 X-2$ & 330.85 & 1549 & & \\
\hline $19 \mathrm{H}-5$ & 173.90 & & 1522 & & $27 X-1$ & 242.86 & 1510 & & & $36 X-3$ & 332.58 & 1527 & & \\
\hline $19 \mathrm{H}-6$ & 175.31 & 1521 & & & $28 X-1$ & 252.69 & 1529 & & & $36 X-4$ & 333.32 & 1509 & & \\
\hline $19 \mathrm{H}-7$ & 176.37 & & 1515 & & $28 X-1$ & 252.80 & & 1463 & 1498 & $36 X-4$ & 333.95 & 1578 & & \\
\hline $19 \mathrm{H}-7$ & 176.44 & 1513 & & & $28 X-2$ & 254.22 & 1527 & & & $36 X-5$ & 335.45 & 1538 & & \\
\hline $20 \mathrm{H}-1$ & 177.40 & & 1524 & & $28 \mathrm{X}-2$ & 254.31 & & 1506 & 1501 & $37 X-2$ & 339.95 & & & 1503 \\
\hline $20 \mathrm{H}-2$ & 178.80 & 1493 & & & $28 X-3$ & 255.32 & 1531 & & & $37 X-4$ & 343.31 & & & 1529 \\
\hline $20 \mathrm{H}-2$ & 178.90 & & 1525 & & $28 X-3$ & 255.40 & & 1513 & 1508 & $37 X-5$ & 344.89 & & & 1516 \\
\hline $20 \mathrm{H}-3$ & 180.30 & 1483 & & & $28 X-4$ & 256.10 & 1524 & & & $37 X-6$ & 346.18 & & & 1508 \\
\hline $20 \mathrm{H}-4$ & 181.81 & 1481 & & & $28 X-4$ & 256.19 & & 1514 & 1512 & $38 \mathrm{X}-1$ & 347.69 & & & 1535 \\
\hline $20 \mathrm{H}-5$ & 183.17 & 1486 & & & $29 X-1$ & 262.09 & 1519 & & & $38 X-1$ & 348.25 & & & 1521 \\
\hline $20 \mathrm{H}-5$ & 183.37 & & 1454 & 1412 & $29 X-2$ & 263.59 & 1520 & & & $38 X-2$ & 350.26 & & & 1559 \\
\hline $20 \mathrm{H}-7$ & 186.10 & 1491 & & & $29 X-3$ & 265.29 & 1517 & & & $39 X-1$ & 358.67 & & & 1553 \\
\hline $21 \mathrm{H}-1$ & 186.80 & 1509 & & & $29 X-3$ & 265.38 & & 1500 & 1498 & $39 X-2$ & 359.80 & & & 1548 \\
\hline $21 \mathrm{H}-2$ & 188.31 & 1503 & & & $29 X-4$ & 266.71 & 1524 & & & $39 X-3$ & 361.22 & & & 1543 \\
\hline $21 \mathrm{H}-2$ & 188.41 & & 1502 & & $29 X-4$ & 266.80 & & & 1508 & $39 X-4$ & 362.57 & & & 1568 \\
\hline $21 \mathrm{H}-3$ & 189.74 & 1522 & & & $29 X-5$ & 268.24 & 1531 & & & $39 X-5$ & 363.86 & & & 1529 \\
\hline $21 \mathrm{H}-3$ & 189.81 & & 1509 & 1415 & $29 X-5$ & 268.32 & & 1506 & 1516 & $39 X-6$ & 365.35 & & & 1574 \\
\hline $21 \mathrm{H}-4$ & 191.30 & 1537 & & & $29 \mathrm{X}-6$ & 269.43 & 1535 & & & $39 X-7$ & 366.52 & & & 1599 \\
\hline $21 \mathrm{H}-6$ & 193.76 & 1612 & & & $29 X-6$ & 269.53 & & 1465 & 1504 & $40 X-1$ & 368.22 & & & 1560 \\
\hline $21 \mathrm{H}-6$ & 194.49 & 1475 & & & $29 X-7$ & 270.36 & 1512 & & & $40 X-2$ & 369.15 & & & 1621 \\
\hline $21 \mathrm{H}-7$ & 195.27 & 1512 & & & $29 X-7$ & 270.46 & & 1402 & & $40 X-3$ & 371.19 & & & 1571 \\
\hline $22 X-1$ & 196.04 & 1505 & & & $30 X-1$ & 271.70 & 1544 & & & $40 X-4$ & 372.61 & & & 1555 \\
\hline $23 X-1$ & 205.08 & & 1456 & 1493 & $30 X-1$ & 271.80 & & 1507 & & $40 X-5$ & 373.70 & & & 1582 \\
\hline $23 X-1$ & 205.32 & 1538 & & & $30 X-2$ & 273.04 & 1523 & & & $40 X-7$ & 375.90 & & & 1604 \\
\hline $23 X-2$ & 206.59 & 1554 & & & $30 X-2$ & 273.14 & & 1501 & & $41 X-1$ & 377.02 & & & 1583 \\
\hline $23 X-2$ & 206.67 & & 1456 & 1497 & $30 X-3$ & 274.72 & 1531 & & & $41 X-2$ & 378.30 & & & 1555 \\
\hline $23 X-3$ & 208.12 & 1527 & & & $30 X-4$ & 276.09 & 1519 & & & $41 X-3$ & 379.56 & & & 1606 \\
\hline $23 X-3$ & 208.21 & & & 1510 & $30 X-4$ & 276.19 & & 1509 & & $41 X-4$ & 381.05 & & & 1568 \\
\hline $23 X-4$ & 209.19 & 1525 & & & $30 X-5$ & 277.55 & 1523 & & & $41 X-5$ & 382.54 & & & 1595 \\
\hline $23 X-4$ & 209.27 & & 1514 & 1512 & $30 X-5$ & 277.65 & & 1511 & 1507 & $41 X-6$ & 384.20 & & & 1568 \\
\hline $23 X-5$ & 211.44 & 1538 & & & $30 X-6$ & 278.78 & 1526 & & & $41 X-7$ & 385.65 & & & 1638 \\
\hline $23 X-6$ & 212.38 & & 1518 & & $30 X-6$ & 278.87 & & 1509 & 1511 & $42 X-1$ & 386.38 & & & 1597 \\
\hline $23 X-6$ & 212.47 & 1526 & & & $30 X-7$ & 280.13 & 1529 & & & $42 X-2$ & 387.53 & & & 1677 \\
\hline $23 X-7$ & 213.45 & & 1467 & 1505 & $30 X-7$ & 280.22 & & 1470 & & $42 X-3$ & 389.04 & & & 1622 \\
\hline $23 X-7$ & 213.52 & 1520 & & & $31 X-1$ & 281.40 & 1513 & & & $42 X-4$ & 391.12 & & & 1615 \\
\hline $24 X-1$ & 214.98 & & 1453 & & $31 X-1$ & 281.49 & & & 1514 & $42 X-5$ & 392.51 & & & 1565 \\
\hline $24 X-2$ & 216.19 & 1515 & & & $31 X-2$ & 282.82 & 1512 & & & $43 X-1$ & 396.26 & & & 1558 \\
\hline $24 X-2$ & 216.30 & & 1497 & 1501 & $31 X-2$ & 282.90 & & & 1410 & $43 X-2$ & 397.69 & & & 1595 \\
\hline $24 X-3$ & 217.70 & 1528 & & & $31 X-3$ & 284.40 & 1519 & & & $43 X-3$ & 398.69 & & & 1557 \\
\hline $24 X-4$ & 218.80 & 1582 & & & $31 X-4$ & 285.81 & 1532 & & & $43 X-4$ & 400.68 & & & 1585 \\
\hline $24 X-4$ & 218.90 & & 1502 & 1505 & $31 X-4$ & 285.91 & & & 1408 & $43 X-5$ & 401.86 & & & 1641 \\
\hline $25 X-1$ & 224.20 & 1533 & & & $31 X-5$ & 287.38 & 1525 & & & $43 X-6$ & 403.52 & & & 1586 \\
\hline $25 X-1$ & 224.30 & & & 1488 & $31 X-5$ & 287.50 & & 1511 & & $43 X-7$ & 404.41 & & & 1677 \\
\hline $25 X-2$ & 225.70 & 1545 & & & $31 X-6$ & 289.03 & 1525 & & & $44 X-1$ & 405.98 & & & 1577 \\
\hline $25 X-2$ & 225.80 & & 1496 & & $32 X-2$ & 292.58 & 1509 & & & $44 X-2$ & 407.17 & & & 1605 \\
\hline $25 X-3$ & 227.20 & 1522 & & & $32 x-3$ & 293.90 & 1526 & & & $44 X-3$ & 408.77 & & & 1629 \\
\hline $25 X-3$ & 227.30 & & 1500 & 1501 & $32 X-4$ & 295.46 & 1519 & & & $44 X-4$ & 410.56 & & & 1586 \\
\hline $25 X-4$ & 228.95 & 1529 & & & $32 X-5$ & 296.85 & 1528 & & & $44 X-5$ & 412.05 & & & 1650 \\
\hline $25 X-4$ & 229.04 & & 1503 & 1502 & $33 X-1$ & 300.63 & 1524 & & & $45 X-1$ & 412.87 & & & 1563 \\
\hline $25 X-5$ & 230.20 & 1512 & & & $33 X-2$ & 301.86 & 1521 & & & $44 X-6$ & 413.31 & & & 1624 \\
\hline $25 X-5$ & 230.30 & & 1502 & 1506 & $33 X-3$ & 303.38 & 1529 & & & $45 X-2$ & 417.21 & & & 1598 \\
\hline
\end{tabular}


Table T21 (continued).

\begin{tabular}{|c|c|c|c|c|}
\hline \multirow{2}{*}{$\begin{array}{l}\text { Core, } \\
\text { section }\end{array}$} & \multirow{2}{*}{$\begin{array}{l}\text { Depth } \\
\text { CSF (m) }\end{array}$} & \multicolumn{3}{|c|}{ Velocity $(\mathrm{m} / \mathrm{s})$} \\
\hline & & $x$-axis & $y$-axis & $z$-axis \\
\hline $45 X-3$ & 418.57 & & & 1636 \\
\hline $45 X-4$ & 420.12 & & & 1610 \\
\hline $45 X-5$ & 421.13 & & & 1650 \\
\hline $45 X-6$ & 422.10 & & & 1661 \\
\hline $46 X-1$ & 424.78 & & & 1715 \\
\hline $46 X-3$ & 427.55 & & & 1609 \\
\hline $46 X-4$ & 428.57 & & & 1661 \\
\hline $46 X-5$ & 430.47 & & & 1694 \\
\hline $46 X-6$ & 432.31 & & & 1787 \\
\hline $47 X-2$ & 435.97 & & & 1664 \\
\hline $47 X-3$ & 437.29 & & & 1727 \\
\hline $47 X-4$ & 438.86 & & & 1749 \\
\hline $47 X-4$ & 438.86 & & & 1652 \\
\hline $47 X-5$ & 440.74 & & & 1726 \\
\hline $47 X-6$ & 441.93 & & & 1670 \\
\hline $47 X-6$ & 441.95 & & & 1640 \\
\hline $47 X-7$ & 442.89 & & & 1671 \\
\hline $47 X-7$ & 442.90 & & & 1675 \\
\hline $48 X-1$ & 443.87 & & & 1731 \\
\hline $48 X-2$ & 445.64 & & & 1854 \\
\hline $48 X-2$ & 445.64 & & & 1863 \\
\hline $48 X-3$ & 447.31 & & & 1796 \\
\hline $48 X-3$ & 447.32 & & & 1767 \\
\hline \multicolumn{5}{|c|}{ 321-U1337B- } \\
\hline $22 \mathrm{H}-1$ & 201.51 & 1544 & & \\
\hline $22 \mathrm{H}-2$ & 202.71 & 1538 & & \\
\hline $22 \mathrm{H}-2$ & 202.38 & 1511 & & \\
\hline $22 \mathrm{H}-3$ & 204.18 & 1492 & & \\
\hline $22 \mathrm{H}-4$ & 205.54 & 1498 & & \\
\hline $22 \mathrm{H}-5$ & 207.48 & 1513 & & \\
\hline $22 \mathrm{H}-6$ & 208.46 & 1557 & & \\
\hline $22 \mathrm{H}-6$ & 208.34 & 1578 & & \\
\hline $22 \mathrm{H}-7$ & 209.45 & 1561 & & \\
\hline $23 \mathrm{H}-1$ & 210.65 & 1527 & & \\
\hline $23 \mathrm{H}-2$ & 212.26 & 1518 & & \\
\hline $23 \mathrm{H}-3$ & 213.71 & 1529 & & \\
\hline $23 \mathrm{H}-4$ & 215.16 & 1524 & & \\
\hline $24 \mathrm{H}-1$ & 220.53 & 1524 & & \\
\hline $24 \mathrm{H}-2$ & 221.74 & 1522 & & \\
\hline $24 \mathrm{H}-3$ & 223.43 & 1526 & & \\
\hline $24 \mathrm{H}-4$ & 224.84 & 1509 & & \\
\hline $24 \mathrm{H}-5$ & 225.94 & 1539 & & \\
\hline $25 \mathrm{H}-1$ & 227.31 & 1531 & & \\
\hline $25 \mathrm{H}-2$ & 228.86 & 1532 & & \\
\hline $25 \mathrm{H}-3$ & 230.07 & 1534 & & \\
\hline $25 \mathrm{H}-4$ & 231.96 & 1537 & & \\
\hline $25 \mathrm{H}-5$ & 232.95 & 1501 & & \\
\hline $26 \mathrm{H}-1$ & 235.16 & 1528 & & \\
\hline $26 \mathrm{H}-2$ & 236.41 & 1512 & & \\
\hline $26 \mathrm{H}-3$ & 238.2 & 1520 & & \\
\hline $26 \mathrm{H}-4$ & 239.72 & 1523 & & \\
\hline $26 \mathrm{H}-5$ & 241.12 & 1516 & & \\
\hline $26 \mathrm{H}-6$ & 242.52 & 1521 & & \\
\hline $27 \mathrm{H}-1$ & 244.8 & 1487 & & \\
\hline
\end{tabular}


Table T22. Thermal conductivity, Hole U1337A.

\begin{tabular}{|c|c|c|}
\hline $\begin{array}{l}\text { Core, section, } \\
\text { interval }(\mathrm{cm})\end{array}$ & $\begin{array}{l}\text { Depth } \\
\text { CSF }(m)\end{array}$ & $\begin{array}{c}\text { Thermal } \\
\text { conductivity } \\
(\mathrm{W} /[\mathrm{m} \cdot \mathrm{K}])\end{array}$ \\
\hline \multicolumn{3}{|l|}{ 321-U1337A- } \\
\hline $2 \mathrm{H}-3,75$ & 9.25 & 0.750 \\
\hline $3 \mathrm{H}-3,75$ & 18.75 & 0.812 \\
\hline $4 \mathrm{H}-3,75$ & 28.25 & 0.742 \\
\hline $5 \mathrm{H}-3,75$ & 37.75 & 0.850 \\
\hline $6 \mathrm{H}-3,75$ & 47.25 & 0.747 \\
\hline $7 \mathrm{H}-3,75$ & 56.75 & 0.790 \\
\hline $8 \mathrm{H}-3,75$ & 66.25 & 0.796 \\
\hline $9 \mathrm{H}-3,75$ & 75.75 & 0.786 \\
\hline $10 \mathrm{H}-3,75$ & 85.25 & 0.917 \\
\hline $11 \mathrm{H}-3,75$ & 94.75 & 0.853 \\
\hline $12 \mathrm{H}-3,75$ & 104.25 & 0.787 \\
\hline $13 \mathrm{H}-3,75$ & 113.75 & 0.819 \\
\hline $14 \mathrm{H}-3,75$ & 123.25 & 0.950 \\
\hline $15 \mathrm{H}-3,75$ & 132.75 & 0.904 \\
\hline $16 \mathrm{H}-3,75$ & 142.25 & 0.796 \\
\hline $17 \mathrm{H}-3,75$ & 151.75 & 0.962 \\
\hline $18 \mathrm{H}-3,75$ & 161.27 & 0.839 \\
\hline $19 \mathrm{H}-3,75$ & 170.75 & 0.857 \\
\hline $20 \mathrm{H}-3,75$ & 180.25 & 0.829 \\
\hline $21 \mathrm{H}-3,75$ & 189.75 & 0.882 \\
\hline $23 X-3,75$ & 208.05 & 0.904 \\
\hline $24 X-3,75$ & 217.65 & 0.875 \\
\hline $25 X-3,75$ & 227.15 & 1.071 \\
\hline $26 X-3,75$ & 236.75 & 1.068 \\
\hline $27 X-1,62$ & 242.82 & 0.787 \\
\hline $28 X-3,75$ & 255.45 & 1.144 \\
\hline $29 X-3,75$ & 265.05 & 1.154 \\
\hline $30 X-3,75$ & 274.55 & 1.070 \\
\hline $31 X-3,75$ & 284.25 & 1.057 \\
\hline $32 X-3,75$ & 293.95 & 0.958 \\
\hline $33 X-3,75$ & 303.45 & 1.278 \\
\hline $34 X-3,75$ & 313.05 & 1.324 \\
\hline $35 X-3,75$ & 322.65 & 1.217 \\
\hline $36 X-3,75$ & 332.25 & 1.038 \\
\hline $37 X-3,60$ & 341.60 & 1.059 \\
\hline $38 X-3,75$ & 351.35 & 0.996 \\
\hline $39 X-3,75$ & 360.95 & 1.159 \\
\hline $40 X-3,75$ & 370.55 & 1.775 \\
\hline $41 X-3,70$ & 380.10 & 1.290 \\
\hline $42 X-3,75$ & 389.75 & 1.199 \\
\hline $43 X-3,89$ & 399.49 & 1.186 \\
\hline $44 X-3,65$ & 408.55 & 1.193 \\
\hline $45 X-3,91$ & 418.41 & 1.316 \\
\hline $46 X-3,60$ & 427.60 & 1.404 \\
\hline $47 X-3,62$ & 437.22 & 1.457 \\
\hline $48 X-3,75$ & 446.95 & 1.644 \\
\hline
\end{tabular}


Table T23. Shipboard composite and corrected composite depths, Site U1337.

\begin{tabular}{|c|c|c|c|c|}
\hline \multirow[b]{2}{*}{ Core } & \multirow{2}{*}{$\begin{array}{l}\text { Depth } \\
\text { CSF }(m)\end{array}$} & \multirow{2}{*}{$\begin{array}{l}\text { Offset } \\
\text { (m) }\end{array}$} & \multicolumn{2}{|c|}{ Top depth $(\mathrm{m})$} \\
\hline & & & CCSF-A & CCSF-B \\
\hline \multicolumn{5}{|c|}{ 321-U1337A- } \\
\hline $2 \mathrm{H}$ & 5.5 & -4.85 & 0.29 & 0.25 \\
\hline $3 \mathrm{H}$ & 15.0 & -3.65 & 10.98 & 9.81 \\
\hline $4 \mathrm{H}$ & 24.5 & -3.65 & 20.48 & 18.29 \\
\hline $5 \mathrm{H}$ & 34.0 & -0.98 & 32.65 & 29.15 \\
\hline $6 \mathrm{H}$ & 43.5 & 0.15 & 43.29 & 38.65 \\
\hline $7 \mathrm{H}$ & 53.0 & 2.63 & 55.26 & 49.34 \\
\hline $8 \mathrm{H}$ & 62.5 & 3.52 & 65.65 & 58.62 \\
\hline $9 \mathrm{H}$ & 72.0 & 4.75 & 76.38 & 68.20 \\
\hline $10 \mathrm{H}$ & 81.5 & 5.63 & 86.76 & 77.47 \\
\hline $11 \mathrm{H}$ & 91.0 & 6.72 & 97.35 & 86.92 \\
\hline $12 \mathrm{H}$ & 100.5 & 7.46 & 107.59 & 96.06 \\
\hline $13 \mathrm{H}$ & 110.0 & 8.40 & 118.04 & 105.39 \\
\hline $14 \mathrm{H}$ & 119.5 & 10.58 & 129.71 & 115.82 \\
\hline $15 \mathrm{H}$ & 129.0 & 12.16 & 140.80 & 125.71 \\
\hline $16 \mathrm{H}$ & 138.5 & 12.59 & 150.72 & 134.57 \\
\hline $17 \mathrm{H}$ & 148.0 & 14.22 & 161.85 & 144.51 \\
\hline $18 \mathrm{H}$ & 157.5 & 16.06 & 173.20 & 154.64 \\
\hline $19 \mathrm{H}$ & 167.0 & 16.96 & 183.59 & 163.92 \\
\hline $20 \mathrm{H}$ & 176.5 & 17.70 & 193.83 & 173.06 \\
\hline $21 \mathrm{H}$ & 186.0 & 18.28 & 203.92 & 182.07 \\
\hline $22 x$ & 195.5 & 18.28 & 213.42 & 190.55 \\
\hline $23 x$ & 204.3 & 19.83 & 223.77 & 199.79 \\
\hline $24 X$ & 213.9 & 20.54 & 234.08 & 209.00 \\
\hline $25 x$ & 223.4 & 21.76 & 244.79 & 218.56 \\
\hline $26 x$ & 233.0 & 21.47 & 254.10 & 226.87 \\
\hline $27 X$ & 242.2 & 24.82 & 266.65 & 238.08 \\
\hline $28 \mathrm{X}$ & 251.7 & 20.96 & 272.29 & 243.12 \\
\hline $29 X$ & 261.3 & 23.67 & 284.60 & 254.11 \\
\hline $30 x$ & 270.8 & 29.65 & 300.08 & 267.93 \\
\hline $31 x$ & 280.5 & 29.73 & 309.86 & 276.66 \\
\hline $32 x$ & 290.2 & 29.64 & 319.47 & 285.24 \\
\hline $33 x$ & 299.7 & 28.85 & 328.18 & 293.02 \\
\hline $34 X$ & 309.3 & 30.10 & 339.04 & 302.71 \\
\hline $35 x$ & 318.9 & 29.49 & 348.02 & 310.73 \\
\hline $36 x$ & 328.5 & 30.31 & 358.44 & 320.03 \\
\hline $37 x$ & 338.0 & 30.91 & 368.54 & 329.05 \\
\hline $38 \mathrm{X}$ & 347.6 & 31.47 & 378.70 & 338.13 \\
\hline $39 x$ & 357.2 & 30.89 & 387.73 & 346.18 \\
\hline $40 x$ & 366.8 & 33.09 & 399.53 & 356.72 \\
\hline $41 x$ & 376.4 & 33.60 & 409.63 & 365.74 \\
\hline $42 x$ & 386.0 & 35.90 & 421.53 & 376.37 \\
\hline $43 x$ & 395.6 & 35.50 & 430.73 & 384.58 \\
\hline $44 X$ & 404.9 & 35.50 & 440.03 & 392.88 \\
\hline $45 x$ & 414.5 & 36.31 & 450.44 & 402.18 \\
\hline $46 \mathrm{X}$ & 424.0 & 42.78 & 466.41 & 416.44 \\
\hline $47 X$ & 433.6 & 44.88 & 478.11 & 426.88 \\
\hline $48 \mathrm{X}$ & 443.2 & 45.36 & 488.19 & 435.88 \\
\hline \multicolumn{5}{|c|}{ 321-U1337B- } \\
\hline $1 \mathrm{H}$ & 1.00 & -0.54 & 0.03 & 0.03 \\
\hline $2 \mathrm{H}$ & 10.50 & -2.96 & 7.11 & 6.35 \\
\hline $3 \mathrm{H}$ & 20.00 & -1.90 & 17.66 & 15.77 \\
\hline $4 \mathrm{H}$ & 29.50 & -1.52 & 27.54 & 24.59 \\
\hline
\end{tabular}

\begin{tabular}{|c|c|c|c|c|}
\hline \multirow[b]{2}{*}{ Core } & \multirow{2}{*}{$\begin{array}{c}\text { Depth } \\
\operatorname{CSF}(\mathrm{m})\end{array}$} & \multirow{2}{*}{$\begin{array}{l}\text { Offset } \\
(\mathrm{m})\end{array}$} & \multicolumn{2}{|c|}{ Top depth (m) } \\
\hline & & & CCSF-A & CCSF-B \\
\hline $5 \mathrm{H}$ & 39.00 & -0.62 & 37.94 & 33.88 \\
\hline $6 \mathrm{H}$ & 48.50 & 0.75 & 48.82 & 43.59 \\
\hline $7 \mathrm{H}$ & 58.00 & 1.85 & 59.42 & 53.05 \\
\hline $8 \mathrm{H}$ & 67.5 & 2.97 & 70.04 & 62.53 \\
\hline $9 \mathrm{H}$ & 77 & 4.40 & 80.97 & 72.29 \\
\hline $10 \mathrm{H}$ & 86.5 & 7.06 & 93.13 & 83.15 \\
\hline $11 \mathrm{H}$ & 96 & 7.77 & 103.34 & 92.26 \\
\hline $12 \mathrm{H}$ & 105.5 & 9.06 & 114.13 & 101.90 \\
\hline $13 \mathrm{H}$ & 115 & 10.44 & 125.01 & 111.62 \\
\hline $14 \mathrm{H}$ & 124.5 & 11.40 & 135.47 & 120.95 \\
\hline $15 \mathrm{H}$ & 134 & 12.44 & 146.01 & 130.37 \\
\hline $16 \mathrm{H}$ & 143.5 & 13.63 & 156.70 & 139.91 \\
\hline $17 \mathrm{H}$ & 153 & 13.96 & 166.53 & 148.68 \\
\hline $18 \mathrm{H}$ & 162.5 & 14.95 & 177.02 & 158.05 \\
\hline $19 \mathrm{H}$ & 172 & 16.54 & 188.11 & 167.95 \\
\hline $20 \mathrm{H}$ & 181.5 & 18.13 & 199.20 & 177.86 \\
\hline $21 \mathrm{H}$ & 191 & 19.07 & 209.63 & 187.17 \\
\hline $22 \mathrm{H}$ & 200.5 & 20.92 & 220.98 & 197.31 \\
\hline $23 \mathrm{H}$ & 210 & 24.29 & 233.85 & 208.80 \\
\hline $24 \mathrm{H}$ & 219.5 & 22.38 & 241.45 & 215.58 \\
\hline $25 \mathrm{H}$ & 226.4 & 22.44 & 248.41 & 221.79 \\
\hline $26 \mathrm{H}$ & 234.3 & 21.76 & 255.63 & 228.24 \\
\hline $27 \mathrm{H}$ & 243.8 & 23.33 & 266.70 & 238.12 \\
\hline \multicolumn{5}{|c|}{ 321-U1337C- } \\
\hline $1 \mathrm{H}$ & 0.00 & 0.00 & 0.00 & 0.00 \\
\hline $2 \mathrm{H}$ & 1.59 & 2.33 & 3.92 & 3.50 \\
\hline $4 \mathrm{H}$ & 169.40 & 23.56 & 192.96 & 172.29 \\
\hline $5 \mathrm{H}$ & 179.35 & 23.87 & 203.22 & 181.44 \\
\hline $6 \mathrm{H}$ & 188.24 & 24.62 & 212.87 & 190.06 \\
\hline $7 \mathrm{H}$ & 193.52 & 24.77 & 218.30 & 194.91 \\
\hline $8 \mathrm{H}$ & 204.01 & 25.80 & 229.81 & 205.19 \\
\hline $9 \mathrm{H}$ & 211.53 & 27.82 & 239.35 & 213.70 \\
\hline $10 x$ & 221.99 & 27.86 & 249.85 & 223.08 \\
\hline $11 x$ & 229.23 & 28.86 & 258.09 & 230.44 \\
\hline $12 x$ & 245.17 & 27.50 & 272.67 & 243.46 \\
\hline $13 x$ & 250.75 & 32.48 & 283.23 & 252.88 \\
\hline $14 X$ & 262.95 & 33.43 & 296.38 & 264.63 \\
\hline $15 X$ & 268.99 & 36.99 & 305.98 & 273.20 \\
\hline $16 \mathrm{X}$ & 278.85 & 36.99 & 315.84 & 282.00 \\
\hline $17 X$ & 286.65 & 37.25 & 323.90 & 289.19 \\
\hline $18 \mathrm{x}$ & 298.32 & 35.71 & 334.03 & 298.24 \\
\hline $19 \mathrm{X}$ & 307.39 & 36.24 & 343.63 & 306.81 \\
\hline $20 x$ & 317.26 & 36.24 & 353.50 & 315.63 \\
\hline $21 x$ & 327.71 & 36.51 & 364.22 & 325.19 \\
\hline $22 x$ & 336.77 & 37.72 & 374.49 & 334.37 \\
\hline $23 x$ & 345.42 & 38.40 & 383.82 & 342.69 \\
\hline $24 X$ & 354.49 & 38.13 & 392.62 & 350.55 \\
\hline $25 x$ & 365.59 & 37.33 & 402.92 & 359.75 \\
\hline $26 x$ & 375.89 & 38.03 & 413.92 & 369.57 \\
\hline $27 X$ & 385.97 & 39.53 & 425.50 & 379.91 \\
\hline $28 \mathrm{X}$ & 402.35 & 41.51 & 443.86 & 396.30 \\
\hline $29 x$ & 407.21 & 50.56 & 457.78 & 408.73 \\
\hline $30 x$ & 412.20 & 54.89 & 467.09 & 417.05 \\
\hline
\end{tabular}

\begin{tabular}{|c|c|c|c|c|}
\hline \multirow[b]{2}{*}{ Core } & \multirow{2}{*}{$\begin{array}{c}\text { Depth } \\
\text { CSF }(m)\end{array}$} & \multirow{2}{*}{$\begin{array}{l}\text { Offset } \\
(\mathrm{m})\end{array}$} & \multicolumn{2}{|c|}{ Top depth (m) } \\
\hline & & & CCSF-A & CCSF-B \\
\hline $31 x$ & 421.99 & 54.70 & 476.69 & 425.62 \\
\hline $32 x$ & 431.59 & 54.70 & 486.29 & 434.19 \\
\hline $33 x$ & 436.39 & 54.70 & 491.09 & 438.47 \\
\hline \multicolumn{5}{|c|}{ 321-U1337D- } \\
\hline $1 \mathrm{H}$ & 0.00 & 0.05 & 0.05 & 0.05 \\
\hline $2 \mathrm{H}$ & 8.00 & 1.05 & 9.05 & 8.08 \\
\hline $3 \mathrm{H}$ & 17.50 & 1.90 & 19.40 & 17.32 \\
\hline $4 \mathrm{H}$ & 27.00 & 2.66 & 29.66 & 26.48 \\
\hline $5 \mathrm{H}$ & 36.50 & 3.87 & 40.37 & 36.04 \\
\hline $6 \mathrm{H}$ & 46.00 & 5.51 & 51.51 & 45.99 \\
\hline $7 \mathrm{H}$ & 55.50 & 6.96 & 62.46 & 55.77 \\
\hline $8 \mathrm{H}$ & 65.00 & 7.37 & 72.37 & 64.61 \\
\hline $9 \mathrm{H}$ & 74.50 & 9.15 & 83.65 & 74.68 \\
\hline $10 \mathrm{H}$ & 84.00 & 10.93 & 94.93 & 84.76 \\
\hline $11 \mathrm{H}$ & 93.50 & 12.53 & 106.03 & 94.67 \\
\hline $12 \mathrm{H}$ & 103.00 & 13.32 & 116.32 & 103.85 \\
\hline $13 \mathrm{H}$ & 112.50 & 15.27 & 127.77 & 114.08 \\
\hline $14 \mathrm{H}$ & 122.00 & 16.25 & 138.25 & 123.44 \\
\hline $15 \mathrm{H}$ & 131.50 & 17.19 & 148.69 & 132.76 \\
\hline $16 \mathrm{H}$ & 141.00 & 18.96 & 159.96 & 142.82 \\
\hline $17 \mathrm{H}$ & 150.50 & 19.93 & 170.43 & 152.17 \\
\hline $18 \mathrm{H}$ & 160.00 & 20.81 & 180.81 & 161.43 \\
\hline $19 \mathrm{H}$ & 169.50 & 21.45 & 190.95 & 170.49 \\
\hline $20 \mathrm{H}$ & 179.00 & 21.88 & 200.88 & 179.36 \\
\hline $21 \mathrm{H}$ & 188.50 & 21.58 & 210.08 & 187.57 \\
\hline $22 \mathrm{H}$ & 193.50 & 23.55 & 217.05 & 193.80 \\
\hline $23 \mathrm{H}$ & 199.70 & 25.55 & 225.25 & 201.11 \\
\hline $24 \mathrm{H}$ & 209.20 & 27.25 & 236.45 & 211.12 \\
\hline $25 \mathrm{H}$ & 218.70 & 26.76 & 245.46 & 219.16 \\
\hline $26 \mathrm{H}$ & 228.20 & 27.51 & 255.71 & 228.31 \\
\hline $27 x$ & 237.70 & 26.67 & 264.37 & 236.05 \\
\hline $28 \mathrm{H}$ & 241.40 & 27.51 & 268.91 & 240.10 \\
\hline $29 \mathrm{H}$ & 248.00 & 29.79 & 277.79 & 248.02 \\
\hline $30 \mathrm{H}$ & 257.50 & 30.76 & 288.26 & 257.38 \\
\hline $31 X$ & 267.00 & 35.51 & 302.51 & 270.10 \\
\hline $32 x$ & 276.20 & 35.51 & 311.71 & 278.31 \\
\hline $33 x$ & 285.80 & 35.12 & 320.92 & 286.54 \\
\hline $34 X$ & 295.30 & 34.44 & 329.74 & 294.41 \\
\hline $35 x$ & 304.90 & 34.44 & 339.34 & 302.98 \\
\hline $36 x$ & 314.50 & 34.91 & 349.41 & 311.97 \\
\hline $37 x$ & 324.10 & 35.11 & 359.21 & 320.72 \\
\hline $38 X$ & 333.60 & 35.42 & 369.02 & 329.48 \\
\hline $39 x$ & 343.20 & 34.44 & 377.64 & 337.18 \\
\hline $40 X$ & 352.80 & 35.04 & 387.84 & 346.29 \\
\hline $41 X$ & 362.40 & 36.21 & 398.61 & 355.90 \\
\hline $42 X$ & 372.00 & 38.31 & 410.31 & 366.35 \\
\hline $43 x$ & 381.60 & 39.67 & 421.27 & 376.13 \\
\hline $44 X$ & 391.20 & 51.81 & 443.01 & 395.54 \\
\hline $45 X$ & 400.50 & 51.86 & 452.36 & 403.89 \\
\hline $46 X$ & 410.10 & 53.73 & 463.83 & 414.14 \\
\hline $47 X$ & 419.60 & 53.62 & 473.22 & 422.52 \\
\hline $48 X$ & 429.10 & 53.19 & 482.29 & 430.62 \\
\hline $49 x$ & 438.80 & 53.19 & 491.99 & 439.28 \\
\hline
\end{tabular}


Table T24. Splice tie points, Site U1337. (Continued on next page.)

\begin{tabular}{|c|c|c|c|c|c|c|}
\hline \multirow{2}{*}{$\begin{array}{l}\text { Hole, core, section, } \\
\text { interval }(\mathrm{cm})\end{array}$} & \multicolumn{2}{|c|}{ Depth $(m)$} & & \multirow{2}{*}{$\begin{array}{l}\text { Hole, core, section, } \\
\text { interval }(\mathrm{cm})\end{array}$} & \multicolumn{2}{|c|}{ Depth $(m)$} \\
\hline & CSF & CCSF-A & & & CSF & CCSF-A \\
\hline $321-$ & & & & $321-$ & & \\
\hline U1337B-1H-3, 134 & 5.34 & 4.80 & Tie to & U1337A-2H-3, 115 & 9.65 & 4.80 \\
\hline U1337A-2H-6, 45 & 13.45 & 8.60 & Tie to & U1337C-2H-3, 137 & 6.28 & 8.60 \\
\hline U1337C-2H-6, 68 & 10.07 & 12.40 & Tie to & U1337A-3H-1, 105 & 16.05 & 12.40 \\
\hline U1337A-3H-6, 70 & 23.20 & 19.55 & Tie to & U1337B-3H-1, 146 & 21.46 & 19.55 \\
\hline U1337B-3Н-6, 148 & 27.49 & 25.58 & Tie to & U1337A-4H-4, 23 & 29.23 & 25.58 \\
\hline U1337A-4H-6, 50 & 32.50 & 28.86 & Tie to & U1337B-4H-1, 88 & 30.38 & 28.86 \\
\hline U1337B-4H-6, 17 & 37.17 & 35.65 & Tie to & U1337A-5H-2, 113 & 36.63 & 35.65 \\
\hline U1337A-5H-4, 124 & 39.74 & 38.76 & Tie to & U1337B-5H-1, 38 & 39.38 & 38.76 \\
\hline U1337B-5H-5, 110 & 46.10 & 45.47 & Tie to & U1337A-6H-2, 32 & 45.32 & 45.47 \\
\hline U1337A-6H-5, 93 & 50.43 & 50.58 & Tie to & U1337B-6H-1, 133 & 49.83 & 50.58 \\
\hline U1337B-6H-5, 113 & 55.63 & 56.38 & Tie to & U1337A-7H-1, 76 & 53.76 & 56.38 \\
\hline U1337A-7H-5, 31 & 59.31 & 61.94 & Tie to & U1337B-7H-2, 59 & 60.09 & 61.94 \\
\hline U1337B-7H-6, 27 & 65.76 & 67.61 & Tie to & U1337A-8H-2, 9 & 64.09 & 67.61 \\
\hline U1337A-8H-5, 64 & 69.15 & 72.67 & Tie to & U1337B-8H-2, 70 & 69.70 & 72.67 \\
\hline U1337B-8H-5, 106 & 74.56 & 77.52 & Tie to & U1337A-9H-1, 78 & 72.77 & 77.52 \\
\hline U1337A-9H-6, 114 & 80.64 & 85.39 & Tie to & U1337B-9H-3, 99 & 80.99 & 85.39 \\
\hline U1337B-9H-5, 117 & 84.16 & 88.56 & Tie to & U1337A-10H-1, 143 & 82.93 & 88.56 \\
\hline U1337A-10H-5, 123 & 88.73 & 94.36 & Tie to & U1337B-10H-1, 80 & 87.30 & 94.36 \\
\hline U1337B-10H-4, 54 & 91.54 & 98.60 & Tie to & U1337A-11H-1, 88 & 91.88 & 98.60 \\
\hline U1337A-11H-5, 114 & 98.15 & 104.87 & Tie to & U1337B-11H-1, 110 & 97.10 & 104.87 \\
\hline U1337B-11H-5, 43 & 102.43 & 110.20 & Tie to & U1337A-12H-2, 74 & 102.74 & 110.20 \\
\hline U1337A-12H-6, 58 & 108.58 & 116.04 & Tie to & U1337B-12H-1, 148 & 106.98 & 116.04 \\
\hline U1337B-12H-5, 40 & 111.90 & 120.96 & Tie to & U1337A-13H-2, 106 & 112.56 & 120.96 \\
\hline U1337A-13H-6, 39 & 117.89 & 126.29 & Tie to & U1337B-13H-1, 85 & 115.85 & 126.29 \\
\hline U1337B-13H-5, 14 & 121.14 & 131.58 & Tie to & U1337A-14H-1, 150 & 121.00 & 131.58 \\
\hline U1337A-14H-7, 20 & 128.70 & 139.28 & Tie to & U1337D-14H-1, 103 & 123.03 & 139.28 \\
\hline U1337D-14H-4, 98 & 127.48 & 143.73 & Tie to & U1337A-15H-2, 107 & 131.57 & 143.73 \\
\hline U1337A-15H-5, 52 & 135.53 & 147.69 & Tie to & U1337B-15H-1, 125 & 135.25 & 147.69 \\
\hline U1337B-15H-5, 98 & 140.98 & 153.43 & Tie to & U1337A-16H-2, 84 & 140.84 & 153.43 \\
\hline U1337A-16H-5, 104 & 145.54 & 158.13 & Tie to & U1337B-16H-1, 100 & 144.50 & 158.13 \\
\hline U1337B-16H-5, 110 & 150.60 & 164.23 & Tie to & U1337A-17H-2, 50 & 150.01 & 164.23 \\
\hline U1337A-17H-5, 84 & 154.84 & 169.06 & Tie to & U1337B-17H-2, 59 & 155.10 & 169.06 \\
\hline U1337B-17H-6, 8 & 160.58 & 174.54 & Tie to & U1337A-18H-1, 98 & 158.48 & 174.54 \\
\hline U1337A-18H-6, 104 & 166.09 & 182.15 & Tie to & U1337B-18H-4, 20 & 167.20 & 182.15 \\
\hline U1337B-18H-6, 58 & 170.58 & 185.53 & Tie to & U1337A-19H-2, 7 & 168.57 & 185.53 \\
\hline U1337A-19H-5, 55 & 173.55 & 190.51 & Tie to & U1337B-19H-2, 47 & 173.97 & 190.51 \\
\hline U1337B-19H-5, 83 & 178.89 & 195.43 & Tie to & U1337A-20H-1, 123 & 177.73 & 195.43 \\
\hline U1337A-20H-5, 47 & 182.97 & 200.67 & Tie to & U1337B-20H-1, 104 & 182.54 & 200.67 \\
\hline U1337B-20H-5, 50 & 188.00 & 206.13 & Tie to & U1337A-21H-2, 35 & 187.85 & 206.13 \\
\hline U1337A-21H-5, 36 & 192.37 & 210.65 & Tie to & U1337B-21H-1, 58 & 191.59 & 210.65 \\
\hline U1337B-21H-3, 54 & 194.54 & 213.60 & Tie to & U1337C-6H-1, 43 & 188.83 & 213.60 \\
\hline U1337C-6H-3, 119 & 192.59 & 217.36 & Tie to & U1337D-22H-1, 31 & 193.81 & 217.36 \\
\hline U1337D-22H-2, 58 & 195.58 & 219.13 & Tie to & U1337C-7H-1, 53 & 193.33 & 219.13 \\
\hline U1337C-7H-6, 121 & 201.51 & 227.31 & Tie to & U1337A-23X-3, 18 & 207.48 & 227.31 \\
\hline U1337A-23X-6, 155 & 211.84 & 231.68 & Tie to & U1337C-8H-2, 5 & 203.86 & 231.68 \\
\hline U1337C-8H-7, 64 & 211.94 & 239.76 & Append to & U1337C-9H-1, 3 & 211.83 & 239.69 \\
\hline U1337C-9H-5, 107 & 218.87 & 246.73 & Tie to & U1337A-25X-2, 7 & 224.97 & 246.73 \\
\hline U1337A-25X-4, 99 & 228.89 & 250.65 & Tie to & U1337B-25H-2, 31 & 228.21 & 250.65 \\
\hline U1337B-25H-5, 150 & 232.40 & 254.84 & Tie to & U1337A-26X-1, 37 & 233.37 & 254.84 \\
\hline U1337A-26X-4, 68 & 238.18 & 259.65 & Tie to & U1337C-11X-1, 125 & 232.15 & 259.65 \\
\hline U1337C-11X-6, 70 & 238.70 & 266.20 & Append to & U1337C-12X-1, 3 & 240.53 & 273.01 \\
\hline U1337C-12X-5, 136 & 247.86 & 280.34 & Tie to & U1337D-29H-2, 105 & 250.55 & 280.34 \\
\hline U1337D-29H-5, 40 & 254.40 & 284.18 & Tie to & U1337C-13X-1, 65 & 250.75 & 284.18 \\
\hline U1337C-13X-6, 23 & 257.83 & 291.26 & Tie to & U1337D-30H-3, 1 & 260.50 & 291.26 \\
\hline U1337D-30H-6, 104 & 266.04 & 296.80 & Tie to & U1337C-14X-1, 33 & 260.03 & 297.02 \\
\hline U1337C-14X-6, 4 & 267.24 & 304.23 & Tie to & U1337D-31X-2, 22 & 268.72 & 304.23 \\
\hline U1337D-31X-5, 20 & 273.21 & 308.72 & Tie to & U1337C-15X-2, 93 & 271.73 & 308.72 \\
\hline U1337C-15X-4, 145 & 275.25 & 312.24 & Tie to & U1337D-32X-1, 53 & 276.73 & 312.24 \\
\hline U1337D-32X-4, 84 & 281.54 & 317.05 & Tie to & U1337C-16X-1, 90 & 279.80 & 317.05 \\
\hline U1337C-16X-4, 27 & 283.67 & 320.92 & Tie to & U1337A-32X-1, 108 & 291.28 & 320.92 \\
\hline U1337A-32X-4, 79 & 295.49 & 325.14 & Tie to & U1337C-17X-1, 93 & 289.43 & 325.14 \\
\hline U1337C-17X-5, 64 & 295.15 & 330.86 & Tie to & U1337A-33X-2, 80 & 302.00 & 330.86 \\
\hline U1337A-33X-4, 133 & 305.53 & 334.38 & Tie to & U1337C-18X-1, 4 & 298.14 & 334.38 \\
\hline U1337C-18X-6, 74 & 306.34 & 342.58 & Tie to & U1337A-34X-3, 18 & 312.47 & 342.58 \\
\hline U1337A-34X-5, 88 & 316.17 & 346.28 & Tie to & U1337C-19X-2, 84 & 310.04 & 346.28 \\
\hline U1337C-19X-5, 29 & 313.99 & 350.23 & Tie to & U1337A-35X-2, 34 & 320.74 & 350.23 \\
\hline U1337A-35X-3, 30 & 322.19 & 351.68 & Tie to & U1337D-36X-2, 77 & 316.77 & 351.68 \\
\hline
\end{tabular}


Table T24 (continued).

\begin{tabular}{|c|c|c|c|c|c|c|}
\hline \multirow{2}{*}{$\begin{array}{l}\text { Hole, core, section, } \\
\text { interval }(\mathrm{cm})\end{array}$} & \multicolumn{2}{|c|}{ Depth (m) } & & \multirow{2}{*}{$\begin{array}{l}\text { Hole, core, section, } \\
\text { interval }(\mathrm{cm})\end{array}$} & \multicolumn{2}{|c|}{ Depth (m) } \\
\hline & CSF & CCSF-A & & & CSF & CCSF-A \\
\hline U1337D-36X-5, 135 & 321.85 & 356.76 & Tie to & U1337C-20X-2, 145 & 320.25 & 356.76 \\
\hline U1337C-20X-7, 63 & 326.43 & 362.94 & Tie to & U1337A-36X-3, 113 & 332.63 & 362.94 \\
\hline U1337A-36X-5, 87 & 335.37 & 365.67 & Tie to & U1337C-21X-1, 115 & 327.95 & 365.67 \\
\hline U1337C-21X-5, 74 & 333.54 & 371.26 & Tie to & U1337A-37X-2, 86 & 340.36 & 371.26 \\
\hline U1337A-37X-6, 59 & 346.09 & 376.99 & Tie to & U1337C-22X-2, 69 & 338.59 & 376.99 \\
\hline U1337C-22X-4, 104 & 341.94 & 380.34 & Tie to & U1337D-39X-2, 120 & 345.90 & 380.34 \\
\hline U1337D-39X-5, 111 & 350.31 & 384.76 & Tie to & U1337C-23X-1, 63 & 346.63 & 384.76 \\
\hline U1337C-23X-4, 95 & 351.46 & 389.58 & Tie to & U1337D-40X-2, 24 & 354.54 & 389.58 \\
\hline U1337D-40X-6, 19 & 360.49 & 395.54 & Tie to & U1337C-24X-2, 111 & 358.21 & 395.54 \\
\hline U1337C-24X-5, 114 & 362.75 & 400.07 & Tie to & U1337A-40X-1, 17 & 366.98 & 400.07 \\
\hline U1337A-40X-5, 46 & 373.26 & 406.35 & Tie to & U1337C-25X-3, 13 & 368.33 & 406.35 \\
\hline U1337C-25X-5, 98 & 372.19 & 410.22 & Tie to & U1337A-41X-1, 22 & 376.62 & 410.22 \\
\hline U1337A-41X-4, 151 & 380.91 & 414.51 & Tie to & U1337C-26X-1, 27 & 374.98 & 414.51 \\
\hline U1337C-26X-6, 11 & 382.31 & 421.84 & Tie to & U1337A-42X-1, 5 & 386.05 & 421.95 \\
\hline U1337A-42X-3, 104 & 390.04 & 425.94 & Tie to & U1337C-27X-1, 13 & 384.43 & 425.94 \\
\hline U1337C-27X-4, 108 & 389.88 & 431.39 & Tie to & U1337A-43X-1, 28 & 395.89 & 431.39 \\
\hline U1337A-43X-7, 79 & 404.89 & 440.39 & Append to & U1337A-44X-1, 5 & 404.95 & 440.45 \\
\hline U1337A-44X-4, 68 & 410.08 & 445.58 & Tie to & U1337C-28X-1, 142 & 395.02 & 445.58 \\
\hline U1337C-28X-6, 98 & 402.08 & 452.64 & Tie to & U1337D-45X-1, 28 & 400.78 & 452.64 \\
\hline U1337D-45X-6, 150 & 408.00 & 459.86 & Tie to & U1337C-29X-2, 27 & 404.97 & 459.86 \\
\hline U1337C-29X-6, 8 & 410.78 & 465.67 & Tie to & U1337D-46X-2, 33 & 411.93 & 465.67 \\
\hline U1337D-46X-4, 42 & 415.02 & 468.75 & Tie to & U1337A-46X-2, 48 & 425.98 & 468.75 \\
\hline U1337A-46X-5, 82 & 430.82 & 473.60 & Tie to & U1337D-47X-1, 38 & 419.98 & 473.60 \\
\hline U1337D-47X-3, 88 & 423.48 & 477.10 & Tie to & U1337C-31X-1, 10 & 422.40 & 477.10 \\
\hline U1337C-31X-5, 62 & 428.92 & 483.62 & Tie to & U1337D-48X-1, 133 & 430.43 & 483.62 \\
\hline U1337D-48X-4, 14 & 433.74 & 486.93 & Tie to & U1337C-32X-1, 33 & 432.23 & 486.93 \\
\hline
\end{tabular}

Table T25. Magnetostratigraphic and biostratigraphic datums, Site U1337. (See table notes.) (Continued on next two pages.)

\begin{tabular}{|c|c|c|c|c|}
\hline \multirow[b]{2}{*}{ Event } & \multirow{2}{*}{$\begin{array}{l}\text { Age } \\
(\mathrm{Ma})\end{array}$} & \multicolumn{2}{|c|}{ Depth $(m)$} & \multirow{2}{*}{$\begin{array}{c}\text { Error } \\
(\mathrm{m})\end{array}$} \\
\hline & & CCSF-A & CCSF-B & \\
\hline \multicolumn{5}{|l|}{ Polarity chron } \\
\hline $\mathrm{C} 1 \mathrm{n} / \mathrm{C} 1 \mathrm{r}$ & 0.78 & 10.65 & 9.51 & \\
\hline $\mathrm{C} 1 \mathrm{r} .1 \mathrm{r} / \mathrm{C} 1 \mathrm{r} .1 \mathrm{n}$ & 0.99 & 14.19 & 12.67 & \\
\hline $\mathrm{C} 1 \mathrm{r} .1 \mathrm{n} / \mathrm{C} 1 \mathrm{r}$ & 1.07 & 15.11 & 13.49 & \\
\hline $\mathrm{C} 1 \mathrm{r} / \mathrm{C} 2 \mathrm{n}$ & 1.78 & 27.20 & 24.29 & \\
\hline $\mathrm{C} 2 \mathrm{n} / \mathrm{C} 2 \mathrm{r}$ & 1.95 & 28.69 & 25.61 & \\
\hline $\mathrm{C} 2 \mathrm{r} / \mathrm{C} 2 \mathrm{An} .1 \mathrm{n}$ & 2.58 & 36.48 & 32.57 & \\
\hline C2An.1n/C2An.1r & 3.03 & 44.87 & 40.06 & \\
\hline C2An.1r/C2An.2n & 3.12 & 46.30 & 41.34 & \\
\hline C2An.2n/C2An.2r & 3.21 & 47.99 & 42.85 & \\
\hline C2An.2r/C2An.3 & 3.33 & 49.75 & 44.42 & \\
\hline C2An.3/C2Ar & 3.60 & 55.57 & 49.61 & \\
\hline $\mathrm{C} 2 \mathrm{Ar} / \mathrm{C} 3 \mathrm{n} .1 \mathrm{n}$ & 4.19 & 70.15 & 62.63 & \\
\hline C $3 n .1 r / C 3 n .2 n$ & 4.49 & 78.32 & 69.92 & \\
\hline$C 3 n \cdot 2 n / C 3 n .2 r$ & 4.63 & 81.26 & 72.55 & \\
\hline C $3 n .2 r / C 3 n .3 n$ & 4.80 & 85.46 & 76.30 & \\
\hline C $3 n .3 n / C 3 n \cdot 3 r$ & 4.90 & 87.16 & 77.82 & \\
\hline$C 3 n .3 r / C 3 n .4 n$ & 5.00 & 89.63 & 80.02 & \\
\hline$C 3 n .4 n / C 3 r$ & 5.24 & 94.49 & 84.37 & \\
\hline C3r/C3An.1n & 6.03 & 112.42 & 100.37 & \\
\hline C3An.1n/C3An.1r & 6.25 & 118.81 & 106.08 & \\
\hline C3An.1r/C3An.2n & 6.44 & 121.80 & 108.75 & \\
\hline C3An.2n/C3Ar & 6.73 & 129.81 & 115.90 & \\
\hline $\mathrm{C} 3 \mathrm{Br} / \mathrm{C} 4 \mathrm{n}$ & 7.53 & 149.85 & 133.79 & \\
\hline $\mathrm{C} 4 \mathrm{n} / \mathrm{C} 4 \mathrm{r}$ & 8.11 & 164.90 & 147.23 & \\
\hline C4r/C4An & 8.77 & 175.03 & 156.28 & \\
\hline $\mathrm{C} 4 \mathrm{Ar} / \mathrm{C} 5 \mathrm{n}$ & 9.78 & 193.97 & 173.18 & \\
\hline \multicolumn{5}{|l|}{ Nannofossils } \\
\hline T Pseudoemiliania lacunosa & 0.44 & 5.81 & 5.19 & 0.67 \\
\hline Bc Reticulofenestra asanoi & 1.14 & 16.11 & 14.38 & 2.03 \\
\hline T Gephyrocapsa (>5.5 $\mu \mathrm{m})$ & 1.26 & 16.11 & 14.38 & 2.03 \\
\hline T Calcidiscus macintyrei & 1.61 & 23.69 & 21.15 & 0.74 \\
\hline
\end{tabular}


Table T25 (continued). (Continued on next page.)

\begin{tabular}{|c|c|c|c|c|}
\hline \multirow[b]{2}{*}{ Event } & \multirow{2}{*}{$\begin{array}{l}\text { Age } \\
(\mathrm{Ma})\end{array}$} & \multicolumn{2}{|c|}{ Depth $(\mathrm{m})$} & \multirow{2}{*}{$\begin{array}{c}\text { Error } \\
(\mathrm{m})\end{array}$} \\
\hline & & CCSF-A & CCSF-B & \\
\hline T Discoaster brouweri & 1.93 & 27.91 & 24.92 & 1.33 \\
\hline T Discoaster pentaradiatus & 2.39 & 36.77 & 32.83 & 1.50 \\
\hline T Discoaster surculus & 2.49 & 38.49 & 34.37 & 0.22 \\
\hline T Reticulofenestra pseudoumbilicus & 3.70 & 58.46 & 52.19 & 2.21 \\
\hline T Ceratolithus acutus & 5.04 & 89.96 & 80.32 & 0.70 \\
\hline B Ceratolithus acutus & 5.35 & 94.60 & 84.46 & 1.04 \\
\hline T Discoaster quinqueramus & 5.58 & 103.66 & 92.55 & 2.66 \\
\hline T Nicklithus amplificus & 5.98 & 113.34 & 101.20 & 0.85 \\
\hline B Nicklithus amplificus & 6.91 & 129.45 & 115.58 & 0.47 \\
\hline TP Reticulofenestra pseudoumbilicus & 7.07 & 190.54 & 170.13 & 0.13 \\
\hline B Amaurolithus spp. & 7.36 & 147.30 & 131.51 & 0.34 \\
\hline B Discoaster berggrenii & 8.29 & 167.13 & 149.22 & 1.58 \\
\hline BP Reticulofenestra pseudoumbilicus & 9.10 & 174.72 & 156.00 & 0.78 \\
\hline T Discoaster hamatus & 9.69 & 192.99 & 172.31 & 0.70 \\
\hline B Discoaster hamatus & 10.55 & 219.06 & 195.59 & 4.33 \\
\hline T Coccolithus miopelagicus & 10.60 & 219.06 & 195.59 & 4.33 \\
\hline B Catinaster coalitus & 10.89 & 224.92 & 200.82 & 0.75 \\
\hline Tc Discoaster kugleri & 11.58 & 242.43 & 216.45 & 2.64 \\
\hline Bc Discoaster kugleri & 11.86 & 255.30 & 227.95 & 0.75 \\
\hline T Cyclicargolithus floridanus & 12.03 & 258.30 & 230.63 & 0.75 \\
\hline T Coronocyclus nitescens & 12.12 & 258.30 & 230.63 & 0.75 \\
\hline T Calcidiscus premacintyrei & 12.45 & 259.80 & 231.96 & 0.75 \\
\hline Tc Cyclicargolithus floridanus & 13.33 & 313.33 & 279.76 & 0.95 \\
\hline T Sphenolithus heteromorphus & 13.53 & 316.81 & 282.87 & 0.75 \\
\hline T Helicosphaera ampliaperta & 14.91 & 349.49 & 312.04 & 0.75 \\
\hline Tc Discoaster deflandrei & 15.66 & 357.87 & 319.53 & 1.50 \\
\hline Bc Sphenolithus heteromorphus & 17.71 & 390.49 & 348.65 & 2.43 \\
\hline Tc Sphenolithus belemnos & 17.95 & 393.43 & 351.28 & 0.80 \\
\hline T Triquetrorhabdulus carinatus & 18.29 & 390.49 & 348.65 & 2.43 \\
\hline B Sphenolithus belemnos & 19.03 & 412.32 & 368.14 & 1.54 \\
\hline X Helicosphaera euphratis/Helicosphaera carteri & 20.90 & & 0.00 & 2.70 \\
\hline Tc Triquetrorhabdulus carinatus & 22.10 & & 0.00 & 0.77 \\
\hline Lowermost observed Discoaster druggii & $\leq 22.41$ & & 0.00 & \\
\hline T Sphenolithus delphix & 23.10 & & 0.00 & 0.53 \\
\hline B Sphenolithus delphix & 23.20 & & 0.00 & 0.20 \\
\hline \multicolumn{5}{|l|}{ Radiolarians } \\
\hline T Stylatractus universus & 0.44 & 2.61 & 2.33 & 7.63 \\
\hline B Collosphaera tuberosa & 0.59 & 2.61 & 2.33 & 7.63 \\
\hline T Anthocyrtidium angulare & 1.21 & 2.61 & 2.33 & 7.63 \\
\hline T Theocorythium vetulum & 1.33 & 16.18 & 14.45 & 4.71 \\
\hline B Theocorythium trachelium & 1.76 & 25.68 & 22.93 & 4.74 \\
\hline B Anthocyrtidium angulare & 1.97 & 25.68 & 22.93 & 4.74 \\
\hline $\mathrm{T}$ Pterocanium prismatium & 2.08 & 25.68 & 22.93 & 4.74 \\
\hline T Didymocyrtis avita & 2.60 & 37.80 & 33.75 & 4.65 \\
\hline T Stichocorys pergrina & 2.90 & 37.80 & 33.75 & 4.65 \\
\hline T Phormostichoartus doliolum & 3.96 & 60.44 & 53.96 & 4.68 \\
\hline B Amphirhopalum ypsilon & 4.03 & 70.38 & 62.84 & 4.32 \\
\hline T Didymocyrtis penultima & 4.26 & 81.15 & 72.46 & 5.17 \\
\hline T Solenosphaera omnitubus & 5.32 & 102.64 & 91.64 & 4.71 \\
\hline T Spongaster berminghami & 5.33 & 102.64 & 91.64 & 4.71 \\
\hline B Didymocyrtis avita & 6.15 & 112.82 & 100.73 & 4.68 \\
\hline T Didymocyrtis antepenultima & 6.17 & 123.19 & 109.99 & 4.70 \\
\hline B Didymocyrtis tetrathalamus & 6.60 & 134.84 & 120.39 & 4.74 \\
\hline T Calocycletta caepa & 6.60 & 134.84 & 120.39 & 4.74 \\
\hline S. delmontensis > S. pergrina & 7.75 & 134.84 & 120.39 & 4.74 \\
\hline B Theocorythium vetulum & 7.98 & 145.94 & 130.30 & 4.69 \\
\hline B Solenosphaera omnitubus & 8.25 & 145.94 & 130.30 & 4.69 \\
\hline T Diartus hughesi & 8.39 & 155.92 & 139.21 & 4.82 \\
\hline T Didymocyrtis laticonus & 8.43 & 155.92 & 139.21 & 4.82 \\
\hline B Didymocyrtis penultima & 8.51 & 167.14 & 149.23 & 4.71 \\
\hline T Botryostrobus miralestensis & 8.59 & 178.47 & 159.35 & 4.73 \\
\hline$D$. pettersoni $>D$. hughesi & 8.76 & 188.87 & 168.63 & 4.72 \\
\hline B Didymocyrtis antepenultima & 10.01 & 199.05 & 177.72 & 4.66 \\
\hline T Cyrtocapsera japonica & 10.31 & 225.45 & 201.29 & 7.89 \\
\hline T Carpocanopsis cristata & 10.88 & 225.45 & 201.29 & 7.89 \\
\hline T Cyrtocapsera cornuta & 11.88 & 258.77 & 231.04 & 4.75 \\
\hline T Cyrtocapsera tetrapera & 11.91 & 258.77 & 231.04 & 4.75 \\
\hline B Diartus pettersoni & 12.11 & 270.53 & 241.54 & 6.43 \\
\hline
\end{tabular}


Table T25 (continued).

\begin{tabular}{|c|c|c|c|c|}
\hline \multirow[b]{2}{*}{ Event } & \multirow{2}{*}{$\begin{array}{l}\text { Age } \\
(\mathrm{Ma})\end{array}$} & \multicolumn{2}{|c|}{ Depth $(m)$} & \multirow{2}{*}{$\begin{array}{c}\text { Error } \\
\text { (m) }\end{array}$} \\
\hline & & CCSF-A & CCSF-B & \\
\hline T Calocycletta robusta & 13.35 & 304.95 & 272.28 & 4.82 \\
\hline T Acrocubus octopyle & 13.88 & 314.37 & 280.68 & 4.46 \\
\hline T Liriospyris parkerae & 13.89 & 314.37 & 280.68 & 4.46 \\
\hline T Didymocyrtis violina & 14.20 & 343.57 & 306.76 & 4.53 \\
\hline T Calocycletta virginis & 14.23 & 343.57 & 306.76 & 4.53 \\
\hline T Calocycletta costata & 14.23 & 343.57 & 306.76 & 4.53 \\
\hline T Dorcadospyris dentata & 14.76 & 343.57 & 306.76 & 4.53 \\
\hline T Liriospyris stauropora & $14.78-14.83$ & 343.57 & 306.76 & 4.53 \\
\hline B Liriospyris parkerae & $14.79-15.03$ & 343.57 & 306.76 & 4.53 \\
\hline T Didymocyrtis prismatica & 15.17 & 343.57 & 306.76 & 4.53 \\
\hline B Calocycletta costata & 17.49 & 390.31 & 348.49 & 7.07 \\
\hline B Dorcadospyris dentata & 17.72 & 390.31 & 348.49 & 7.07 \\
\hline T Dorcadospyris scambos & 18.53 & 414.52 & 370.11 & 4.77 \\
\hline B Stichocorys wolffii & 18.57 & 414.52 & 370.11 & 4.77 \\
\hline B Stichocorys delmontensis & 20.68 & 455.33 & 406.54 & 4.80 \\
\hline T Lophocyrtis pegetrum & 20.89 & 471.28 & 420.78 & 4.63 \\
\hline T Theocyrtis anossa & 21.38 & 471.28 & 420.78 & 4.63 \\
\hline \multicolumn{5}{|l|}{ Foraminifers } \\
\hline T Globorotalia (Truncorotalia) tosaensis & 0.61 & 7.29 & 6.51 & 1.14 \\
\hline T Globigerinoides fistulosus & 1.77 & 25.51 & 22.77 & 1.07 \\
\hline T Globorotalia pseudomiocenica & 2.30 & 32.87 & 29.34 & 1.06 \\
\hline T Globorotalia (Menardella) multicamerata & 2.98 & 32.87 & 29.34 & 1.06 \\
\hline T Dentoglobigerina altispira & 3.47 & 48.53 & 43.33 & 3.56 \\
\hline T Sphaeroidinellopsis seminulina & 3.59 & 48.53 & 43.33 & 3.56 \\
\hline X Pulleniatina spp. sinistral $\rightarrow$ dextral & 4.08 & 66.75 & 59.60 & 1.14 \\
\hline T Globoturborotalita nepenthes & 4.37 & 88.81 & 79.29 & 1.77 \\
\hline B Sphaeroidinella dehiscens s.I. & 5.54 & 86.67 & 77.38 & -0.09 \\
\hline B Globorotalia tumida & 5.57 & 102.05 & 91.11 & 2.74 \\
\hline B Globorotalia plesiotumida & 8.58 & 154.01 & 137.51 & 1.47 \\
\hline B Globoturborotalita nepenthes & 11.63 & 252.71 & 225.63 & 1.56 \\
\hline T Globorotalia (Fohsella) fohsi s.l. & 11.79 & 262.01 & 233.94 & 1.51 \\
\hline B Globorotalia (Fohsella) fohsi s.l. & 13.41 & 284.28 & 253.82 & 4.14 \\
\hline B Globorotalia (Fohsella) praefohsi & 13.77 & 317.87 & 283.81 & 1.52 \\
\hline T Clavatorella bermudezi & 13.82 & 321.36 & 286.93 & 1.97 \\
\hline B Globorotalia (Fohsella) peripheroacuta & 14.24 & 337.58 & 301.41 & 1.51 \\
\hline B Orbulina spp. & 14.74 & 344.73 & 307.79 & 1.82 \\
\hline B Clavatorella bermudezi & 14.89 & 344.73 & 307.79 & 1.82 \\
\hline B Praeorbulina glomerosa & 16.27 & 352.15 & 314.42 & 0.45 \\
\hline T Catapsydrax dissimilis & 17.54 & 404.11 & 360.81 & 0.98 \\
\hline T Globoquadrina binaiaensis & 19.09 & 430.48 & 384.36 & 4.04 \\
\hline T Paragloborotalia kugleri & 21.12 & 457.92 & 408.85 & 2.22 \\
\hline T Paragloborotalia pseudokugleri & 21.31 & 448.61 & 400.54 & 1.06 \\
\hline B Globoquadrina dehiscens & 22.44 & 457.92 & 408.85 & 2.22 \\
\hline T Globigerina ciperoensis & 22.90 & 485.80 & 433.75 & 2.16 \\
\hline B Paragloborotalia kugleri & 23 & 492.19 & 439.46 & 1.63 \\
\hline
\end{tabular}

Notes: $\mathrm{B}=$ bottom, $\mathrm{BC}=$ bottom common occurrence, $\mathrm{BP}=$ bottom paracme, $\mathrm{T}=$ top, $\mathrm{Tc}=$ Top common occurrence, $\mathrm{TP}=$ top paracme, $\mathrm{X}=$ abundance crossover. 
Table T26. Vertical seismic profile direct arrival times. (See table notes.)

\begin{tabular}{ccccc}
\hline \multicolumn{2}{c}{ Receiver depth $(\mathrm{m})$} & & \multicolumn{2}{c}{ One-way traveltime $(\mathrm{s})$} \\
\cline { 1 - 2 } \cline { 5 - 5 } WRF & WSF & & Measured & Corrected \\
\hline 4688.1 & 214.1 & & 3.1076 & 3.1136 \\
4703.1 & 229.1 & & 3.1167 & 3.1227 \\
4718.0 & 244.0 & & 3.1256 & 3.1316 \\
4733.1 & 259.1 & & 3.1343 & 3.1403 \\
4748.1 & 274.1 & & 3.1432 & 3.1492 \\
4763.0 & 289.0 & & 3.1519 & 3.1579 \\
4777.7 & 303.7 & & 3.1602 & 3.1662 \\
4792.7 & 318.7 & & 3.1688 & 3.1748 \\
4808.1 & 334.1 & & 3.1774 & 3.1834 \\
4822.9 & 348.9 & 3.1860 & 3.1920 \\
4838.1 & 364.1 & 3.1940 & 3.2000 \\
4853.1 & 379.1 & 3.2025 & 3.2085 \\
4868.0 & 394.0 & 3.2102 & 3.2162 \\
4883.0 & 409.0 & 3.2179 & 3.2239 \\
4898.1 & 424.1 & 3.2255 & 3.2315 \\
4912.8 & 438.8 & 3.2325 & 3.2385 \\
\hline
\end{tabular}

Notes: Measured traveltimes are times between arrival of the pulse at a hydrophone located $2 \mathrm{~m}$ below the air guns and at the receivers in the borehole. Corrected traveltimes are between sea level and the borehole receivers.

Table T27. Temperature data and thermal resistance, Site U1337. (See table notes.)

\begin{tabular}{|c|c|c|c|c|c|}
\hline \multirow[b]{2}{*}{ Core } & \multirow[b]{2}{*}{ Tool } & \multirow{2}{*}{$\begin{array}{c}\text { Depth } \\
\operatorname{DSF}(m)\end{array}$} & \multicolumn{2}{|c|}{ Temperature $\left({ }^{\circ} \mathrm{C}\right)$} & \multirow{2}{*}{$\begin{array}{l}\text { Thermal } \\
\text { resistance } \\
\left(\mathrm{m}^{2} \mathrm{~K} / \mathrm{W}\right)\end{array}$} \\
\hline & & & At mudline & In situ & \\
\hline \multicolumn{6}{|l|}{ 321-U1337A- } \\
\hline $5 \mathrm{H}$ & APCT-3 & 43.5 & 1.75 & 3.14 & 59.5 \\
\hline $7 \mathrm{H}$ & & 62.5 & 1.75 & 3.77 & 84.2 \\
\hline $9 \mathrm{H}$ & & 81.5 & 1.75 & 4.43 & 108.2 \\
\hline $11 \mathrm{H}$ & & 100.5 & 1.60 & 5.08 & 131.4 \\
\hline $13 \mathrm{H}$ & & 119.5 & 1.71 & 5.84 & 154.0 \\
\hline \multicolumn{6}{|l|}{ 321-U1337B- } \\
\hline $15 \mathrm{H}$ & & 143.5 & 1.56 & 6.56 & 181.7 \\
\hline $17 \mathrm{H}$ & & 162.5 & 1.53 & 7.15 & 203.0 \\
\hline $19 \mathrm{H}$ & & 181.5 & 1.53 & 7.80 & 223.7 \\
\hline \multicolumn{6}{|l|}{ 321-U1337C- } \\
\hline Base of $17 X$ & SET & 298.1 & 1.53 & 11.24 & 340.2 \\
\hline & & Average: & 1.634 & & \\
\hline
\end{tabular}

Notes: Thermal resistance determined from the trend of in situ thermal conductivities with depth (Fig. F47). APCT-3 = advanced piston corer temperature tool, SET = sediment temperature tool. 